\title{
ÉLITES Y QUINTAS: EL DEBATE PARLAMENTARIO SOBRE EL RECLUTAMIENTO MILITAR DURANTE EL SIGLO XIX
}

INTRODUCCIÓN 6

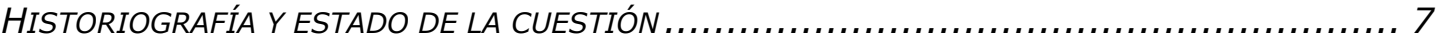

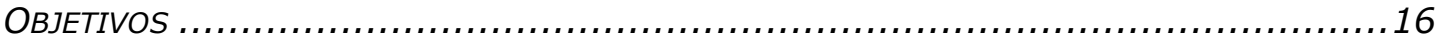

MARCO HISTÓRICO Y DESARROLLO DE LA INVESTIGACIÓN $\ldots \ldots \ldots \ldots \ldots \ldots \ldots \ldots \ldots \ldots \ldots \ldots \ldots \ldots, \ldots \ldots \ldots$

FUENTES UTILIZADAS $\ldots \ldots \ldots \ldots, \ldots, \ldots, \ldots, \ldots, \ldots, \ldots, \ldots, \ldots, \ldots, \ldots, \ldots, \ldots, \ldots, \ldots, \ldots, 22$

EN LO QUE SE REFIERE A LAS FUENTES EMPLEADAS, ADEMÁS POR SUPUESTO DE LAS BIBLIOGRÁFICAS, HEMOS ACUDIDO PRINCIPALMENTE A TRES FUENTES DE ARCHIVO:..........22

1.- LOS PRECEDENTES DEL SIGLO XVIII: EL MANTENIMIENTO DE LOS SISTEMAS MEDIEVALES.

2.- EVOLUCIÓN LEGISLATIVA ENTRE 1800 Y 1912: LOS CAMBIOS EN EL CONCEPTO DEL RECLUTAMIENTO Y DE LA PROPIA FIGURA DEL SOLDADO 37

2.1.- LA SOMBRA DE LA REVOLUCIÓN FRANCESA Y EL ANTECEDENTE DE

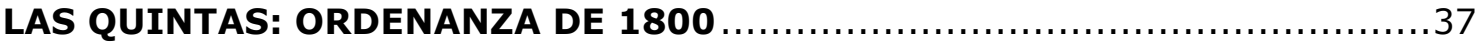

CONTEXTO HISTÓRICO: LA QUIEBRA DEL EJÉRCITO ....................................... 38 DESARROLLO DE LA NORMA: EL INTENTO DE MODERNIZACIÓN DE LAS OPERACIONES DE

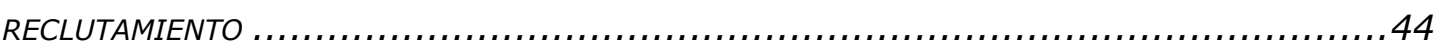

a) Elaboración del padrón de vecinos: el objetivo militar por encima del fiscal................................................................................4 45 b) El reparto de cupos: la actuación de los intendentes y los justicias de cada

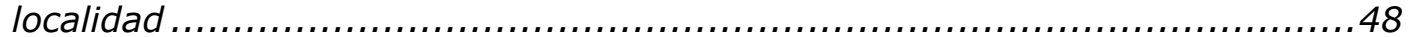

c) El alistamiento y tallaje de los mozos..................................... 51

d) El juicio de excepciones: el examen de las alegaciones físicas presentadas

..................52

e) Exenciones: el mantenimiento de los principios del Antiguo Régimen .....55

f) El sorteo: la supuesta aleatoriedad de un acto marcado por las exenciones..........................................................................65 65

g) La lucha contra el prófugo ................................................69

h) Conducción de los reclutas a su destino ................................... 72

i) Gratificaciones a los reclutas: el intento de hacer más atractivo el servicio en el Ejército.......................................................................... 75

j) Sistemas de control del proceso: la lucha contra el fraude....................77

LA LIMITADA APLICACIÓN DE LA NORMA Y SUS AÑADIDOS.................................. 79 
a) La necesidad de reducir el número de exentos ante la situación de excepcionalidad que vivía el país: Orden de la Junta Suprema y Gubernativa del Reino de 18 de noviembre de 1808. 80 b) El retorno al pasado: Real Instrucción Adicional a los Artículos $X$ y XXXV de la Ordenanza de Reemplazos de 27 de Octubre de 1800, de 26 de noviembre de 1817, y Real Instrucción Adicional a la Ordenanza de Reemplazos de Octubre de 1800, de 21 de enero de 1819 ......................................8 84

\section{2.- EL RECLUTAMIENTO LIBERAL: LA LEGISLACIÓN DE LAS CORTES DE

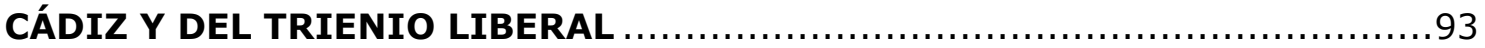

CONTEXTO HISTÓRICO: LA QUIEBRA DEL ANTIGUO RÉGIMEN.................................. 94

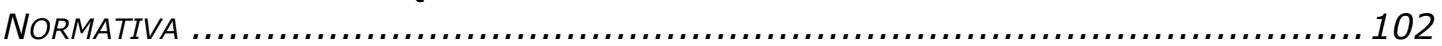

a) El concepto de ciudadano-soldado: La Constitución de 1812 ..............102

a) El fin de las exenciones estamentales: Ley de 14 de mayo de 1821 de reemplazo del Ejército permanente ..............................................114

b) La defensa del nuevo orden constitucional: Ley constitutiva del Ejército de 9 de Junio de 1821 ............................................................. 116

c) El nuevo reconocimiento de las exenciones eclesiásticas: Decreto de 31 de octubre de 1822 para llevar a efecto el reemplazo extraordinario del Ejército........................................................................ 123

d) El inicio de los reclutamientos modernos: Ordenanza General para el reemplazo del Ejército de 3 de febrero de 1823 ..................................127 APLICACIÓN Y AÑADIDOS DE LAS NORMAS: LA LIMITADA VIGENCIA ANTE EL REGRESO DEL ABSOLUTISMO ................................................................... 136

\section{3.- EL FIN DE LOS SISTEMAS DE RECLUTAMIENTO DEL ANTIGUO

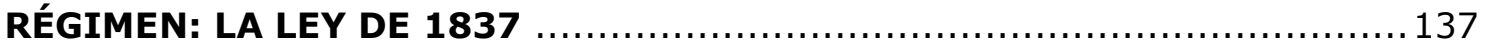

LA LUCHA CONTRA EL CARLISMO COMO CONTEXTO HISTÓRICO ............................. 140

LA ADOPCIÓN DE LOS NUEVOS CONCEPTOS LIBERALES EN EL DESARROLLO DE LA NORMA ..... 145

a) Elaboración del padrón de vecinos: documento básico para el reparto de

los cupos ...................................................................... 146

b) Formación del alistamiento para el reemplazo..............................149

c) Reclamaciones y rectificación del alistamiento.............................. 150

d) Un sorteo por franjas de edad ........................................... 152

e) Actuación de las Diputaciones Provinciales .................................. 154

f) Reparto de los cupos y la novedad del sorteo de quebrados...............157

g) Llamamiento, declaración, reconocimiento y posibles exenciones de los

soldados ........................................................................ 159

h) Conducción de los reclutas a su destino .................................. 165

i) La sustitución: el primer reconocimiento legal de esta polémica figura.169

j) La suavización en las penas impuestas a los prófugos......................170

LA LARGA APLICACIÓN TEMPORAL DEMUESTRA LA IMPORTANCIA DE LA LEY................. 172

2.4.- UN PROYECTO MODERNIZADOR QUE SE CONVIRTIÓ EN REFERENTE PARA LOS AÑOS POSTERIORES: EL PROYECTO DE LEY DE $1850 \ldots \ldots \ldots \ldots 187$

LA INFLUENCIA MODERADA EN UN CONTEXTO POLÍTICO DE PREDOMINIO DEL EJÉRCITO.........188

LA BÚSQUEDA DE LA UNIFICACIÓN LEGISLATIVA NO EXENTA DE POLÉMICA EN EL DESARROLLO DE LA NORMA.

a) Elaboración del padrón de vecinos: herramienta necesaria para conocer el número de posibles reclutas....................................................... 199

b) Formación, reclamaciones y rectificación del alistamiento para el reemplazo: la posibilidad de recurrir el documento................................201

c) Un sorteo gestionado por los Ayuntamientos ................................204

d) El reparto del contingente: las Diputaciones provinciales pierden protagonismo .................................................................... 206

e) Exenciones: la confirmación de la redención como alternativa a la sustitución .................................................................... 209 
f) Llamamiento y declaración de soldados y suplentes........................216

g) Conducción y entrega de los reclutas en la caja de la provincia ...........219

h) La lucha contra el prófugo y contra el fraude en su captura ................222

i) Las reclamaciones ante el consejo provincial y el ministerio de la Gobernación....................................................................... 225

j) Disposiciones penales: las causas criminales frente a las prácticas irregulares ..................................................................... 226

k) El problema de la especulación con la sustitución y el reconocimiento de la redención en metálico .............................................................. 228 LA CONVOCATORIA DE QUINTAS EN FUNCIÓN DE ESTE PROYECTO NUNCA APROBADO ES EL

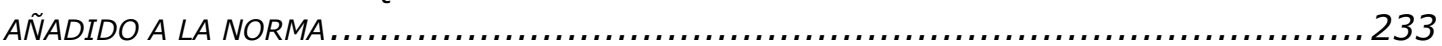

2.5.- UNA NORMA PROGRESISTA CON APOYO MODERADO: LA LEY DE 1856

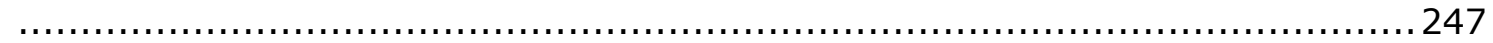

LA IMPRONTA DE ESPARTERO MARCA EL CONTEXTO HISTÓRICO ..............................251 LA PLASMACIÓN DE LOS IDEALES PROGRESISTAS SE PRODUCE EN EL DESARROLLO DE LA NORMA.......................................................................... 255

a) El reparto del contingente, competencia del Gobierno .....................261

b) La elaboración del padrón de vecinos, una importante competencia municipal......................................................................... 264

c) Formación, reclamaciones y rectificación del alistamiento para el reemplazo: una clasificación inicial de los futuros reclutas.......................266

d) El sorteo: la intervención estatal para evitar fraudes......................271

e) La reducción en el número de exenciones..................................275

f) Llamamiento y declaración de soldados y suplentes: la supervisión de la Diputación provincial ............................................................. 278

g) Conducción y entrega de los reclutas en la caja de la provincia: citación personal para evitar engaños ................................................. 282

h) La lucha contra el prófugo ...............................................28 284

i) Las reclamaciones ante la Diputación provincial y el ministerio de la Gobernación..................................................................... 287

j) La sustitución y la redención en metálico: el fondo de redención del servicio militar................................................................... 290

k) Disposiciones penales: el castigo frente a las irregularidades ..............294

LARGA VIGENCIA Y ESCASOS CAMBIOS EN LA APLICACIÓN DE LA NORMA ....................295

2.6.- UNA SITUACIÓN CONVULSA HACE FRACASAR LOS INTENTOS DE

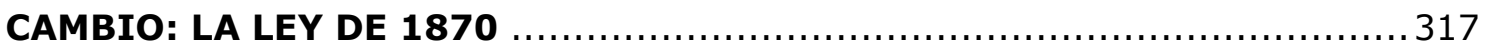

LAS PARADOJAS DE UNA SITUACIÓN REVOLUCIONARIA MARCAN EL CONTEXTO HISTÓRICO ... 318 LIMITADA APLICACIÓN DE LA NORMA E IMPORTANTES NOVEDADES QUE LA MODIFICARON ......371

a) El proyecto abolicionista de Ruiz Zorrilla en 1872 ..........................378

b) La norma republicana que suprimía las quintas: La Ley de 17 de Febrero

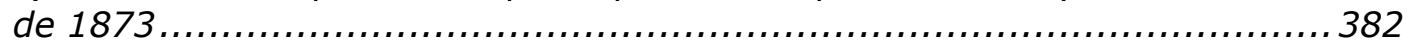

\section{7.- EL FIN DE LAS ASPIRACIONES ABOLICIONISTAS: LA LEY DE 1877 .391}

NUEVAS FUNCIONES REPRESIVAS OTORGADAS AL EJÉRCITO COMO CONTEXTO HISTÓRICO .... 394 UNA VUELTA AL PASADO SIGUIENDO EL MODELO ALEMÁN A LO LARGO DEL DESARROLLO DE LA NORMA ........................................................................ 399 LA CONSOLIDACIÓN DEL SISTEMA EN LA APLICACIÓN Y AÑADIDOS A LA NORMA ...............412 $\checkmark$ LA UNIFICACIÓN DE LA VARIEDAD LEGISLATIVA EN EL REGLAMENTO DE 1877 Y LEY DE

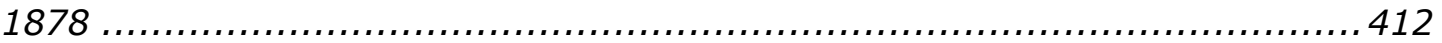

a) Principios generales: las limitaciones a la libertad de los jóvenes........4 413

b) La diversidad de las exenciones ...........................................417

c) La distribución del contingente: el ministerio de Guerra solicita y el de Gobernación dispone ........................................................... 422

d) El alistamiento y su rectificación............................................... 425

e) La exhaustiva regulación del sorteo ...................................4 430 
f) Llamamiento y declaración de los soldados..................................433

g) El ingreso en el servicio y la conducción a la caja de reclutamiento......435

h) Las reclamaciones ante las comisiones provinciales de reclutamiento $y$

contra sus fallos ................................................................. 438

i) El ingreso en el servicio activo ......................................... 441

j) La nueva categoría del recluta disponible ...............................443

k) La sustitución y la redención en metálico: reconocimiento legal sin apenas oposición parlamentaria......................................................... 445

1) La búsqueda de los voluntarios: enganchados y reenganchados ..........449 44

$m$ ) La reserva y las asambleas: el objetivo es mantener la disciplina militar para aquellos que no se incorporasen al servicio activo.........................450

n) La lucha contra el prófugo: destino, Ultramar .............................454

o) Disposiciones penales: la lucha contra los incumplimientos................456 456

p) Reglamento de exenciones físicas: una mayor atención hacia las enfermedades psiquiátricas .................................................... 458

$\checkmark$ LOS LÍMITES A LA SUSTITUCIÓN Y LA REDUCCIÓN EN LA CUANTÍA DE LA REDENCIÓN: LEY DE RECLUTAMIENTO Y REEMPLAZO DE 8 DE ENERO DE 1882, REFORMANDO LA LEY DE $1878 \ldots 463$

\section{8.- UN INTENTO DE FRENAR LAS CRÍTICAS: LA LEY DE $1885 \ldots \ldots \ldots \ldots . \ldots 79$}

LA NUEVA DIVISIÓN TERRITORIAL MILITAR ESPAÑOLA COMO CONTEXTO HISTÓRICO ...........480

DESARROLLO DE UNA NORMA QUE APENAS TRANSFORMÓ LA LEGALIDAD VIGENTE .............485

a) Disposiciones generales: el teórico mantenimiento de los años de servicio militar .......................................................................... 485

b) El alistamiento: la lucha contra el fraude.................................4.490

c) Exenciones: la diferenciación entre exenciones totales y parciales .......4497

d) Clasificación y declaración de los soldados...................................504

e) La lucha contra el prófugo: la reducción de la pena temporal ..............506

f) Conducción e ingreso de los reclutas en la caja de la provincia.............509

g) Las reclamaciones ante las comisiones provinciales de reclutamiento $y$ contra sus fallos ............................................................... 511

h) Unos criterios fijos para la distribución del contingente y el destino de los mozos sorteados................................................................. 515 i) La sustitución y la redención en metálico: la creciente pérdida de privilegios ante la protesta social ............................................517

j) Disposiciones penales: la sanción de los incumplimientos ..................521

k) Reglamento de exenciones físicas: tipología inalterada de enfermedades con cambios en el procedimiento de actuación de las autoridades competentes 523

EL DESCONTENTO SOCIAL OBLIGA A NUEVOS AÑADIDOS A LA NORMA ......................5 527

a) Una mayor solicitud de soldados para Ultramar en las disposiciones aclaratorias de la ley ...........................................................5.5. 527

b) El intento de un servicio universal, excepto en Ultramar, según el Proyecto de reforma del General Cassola .................................................. 532

c) El fin de la redención y la sustitución para los destinos peninsulares en el Proyecto de reforma del ministro Azcárraga ...................................... 535

d) La necesidad de efectivos para hacer frente a la guerra colonial en la Ley

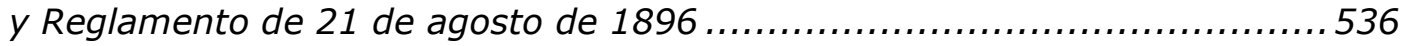

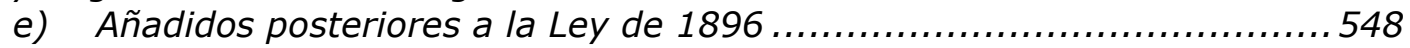

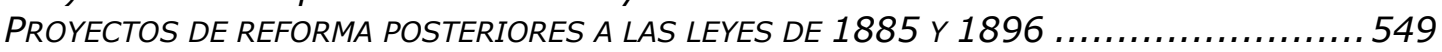

$\checkmark \quad$ Los intentos de cambio tras el Desastre del 98 en el Proyecto de reforma

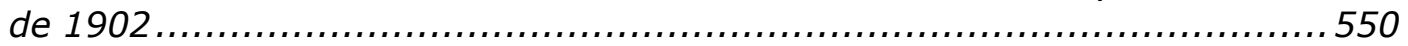
$\checkmark$ El primer planteamiento de las cuotas en el Proyecto de reforma de 1903........................................................................... 559 $\checkmark$ El intento de mejorar la instrucción según el Proyecto de reforma de 1906. 563

2.9.- LA TEÓRICA UNIVERSALIZACIÓN DEL SERVICIO MILITAR: LA LEY DE 1912 569 
LOS PROYECTOS PREVIOS

EL SERVICIO MILITAR OBLIGATORIO MARCA EL DESARROLLO DE LA NORMA.

a) Disposiciones generales: el intento por incorporar a los estratos sociales superiores al servicio ............................................................. 595

b) Autoridades que intervienen en las operaciones de reclutamiento y reemplazo: la importancia de Ayuntamientos y consulados .................... 598

c) El alistamiento y su rectificación............................................6 604

d) El sorteo y la lucha por su no repetición ......................................6 608

e) Exenciones y excepciones del servicio militar .............................609

f) Clasificación de los soldados: la aptitud o ineptitud para el servicio ..... 614

g) La lucha contra el prófugo: el papel de las comisiones mixtas de

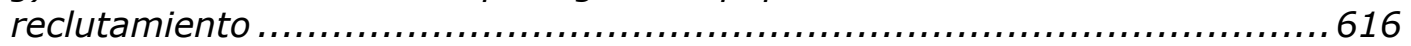

h) Las prórrogas: el retraso en la incorporación al servicio ...................617

i) Conducción e ingreso de los reclutas en la caja de la provincia............621

j) Las diferentes situaciones militares a los largo de los dieciocho años de

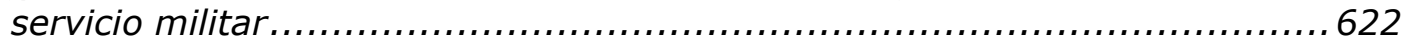

k) La distribución del contingente y destino de los mozos sorteados ........625

I) La posibilidad de concesión de licencias temporales a los reclutas .......627

m) La importancia concedida a la instrucción militar ...........................628

n) Reducción del tiempo de servicio en filas: el soldado de cuota o el mantenimiento de la discriminación..............................................629

o) Disposiciones penales, especiales y transitorias..........................634

p) Un Reglamento de exenciones físicas que contempla nuevas categorías de enfermedades $y$ defectos físicos...............................................6 638

CONCLUSIONES

LOS PRECEDENTES: EL RECLUTAMIENTO DURANTE EL SIGLO XVIII MANTIENE LOS SISTEMAS

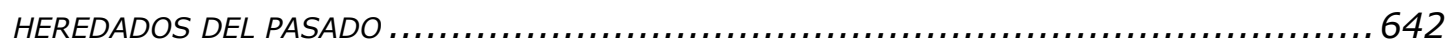

LA ORDENANZA DE 1800 O LA CONSOLIDACIÓN DEL SISTEMA DE QUINTAS.................644

EL TRIUNFO DE LA DOCTRINA LIBERAL EN LA LEGISLACIÓN DE LAS CORTES DE CÁDIZ Y DEL

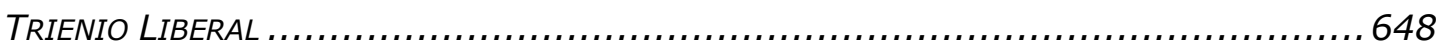

EL FIN DE LOS SISTEMAS ANTIGUORREGIMENTALES EN LA LEY DE $1837 \ldots \ldots \ldots \ldots \ldots \ldots \ldots . . \ldots 53$

LA MODERNIZACIÓN DEL REEMPLAZO EN EL PROYECTO DE LEY DE $1850 \ldots \ldots \ldots \ldots \ldots \ldots \ldots \ldots . \ldots 68$

LA IMPLANTACIÓN DE IDEAS PROGRESISTAS CON LA LEY DE $1856 \ldots \ldots \ldots \ldots \ldots \ldots \ldots \ldots \ldots \ldots . \ldots 62$

EL DESENCANTO POR LAS PROMESAS REVOLUCIONARIAS DEL SEXENIO PRODUCIDO POR LA LEY

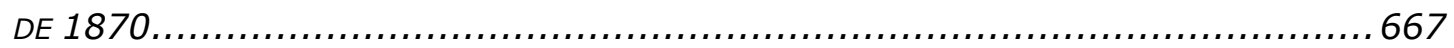

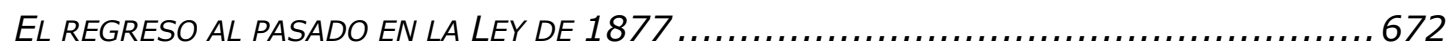

EL INTENTO DE ASEGURAR UNA RÁPIDA MOVILIZACIÓN EN LA LEY DE $1882 \ldots \ldots \ldots \ldots \ldots \ldots . . \ldots 77$

EL INTENTO DE SUPERAR LAS CRÍTICAS A LA EXISTENCIA DE PRIVILEGIOS ECONÓMICOS: LA LEY

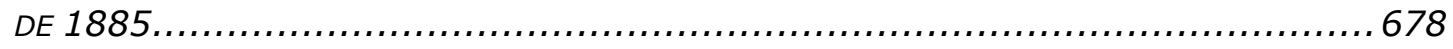

EL FIN DE LA REDENCIÓN Y LA SUSTITUCIÓN, EL INICIO DE LAS CUOTAS: LA LEY DE 1912 .. 686 


\section{ÉLITES Y QUINTAS: EL DEBATE PARLAMENTARIO SOBRE EL RECLUTAMIENTO MILITAR DURANTE EL SIGLO XIX}

\section{Introducción}

Los análisis históricos sobre los ejércitos y sus hazañas, sus grandes hombres y personajes, sus gestas, campañas, batallas y también fracasos, han sido muy frecuentes a lo largo del tiempo. Sin embargo, la incidencia que han tenido los ejércitos en el conjunto de la sociedad, en especial en lo que se refiere al servicio militar y su forma de ejecutarlo, es decir, el peso que ha tenido para el gran conjunto de la población, ha sido más ignorado ${ }^{1}$.

Más allá de la visión tradicional de un Ejército dirigido por personajes distinguidos como protagonista de algunos de los hechos históricos más relevantes de la historia de España, pretendemos con este trabajo acercarnos al debate parlamentario y a la regulación

\footnotetext{
1 "Decimos esto por considerar que las fuerzas armadas cuentan con otras áreas de investigación aparte de la mencionada referida al cuerpo de oficiales y oficiales generales. Existen otros elementos que conforman el Ejército como son, el cuerpo de suboficiales; la clase de tropa; la legislación de carácter técnico y político que han ido configurando los sucesivos modelos de nuestras fuerzas armadas, su dotación material, su actuación profesional,..." (GONZÁLEZ ASENJO, A. J., "La resistencia al servicio militar en Galicia", Estudios de Historia Social, $34-35$ (1985), Madrid, Ministerio de Trabajo y Seguridad Social, p. 198).
} 
jurídica del proceso de reclutamiento y a la incidencia política que ésta tuvo.

El Ejército español jugó un rol esencial en diversos ámbitos durante el siglo XIX y condicionó nuestro devenir histórico, ya sea desde el punto de vista político, al constituirse como una pieza clave en la consolidación del liberalismo y al participar en la vida pública del país; pero también social y económico, ya que el fin del Antiguo Régimen y el inicio del sistema liberal, así como la transición que vivieron los hombres de súbditos a ciudadanos, supusieron la aparición del ciudadano-soldado y de una nueva obligación para toda la ciudadanía: la de defender, incluso hasta la muerte, a la patria con las armas en la mano. Lógicamente, esta nueva obligación tuvo grandes repercusiones en la vida diaria de la juventud y de sus familias: "La "cuestión de quintas" hizo correr ríos de tinta en los periódicos españoles de la época, ocupó sesiones parlamentarias, se convirtió en tema literario y actuó como elemento detonante de la protesta social" ${ }^{2}$.

\section{Historiografía y estado de la cuestión}

En las últimas décadas se han realizado importantes avances en lo que se refiere a la historiografía militar española, también la contemporánea, lejos ya de la pura erudición corporativa y de las narraciones de militares retirados, integrando la historia militar en un contexto global que tiene en cuenta las variables socioeconómicas y políticas del momento a la hora de explicar la evolución de la institución castrense. Sin embargo, y a pesar de las interesantes aportaciones de historiadores españoles y extranjeros a la historia del Ejército y los militares durante el siglo XIX, donde se pone de relieve social en el siglo XIX español, Madrid, Ministerio de Defensa, 1996, p. 216. 
la importancia histórica de la milicia armada como institución, su organización y la visión que al respecto tenía la opinión pública ${ }^{3}$, todavía queda un amplio campo por cubrir, tanto de hechos militares, batallas, técnicas y tácticas, como de sociología y legislación militar desde una perspectiva integradora, ya que la mayor parte de los trabajos referidos analizan el papel del Ejército en el diseño y

${ }^{3}$ SOTTO Y MONTES, J., "El reclutamiento militar en España", en Revista de Historia Militar, 16 (1964), Madrid, Instituto de Historia y Cultura militar; AZCÁRATE, P., La tradición liberal del Ejército español en el siglo XIX, Roma, Realidades, 1966; ALONSO BAQUER, M., El Ejército en la sociedad española, Madrid, Ediciones del Movimiento, 1971; ALONSO BAQUER, J.R., El modelo español de pronunciamiento, Madrid, Rialp, 1983; ALONSO, J.R., Historia política del Ejército español, Madrid, Ediciones del Movimiento, 1974; CHRISTIANSEN, C., Los orígenes del poder militar en España, 1800-1854, Madrid, Aguilar, 1974; PÉREZ GARZÓN, S., Milicia Nacional y revolución burguesa, Madrid, CSIC, 1978; HEADRICK, D. R., Ejército y política en España (1866-1898), Madrid, Tecnos, 1981; PAYNE, S. G., Los militares y la política en la España contemporánea, Ruedo Ibérico, 1976; PAYNE, S. G., Ejército y sociedad en la España liberal (1808-1936), Madrid, Akal, 1977; FERNÁNDEZ BASTARRECHE, F., El Ejército español en el siglo XIX, Madrid, Siglo XXI de España Editores, 1978; FERNÁNDEZ BASTARRECHE, F., "El servicio militar en la España del siglo XIX. Una epidemia de los tiempos contemporáneos", Historia 16, 140 (1987), Madrid; CARDONA, G., El poder militar en la España contemporánea hasta la guerra civil, Madrid, Siglo XXI de España Editores, 1983; CORONA BARATECH, C., "Las milicias Provinciales del siglo XVIII como Ejército peninsular de reserva", (1983), Madrid, Servicio de Publicaciones del EME; CARDONA, G., El problema militar en España, Madrid, Historia 16, 1990; SECO SERRANO, C., Militarismo y civilismo en la España contemporánea, Madrid, Instituto de Estudios Económicos, 1984; BUSQUETS BRAGULAT, J., El militar de carrera en España, Barcelona, Ariel, 1984; BALLBÉ, M., Orden público y militarismo en la España constitucional (1812-1983), Madrid, Alianza, 1985; VVAA, Las Fuerzas Armadas Españolas. Historia Institucional y Social, Madrid, Alhambra, 1986, LLEIXÁ, J., Cien años de militarismo en España: funciones estatales confiadas al Ejército en la Restauración y el franquismo, Barcelona, Anagrama, 1986; MAS CHAO, A., La evolución de la conciencia africanista en el Ejército español, Madrid, SGE, 1988; BACHOUD, A., Los españoles ante las campañas de Marruecos, Madrid, Espasa-Calpe, 1988 BLANCO VALDÉS, R. L., Rey, Cortes y fuerza armada en los orígenes de la España liberal, 1808-1823, México, Siglo XXI, 1988; CEPEDA GÓMEZ, J., El Ejército español en la política española (1787-1843), conspiraciones y pronunciamientos en los comienzos de la España liberal, Madrid, Fundación Universitaria Española, 1990; ALBI, J., Banderas olvidadas: el Ejército realista en América, Madrid, Ediciones de Cultura Hispánica, 1990; NUÑEZ FLORENCIO, R., El antimilitarismo en el pensamiento político español en torno al desastre (1891-1906), Madrid, Universidad Autónoma de Madrid, 1989; NUÑEZ FLORENCIO, R., Militarismo y antimilitarismo en España (1888-1896), Madrid, CSIC, 1990; NUÑEZ FLORENCIO, R., "Militares y política militar en la España de la Restauración", Bulletin d'histoire contemporaine de l'Espagne, 16 (1992), Talence, Maison des Pays Iberiques; NUÑEZ FLORENCIO, R., El Ejército español en el Desastre de 1898, Madrid, Arco Libros, 1997; PUELL DE LA VILLA, F., Historia del Ejército en España, Madrid, Alianza, 2005; VVAA, Aproximación a la historia militar de España, Madrid, Ministerio de Defensa, 2006. 
transformación del Estado y su vinculación con las élites políticas y económicas del país, dejando de lado otros apartados de interés:

"La Historia Militar es un apartado más de la Historia, y sus causas, consecuencias y conclusiones han de integrarse en el devenir histórico general de una época o de un espacio geográfico [...]. Una excesiva compartimentación y especialización puede aportar datos de gran valor para reconstruir un apartado más de la historia, pero suele empujar a los historiadores a interpretaciones personales, protectoras y magnificadoras del hecho objeto de la investigación, provocando el cuestionamiento de juicios de valor admitidos por la generalidad, pero que desde una óptica tan próxima se distorsionan y engañan al observador ${ }^{\prime 4}$.

Es más, la mayor parte de las investigaciones realizadas hasta nuestros días inciden en el papel que, como agente político, ha tenido el Ejército y el militarismo en la historia de España. La importancia, presencia y condicionalidad que, sobre la historia española contemporánea, ha tenido el Ejército como institución pero también para la realidad diaria en la vida de la ciudadanía, obliga a un acercamiento al mismo desde múltiples perspectivas: legislativo, sociológico e institucional, además del tradicional sobre técnicas y acontecimientos bélicos. Se debe por tanto integrar la historia militar en el devenir histórico global del país, y en este sentido se han dado importantes pasos, si bien son numerosos los aspectos todavía poco estudiados sobre la presencia del Ejército en la realidad española contemporánea.

Desde la perspectiva de la Historia del Derecho se ha realizado una significativa contribución en los últimos años, en particular en lo relativo al impacto institucional de las cuestiones bélicas y de la

\footnotetext{
${ }^{4}$ FEIJÓo GÓMEZ, A., Quintas y protesta social en el siglo XIX español, pp. 21 y 22.
} 
relación entre el Ejército y la Armada y las diferentes ramas de la administración hispánica 5 .

Si nos centramos propiamente en el reclutamiento, la sociología militar y el debate político que éste originó, también se han producido interesantes aportaciones en los últimos años, si bien reducidas, tanto para los años modernos como para la centuria decimonónica, desde una perspectiva tanto nacional como local. Existen algunas obras generales para el reclutamiento, o que hacen referencia al mismo, a lo largo de la historia de España desde la Antigüedad hasta nuestros días, normalmente dirigidas a un público no especializado. En este sentido podemos destacar el ya superado y somero artículo del militar Sotto y Montes y el más reciente de Crespo-Francés y Valero ${ }^{6}$.

Si nos introducimos primero en la época moderna, sin duda han sido dos autores los que más han trabajado las cuestiones del

\footnotetext{
${ }^{5}$ En este sentido son de singular relieve las aportaciones realizadas a través de los estudios colectivos coordinados por los profesores Martínez Peñas y Fernández Rodríguez, de la Universidad Rey Juan Carlos, en el ámbito de la Historia del Derecho, entre los que pueden citarse, desde la perspectiva de la historia del Derecho y las instituciones: MARTÍNEZ PEÑAS, L., GRANDA, S., y FERNÁNDEZ RODRÍGUEZ, M. (coords.), Perspectivas jurídicas e institucionales sobre guerra $y$ Ejército en la Monarquía Hispánica, Madrid, Dyckinson, 2011; MARTÍNEZ PEÑAS, L. y FERNÁNDEZ RODRÍGUEZ, M. (coords.), Reflexiones sobre poder, guerra y religión en la Historia de España, Madrid, Universidad Rey Juan Carlos, 2011; MARTÍNEZ PEÑAS, L., y FERNÁNDEZ RODRÍGUEZ, M. (coords.), El Ejército y la Armada en el Noroeste de América: Nootka y otras cuestiones, Madrid, Dirección General de Relaciones Institucionales del Ministerio de Defensa, 2011; MARTÍNEZ PEÑAS, L. y FERNÁNDEZ RODRÍGUEZ, M. (coords.), De las Navas de Tolosa a la Constitución de Cádiz: el ejército y la guerra en la construcción del Estado, Valladolid, Universidad Rey Juan Carlos, 2012; MARTÍNEZ PEÑAS, L., BRAVO DÍAZ, D., y FERNÁNDEZ RODRÍGUEZ, M. (coords.), La presencia española en África: del fecho de allende a la crisis de Perejil, Valladolid, Asociación Veritas, 2012; MARTÍNEZ PEÑAS, L., y FERNÁNDEZ RODRÍGUEZ, M. (coords.), Amenazas y orden público: efectos y respuestas, de los Reyes Católicos al Afganistán contemporáneo, Valladolid, Asociación Veritas, 2013. Su último trabajo al respecto, MARTÍNEZ PEÑAS L. y FERNÁNDEZ RODRÍGUEZ, M., La guerra y el nacimiento del Estado Moderno, Madrid, Asociación Veritas, 2014, es una monografía que ofrece una visión de conjunto y transversal del impacto de la guerra y las instituciones militares en los siglos XV y comienzos del XVI.

${ }^{6}$ SOTTO Y MONTES, J., "El reclutamiento militar en España", Revista de Historia Militar 16 (1964), Madrid, Instituto de Historia y Cultura Militar; CRESPO-FRANCÉS Y VALERO, J. A., A las armas: Reclutamiento y servicio militar en España desde sus orígenes hasta nuestros días, Madrid, Multimedia Militar, 2009.
} 
reclutamiento. Nos referimos a los profesores Enrique Martínez Ruiz y Cristina Borreguero Beltrán.

Del primero destaca su magna obra Los soldados del rey: los Ejércitos de la monarquía hispánica (1480-1700), la más importante investigación realizada hasta la fecha sobre los Ejércitos de la Monarquía Hispánica en sus años de mayor esplendor, donde se analiza la defensa interior del Reino y las acciones armadas exteriores de los Habsburgo, además de los sistemas existentes para nutrir de reclutas al Ejército. Esta muy destacada investigación se ha visto acompañada de numerosos artículos relacionados con el reclutamiento y el fenómeno de los prófugos entre los siglos XV y XIX

Respecto a la profesora Borreguero Beltrán, además de su tesis doctoral convertida en publicación y centrada en el reemplazo por quintas en España durante el siglo XVIII desde una perspectiva jurídica y social, tenemos numerosos artículos relacionados con la temática que abarcan desde los motines de quintas hasta la lucha contra el prófugo ${ }^{8}$.

\footnotetext{
7 Entre las obras del profesor Martínez Ruiz, destacamos: MARTÍNEZ RUIZ, E., Los soldados del rey: los Ejércitos de la monarquía hispánica (1480-1700), San Sebastián de los Reyes, Actas, 2008; MARTÍNEZ RUIZ, E., "Desertores y prófugos en la primera mitad del siglo XIX", Hispania, 107 (1967), Madrid, Consejo Superior de Investigaciones Científicas; MARTÍNEZ RUIZ, E., "Reclutamiento y reemplazo en los orígenes de la Guardia Civil", Revista de Estudios Históricos de la Guardia Civil, Madrid, Ministerio de Defensa, 11 y 12 (1973); MARTÍNEZ RUIZ, E., "Algunas disposiciones sobre el reclutamiento de marinos a finales del siglo XVIII", Chrónica Nova, Granada, Universidad de Granada, 13 (1982); MARTÍNEZ RUIZ, E.; "Le recrutement militarire espagnol au XIXe siécle", Les cahiers de Montpellier, no 21, t. I, 1990; MARTÍNEZ RUIZ, E., "La celebración de quintas, una cadencia temporal en la España del Antiguo Régimen", Revista de Historia Moderna, 11 (1992), Alicante, Universidad de Alicante; MARTÍNEZ RUIZ, E., "El reclutamiento militar y sus implicaciones sociales en el marco de la Constitución de 1845", Revista de Derecho Político, 39 (1994), Madrid, UNED; MARTÍNEZ RUIZ, E., "Condiciones básicas del reclutamiento militar en España", MARTÍNEZ RUÍZ, E., PAZZIS PI CORRALES, M. y TORREJÓN CHAVES, J. (coords.), Los Ejércitos y las armadas de España y Suecia en una época de cambios (1750-1870), Puertollano, Fundación Berndt Wistedt, 2001.

8 BORREGUERO BELTRÁN, C., Reclutamiento militar por quintas en la España del siglo XVIII: orígenes del servicio militar obligatorio, Valladolid, Universidad de Valladolid, 1989; BORREGUERO BELTRÁN, C., "Administración y reclutamiento
} 
Para los tiempos modernos podemos destacar además varias publicaciones que optan por un somero análisis del reemplazo a escala nacional, o se centran en la oficialidad más que en el soldado raso, o bien descienden a un nivel local o se ciñen a un cuerpo armado particular para su análisis social ${ }^{9}$.

Al introducirnos en la conscripción durante el siglo XIX, sin duda debemos destacar dos importantes obras que han constituido una referencia para nuestra investigación. La primera es la tesis doctoral de Albino Feijóo, posteriormente convertida en publicación ${ }^{10}$, que intenta abarcar, de una forma exitosa, casi todos los aspectos relacionados con el reclutamiento durante el siglo XIX. Sin embargo, esta amplitud de miras lleva al autor a un somero análisis de las distintas temáticas relacionadas con el reemplazo: antecedentes históricos, visión de la prensa, debates parlamentarios, evolución jurídica, enfoques políticos y de tratadistas militares, condiciones de

militar en el Ejército borbónico del siglo XVIII", Cuadernos de investigación histórica, 12 (1989), Valladolid, Universidad de Valladolid; BORREGUERO BELTRÁN, C., "Los motines de quintas", Cuadernos de Historia Moderna, 10 (1989-1990), Madrid, Universidad Complutense de Madrid; BORREGUERO BELTRÁN, C., "Extranjeros al servicio del Ejército español del siglo XVIII", Coloquio Internacional Carlos III y su Siglo, Vol. 2, Poder y sociedad en la época de Carlos III, Madrid, Universidad Complutense de Madrid, 1990; BORREGUERO BELTRÁN, C., "Del Tercio al Regimiento" Estudis: Revista de historia moderna, 27 (2001), Valencia, Universidad de Valencia; BORREGUERO BELTRÁN, C., "El impacto social del reclutamiento y de otros impuestos militares en el siglo XVIII", MARTÍNEZ RUÍZ, E., PAZZIS PI CORRALES, M., TORREJÓN CHAVES, J. (coords.), Los Ejércitos y las armadas de España y Suecia en una época de cambios (1750-1870), Puertollano, Fundación Berndt Wistedt, 2001; BORREGUERO BELTRÁN, C.: "El soldado en el nuevo modelo de Ejército", FRIEYRO LARA, B. (coord.), Guerra, Ejército y sociedad en el nacimiento de la España contemporánea, Granada, Universidad de Granada, 2009.

9 CONTRERAS GAY, J., "Aproximación al estudio de los sistemas de reclutamiento en la España moderna", Anuario de Historia Contemporánea, 8 (1981), Granada, Universidad de Granada; CALVO POYATO, J., "Medio siglo de levas, reclutas y movilizaciones en el Reino de Córdoba: 1657-1712", Axerquia, 3 (1983), Córdoba, Diputación Provincial de Córdoba; MONTORO OBRERO, G., "Las clases de tropa en las ordenanzas militares en los siglos XVII y XVIII", en Revista de Historia Militar, no 66 (1989), Madrid; ANDÚJAR CASTILLO, F., Los militares en la España del siglo XVIII: un estudio social, Granada, Universidad de Granada, 1991; RIBOT GARCIAA, L.A., "El reclutamiento militar en España a mediados del siglo XVII. La "composición" de las milicias de Castilla", Cuadernos de Investigación Histórica, 9 (1986), Madrid, Fundación Universitaria Española.

${ }^{10}$ FEIJÓO GÓMEZ, A., Quintas y protesta social en el siglo XIX español. 
vida, higiénicas y sanitarias de los soldados, oposición violenta y no violenta al reclutamiento y motivos del rechazo popular al mismo, así como un análisis de las sociedades de seguros para las quintas y del Fondo de Redenciones y Enganches Militares.

La segunda investigación, también de gran ayuda para nuestro estudio, es el libro del militar Puell de la Villa El soldado desconocido ${ }^{11}$. En ella abarca multitud de temas relacionados con el Ejército entre 1700 y 1912, desde las condiciones de vida del soldado, su origen social, formación, sueldo, alimentación, vestuario, instrucción y disciplina, pasando por las unidades destinadas a Ultramar y la evolución en el concepto de soldado y los modelos de reclutamiento, poniendo en relación los hechos históricos acaecidos precisamente con estos cambios en los modelos de ingreso de efectivos en la institución castrense. De este mismo autor contamos con un análisis más profundo sobre la Ordenanza de reemplazo anual de 1770 y sobre el reclutamiento durante la Guerra de Independencia española ${ }^{12}$.

Además de estos dos estudios, disponemos de otras investigaciones, más limitadas en profundidad y extensión, que abarcan temáticas relacionadas con la conscripción a escala nacional. Así, podemos destacar los trabajos, centrados especialmente en el fenómeno de la redención, sus injusticias y sus implicaciones sociales durante el siglo XIX, así como las propuestas de reforma, de la profesora Valentina Fernández Vargas $^{13}$ y de los profesores

\footnotetext{
11 PUELL DE LA VILLA, F., El soldado desconocido: de la leva a la "mili" (17001912), Madrid, Biblioteca Nueva, 1996.

12 PUELL DE LA VILLA, F., "La ordenanza del reemplazo anual de 1770", Hispania, 189 (1995), Madrid, CSIC; PUELL DE LA VILLA, F., "EL reclutamiento y la movilización", La Guerra de la Independencia Española: Una visión militar. Actas del VI Congreso de Historia Militar, Madrid, Ministerio de Defensa, 2009.

13 FERNÁNDEZ VARGAS, V., "El servicio militar en el siglo XIX. Una percepción social", FERNÁNDEZ ALBADALEJO, P. y ORTEGA LÓPEZ, M., (eds.), Antiguo régimen y liberalismo: homenaje a Miguel Artola, Política y cultura, vol. 3; Madrid, Alianza, 1995; FERNÁNEZ VARGAS, V., Sangre o dinero: el mito del Ejército nacional, Madrid, Alianza, 2004.
} 
Fernández Rodríguez y Martínez Peñas ${ }^{14}$; el acercamiento de Castellano Gil a los orígenes del servicio ${ }^{15}$, y los estudios de Nuria Sales de Bohígas, una de las primeras en introducirse con seriedad en esta temática ya en los años 70 y 80 para los ámbitos americano, catalán y español, y que ha analizado aspectos como la utilización de esclavos y vagos para nutrir a los ejércitos emancipadores de las Indias, el rechazo social a las quintas, las injusticias del sistema, las sustituciones y exenciones, la literatura relacionada con estos aspectos, comparando además los casos francés y español, la aparición y quiebra de las sociedades de seguros contra quintas en los años previos a la Gloriosa, así como el servicio militar y sus desigualdades a lo largo del siglo $\mathrm{XIX}^{16}$.

Respecto a los medios para nutrir las fuerzas armadas durante la Guerra de Independencia y los primeros años del liberalismo decimonónico, podemos destacar las investigaciones de Casado Burbano y su análisis jurídico entre 1812 y $1823^{17}$, y de Consuelo Maqueda sobre la conscripción durante el reinado de Fernando VII ${ }^{18}$. También contamos con estudios esporádicos para otros márgenes temporales, especialmente para el Sexenio Revolucionario y el

\footnotetext{
${ }^{14}$ FERNÁNDEZ RODRÍGUEZ, M. y MARTÍNEZ PEÑAS, L., "Problemática social en la legislación de reclutamiento decimonónica: exenciones, sustitución y redención", en VVAA, Luces y sombras de la seguridad, Instituto Universitario General Gutiérrez Mellado, Madrid, 2010.

15 HERRERO BRASAS, J. A., Informe crítico sobre el servicio militar, Madrid, Ars Media, 1989.

${ }^{16}$ SALES DE BOHÍGAS, N., "Servei militar i societat a L'Espanya del segle XIX", La formación de la Catalunya moderna, Barcelona, Ariel, 1970; SALES DE BOHÍGAS, N., "Servei militar i societat a l'Espanya del segle XIX", Recerques, 1 (1970), Barcelona; SALES DE BOHÍGAS, N., "Esclavos y reclutas en las guerras de independencia de Sudamérica, 1816-1826", Revista de Historia de América, 69 (1970), México; SALES DE BOHÍGAS, N., Sobre esclavos, reclutas y mercaderes de quintos, Esplugues de Llobregat (Barcelona), Ariel, 1974; SALES DE BOHÍGAS, N., "Sociedades de seguros contra quintas", en LIDA, C. E. y ZAVALA, I. M. (comps.), La revolución de 1868: historia, pensamiento, literatura, New York, Las Américas publishing, 1970; "Servei militar i societat: la desigualtat enfront del servei militar, seagles XVIII-XIX", L'Avenç, 98 (1986).

17 CASADO BURBANO, P., Las fuerzas armadas en el inicio del constitucionalismo español, Madrid, Editoriales de Derecho Reunidas, 1982.

18 MAQUEDA ABREU, C., "La Restauración de Fernando VII y el reclutamiento militar", Revista de Historia Militar, 62 (1987), Madrid, Servicio Histórico Militar.
} 
rechazo popular a las quintas ${ }^{19}$, así como para la Guerra de Cuba y los prófugos y desertores del Ejército que originó el conflicto ${ }^{20}$. Para los años posteriores a 1912 y previos a la guerra civil, incluyendo las reformas azañistas, es necesario acudir a la obra de García Moreno ${ }^{21}$. Y desde una perspectiva enormemente crítica hacia el servicio obligatorio en sus últimos años de existencia, pero también con algunas referencias históricas al pasado de la conscripción, destacar la obra de Herrero Brasas ${ }^{22}$.

Para finalizar este repaso bibliográfico, debemos detenernos en los análisis de tipo local o regional, con distintas secuencias temporales, que se han realizado hasta la fecha sobre el tema del reclutamiento. Su interés reside principalmente en haber descendido a cifras concretas para evaluar el impacto socioeconómico del reemplazo en lugares como Extremadura, Asturias, Galicia, La Laguna (Tenerife), Navarra, Lleida, La Rioja, Málaga, Granada y Murcia ${ }^{23}$.

19 FERNÁNEZ BASTARRECHE, F., "La cuestión de las quintas en el Sexenio Revolucionario", Revista de Historia Militar, 43 (1977), Madrid, Servicio Histórico Militar; FERNÁNDEZ MUÑIZ, A.M., "Las quintas. Sistema de reclutamiento: explotación para unos, negocio para otros (1868-1898), Estudios de Historia Social 1-4 (44-47), 1988, Ministerio de Trabajo y Seguridad Social, Madrid.

20 SECO SERRANO, C., "Prófugos y desertores en la Guerra de Cuba", Estudios de Historia Social, 22-23 (1982), Madrid, Ministerio de Trabajo y Seguridad Social.

${ }^{21}$ GARCÍA MORENO, J.F., Servicio militar en España (1913-1935), Madrid, Adalid, Servicio de Publicaciones del Estado Mayor del Ejército, 1988.

22 HERRERO BRASAS, J. A., iRompan filas! La cara oculta del servicio a la patria, Madrid, Temas de Hoy, 1995.

23 GUTIÉRREZ MACÍAS, V., Las quintas y la tradición extremeña, Badajoz, Diputación Provincial de Badajoz, 1983; MORO BARREÑADA, J.M., "La "contribución de sangre" en Asturias: servicio militar, traficantes y sustitutos de quintas", Astura, 1 (1984), Oviedo, Museo de Bellas Artes de Asturias; GONZÁLEZ ASENJO, A. J., "La resistencia al servicio militar en Galicia", Estudios de Historia Social, 34-35 (1985), Madrid, Ministerio de Trabajo y Seguridad Social; CASTELLANO GIL, J. M., Quintas, prófugos y emigración: La Laguna (1886-1935), Tenerife, Centro de la Cultura Popular Canaria, 1990; ESPARZA ZABALEGUI, J.M., Abajo las quintas: oposición histórica navarra al Ejército español, Tafalla, 1994; MOLINA LUQUE, J. F., Quintas y servicio militar: aspectos sociológicos y antropológicos de la conscripción (Lleida, 1878-1960), Lleida, Server de Publicacions de la Universitat de Lleida, 1998; FRIEYRO DE LARA, B., El reclutamiento militar en la crisis de la Restauración: el caso riojano (1896-1923), Logroño, Instituto de Estudios Riojanos, 2000; JIMÉNEZ GUERRERO, J., El reclutamiento militar en el siglo XIX: las quintas en Málaga (1837-1868), Málaga, Universidad de Málaga, 2001; FRIEYRO DE LARA, B., De campesino a soldado. Las quintas en Granada (1868-1898), Granada, Universidad de Granada, 2002; GARCÍA GARCÍA, A., y SEMPERE DOMENECH, M., "Conflicto y 


\section{Objetivos}

Después de haber identificado las principales lagunas en la historiografía del reclutamiento en el siglo XIX, creemos que restan dos huecos importantes. Por eso, los objetivos planteados en la presente investigación son dos muy concretos: por una parte, analizar y valorar la evolución en materia legislativa del proceso de reclutamiento en España a lo largo del siglo XIX y hasta 1912 y, por otra, examinar y estudiar las implicaciones políticas que, especialmente en sede parlamentaria, tuvieron la aprobación y puesta en práctica de las distintas leyes que se fueron implantando por parte de las Cortes Generales.

Era por tanto necesario un amplio análisis legislativo sobre el reclutamiento y sus implicaciones políticas durante el siglo XIX para permitir un mejor conocimiento sobre la institución armada. Tales implicaciones políticas tratarán asimismo de ser estudiadas acudiendo a la prensa española del momento. Para ello analizaremos, en los momentos del debate parlamentario de cada una de las leyes, dos publicaciones de importancia en ese momento histórico que hemos seleccionado entre la enorme colección de publicaciones periódicas de la que disponemos ${ }^{24}$. Dichos periódicos nos permitirán recoger la distinta perspectiva que, respecto al reclutamiento, tenían las mismas al estar ubicadas en distinto espectro ideológico, muchas veces incluso contrario, que nos permitan así señalar su posición/postura ante las novedades planteadas, sus propuestas al respecto y la problemática social que el reemplazo planteaba a sus lectores.

quintas. Resistencia al servicio militar obligatorio: exenciones, exclusiones, redenciones y sustituciones en la Murcia del siglo XIX", en La era Isabelina y la revolución 1843 - 1875: Actas de las XIII Jornadas Nacionales de Historia Militar, Sevilla, Cátedra General Castaños, 2009, pp. 337-356.

${ }^{24}$ Para conocer la evolución de la prensa en España durante los últimos cuatro siglos, ver SEOANE M. C. y SANZ. D., Cuatro siglos de periodismo en España. De los avisos a los periódicos digitales, Madrid, Alianza Editorial, 2007. 
Se trataría por tanto de integrar la historia del Ejército español, tan presente en nuestra contemporaneidad, con la realidad del conjunto de la masa de soldados, más allá de la oficialidad, para conocer qué normas y cómo se les obligaba a pagar la contribución de sangre y qué debate político originaron las mismas ante el impacto que el reclutamiento tenía sobre el conjunto de la población.

El servicio militar obligatorio surgió en Europa al calor de la Revolución Francesa y el expansionismo napoleónico como forma de nutrir unos ejércitos encargados de defender no ya un reino formado por súbditos del rey, sino una nación compuesta por ciudadanos en un contexto de guerra globalizada. En España, asistimos a lo largo del siglo XIX y ya desde el inicio de la Guerra de Independencia, a la progresiva implementación de un sistema basado en el servicio universal obligatorio a través de un sorteo y con importantes exenciones y con figuras tan polémicas como la sustitución y la redención en metálico, situaciones éstas no exentas de discusión política en el seno del debate parlamentario y origen de numerosas protestas populares entre aquellos que, por sus medios económicos, se veían incapaces de acogerse a ellas ${ }^{25}$. A ello se unía que, a pesar de la supuesta universalidad del servicio, no todos los jóvenes acudían al mismo, sino que dependía de un complejo proceso que culminaba en un sorteo que establecía qué mozos debían ingresar en filas.

Estas desigualdades, y el hecho de que el peso de la prestación recayese siempre en los más humildes, fue origen y justificación, además de numerosas protestas y movimientos sociales, de todo tipo de iniciativas, tanto legales (sustitución, redención y cuotas) como

\footnotetext{
25 "Incluso después de 1912, y hasta las leyes republicanas, aunque el servicio era "personal e intransferible" y teóricamente igualitario para todos los ciudadanos, existió la posibilidad de las cuotas militares que permitían "dulcificar" (a los que quisieran y pudieran pagarlas) la prestación del servicio militar" (MOLINA LUQUE, J. F., Quintas y servicio militar: aspectos sociológicos y antropológicos de la conscripción (Lleida, 1878-1960), Servei de Publicacions, Universitat de Lleida, 1998, p. 5).
} 
ilegales (prófugos, mutilados, desertores) para evitar o aminorar el peso del servicio, actuaciones éstas que chocaban con la versión oficial y militar que defendía la obligación que tenían todos los españoles de defender, hasta la última gota de sangre, a la patria con las armas en la mano:

"Las elevadas proporciones de jóvenes que esquivaban el servicio militar, la antipatía popular hacia el sistema de quintas (reflejado en refranes populares al estilo de "Hijo quinto sorteado, hijo muerto y no enterrado" o "Quintado mareado, piel y huesos sorteados") y los conflictos sociales originados en la contestación popular a la conscripción (ante la Guerra de Cuba, la Semana Trágica o la Guerra de Marruecos, por ejemplo) nos muestran cómo ese discurso militar no tan sólo no había sido recibido por la población, sino que el impacto de la conscripción militar obligatoria podía calificarse de doloroso y desconcertante"126.

El establecimiento de un ejército nacional basado en la conscripción obligatoria tuvo lógicamente unos efectos enormes para la sociedad que la sufrió. La dureza del servicio, su larga duración, las condiciones infrahumanas en las que en muchas ocasiones vivía el soldado, las elevadas tasas de enfermedad y mortalidad, la posibilidad de ser destinado a lugares lejanos de los que, en muchas ocasiones, nunca se volvía, las injusticias en cuanto su cumplimiento, la realidad de que parte de la gente joven más preparada perdiese sus años laboralmente más eficaces en el cumplimiento de este deber, y la amarga realidad para unas padres muchas veces convencidos de no ver regresar a un descendiente fundamental para su manutención ${ }^{27}$, generaron una imagen, pero también una realidad, enormemente negativa, lógica teniendo en cuenta su impacto en la

26 MOLINA LUQUE, J. F., Quintas y servicio militar: aspectos sociológicos y antropológicos de la conscripción (Lleida, 1878-1960), p. 5.

27 Sobre las condiciones de vida del soldado ver HEADRICK, D. R., Ejército y política en España (1866-1898), pp. 107-110. 
sociedad española de los siglos XIX y XX. A ello se une que fueron las clases populares, en España fundamentalmente campesinas, las que más sufrieron el peso del reclutamiento al carecer de los medios económicos que otros grupos sociales podían destinar para evitar el servicio: "Para el campesinado, el servicio militar representó una violencia difícil de captar a los ojos contemporáneos" ${ }^{28}$. De ahí la aparición de diversas estrategias, legales e ilegales, que tenían como objetivo eludir el servicio, y el ahorro durante años por parte de las familias para evitar la marcha de un hijo y asegurar su futuro a través de la sustitución y la redención. El impacto que tenía el servicio militar entre los jóvenes y sus familias tenía su manifestación lúdica en las fiestas de quintos, rituales pero también protestas contra el servicio, y de cuyo recuerdo nos quedan hoy en día, con un sentido muy distinto, las fiestas de quintos en muchos pueblos españoles.

Marco histórico y desarrollo de la investigación

El marco cronológico en el que hemos acotado nuestro estudio se establece en dos fechas muy concretas: 1800, año de la aprobación de una ordenanza sobre el reemplazo de gran importancia para el primer tercio del siglo XIX; y 1912, cuando una nueva ley, aprobada por el Gobierno de Canalejas, vino a suprimir definitivamente la redención y la sustitución e implantó el servicio militar obligatorio para toda la población sin posibilidad de exención económica.

Hemos iniciado nuestro estudio con un estado de la cuestión sobre los análisis que actualmente existen en España acerca del servicio militar, su evolución y su impacto social.

28 MOLINA LUQUE, J. F., Quintas y servicio militar: aspectos sociológicos y antropológicos de la conscripción (Lleida, 1878-1960), p. 6. 
Ahora nos introduciremos en el grueso del estudio al analizar, de forma conjunta, los aspectos jurídicos y políticos que vinieron a desarrollar y condicionar la práctica del reclutamiento. Realizaremos para ello un intenso examen de las distintas leyes que se fueron aprobando desde 1800, sin olvidar los precedentes de los siglos anteriores, y los cambios que las mismas fueron introduciendo, lo que nos permitirá obtener conclusiones desde una doble perspectiva: aspectos ideológico-políticos de aquellos que aprobaron las distintas normas; y la aplicación práctica de todo el proceso de reclutamiento en sus distintas fases, desde el alistamiento hasta el ingreso en filas. Su incidencia y efectos sociales, así como las distintas visiones ideológicas de la conscripción, serán recogidas, además de analizando los debates parlamentarios, a través del estudio de distintas publicaciones periódicas que, con el paso de los años, muestren una visión distinta, cuando no contraria, de todo el proceso de reclutamiento.

El estudio se ha estructurado en función de las nueve grandes leyes de reclutamiento y reemplazo que, desde 1800 y hasta 1912, se fueron aprobando en las Cortes. Todas ellas tienen una estructura bastante similar, con excepciones, como señalaremos en su momento, y con cambios en el orden de sus principales capítulos e incluso ausencia de alguno de ellos, por lo que hemos estructurado su análisis en los siguientes puntos:

1. Contexto histórico

2. Desarrollo de la norma

- Disposiciones generales

- La elaboración del padrón de vecinos

- El alistamiento

- Clasificación y declaración de los soldados

- La distribución del contingente 
- Conducción e ingreso de los reclutas en caja

- Reclamaciones

- Exenciones

- La lucha contra el prófugo

- La sustitución y la redención en metálico

- Disposiciones penales

3. Añadidos a la norma

- El reglamento de exenciones físicas (en el caso de haberse aprobado uno nuevo)

En cuanto a las hipótesis de trabajo planteadas a la hora de abordar el presente trabajo de investigación, podemos enumerar las siguientes:

a) La legislación sobre reclutamiento militar a lo largo del siglo XIX conformó un cuerpo legislativo de gran importancia en la vida política y social de la España de su tiempo.

b) La implicación de los poderes constitucionales en el proceso legislativo sobre reclutamiento militar se realizó al máximo nivel, en las Cortes y directamente en el poder ejecutivo a través de los decretos del gobierno.

c) El proceso de reclutamiento fijado en la legislación afectaba verticalmente a todos los niveles de la administración y de las instituciones: gobierno de la nación, diputaciones provinciales, municipios.

d) El proceso de reclutamiento fijado en la legislación afectaba horizontalmente a los principales ejes institucionales del Estado: los poderes políticos, judiciales, militares e incluso eclesiásticos.

e) El desarrollo de la legislación sobre reclutamiento militar no fue un proceso sistemático unidireccional, sino que estuvo 
condicionado por los avatares políticos de la España de su tiempo, de forma que con frecuencia una ley contradecía o desandaba los preceptos y los planteamientos de sus predecesoras.

f) Pese a lo anterior, existen unos ejes evolutivos generales que parecen trazar unas líneas de avance que van consolidándose con el tiempo, como el rechazo a los privilegios de clase o la paulatina supresión de figuras como la redención en metálico.

g) La preocupación social sobre el reclutamiento y el rechazo de amplias capas de la población hacia el mismo o, cuando menos, hacia la legislación que lo regulaba, tiene su reflejo en los debates políticos y en la toma de posición al respecto por los diferentes grupos políticos.

Por último, finalizaremos nuestro trabajo con unas conclusiones globales que nos permitan ofrecer una amplia perspectiva sobre la evolución legislativa y política del servicio militar a lo largo del siglo XIX, que nos permita conocer cómo se fue transformando el proceso con el paso de los años y las visiones que los distintos partidos e ideologías políticas fueron teniendo respecto a la contribución de sangre. También reflejaremos en este apartado el cumplimiento o la variación de las hipótesis de trabajo que nos planteamos en este estudio.

\section{Fuentes utilizadas}

En lo que se refiere a las fuentes empleadas, además por supuesto de las bibliográficas, hemos acudido principalmente a tres fuentes de archivo:

1. Los debates en Cortes recogidos en los diarios de sesiones, fundamentalmente del Congreso de los Diputados pero también del Senado, donde los distintos diputados y senadores, en representación de un determinado partido, ofrecían sus visiones 
políticas y opiniones ideológicas sobre el reclutamiento, en especial durante los meses de discusión de un nuevo texto legislativo.

2. Las distintas leyes, decretos, normas, reglamentos, órdenes, ordenanzas, disposiciones, etc. que, a nivel estatal, vinieron a regular y transformar el proceso de incorporación al servicio militar y que están publicadas en la Gaceta de Madrid y en distintas colecciones legislativas, boletines, anuarios, gacetas, etc. que fueron apareciendo para recopilar la legislación referente a esta temática. Su dispersión, diversidad y las dificultades para ser encontradas en los diversos centros documentales y archivísticos han venido a complejizar el trabajo de archivo.

3. Para el caso de las publicaciones periódicas, hemos realizado una selección de dos periódicos de especial relevancia en los momentos de debate en Cortes de las distintas leyes. Para ello hemos tenido en cuenta su interés histórico y su ubicación en un espectro ideológico distinto, cuando no contrario, para poder así analizar su perspectiva e ideas principales respecto a la cuestión del reclutamiento y las soluciones que planteaban. Debemos tener en cuenta que, hasta mediados del siglo XIX, apenas existen artículos periodísticos que se centren exclusivamente en la cuestión del reclutamiento, limitándose en muchas ocasiones a reflejar los discursos de los diputados respecto a esta temática en los momentos de discusión de las distintas leyes. A partir de 1850, sin embargo, las referencias y el número de artículos referentes a esta cuestión se incrementa considerablemente, así como la profundidad en su análisis.

Hay que señalar también la imposibilidad de analizar la prensa decimonónica en su globalidad, pues en nuestro caso sería un objetivo inalcanzable. Es por esa razón por la que 
hemos realizado tal selección de publicaciones periódicas, con algunos de los ejemplos más significativos de la prensa conservada. Hemos acudido a diversas hemerotecas, tales como la Biblioteca Nacional, incluida su Hemeroteca Digital, o la Hemeroteca Municipal de Madrid, y consultado diversas direcciones web $^{29}$ para poder analizar los periódicos seleccionados.

Las publicaciones seleccionadas ${ }^{30}$, para el análisis de las distintas leyes, han sido las siguientes:

$\checkmark$ Legislación de las Cortes de Cádiz: El Conciso y el Censor General.

$\checkmark$ Legislación del Trienio Liberal: El espectador y El Censor. Ley de 1837: El Eco del comercio y El Español.

$\checkmark$ Proyecto de ley de 1850: El Clamor Público y La Época.

$\checkmark$ Ley de 1856: La Esperanza y La Soberanía Nacional.

$\checkmark$ Ley de 1870: El Combate y La Iberia.

$\checkmark$ Ley de 1873: La Época y La Discusión.

Ley de 1877: La Época y El Imparcial.

Ley de 1885: La Época y El Globo.

Ley de 1912: El Socialista y El Siglo Futuro.

\footnotetext{
${ }^{29}$ Para el caso de El Socialista, ver la dirección web http://archivo.fpabloiglesias.es/ ${ }^{30}$ Hemos tenido en cuenta las características señaladas en el libro SEOANE M. C. y SANZ. D., Cuatro siglos de periodismo en España. De los avisos a los periódicos digitales. Obviamos el análisis de publicaciones periódicas para la Ordenanza de 1800 ante la inexistencia de una mínima libertad de prensa que permita observar las posturas hacia la misma.
} 


\section{1.- Los precedentes del siglo XVIII: el mantenimiento de los sistemas medievales}

Como paso previo al análisis del reclutamiento en el periodo contemporáneo debemos realizar un somero repaso sobre los sistemas empleados durante el siglo XVIII para nutrir de tropas al Ejército, y así poder conocer la evolución que, en la centuria previa a la decimonónica, sufrieron los distintos sistemas encargados de encontrar efectivos para la Milicia. Hasta el siglo XVI, los mecanismos para el reclutamiento mantuvieron sus características medievales: los soldados reclutados y dirigidos por la nobleza, las milicias concejiles y los soldados mercenarios contratados por la Corona a cambio de un sueldo.

Tras los intentos de Cisneros a fines del siglo XV de consolidar un Ejército permanente que se impusiese a la heterogeneidad de milicias concejiles y ejércitos medievales, con Carlos $V$ y Felipe II se consolidaron los dos sistemas de reclutamiento clásicos de los años modernos para el Ejército de la Monarquía: el voluntariado a través de banderines de enganche, y la leva forzosa, método éste empleado en contadas ocasiones durante el siglo XVI por el malestar social que generaba ${ }^{31}$.

El siglo XVII fue "[...] un momento de transición o de inestabilidad en cuanto a las formas para nutrir las filas del Ejército real, pues aún restan muchos pasos que dar para institucionalizar el servicio militar en España como un deber medianamente aceptado por el ciudadano normal ${ }^{\prime 32}$. Los sistemas utilizados prácticamente no variaron con respecto a la centuria anterior: continuaron las movilizaciones de voluntarios, dependientes cada compañía de la

\footnotetext{
${ }^{31}$ CONTRERAS GAY, J., "Aproximación al estudio de los sistemas de reclutamiento en la España moderna", p. 8.

32 CONTRERAS GAY, J., "Aproximación al estudio de los sistemas de reclutamiento en la España moderna", p. 7.
} 
figura de un capitán ${ }^{33}$, encargado de preparar y reclutar a los miembros de su propia compañía, para ser destinados principalmente a Flandes e Italia. Esta tipología de reclutamiento, negocio para el asentista y garantía de soldados para la Corona ${ }^{34}$, también lo realizó la Monarquía de forma indirecta a través de asientos o contratos con personas cercanas a la Corona y con una importante influencia local debido a las limitaciones del sistema anterior y a la crisis demográfica castellana ${ }^{35}$, pero el sistema entraría en decadencia por los altos precios solicitados por los asentistas ${ }^{36}$. Este reclutamiento voluntario era la solución menos onerosa para los grupos populares, al afectar solamente a aquellos que, voluntariamente, buscasen en las armas una forma de vida, y además garantizaba unas tropas de mayor calidad y no repercutía en el día a día de pueblos y ciudades. A ello se sumaban otras motivaciones:

"Otros argumentos favorables al sistema es que no privaba a la agricultura de tantos brazos, y libraba a la sociedad de sus elementos más agresivos y antisociales. También en las áreas geográficas estranguladas a nivel económico y sin vías de desarrollo, o en los años difíciles, un Ejército profesional compuesto básicamente de mercenarios y de voluntarios podía ser la válvula de escape al problema del paro, absorbiendo una importante mano de obra excedente ${ }^{137}$.

33 Este sistema es denominado por el profesor Martínez Ruiz reclutamiento administrativo o de Comisión, MARTÍNEZ RUIZ, E., Los soldados del rey: los Ejércitos de la monarquía hispánica (1480-1700), pp. 900-904.

34 MARTÍNEZ RUIZ, E., Los soldados del rey: los Ejércitos de la monarquía hispánica (1480-1700), p. 907.

35 Esta tipología es denominada reclutamiento intermediario por Martínez Ruiz, MARTÍNEZ RUIZ, E., Los soldados del rey: los Ejércitos de la monarquía hispánica (1480-1700), pp. 904-905.

36 BORREGUERO BELTRÁN, C., Reclutamiento militar por quintas en la España del siglo XVIII: orígenes del servicio militar obligatorio, pp. 33-37.

37 CONTRERAS GAY, J., "Aproximación al estudio de los sistemas de reclutamiento en la España moderna", p. 19. 
Otro sistema de reclutamiento empleado durante el siglo XVII fueron las levas forzosas de vagabundos, presos y ociosos ${ }^{38}$, método éste utilizado en los momentos en que se necesitaban grandes contingentes militares para hacer frente a enemigos en el propio territorio español, es decir, su uso se extendió a partir del conflicto franco-español de 1635 y la crisis de 1640. Este era un medio que permitía, además de nutrir al Ejército de efectivos, reducir el número de marginados sociales que acudían a las ciudades en busca de mejor suerte y a quienes se les responsabilizaba en gran parte de la inseguridad y el malestar ciudadanos ${ }^{39}$. La cara opuesta estaba en la escasa calidad de los nuevos soldados forzosos, su inexperiencia y pasividad, con una actitud normalmente negativa hacia el servicio y en muchos casos dispuestos a una pronta deserción ${ }^{40}$ : "el soldado forzado tomaba las armas con desgana, su instrucción era deficiente y en conjunto su actuación inoperante" ${ }^{41}$.

Un tercer sistema que alcanzó una notable importancia durante las guerras del siglo XVII fueron los servicios de milicias, tropas populares voluntarias encargadas de defender su territorio de invasiones extranjeras ${ }^{42}$, especialmente en zonas fronterizas 0 conflictivas, y que se constituyeron como la reserva del Ejército en caso de necesidades bélicas en territorio peninsular. Por ello, en

38 BORREGUERO BELTRÁN, C., Reclutamiento militar por quintas en la España del siglo XVIII: orígenes del servicio militar obligatorio, pp. 37-38.

39 "Las levas de individuos marginales [...] contribuyeron a generalizar intensamente todas las facetas negativas de la milicia, pues la falta de espíritu militar y la práctica de actos abusivos y delictivos por los individuos movilizados por este procedimiento hicieron frecuente la estampa de hordas de soldados desarrapados e indisciplinados, entregados al robo y al juego, buscadores de amores fáciles y extorsionadores de las poblaciones donde se alojan o por las que transitan", MARTÍNEZ RUIZ, E., Los soldados del rey: los Ejércitos de la monarquía hispánica (1480-1700), pp. 909-910.

40 CONTRERAS GAY, J., "Aproximación al estudio de los sistemas de reclutamiento en la España moderna", pp. 19-22.

${ }^{41}$ BORREGUERO BELTRÁN, C., Reclutamiento militar por quintas en la España del siglo XVIII: orígenes del servicio militar obligatorio, p. 38.

${ }^{42}$ CONTRERAS GAY, J., "Aproximación al estudio de los sistemas de reclutamiento en la España moderna", pp. 22-26; y BORREGUERO BELTRÁN, C., Reclutamiento militar por quintas en la España del siglo XVIII: orígenes del servicio militar obligatorio, pp. 43-46. 
ocasiones también sirvieron fuera de su territorio en incluso en Ultramar.

Durante el siglo XVII también se acudió, de forma esporádica, al reclutamiento y repartimiento forzosos ${ }^{43}$. El repartimiento lo hacía el Consejo de Castilla en función de la población de cada provincia castellana, si bien eran las instituciones locales las encargadas de su ejecución: "este reclutamiento se dirigía a conseguir efectivos por vía de contribución a las ciudades, villas y señores $[\ldots]^{\prime 44}$. Las villas y ciudades podían acudir para su cumplimiento a la contratación de voluntarios, también de sustitutos, o al pago de una cantidad determinada de dinero, normalmente repartida de forma equitativa entre todo el vecindario. En el caso de no existir un número suficiente de voluntarios, o no disponer el municipio de la cantidad económica solicitada, las corporaciones locales debían acudir al sorteo, sistema que daba lugar a numerosos fraudes y generaba un fuerte descontento entre los grupos populares. Estamos ante un sistema complejo para las autoridades encargadas de ejecutarlo, costoso, poco eficaz y que además provocaba un enorme descontento ${ }^{45}$.

Por último, para el siglo XVII, continuó una prestación heredada del Medievo: nos referimos al servicio militar de la nobleza ${ }^{46}$, delimitada a dos tipos de prestaciones: "una obligatoria, de origen feudal, que consistía en acudir a la llamada del rey y otra voluntaria basada en un servicio personal en los Ejércitos permanentes"47. A pesar de su escasa efectividad y de las resistencias señoriales, durante el siglo XVII los monarcas convocaron con cierta frecuencia a

\footnotetext{
43 BORREGUERO BELTRÁN, C., Reclutamiento militar por quintas en la España del siglo XVIII: orígenes del servicio militar obligatorio, pp. 39-40.

${ }^{44}$ BORREGUERO BELTRÁN, C., Reclutamiento militar por quintas en la España del siglo XVIII: orígenes del servicio militar obligatorio, p. 39.

${ }^{45}$ CONTRERAS GAY, J., "Aproximación al estudio de los sistemas de reclutamiento en la España moderna", pp. 28-38.

${ }^{46}$ BORREGUERO BELTRÁN, C., Reclutamiento militar por quintas en la España del siglo XVIII: orígenes del servicio militar obligatorio, pp. 40-43.

47 BORREGUERO BELTRÁN, C., Reclutamiento militar por quintas en la España del siglo XVIII: orígenes del servicio militar obligatorio, p. 40.
} 
las tropas nobiliarias. Los nobles en muchas ocasiones prefirieron pagar una compensación económica que acudir a esa vieja obligación feudal de batallar junto a su rey.

El siglo XVIII, en lo que al reclutamiento se refiere, constituyó un claro precedente de lo ocurrido durante el ochocientos, pues en estos años se pusieron las bases y se realizaron las primeras pruebas de los sistemas empleados posteriormente. La llegada al trono de una nueva dinastía, la Borbónica, con intensos aires reformistas, también en el ámbito militar ${ }^{48}$, y en el contexto de una guerra sucesoria frente al enemigo Habsburgo, trajo consigo la necesidad de una enorme cantidad de tropas para el Ejército. Finalizada la contienda y con el paso de los años,

"[...] la falta de tropas se acabaría convirtiendo en una constante secular y objeto de preocupación por parte de los sucesivos gobernantes, traduciéndose muy pronto en la implantación de métodos coercitivos de reclutamiento, a todas luces impopulares, en lugar de desarrollar una política tendente a incentivar la atracción de la sociedad por la carrera de las armas [...].

Resultado de la acuciante falta de tropas fueron los distintos sistemas de reclutamiento, a los que se sumarían la formación de batallones de milicias en lo que llegó a ser un primer intento de imposición de servicio militar obligatorio a partir del año 1734.

La diversificación de los sistemas de reclutamiento militar constituye la prueba más fehaciente de la necesidad de tropas durante el siglo XVIII. A pesar de ello, el problema se mantuvo inalterable a lo largo de toda la centuria"49.

\footnotetext{
48 "Cuando en el siglo XVIII se instala en España la dinastía borbónica procedente de Francia y se reorganiza el Ejército se va a copiar el modelo galo, no solo en lo que se refiere a la organización de las unidades sino también en el modo de nutrirlas" (GONZÁLEZ ASENJO, A. J., "La resistencia al servicio militar en Galicia", p. 200).

${ }^{9}$ ANDÚJAR CASTILLO, F., Los militares en la España del siglo XVIII: un estudio social, p. 66.
} 
A continuación resumimos las características de los cinco principales sistemas de reclutamiento de soldados utilizados en España durante el siglo XVIII, teniendo en cuenta que se carecía de un sistema fijo y uniforme para el reemplazo y que, los métodos que a continuación relatamos, se alternaban en función de las circunstancias:

1. Reclutas o levas voluntarias, sistema tradicional durante los tiempos modernos y el preferido por las autoridades al no suponer una imposición traumática sobre la población y asegurar al Ejército unas tropas de mayor calidad que los otros sistemas, además de asegurar un menor número de deserciones que los otros métodos. Sin embargo, el reclutamiento voluntario irá perdiendo importancia a la lo largo del siglo XVIII en detrimento de las quintas forzosas, situación ésta que se explica por la reducción en el número de voluntarios ante la progresiva degradación en la imagen del oficio de soldado y las negativas condiciones de vida por las que pasaba la tropa. A ello se unió la mejora de las condiciones económicas generales del país durante la segunda mitad de siglo, lo que vino a reducir el escaso atractivo que podía tener, por los míseros jornales, el oficio de soldado ${ }^{50}$.

2. El servicio militar de la nobleza, obligación para este estamento en caso de ser llamados por el rey, exentos sin embargo de los reclutamientos forzosos. Tales convocatorias apenas dieron resultados a lo largo del siglo XVIII a pesar del deseo de los Borbones de atraer a la nobleza al servicio de las armas para hacer de ellos uno de los ejes de la fuerza militar ${ }^{51}$.

3. Levas de vagos, mendigos, ociosos y maleantes, sistema utilizado con la doble intención de acabar con el problema de la

\footnotetext{
50 BORREGUERO BELTRÁN, C., Reclutamiento militar por quintas en la España del siglo XVIII: orígenes del servicio militar obligatorio, pp. 56-58.

${ }^{51}$ BORREGUERO BELTRÁN, C., Reclutamiento militar por quintas en la España del siglo XVIII: orígenes del servicio militar obligatorio, pp. 58-60.
} 
falta de tropas y cubrir bajas de los regimientos, especialmente americanos, y de "limpiar" a la sociedad de delincuentes, malhechores, vagos y ociosos. Este sistema tan sólo era empleado en momentos de conflicto bélico cuando existía una perentoria necesidad de tropas:

"Las levas tenían como finalidad el ser un castigo para los ociosos y vagos y reportaban al Ejército la posibilidad de paliar de forma momentánea sus necesidades de hombres, aún a costa de que entre sus filas si integrases malhechores, delincuentes, prófugos de la justicia y los vagabundos mismos ${ }^{\prime 25}$.

Este método, si tenemos en cuenta que acudía a marginados sociales de "dudosa" conducta para nutrir las filas del Ejército, provocaba una notable reducción en la "calidad" de las tropas, por lo que encontró rechazos dentro de la propia institución militar ${ }^{53}$. Sin embargo, "su uso se prolongó hasta el siglo XIX siendo la última la realizada en $1817^{\prime \prime 5}$, ya que, a pesar de la resistencia de estos individuos a ser aprehendidos, una vez capturados, "[...] el Ejército era el destino más deseado por los vagos $^{\prime 55}$. A partir de la década de 1780, prácticamente la totalidad de los vagos aprehendidos fueron destinados a la institución armada para evitar así el reclutamiento por quinta:

52 ANDÚJAR CASTILLO, F., Los militares en la España del siglo XVIII: un estudio social, p. 68.

53 ANDÚJAR CASTILLO, F., Los militares en la España del siglo XVIII: un estudio social, pp. 74-75.

${ }^{54}$ CRESPO-FRANCÉS Y VALERO, J.A., A las armas: Reclutamiento y servicio militar en España desde sus orígenes hasta nuestros días, p. 196.

${ }^{55}$ BORREGUERO BELTRÁN, C., Reclutamiento militar por quintas en la España del siglo XVIII: orígenes del servicio militar obligatorio, p. 61. 
"[...] a finales del siglo XVIII se pretendió con la leva reemplazar a la quinta. La concepción había cambiado: de aquellas redadas con fines altruistas, donde una minoría era encaminada hacia el Ejército, se pasó a estas levas generales, con fines exclusivamente militares ${ }^{\prime 56}$.

4. Las milicias provinciales, ya utilizadas en el siglo XVII para defender zonas conflictivas 0 fronterizas, pero que durante el XVIII recibieron un enorme interés por parte de la nueva dinastía al ser vistas como una solución al problema de la defensa interior como Ejército nacional de reserva ${ }^{57}$. Adquirieron un carácter forzoso, ya no voluntario, a nivel de todo el Estado, al obligar a todos los mozos solteros y casados sin hijos entre dieciocho y cuarenta años a participar en un sorteo que determinaría qué mozos se integrarían en la milicia provincial. Cada pueblo debería aportar un número de hombres en función de su vecindario ${ }^{58}$, no admitiéndose vagabundos 0 malentretenidos ni voluntarios ${ }^{59}$.

5. Reclutamiento forzoso, derecho del rey y obligación del contribuyente pechero ${ }^{60}$, sistema ya empleado, aunque de forma muy limitada, en las centurias anteriores ${ }^{61}$, y que alcanzó una importante extensión durante el siglo XVIII ${ }^{62}$

\footnotetext{
56 BORREGUERO BELTRÁN, C., Reclutamiento militar por quintas en la España del siglo XVIII: orígenes del servicio militar obligatorio, p. 67.

57 BORREGUERO BELTRÁN, C., Reclutamiento militar por quintas en la España del siglo XVIII: orígenes del servicio militar obligatorio, pp. 70-71.

${ }^{58}$ CRESPO-FRANCÉS Y VALERO, J.A., A las armas: Reclutamiento y servicio militar en España desde sus orígenes hasta nuestros días, pp. 197-202.

59 BORREGUERO BELTRÁN, C., Reclutamiento militar por quintas en la España del siglo XVIII: orígenes del servicio militar obligatorio, p. 77.

${ }^{60}$ BORREGUERO BELTRÁN, C., Reclutamiento militar por quintas en la España del siglo XVIII: orígenes del servicio militar obligatorio, pp. 83-91.

61 Se desconoce la fecha exacta del comienzo de los sorteos, si bien parece probable que los primeros se realizasen a finales del siglo XV, BORREGUERO BELTRÁN, C., Reclutamiento militar por quintas en la España del siglo XVIII: orígenes del servicio militar obligatorio, p. 86 y 87.

62 "Este sistema [...] fue impuesto en el año 1704 y se mantuvo básicamente en vigor hasta 1837" (GONZÁLEZ ASENJO, A. J., "La resistencia al servicio militar en Galicia", p. 200).
} 
ante la ya comentada escasez de tropas y las nuevas necesidades que tenía un Ejército cada vez mayor y además permanente, y con unas necesidades de hombres cada vez más importantes. Este sistema, de influencia francesa ${ }^{63}$, precedente del reclutamiento obligatorio y de enorme rechazo social al constituir una obligación en función del sorteo celebrado para uno de cada cinco mozos útiles (de ahí el nombre de "quintas") ${ }^{64}$ y al existir una enorme cantidad de exenciones de tipo nobiliario, laboral (oficios "útiles") y territorial (Cataluña y País Vasco), hundía sus raíces en el siglo XVII, pero era tan sólo utilizado de forma esporádica cuando la necesidad de tropas se hacía muy urgente, y no mantuvo un carácter anual hasta fines del siglo XVIII, consolidándose ya entrado el siglo XIX:

"El sistema de quintas se ha interpretado como el precedente inmediato del reclutamiento obligatorio característicos del Ejército decimonónico aunque distaba mucho de asemejarse a este dado la gran cantidad de privilegios personales $y$ territoriales que implicaba"65.

Se trata por tanto de un sistema coercitivo que definitivamente introdujo en el Ejército a los más desfavorecidos de la sociedad estamental, es decir, aquellos que, dentro del estamento no privilegiado, no tenían capacidad económica suficiente para burlar los sorteos a través de diversas estrategias fraudulentas

${ }^{63}$ CRESPO-FRANCÉS Y VALERO, J.A., A las armas: Reclutamiento y servicio militar en España desde sus orígenes hasta nuestros días, p. 185.

64 "Se denominó la "quinta" porque en un principio se escogía una quinta parte de los mozos en edad militar mediante sorteo" (HEADRICK, D. R., Ejército y política en España (1866-1898), p. 100).

65 ANDÚJAR CASTILLO, F., Los militares en la España del siglo XVIII: un estudio social, p. 69. 
(entrega de una cantidad de dinero por no ser incluido en el sorteo, fuga durante el día en que se celebraba el acto, sustitución por un recluta a cambio del pago del dinero acordado, sobornos, automutilación, deserción una vez incorporado a filas, etc.), y que les obligaban a servir durante un mínimo de cinco y un máximo de ocho años, en función de la ordenanza, y en unas condiciones de vida durísimas, siempre con la amenaza del estallido de una nueva guerra. Este sistema no suponía la quinta propiamente dicha, ya que los pueblos podían cubrir el cupo solicitado por la Corona a través de vagos y vagabundos:

"A lo largo del siglo XVIII el reclutamiento obligatorio [...] fue afianzándose, si bien las llamadas al reclutamiento, que ya empiezan a denominarse popularmente "quintas", no fueron regulares, sino esporádicas a tenor de las circunstancias bélicas" ${ }^{\prime 66}$.

El sistema de quintas terminaría por ser el más utilizado en las últimas décadas del siglo XVIII, y se regularizó e institucionalizó en mayor medida con la publicación de la Real Ordenanza para el reemplazo del Ejército de $1770^{67}$ por parte de Carlos $\mathrm{III}^{68}$, que venía a establecer la quinta como una obligación anual y permanente que tenía la población con el Ejército y la Monarquía ${ }^{69}$. Este sistema fue empleado por la Corona

${ }^{66}$ BORREGUERO BELTRÁN, C., Reclutamiento militar por quintas en la España del siglo XVIII: orígenes del servicio militar obligatorio, p. 91.

67 Real Ordenanza para el Reemplazo anual del Ejército de 3 de Noviembre de 1770, Madrid, Secretaría del Despacho de Guerra, 1770.

68 Estas ordenanzas son consideradas modélicas por parte del profesor Martínez Ruiz y el inicio del proceso que lleva al reclutamiento obligatorio, MARTÍNEZ RUIZ, E., "Condiciones básicas del reclutamiento militar en España (1768-1885)", p. 141. 69 Estas ordenanzas sufrieron añadidos posteriores en los años 1773 y 1775 que vinieron a comprobar la ineficacia del procedimiento, MARTÍNEZ RUIZ, E., 
ante la falta de voluntarios y cuando la necesidad de tropas se hacía urgente ante situaciones de conflicto internacional ${ }^{70}$. Dicho texto legislativo supuso el primer intento de introducción definitiva del servicio militar obligatorio al prohibir expresamente la sustitución, causando el menor perjuicio para los súbditos. Sin embargo, la implantación del servicio obligatorio mediante la quinta encontró fuertes resistencias populares, en especial en Cataluña, Navarra y País Vasco, pero también en el resto de territorios de la Monarquía, lo que queda reflejado en "[...] los diversos medios de corrupción en los sorteos para evitar la incorporación a filas, y como consecuencia, la sensible baja en la calidad del reclutamiento al ser quintados los más desfavorecidos de la sociedad"71. La quinta no supuso por tanto la llegada al Ejército de tropas de mayor calidad, ni la anualidad en la incorporación de nuevas tropas, ya que sólo se llegaron a realizar reemplazos en 1771, 1773, 1775 y 1776 :

"En las últimas décadas del siglo XVIII, el sistema de reemplazo anual parecía haber sido erradicado definitivamente; los soldados se reclutaban recurriendo a prácticas antiguas. Las causas que llevaron a evitar la quinta fueron, sobre todo, las enormes dificultades que imposibilitaban su ejecución: fraudes sistemáticos, porcentaje altísimo de exentos, perjuicios a la agricultura y elevada mortandad"72.

\footnotetext{
"Condiciones básicas del reclutamiento militar en España (1768-1885)", p. 160162.

70 "Carlos III implantó el sistema de quintas para cubrir anualmente el reemplazo del Ejército, al reconocer la imposibilidad de que los regimientos cubriesen sus bajas con la recluta y realizasen, por tanto, su propio reemplazo" (CRESPOFRANCÉS Y VALERO, J.A., A las armas: Reclutamiento y servicio militar en España desde sus orígenes hasta nuestros días, p. 195).

71 ANDÚJAR CASTILLO, F., Los militares en la España del siglo XVIII: un estudio social, p. 81.

72 BORREGUERO BELTRÁN, C., Reclutamiento militar por quintas en la España del siglo XVIII: orígenes del servicio militar obligatorio, p. 108.
} 
Sin embargo, esa supuesta periodicidad anual ya suponía una importante novedad legislativa ${ }^{73}$.

73 MARTÍNEZ RUIZ, E., "Condiciones básicas del reclutamiento militar en España (1768-1885)", p. 143. 


\section{2.- Evolución legislativa entre 1800 y 1912: los cambios en el concepto del reclutamiento y de la propia figura del soldado}

\section{1.- La sombra de la Revolución Francesa y el antecedente de las quintas: Ordenanza de 1800}

Iniciamos nuestro repaso legislativo del reclutamiento militar durante el siglo XIX con un texto aprobado precisamente el año que vino a inaugurar el siglo. Se trata "[del] antecedente más claro de las quintas decimonónicas"74, una norma renovadora que perfilará las características del sistema para los años venideros, marcados por la sombra de la Revolución Francesa. Serán, por tanto, los Borbones quienes perfilen las formas de ingreso en el Ejército, de inspiración francesa.

Con esta Ordenanza se consolidó definitivamente el servicio obligatorio periódico como una contribución más a la que estaba sometida la población y se regularizó el sistema de quintas. Esta forma de reemplazo marcará de una forma crucial la vida de los pueblos en una España marcadamente rural, al tiempo que se irá incrementando el rechazo hacia ella por las injusticias que le eran inherentes.

El nuevo texto legal, aprobado el 27 de octubre de $1800^{75}$ siendo Secretario del Despacho de Guerra el oscense Antonio Coronel y Ferraz ${ }^{76}$, marcó un cambio de rumbo no solo en la forma de reclutar a los soldados, sino en la propia estructura del Ejército.

\footnotetext{
${ }^{74}$ FEIJÓO GÓMEZ, A., Quintas y protesta social en el siglo XIX español, p. 36.

75 Ordenanza de 27 de octubre de 1800, libro IV, Título VI de la Novísima Recopilación, pp. 82-104. En adelante, Ordenanza de 27 de octubre de 1800.

76 Diccionario Biográfico Español, edición digital, RAH, http://www.rah.es/cdeb.htm
} 
El Ejército del siglo XVIII mantenía intactas las características de las centurias precedentes: mando supremo y único del monarca, principio de obediencia a la autoridad, puestos de mando ocupados en exclusiva y como privilegio por el estamento nobiliario y una tropa reclutada por métodos escasamente reglamentados. Tales sistemas fueron perfilándose con mayor nitidez a medida que avanzaba la centuria dieciochesca, y tendrán su momento de primacía en función de las circunstancias políticas y socioeconómicas del momento: mercenarios a sueldo, voluntarios, levas de vagos y levas por sorteo entre una población civil no contemplada al completo, ya que los privilegios y las exenciones personales y territoriales eran muchas $y$ variadas.

Contexto histórico: la quiebra del Ejército ${ }^{77}$

La institucionalización definitiva del sistema de quintas y de levas forzosas se produjo en el siglo XVIII, si bien ambas habían sido utilizadas previamente: "la vieja estampa del capitán que recorre una comarca con su patente, bandera y oficiales reclutando a los mozos desaparece al asumir el Estado esa función de manera más sistemática y periódica"78. La clave para la consolidación de los sistemas forzosos estuvo en el estallido de la Guerra de Sucesión española ${ }^{79}$, percibido con frecuencia en España como una mera

\footnotetext{
77 Hemos publicado previamente sobre esta norma el trabajo RIVILLA MARUGÁN, G., y MARTÍNEZ PEÑAS, L., "La pervivencia de elementos del Antiguo Régimen en la Ordenanza de reclutamiento de 1800", en CODEX. Boletín de Estudios HistóricoJurídicos, Córdoba, 5 (2012).

78 MARTÍNEZ RUIZ, E., "La celebración de quintas, una cadencia temporal en la España del Antiguo Régimen", P. 216.

79 Sobre el carácter internacional de la guerra de Sucesión, pueden verse GARCÍA GONZÁLEZ, F. (Coord.), La guerra de sucesión en España y la batalla de Almansa: Europa en la encrucijada, Madrid, Sílex, 2009; MARTÍNEZ PEÑAS, L., "La Casa Real de Felipe V en la jornada de Italia", en LABRADOR, F., y GAMBRA, A., (coords.), Las Casas de la monarquía hispana: La Casa de Castilla, Editorial Polifemo, Madrid, 2010.
} 
guerra civil, cuando se trató, en realidad, de un verdadero conflicto internacional que arrastró a la mayor parte de las grandes potencias europeas de su tiempo. Al respecto, es bien ilustrativo que, pese a la importancia que se presta en la historiografía hispánica a las batallas de Almansa, Brihuega y Villaviciosa, la suerte del conflicto se dirimió en los campos de Ourdenaarde, Malplaquet o Blenheim, lejos del solio peninsular.

El conflicto generalizado en Europa impidió a la nueva dinastía borbónica acudir a los sistemas tradicionales de reemplazo, en especial la recluta de mercenarios extranjeros. La guerra generalizada en Europa dificultó enormemente la capacidad de la Corona para renovar sus efectivos militares. Esta circunstancia explica el especial interés y empeño que pusieron las autoridades borbónicas en regular y consolidar un sistema de reemplazo coherente y eficaz, tal y como lo demuestran las diferentes normas referentes a este tema que se fueron aprobando a lo largo del siglo XVIII. En sintonía con este grado de empeño que pusieron los gobernantes, encontramos un creciente rechazo popular a un sistema, el de quintas, que marcará la vida cotidiana de los pueblos.

A lo largo de los siglos XVII y XVIII, las reclutas forzosas realizadas mediante sorteo se convirtieron en el principal medio de reclutamiento para el Ejército. La existencia de una milicia permanente de un tamaño cada vez mayor hizo necesario disponer de una tropa cada vez más numerosa ${ }^{80}$. El reclutamiento forzoso era excepcional en el siglo XVII, se extendió durante el siglo XVIII y se consolidó y regularizó gracias a la Ordenanza de 1770 y especialmente a la de 1800 . El sistema de quintas, por tanto, procede del Antiguo Régimen, y se ha considerado el precedente reclutamiento obligatorio propio del siglo XIX, aunque esta afirmación conviene contemplarla con precaución por la enorme cantidad de ${ }^{80}$ ANDÚJAR CASTILLO, F., Los militares en la España del siglo XVIII: un estudio social, p. 68. 
exenciones personales, laborales, territoriales y estamentales que encontramos en una legislación anclada en la desigualdad personal propia del Antiguo Régimen.

La Ordenanza de 1800, inspirada en la de 1770 aunque sin la anualidad del llamamiento ${ }^{81}$, muestra un origen político bien definido, la quiebra del Ejército que, para la Monarquía española, supuso el reinado de Carlos IV y los conflictos internacionales en los que se vio envuelto este monarca, en especial los derivados de la lucha contra la revolución francesa, puesto que no conviene olvidar las desastrosas campañas contra la Francia revolucionaria desarrolladas por las tropas españolas, en el marco de los intentos de las monarquías absolutas de acabar con el experimento revolucionario galo por la vía de las armas.

Nos encontramos con una Monarquía que se siente indefensa y desconcertada al ponerse de manifiesto lo escasamente adecuado de su aparato militar, y que en lo político se vio completamente sorprendida por el feroz estallido francés. Ello hizo que, tal y como indica Puell de la Villa ${ }^{82}$, en España se superpusieran dos procesos:

"El iniciado por la última de las levas honradas -la proclamada por Carlos IV para vengar la muerte de Luis XVI-, que significó la eliminación del soldado profesional y determinó la hegemonía del soldado de quintas como base del reemplazo del Ejército hasta comienzos del siglo XX. El otro proceso, cuyas últimas consecuencias conducirían a la consagración de la figura del ciudadano-soldado, tal como hoy lo concebimos, tuvo una gestación mucho más lenta y azarosa: se enunció y sacralizó en las Cortes de Cádiz, las sucesivas constituciones liberales la dieron forma teórica, fue principio inspirador de la revolución democrática de 1868 y se configuró

\footnotetext{
81 PUELL DE LA VILLA, F., El soldado desconocido: de la leva a la "mili" (17001912), p. 178.

82 PUELL DE LA VILLA, F., El soldado desconocido: de la leva a la "mili" (17001912), p. 143.
} 
definitivamente durante la primera mitad de nuestro siglo [el siglo $X X]^{\prime \prime 83}$.

Fue la llamada Guerra de los Pirineos, del Rosellón o de la Convención ${ }^{84}$, ocurrida entre 1793 y 1795, el acontecimiento que vino a señalar la definitiva quiebra del Ejército español y que marcó el futuro para los sistemas de reclutamiento en España:

"[...] por mucho que fuera el entusiasmo popular y abundantes los donativos para sufragar los gastos de una guerra ante la que no había reticencias, prácticamente, la situación real de nuestro Ejército no podría variarse -ausentes los frutos con las reformas que se habían perseguido con las reformas precedentes arbitradas a lo largo del siglo-" 85 .

A pesar de la euforia popular, los éxitos iniciales del Capitán General de Cataluña, el general Ricardos, en el Rosellón durante los meses estivales de 1793 y del pomposo título de Príncipe de la Paz recibido al finalizar la contienda por el favorito del rey, Manuel de Godoy, la derrota del Ejército español resultaba incuestionable y venía a mostrar la quiebra y la decadencia de unos de los instrumentos fundamentales para la Monarquía: el Ejército ${ }^{86}$. Por ello podemos considerar esta derrota como el principio del fin de un Ejército con características de Antiguo Régimen.

83 PUELL DE LA VILLA, F., El soldado desconocido: de la leva a la "mili" (17001912), p. 144??

84 Ver ANES, G, España a fines del siglo XVIII, Tarragona, Hemeroteca de Tarragona, 1982; HAMNET, B.R., La política española en una época revolucionaria, 1790-1820, México, Fondo de Cultura Económica, 1985; GIMÉNEZ LÓPEZ, E., El fin del Antiguo Régimen: el reinado de Carlos IV, Madrid, Temas de Hoy, 1996.

85 MARTÍNEZ RUIZ, E., "La celebración de quintas, una cadencia temporal en la España del Antiguo Régimen", p. 216.

86 PUELL DE LA VILLA, F., El soldado desconocido: de la leva a la "mili" (17001912), p. 144. 
El ejército basado en los profesionales voluntarios que había sido característico de la Edad Moderna, fue sustituido, a través de un largo y complejo proceso, por otro de características "liberales". Como muestra del impacto de la Guerra de los Pirineos, señalar que fue éste uno de los primeros conflictos donde se recurrió sistemáticamente a gentes del "común", especialmente en Cataluña, como elemento de ayuda imprescindible del Ejército regular, dejando así a las claras las insuficiencias del Ejército de la Corona y el papel relevante que se le tendrá guardado en el futuro a las clases populares como cantera del mismo. Es más, se ha identificado la fase inicial de la campaña de los Pirineos como la primera "guerra nacional" de la Historia Contemporánea de España, ya que "en ella combatieron dos Ejércitos reclutados por una movilización general: el español por el Ilamamiento de Carlos IV y el francés por el [...] decreto de la Convención" ${ }^{87}$. Este entusiasmo popular inicial, aunque efímero, fue alentado por la idea de lucha contra unos revolucionarios franceses que atacaban los valores de la tradición, el dogma católico y la Monarquía.

Otro acontecimiento enmarcado en las convulsiones de la Revolución Francesa impulsó la aprobación de un nuevo texto legal. Nos referimos a la célebre batalla de Valmy, el 20 de septiembre de 1792, cuando un ejército popular de sans-culottes parisinos derrotó a otro tradicional de profesionales prusianos. Era la primera victoria de un ejército surgido de la Revolución e inspirado en los derechos liberales y las ideas nacionalistas sobre una estructura militar netamente propia del Antiguo Régimen. El impacto de Valmy ${ }^{88}$ fue enorme y marcó el inicio de un largo, profundo e intenso proceso de reconversión militar que, lógicamente, también afectó a todo lo relacionado con el reclutamiento en España.

87 PUELL DE LA VILLA, F., El soldado desconocido: de la leva a la "mili" (17001912), p. 146. 
En este contexto, la Ordenanza de 1800 trató de corregir las deficiencias existentes en las normas sobre reclutamiento aprobadas en 1770 y $1773^{89}$, y se enmarcaba dentro del amplio conjunto de reformas impulsadas por Godoy, auténtico valido en la Corte de Carlos IV, al que, como ha sido tradicional en la historiografía hispánica sobre el valimiento, se le ha culpado, en ocasiones con manifiesta injusticia, de la mayor parte de los males de la España de su tiempo ${ }^{90}$. El objetivo de la norma era modernizar las operaciones de reclutamiento, y "la confección del padrón municipal, la posibilidad de reclamar contra el alistamiento y la creación de una unidad militar específicamente dedicada a la conducción de los reclutas $[. . .]^{\prime \prime 1}$, así lo demuestran. Se trata de una norma fundamental en la regulación del sistema de quintas y en la imposición del reclutamiento obligatorio. Pese a ello, para la historiografía ha pasado prácticamente desapercibida con alguna notable excepción:

"Una ordenanza que tiene indudable trascendencia, pues por una parte marca el último intento de racionalizar el "Ejército real", y por otro, es el punto de partida de las disposiciones sobre el particular emitidas en el siglo XIX para asegurar el reemplazo del "Ejército nacional' ${ }^{\prime \prime 92}$.

Esta ordenanza se empleó en el reclutamiento de los soldados de la Guerra de la Independencia y en el intento de sofocar los procesos de emancipación iberoamericanos, se mantuvo tras el

89 MAQUEDA ABREU, C., "La Restauración de Fernando VII y el reclutamiento militar", p. 72.

90 Sobre Godoy, quizá la monografía más completa sea LA PARRA, E., Manuel Godoy, la aventura del poder, Barcelona, Tusquets, 2002; sus memorias se encuentran publicadas en GODOY, M., Memorias, Alicante, Universidad de Alicante, 2006. Sobre la institución del valimiento, ver ESCUDERO, J. A., (dir.), Los validos, Madrid, Editorial Dyckinson, 2005.

91 PUELL DE LA VILLA, F., El soldado desconocido: de la leva a la "mili" (17001912), p. 178.

92 MARTÍNEZ RUIZ, E., "La celebración de quintas, una cadencia temporal en la España del Antiguo Régimen", p. 217. 
paréntesis gaditano, y reguló, con ligeras modificaciones en 1817 y 1819, los procesos de alistamiento que nutrieron al Ejército isabelino en su lucha contra el pretendiente carlista. Además, su espíritu se mantuvo en leyes posteriores y su influencia prácticamente llegó hasta la legislación de 1912.

Adolece, en cualquier caso, de los defectos propios de su tiempo: unos años entre dos épocas, una España que aún tenía un pie en el Antiguo Régimen, pese a los cambios producidos en los cien años anteriores merced al impacto cada vez mayor de las ideas de la Ilustración que monarcas como Carlos III impulsaron -todo para el pueblo, pero sin el pueblo- y otro en los albores del Estado liberal, puesto que, pese a los notables esfuerzos por confinar la revolución al Norte de los Pirineos, el pensamiento político revolucionario había sabido permear los controles fronterizos y la vigilancia inquisitorial e iba cobrando fuerza en sectores cada vez más amplios de la sociedad española.

Desarrollo de la norma: el intento de modernización de las operaciones de reclutamiento

La Ordenanza de 1800 está formada por un total de 21 capítulos y 74 artículos. Se observa en ella un intento, a la postre frustrado, de modernización de todas las operaciones relacionadas con el reclutamiento. También se buscó un texto sencillo y de fácil comprensión, aunque minucioso. El objetivo básico de la norma, de inspiración ilustrada, se proclamó en el preámbulo: "[...] distribuir la contribución a este servicio de tal manera que, dejando a la agricultura los brazos necesarios, no faltasen tampoco en las artes y oficios"$^{\prime \prime 3}$. Es decir, el reclutamiento suponía una carga excesiva para

${ }^{93}$ Ordenanza de 27 de octubre de 1800. 
las clases populares y trabajadoras, y por ello se intenta, con la nueva regulación, disminuir el número de exentos e imponer una mayor justicia en todo el proceso ${ }^{94}$.

a) Elaboración del padrón de vecinos: el objetivo militar por encima del fiscal

Los dos primeros capítulos de la ordenanza hacen referencia al padrón de vecinos, plataforma para el repartimiento de los cupos y elemento básico para conocer el número de jóvenes con los que se cuenta: "de la importancia que al exacto cumplimiento de este trabajo se le otorgaba da buena nota la reglamentación que, del modo y manera de efectuarse, se regulaba en las pertinentes disposiciones legales que tendrían vigencia durante el siglo XIX"95. Su importancia para la Historia va más allá del análisis del reclutamiento, ya que puede constituirse en una fuente sociológica de primer nivel.

El primer capítulo se encarga de todas las diligencias a realizar para la elaboración del padrón. Serían los corregidores y justicias de las distintas localidades los encargados de elaborarlo en el breve plazo de ocho días transcurridos desde el envío de la orden por parte de los intendentes de cada provincia ${ }^{96}$. Este padrón incluiría a todos los vecinos, de cualquier condición, con "[...] casa abierta en el pueblo $[\ldots]$ ", aunque residiesen durante largas temporadas fuera de la población o no se encontrasen en ella de forma provisional. Los

\footnotetext{
94 "Minorar el número de exentos, si perjuicio del gobierno de mis pueblos: del servicio de la Iglesia y de la justa libertad de las personas destinadas a él; del número conveniente de profesores para la ilustración y cultura de mis vasallos; de los justos fueros de la distinguida Nobleza de mis reinos; y, finalmente, [...] aliviar en lo posible la clase de labradores, digna de mis paternales atenciones, y acreedora por su honradez y lealtad a esta y otras consideraciones [...] como que ella es nervio y fundamento de la prosperidad del Estado [...]" (Ordenanza de 27 de octubre de 1800).

95 JIMÉNEZ GUERRERO, J., El reclutamiento militar en el siglo XIX: las quintas en Málaga (1837-1868), p. 31.

${ }^{96}$ Ordenanza de 27 de octubre de 1800, art. 1.
} 
Justicias podrían contar con la colaboración en esta tarea de comisarios en el área de su jurisdicción ${ }^{97}$.

Una vez elaborado el padrón de vecinos, se reuniría al completo todo el Ayuntamiento, incluidos síndico y diputados del común, así como el párroco de cada pueblo y un vecino, "persona honrada", de cada lugar o aldea. La presencia del párroco es reflejo de una mentalidad propia del Antiguo Régimen, ya que se acude a la autoridad eclesiástica como garante de la limpieza del proceso, si bien la norma declara que la asistencia de éstos se produce "puramente [...] como testigos de autoridad y distinción" ${ }^{98}$, pudiendo presentar ante el Ayuntamiento cualquier agravio o injusticia que hubiesen observado en estas tareas.

En esta reunión del Ayuntamiento se procedería, por parte del escribano, a la lectura del padrón, anotándose en el mismo los vecinos que gocen de la condición de hijosdalgo y los ordenados in sacris $^{99}$. A continuación se extendería el acta, anotándose en ella las posibles protestas de los concurrentes al acto ${ }^{100}$ y señalando la condición de privilegiada de aquellos miembros del estamento nobiliario ${ }^{101}$. Se muestra de nuevo una mentalidad propia de un sistema social garante de las desigualdades estamentales y de los privilegios personales, muy lejano a la igualdad jurídica entre ciudadanos impulsada por el proceso revolucionario francés. También quedarían exentos, aunque no por motivos estamentales, todos los pueblos y lugares donde existiese la matrícula de mar. Dicha exención afectaba a todos aquellos territorios cargados con la contribución de la matrícula, donde ni siquiera era necesario la

\footnotetext{
97 Ordenanza de 27 de octubre de 1800, art. 2.

98 Ordenanza de 27 de octubre de 1800, art. 3.

99 Ordenanza de 27 de octubre de 1800, art. 4.

100 "[...] De esta manera funcionaba el principio que bien podíamos denominar de "fiscalización mutua" ya que eran los propios mozos o sus parientes los que se encargaban de controlar en esta sesiones las posibles las posibles exclusiones de los listados" (JIMÉNEZ GUERRERO, J., El reclutamiento militar en el siglo XIX: las quintas en Málaga (1837-1868), p. 80).

${ }^{101}$ Ordenanza de 27 de octubre de 1800, art. 5.
} 
elaboración del padrón del vecindario. ${ }^{102}$ Se demuestra así el interés primordialmente militar que tenían los padrones, por encima del fiscal o económico.

Una copia del padrón y actas elaborados serían remitidos al corregidor y éste, a su vez, lo remitirá al intendente, mientras que los originales se depositarán en el archivo del Ayuntamiento ${ }^{103}$. Ambos procesos, nimios en apariencia, manifiestan dos de las tendencias que la dinastía borbónica trató de implantar desde su llegada al trono español: centralización y control de la administración por parte del Gobierno central ${ }^{104}$ (son el intendente y el corregidor, nombrados por la Corona, quienes impulsan y controlan todo el proceso), así como control de la burocracia y eficacia en la gestión (como demuestra el depósito de la documentación en el archivo municipal). Con los padrones locales se elaboraría el padrón general de la provincia y el de todo el reino ${ }^{105}$.

Este primer capítulo, además de mostrar la importancia que las instancias locales tenían para el inicio del proceso, finaliza con una amenaza a los miembros del Ayuntamiento que participasen en la elaboración del padrón, "la base de la igualdad en la contribución a éste servicio", y que cometiesen fraude, castigando el delito con la privación de empleo y una multa de 100 ducados $^{106}$.

Superada la plataforma municipal, el segundo capítulo regula los pasos a seguir por las autoridades de la Corona en el proceso de reclutamiento. Una vez que el intendente tuviese en sus manos

\footnotetext{
102 Ordenanza de 27 de octubre de 1800, art. 8.

103 Ordenanza de 27 de octubre de 1800, art. 6.

104 Ver FERNÁNDEZ DÍAZ, R., La España de los Borbones: las reformas del siglo XVIII, Madrid, Historia 16, Temas de Hoy, 1996; JUAN VIDAL, J., Política interior y exterior de los Borbones, Madrid, Istmo, 2001.

105 MARTÍNEZ RUIZ, E., "La celebración de quintas, una cadencia temporal en la España del Antiguo Régimen", p. 218.

${ }^{106}$ Ordenanza de 27 de octubre de 1800, art. 7.
} 
"[...] los testimonios de los padrones de todos los pueblos de la provincia en su poder, formará un estado, en el cual se lean los nombres de los pueblos, y al frente el número de vecinos útiles que, bajados clérigos in sacris e hijosdalgo, hubiere en cada uno; y por el fin de él un resumen de todo el vecindario de la Intendencia ${ }^{1107}$.

Una copia de dicho documento sería enviada al Secretario del Despacho de la Guerra, mientras que el original quedaría en manos del intendente ${ }^{108}$.

Para asegurar la actualización de unos datos fundamentales a la hora de iniciar el proceso de reclutamiento, el Monarca ordenaba a los intendentes la elaboración del padrón cada diez años, siguiendo las mismas instrucciones que se han señalado anteriormente ${ }^{109}$.

b) El reparto de cupos: la actuación de los intendentes y los justicias de cada localidad

El tercer capítulo es el que se encarga en sentido estricto del reemplazo, al ordenar a los intendentes, previa orden del ministerio de Guerra, su realización en cada provincia, siempre teniendo en cuenta "[...] el vecindario útil para este servicio $[\ldots]^{\prime 110}$. El mismo intendente haría pública la orden de reemplazo y repartiría el cupo de la provincia entre las distintas localidades en función de su número de habitantes ${ }^{111}$.

Se centra asimismo este tercer capítulo en los jóvenes afectados por esta contribución: todos aquellos mozos solteros entre los diecisiete y los treinta y seis años cumplidos, superiores en altura

\footnotetext{
107 Ordenanza de 27 de octubre de 1800 , art. 8.

108 Ordenanza de 27 de octubre de 1800, art. 8.

109 Ordenanza de 27 de octubre de 1800, art. 8.

110 Ordenanza de 27 de octubre de 1800 , art. 9.

${ }^{111}$ Ordenanza de 27 de octubre de 1800, art. 9.
} 
a los cinco pies ${ }^{112}$, es decir, 1,625 m., y que no estuviesen eximidos o excluidos por algún motivo. Se incluyen los viudos ${ }^{113}$, pero no "los negros, mulatos, carniceros, pregoneros, verdugos, y cualquiera en quien por sentencia de tribunal se haya ejecutado pena infame [...]"114. Finaliza el artículo con una extraña declaración: "[...] será de mi desagrado que con este motivo [la pena infame sentenciada por un tribunal] procedan las Justicias a inquietar a las familias, dando ocasión a que queden infamadas las que estaban tenidas antes en buena reputación" ${ }^{115}$.

Enrique Ruiz Martín invita a la reflexión y duda sobre si la perpetración de un delito podía ser un medio para librarse del servicio militar:

"La primera parte nos enfrenta a un juicio de valor que puede estimarse caprichoso, radical o injusto y nos habla de la estimación en que se tiene a determinadas personas o profesiones. En cambio, la parte final del artículo es muy sugerente. No se nos alcanzan las razones que un Justicia pudiera tener para proceder contra alguien e "infamarlo" con objeto de que no pudiera servir en el Ejército, cosa que era deseada por bastantes, toda vez que la opinión generalizada era enemiga de las quintas y consideraba el servicio militar no honroso, sino molesto, odioso y hasta dramático. Por ello, con ese proceder de los Justicias ¿estaremos más bien ante un posible camino para evadirse del servicio militar? ¿Será la perpetración de un delito un procedimiento utilizado para no ser incluido en el alistamiento? $[\ldots]^{\prime 116}$.

El capítulo cuarto regula el modo de actuación de los justicias de las distintas localidades en caso de una posible ausencia de un

\footnotetext{
112 Ordenanza de 27 de octubre de 1800, art. 10.

113 Ordenanza de 27 de octubre de 1800, art. 11.

${ }^{114}$ Ordenanza de 27 de octubre de 1800, art. 13.

115 Ordenanza de 27 de octubre de 1800, art. 13.

116 MARTÍNEZ RUIZ, E., "La celebración de quintas, una cadencia temporal en la España del Antiguo Régimen", p. 219.
} 
mozo. Estas autoridades tenían la obligación de elaborar el alistamiento de todos los mozos solteros del pueblo entre diecisiete y treinta y seis años, independientemente de no llegar a la talla mínima exigida o gozar de alguna exención. Para ello se valdrían del padrón elaborado cada diez años, de los libros de bautismo o de cualquier medio que considerasen necesario. En este documento se debían incluir también los criados domésticos y jornaleros que trabajasen en alguna hacienda o cortijo jurisdicción de la localidad. Aquellos jóvenes que pasasen temporadas fuera de su residencia habitual por motivos de trabajo, serían alistados en la localidad donde residiesen habitualmente, y no donde se encontrasen trabajando en el momento del alistamiento. Se prohibió además a los jóvenes que habitualmente saliesen de su lugar de residencia por trabajo a hacerlo sin una licencia expedida por el justicia de la localidad. Este documento debía incluir el nombre del individuo a quien afectase, su futuro lugar de trabajo, y señalar el nombre del padre, hermano o pariente que le sustituiría en caso de que sobre él recayese la suerte del soldado. Estas licencias serían recogidas en un libro que firmarían el juez, el síndico y el escribano del Ayuntamiento ${ }^{117}$.

Concluye este cuarto capítulo con una serie de penas para aquellos que, habiendo recibido licencia para marchar de su localidad de residencia y le tocase la suerte de soldado, no presentasen a su "fiador", que estaría obligado a cubrir su plaza. Si este personaje no fuese apto, se le exigirá al mozo una multa de 100 ducados y, en el caso de no poder pagarlos, cumpliría sus servicios como soldado de la Corona durante el doble de tiempo que establece la orden para el soldado ordinario, es decir, dieciséis años. En el caso de descubrirse a un joven sin licencia fuera de su localidad de residencia, se vería obligado a realizar el servicio de las armas en caso de ser considerado apto, y en el supuesto de no serlo, se verá obligado a

117 Ordenanza de 27 de octubre de 1800 , arts. 14 y 15. 
abonar un multa de 30 ducados al Fisco de la Guerra"18: "de esta forma se atajaba la posibilidad de que algún mozo, mediante desplazamientos temporales en determinadas fechas, pudiera eludir el alistamiento sin alegar en su lugar de residencia que ya estaba alistado en alguno de los que visitaba sin ser cierto" ${ }^{119}$.

El quinto capítulo reguló la actuación de los Alcaldes y Jueces de Madrid, ciudad exenta, así como de las localidades del entorno, con la misma condición, al estar obligados a perseguir y capturar a aquellos jóvenes de otras localidades no exentas que se introdujesen en la localidad en tiempos del sorteo. También debían cumplir con las peticiones que los justicias de otras localidades les envasen en su búsqueda de jóvenes huidos. Solicitó el Monarca que los alcaldes y justicias de los territorios exentos "empleen su celo en descubrir tales mozos, a quienes su desaplicación al trabajo, y a la facilidad de hallar en Madrid arbitrios con que poder vivir, los arrastra a expatriarse en gravísimo perjuicio de las costumbres, de la agricultura y de las artes, y finalmente del servicio de mis armas, adonde por su talla y robustez se emplearían con más decoro que en servir en los coches y en las cuadras" ${ }^{\prime 20}$.

c) El alistamiento y tallaje de los mozos

La Ordenanza de 1800 se centró en su sexto capítulo en todo lo relacionado con el proceso de alistamiento. Éste sería elaborado por los justicias de las localidades en un plazo de seis días tras recibir la orden del intendente. A continuación se convocaría, mediante pregón, a los mozos alistados a que concurriesen al Ayuntamiento, para notificarles su inclusión en el alistamiento, escuchándose en el mismo

\footnotetext{
118 Ordenanza de 27 de octubre de 1800 , arts. 16 y 17.

119 MARTÍNEZ RUIZ, E., "La celebración de quintas, una cadencia temporal en la España del Antiguo Régimen", p. 219.

120 Ordenanza de 27 de octubre de 1800, art. 18.
} 
acto las posibles reclamaciones. El paso siguiente sería el tallaje de los mozos, anotando en el alistamiento aquellos que no cumpliesen los requisitos exigidos. Si existiese alguna reclamación en esta fase se volvería a tallar al mozo en cuestión, con el objeto de evitar fraudes. Se solicitó además a los jueces que interviniesen en el proceso que fuesen escrupulosos en vigilar cualquier posible engaño o fraude en las mediciones ${ }^{121}$. Sin embargo, tal y como indica Cristina Borreguero, "el medidor fue objeto de sobornos, por lo que el Procurador Síndico presenciaba de cerca la medida y la comprobaba declarando la llegada o no de los mozos a la talla. Pero a pesar de esto, en ocasiones, los medidores fueron depuestos de sus cargos" ${ }^{122}$. Lógicamente, todos aquellos que no cumpliesen la talla mínima quedarían exentos de servir al Ejército.

Se estableció asimismo la obligación de acudir al acto "[...] a los que notoriamente estén conocidos en el pueblo por ciegos, cojos, mancos, baldados y estropeados, y a cuantos sean a vista de todos enteramente inútiles para el servicio de las armas, poniendo en el alistamiento nota expresiva del defecto al lado del nombre de cada uno"123.

d) El juicio de excepciones: el examen de las alegaciones físicas presentadas

El capítulo sexto reguló uno de los actos más delicados y complejos de todo el proceso, el juicio de excepciones, ${ }^{124}$ previo al

\footnotetext{
${ }^{121}$ Ordenanza de 27 de octubre de 1800 , arts. 20 y 21 y 23.

122 BORREGUERO BELTRÁN, C., Reclutamiento militar por quintas en la España del siglo XVIII: orígenes del servicio militar obligatorio, p. 145.

${ }^{123}$ Ordenanza de 27 de octubre de 1800, art. 24.

124 "Las razones por las que se ordenó la celebración de un juicio en el que se oyeran las alegaciones que los mozos tenían que realizar en orden a lograr su no inclusión a filas, fueron las numerosas protestas y quejas que los jóvenes efectuaban" (JIMÉNEZ GUERRERO, J., El reclutamiento militar en el siglo XIX: las quintas en Málaga (1837-1868), p. 151).
} 
sorteo, y la propia norma así lo indica: "El juicio de excepciones es uno de los actos del sorteo de más importancia y consecuencias" ${ }^{125}$. Se estableció la obligación de acudir para todos los mozos por su propio interés, y una duración máxima de tres días ${ }^{126}$.

Dicho acto comenzaría, una vez excluidos los "notoriamente inútiles", con la lectura de la ordenanza completa, para que nadie pudiese alegar desconocimiento de la misma. Se señala también que no se daría por exento a nadie que lo hubiese sido en sorteos anteriores, "porque la causa de exención ha de subsistir, y se ha de reconocer y declarar al tiempo del actual"127. Serían "peritos jurados y fidedignos", dos profesores de medicina o cirugía llamados expresamente al acto, los que examinarían a aquellos que alegasen "accidente o achaque habitual, que para el servicio le haga inútil"128. Se señala que no se admitiría ningún certificado anterior de médicos y cirujanos donde se confirme el "achaque", y prohibía a este colectivo expedir tal documento en tiempos del sorteo, bajo la pena de suspensión de oficio durante dos años. En el supuesto de que los médicos encargados de examinar a los mozos "faltaren a la verdad", perderían su capacidad para ejercer su trabajo durante ocho años y se verían obligados a abonar una multa de 100 ducados, "pues la experiencia ha mostrado el abuso, que algunos físicos han hecho, de la confianza que se pone en sus conocimientos en negocio de tanta importancia"129.

Establece la ordenanza que cualquier solicitud de excepción se había de realizar mientras durase el juicio, y habían de estar presentes cuando se realizase el resto de mozos sorteables o algún

\footnotetext{
125 Ordenanza de 27 de octubre de 1800, art. 25.

126 Ordenanza de 27 de octubre de 1800, art. 30.

127 Ordenanza de 27 de octubre de 1800, art. 27.

128 Ordenanza de 27 de octubre de 1800, art. 28.

${ }^{129}$ Ordenanza de 27 de octubre de 1800, art. 29.
} 
familiar que los representase, sin existir la posibilidad de alegación una vez hubiese finalizado éste ${ }^{130}$.

En el supuesto de que el justicia de la localidad no hubiese admitido alguna prueba, existía la posibilidad de acudir a la junta provincial de agravios o al propio Consejo de la Guerra ${ }^{131}$. Esta posibilidad de recurrir, realmente limitada, había sido recogida ya seis años antes por la legislación ${ }^{132}$, ya que "[...] el juicio de excepciones no debió ser muy eficaz en las décadas finales del siglo XVIII ya que fueron muchos los recursos a las juntas provinciales de agravios"133.

Una vez concluido el juicio de excepciones, "el Escribano de Ayuntamiento lo pondrá por diligencia a continuación de las excepciones que se alegaron por los mozos; por manera que conste en todo tiempo, quien alegó excepción y cual fue, si hubo o no contradicción, y el juicio que dio la Justicia acerca de ello". Para evitar fraudes, se señala que

"si se hallare que por omisión grave, fraude o colusión de Juez o de escribano se dejó de oír a alguno de los sorteables excepción que alegó, o contradicción que puso, o las pruebas que se presentaron en término del juicio para poder calificarla, y de ello resultó, que se incluyese o excluyese indebidamente alguno, incurrirán los susodichos irremisiblemente en perdimiento de su oficio, quedarán inhábiles para

\footnotetext{
130 Ordenanza de 27 de octubre de 1800 , art. 30.

131 Ordenanza de 27 de octubre de 1800, art. 31.

132 "Por Real Orden de 7 de agosto de 1794, inserta en circular de 20 de Diciembre de 96 , se sirvió S.M resolver, que todos los recursos de agravio, apelación o queja de las providencias de las Juntas Provinciales relativos a sorteos para reemplazo del Ejército, se substancien y determinen en el Consejo Supremo de la Guerra por las respectivas Salas a que corresponda según la calidad y naturaleza del negocio; a excepción de las cuestiones sobre goce de nobleza; en las cuales se observe la Ordenanza del año de 73, adicional a la de reemplazos" (Real Orden de 7 de Agosto de 1794).

133 BORREGUERO BELTRÁN, C., Reclutamiento militar por quintas en la España del siglo XVIII: orígenes del servicio militar obligatorio, p. 296 y ss. Señala Cristina Borreguero en la obra citada, que la Junta Provincial de Agravios arranca de la Real Ordenanza de 1762 ante el elevado número de quejas y la incapacidad del Consejo de Guerra por resolver todas ellas. Se encargaba de decidir los recursos presentados en su provincia contra los actos de la quinta.
} 
obtener otro de Justicia, y serán condenados en las costas y perjuicios que hayan ocasionado, y en cien ducados de multa para el Fisco de la Guerra"134.

También solicitó el Monarca que los justicias y las juntas de agravios que juzgasen las excepciones no debían caer en una "misericordia intempestiva" que dañaría la justicia ${ }^{135}$. Además, y como aviso final, se indicó que "[...] los mozos solteros que, siendo hábiles para el servicio, alegaren excepciones falsas, achaques 0 accidentes que realmente no padezcan $[\ldots] "$, cumplirían de forma obligatoria el servicio de las armas, adscribiéndose al cupo asignado a su localidad de residencia ${ }^{136}$.

e) Exenciones: el mantenimiento de los principios del Antiguo Régimen

El séptimo capítulo se centra en uno de los puntos más polémicos en cualquier legislación sobre reclutamiento, el caso de las exenciones, y a ellas se dedica el capítulo más extenso de toda la ordenanza. Se inició el mismo con una llamada de atención al "crecido número de exentos" y a las vejaciones que, por esta circunstancia, habían sufrido numerosos vasallos de la Corona. De ahí la necesidad una regulación coherente, si bien no se redujo demasiado el número de unas exenciones ciertamente elevadas. ${ }^{137}$ Muestra el texto "[...] un sistema de exenciones propio por completo del Antiguo Régimen, donde la pertenencia, por nacimiento u oficio, a

\footnotetext{
134 Ordenanza de 27 de octubre de 1800, art. 32.

135 Ordenanza de 27 de octubre de 1800, art. 33.

136 Ordenanza de 27 de octubre de 1800, art. 34.

137 Ordenanza de 27 de octubre de 1800, art. 35.
} 
un determinado estamento determinaba el nivel social $y$, en ocasiones, jurídico, de cada individuo"138.

Señalan los profesores Manuela Fernández y Leandro Martínez la existencia de tres grupos de exenciones:

"En primer lugar, se situarían las basadas en la clase social o condición del mozo: nobles, hidalgos, religiosos... Se trata, por tanto, de una clara muestra de la pervivencia, ya iniciado el siglo XIX, de los modelos sociales del Antiguo Régimen, donde nobles y religiosos disfrutaban de un estado privilegiado frente al resto de la sociedad. Un segundo grupo de exenciones lo constituirían aquellas donde la causa de la exclusión es la importancia para el Estado del oficio desempeñado por el mozo: maestros de escuela, maestros de determinadas industria, personal cualificado de las fábricas de armamento, personal de las torres y faros de vigilancia costera, etc. Por último, nos encontramos con exenciones relacionadas con las necesidades familiares del mozo, como era el caso de los hijos de viuda y de otros supuestos en los que el mantenimiento económico de la familia dependía del joven exceptuado"139.

Los primeros en quedar eximidos del sorteo son los hijosdalgo, enmarcados en esa primera categoría que establecen los dos autores citados previamente. Señala la ordenanza que ni los justicias ni las juntas de agravios podían atender a cuestiones de nobleza, ya que de los "derechos de sangre" solamente se pueden ocupar los tribunales competentes, es decir, las salas de hijosdalgo, Consejo de Navarra, audiencias y tribunales superiores ${ }^{140}$. El hidalgo que residiese fuera

\footnotetext{
138 FERNÁNDEZ RODRÍGUEZ, M. y MARTÍNEZ PEÑAS, L., "Problemática social en la legislación de reclutamiento decimonónica: exenciones, sustitución y redención", p. 321.

139 FERNÁNDEZ RODRÍGUEZ, M. y MARTÍNEZ PEÑAS, L., "Problemática social en la legislación de reclutamiento decimonónica: exenciones, sustitución y redención", p. 322.

${ }^{140}$ Ya por los artículos 11 y 17 de la Ordenanza de 17 de marzo de 1773, adicional de la de 3 de noviembre de 1770 para el reemplazo del Ejército, se eximía los hijosdalgo del servicio, y se prevenía lo siguiente: "Para que los recursos vayan a
} 
de su lugar de origen tenía que demostrar, ante las autoridades competentes, su condición nobiliaria antes del alistamiento o de la conclusión del juicio de excepciones. En caso de no hacerlo, quedaría sujeto al sorteo ${ }^{141}$.

Llama la atención como la ordenanza recoge el derecho del hidalgo a hacer valer su condición social para la exención, independientemente de su dedicación a algún oficio útil, clara muestra de una mentalidad ilustrada comprometida con el trabajo y que rechaza esa vieja idea nobiliaria de oficios viles: "[...] y prohíbo que, [...] a pretexto de que el hijodalgo viva aplicado a algún oficio, se le prive de la exención que le da su calidad"142. Sin embargo, a continuación muestra un regreso a la mentalidad propia de la época al alentar a la nobleza del reino a empuñar las armas, tal y como era su obligación medieval y origen de su condición privilegiada, en el caso de necesidad para el Estado o la Corona: "Pero no relevo a los hidalgos de mis reinos de la obligación de presentarse voluntariamente, cuando la necesidad del Estado lo requiera, y tenga yo por conveniente hacer de ellos llamamiento" ${ }^{143}$.

\footnotetext{
Ios Tribunales competentes, declaro, que las cuestiones sobre goce de nobleza son propios de las Salas de Hijosdalgo, Consejo de Navarra, Audiencias y Tribunales superiores, donde conforme a las leyes, cédulas y ordenanzas, se acostumbran ventilar y decidir estos juicios; y mando, que los Intendentes y Juntas de agravios no se embaracen en decidir estas controversias, antes se arreglen a la disposición literal del citado artículo 17; y que si los interesados no se hallaren en el goce y actual posesión de hidalguía, los remitan al Tribunal competente, para que acudan a acreditar esta calidad con audiencia y citación de mi Fiscal, y entre tanto les incluyan en el sorteo con reserva de su derecho; porque mi voluntad es, que en esto se proceda según el último estado y posesión, que es lo que únicamente se debe atender para el alistamiento, medida y sorteo. Las Justicias ordinarias y los Intendentes no han de tomar conocimiento en esta parte de otra cosa, que del último estado de posesión en los pueblos de la naturaleza del interesado; y el que se hallare domiciliado en otro dentro de la provincia, debe hacer constar su posesión al tiempo de formalizarse el alistamiento en la forma que disponen las leyes; pero no haciéndolo, quedará sujeto por entonces al sorteo, y salvo sus recursos a las Salas de Hijosdalgo para lo sucesivo", Real Ordenanza de 17 de Marzo de 1773, Madrid, Imprenta de Pedro Marín, 1773.

${ }^{141}$ Ordenanza de 27 de octubre de 1800, art. 35, 1.

142 Ordenanza de 27 de octubre de 1800, art. 35, 2.

143 Ordenanza de 27 de octubre de 1800, art. 35, 2.
} 
Además del ya extenso grupo nobiliario, el predominio de una mentalidad antiguorregimental y de los esquemas sociales propios del siglo XVIII se muestra en las exenciones existentes para el otro grupo privilegiado de la sociedad: el clero. Así, se declaró exentos del servicio los novicios de las órdenes religiosas que llevasen al menos seis meses ejerciendo como tal y los ministros y oficiales titulares de los tribunales de Inquisición ${ }^{144}$. En cambio, los clérigos tonsurados sí participarían en el sorteo.

Estos son los oficios que quedaban exentos del servicio por su especial interés en la formación de la población y el desarrollo científico del país, y que se enmarcan dentro de ese segundo grupo de exenciones que establecen los profesores Manuela Fernández y Leandro Martínez ${ }^{145}$ : maestros de primeras letras; doctores y licenciados de universidad; bachilleres que hubiesen recibido su grado en las facultades mayores de Teología, Cánones, Leyes y Medicina y que continuasen con sus estudios superiores; catedráticos de los colegios de Medicina y alumnos y colegiales que hubiesen obtenido el título de bachiller en tales centros; catedráticos de Física Experimental, Matemáticas, Química, Farmacia y Botánica que enseñasen en seminarios y facultades; así como directores y subdirectores de las academias de las Nobles Artes ${ }^{146}$. La exención no se extendía "[...] a los Maestros de otras casas de enseñanza", mientras que los Bachilleres tendrían que demostrar su condición presentando, en el juicio de excepciones, el título que así lo acreditase, así como una cédula jurada de su catedrático o maestro que confirmase su asistencia continuada a su universidad o colegio y su aplicación en el estudio ${ }^{147}$.

\footnotetext{
${ }^{144}$ Ordenanza de 27 de octubre de 1800, art. 35, 3 y 4.

145 FERNÁNDEZ RODRÍGUEZ, M. y MARTÍNEZ PEÑAS, L., "Problemática social en la legislación de reclutamiento decimonónica: exenciones, sustitución y redención", p. 324.

146 Ordenanza de 27 de octubre de 1800, art. 35, 5, 6 y 10.

147 Ordenanza de 27 de octubre de 1800, art. 35, 10.
} 
También las profesiones vinculadas al sector sanitario gozaron de una especial protección por parte de la Corona, al quedar exentos del servicio los médicos en su totalidad y los cirujanos romancistas, en este caso uno por villa y, en caso de haber varios, el que lo fuese del partido o el de mayor antigüedad. Similar disposición se estableció con los boticarios y albéitares, en este caso uno por cada villa y dos o tres en las ciudades ${ }^{148}$.

Además de estas profesiones relacionadas con el ámbito educativo y sanitario, existían otros oficios vinculados al gobierno y la administración del Reino y al Derecho que quedaron exentos de prestar el servicio, a saber: "[...] Alcaldes ordinarios, Regidores y Síndicos o Procuradores generales de las villas y ciudades"149, aunque se excluían otros oficiales de la administración y alcaldes de hermandad "por ser perjudicial tanta exención"150; "abogados, Relatores, Agentes Fiscales que sean Letrados; Escribanos de Cámara, de Ayuntamiento, los de Número que tuvieren la aprobación de mi Consejo, y los de Provincia; los Notarios de Poyo y de Número de los Tribunales eclesiásticos y Vicarías; los Alcaldes de las cárceles de Chancillerías y Audiencias; Ios Archiveros de Archivos Reales de dichos Tribunales, y los Catedráticos de Latinidad, a saber, los que están enseñando en las Universidades y Seminarios, o en las ciudades y Villas adonde hay Corregidor, Gobernador o Alcalde mayor, y tienen dotación de trescientos ducados a lo menos [... $]^{\prime 151}$; "[...] los correos de Gabinete nombrados por los Superintendentes general; a los dependientes de los correos marítimos que tengan la misma calidad; a doce conductores de valijas que tengan igual nombramiento para llevar la correspondencia por las carreras principales del Reino; a los maestros de postas; y a los oficiales de dicha renta, destinados de asiento en alguna oficina con dotación fija

\footnotetext{
148 Ordenanza de 27 de octubre de 1800, art. 35, 9.

149 Ordenanza de 27 de octubre de 1800, art. 35, 7.

150 Ordenanza de 27 de octubre de 1800, art. 35, 7

${ }^{151}$ Ordenanza de 27 de octubre de 1800, art. 35, 8.
} 
al servicio de ella $[\ldots]^{152}$; "[... Contadores, Tesoreros, Administradores, Guarda-almacenes, Comandantes de los resguardos, Secretarios de las Juntas Provinciales, Fieles y oficiales de número, o agregados con dotación fija en las oficinas de Contaduría, tesorería de Ejército o Provincia $[\ldots]^{153}$.

Señala este artículo 35 de la ordenanza que ya en 1799 se había iniciado una reforma para reducir y suprimir muchos oficios de la Hacienda pública, con los que se había reducido el número de exentos en esta contribución ${ }^{154}$. Sin embargo, continuaron siéndolo "[...] los Contadores, Tesoreros, Administradores, Guarda-almacenes, Comandantes de los resguardos, Secretarios de las Juntas Provinciales, Fieles y oficiales de número, o agregados con dotación fija en las oficinas de Contaduría, tesorería de Ejército o Provincia $[\ldots]^{\prime 155}$.

Nos quedaría por último analizar el tercer grupo de exenciones vinculada a las obligaciones familiares y necesidades económicas del mozo y del propio Estado. Se inicia este apartado concediendo la exención en el servicio para los mozos solteros cabezas de familia que tengan trabajo y la necesidad de mantener a su prole, independientemente de su dedicación laboral, ya sea en el campo, la artesanía o el comercio. Se justificó esta medida, amén de los graves problemas que supondría la marcha del progenitor para la familia en cuestión, por los perjuicios que se causaría a la economía del país: "[...] porque siendo cabezas de familia, podría quedarse en cualquiera de estos casos, si les tocase la suerte, sin persona que cuidase del sustento de ella, y la casa yerma en perjuicio del Estado"156.

\footnotetext{
152 Ordenanza de 27 de octubre de 1800, art. 35, 11.

153 Ordenanza de 27 de octubre de 1800, art. 35, 12.

154 Real Decreto de 25 de septiembre de 1799, Madrid, Imprenta Real, 1779.

155 Ordenanza de 27 de octubre de 1800, art. 12.

${ }^{156}$ Ordenanza de 27 de octubre de 1800, art. 35, 13.
} 
Se esgrimieron los mismos motivos para declarar exentos a los hijos únicos de viuda $o$ de padres pobres e impedidos que dependiesen del hijo para su sustento, así como los mozos cuyo padre tenga al menos sesenta años en el momento de alistamiento. También se concedió la exención para los hijos únicos de un padre impedido, aunque de situación acaudalada, siempre que "[esté] empleado en el manejo del caudal o la hacienda de su padre, siendo esto su destino y principal ocupación"157. Se aclara que se entendía por familia de hijo único: además de aquella que tuviese un solo descendiente varón, también lo sería considerada aquella formada por un hijo en edad de reclutamiento y otros hermanos menores de diecisiete años o hermanos con algún impedimento corporal que les impidiese cuidar del sustento de los padres ${ }^{158}$.

Continúa el capítulo de las exenciones con aquellas que se concedían buscando las prosperidad y el crecimiento económico del Estado o la defensa de intereses estratégicos del Reino, "queriendo combinar, cuanto a la exención de él [servicio], las artes y manufacturas esenciales con la agricultura, que es la primera y principal de todas, para que, sin perjuicio del servicio, no falten manos en ellas"159. Se incluían en este grupo a los maestros de la industria textil con título expedido por un gremio, impresores, maestros, empleados, facultativos y directores de las reales fábricas de pólvora, municiones, armas, fundiciones, minas y casas de Moneda; "[...] los maestros de instrumentos de matemáticas y Ciencias naturales; y también los de máquinas que sirven en las manufacturas, con tal que hayan obtenido del mi Consejo o Junta de Comercio despacho de calificación y aprobación, por la utilidad de sus inventos" $^{\prime 160}$. Para evitar engaños en sus propias reales fábricas, el monarca diseñó una especial vigilancia en este ámbito de jurisdicción

\footnotetext{
157 Ordenanza de 27 de octubre de 1800, art. 35, 14.

158 Ordenanza de 27 de octubre de 1800, art. 35, 14.

159 Ordenanza de 27 de octubre de 1800, art. 35, 17.

160 Ordenanza de 27 de octubre de 1800, art. 35, 17.
} 
real: "Y para que en cuanto a empleados facultativos y maestros de mis reales Fábricas y minas no haya fraude, mando a los Superintendentes, Gobernadores o Comisionados que por nombramiento o encargo mío cuidan principalmente de estos establecimientos, den lista puntual a las Justicias, y estas se las pidan, para que únicamente queden exentos los que llevo declarado, y no otros, sin fraude ni arbitrio alguno"161.

Se incluían en esta condición de exentos a los comerciantes al por mayor matriculados en los consulados de comercio o Ayuntamiento donde no existiesen los primeros, a los cambistas de letras, los propietarios de navíos que actuasen en un puerto peninsular o colonial, y a los propietarios de al menos cuatro telares. La exención se extendía para un hijo que estuviese trabajando en el negocio hasta la edad de veinticinco años ${ }^{162}$.

Relacionado con las necesidades militares del reino existían nuevas exenciones vinculadas a la cría de caballos: el hijo mayor de veinticinco años cuya familia mantuviese, desde tres años antes de la publicación del sorteo, cuatro yeguas y un caballo o dos caballos destinados a la monta, quedaría exento. Si el cabeza de familia poseyese doce yeguas o tres caballos "padre", la exención se produciría independientemente de la edad del joven. Si poseyese cuatro yeguas más, otro de sus hijos podría quedar exento. Lo mismo sucedía para el mozo o viudo sin hijos propietario de al menos seis yeguas o tres caballos "padres"163.

También los hijos de labradores tenían la posibilidad de evitar el sorteo, aunque de forma muy limitada. Se justificó esta opción en que "[...] el fin principal de esta ordenanza se encamina al alivio de los labradores por medio de una distribución justa de la carga del servicio, con lo cual se fomenta aquella clase, y una población

\footnotetext{
161 Ordenanza de 27 de octubre de 1800, art. 35, 17.

162 Ordenanza de 27 de octubre de 1800, art. 35, 18.

163 Ordenanza de 27 de octubre de 1800, art. 35, 23.
} 
robusta y ocupada que es el nervio y fuerza del Estado". Así, se declararon exentos del reemplazo aquellos jóvenes oriundos de las provincias del interior peninsular que viviesen y trabajasen con su familia tierras, propias o ajenas, situadas a dos mil varas de distancia de su localidad de residencia ${ }^{164}$. Esta es la única excepción que existía para el colectivo popular más numeroso, el campesino.

Mostrando una particular preocupación por la defensa de las costas en un contexto internacional inestable, las autoridades declararon exentos del servicio a los jóvenes que residiesen con sus padres torreros, encargados de vigilar las torres y atalayas que protegen las costas ${ }^{165}$, así como "[...] los individuos de maestranza de los tres Departamentos de Marina, carpinteros de ribera, calafates, toneleros, y demás dependientes empleados en la construcción, carena y armamento de los buques de guerra, y los marineros matriculados para el servicio de la Armada"166.

Fuera de las exenciones otorgadas por motivos de interés económico o estratégico del Estado, también se especificaron otras posibles exenciones vinculadas a situaciones familiares particulares. Así, para el caso de aquellas familias que tuviesen al menos dos hijos entre los diecisiete y treinta y cinco años, cuando uno de los hermanos obtuviese la suerte del soldado en el sorteo, los otros quedarían exentos. En el supuesto de que dos hermanos residiesen en localidades distintas, y ambos saliesen elegidos en el sorteo, quedaría exento aquel que viviese con sus padres o contribuyese con su manutención "[...] y cuando en este hecho hubiere duda, quedará al arbitrio justo del padre la elección, y no queriendo elegir, lo decidirá la suerte"167. Asimismo, quedarían exentos aquellos mozos

\footnotetext{
164 Ordenanza de 27 de octubre de 1800, art. 35, 23.

165 Ordenanza de 27 de octubre de 1800, art. 35, 24.

166 Ordenanza de 27 de octubre de 1800, art. 35, 25.

167 Ordenanza de 27 de octubre de 1800, art. 35, 19.
} 
que hubiesen contraído matrimonio hasta quince días antes de la publicación de la orden del sorteo en la capital de provincia ${ }^{168}$.

Para el caso de los veteranos del Ejército también existían exenciones: quedaban fuera del sorteo los retirados con licencia y los quintos que ya hubiesen prestado servicio al ser designados en sorteos anteriores ${ }^{169}$.

El elevado número de exentos impide hablar todavía de la igualdad jurídica en las obligaciones de los ciudadanos que defiende el liberalismo. Las exenciones estamentales manifiestan el predominio de una mentalidad propia del Antiguo Régimen e impiden hablar de una legislación moderna acorde con las tendencias revolucionarias predominantes en Francia.

Señalar por último que este texto legal prohibió expresamente la sustitución o "compra de otro hombre", a pesar de estar contemplada en normativas anteriores. La motivación reside en la disminución de la calidad de las tropas y en el posible perjuicio que se cause a las familias: "[...] la experiencia ha mostrado de cuánto perjuicio ha sido o las provincias y familias este medio ruinoso, y también a mi servicio y buena calidad de las Tropas, por lo poco que se puede esperar de quien se vende para servir por otro $[\ldots]^{170}$. Sin embargo, sí deja la norma una pequeña puerta abierta para casos excepcionales que serían resueltos por el propio Monarca. ${ }^{171}$

\footnotetext{
168 Ordenanza de 27 de octubre de 1800, art. 35, 20.

169 Ordenanza de 27 de octubre de 1800, art. 35, 21.

170 Ordenanza de 27 de octubre de 1800, art. 46.

171 "Todavía si algún caso ocurriere de tanta urgencia, en el cual, por evitar la ruina de una familia, u otro perjuicio de consecuencia hacia el bien público, conviniere, que el que salió soldado no continúe en el servicio, reservo esta declaración en mí, para que, oído el Inspector, y demás que tenga por oportuno, acuerde lo conveniente a favor del servicio y de la familia del sorteado" (Ordenanza de 27 de octubre de 1800, art. 46).
} 
f) El sorteo: la supuesta aleatoriedad de un acto marcado por las exenciones

Aquellos que no gozasen de exención participarían en el sorteo de quintos, a saber: los que no gozasen de la condición nobiliaria, los hijos de la oficialidad militar, los alcaldes, síndicos o procuradores menores de veinticinco años, los alcaldes de Hermandad y alguaciles, clérigos tonsurados, "los familiares de la Inquisición, Ministros y Hospederos de Cruzada, Hermanos y Síndicos de Órdenes Religiosas, Comisarios y Cuadrilleros de la hermandad", los hermanos de obispos y arzobispos, los bachilleres en Filosofía y Gramáticos (profesiones no útiles), sangradores y barberos, "los Procuradores, Receptores, Escribanos Reales, Agentes, Solicitadores de pleitos; escribientes y oficiales de Escribanías y Notarías, Secretarías, Juntas, Asientos y otras oficinas de provisiones; y mancebos de comerciantes", dependientes de hospitales, "los empleados y dependientes de cualquiera de las rentas Reales que no quedan comprendidos en los siguientes XI y XII del citado artículo, como postillones, conductores particulares de valijas destinados por los pueblos, guardas de a pié 0 de a caballo, caseros, sin sueldo de mi Real Erario, de Administraciones y de Tesoreros; y los oficiales que no están con dotación fija sirviendo en oficina de la respectiva Renta, como los agregados sin sueldo, meritorios y entretenidos", músicos, criados, viudos sin familia, comerciantes, fabricantes y artesanos no recogidos en el capítulo de exenciones, milicianos urbanos, criadores de yeguas, pastores trashumantes, "los pastores y los individuos de la Cabaña Real de la carretería; los guardas y los celadores de los montes del Reino, así de lo interior como de Marina" y los expósitos $^{172}$. Las exenciones nobiliarias, propias del Antiguo Régimen, ponían en cuestión la supuesta aleatoriedad de un sorteo que

172 Ordenanza de 27 de octubre de 1800, art. 38. 
presumiblemente afectaría a toda la población. De esta forma, la obligación de cumplir con el Ejército dejaba fuera al grupo cuya función social era precisamente la militar.

Los capítulos 9, 10 y 11 regulan todo lo concerniente al sorteo. El acto se celebraría una vez que hubiese finalizado el juicio de excepciones. En él, el síndico o, en su defecto, un regidor del Ayuntamiento, procedería al encantaramiento, es decir, introduciría, escrito en una cédula "arrollada" en una bola, el nombre de los mozos sorteables en una bolsa o cántaro, previa lectura del mismo. No se incluirían en la bolsa o cántaro el nombre de los prófugos y huidos. En otra bolsa o cántaro similar, se introducirían tantas cédulas metidas en bolas como mozos sorteados, conteniendo algunas la palabra "soldado" y quedando otras en blanco. El número de cédulas que contuviesen la palabra "soldado" dependería del número de jóvenes asignados al cupo del Ayuntamiento en cuestión. Una vez introducidas las bolas, dos niños se encargarían de sacar las mismas de cada cántaro o bolsa, una por una, asignando a cada mozo bien la cédula con el concepto "soldado", bien la cédula en blanco. Todos los jóvenes se podrían acercar a observar sus cédulas para comprobar la legalidad del acto, mientras que el escribano redactaría los resultados del sorteo en los autos de alistamiento ${ }^{173}$.

Se insiste en los artículos 37 y 38 en la necesidad de un sorteo limpio, escrupuloso y que no dejase lugar a dudas, "[...] por la consideración y amor que me merecen mis vasallos, y el deseo que tengo de que no se les agravie". Encomienda el Monarca a su Consejo de Guerra la vigilancia de los sorteos y de la actuación de los justicias y escribanos, así como de los eclesiásticos que asistiesen al mismo, insistiendo en "[...] que en ningún caso remitan de la severidad

${ }^{173}$ Ordenanza de 27 de octubre de 1800, art. 36. 
conveniente para castigar cualquier dolo, omisión y culpa grave que cometiesen los funcionarios públicos ${ }^{174}$.

Una vez regulado lo concerniente al sorteo, el capítulo décimo se encargó de la posibilidad de anular o repetir el mismo. Ningún sorteo sería declarado nulo por la inclusión indebida de algún mozo, pero si algún joven que debería estar incluido no lo estuviere, en esta ocasión se declararía nulo y se repetiría el acto tres días después de que los justicias recibiesen la orden de hacerlo ${ }^{175}$. Incluso

"[...] la anulación de los sorteos se constituía en un método para retrasar la entrega de los cupos. A veces, el conocimiento de la existencia de alguna irregularidad era ocultada por el mozo a la espera del resultado del sorteo. Si éste le era desfavorable realizaba la reclamación [...] con lo que se tenía, inevitablemente, que realizar la repetición del mismo. Si por el contrario la suerte le era favorable se imponía el silencio" ${ }^{176}$.

Vinculado al acto del sorteo, el artículo 40 hace una breve referencia a la cuestión de los quebrados, posteriormente llamado sorteo de décimas. Según Cristina Borreguero, "el término quebrado indica exactamente el sistema que llevaba a cabo el contador para repartir algunos mozos sobrantes del cupo Provincial que faltaban de incluir en el reparto"177. Cuando, una vez repartidos por las localidades de una provincia los mozos que debían acudir al Ejército en función de su población, quedaba alguna plaza por cubrir, se imponía un reparto de quebrados entre localidades ${ }^{178}$. El citado

\footnotetext{
${ }^{174}$ Ordenanza de 27 de octubre de 1800 , art. 37 y 38.

175 Ordenanza de 27 de octubre de 1800, art. 39.

176 JIMÉNEZ GUERRERO, J., El reclutamiento militar en el siglo XIX: las quintas en Málaga (1837-1868), p. 133.

177 BORREGUERO BELTRÁN, C., Reclutamiento militar por quintas en la España del siglo XVIII: orígenes del servicio militar obligatorio, p. 177.

178 JIMÉNEZ GUERRERO, J., El reclutamiento militar en el siglo XIX: las quintas en Málaga (1837-1868), p. 114.
} 
artículo 40 regula esta cuestión, debiéndose realizar el sorteo entre todos los jóvenes en situación de posible recluta de las localidades que se viesen afectadas por esta situación. El mismo se celebraría en el pueblo decidido por el intendente, aunque también existe la posibilidad de que "[...] los mismos pueblos conviniesen en sortear entre sí a quién ha de tocar el quebrado"179.

Lógicamente toda administración que busque la eficacia en su gestión debe dejar constancia expresa por escrito de un acto de tanto impacto social y de suma importancia para la seguridad interior y el prestigio internacional del Estado. Por este motivo, "[...] de todos los autos del sorteo, a saber, alistamiento, comprobación de él, medida, exclusión de los notoriamente inútiles, diligencia de haber citado a los mozos para el juicio de excepciones, lectura a presencia de ellos en toda esta ordenanza, excepciones y contradicciones puestas, y juicio que se dio sobre ellas, encantaramiento de los sorteables, y finalmente del sorteo mismo y nota de los prófugos $[\ldots]^{\prime 180}$, se expedirían testimonios por escrito de manos del corregidor del partido, que lo enviará al intendente de la provincia. Asimismo, el corregidor elaboraría otro documento con los nombres de los mozos que salieron en suerte en un plazo máximo de quince días ${ }^{181}$.

Con estos testimonios remitidos por los pueblos los intendentes elaborarían un informe sobre la situación de su provincia en materia de reclutamiento, donde se indicarían, en cuatro columnas, los siguientes aspectos: nombre de la localidad, número de mozos alistados en cada una, jóvenes que quedaron exentos y los que tienen la obligación de servir en el Ejército de la Monarquía. Este informe se remitiría al ministerio de la Guerra y un duplicado a la Intendencia del Ejército en su provincia correspondiente ${ }^{182}$.

\footnotetext{
179 Ordenanza de 27 de octubre de 1800, art. 40.

180 Ordenanza de 27 de octubre de 1800, art. 40.

181 Ordenanza de 27 de octubre de 1800, art. 41.

182 Ordenanza de 27 de octubre de 1800, art. 42.
} 
Los capítulos 12 y 13 atendieron al cumplimiento de las obligaciones de los mozos. En primer lugar, se prohibió a los mozos que tuviesen la obligación de incorporarse a filas exigir gratificaciones a aquellos que quedaron en el sorteo libres de la suerte del soldado, y se exigió a los justicias que vigilasen con celo esta circunstancia, aunque sí que se admitían gratificaciones voluntarias ${ }^{183}$. También se prohibió el internamiento en prisión de los mozos elegidos en el sorteo, ya que su honradez había quedado suficientemente demostrada con la asistencia al acto. Era ésta una práctica habitual para evitar la huída de los mozos designados soldados ${ }^{184}$. Se solicitó asimismo a los mozos que hubiesen acudido al sorteo el respeto a los vecinos del pueblo y que no perturbasen el orden público. ${ }^{185}$ Por último, el capítulo número 12 estableció el número de años que habían de cumplir en el Ejército los futuros soldados, un total de ocho años completos ${ }^{186}$.

g) La lucha contra el prófugo

Se centran los capítulos 14 y 15 en una de las cuestiones más delicadas en todo el proceso de reclutamiento, por ser una constante a lo largo de todo el siglo XIX, la lucha contra el prófugo. La ordenanza concretó qué actitud se consideraba delictiva y cual no. Así, se entendía por prófugo todo aquel que le había tocado la suerte del soldado y no había acudido el día señalado para ir a servir a su plaza; aquel que saliese de su localidad de residencia sin la autorización correspondiente cuando ya se hubiese publicado la orden de reemplazo en la capital de provincia; aquel que, sin haber

\footnotetext{
183 Ordenanza de 27 de octubre de 1800, art. 43.

184 MARTÍNEZ RUIZ, E., "La celebración de quintas, una cadencia temporal en la España del Antiguo Régimen", P. 222.

185 Ordenanza de 27 de octubre de 1800, art. 44.

186 Ordenanza de 27 de octubre de 1800, art. 45.
} 
abandonado su lugar de residencia, no se presentase a los distintos actos que se celebrasen a lo largo del proceso; y aquel que, "[...] habiéndole tocado suerte de soldado, se fugare u ocultare, y no se presentase para ir a servir su plaza $[\ldots]^{\prime \prime 187}$.

Eran los justicias de cada localidad los encargados de denunciar al prófugo, fuese o no apto para el servicio, por no asistir al acto del sorteo, mientras que el escribano lo debía formalizar en la diligencia del sorteo. Sería la justicia quien lo declararía en rebeldía y, una vez capturado, se le impondría la pena, en el caso de ser apto para el servicio, de permanecer en el Ejército durante dieciséis años y pagar las costas del proceso. En el supuesto de que fuese considerado no apto, se le condenaría al pago de las costas y de una multa de 30 ducados, destinados a su captor o al fisco de la guerra en su defecto. En el caso de que un prófugo se presentase voluntariamente a la Justicia en un plazo de tres días desde que fuese declarado como tal, las penas serían más benignas: tendría que prestar "solo" servicio por los ocho años reglamentarios si fuese considerado apto, y pagar las costas del juicio y una multa de diez ducados si no lo fuese ${ }^{188}$.

Las penas se extendían hacia aquellos que hubiesen colaborado, auxiliado o encubierto al prófugo: si fuese su padre, pariente o amo se le impondrá una multa de 200 ducados, el pago de las costas $y$, en el supuesto de ser considerados aptos para el servicio, cumplirían los ocho años pertinentes en lugar del prófugo. En el caso de ser un funcionario del Ayuntamiento, se le inhabilitaría para el puesto y pagaría las costas y 100 ducados de multa, que se elevaban a doscientos en el caso de que el funcionario fuese padre del prófugo. Cualquier otra persona que ayudase o encubriese al prófugo se vería obligado a realizar la prestación militar por ocho años en su sustitución, y si fuese considerado no apto, pagaría 100 ducados de multa y las costas del proceso. En el supuesto de que un 
prófugo apto para el servicio se presentase voluntariamente para su prestación, sus sustitutos serían liberados y se les concedería licencia para regresar a su domicilio, si bien no se produciría una reducción del tiempo de prestación para el prófugo que se hubiese presentado de forma voluntaria. Por último, en el caso de que sea un gremio o comunidad quien auxiliase al prófugo, sería el Consejo de Guerra el encargado de decidir la actuación a seguir y las posibles penas y multas que se impongan ${ }^{189}$.

Quedaba por conocer como se iban a cubrir esas plazas asignadas en el reparto de cupos a una localidad en cuestión cuando había prófugos que habían huido antes de la celebración del sorteo. Cuando se produjese esta situación, se sortearían nuevos mozos hasta completar el contingente. Estos soldados quedarían libres en el momento en que el prófugo decidiese regresar voluntariamente ${ }^{190}$. En el caso de las plazas que iban a ser cubiertas por jóvenes que, habiéndoles tocado la suerte del soldado en el sorteo, hubiesen huido, se procedería a su reemplazo a través de un nuevo sorteo entre los jóvenes que hubiesen participado en el proceso anterior. Si el prófugo regresaba voluntariamente, "[...] quedará el mozo sorteado en lugar suyo libre del servicio por aquella vez $[\ldots]^{\prime 191}$. Como recompensa para aquellos que hubiesen colaborado en la búsqueda o a través de una simple denuncia "cierta" sobre el paradero de un prófugo, se les concedería la exención del servicio a él mismo a algún pariente suyo "[...] encantarado o sorteado $[\ldots]^{192}$.

\footnotetext{
189 Ordenanza de 27 de octubre de 1800, art. 50.

190 Ordenanza de 27 de octubre de 1800, art. 52.

191 Ordenanza de 27 de octubre de 1800, art. 53.

192 Ordenanza de 27 de octubre de 1800, art. 54.
} 
h) Conducción de los reclutas a su destino

Los tres siguientes capítulos de la Ordenanza de 1800 se centran en los primeros pasos que han de dar y el trato que han de recibir los recién llegados al Ejército como soldados sorteados.

En concreto, el capítulo 16 estableció las actuaciones a realizar para asistir y conducir a su destino, la caja de reclutas ${ }^{193}$, a los soldados sorteados. Se trata de la última de las operaciones de la recluta que afectaban a los Ayuntamiento. Así, en su mismo pueblo de residencia se le tomaría la filiación y se le gratificaría con dos reales diarios de los caudales públicos municipales hasta que fuese entregado al oficial de la caja. Al día siguiente del sorteo, los mozos marcharían hacia la caja particular del corregimiento acompañados por un comisionado, una autoridad del consistorio, que les asistiría en su viaje. Harían el mismo tránsito los mozos que participaron en sorteo con ellos y no habían recibido la suerte del soldado para que pudiesen comprobar la legalidad del proceso de admisión o reprobación de los sorteados en su caja correspondiente. El comisionado y los jóvenes acompañantes recibirían un jornal de los propios del concejo, y llevarían de vuelta a los mozos desechados. Una vez hubiesen regresado a su lugar de origen, se procedería a un nuevo sorteo con el objeto de cubrir los puestos de los jóvenes que hubiesen sido rechazados en la misma caja ${ }^{194}$.

El mismo día de llegar a la caja de su corregimiento, un oficial destinado al efecto tallaría a los soldados, declarándolos aptos o

\footnotetext{
193 "Era esta una actuación que comportaba numerosos problemas que se generaban no sólo por los retrasos que en su cumplimiento se producían [...], sino también por los gastos que ocasionaban, así como por las dificultades que originaban tanto el traslado de los mozos desde los pueblos hasta la capital, como su alojamiento" (JIMÉNEZ GUERRERO, J., El reclutamiento militar en el siglo XIX: las quintas en Málaga (1837-1868), p. 133).

194 Ordenanza de 27 de octubre de 1800 , arts. 55 y 56.
} 
desechados $^{195}$. Para otorgar una mayor legalidad a este acto de mediciones y reconocimiento, asistiría al mismo un comisionado de Guerra y en su defecto un escribano del Ayuntamiento ${ }^{196}$. Ya hemos indicado que los mozos desechados regresarían junto al comisionado a su lugar de residencia y se procedería a realizar un nuevo sorteo para cubrir su vacante.

Este oficial de Guerra tenía que expedir un recibo al comisionado acompañante de los quintos donde se indicaba el motivo de su rechazo a alguno de ellos, sirviendo este documento como prueba en caso de abuso o reclamación. En el caso de que este oficial "[...] por ridículos reparos [...] desechare algún mozo, o se verificare malicia o fraude en el Oficial aprobante, con abuso de la confianza de su Comisión y de su honor, se la castigará severamente según la calidad del exceso, privándole, si lo mereciere, de su empleo $[\ldots]^{\prime 197}$.

Una vez tallados y comprobada la salud de los mozos, el capítulo 17 reguló las praxis a seguir una vez que el mozo ingresase en la caja. En primer lugar, el oficial que se hubiese hecho cargo del sorteado recibiría 60 reales para comprar zapatos, medias y camisas como vestuario del recluta hasta que llegase al regimiento al que había sido destinado y recibiese su vestimenta oficial. Una vez que el soldado fuese entregado en su caja, se consideraría efectivo "[...] para el abono de todos sus goces [...]", y el oficial certificaría en un documento esta circunstancia ${ }^{198}$. Desde el momento del ingreso, los oficiales destinados a las cajas particulares, coordinados por un oficial de la caja general, serían los encargados de recibir, reconocer, socorrer e imponer la disciplina entre los sorteados. Asimismo, el

\footnotetext{
195 "Lo habitual era que se descubrieran numerosas deficiencias, lo que ciertamente demostraba la existencia de irregularidades a la hora de calificar a los mozos como aptos para el servicio" (JIMÉNEZ GUERRERO, J., El reclutamiento militar en el siglo XIX: las quintas en Málaga (1837-1868), p. 178).

196 Ordenanza de 27 de octubre de 1800, art. 57.

197 Ordenanza de 27 de octubre de 1800, art. 57.

198 Ordenanza de 27 de octubre de 1800 , arts. 58 y 59.
} 
oficial de la caja general sería el encargado de informar de todo lo relativo a la recepción de los reclutas al intendente de la provincia ${ }^{199}$.

Se dedica el capítulo 18 a señalar qué actuaciones había de seguir la oficialidad a la hora de conducir a los reclutas a sus respectivos regimientos. Comienza expresando las virtudes de que "[...] los sorteados de cada provincia o partido [fuesen destinados] a un mismo Regimiento, porque de esta suerte militarán con más gusto bajo unas propias banderas, por conformarse más los genios y costumbres; se auxiliarán recíprocamente, y podrán usar juntos de licencia en tiempos de paz, con más utilidad de las provincias y la suya propia $[\ldots]^{\prime 200}$. Por ello, se ordeno al Inspector General de Infantería que los mozos de una procedencia común o cercana fuesen destinados, siempre que se pudiese, a un mismo regimiento. Una vez distribuidos por regimientos en función de las necesidades militares y del lugar de origen, un grupo de oficiales conducirían a los mozos a sus destinos respectivos ${ }^{201}$. En este tránsito los reclutas deberían cobrar los 2 reales diarios expresados anteriormente, y debían ser tratados "[...] con el mayor cuidado [...]"202. En el caso de que algún joven intentase desertar en el transcurso del viaje, se vería obligado a cumplir dieciséis años de servicio, el doble de lo estipulado en la ordenanza. Si alguno de los soldados causase algún desorden en el camino, responsables de ello serán los oficiales encargados de su custodia, que recibirían el castigo correspondiente por falta u omisión ${ }^{203}$.

\footnotetext{
199 Ordenanza de 27 de octubre de 1800, art. 60.

200 Ordenanza de 27 de octubre de 1800, art. 61.

201 Ordenanza de 27 de octubre de 1800, arts. 61 y 62.

202 Ordenanza de 27 de octubre de 1800, art. 62.

203 Ordenanza de 27 de octubre de 1800, arts. 63 y 64.
} 
i) Gratificaciones a los reclutas: el intento de hacer más atractivo el servicio en el Ejército

Se ocupa el capítulo 19 de la ordenanza de las gratificaciones que habían de cobrar los reclutas, así como de sus permisos y el trato que habían de recibir por parte de la oficialidad, con el objetivo de hacer más atractivo el servicio de las armas ${ }^{204}$. Una vez cumplido el primer año de servicio, tendrían los soldados, en tiempos de paz, cuatro meses de permiso al año durante los meses de verano para poder atender sus tareas agrícolas. En el caso de que un recluta necesitase presentarse en su lugar de residencia por asuntos propios, siempre que fuesen justificados, se le podría conceder este permiso en meses distintos a los del verano ${ }^{205}$. También insistió el texto en el buen trato que habían de recibir los soldados, "[...] con la distinción correspondiente a la profesión honrosa de las armas, porque se precien de ella, y del mérito inmortal que se granjean los bravos defensores de la religión y de la Patria"206.

Se contempló asimismo la posibilidad de ascenso en el escalafón militar, recibiendo además recompensa monetaria "[...] para su mayor decencia $[\ldots]^{\prime 207}$ : en el caso de que un recluta ascienda a cabo recibirá 60 reales, y si lo hace a sargento 120, siempre a cuenta del regimiento ${ }^{208}$. Una vez que el sorteado cumpliese sus ocho años de servicio en el Ejército, recibiría "[...] todos sus alcances de masita, el importe de dos meses de pan $y$ prest, y dos tercios de la gratificación que hubiere devengado; y también se le dejará llevar el vestuario [... $]^{\prime 209}$.

204 PUELL DE LA VILLA, F., El soldado desconocido: de la leva a la "mili" (17001912), p. 178.

${ }^{205}$ Ordenanza de 27 de octubre de 1800, art. 65.

206 Ordenanza de 27 de octubre de 1800, art. 66.

207 Ordenanza de 27 de octubre de 1800, art. 66.

208 Ordenanza de 27 de octubre de 1800, art. 67.

${ }^{209}$ Ordenanza de 27 de octubre de 1800, art. 68. 
El capítulo 20 por su parte ofreció a los reclutas nuevas ventajas una vez que finalizasen su prestación militar, buscando salidas profesionales para un colectivo en una situación laboral y personal muy complicada tras ocho años de ausencia de su lugar de residencia. Por ello, y aludiendo a una legislación anterior, se ofrecían numerosos puestos de trabajo para los licenciados en la administración pública, preferentemente local, y en la Hacienda Real $^{210}$. También solicitó el Monarca que, de forma preferente, se le presentasen soldados licenciados para cubrir las vacantes en los cargos administrativos, y de esta misma forma debían actuar sus secretarios de Estado y de Despacho ${ }^{211}$. Con el objeto de no menoscabar el futuro del soldado una vez hubiese finalizado su prestación, y también remitiéndose a una legislación anterior ${ }^{212}$, se concedió a éstos la capacidad de poder solicitar licencia para obtener una capellanía en el estamento eclesiástico o un título de nobleza si hubiesen recaído sobre ellos durante su servicio, "[...] porque la milicia, lejos de privar al soldado de los derechos de sangre, los recomienda y ennoblece" ${ }^{213}$.

\footnotetext{
210 "Por Real Decreto de 27 de agosto de 1787, Real Orden de 13 de Abril y Real Decreto de 25 de septiembre de 1799, (ley 4, tit. 9) se ha prometido a los soldados, que sirvieren honradamente por el tiempo que señalan, varios empleos en mi Real Hacienda; y desde entonces se ha tenido en cuenta de atender el mérito de los que siguen la carrera militar, para colocarlos en varios empleos de administración y recaudo de ella" (Ordenanza de 27 de octubre de 1800, art. 69).

211 "[...] $Y$ por cuanto el soldado que sirvió con honradez a la Patria, es un ciudadano benemérito de ella, y digno de galardón con preferencia a los que permanecen a cubierto, mientras el expone su vida al frente del enemigo; quiero, que no solamente se observen desde hoy en adelante los expresados decretos, pero también que por todos los ramos sean atendidos, y se me propongan, con preferencia a otros, los soldados que sean a propósito para los empleos que vacaren en cada uno [...]" (Ordenanza de 27 de octubre de 1800, art. 69).

212 Real resolución de 28 de agosto de 1795, Madrid, Imprenta Real, 1795; Real Resolución de 17 de septiembre de 1799, Madrid, Imprenta Real, 1779.

${ }^{213}$ Ordenanza de 27 de octubre de 1800, art. 70.
} 
j) Sistemas de control del proceso: la lucha contra el fraude

La aplicación de una normativa que obligaba a muchos jóvenes a separarse de sus familias y sus trabajos durante ocho largos años dio lugar a todo tipo de fraudes, sobornos y engaños, con el objetivo de evitar el servicio ${ }^{214}$. A ello se unía la injusticia inherente a la propia norma que dejaba exentos a numerosos colectivos sociales y al estamento supuestamente encargado de empuñar las armas. Para evitar estos engaños la ordenanza, en su capítulo 21 , trató de establecer sistemas de vigilancia y control de todo el proceso. Así, para velar por la correcta ejecución de las distintas fases del reclutamiento se ordenó la formación en cada intendencia de una junta compuesta por el capitán o el comandante general y el auditor de Guerra. En Navarra esta junta la formarían el Virrey el Consejo del Reino, en Vizcaya el Corregidor y un oficial de nombramiento regio, en Guipúzcoa el Corregidor y el Comandante General de la provincia, en Álava el Diputado General junto a un oficial designado por el rey, en Asturias el Regente de la Audiencia y un oficial, en Santander el Alcalde Mayor y un oficial, en Andalucía el Capitán General y un Comisario de Guerra, mientras que en Granada formarían parte de la junta el Capitán de la costa de Granada y un comisario de Guerra ${ }^{215}$.

El cometido de estas juntas era variado: controlaban todo el proceso, decidían sobre reclamaciones o agravios e imponían multas y penas a aquellos que hubiesen violado lo estipulado en la ordenanza en un plazo máximo de veinte días. Así, tal y como indica la norma,

\footnotetext{
214 "La ignorancia, mala voluntad, contemplación y soborno podrían interponerse para viciar la exacta ejecución de esta ordenanza" (Ordenanza de 27 de octubre de 1800 , art. 71).

215 Ordenanza de 27 de octubre de 1800, art. 71.
} 
"[...] en estas Juntas se han de oír los recursos de los quejosos y agraviados por las Justicias en los actos del sorteo; y también los que se dieren de la omisión, extorsiones, y cualquier otro desorden de las mismas Justicias y Escribanos, con que se haya defraudado el servicio o vejado a mis vasallos; sobre todo lo cual recibirán informaciones sumarias, y oyendo de plano a los interesados, procederán las Juntas a declarar lo que sea justo, y a imponer multas y penas a los culpados, arreglándose a lo que va prevenido en la ordenanza"1216.

Admitió la ordenanza la posibilidad de apelar a una instancia superior las decisiones de estas juntas, en concreto al Consejo de Guerra, si bien ambos organismos, juntas y Consejo, no podían decidir en cuanto al goce de títulos nobiliarios, ya estas cuestiones eran competencia de las Salas de Hijosdalgo de las Chancillerías y de otros tribunales. ${ }^{217}$

Finaliza la ordenanza de con dos capítulos complementarios: por una parte se señaló la posibilidad de acudir a los otros dos métodos de reclutamiento para nutrir de efectivos al Ejército, ya en franca decadencia, propios de la Edad Moderna: reclutas voluntarias $^{218}$ y levas de vagos y ociosos ${ }^{219}$; y por otra se derogaron las normativas anteriores en materia de reclutamiento, teniendo vigencia en exclusiva la aprobada en octubre de $1800^{220}$ :

\footnotetext{
${ }^{216}$ Ordenanza de 27 de octubre de 1800, art. 72.

217 Ordenanza de 27 de octubre de 1800, art. 72.

218"Ordeno, que continúen con actividad, como hasta aquí, las reclutas voluntarias para facilitar el reemplazo de mis tropas, procurando sean de gentes honradas, no criminosas, y tales que puedan y deban participar del honor a que son acreedores los sorteados; con lo cual habrá menos reemplazos que pedir, y no padecerá el mérito y concepto que debe tener el servicio militar" (Ordenanza de 27 de octubre de 1800 , art. 73).

219 "También se usará del medio de las levas en capitales y pueblos de numeroso vecindario, para purgarles de gentes ociosas y baldías, [...] pero de tal modo en la aplicación a las armas, que bajo mis banderas solamente militen el valor y la honradez, para mantener en vigor la principal fuerza de mi Ejército" (Ordenanza de 27 de octubre de 1800, art. 73).

${ }^{220}$ Ordenanza de 27 de octubre de 1800, art. 74.
} 
"[...] Y por cuanto en ella se contienen todas las reglas que quiero se observen en lo sucesivo en el reemplazo de mi Ejército, derogo y anulo, usando de mi poderío Real en esta parte, las ordenanzas anteriores de 3 de noviembre de 1770 y 17 de marzo de 1773, y las posteriores resoluciones que con ocasión de ellas se han expedido en diversos años para declaración de varias dudas, y otros cualquier decretos y providencias generales o particulares, aunque de ellas no se haga aquí mención, en cuanto sean contrarias a esta ordenanza $[\ldots]^{\prime \prime}$.

La limitada aplicación de la norma y sus añadidos

Según Puell de la Villa, Godoy siempre desconfió de la viabilidad de aplicar su propia ordenanza ${ }^{221}$. Estas circunstancias, junto a la invasión de las tropas napoleónicas en 1808, provocaron que la norma no empezase a aplicarse de forma regular hasta el regreso de Fernando VII en 1814. El monarca deseado se valió de este texto legal a la hora de nutrir de soldados a su Ejército y pasó por alto la legislación revolucionaria aprobada por las nuevas autoridades del país durante su ausencia en Bayona. Sí que se aplicó la norma, aunque de forma limitada, en los últimos años de la Guerra de Independencia, mientras los diputados gaditanos discutían una nueva ley sobre la materia, nunca aprobada. Lógicamente, en los años del Trienio Liberal se volvió a aplicar la legislación revolucionaria salida de Cádiz que posteriormente analizaremos.

221 PUELL DE LA VILLA, F., El soldado desconocido: de la leva a la "mili" (17001912), p. 180. 
a) La necesidad de reducir el número de exentos ante la situación de excepcionalidad que vivía el país: Orden de la Junta Suprema y Gubernativa del Reino de 18 de noviembre de 1808.

No sería hasta después de la guerra de la Independencia cuando se pondría en funcionamiento con regularidad la Ordenanza de 1800, "[cuando Fernando VII] se mostró encantado de servirse de una norma, dictada por sus augustos antecesores, que le permitía obviar cualquier referencia a la legislación elaborada durante el tiempo de su cautiverio"222. Sí se utilizó de una forma irregular en los últimos tiempos del conflicto para abastecer de soldados al Ejército regular mientras las Cortes gaditanas elaboraban las disposiciones que regulasen el reclutamiento siguiendo los nuevos postulados liberales. Es más, ya en noviembre de 1808, apenas medio año después del inicio de la guerra, la Junta Suprema Central y Gubernativa del Reino dirigida por el conde de Floridablanca, detentadora de los poderes ejecutivo y legislativo tras las abdicaciones de Bayona y encargada de coordinar el esfuerzo bélico, aprobó, en nombre de Fernando VII, una orden que venía a completar la Ordenanza de 1808.

La justificación de esta nueva disposición era clara: la situación de excepcionalidad que vivía el país con la invasión de las tropas napoleónicas obligaba a rectificar el reclutamiento y, en concreto, a reducir el número de exentos para aumentar el tamaño del Ejército para hacer frente a la amenaza francesa:

"Pero si aquellas reglas [la Ordenanza de 27 de octubre de 1800] fueron convenientes al tiempo en que se dieron, y a circunstancias ordinarias y comunes, hoy que España está invadida

222 PUELL DE LA VILLA, F., El soldado desconocido: de la leva a la "mili" (17001912), p. 180. 
por el tirano que domina Francia, detenido bajo su poder la augusta persona de nuestro amado soberano Fernando VII, que Dios guarde; quebrantadas pérfidamente las santas leyes de la amistad y alianza que unían las dos Coronas, hollado el decoro y honor de la nación, y atentada su independencia y libertad adquirida a costa de mucha sangre derramada en innumerables batallas por espacio de ocho siglos; ahora en tan urgente situación de peligro como el en que está la madre Patria, para salir del cual curiosamente necesita del esfuerzo de sus hijos, son necesarias otras reglas, y disminuir el número de exentos, para que alistados los demás en las banderas, acudan a la defensa de tan justa causa, y a arrojar ese enemigo orgulloso de la tierra que infamemente huella, a vengar la augusta persona de nuestro deseado Rey, a defender nuestra Religión y nuestra honra, nuestras familias y hogares, nuestra independencia y libertad. Porque si en tanta ocasión no lo hacemos ¿para cuando guardamos nuestra lealtad y patriotismo? ¿Acaso para cuando juzgados de aquél pérfido, $y$ atados al carro de su triunfo ponga sobre nuestra cerviz su infame planta, y a manera de esclavos sean conducidos bajo su bandera a ser instrumento vil en remotos olimpos y bajo de otro cielo de nuevas inspiraciones $y$ conquistas?. Los trabajos y privaciones que suframos en tan honrosa contienda, el quebranto de nuestros intereses, y aún la pérdida de la vida, de nuestra religión, nuestra libertad y nuestra honra"223.

La nueva orden, compuesta por un total de 14 artículos, venía exclusivamente a bajar la edad que obligaba a un joven a participar en el sorteo que quintas y a reducir, tal y como indica su preámbulo, el número de exentos. Así, se aumentó entre los dieciséis y los cuarenta años la edad de los mozos "[...] contribuyentes al aumento y reemplazo del Ejército" 224 , y se insistió en que los viudos, sin familia que mantener, también lo serían ${ }^{225}$, de la misma forma que lo recogía la Ordenanza de 1800.

\footnotetext{
${ }^{223}$ Orden de la Junta Suprema y Gubernativa del Reino, 18 de noviembre de 1808, BHM-C30843-77. En adelante, Orden de la Junta Suprema y Gubernativa del Reino. ${ }^{224}$ Orden de la Junta Suprema y Gubernativa del Reino, art. 1.

225 Orden de la Junta Suprema y Gubernativa del Reino, art. 2.
} 
La talla mínima para participar en el sorteo se estableció en cinco pies sin calzado ordinario, aunque se redujo en una pulgada para aquellos jóvenes "[...] que fueren fornidos y robustos [...]"226.

Un carácter verdaderamente revolucionario se observa en el artículo número 4. Por primera vez, una normativa sobre reclutamiento en España olvidó la exención de la nobleza por motivos de sangre para esta contribución. Se justificó por la situación de excepcionalidad que vivía el país y en la obligación que tenía el estamento nobiliario de empuñar las armas en defensa de su Rey. Se implora a la nobleza a presentarse voluntaria para servir al Ejército. En caso de no alcanzar el contingente de nobles asignado por la junta Provincial a su localidad con voluntarios, participarían en el sorteo que designaba a los nuevos reclutas, aunque un sorteo exclusivo para la nobleza ${ }^{227}$. Además, y como resto de los privilegios estamentales, "los nobles voluntarios servirán en el Ejército en la clase de distinguidos o en la de cadetes, [...] pero los quintados servirán sin ninguna distinción $[\ldots]^{\prime \prime 228}$. Por lo tanto, aquellos nobles que no se presentasen voluntarios para servir en el Ejército tendrían una posición y un trato igual al resto de los reclutas.

Nuevas exenciones estamentales, recogidas en la Ordenanza de 1800, fueron derogadas en los artículos 5, 6 y 7 . Ahora es el turno del clero: perdieron la exención y quedaron sujetos al sorteo los tonsurados sin y con beneficio eclesiástico o capellanía y los novicios de las órdenes religiosas ${ }^{229}$.

\footnotetext{
${ }^{226}$ Orden de la Junta Suprema y Gubernativa del Reino, art. 3.

227 "En consecuencia, las Juntas de las Provincias dispondrán que las Justicias y Ayuntamiento llamen a los nobles, que no tuvieran otra excepción que la nobleza, y les conviden a que voluntariamente se alisten para servir al Ejército, y les adviertan que si no se presentaren voluntariamente, lo que no se espera de su fidelidad, a llenar el contingente que se asigne según el número que hubiere de ellos en el pueblo, serán sorteados para completarle aquellos que no lo hicieren" Orden de la Junta Suprema y Gubernativa del Reino, art. 4.

${ }^{228}$ Orden de la Junta Suprema y Gubernativa del Reino, art. 4.

${ }^{229}$ Orden de la Junta Suprema y Gubernativa del Reino, arts. 5, 6 y 7.
} 
También perdieron la exención parte de los miembros del tercer estado que la disfrutaban en la normativa anterior, gracias a su dedicación profesional o a su situación familiar: doctores, licenciados, bachilleres y profesores de facultad, con la única excepción de los doctores con cátedra en propiedad; hijos de familias comerciantes al por mayor o propietaria de cuatro telares ${ }^{230}$; hijos de familias labradoras que habitasen en una casa establecida a más de 2.000 varas de distancia ${ }^{231}$.

En el artículo 10 se reformó el 35 de la Ordenanza de 1800, ya que dejaron de estar exentos los hermanos de aquel mozo que hubiese obtenido la "suerte de soldado" en el sorteo. La nueva situación obligaba tan solo a conceder la exención a dos hermanos en el caso de ser cuatro los considerados aptos para el servicio, y tres si son seis. Asimismo perdieron su exención de participar en el sorteo los retirados del Ejército y los quintos que hubiesen cumplido su servicio, debiendo participar de nuevo en él en el caso de que, con el número de jóvenes existente en el pueblo, no se completase el contingente asignado a la localidad ${ }^{232}$.

Por lo demás, señaló esta orden que el proceso de reclutamiento se regularía siguiendo la Ordenanza de 1800.

\footnotetext{
${ }^{230}$ Orden de la Junta Suprema y Gubernativa del Reino, 18 de noviembre de 1808, BHM-C30843-77.

${ }^{231}$ Orden de la Junta Suprema y Gubernativa del Reino, arts. 8, 9 y 12.

${ }^{232}$ Orden de la Junta Suprema y Gubernativa del Reino, arts. 10 y 11.
} 
b) El retorno al pasado: Real Instrucción Adicional a los Artículos $X$ y XXXV de la Ordenanza de Reemplazos de 27 de Octubre de 1800 , de 26 de noviembre de 1817, y Real Instrucción Adicional a la Ordenanza de Reemplazos de Octubre de 1800, de 21 de enero de 1819

Una vez firmado el Tratado de Valençay ${ }^{233}$ y finalizada la contienda, Fernando VII se dispuso a retornar, también en lo concerniente al reclutamiento, a la situación previa al conflicto, sin extraer prácticamente conclusiones de las guerras que habían asolado Europa en las dos últimas décadas: "Como el Ejército español ha salido vencedor de la contienda, no hay razones para dudar de su eficacia ni para modificar su estructura"234. Sería el proceso de emancipación de las repúblicas iberoamericanas, unos conflictos lejanos para una población agotada tras años de esfuerzo, el motivo que obligase al Monarca a tomar sus primeras medidas en materia de reclutamiento:

"[...] como lo ocurrido durante los años de la Guerra de la Independencia no se pudo encerrar en un paréntesis destinado al olvido y a la postergación, los gobiernos de la primera etapa del reinado de Fernando VII -sobre los que pesa la amenaza constante del pronunciamiento y el agobio de la guerra insurreccional de las colonias americanas- han de plantearse la reforma militar, que se persigue con una abundante legislación publicada en 1818 y 1819, presidida, sobre todo, por criterios conservadores-restauracionistas [...], más que por un auténtico deseo de renovación"1235.

\footnotetext{
233 NAVAS SIERRA, J. A., "El tratado de Valençay o el fracaso del pacto imperial napoleónico", Anuario de Historia de América Latina, 27 (1990); SÁNCHEZ MANTERO, R., Fernando VII, Madrid, Arlanza, 2001.

234 MAQUEDA ABREU, C., "La Restauración de Fernando VII y el reclutamiento militar", p. 81.

235 MAQUEDA ABREU, C., "La Restauración de Fernando VII y el reclutamiento militar", p. 72.
} 
Con este objetivo restauracionista ordenó el Monarca el establecimiento de una Comisión del Consejo de Guerra para adaptar la legislación y el abastecimiento de soldados para el Ejército ${ }^{236}$ a la nueva problemática situación que se abría en el país con unas lejanas guerras que amenazaban con desmembrar al Imperio Español ${ }^{237}$. Tal y como indica Puell de la Villa,

"A la vista del dictamen de la Comisión, da la sensación de que sus miembros habían vivido ajenos a la convulsión sufrida por el país. Después de seis meses elaborándolo, su retrógrado plan nos traslada al entorno dieciochesco [...]: antes que recurrir a la quinta, proponían que el rey dictara una leva general de vagos [y] que la justicia detuviera a los desertores y dispersos del Ejército [...]. La redada de vagos, desertores, etc. -ordenada por el ministro de la Guerra, Francisco Ballesteros, el 22 de mayo de 1816-, desengañó definitivamente a los que todavía creían posible la vuelta a los antiguos sistemas de reclutamiento: tan solo 1330 hombres útiles llegaron a ingresar en los regimientos ${ }^{\prime 238}$.

Un fracaso tan absoluto obligó a las autoridades fernandinas a replantearse el medio más eficaz para nutrir de efectivos al Ejército

\footnotetext{
236 "Conforme en un todo con el parecer del expresado mi Consejo, resolví que con anterioridad al medio ordinario de la quinta, se pusiesen en ejecución las tres medidas siguientes: primera, las de una leva general practicada en todo el Reino, bajo las sabias precauciones anunciadas en la referida consulta; segunda, que se comunicasen las órdenes más enérgicas a todas las Autoridades, tanto militares como ordinarias, para la persecución y presentación en sus respectivos cuerpos del excesivo número de desertores dispersos que se abrigaban en los pueblos y aldeas del Reino; y tercera, la rebaja de cuatro años de su empeño a favor de los milicianos que quisieren voluntariamente pasar a servir en el Ejército; reservándome echar mano, como último recurso del medio de la quinta para en el caso de no poder producir las medidas anteriores un resultado suficiente, como me prometía, para cubrir las referidas bajas [...]." Real Instrucción Adicional a los Artículos X y XXXV de la Ordenanza de Reemplazos de 27 de Octubre de 1800, 26 de noviembre de 1817. En adelante, Real Instrucción Adicional de noviembre de 1817.

237 "Orden circular de 16 de Octubre de 1815 para la formación de una Comisión para la reforma de las Ordenanzas generales", Decretos del rey Don Fernando VII, Madrid, Imp. Real, 1814-20, t. II, pp. 715 y 716.

238 PUELL DE LA VILLA, F., El soldado desconocido: de la leva a la "mili" (17001912), p. 180.
} 
de un país esquilmado tras seis años de guerra. Por ello se decidió volver al sistema de quintas tomando como base la Ordenanza de 1800 , pero introduciendo una serie de modificaciones a través de la Real Instrucción Adicional a los Artículos X y XXXV de la Ordenanza de Reemplazos de 27 de octubre de 1800. El objetivo básico de este nuevo texto será limitar las exenciones estamentales recogidas en la Ordenanza de $1800^{239}$.

Esta instrucción adicional regresa, en lo que se refiere a la edad de los mozos participantes en el sorteo, a la legislación de 1800, entre los diecisiete y los treinta y seis años, "[...] cuya estatura sin su calzado ordinario no baje de cinco pies menos media pulgada [... $]^{\prime 240}$. Por tanto, se rebaja una pulgada la talla, estableciéndose en 1,597 $\mathrm{m}$.

De mayor impacto y trascendencia fueron los cambios en materia de exenciones estamentales. La eliminación de muchas de ellas refleja la imposibilidad de volver al pasado después de los cambios introducidos por las Cortes gaditanas y la nueva mentalidad liberal. A ello se une la problemática situación de un país, arrasado por una guerra total contra Napoleón, y que debería afrontar más tarde numerosas guerras en el lejano ámbito americano.

Se inició esta instrucción adicional declarando a las personas exentas del servicio. En primer lugar, los miembros del estamento clerical: clérigos tonsurados que tengan beneficio eclesiástico hasta la edad de veintitrés años, así como ministros y oficiales titulares de los tribunales de la Inquisición ${ }^{241}$.

\footnotetext{
239 "[...] finalmente con el recto fin de que aumentándose en lo posible el número de contribuyentes a este importantísimo e indispensable servicio, sea menor el gravamen de las muy recomendables clases de labradores, artesanos y comerciantes, firmes apoyos de la subsistencia pública [...]" (Real Instrucción Adicional de 26 de noviembre de 1817).

${ }^{240}$ Real Instrucción Adiciona de 26 de noviembre de 1817.

${ }^{241}$ Real Instrucción Adicional de 26 de noviembre de 1817, arts. 1 y 2.
} 
A continuación se incluyeron las exenciones laborales o por interés socioeconómico: catedráticos, doctores y licenciados universitarios, catedráticos de medicina y cirugía, directores y subdirectores de las academias de Artes, alcaldes, regidores y síndicos o procuradores generales mayores de veinticinco años, aunque no otros oficiales municipales ni alcaldes de hermandad ${ }^{242}$, "[...] Relatores, Agentes fiscales que sean letrados, y Escribanos de Cámara de dotación y con ejercicio de los Tribunales; los escribanos de Ayuntamiento con título Real, los de número y provincia que tuviesen la aprobación del Consejo Real y estén en ejercicio; los Notarios de poyo y número de los Tribunales Eclesiásticos y Vicarías, siéndolo de dotación y con ejercicio; pero no los de diligencias de estos ni otros titulares. También serán exentos los Archiveros de archivos Reales, y de dichos Tribunales, y los Catedráticos de latinidad, a saber, los que están enseñando en las universidades y seminarios, o en las ciudades y villas donde hay Corregidores, Gobernador o Alcalde Mayor, y tengan dotación de 300 ducados a lo menos $[\ldots]^{\prime \prime 243}$.

Se incluyeron asimismo los médicos y cirujanos y un boticario, mariscal y albéitar por cada villa, los profesores de primeras letras, ${ }^{244}$ maestros de tejidos, tintoreros y maestros de imprenta que fuesen cabeza de familia con título reconocido por un gremio, así como "[...] Maestros, empleados facultativos, y Directores de las Reales Fábricas de pólvora, municiones, armas, fundiciones, minas y casas de moneda; los Maestros de instrumentos de matemáticas y ciencias naturales y también los de máquinas que sirvan para las manufacturas, con tal que hayan obtenido del Consejo despacho de

\footnotetext{
${ }^{242}$ Real Instrucción Adicional de 26 de noviembre de 1817, arts. 3, 4, 5 y 6.

${ }^{243}$ Real Instrucción Adicional de 26 de noviembre de 1817, art. 7.

${ }^{244}$ Real Instrucción Adicional de 26 de noviembre de 1817, arts. 8, 9, 10 y 16.
} 
calificación y aprobación por la utilidad de sus inventos, y que sean cabezas de familia"245.

También se contemplaron entre los exceptuados variados oficios vinculados a la Real Hacienda: "[...] los Correos de Gabinete, nombrados por el Superintendente general; como también los Contadores, tesoreros, Administradores, Guarda-almacenes y Comandante de resguardo empleados así en el ramo de Correos, como en los demás de las Real Hacienda"246; y al oficio de la marinería: "[...] los individuos de la maestranza de los tres Departamentos de Marina, Carpinteros de Ribera, Calafates, Tenederos y demás dependientes empleados en las construcción, carena y armamento de los buques de guerra, y los marineros soldados distinguidos" ${ }^{247}$.

Por lo que respecta a las exenciones por motivos familiares o personales, este apartado se vio reducido a los mozos solteros cabeza de familia; a los hijos únicos de viuda o padre pobre, impedido o mayor de sesenta años, o que no fuesen pobres pero el mozo mantenga con su trabajo la tierra o el oficio de los padres; al hermano de un soldado que hubiese salido designado en el sorteo para el servicio; a los soldados retirados con licencia y los quintos que ya hubiesen prestado su servicio; y a los mozos labradores del reino de Castilla que viviesen y trabajasen con su familia a una distancia de 2.000 varas de distancia de su localidad de origen ${ }^{248}$.

El último artículo de esta instrucción adicional vino a confirmar, para evitar dudas, los jóvenes que sí estarían incluidos en el sorteo de quintas. Es aquí donde encontramos lo más novedoso de la norma, ya que se retiró la exención para el estamento nobiliario y buena parte del clerical. Así, se declaró que "los hijosdalgo, aunque

\footnotetext{
${ }^{245}$ Real Instrucción Adicional de 26 de noviembre de 1817, art. 17.

${ }^{246}$ Real Instrucción Adicional de 26 de noviembre de 1817, art. 11.

${ }^{247}$ Real Instrucción Adicional de 26 de noviembre de 1817, art. 21.

${ }^{248}$ Real Instrucción Adicional de 26 de noviembre de 1817, arts. 12, 13, 14, 18, 19 y 20.
} 
estén en goce y posesión de su hidalguía, serán incluidos en el presente sorteo"249, aunque se les concedía el privilegio de servir como soldados distinguidos:

"[...] esto significaba que mantenían el tratamiento de don, figuraban en los primeros lugares de la lista de revista, sólo podrían recibir órdenes de los oficiales y estaban exentos de realizar servicios mecánicos: todos ellos eran rancios privilegios de los que ya gozaba cualquier hidalgo que se hubiera alistado voluntariamente ${ }^{\prime 250}$.

Las necesidades militares obligaron a la abolición de los privilegios seculares del estamento nobiliario en materia de reclutamiento. A pesar de los intentos del monarca de regresar al Antiguo Régimen, no se podían obviar los años de la guerra contra los franceses, ni las ideas reformistas difundidas por el país durante ese periodo, y se hacía necesario el establecimiento de la igualdad entre pecheros y privilegiados en cuanto a su contribución al Ejército.

Puesta fin a esta desigualdad estamental, se instauró por primera vez la posibilidad de la redención en metálico, limitada en exclusiva a los hidalgos. La cantidad a entregar para que un noble no acudiese al servicio militar era realmente elevada según la norma de $1817,20.000$ reales de vellón. ${ }^{251}$ Se trata del principal problema que suponía esta figura

"[...] su injusticia consustancial, implícita en su misma naturaleza, por cuanto condicionaba el prestar servicio en armas a la Nación a la disponibilidad de determinados recursos económicos $y$, en este primer momento, a pertenecer a una determinada clase social. Así, mientras que campesinos, labriegos, asalariados y clases

\footnotetext{
${ }^{249}$ Real Instrucción Adicional 26 de noviembre de 1817, art. 24.

250 PUELL DE LA VILLA, F., El soldado desconocido: de la leva a la "mili" (17001912), p. 181.

${ }^{251}$ Real Instrucción Adicional de 26 de noviembre de 1817, art. 25.
} 
trabajadoras urbanas no tenían recurso legal alguno para esquivar el sorteo, los jóvenes de familias nobles acaudaladas no tenían por qué servir" ${ }^{\prime 252}$.

El origen de la redención en metálico habría que buscarlo en la legislación militar de la Francia postnapoleónica con predominio burgués. Se abre la puerta a la posibilidad de permutar el servicio militar por el pago al fisco público de una determinada cantidad de dinero ${ }^{253}$, si bien este derecho en principio era exclusivo del estamento nobiliario: "este precepto sentó el precedente jurídico de las futuras leyes de reclutamiento constitucionales, del que haría amplio uso la burguesía liberal y a la que no repugnó su ominoso nacimiento" ${ }^{254}$.

Continúa esta real instrucción en su artículo 24 con el listado de todas aquellas categorías sociales y profesionales que debían participar en el sorteo de reclutas. Además de los hidalgos mencionados en líneas anteriores, se puso fin a la exención de la que gozaban algunas figuras del clero en legislaciones previas, caso de los tonsurados sin beneficio eclesiástico, novicios de las órdenes religiosas, ministros y oficiales de los tribunales de la Inquisición, ministros y hospederos de Cruzada, hermanos y síndicos de órdenes religiosas, comisarios y cuadrilleros de Hermandad ${ }^{255}$.

\footnotetext{
252 FERNÁNDEZ RODRÍGUEZ, M. y MARTÍNEZ PEÑAS, L., "Problemática social en la legislación de reclutamiento decimonónica: exenciones, sustitución y redención", p. 324.

253 "El reclutamiento era una institución temida por todos, pues el destino del soldado era duro y peligroso; por lo tanto, todo el mundo buscaba ansiosamente la forma de librarse de él. [...]. La redención del servicio constituía una tasa regresiva: para los ricos equivalía al previo de un buen caballo; para las familias de clase media, en cambio significaba tener que contraer una deuda a veinte años, o incluso la ruina. [...]. Sin embargo, tan grande era el miedo al servicio militar que cualquier familia capaz de entregar el dinero necesario para liberar a sus hijos se apresuraba a hacerlo; muchos vendían todo lo que tenían antes que dejar que la quinta se llevara a su hijo" (HEADRICK, D. R., Ejército y política en España (1866-1898), pp. 101-102).

254 PUELL DE LA VILLA, F., El soldado desconocido: de la leva a la "mili" (17001912), p. 181.

${ }^{255}$ Real Instrucción Adicional de 26 de noviembre de 1817, art. 24.
} 
El último apartado de la instrucción se dedicó a diferenciar aquellos miembros del tercer estado en los que podría haber duda en cuanto a su inclusión en el sorteo de quintas pero que habían de participar en él: bachilleres; alumnos y colegiales internos de los colegios de Medicina, Cirugía, Farmacia y Veterinaria; abogados (aunque para ellos también existe la posibilidad de redimirse a cambio de 20.000 reales de vellón); alcaldes de Hermandad y de Concejo; sangradores; barberos; oficiales de la renta de Correos y de la Real Hacienda no mencionados en el art. 11, que mantendrían una tercera parte de su sueldo si tuviesen que ingresar en el Ejército y su mismo puesto de trabajo al licenciarse; mozos solteros sin casa abierta o que, teniendo casa abierta, no se dedicasen a la agricultura; maestros y artesanos no mencionados en los artículos 16 y 17; hijo de padre impedido acaudalado; comerciantes, cambistas, tratantes y fabricantes, aunque sean al por mayor; criadores de yeguas y sus hijos; torreros; hijos de oficiales militares; los alcaldes, síndicos o procuradores generales, y regidores que fuesen menores de veinticinco años; los procuradores receptores, escribanos reales, agentes solicitadores de pleitos, escribientes y oficiales de Escribanías y notarios secretarios, juntas, asientos y otras oficinas de provisiones; dependientes de los hospitales; viudos; criados, aunque sean de la nobleza; milicianos urbanos; pastores trashumantes y expósitos $^{256}$.

A pesar de las protestas de la nobleza por haber perdido uno de sus privilegios seculares, a partir de esa fecha las convocatorias de quintas se hicieron siguiendo lo estipulado en esta real instrucción y en otra aprobada en enero de 1819 que vino a confirmar a su predecesora de dos años antes ${ }^{257}$. Lo mismo ocurrió tras el paréntesis del Trienio Liberal y la reimplantación de Fernando como monarca

\footnotetext{
${ }^{256}$ Real Instrucción Adicional de 26 de noviembre de 1817, art. 25.

257 Real Instrucción Adicional a la Ordenanza de Reemplazos de Octubre de 1800, Madrid, 21 de enero de 1819 (AHN, Cons. Lib. 1507, núm. 96).
} 
absoluto en 1823. Una vez instituido con todos los poderes, Fernando VII se dispuso a disolver el Ejército constitucional a fines de 1823, licenciando a sus efectivos, y a organizar el nuevo Ejército en abril y mayo de 1824, con nuevos soldados reclutados a través de sucesivas quintas en 1824 y $1826^{258}$, inspiradas en la legislación de 1800,1817 y 1819.

258 BORREGUERO BELTRÁN, C., Reclutamiento militar por quintas en la España del siglo XVIII: orígenes del servicio militar obligatorio, p. 117. 


\section{2.- El reclutamiento liberal: La legislación de las Cortes de Cádiz y del Trienio Liberal}

La quiebra con los sistemas de reclutamiento heredados del Antiguo Régimen se inició en las Cortes de Cádiz y se consolidó durante el periodo del Trienio Liberal. Hemos analizado las normas que vinieron a impulsar el nuevo sistema de forma conjunta, tanto en los años de la guerra de la Independencia (1808-1812) como en periodo posterior al levantamiento de Riego (1820-1823), obviando el paréntesis absolutista fernandino (1814-1820)

Las publicaciones seleccionadas al efecto han sido, para el caso del periodo gaditano, El Conciso ${ }^{259}$ y El Censor General ${ }^{260}$; y para el periodo del Trienio Liberal, El Espectador ${ }^{261}$ y El Censor ${ }^{262}$. Debemos

\footnotetext{
259 "El Conciso, de Gaspar María de Ogirando, fue quizás el título más destacado de este período, y una importante fuente para seguir el desarrollo de los acontecimientos contemporáneos. Se trata de un periódico polemista, de pequeño tamaño, gran defensor de la libertad de imprenta" (http://hemerotecadigital.bne.es).

260 "Con la invasión napoleónica y la Guerra de la Independencia la prensa española vivió un período de esplendor. Las Cortes de Cádiz establecieron la libertad de imprenta y eliminaron la censura previa, ratificada después por la Constitución de 1812, dando lugar al nacimiento de la prensa política y, por ello, a la aparición de periódicos de diferente signo, como los liberales Semanario Patriótico o El Robespierre Español y otros, como El Censor General, absolutista.

Este periódico se imprimió por primera vez en 1811 en el establecimiento gaditano de Guerrero y desde 1814 en Madrid en el de Álvarez, saliendo dos veces por semana. En el 'Prospecto' sus editores se proponían "ilustrar" y "hacer recta la opinión pública" para lo cual todo documento político, plan o reforma que saliera a la luz en Cádiz o provincia debería ser analizado con el fin de "hacer bien a la patria". Se oponía a las nuevas reformas, por lo que fue muy criticado por los periódicos liberales. Así, defendía al Santo Oficio en la sección 'Apología del Altar y del Trono' del Padre Vélez que preconizaba la vuelta a los valores más tradicionales de la Iglesia, en contra de la libertad de expresión y el laicismo del Estado [...]" (http://hemerotecadigital.bne.es).

261 "Uno de los grandes periódicos del Trienio Liberal, fundado por Evaristo San Miguel (1785-1862), al que se le atribuye la autoría del Himno de Riego, que comienza a aparecer el 15 de abril de 1821. En su prospecto señala que estará dirigido "al público indulgente y tolerante" y en el que se escribirá sobre política, filosofía, moral, ciencias, literatura, del gobierno, de Europa, de España... De cuatro páginas por número y a dos columnas, aumentará el tamaño de su formato, siendo un diario moderno que introducirá las "Cartas de los lectores", al estilo de The Spectator londinense que había conocido San Miguel durante su exilio en la capital británica. Estará estructurado en secciones de noticias nacionales y extranjeras,
} 
tener en cuenta que las publicaciones de estos años apenas recogen numerosas noticias relacionadas con el reclutamiento, pero casi siempre breves referencias de los debates en Cortes, sin editorializar sobre esta cuestión. No sería hasta "[...] el Bienio Progresista cuando la prensa incorporó definitivamente la cuestión de las quintas a sus editoriales $^{\prime 263}$.

\section{Contexto histórico: la quiebra del Antiguo Régimen}

La España de 1808 era una España convulsa en el extremo de una Europa convulsa. La monarquía se vio sumida en una profunda crisis interna, en la que la relación entre el rey, Carlos IV, el príncipe de Asturias, Fernando, futuro Fernando VII, se vio enturbiada,

Cortes, variedades, artículos doctrinales, políticos y divulgativos, anécdotas, anuncios (de bibliografía, etc.).

Afín ideológicamente a El universal, de carácter constitucionalista y liberal entre templado y exaltado, se le considera también órgano oficioso de la masonería, del que su fundador formaba parte [...].

Su último número apareció el 31 de marzo de 1823, tras marcharse Fernando VII a Sevilla con la entrada en España de los Cien mil hijos de San Luis" (http://hemerotecadigital.bne.es).

262 "Considerada como una publicación de excepcional calidad y la de más prestigio del Trienio Liberal, formalmente se la define como una revista, dada la amplitud de sus números, en torno a las ochenta páginas cada uno. Es fundada por el impresor y editor León Amarita y dirigida por el afrancesado sacerdote Sebastián Miñano, al que se suman en la redacción los también clérigos josefinos y literatos Alberto Lista y José Manuel Gómez Hermosilla, empezando a publicarse a partir del cinco de agosto de 1820, una vez promulga la amnistía política. De carácter constitucionalista, su tendencia es de un liberalismo supermoderado, enmarcado más bien en el despotismo ilustrado, a juicio de María Cruz Seoane.

[...]

Es un periódico político templado y equilibrado, pero también literario, que va a dar cabida asimismo a un incipiente periodismo costumbrista. Ofrece extensos artículos doctrinales sobre el constitucionalismo, la libertad de imprenta o sobre el papel del clero regular, así como crónicas parlamentarias. Hermosilla se dedicará más a los textos políticos, mientras que Lista será el autor de la mayor parte de los artículos de literatura dramática y crítica literaria y teatral, siendo claro defensor del neoclasicismo a ultranza. Asimismo ofrece noticias de otros periódicos. [...].

Estuvo apareciendo cada sábado, hasta que publica su último número el 13 de julio de 1822 al entender sus artífices la dificultad de seguir editándolo por la exasperación de los ánimos y la agitación política que sigue al fallido golpe de Estado absolutista del día siete" (http://hemerotecadigital.bne.es).

${ }^{263}$ FEIJÓO GÓMEZ, A., Quintas y protesta social en el siglo XIX español, p. 100. 
cuando no rota, por dos sucesos: la conjura de El Escorial y el motín de Aranjuez. Si en el primero, Fernando se vio implicado en una extraña conspiración para lograr la renuncia al trono de su propio padre, participación que el príncipe llegó a admitir y por la que finalmente obtuvo el perdón paterno, los sucesos derivados del motín de Aranjuez ${ }^{264}$, en el mismo año 1808 , si condujeron a la abdicación de Carlos IV ante la presión de los amotinados, que reclamaban que se sentara en el trono a Fernando:

"El Rey nuestro Señor, acompañado de sus amados hermanos, tío y sobrinos, se trasladó ayer 24 del corriente desde el real sitio de Aranjuez al palacio de esta villa, donde permanecen S.M, y A.A. sin novedad en su importante salud. El júbilo y regocijo de los leales habitantes de Madrid ha sido qual correspondía a las extraordinarias circunstancias actuales, y los aplausos, vivas y demás expresiones de fidelidad y ternura del inmenso concurso que había acudido a solemnizar la primera entrada de nuestro joven Monarca, han manifestado bien a las claras los afectos de todos los corazones, y la veneración de sus pueblos, que llenos de amor a su real Persona, y de las esperanzas que promete un reinado que empieza baxo tan felices auspicios, se dan la enhorabuena de vivir baxo su a gusto imperio.

El Sr. Rey D. Carlos Quarto se sirvió expedir el real decreto siguiente: Como los achaques de que adolezco no me permiten soportar por más tiempo el grave peso del gobierno de mis reinos, y me sea preciso para reparar mi salud gozar en clima más templado de la tranquilidad de la vida privada; he determinado, después de la mas seria deliberación, abdicar mi corona en mi heredero y mi mui caro hijo el Príncipe de Asturias. Por tanto es mi real voluntad que sea reconocido y obedecido como Rei [sic] y Señor natural de todos mis reinos y dominios. $Y$ para que este $\mathrm{mi}$ real decreto de libre $y$ espontánea abdicación tenga su exacto y debido cumplimiento, lo comunicaréis al consejo y demás a quienes corresponda.

264 DIEGO PAREJA, L. M., "El motín de Aranjuez", Revista española de historia militar, 90-91 (2007), pp. 220-226; LINDO MARTÍNEZ, J. L., "El motín de Aranjuez, inicio de la guerra de la Independencia, un acontecimiento histórico falseado", en Ars et sapientia: Revista de la asociación de amigos de la Real Academia de Extremadura de las letras y las artes, Madrid, no 31 (2010), pp. 59-87. 
Dado en Aranjuez, a 19 de marzo de 1808.- Yo, el Rey.- A don Pedro Cevallos"265.

Sin embargo, tan pronto como se vio con fuerza suficiente como para no sentirse amenazado por los amotinados, Carlos IV pretendió anular su abdicación, señalando que había sido hecha bajo coacción, motivo que la invalidaba jurídicamente. El que Fernando VII no aceptara la anulación de la abdicación que le convertía en rey solo contribuyó a añadir más confusión a la situación del gobierno de España, precisamente en uno de los momentos en que más necesitada estaba la nación de una mano firme al frente de los asuntos de Estado.

Los desencuentros entre el regio padre y el regio hijo tenían mucho que ver con el papel desempeñado por Manuel de Godoy al frente del gobierno de la Monarquía. Fernando deseaba apartar al valido de su posición preeminente en los asuntos de Estado, pero el apoyo decidido de Carlos IV hacia el Príncipe de la Paz lo hacía imposible mientas don Carlos se sentara en el trono. Con dos partidos enfrentados por el poder, uno agrupado en torno al príncipe de Asturias y el otro centrado en el Príncipe de la Paz, era aún más difícil que la dirección de la política hispánica en los momentos previos a la ocupación francesa fuera coherente ${ }^{266}$.

La invasión napoleónica y el posterior estallido de la guerra de Independencia, tras los sucesos del 2 de mayo en Madrid y otros que, menos conocidos, contribuyeron igualmente a aglutinar la resistencia española contra el francés ${ }^{267}$, que de la condición de molesto ocupante pasó a la de odiado invasor, supusieron el derrumbamiento

\footnotetext{
265 Gaceta de Madrid, de 25 de marzo de 1808.

266 Sobre la lucha entre ambos partidos, ver LA PARRA LÓPEZ, E. M., "De la disputa cortesana a la crisis de la monarquía. Godoyistas y fernandinos en 1806-1807", en Cuadernos de Historia Moderna. Anejos, 6 (2007), pp. 255-267.

267 De sumo alcance en su tiempo fue el saqueo de Córdoba por el ejército francés, tras haber derrotado a un ejército español comandado por el general Cuesta en el puente de Alcolea.
} 
de las estructuras de poder en España. Colapsado, capturado o colaborando con el invasor el gobierno central, buena parte de la estructura del Estado se desplazó a las juntas provinciales, que, a su vez, constituyeron una Junta Central como autoridad superior. Esta junta, avanzada la guerra, derivó hacia la creación de un Consejo de Regencia ${ }^{268}$, que ejercía su poder en nombre de Fernando VII, retenido en Bayona por Napoleón, donde el Emperador de los franceses había forzado tanto a Fernando como a su padre a abdicar en su persona, para inmediatamente entregar el trono de España a su hermano, José Bonaparte.

El paso decisivo en la labor del Consejo de Regencia fue la convocatoria de unas Cortes Constituyentes como reacción al proceso impulsado por Napoleón y que había dado lugar al Estatuto de Bayona, nacido con la intención de ser una constitución para España, de corte sumamente liberal, pero cuya legitimidad había sido rechazada mayoritariamente por los españoles, que para nada sintieron que los procuradores desplazados a Francia para aprobar el texto fueran sus representantes. El estatuto de Bayona fue posteriormente completado por los llamados "Decretos de Chamartín", publicados por José Bonaparte, siete leyes, igualmente de marcado signo liberal, que, entre otras cosas, suprimían la inquisición y el régimen señorial, aún vigente legalmente en España.

Las Cortes Constituyentes se reunieron a partir de 1810 en Cádiz, ciudad que por sus condiciones geográficas reunían unas

\footnotetext{
268 Sobre las juntas provinciales y central y el Consejo de Regencia, ver MOLINER PRADA, A., "De las Juntas a la Regencia: la difícil articulación del poder en la España de 1808", Historia mexicana, Vol. 58, no. 1 (2008) (Ejemplar dedicado a: 1808: una coyuntura germinal), pp. 135-177; HOCQUELLET, R., Élites locales y levantamiento patriótico: la composición de las juntas provinciales de 1808", en Historia y política: Ideas, procesos y movimientos sociales, 19 (2008) (Ejemplar dedicado a: 1808, crisis y soberanía), pp. 129-150; DUFOUR, G., "De Aranjuez a Cádiz: (por la libertad y la Constitución): bicentenario de La Junta Central Suprema 1808-2008", 2010; LA PARRA LÓPEZ, E.," La Central y la formación de un nuevo ejercito: la Junta Militar (1808-1809)", en Antiguo Régimen y liberalismo : homenaje a Miguel Artola, Vol. 3, Madrid, Alianza, 1994 (Política y cultura), pp. 275-284.
} 
inmejorables condiciones de defensa frente a la amenaza francesa, que pronto se materializó en forma de asedio ${ }^{269}$.

Fue durante las Cortes de Cádiz donde se fraguó el modelo de Ejército y de reclutamiento liberal decimonónico ${ }^{270}$ :

"Bajo la influencia de Locke, Constant, Rousseau, Bonnin o J. B. Say, se discutió la necesidad de los Ejércitos permanentes, su operatividad y su influencia en la economía, se limitó su poder a través del control constitucional y parlamentario, y se apostó por un Ejército permanente $y$ forzoso, en perjuicio del modelo de Ejército de voluntarios. En realidad lo que se hizo con esto, como en la adopción de un sistema de reclutamiento, fue imitar el modelo francés, desarrollado desde 1789: un Ejército permanente reclutado con ciudadanos, sometido al poder civil y fundamentado en la responsabilidad de todos los ciudadanos para su mantenimiento y reemplazo. El sistema de reclutamiento, por tanto, se basó en: el Requerimiento, figura jurídica incorporada a la Constitución francesa de 1791, y que obligaba a todos los ciudadanos a defender a la patria con las armas en la mano: la Conscripción, adoptada por la Convención, y que implicaba el reclutamiento de un grupo de ciudadanos (entre dieciocho y cuarenta años) llamados en cualquier momento para el servicio armado; y el Servicio Militar Obligatorio, que sintetizaba los dos métodos anteriores desde la Ley Saint-Cyr desde 1818, al mantener el Requerimiento, que obligaba a todos los franceses a defender a la patria, y la Conscripción, que disponía el alistamiento y sorteo de todos los ciudadanos de una edad determinada; y la redención y la sustitución" ${ }^{271}$.

\footnotetext{
269 Uno de los estudios más completos sobre el periodo constituyente y su obra jurídica es ESCUDERO, J. A., Cortes y Constitución de Cádiz, Madrid, Espasa Calpe, 2012. Entre los artículos allí reunidos, cabe citar, por su relación con el tema del presente trabajo PÉREZ FERNÁNDEZ-TURÉGANO, C., "La Armada"; MARTÍNEZ PEÑAS, L., "El ejército"; y DOMÍNGUEZ NAFRÍA, J. C., "Ejércitos permanentes y milicias nacionales en la Constitución de Cádiz".

${ }^{270}$ FEIJÓO GÓMEZ, A., Quintas y protesta social en el siglo XIX español, p. 207.

${ }^{271}$ FEIJóo GÓMEZ, A., Quintas y protesta social en el siglo XIX español, pp. 207 y 208.
} 
Sin embargo, la vigencia de la Constitución de Cádiz fue corta: en 1814 Fernando VII regresaba a España, y con el apoyo de las tropas del general Eguía y de buena parte del sector conservador de las Cortes, anuló la Constitución, detuvo a buena parte de los parlamentarios liberales e instauró de nuevo un gobierno de corte absolutista, ante la incredulidad de la España liberal, que, desengañada, contempló como el rey cuyo regreso había anhelado demolía la obra jurídica que habían defendido durante los años de guerra contra los franceses.

El regreso al absolutismo estuvo lejos de ser aceptado de buen grado por la totalidad de la población, y una institución en concreto se convirtió en portavoz visible de la lucha por el regreso a los principios de gobierno de 1812: el Ejército, cuyo papel en la vida política española del siglo XIX fue enorme. Un gran número de oficiales se opuso al régimen de Fernando VII, por la conjunción de un gran número de factores, que abarcan desde la profunda implantación de las doctrinas liberales entre quiénes habían luchado en la guerrilla o incluso entre quienes habían sido capturados por los franceses, cautiverio en el cual, paradójicamente, habían recibido la influencia de las ideas revolucionarias emparentadas con conceptos liberales como la soberanía nacional o la división poderes, pasando por los problemas inherentes al propios ejército -saturación de las escalas, conflicto entre los oficiales de carrera de más edad, procedentes del ejército regular, y los más jóvenes, procedentes en muchos casos de la guerrilla- o por el papel, no desdeñable, de las sociedades secretas, a las que estaban adscritos un número elevado de oficiales de graduaciones altas y medias. Todo ello impulsó a determinados sectores del Ejército a tomar un papel activo en la lucha política, ya fuera por medios legales o a través de asonadas, pronunciamientos y golpes de Estado. A este fenómeno, no sin razón, 
se le ha denominado pretorianismo, en referencia a la creciente influencia de la guardia del Pretorio en el periodo imperial romano ${ }^{272}$.

A lo largo de seis años, los pronunciamientos militares de signo liberal se sucedieron constantemente contra el gobierno de Fernando VII: Francisco Javier Mina en 1814; Díaz Porlier en 1815, la "conspiración del Triángulo", de origen masónico, en 1816; el pronunciamiento de Milán del Bosch en 1817; la conspiración de Juan Van Halen ese mismo año; la del coronel Joaquín Vidal en 1819 o el intento fallido de La Bisbal en $1820^{273}$.

Sin embargo,

\begin{abstract}
"las consecuencias de estos pronunciamientos fracasados fueron trágicas para sus líderes, ya que Fernando VII se mostró implacable con ellos: Francisco Javier Mina huyó a México, donde, en un trágico giro del destino, prefirió combatir con los independentistas liberales mejicanos que con el Ejército español que defendía los derechos de un monarca absoluto. Capturado por tropas realistas, el que fuera héroe de la lucha contra los franceses murió fusilado por soldados españoles, por traidor a la patria, en un lugar llamado el Cerro del Bellaco, no muy lejos de la localidad mejicana de Guanajuato. Díaz Porlier fue ejecutado en la horca en 1815, con tan solo veintisiete años de edad, tras el fracaso de su sublevación doceañista, iniciada en La Coruña. Lacy fue fusilado en 1817 en los fosos del castillo de Palma de Mallorca, tras haberse sumado al dirigido por Milán del Bosch. El más legendario de los guerrilleros contra las fuerzas napeoleónicas, "El Empecinado", terminó sus días ahorcado en la plaza de la localidad castellana de Roa, en 1825, tras
\end{abstract}

\footnotetext{
${ }^{272}$ Entre los trabajos que se han ocupado de este fenómeno deben secarse SECO SERRANO, C., Militarismo y civilismo en la España Contemporánea; BALLBÉ, M., Orden público y militarismo en la España contemporánea; MARTÍNEZ PEÑAS, L., "Pretorianismo en el reinado de Fernando VII: El ejército como defensor del doceañismo", en AGUILAR GIL, M (coord.). Construcciones y deconstrucciones de la sociedad, Almagro, Sociedad castellano-manchega de Sociología, 2010, pp. 65-76. Para el reinado de Alfonso XIII, BOYD, C. P., La política pretoriana en el reinado de Alfonso XIII, Madrid, Alianza Editorial, 1990.

${ }^{273}$ Esta sucesión de golpes militares ha llevado a Raymond Carr a afirmar que "el pronunciamiento fue el instrumento de la revolución liberal en el siglo XIX" (España, 1808-1975, Barcelona, Ariel, 2005, p. 135).
} 
haber sido exhibido públicamente dentro de una jaula. Espoz y Mina debió pasar largos años en el exilio, al igual que Milán del Bosch y otros muchos oficiales liberales"274.

En 1820, finalmente, triunfó el pronunciamiento del coronel Riego, que obligó a Fernando VII, según las propias palabras del monarca, a marchar por la senda constitucional, devolviendo la vigencia a la Constitución de Cádiz y colocando en el poder a un gobierno liberal, que habría de conseguir mantenerse al frente de los designios de España durante tres años, dando su nombre al periodo comprendido entre 1820 y 1823: el Trienio Liberal.

La extensión de la doctrina liberal al calor de la Guerra de la Independencia motivó la aparición de un nuevo corpus jurídico en materia de quintas, que, iniciado en Cádiz, se desarrolló durante el Trienio Liberal, y en el que se venía a recoger la doctrina jurídica liberal de influencia francesa ${ }^{275}$ en las cuestiones relacionadas con el reclutamiento ${ }^{276}$.

\footnotetext{
${ }^{274}$ MARTÍNEZ PÉREZ, L., "Pretorianismo en el reinado de Fernando VII: El ejército como defensor del doceañismo", pp. 68.

275 "El ejército español estaba organizado de acuerdo con el patrón francés, al igual que la mayoría de los ejércitos de la época. Desde los tiempos de Luis XIV, la dinastía borbónica, estrechamente vinculada a Francia, había aportado ideas francesas a las reformas del siglo XVIII. Por último, el impacto del sistema militar de Napoleón mantuvo el ejemplo francés en primera línea.

La organización fundamental del ejército español varió poco a lo largo del siglo XIX. Incluso después de la guerra franco-prusiana, el ejército español tardó en abandonar los métodos franceses. [...]. Hubo modernizaciones de armamento y tácticas, desaparecieron algunas viejas unidades y se crearon otras nuevas, el ejército creció en tamaño, al tiempo que mejoraban tanto la preparación de los oficiales como el estilo profesional. Con todo, y sobre todo en relación con los cambios económicos, políticos y sociales que tuvieron lugar en España desde los tiempos de Napoleón hasta la guerra con los Estados Unidos, es preciso admitir que la organización del ejército siguió siendo relativamente estática" (HEADRICK, D. R., Ejército y política en España (1866-1898), p. 38).

276 "El Ejército nacional, es decir, aquel que de forma periódica y obligatoria recluta a ciudadanos de determinada edad y circunstancias, tiene su origen ligado a la Revolución Francesa y a su filosofía de que todo ciudadano ha de ser soldado y todo soldado ciudadano" (FERNÁNDEZ VARGAS, V., Sangre o dinero: el mito del Ejército nacional, p. 15).
} 


\section{Normativa}

a) El concepto de ciudadano-soldado: La Constitución de 1812

Durante los primeros años de la Guerra de la Independencia asistimos a un auténtico caos normativo en el proceso de reclutamiento. Hasta que, en 1810 , el poder ejecutivo se centralizó en Cádiz, "[...] el reclutamiento de las tropas regulares se ejerció sin un mínimo de organización, quedó a menudo en manos de los propios jefes de los Ejércitos de operaciones y no se sujetó a la normativa existente" ${ }^{277}$.

La Comisión Ejecutiva de la Junta Suprema Central, refugiada en la Isla de San Fernando ante el avance de las tropas napoleónicas, sí que dispuso un alistamiento general de toda la población siguiendo las directrices de la Ordenanza de 1800, aunque con algunas rectificaciones que venían a eliminar exenciones. Así, "en el padrón tendrían que figurar todos los hombres de dieciséis a cuarenta y cinco años, sin excepción alguna [...], y sin tener en cuenta las exenciones previstas en aquella norma $[\ldots]^{\prime 278}$.

La cuestión de las exenciones y la redención en metálico en particular, y el tema militar en general, fueron asunto de duro debate en el seno de las Cortes gaditanas durante sus casi tres años de duración, debido a las circunstancias por las que atravesaba el país. Fueron muchas las sesiones que los primeros diputados en la historia de España dedicaron a cuestiones militares de todo tipo, hasta tal punto que "raro era el día en el que no apareciese en el Diario alguna

\footnotetext{
277 PUELL DE LA VILLA, F., El soldado desconocido: de la leva a la "mili" (17001912), p. 183.

278 PUELL DE LA VILLA, F., El soldado desconocido: de la leva a la "mili" (17001912), p. 183.
} 
referencia"279. La prensa por su parte también recogió el debate y emitió sus propias opiniones, si bien muy limitadas, respecto al Ejército, centrándose más en el desarrollo del conflicto y en los desmanes de las tropas napoleónicas ${ }^{280}$ que en el sistema para nutrir de efectivos a la fuerza armada.

En el caso de El Conciso, sus opiniones en este asunto fueron mínimas, aunque se achacaron las derrotas militares no tanto al sistema de reclutamiento y a las exenciones, sino a la falta de disciplina y de una buena dirección en el seno del Ejército ${ }^{281}$. Y para absolutista Censor General, los problemas del país se centraban, además del triunfo en la guerra que las Cortes venían a dificultar ${ }^{282}$, en las características del sistema político monárquico, en la preponderancia de la Iglesia católica, en la tiranía francesa y en la usurpación del poder de la Corona que suponía el Parlamento gaditano ${ }^{283}$.

Los sistemas de reclutamiento quedaban para la prensa, independientemente de su condición ideológica, por tanto en un segundo plano, centrándose principalmente en las operaciones en el campo de batalla, en la dramática situación por la que atravesaba el país, en las características del sistema político en ciernes y en los debates en Cortes. Poco o nada se señalaba sobre las consecuencias

279 CEPEDA GÓMEZ, J., El Ejército español en la política española (1787-1843), conspiraciones y pronunciamientos en los comienzos de la España liberal, p. 155.

280 El Censor General, 02/07/1812, p. 15.

${ }^{281}$ El Conciso, $14 / 02 / 1811$, no 22, p. 6.

282 "Es bien sabido el proverbio del ilustre General Montecuculi: iPara hacer la guerra se necesita dinero, dinero, y dinero.i Que campo tan extenso para el asiduo trabajo del Congreso, en la general escasez que padecemos, quando aun por nuestras antiguas leyes $y$ por el bien eminente de la Patria, y por la expresa voluntad de nuestro muy amado Soberano el Señor D. Fernando Vil, corresponde directamente á las Cortes!" (El Censor General, 24/01/1812, p. 8).

283 "iIlusosi Vosotros decía que la Soberanía está, en la Nación; pues advertid que la Nación está dominada por las tropas de un 'tirano; que en vuestra elección apenas ha tenido parte, que ignora vuestros intentos; y que por lo mismo atacáis con vuestra conducta esos mismos derechos de Soberanía, que fingís para reynar, quando así anteponéis vuestros votos á los suyos" (El Censor General, 13/06/1814, pp. 13-14). 
que, para el conjunto de la sociedad, tenía el ingreso de los jóvenes en el Ejército.

Respecto a nuestro tema de estudio, el reclutamiento, algunos diputados, como el liberal moderado Canga Argüelles estimaban que, ante la gravedad de la situación que el conflicto bélico traía aparejado "[...] una guerra que tiene a la nación al borde de la ruina"284, era necesario acabar con todo privilegio y exención para situar a toda la nación en pie de guerra, lo cual suponía implantar el alistamiento universal. La prensa liberal también reflejaba en sus páginas las enormes dificultades económicas y hacendísticas del momento, lo cual tenía gran incidencia en las posibilidades del reclutamiento y en el desarrollo de la propia guerra ${ }^{285}$.

Otros diputados se mostraban menos radicales. Por ejemplo, el diputado Aner estimaba que había que tener en cuenta las capacidades físicas de los reclutas para poder soportar la dureza del servicio militar, además de la necesidad de reducir los márgenes de edad para la prestación a la franja comprendida entre los dieciocho y los cuarenta, y no entre los dieciséis y los cuarenta y cinco, como estaba implantado legalmente. Incluso algunos diputados -caso de los moderados Utges, Creus y Mejía ${ }^{286}$ - defendieron exenciones que impidiesen el freno del desarrollo económico en los terrenos agrícola e industrial, así como exenciones para determinadas condiciones familiares. Por su parte, la redención económica era bien considerada, siempre que sirviese para mantener un ejército mejor preparado y equipado: "¿Y que vale más, tener 400.000 hombres en campaña, mal vestidos y armados, o tener 150.000 equipados con todo lo necesario?". La respuesta del diputado conservador Burrull a

\footnotetext{
${ }^{284}$ Diario de Sesiones de las Cortes, 22/01/1811, no 118, p. 425.

285 El Conciso, 10/02/1811, no 20, p. 4.

286 Diario de Sesiones de las Cortes, 22/01/1811, no 118, pp. 425-428, $11 / 02 / 1811$, no 138 , pp. 531-533, 12/02/1811, no 139, p. 536 07/09/1811, no 340, pp. 1791-1795.
} 
estas palabras fue categórica, logrando que se impusiera el rechazo a las exenciones y la redención:

"La nobleza y los pudientes vayan a campaña; esto anima a las demás clases; y si se necesita dinero, que se les pida; porque siendo necesario para la salvación de la Patria ni deben extrañarlo, ni excusarse por término alguno; y si se opusiesen á ello, se debe considerar este acto como falta de patriotismo. Los que no tienen caudal ofrecen su hijos para oponerse al tirano; y los que poseen caudales, deben presentar, no solo á sus hijos, sino también sus caudales ${ }^{\prime 287}$.

Meses más tarde, en septiembre de 1811, la redención de un máximo del 30\% de los alistados, a cambio del pago de 10.000 reales, fue planteada por la Comisión de Guerra y aprobada por las Cortes, ante la necesidad de recabar fondos para pertrechar a las tropas $^{288}$, no sin ser objeto de importantes discrepancias por parte de diputados exaltados como Golfín, Martínez Tejada o Calatrava, que pronosticaron el descontento, la amargura y la irritación populares y el rechazo hacia el servicio militar, dadas las injusticias que la redención implicaba, al no contribuir todos los ciudadanos de la misma forma al sostenimiento militar de la nación y por chocar la redención con el espíritu de la futura carta magna.

\footnotetext{
287 Discurso del Sr. Burrull, Diario de Sesiones de las Cortes, 12/02/1811, no 139, p. 537.

288 "El principio que debe regir es que nuestros soldados, cualquiera que sea el número de ellos, deben estar vestidos y mantenidos; porque más vale tener 2.000 o hombres bien equipados y mantenidos, que 40.000 muertos de hambre y desnudos. De lo que principalmente se quejan los soldados no son de estas exenciones, sino la falta de vestuario, de la ración y del prest" (Discurso del Sr. Creus, Diario de Sesiones de las Cortes, 07/09/1811, no 340, p. 1792). La respuesta del Diputado Martínez fue la siguiente: "Búsquense otros medios que alcancen á cubrir las necesidades de los Ejércitos. Nada importa que sean duros, con tal que sean justos. Quédese sin camisa el pobre; pero quédese también sin ella el rico: sea igual la carga, séanlo las fatigas, los sacrificios" (Discurso del Sr. Martínez, Diario de Sesiones de las Cortes, 07/09/1811, n 340, p. 1793).
} 
Sus defensores argumentaron que la exención no era un privilegio, ya que no era una ley privada que afectase a una determinada persona, sino que estaba abierta a toda la población ${ }^{289}$. Incluso se utilizó como argumento una posible falta de capacidad para el esfuerzo y el trabajo de los hijos de familias pudientes, debido a su falta de costumbre:

"[...] debo añadir y hacer presente que los jóvenes á quienes se trata de licenciar del servicio mediante el donativo que se señala, no son los más aptos para la guerra, si ya no que enteramente inútiles. Se trata de aquellos jóvenes que por haber nacido de Padres pudientes se han criado en la molicie y en el regalo: su educación, por consiguiente, ha sido análoga á la delicadeza de su crianza: han pasado su adolescencia entre los halagos del mimo paternal, sin otra ocupación que la que les sugerían sus caprichos, ó bien el dulce ocio de las letras. Una educación de esta especie no puede constituir una naturaleza robusta. Y si la dureza, la vigilancia, el trabajo y las fatigas deben ser inseparables del soldado! ¿cómo podrían serlo buenos los jóvenes de quienes se trata? ya que su crianza, su educación y sus ocios les han hecho útiles para la guerra, y absolutamente imposibilitados para sobrellevar las penalidades anejas a la carrera del honor, ¿nos empeñaremos, á pesar de estas consideraciones, á sacrificar infructuosamente estas víctimas al furor de Marte? ¿no será más prudente y más acertado sacar de estos jóvenes otro partido que sea más ventajoso al Estado? De esto se trata, señor. Ellos, pues, ya que no tienen resistencia para sobrellevar las fatigas militares, mantengan con ese donativo, á que se les obliga para alcanzar su licencia, á los soldados robustos; vístanlos y equípenlos; pues de este modo, siendo aquellos inútiles para las campañas, harán útiles con sus caudales á los beneméritos defensores de la Patria"290.

289 Diario de Sesiones de las Cortes, 07/09/1811, no 340, pp. 1791-1795 y 09/09/1811, no 341, pp. 1801-1802.

290 Discurso del Sr. Cárdenas, Diario de Sesiones de las Cortes, 07/09/1811, no 340, pp. 1794 у 1795. 
La Constitución de $1812^{291}$ supuso un nuevo concepto de Ejército y de sistema reclutamiento ${ }^{292}$, que venía a superar al establecido por la Ordenanza de $1800^{293}$. Suponía la transición del concepto de soldado-súbdito sometido a la autoridad monárquica propia del Antiguo Régimen, al de ciudadano-soldado que, bajo el auspicio de la soberanía nacional, estaba obligado a defender a su patria según lo establecido por la ley, concepto éste aparecido con la

291 "Con la Constitución de Cádiz de 1812, los legisladores reconocieron como fuerzas combatientes e integrantes del Ejército a lo que denominaban milicias nacionales, junto a las tropas regulares. El reconocimiento legal supuso la desaparición, al menos formal, de las organizaciones de voluntarios armados por las distintas Juntas, quedando todos ellos integrados en un solo cuerpo [...]. En síntesis, la Milicia estaba separada del Ejército regular y compuesta por dos armas: infantería y caballería. Los oficiales eran elegidos por la propia tropa. El número de ciudadanos obligados a servir en la Milicia se fijó en treinta por cada mil trescientos habitantes mayores de 30 años y menores de 50. Cumplían tareas de seguridad, orden y paz en el interior del país" (CRESPO-FRANCÉS Y VALERO, J.A., $A$ las armas: Reclutamiento y servicio militar en España desde sus orígenes hasta nuestros días, p. 241).

292 Sobre los debates en Cortes acerca de aquello que debía recoger la Constitución referente al Ejército, ver Diario de Sesiones de las Cortes, 16/01/1812, no 470, pp. 2633 y 2634 . En estos debates aparece ya el temor de los diputados a que el Ejército actuase como un instrumento al servicio de los intereses del Rey, de ahí la necesidad de contar con unas milicias fuertes, baluartes de la libertad y fuera del alcance del rey, controladas por las Cortes y que viniesen a defender el nuevo orden liberal y actuasen como contrapeso del poder monárquico: "El Ejército ha de atender principalmente a la defensa exterior del Estado, y las Milicias á conservar el orden interior, y mantener en toda su integridad la Constitución siempre que se quisiese destruirla violentamente. El primero debe estar en consecuencia a disposición de la potestad ejecutiva, y las segundas en una absoluta independencia de ella. El Ejército, porque siendo quien ha de presentar resistencia a una invasión extranjera, pagado como es inmediatamente por el Rey, necesariamente dependerá de éste, el cual por su naturaleza debe dirigir la guerra; las Milicias estarían independientes, porque consistiendo su principal obligación en sostener la Constitución y las leyes, no han de quedar á las órdenes de aquella potestad [...]. Estando de esta manera separadas é independientes del Rey las milicias, no cabe duda que si un mal consejo le arrastrase á aquel á invadir la Constitución, este fuerza presentaría una resistencia grande y proporcionada para repeler cualquier ataque y deshacer empresa tan temeraria." (Discurso del Sr. Conde de Toreno, Diario de Sesiones de las Cortes, 16/01/1812, no 470, pp. 2633). Otros diputados, por el contrario, defendieron que la fuerza armada quedase a disposición del Monarca para la conservación del orden interior del Estado ya que, con las nuevas circunstancias, resultaría poco probable un levantamiento militar para esclavizar a la Nación. Las milicias no deberían existir como instrumento para asegurar la Constitución y la libertad, sino como cuerpo supletorio del Ejército permanente. Discursos del Sr. Aner y del Sr. Oliveros, Diario de Sesiones de las Cortes, 16/01/1812, no 470, pp. 2633-2638.

293 "Las Cortes de Cádiz además de atender a las necesidades más perentorias de la guerra intentaron dar forma a un sistema de reclutamiento para el futuro". (CRESPO-FRANCÉS Y VALERO, J.A., A las armas: Reclutamiento y servicio militar en España desde sus orígenes hasta nuestros días, p. 20). 
Revolución Francesa. La fundamentación teórica del servicio militar obligatorio es realmente revolucionaria, ya que se basa en el principio de igualdad de todos los ciudadanos, "pero no dejará de ser un impuesto de sangre para las clases bajas y el sexo masculino y [...] un ligero impuesto económico para las clases acomodadas"294.

En cuestiones militares, se inició la constitución gaditana declarando la obligatoriedad que tenían todos los españoles de defender la Patria con las armas cuando fuesen llamados por la ley ${ }^{295}$, sin posibilidad de excusarse del servicio militar. Quedó establecido por tanto el servicio militar obligatorio. Además, se otorgó a las Cortes la facultad de fijar anualmente, a propuesta del Rey, las fuerzas militares del país, compuestas por un Ejército permanente y unas milicias nacionales ${ }^{296}$. Por primera vez en la historia de España es una cámara legislativa de composición popular la encargada de fijar el contingente militar en función de las necesidades existentes ${ }^{297}$, suponiendo además un freno al poder regio ${ }^{298}$. El

\footnotetext{
294 MOLINA LUQUE, J.F., Quintas y servicio militar: aspectos sociológicos y antropológicos de la conscripción (Lleida, 1878-1960), P. 21.

295 Esta premisa fue planteada por Canga Argüelles, Diario de Sesiones de las Cortes, 19/01/1811, no 115, p. 407.

${ }^{296}$ Constitución de 19 de marzo de 1812, arts. 9, 131, 357 y 361. Para la Milicia Nacional ver, PÉREZ GARZÓN, S., Milicia Nacional y Revolución burguesa.

297 "Esta sería [...] la síntesis del pensamiento político-militar de aquellos primeros diputados de España: el Ejército permanente es un instrumento del Rey que le da una inmensa fuerza para ayudarle a su inevitable tendencia hacia el absolutismo y, por ello, se hace preciso contrarrestarlo con la creación de las Milicias, cuerpo armado de total dependencia del poder legislativo" (CEPEDA GÓMEZ, J., El Ejército español en la política española (1787-1843), conspiraciones y pronunciamientos en los comienzos de la España liberal, p. 138).

298 "Aunque el origen remoto de estos preceptos pudiera hallarse en textos jurídicos de algunos de los viejos reinos hispánicos, su antecedente próximo se encontraba en la Constitución francesa de 1791, la cual, siguiendo la pauta del constitucionalismo inglés, atribuía al poder legislativo la facultad de establecer anualmente, a propuesta del Rey, el número de hombres y navíos de que se compondrían el Ejército y la armada. Su fundamentación doctrinal no se presentaba en forma distinta a la de las cargas e impuestos que debía satisfacer el ciudadano, entre las que se consideraba como la más gravosa y, por tanto, como la más necesitada de todo género de garantías. Por un lado, estaban en juego los más altos intereses de los ciudadanos y, por otro, había de evitarse a toda costa que esta facultad quedase en manos del Rey, con lo que su poder se haría invulnerable" (CASADO BURBANO, P., Las fuerzas armadas en el inicio del constitucionalismo español, pp. 149 y 150).
} 
Ejército pasó a depender del poder legislativo y dejó de depender del Monarca ${ }^{299}$. Sin embargo, no profundizó el texto constitucional en el desarrollo de las operaciones de reclutamiento ${ }^{300}$.

Más allá de los principios generales que establece la Constitución respecto a la institución militar, el objetivo de aprobar una ley que regulase todo lo relativo al Ejército quedó truncado con el regreso de Fernando VII y la reacción absolutista de 1814. Las Cortes sí llegaron a aprobar la creación de una Comisión de Guerra que elaborase un proyecto de ley militar que mejorase la organización del Ejército y acabase con el caos, la confusión y la heterogeneidad normativa que la guerra contra el invasor había supuesto ${ }^{301}$. En las discusiones sobre quienes debían de ser los miembros de aquella Comisión, marcadas por la desconfianza de muchos diputados hacia el Ejército como herramienta al servicio de los deseos absolutistas del monarca, quedó bien claro el nuevo concepto de soldado que la Constitución había traído consigo y que los diputados defendían:

"El sistema militar que en adelante deberá gobernarnos merece el mayor detenimiento y circunspección, como que de su buena o mala forma dependerá el asegurar la libertad civil, y la existencia de la Constitución política de la Monarquía. Todos sabemos que los Ejércitos, que no deben ser mas que una porción de ciudadanos

\footnotetext{
299 BUSQUETS BRAGULAT, J., El militar de carrera en España, 1984, p. 27.

300 "Las Cortes de Cádiz aprobaron numerosos decretos extraordinarios de reclutamiento, normativas para modificar la Ordenanza de 1800, y lograron que el esfuerzo exigido por el reclutamiento se repartiese igual entre todos los españoles" (FEIJÓo GÓMEZ, A., Quintas y protesta social en el siglo XIX español, p. 213).

301 "No es necesario detenerse á probar que la subordinación, cuya falta inutiliza las mejores disposiciones; el espíritu militar, suplemento necesario de las leyes; el órden, sin el cual ningún cuerpo puede existir, y hasta la adquisición misma de las cualidades físicas y morales que deben caracterizar á los militares, son efectos de la buena constitución y organización de los Ejércitos. El nuestro, si no carece absolutamente de ella, no la tiene tan clara, tan universal, y tan generalmente observada como era preciso; y estos defectos son de la mayor trascendencia actualmente, que combatimos con un enemigo que, por sola la mayor perfección de su ordenanza, resiste á los prodigiosos esfuerzos del patriotismo y del valor individual, y retarda el triunfo de la causa más justa que los hombres han defendido jamás" (Informe de la Comisión de Guerra, Diario de Sesiones de las Cortes, 15/06/1812, no 589, p. 3316).
} 
armados destinados a proteger y defender las clases pacíficas y productoras del Estado, han sido por desgracia en los Gobiernos modernos unos meros instrumentos del capricho de loa gobernantes para oprimir estas clases. [...] debemos como ellos formar del soldado un apoyo de los derechos sociales, un defensor de la independencia nacional, y no un mercenario, pronto solo á saciar la ambición y deseos inmoderados de los Príncipes; un amigo de SUS conciudadanos, no un enemigo de ellos y de la libertad de su Patria ${ }^{\prime \prime 302}$.

El regreso en 1814 de Fernando VII de su cautiverio en Bayona impidió la aplicación real de la nueva doctrina emanada de las Cortes, ya que la liberación del monarca deseado implicó la vuelta al más rígido absolutismo y a la legislación del Antiguo Régimen, e impidió, además, la aprobación de una ley constitutiva del Ejército, cuya promulgación hubo de esperar hasta el Trienio Liberal ${ }^{303}$. Por lo tanto, los nuevos principios acerca del reclutamiento surgidos en Cádiz no pudieron aplicarse, y no hubo novedades legislativas en la materia durante los seis años de gobierno absolutista. Fernando VII se limitó a derogar la legislación gaditana, a disolver la Milicia Nacional y a reimplantar la Ordenanza de 1800 con algunos añadidos en 1817 y 1819, que ya analizamos al estudiar el texto aprobado el primer año del siglo XIX:

"En el reinado de Fernando VII no hay, prácticamente, novedades en la legislación militar relativa al reclutamiento, especialmente en el primer periodo absolutista (1814-1820), hecho tanto más destacable por cuanto no faltaron ocasiones $y$ circunstancias que exigieron la reforma o remodelación del Ejército,

302 Discurso del Sr. Conde de Toreno, Diario de Sesiones de las Cortes, 15/06/1812, no 593, p. 3350. Ver también CEPEDA GÓMEZ, J., El Ejército español en la política española (1787-1843), conspiraciones y pronunciamientos en los comienzos de la España liberal, pp. 137 y 138.

303 MAQUEDA ABREU, C., "La Restauración de Fernando VII y el reclutamiento militar", pp. 76 y 77. 
pero tanto una como otra no se enfocaron nunca desde un punto de vista revolucionario, razón por la que las coordenadas militares siguieron dentro de unos planteamientos que, tras las consecuencias de la Revolución Francesa y el Imperio Napoleónico, empezaron a quedar trasnochados en una Europa decididamente restauracionista" ${ }^{\prime 304}$.

Se perdió, por tanto, la oportunidad de implantar una necesaria reforma en el Ejército que, además, tenía que afrontar los procesos de emancipación americanos y se regresó al concepto de milicia anterior a 1808. Sin embargo, los seis años de Sexenio Absolutista no pudieron enterrar los principios liberales extendidos en los tiempos de la guerra contra los franceses. El inicio de una nueva etapa, el Trienio Liberal (1820-1823), supuso el regreso al poder de los liberales, la reimplantación de la Carta Magna gaditana y el restablecimiento de la Milicia Nacional ${ }^{305}$. El problema del reclutamiento se reavivó a partir de 1820, ya que era necesario justificar la desobediencia y la rebeldía de aquellos que se habían sublevado contra el absolutismo fernandino y que ahora habían asumido cargos de gobierno ${ }^{306}$.

\footnotetext{
304 MAQUEDA ABREU, C., "La Restauración de Fernando VII y el reclutamiento militar", p. 71.

305 "El único intento serio por crear un Ejército voluntario se produce con las Milicias burguesas, que a principios del siglo XIX se convirtieron en la principal garantía de las libertades, de la propiedad privada, del nuevo concepto de patria, y fueron el más fiel reflejo de la voluntad de cambio político en la España decimonónica. Los políticos recurrieron a la Milicia como fuerza de choque contra el Antiguo Régimen y para mantener los logros revolucionarios, pero cuando estos logros se consideraron a salvo la Milicia apareció como un peligro para la burguesía, sobre todo cuando dejó de ser una fuerza de propietarios y se convirtió en una fuerza de ciudadanos neutrales y hasta jornaleros (Voluntarios de la Libertad), que cuestionaban los principios del liberalismo doctrinario" (FEIJÓo GÓMEZ, A., Quintas y protesta social en el siglo XIX español, p. 228).

306 "Todos coincidieron en que la rebeldía estaba justificada por defender los principios nacionales y constitucionales, enterrados ilegalmente en 1814. El Ejército se arrogó, por primera vez, el derecho a implantar un orden político distinto, el derecho a la revolución; los militares sabían de la ilegalidad de su acción, pero la justificaron por la defensa de principios superiores (libertad, patria, constitución) y porque sólo ellos podían hacer lo que era justo y lo que todo el pueblo pedía. Se cuestionó, por lo tanto, la obediencia ciega, que desde ahora quedó limitada por la Constitución y por otros valores superiores y difícilmente cuantificables [...]" (FEIJÓo GÓMEZ, A., Quintas y protesta social en el siglo XIX español, p. 209).
} 
Nuevas leyes vendrían a desarrollar los conceptos que, en materia de reclutamiento, la Constitución de Cádiz había recogido. Nos referimos especialmente a la Ley de 14 de mayo de 1821 de reemplazo del Ejército permanente; a la Ley constitutiva del Ejército, aprobada por las Cortes el 9 de junio de 1821; al Decreto de 21 de octubre de 1822 para llevar a efecto el reemplazo extraordinario del Ejército, decretado en 22 de este mes, se hacen algunas explicaciones, adiciones y modificaciones a la Ordenanza de 1800 y resoluciones posteriores; y a la Ordenanza General para el reemplazo del Ejército de 3 de febrero de $1823^{307}$. A pesar de sus contenidos casi siempre similares, en ocasiones estos textos presentan importantes contradicciones jurídicas, en especial en lo que se refiere a la redención pecuniaria, ya que la Ley Constitutiva del Ejército de 1821 prohibió la redención en metálico, mientras que la Ordenanza de 1823 volvió a autorizarla.

Para profundizar en su análisis hemos acudido a dos publicaciones periódicas de distinto signo ideológico para poder observar así la forma en que asumían las novedades legislativas y sus implicaciones sociales. Estos dos periódicos analizados, en un periodo de mayor libertad de prensa tras el paréntesis absolutista, han sido El

\footnotetext{
307 Ley de 14 de mayo de 1821 de Reemplazo del Ejército Permanente (Colección de Decretos y Órdenes Generales expedidos por las Cortes ordinarias de los años 1820 y 1821, Madrid, Imprenta Nacional, 1821). En adelante, Ley de 14 de Mayo de 1821 de reemplazo del Ejército permanente. Ley constitutiva del Ejército de 9 de Junio de 1821 (Colección de Decretos y Órdenes Generales expedidos por las Cortes Ordinarias de los años 1820 y 1821, Madrid, Imprenta Nacional, 1821). En adelante, Ley constitutiva del Ejército de 9 de junio de 1821; Decreto de 31 de octubre de 1822 para llevar a efecto el reemplazo extraordinario del Ejército, decretado en 22 de este mes, se hacen algunas explicaciones, adiciones y modificaciones a la Ordenanza de 1800 y resoluciones posteriores (Colección de Decretos y Órdenes Generales expedidos por las Cortes Extraordinarias (sic) que comprende desde 3 de octubre de 1822 hasta 19 de febrero de 1823, Madrid, Imprenta de Don Tomás Albán y Compañía, 1823). En adelante, Decreto de 31 de octubre de 1822 para llevar a efecto el reemplazo extraordinario del Ejército; Ordenanza General para el reemplazo del Ejército de 3 de febrero de 1823 (Colección de Decretos y Órdenes Generales expedidos por las Cortes Estraordinarias (sic) que comprende desde 3 de Octubre de 1822 hasta 19 de Febrero de 1823, Madrid, Imprenta de Don Tomás Albán y Compañía, 1823). En adelante, Ordenanza General para el reemplazo del Ejército de 3 de febrero de 1823.
} 
Espectador, de carácter constitucionalista y liberal ${ }^{308}$, y El Censor ${ }^{309}$.

Debemos tener en cuenta el gran protagonismo concedido en sus textos al Ejército, sus hazañas y sus grandes figuras, si bien el sistema de nutrir sus filas era prácticamente ignorado.

308 "Uno de los grandes periódicos del Trienio Liberal, fundado por Evaristo San Miguel (1785-1862), al que se le atribuye la autoría del Himno de Riego, que comienza a aparecer el 15 de abril de 1821. En su prospecto señala que estará dirigido "al público indulgente y tolerante" y en el que se escribirá sobre política, filosofía, moral, ciencias, literatura, del gobierno, de Europa, de España... De cuatro páginas por número y a dos columnas, aumentará el tamaño de su formato, siendo un diario moderno que introducirá las "Cartas de los lectores", al estilo de The Spectator londinense que había conocido San Miguel durante su exilio en la capital británica. Estará estructurado en secciones de noticias nacionales y extranjeras, Cortes, variedades, artículos doctrinales, políticos y divulgativos, anécdotas, anuncios (de bibliografía, etc.).

Afín ideológicamente a El universal, de carácter constitucionalista y liberal entre templado y exaltado, se le considera también órgano oficioso de la masonería, del que su fundador formaba parte y, según Juan Pérez de Guzmán, inspiraba gobiernos y Cortes y tertulias políticas, moderándose al llegar San Miguel a la presidencia del gobierno en agosto de 1822 y convirtiéndose en órgano oficioso de su ministerio.

[...]

Su último número apareció el 31 de marzo de 1823, tras marcharse Fernando VII a Sevilla con la entrada en España de los Cien mil hijos de San Luis" (http://www.bne.es/es/Catalogos/HemerotecaDigital).

309 "Considerada como una publicación de excepcional calidad y la de más prestigio del Trienio Liberal, formalmente se la define como una revista, dada la amplitud de sus números, en torno a las ochenta páginas cada uno. [...]. De carácter constitucionalista, su tendencia es de un liberalismo supermoderado, enmarcado más bien en el despotismo ilustrado [...].

Esta cabecera, que ya había sido utilizada en el siglo XVIII en el periodismo español, es adoptada ahora con el fin, según su prospecto, de censurar los abusos del poder y rebatir las ideas de otras publicaciones, atacando duramente al El zurriago, el periódico exaltado por excelencia del periodo, y manteniendo una máxima enemistad con El universal, siendo a su vez acusado de estar financiado por manos foráneas, en concreto francesas.

Es un periódico político templado y equilibrado, pero también literario, que va a dar cabida asimismo a un incipiente periodismo costumbrista. Ofrece extensos artículos doctrinales sobre el constitucionalismo, la libertad de imprenta o sobre el papel del clero regular, así como crónicas parlamentarias. [...].

Estuvo apareciendo cada sábado, hasta que publica su último número el 13 de julio de 1822 al entender sus artífices la dificultad de seguir editándolo por la exasperación de los ánimos y la agitación política que sigue al fallido golpe de Estado absolutista del día siete"

(http://www.bne.es/es/Catalogos/HemerotecaDigital). 
a) El fin de las exenciones estamentales: Ley de 14 de mayo de 1821 de reemplazo del Ejército permanente

La primera de estas Leyes pretendía asegurar el reemplazo del Ejército permanente para el año 1821, y fue impulsada por el Secretario del Despacho de Guerra Tomás Moreno y Daoiz ${ }^{310}$. En estos momentos el Ejército era visto, por parte de la prensa liberal, como un símbolo de la libertad y de la soberanía nacional: "En este momento se halla el pueblo reunido esperando la entrada de los militares triunfantes. iLoor al ejército español, en cuyas virtudes descansa la patria libre!"311. Además, venían a confirmar la equivalencia entre soldado y ciudadano:

"Ciudadanos: los soldados de un gobierno absoluto son los opresores de sus mismos hermanos, y esclavos como Ellos; los tiranos que ni aun se dignan prestar la menor atención á su suerte, creen que la sangré de aquellos es toda suya, y si la vierten para defenderles se juzgarían degradados sí prestasen el mas pequeño signo de agradecimiento; su orgullo les ha hecho aspirar á la clase de los dioses, y ni aun pueden llegar á ellos los inciensos que les presentan sus siervos; pero vosotros sois ya ciudadanos, sois soldados de un pueblo libre, de un gobierno constitucional $[\ldots]^{\prime \prime 312}$.

La prensa más templada ideológicamente remarcaba sin embargo el deber de obediencia en el seno del Ejército: "El régimen de los militares debe ser esencialmente absoluto: su dogma es la obediencia"313. Además, aunque se confirmaba el carácter de

\footnotetext{
310 "Militar y político, se desconocen sus fechas de su nacimiento y muerte. Tuvo una dilatada carrera que culminó como titular de la cartera de Guerra entre marzo de 1821 y enero de 1822" (Diccionario Biográfico Español, edición digital, RAH, http://www.rah.es/cdeb.htm).

${ }^{311}$ El Espectador, 05/05/1821, no 21, p. 3.

312 El Espectador, 07/06/1821, no 54, p. 2.

313 El Censor, 05/05/1821, no 40, p. 72.
} 
ciudadano que tenían los soldados, también se reclamaban límites a sus libertades:

"El militar es sin disputa alguna un ciudadano; pero mientras que está debajo de las banderas, se halla sujeto á muchas mas obligaciones que todos los demás, y debe carecer del uso de algunas de sus libertades: de lo contrario el soldado, lejos de ser el protector, no vendrá á ser sino el verdugo de sus compatricios"1314.

Más allá de aprobar el ingreso en el Ejército de 17.095 hombres, lo más significativo de esta nueva ley es el importante papel que concedió a las Diputaciones provinciales, encargadas de realizar el reparto del cupo entre los pueblos de su circunscripción en función del número de habitantes de cada uno. Para ello deberían tener en cuenta el censo poblacional elaborado en 1797. Las Diputaciones asumirían, asimismo, las funciones que, según la Ordenanza de 1800, debían de realizar las juntas de agravios.

Todas las operaciones del sorteo y reemplazo se debían realizar en función de la Ordenanza de 1800 y de su Reglamento adicional de 1819, pero como novedad se concedió a cada provincia la posibilidad de reclutar a los mozos que le hubiesen sido asignados a través del sorteo o a través de sustitutos voluntarios entre dieciocho y treinta y seis años, siempre que cumpliesen con los requisitos mínimos establecidos en la Ordenanza de 1800. Todos los sustitutos debían presentar un certificado del Ayuntamiento donde residiesen que hiciese constar su nacionalidad española, el estar libre del sorteo de ese año, su buena conducta y el no haber estado procesado criminalmente $^{315}$. También se admitió la sustitución en masa para

${ }^{314}$ El Censor, 12/05/1821, no 41, p. 47.

315 El Diputado Sánchez Salvador solicitó incluir otro requisito, a la postre rechazado, para el sustituto, el ser natural de la provincia del sustituido, "[...] porque de lo contrario las provincias ricas harían un mercado de reemplazos con los naturales de las más pobres; y también porque la población lo exigía así, pues de otro modo, sacando las provincias ricas los mozos de las pobres, la despoblación 
todas las provincias y municipios ${ }^{316}$. Si algún sustituto voluntario desertase antes de cumplir los dos años de servicio, la provincia, municipio o individuo a quien sustituyese debería reponerlo de forma inmediata ${ }^{317}$.

La segunda novedad de importancia que recoge la ley es la supresión de las exenciones propias del Antiguo Régimen, y es que las exenciones nobiliarias y la de los tonsurados y ordenados menores quedaron abolidas, sin contemplarse la posibilidad de la redención en metálico. También se suprimieron las antiguas exenciones concedidas a familiares del extinto tribunal de la Inquisición, los bachilleres de las facultades mayores, los alcaldes, regidores y síndicos de los Ayuntamiento, los postillones de las casas de postas y los maestros impresores y tintoreros textiles ${ }^{318}$.

b) La defensa del nuevo orden constitucional: Ley constitutiva del Ejército de 9 de Junio de 1821

La segunda de las leyes a la que hemos hecho referencia, la Ley constitutiva del Ejército de 1821, ratificada tras largos debates en Cortes, se nos presenta como la primera ley aprobada en España

iría creciendo progresivamente" (Discurso del Sr. Sánchez Salvador, Diario de Sesiones de las Cortes, 12/05/1821, no 74, p. 1576).

316 "Distribuido el contingente entre todas las provincias de la Península e islas adyacentes con exacta proporción á su población, las Diputaciones Provinciales repartirán el cupo correspondiente a cada Pueblo, sin perjuicio de poder llenar en masa el de toda la Provincia por medio de voluntarios, y esta misma libertad se deja a cada pueblo y aun á cada individuo Particular. Pero las Cortes no quieren que la noble Profesión militar pueda llegar jamás á envilecerse, ni que la defensa de nuestra libertad y de nuestra gloria se confíe a manos corrompidas o criminales, y por eso la Comisión ha fijado las calidades indispensables que han de tener los sustitutos. Por lo demás, la Comisión ha creído que en los pueblos en que haya de cubrirse el cupo por medio del sorteo, debe arreglarse éste á la ordenanza dl reemplazos de 1800 y al reglamento adicional de 1819 con algunas ligeras modificaciones que el orden constitucional hace absolutamente indispensables (Diario de Sesiones de las Cortes, 09/05/1821, no 71, p. 1501).

317 Ley de 14 de Mayo de 1821 de reemplazo del Ejército permanente, arts. 1-18.

${ }^{318}$ Ley de 14 de Mayo de 1821 de reemplazo del Ejército permanente, art. 19. 
nacida con la vocación de organizar todo el entramado militar del país, con el objetivo desarrollar aquello que la Constitución de 1812 señalaba sobre el Ejército, "sin menoscabo de que después leyes ordinarias desglosasen los detalles" ${ }^{319}$. Por tanto, las cuestiones relativas al reclutamiento sólo constituyen una parte de la misma, y a ellas se dedican los capítulos I, II y III del texto. La prensa liberal mostró todo su apoyo a la aprobación de un texto legislativo que venía a establecer sus principios ideológicos en materia militar:

"Las cortes han discutido en su totalidad el proyecto de ley constitutiva ó reglamentaria del ejército ( $\mathrm{sic}$ ), que en nuestro concepto es digna de su liberalismo y de sus luces. Resta que se ponga en planta esta ley justa y que el egército (sic) español salga del cabos en que se halla. Esta porción tan benemérita de ciudadanos, este baluarte de nuestras libertades, estos hombres que renuncian a tantos goces y á la vida misma, si es preciso, en obsequio de su patria, son dignos de todas las atenciones de un gobierno que quiera merecer la confianza de los pueblos. Ya es tiempo que el egército (sic) español que hasta el presente merece tanto de la patria, se consolide para siempre en sus principios y se ponga en estado de ser una barrera incontrastable contra los ataques de sus adversarios ${ }^{\prime \prime 320}$.

Comienza la ley estableciendo la obligatoriedad que tienen todos los españoles de defender a la Patria con las armas, ya que la fuerza militar nacional estaría formada por todos los españoles que arma el Estado para su defensa ${ }^{321}$, y cuyo contingente sería

319 BUSQUETS BRAGULAT, J., El militar de carrera en España, Barcelona, Ariel, 1984 , p. 26.

${ }^{320}$ El Espectador, 08/06/1821, no 55, p. 4.

321 "El paso de la concepción del Estado como patrimonio de una persona o de una familia o la del Estado como patrimonio de la nación, a quien se atribuía la soberanía, llevó consigo el tránsito de la idea del soldado como persona al servicio de otra, a la del soldado como ciudadano que se arma para la defensa de su patria. Por otra parte la consagración del principio de igualdad de todos los ciudadanos, que implicaba el reparto equitativo entre todos ellos de gravámenes y cargas, con abolición de todo privilegio, supuso la generalización de esta contribución personal 
establecido anualmente por las Cortes en función de las necesidades militares y de la población residente en cada provincia y municipio ${ }^{322}$. Como novedad jurídica e ideológica, por primera vez se estableció, como tarea del Ejército, además de la defensa del país de los enemigos y agresiones exteriores y del mantenimiento del orden público, la defensa de la libertad política, del orden constitucional y del cumplimiento de las leyes ${ }^{323}$. El Ejército no sería por tanto un mero instrumento al servicio del Rey, sino que una de sus tareas esenciales sería la de asegurar el orden constitucional frente a las agresiones del absolutismo, quedando sometido al poder legislativo. El Ejército se constituye así en una herramienta al servicio y sometida a la soberanía popular. Por ello constituiría un delito de traición el uso de la fuerza armada con los siguientes fines:

"10. Para ofender la persona sagrada del Rey.

$2^{\circ}$. Para impedir la libre elección de Diputados de Cortes.

$3^{\circ}$. Para impedir la celebración de las Cortes en las épocas y casos que previene la Constitución.

$4^{\circ}$. Para suspender o disolver las Cortes ó la Diputación permanente de las mismas.

50. Para embarazar de cualquier manera las sesiones ó deliberaciones de las Cortes ó de su Diputación permanente"1324.

Además se estableció que ningún militar debería obedecer a un superior que abusase de la fuerza armada en los casos indicados, subjetiva premisa que podría conllevar problemas de indisciplina ${ }^{325}$.

que representaba el cumplimiento del servicio militar" (CASADO BURBANO, P., Las fuerzas armadas en el inicio del constitucionalismo español, p. 205).

322 El criterio utilizado para el reparto de los cupos, la población existente en cada Provincia, originó un largo debate en el seno de las Cortes sobre la oportunidad del mismo. A este respecto ver Diario de Sesiones de las Cortes, 17/04/1821, no 51, p. 1095-1105.

${ }^{323}$ Ley constitutiva del Ejército de 9 de junio de 1821, arts. 1, 2, 6, 10, 11, 12, 21, 22 y 26.

${ }^{324}$ Ley constitutiva del Ejército de 9 de junio de 1821, art. 7. 
Otra novedad del texto legislativo hace referencia al modo de realizar el reemplazo del Ejército permanente, ya que éste se vería suministrado de efectivos mediante tres vías: a través de miembros de las milicias provinciales activas cuando así lo considerasen pertinente las Cortes $^{326}$; a través de la contribución que cada provincia debía realizar en función del cupo que se le hubiese asignado; y a través de voluntarios. La prensa liberal defendió el ingreso igualitario en el Ejército que recogía la ley al poner fin a las desigualdades estamentales, además de una mejora en las condiciones socioeconómicas de las tropas y del equipamiento militar $^{327}$. Este sería un sistema que viniese a acabar con los graves quebrantos populares al poner fin a la desigualdad por nacimiento. Sería además una herramienta para consolidar la igualdad ante la ley y par atraer a las clases populares al Liberalismo y permitir su definitivo triunfo:

"Ya es tiempo de que las clases inferiores de este egército (sic) se acaben de identificar con el sistema de la libertad viendo que desaparecen las barreras que las humillaban, y que viene al suelo el edificio gótico de tantos privilegios y desuniones tan odiosas como inútiles ${ }^{\prime \prime 328}$.

El método prioritario para cubrir las necesidades militares del Ejército permanente sería el recurso a las milicias activas, cuyos cuerpos deberían tener mucha fuerza en tiempos de paz, mientras que los del Ejército permanente solo deberían tener la fuerza precisa

\footnotetext{
325 Ley constitutiva del Ejército de 9 de junio de 1821, art. 8.

${ }^{326}$ Los diferentes medios de reemplazo del Ejército originaron numerosos debates en el Parlamento. Ver Diario de Sesiones de las Cortes, 26/04/1821, no 58, p. 1287-1294.

327 "Antes el ejército (sic) era corto y estaba desnudo, mal pagado y peor mantenido; ahora debe ser proporcionado en número á la extensión de nuestras posesiones, y estar completamente provisto y equipado de cuanto necesita" (EI Censor, 09/06/1821, no 45, p. 47).

${ }^{328}$ El Espectador, 08/06/1821, no 55, p. 4.
} 
para los servicios indispensables y para mantener la debida instrucción ${ }^{329}$. Se concedió por tanto un enorme peso y responsabilidad en las tareas militares a la Milicia Nacional, ya que contaba con la ventaja de la formación militar previa de sus miembros, mientras que el Ejército permanente vería incrementada su importancia en un contexto bélico ${ }^{330}$. Sería el secretario del despacho de la Guerra el encargado de suministrar la información precisa anualmente a las Cortes para que éstas decidiesen el modo de realizar el reemplazo. En el caso de que las fuerzas de la Milicia Nacional no fuesen suficientes para cubrir las necesidades del Ejército permanente, las Cortes recurrirían al reparto de los cupos entre las distintas provincias en función de su población, aunque nada se indica sobre el modo de selección de los reclutas ${ }^{331}$, cuyo tiempo de prestación no podría exceder los seis años. La posibilidad de que algunas provincias se eximiesen en su contribución en hombres al Ejército fue defendida por diputados a Cortes como el liberal exaltado Sr. Puigblanch ${ }^{332}$, quien argumentó el profundo descontento que la quinta tendría en Cataluña, tal y como la Historia demostraba:

\footnotetext{
329 "El Ejército permanente de este modo deberá ser muy corto en tiempo de paz y también lo serán los gastos; y el servicio que antes duraba ocho años, vendrá casi $\&$ reducirse á la mitad. Estas ventajas son tan grandes y tan claras, que yo no sé quién pueda dudar de la utilidad de que de la Milicia activa se saque el reemplazo para el Ejército (Discurso del Sr. Romero Alpuente, Diario de Sesiones de las Cortes, 26/04/1821, no 58, p 1288).

330 CASADO BURBANO, P., Las fuerzas armadas en el inicio del constitucionalismo español, pp. 152 y 153.

${ }^{331}$ Incluso algunos diputados se mostraron contrarios al sorteo: "¿Qué conveniencia puede haber en obligar a tomar las armas a quien resiste tomarlas, no habiendo necesidad de obligarle? ¿Qué conveniencia puede haber en coartar más allá de lo justo la libertad de los ciudadanos? Para hacer amar el gobierno constitucional como el más favorable á la justa libertad ¿será buen medio el ponerla más fuertes trabas que las que le tenía puestas el gobierno despótico? ¿será buen medio el generalizar en todas las provincias el modo más duro que se conoce de reemplazar el Ejército, al cual han estado sujetas algunas de ellas, en lugar de extender ó estas el modo más suave que hasta ahora ha regido en otras más afortunadas? (Discurso del Sr. Quintana, Diario de Sesiones de las Cortes, 26/04/1821, no 58, p 1292).

332 Discurso del Sr. Puigblanch, Diario de Sesiones de las Cortes, 28/04/1821, no 60, pp. 1314 y 1315.
} 
"Ha habido poderosas razones para que los catalanes se hayan resistido siempre a la quinta. En aquella provincia, muy industriosa, como todos saben, la falta de un individuo en una casa puede por lo mismo causar la ruina de la familia, lo cual no es tan fácil se verifique en las demás provincias. Además, si se niega a aquella el que pueda sustituir un hombre por otro, habrá allí grande repugnancia á entrar aun en la Milicia activa; cuando si se le permite la sustitución, como he dicho, sobre contribuir siempre la provincia con el cupo que le corresponda, entrarán todos con gusto en la Milicia y habrá siempre mucha fuerza armada, como desea la Comisión. [...] En fin, deseo que se guarde la igualdad; pero si se manda la quinta en mi provincia excluyéndose la sustitución, estoy seguro que va á ser ella la más perjudicada. Serán siempre gravadas sin necesidad las demás provincias de España, pero no tanto como Cataluña. En estas no hay tanta industria: están ya acostumbradas a la quinta: los jóvenes tienen en general menos salidas por faltarles en ellas una colocación en los diferentes ramos de industria y comercio que no tienen. [...]. Por estas razones, pues, y por otras que omito, será más gravada Cataluña con la quinta que las demás provincias. Pero deseando yo la igualdad, y siendo justo la haya en todas ellas, creo deben las Cortes mitigar el rigor de esta ley y hacer que en toda la España puedan ser sustituidos por otros los que salgan en suerte para el reemplazo ${ }^{\prime 333}$.

Esta defensa de la exención provincial fue rotundamente contestada por el Sr. Moreno Guerra haciendo referencia a la igualdad de todos los españoles ante la ley y a la libertad del pueblo español ${ }^{334}$. Sí se prohibió expresamente la redención en metálico ${ }^{335}$,

\footnotetext{
333 Discurso del Sr. Puigblanch, Diario de Sesiones de las Cortes, 17/04/1821, no 51 , p. 1101.

334 "Desde que se restableció nuestra Constitución, los españoles tenemos iguales derechos y obligaciones iguales para con la Nación, tanto las provincias, como los pueblos y las personas; y bajo este principio, pensando exactamente, y llevando las cosas á SU origen, es necesario hacernos superiores á toda preocupación popular, y es necesario saber que nada afianza más la libertad que el poner las armas en manos del pueblo de todas las provincias de un modo uniforme. El pueblo debe tener las armas si quiere ser libre; mientras exclusivamente y con privilegios las llevaron y tuvieron los nobles, el pueblo fue esclavo, y hubo por esta señores y vasallos, etc., etc. Napoleón, en su manuscrito de Santa Elena, manifiesta esto bien claro, pues dice que las revoluciones de Europa no debían atribuirse a él, ni á los filósofos que le habían precedido, sino á haber dado las armas al pueblo todo. Así,
} 
pero la ley se abstuvo de tratar el tema de la sustitución ${ }^{336}$, a pesar de la encendida defensa que algunos diputados hicieron de la misma:

"Mi digno compañero el Sr. Ramonet ha dicho, y yo repito, que no quiere que por dinero, por puro metálico, se quede libre ningún ciudadano de servir a la Patria con las armas en la mano cuando sea llamado por la ley. Está bien que entre otro en su lugar á servirla, del modo que ellos entre sí se convengan: este es un acto de propiedad, de libertad; es un contrato de particular a particular"1337.

Por lo que respecta a los voluntarios que deseasen ingresar en el Ejército ${ }^{338}$, éstos no servirían para cubrir el cupo de ninguna localidad, y habían de cumplir una serie de requisitos: ser españoles, solteros $^{339}$ de entre diecinueve y treinta años, con licencia del padre y no estar procesados criminalmente ${ }^{340}$. Se les concedió la posibilidad

pues, me parece que no es liberalidad fundarse en las preocupaciones antiguas para quitar al pueblo el poder, que está y estará siempre en las armas" (Discurso del Sr. Moreno Guerra, Diario de Sesiones de las Cortes, 28/04/1821, nº 60, p. 1315).

335 Ley constitutiva del Ejército de 9 de junio de 1821, arts. 23-25, 27, 36 y 38.

336 CASADO BURBANO, P., Las fuerzas armadas en el inicio del constitucionalismo español, p. 220.

${ }^{337}$ Discurso del Sr. Palarea, Diario de Sesiones de las Cortes, 28/04/1821, no 60, p. 1321.

338 Diputados como el Sr. Janer mostraron una postura contraria a la quinta y apostaron por el voluntariado como único sistema para el reemplazo del Ejército: "[...] es muy reciente la quinta en España, y el Ejército ha sido muy bueno aun cuando no ha habido quintas. En todo el largo tiempo de las mayores glorias militares de España, siempre los soldados fueron voluntarios. Aquellos famosos tercios de infantería española que, según el historiador inglés Robertson, llenaron de terror y asombro á toda la Europa por espacio de ciento cincuenta años, que ganaron tantas victorias y dieron tantas pruebas de valor y disciplina militar, se componían todos de tropas voluntarias [...]" (Discurso del Sr. Janer, Diario de Sesiones de las Cortes, 17/04/1821, no 51, p. 1103).

339 "¿qué puede esperar la Patria del que empieza la carrera militar abandonando las sagradas obligaciones de padre y esposo? ¿Será buen soldado el que no es buen ciudadano? ¿cumplirá con los deberes de la milicia quien abandona cuanto hay de más amable sobre la tierra, quien rompe lazos tan sagrados para vivir una vida libre acaso licenciosa?" (Discurso del Sr. Zapata, Diario de Sesiones de las Cortes, 28/04/1821, n 60, p. 1316).

340 "En el día, que está tan acreditado entre todas las naciones, desde la guerra pasada, que nuestro Ejército es una reunión de hombres de bien, de ciudadanos honrados, la Comisión quiere que continúe lo mismo en adelante, y que las Cortes lo decreten de un modo positivo y solemne; y á esto tiende el artículo presente y el 
de elegir el arma en el que iban a servir, aunque no se señaló el número de años que había de permanecer en el Ejército un soldado voluntario $^{341}$. Para hacer más atractivo el oficio de soldado, se les concedió una serie de prebendas y premios: sueldo fijo, pensiones de viudedad para sus mujeres e hijos, así como pensiones y empleos civiles para los inutilizados, si bien dejarían de gozar de un fuero militar propio por considerarse incompatible con la igualdad ante la ley. Por el contrario los militares gozarían de todos los derechos civiles de forma similar al resto de los ciudadanos ${ }^{342}$.

c) El nuevo reconocimiento de las exenciones eclesiásticas: Decreto de 31 de octubre de 1822 para llevar a efecto el reemplazo extraordinario del Ejército

El tercer texto al que haremos referencia es un decreto que vino a aclarar la forma en que se habían de realizar las operaciones del reemplazo extraordinario, aprobado por las Cortes en octubre de $1822^{343}$ ante la situación convulsa que vivía el país con la invasión de los Cien Mil Hijos de San Luis, bajo el ministerio de Mariano Zorraquín $^{344}$. Este decreto supuso una serie de modificaciones en las Ordenanzas de 1800 y 1819, así como en la Ley constitutiva del Ejército de 1821. El objetivo era asegurar una correcta realización de las operaciones de reemplazo y alcanzar una mayor eficacia de las

que sigue, para que jamás se vea el escandaloso ejemplar de castigar á un criminal echándole á las armas y poniéndole éstas en sus manos, confiando la defensa de la Nación y de las leyes á un enemigo de aquella y de estas" (Discurso del Sr. Palarea, Diario de Sesiones de las Cortes, 28/04/1821, n० 60, p. 1317).

${ }^{341}$ Ley constitutiva del Ejército de 9 de junio de 1821, arts. 28-30 y 34.

342 Ley constitutiva del Ejército de 9 de junio de 1821, arts. 103-110 y 118-120.

343 Decreto de 31 de octubre de 1822 para llevar a efecto el reemplazo extraordinario del Ejército.

344 "Militar liberal, probablemente riojano. Diputado en las Cortes de Cádiz, encarcelado durante el Sexenio Absolutista y liberado al comienzo del Trienio, formó parte del Gobierno de Calatrava como ministro de Guerra" (Diccionario Biográfico Español, edición digital, RAH, http://www.rah.es/cdeb.htm). 
autoridades competentes, sobre todo en lo que concernía a las exenciones, apartado donde encontramos las principales novedades.

Así, se señala que el sorteo, de cuya gestión se encargarían las Diputaciones provinciales, se realizaría entre todos los mozos solteros y viudos sin hijos, comprendidos entre los dieciocho y treinta y seis años, y en él participarían incluso los jóvenes que tuviesen alguna excepción física o legal ${ }^{345}$. Una vez realizado el sorteo, los Ayuntamiento analizarían y decidirían, en un plazo máximo de tres días, las solicitudes de exención presentadas por parte de los interesados o de cualquier persona en su nombre, existiendo la posibilidad de reclamación ante la Diputación. También se enumeraron en el decreto los únicos casos en que se admitiría una exención, ya sea de tipo físico, familiar, laboral o por la ocupación de determinados cargos o puestos ${ }^{346}$ : los incapacitados físicos o

\footnotetext{
${ }^{345}$ A esta disposición se opusieron numerosos diputados: "No digo yo que antes del sorteo se ventilen todas las excepciones; pero la medida y las excepciones visibles, notorias, que saltan á los ojos, creo que es muy ventajoso se examinen antes, y que este número de personas no entren en sorteo. Es necesario tener presente que al tiempo de hacer el sorteo se han de incluir precisamente en las bolillas los nombres de todos los mozos que han de entrar en él. Hay poblaciones en las que estas bolillas exceden de 1.500. Para extender las cédulas necesitan los Ayuntamiento un trabajo bastante penoso; después de eso hay que introducirlas una a una, y otras tantas numeradas, y para extraerlas se repite la misma operación: todos estos actos multiplican muchísimo la dificultad del sorteo" (Discurso del Sr. Oliver, Diario de Sesiones de las Cortes, 25/10/1822, no 23, p. 339).

346 Algunos diputados se opusieron a un elevado número de exenciones por el descontento que éstas causaban entre la población: "Todos los señores militares saben cuánto ha sido el odio que se ha tenido siempre al servicio militar que se hacía por sorteo, cuánta la repugnancia de los individuos que se sujetaban á este sorteo; y también podrían saber todos los Sres. Diputados, o á al menos lo sabrán muchos que hayan podido tocarlo más de cerca, que este odio en el sorteo que se hizo en el año pasado so notó disminuido considerablemente y en muchos grados. ¿Y cuál puede ser la causa? Yo hallo que son dos: la una es la seguridad que no había antes, de que se les dará la licencia el día que cumplan su tiempo de servicio; y la segunda es la disminución que se había hecho en el número de excepciones; y seguramente, a proporción que éstas se aminoren, sería menor la repugnancia, porque siempre habrá mayor probabilidad de que no toque la suerte de servir" (Discurso del Sr. Gómez Becerra, Diario de Sesiones de las Cortes, 25/10/1822, no 23, p. 344). Diputados como los Sres. Pedralvez y Buey propusieron sin embargo que los doctores, abogados y estudiantes de Bachiller deberían poder acogerse a algún tipo de exención: "Tenga, pues, paciencia la Patria en dejar continuar los estudios \& los bachilleres, y sacar\& más utilidades de éstos permitiéndoles concluir su carrera, que no mandándoles ir al servicio de Ias armas: lo contrario es
} 
enfermos crónicos catalogados por el examen médico; los que no alcanzasen la talla de cinco pies menos una pulgada; los ordenados in sacris (de nuevo, los eclesiásticos quedan exentos del servicio militar); los licenciados en el Ejército; los que hubiesen presentado a un sustituto y los redimidos en metálico (de nuevo se admite la opción de la redención, prohibida expresamente por la Ley constitutiva del Ejército de 1821, aunque no se establece la cuota a pagar ni se señala más al respecto); los individuos que formasen parte de la Milicia Nacional activa; Ios matriculados en la armada; los hijos y nietos únicos de viuda, padre o abuelos sexagenarios o inhábiles para el trabajo que necesitasen del trabajo personal del hijo para su supervivencia; los jefes políticos, magistrados, jueces de primera instancia y catedráticos de establecimientos públicos; los maestros de primeras letras cuando fuesen los únicos que hubiese en una localidad; y los diputados a Cortes, diputados provinciales, alcaldes, regidores y síndicos en ejercicio hasta que finalizasen sus funciones $^{347}$. No fueron admitidas por el contrario las propuestas de

truncarles, es inhabilitarles para su primitivo objeto, que ya les cuesta muchos años y muchos gastos" (Discurso del Sr. Pedralvez, Diario de Sesiones de las Cortes, 27/10/1822, no 23, p. 361).

347 Las exenciones por la ocupación de cargos públicos también recibieron la oposición de algunos diputados, que criticaban que el peso del reemplazo recayese siempre sobre las clases productoras: "Si alguna excepción puede admitirse, ha de ser solamente aquella que sirva para fomentar las artes, el comercio, la agricultura, ó cualquiera otro ramo de felicidad pública; pero veo que nada de esto se consigue por las excepciones que se proponen, estableciéndose por el contrario un privilegio sumamente injusto, como voy á demostrar. La Comisión exceptúa del sorteo para el reemplazo del Ejército a unas clases que no son tan necesarias como se quiere suponer y cuyos individuos podrán reemplazarse por otros tan idóneos; unas clases demasiado premiadas ya con los destinos que tienen, y que podrían volver á ocupar los individuos que ahora las tienen, después de haber servido en el Ejército. Señor, los magistrados y los jefes políticos, que han merecido un premio como es el de su clase, un premio que les asegura la subsistencia, un premio por el cual están constituidos en un rango en cierto medo superior á las demás clases del Estado, no han de acudir también á defender la Patria lo mismo que los demás que aumentan directamente la riqueza y felicidad pública, y que por lo menos no son inferiores en mérito a ellos? Yo creo que establecer lo contrario seria una injusticia y una excepción opuesta enteramente a la letra y espíritu de la Constitución [...]. Bastantes exenciones ha habido hasta ahora, gravando siempre sobre las clases productoras, y por lo mismo es necesario que desaparezca de entre nosotros este sistema de desigualdad y de suma injusticia, que en otro tiempo ha oprimido al 
exceptuar del servicio a médicos, cirujanos y doctores. Para el caso de estos últimos, se consideró más importante para las necesidades de la Patria el contar con el mayor número posible de soldados que cualquier otra consideración:

"[...] este grado, que se considera como un premio del saber, las más de las veces prueba las mayores facultades del que la obtiene, y no su suficiencia. Cualquiera que haya estado en la Universidad conocerá fácilmente esta verdad: yo también soy doctor, $y$ así creo que mis razones o dictamen en esta parte no puede ser sospechoso. ¿Y como podría suceder otra cosa, Señor, hasta aquí, estando las Universidades montadas de un modo tan heterogéneo en toda la Península, ya en el plan de enseñanza, ya en fondos para sostener los establecimientos; montadas; por fin, bajo un plan de enseñanza tan diverso, y en algunas tan contrario ú las mismas luces? Hé aquí la razón por que no son sinónimas en el día las palabras "doctor y sabio" [...]. No es razón suficiente que los doctores hayan sido excluidos hasta ahora, pues es tiempo que se concedan sólo con la mayor justicia y necesidad las excepciones, $y$ estas dos circunstancias faltan en nuestro caso para conceder dicha excepción. Por tanto, me opongo a que se exceptúen a los doctores del sorteo para el reemplazo del Ejército, pues en el día necesitamos, más que de doctores, de soldados que defiendan la Pátria y sus libertades"1348.

Para los casos de exención física o falta de talla, sería un facultativo o facultativos en medicina y cirugía nombrados por el consistorio los encargados de realizar el examen físico pertinente y la medición del mozo ${ }^{349}$. A pesar de los intentos de algunos diputados porque los extranjeros fuesen admitidos como voluntarios para el

débil" (Discurso del Sr. Ayllón, Diario de Sesiones de las Cortes, 27/10/1822, no 25 , p. 360).

${ }^{348}$ Discurso del Sr. Navarro Tejelbo, Diario de Sesiones de las Cortes, 28/10/1822, no 26, p. 375).

349 Decreto de 31 de octubre de 1822 para llevar a efecto el reemplazo extraordinario del Ejército, arts. 1, 2, 6-17 y 22. 
Ejército, el artículo constitucional que lo rechazaba impidió su aprobación ${ }^{350}$.

d) El inicio de los reclutamientos modernos: Ordenanza General para el reemplazo del Ejército de 3 de febrero de 1823

El último de los textos al que debemos hacer referencia por su importancia, simplemente teórica, que no práctica -dada su nula aplicación debido al fin del régimen liberal que supuso la actuación de la Santa Alianza y el regreso al más rígido absolutismo-, es la Ordenanza General para el reemplazo del Ejército de 3 de febrero de 1823, aprobada por las Cortes extraordinarias tan solo dos meses antes de la entrada en España de las tropas comandadas por el Duque de Angulema. Esta situación de excepcionalidad y la necesidad de que toda la ciudadanía empuñase las armas para defender a la Patria fue remarcada por la prensa liberal:

"Cuando la patria se ve insultada y amenazada, todo ciudadano está obligado á acudir á su defensa, y especialmente los militares en cuyo esfuerzo deposita aquella su confianza y seguridad, virtudes que cada día más los distinguen en la victoriosa defensa de los derechos públicos ${ }^{\prime \prime 351}$.

\footnotetext{
350 "[...] porque el extranjero que no tiene un medio de vivir sino este, y no aspirase sino á seguir su carrera y buscar el asilo en España, podría causar un alivio que hasta cierto grado podría convenir. En la marina se permite tener doce plazas de extranjeros. Así, soy de parecer que se deje abierta la puerta para cuando la Nación necesite de esta medida: puede valerse algún día de regimientos extranjeros, y quizá en el día convendría dejar algunas plazas en los cuerpos para extranjeros, que causasen este auxilio á los demás soldados españoles (Discurso del Sr. Valdés, Diario de Sesiones de las Cortes, 22/05/1822, no 105, p. 1491).

${ }^{351}$ El Espectador, 04/02/1823, no 661, p. 4.
} 
Se trata de un texto amplio, destinado a regular de forma intensa todas las operaciones relacionadas con el reclutamiento, y que inauguró la era de los reclutamientos modernos en España ${ }^{352}$. Sin embargo, la ordenanza fue aprobada de forma apresurada y sin apenas discusión en Cortes ante la situación excepcional en que se encontraba el país.

Para asegurar una correcta realización de todas sus fases, su primer capítulo se centraba en la elaboración del padrón, documento clave a la hora de conocer cuantos mozos podrían ser llamados a filas. El padrón no tendría un objetivo exclusivamente militar, sino que serviría para una administración más eficaz en otras materias, y debía de ser elaborado por el Ayuntamiento en el mes de enero de cada año, incluyendo en él a todos los habitantes del pueblo y lugares vinculados, ya estuviesen residiendo en el municipio o se encontrasen fuera de él de forma temporal. Los pueblos con mucho vecindario podrían ser divididos en distritos de, al menos, 15.000 almas, para simplificar las tareas de elaboración del padrón. Estos distritos tendrían su padrón particular y serían considerados como municipios independientes a todos los efectos en lo que al reemplazo se refiere. Los padrones elaborados por los Ayuntamientos serían enviados, a principios de febrero, a la Diputación provincial, de nuevo institución clave en todo el proceso, encargada de velar por la legalidad de todos los actos y capacitada para imponer multas a las autoridades locales que no cumplan con exactitud la ordenanza. Los extractos de población que les enviasen los municipios serían recibidos y examinados por parte de las Diputaciones, que, además, deberían decidir sobre las reclamaciones que particulares y municipios presentasen sobre fraudes respecto a la población. También serían

352 FEIJÓo GÓMEZ, A., Quintas y protesta social en el siglo XIX español, pp. 207 y 235. 
las Diputaciones las encargadas de realizar el repartimiento ${ }^{353}$ de los mozos que cada localidad debía aportar en función de su población y del decreto emitido por el gobierno donde se recogería el número de reclutas que cada provincia debía entregar ${ }^{354}$.

Una vez elaborado el padrón, se procedería en los distintos Ayuntamiento, a puerta abierta y con presencia del cura párroco del pueblo $^{355}$ para que pueda suministrar las noticias que se le pidiesen, a la formación del alistamiento ${ }^{356}$, documento que incluiría a todos los españoles varones solteros y viudos sin hijos entre dieciocho y veinticinco años, así como a los casados menores de veinte. El alistamiento se publicaría en los espacios públicos habituales durante al menos tres días para que pudiese ser consultado por los interesados. La rectificación del mismo se realizaría el primer día festivo del mes de marzo y los días siguientes previo anuncio público para que pudiesen acudir los interesados y presentar sus reclamaciones. Los miembros del consistorio deberían escuchar tales reclamaciones y examinar las pruebas presentadas, tomando a continuación una decisión. Si las justificaciones no se pudiesen practicar en el acto, el Ayuntamiento podría imponer un plazo de tiempo prudente para su presentación. Todo lo sucedido se debería recoger en un acta. También existía la posibilidad de reclamar las decisiones del Ayuntamiento a la Diputación provincial en un plazo

\footnotetext{
353 "El reparto de los cupos era una de las operaciones más complejas, debido a la inexactitud de los censos y padrones, a los esfuerzos por ocultar población por parte de Ayuntamiento y Diputaciones, y también por los intereses caciquiles en la Diputación, que inclinaban la balanza del lado de los pueblos más influyentes" (FEIJÓO GÓMEZ, A., Quintas y protesta social en el siglo XIX español, p. 240).

354 Ordenanza General para el reemplazo del Ejército de 3 de febrero de 1823, arts. $1-8,40-42,45-46$ y 99.

${ }^{355}$ Casi la mitad de los diputados, 42 frente a 43 , votaron en contra de la presencia del cura párroco de la localidad en estos actos, Diario de Sesiones de las Cortes, 13/01/1823, no 102, p. 1327.

356 "El alistamiento general para el reemplazo del Ejército se convirtió en el documento fundamental para las operaciones de reemplazo, ya que sirvió para decretar el contingente militar anual, adjudicar los cupos, y realizar el sorteo, e implicaba varias operaciones distintas: alistamiento, juicio de exenciones y rectificación del alistamiento" (FEIJÓo GÓMEZ, A., Quintas y protesta social en el siglo XIX español, p. 236).
} 
máximo de dos días desde su publicación. Las decisiones de la Diputación no admitirían por el contrario ningún recurso. La institución provincial también resolvería cuando se produjesen disputas entre dos o más municipios que pretendiesen incluir en su alistamiento a un mismo mozo. Si los pueblos fuesen de distintas provincias, sus respectivas Diputaciones deberían llegar a un acuerdo y, en el caso de no hacerlo, sería el Gobierno el encargado de decidir $^{357}$.

Rectificado el alistamiento, se llevaría a cabo una de las fases más significativas de todo el proceso, el sorteo, de cuya realización y legalidad sería responsable el Ayuntamiento. Para ello se sacarían del alistamiento cuatro listas comprendidas por los jóvenes de distintas edades: dieciocho y diecinueve, veinte y veintiuno, veintidós y veintitrés años. No se trata, por tanto, de un sorteo puro, sino que se realizaría en función de la edad de los mozos. Es más, una vez celebrado el sorteo, las vacantes solicitadas serían cubiertas por aquellos ubicados en la franja entre dieciocho y diecinueve años $y$, solo en el caso de no poderse cubrir el cupo con esta franja de edad, se acudiría a los años sucesivos. Si con los reclutas comprendidos en estas edades no se cubriese el cupo de la localidad, se podría acudir al alistamiento de jóvenes entre veinticinco y treinta años, realizándose un sorteo por cada año de edad.

El acto del sorteo se realizaría el primer domingo del mes de abril y los días siguientes si fuese necesario empezando por los mozos de dieciocho y diecinueve años y continuando por las siguientes franjas de edad y en presencia de los interesados. Para su ejecución, se escribiría el nombre de los jóvenes en papeletas iguales y en otras papeletas, también iguales, tantos números como mozos debiesen realizar la prestación militar en esa franja de edad. Las papeletas se introducirían, previa lectura pública, en dos bolsas o

357 Ordenanza General para el reemplazo del Ejército de 3 de febrero de 1823, arts. 9 y $12-22$. 
cantarillos por parte del presidente y el síndico del Ayuntamiento, y dos niños menores de diez años procederían a su extracción y entrega al síndico y presidente municipales, que las leerían en voz alta y las mostrarían al público asistente. El secretario del Ayuntamiento sería el encargado de escribir en un acta el nombre de los mozos que fuesen saliendo y el número que les hubiese correspondido, documento que debería ser firmada por los distintos miembros del consistorio. No se admitiría en este acto ninguna reclamación sobre la inclusión o exclusión de algún mozo. Para el caso de los reemplazos extraordinarios, se seguirían éstas mismas reglas en el sorteo, pero cuando una localidad no tuviese el número suficiente de reclutas para completar el cupo, se podría recurrir a los jóvenes de hasta treinta y seis años cumplidos y a los casados sin hijos $^{358}$.

Cuando los distintos Ayuntamientos recibiesen el cupo de reclutas que les hubiese correspondido, citarían por edictos a todos los mozos alistados y personalmente a aquellos que hubiesen obtenido los primeros números en el sorteo, teniendo en cuenta tanto a soldados como suplentes. Una vez reunido el consistorio el día señalado, se procedería a tomar declaración, a la medición y examen médico por parte de facultativos designados por las autoridades municipales, de los reclutas, anotándose como tal a los faltos de talla (cinco pies menos una pulgada) y aquellos que sufriesen un defecto físico visible o una enfermedad notoria ${ }^{359}$. Si la enfermedad o defecto no fuese notoria, el consistorio decidiría en función del juicio de los facultativos médicos. La propia prensa liberal del momento también alabó que toda la ciudadanía, independientemente de su origen, tuviese que empuñar las armas en caso de necesidad, insistiendo

358 Ordenanza General para el reemplazo del Ejército de 3 de febrero de 1823, arts. $23-34,74,75,78,79$ y 120.

359 "Su faceta más radical [la de la ordenanza] fue la absoluta supresión de cualquier caso de exenciones -excepto las suscitadas por incapacidad física-" (PUELL DE LA VILLA, F., El soldado desconocido: de la leva a la "mili" (1700-1912), p. 186). 
incluso en una actitud positiva hacia el reclutamiento cuando las circunstancias lo requiriesen si todos los ciudadanos tenían unas mismas obligaciones:

"Los pueblos se prestan gustosos á lodos los sacrificios, cuando conocen que la necesidad es verdadera, y la distribución arreglada. Ven ya que nadie se exceptúa de la obligación de acudir á las armas cuando la ley lo manda, y sí fuese necesario que la España desplegase toda su fuerza para escarmentará los déspotas, no seria esta provincia la última en acudir á la voz de alarma nacional ${ }^{\prime \prime 360}$.

En este acto los mozos podrían presentar sus justificaciones y documentos para ser declarados excluidos del servicio, y el Ayuntamiento decidiría por votación, quedando la Diputación como tribunal de apelación. También declararía excluidos a los que se hallasen inscritos en la lista de hombres de mar, a los que ya hubiesen realizado por un espacio de seis años o estuviesen realizando el servicio en el Ejército, armada o Milicia Nacional, a los que hubiesen presentado sustituto, a los que se hubiesen redimido en metálico y a aquellos que estuviesen ocupando cargos públicos en Ayuntamiento, Diputación o Cortes Generales hasta la finalización de su tarea. Los miembros de la Milicia Nacional estarían exentos a no ser que las Cortes ordenasen que el Ejército fuese reemplazado por aquella milicia. Nada se señala sobre los eclesiásticos, obligados por tanto a cumplir con el servicio militar.

Se contempla, por primera vez en una ley española sobre reclutamiento, la obligación que tenían las instituciones públicas de socorrer al padre o abuelo impedido mayor de setenta años o madre o abuela viuda o impedida mayor de sesenta en situación de pobreza cuyo hijo o nieto hubiese obtenido la suerte del soldado y sin cuyo

${ }^{360}$ El Espectador, 04/02/1823, no 661, p. 3. 
trabajo su sustento quedaría en cuestión. No sería, por tanto, motivo de exclusión este tipo de situaciones familiares como lo serían en leyes posteriores, pero la Diputación provincial estaría obligada a socorrer a la familia del recluta con entre dos y cuatro reales diarios. Estos socorros se pagarían mensualmente a cargo de los fondos municipales de beneficencia ${ }^{361}$ en primera instancia o a través de los fondos provinciales en el caso de no ser suficiente con los del Ayuntamiento ${ }^{362}$.

Cuando los municipios hubiesen completado su cupo de reclutas, soldados y suplentes se pondrían en marcha hacia la capital de la provincia con la mayor brevedad posible, sin fijarse un día concreto de entrega en caja, y a la razón de cinco leguas diarias acompañados por un comisionado pagado por el Ayuntamiento, con el objeto de ser entregados en la caja de reclutas. Este comisionado iría acompañado de tres certificados: uno donde se recogiesen las diligencias practicadas en la toma de declaración de los soldados y suplentes para entregarla en la Diputación provincial; otra con el nombre de soldados y suplentes que entregaría al comandante de la caja; y otra con las filiaciones de los reclutas según un modelo previamente establecido, para entregarlas a la vuelta del trayecto en el Ayuntamiento. Soldados y suplentes serían socorridos con tres reales por jornada de marcha, hasta su entrega en caja o hasta el regreso a su localidad. Este trayecto también podría ser realizado por aquellos interesados en la medición o reconocimiento de algún individuo excluido por el Ayuntamiento, y recibiría la misma paga si su reclamación resultase justa.

Respecto a los suplentes, sólo ingresarían en caja cuando algún alistado se encontrase preso por causa criminal o prófugo. El suplente

361 CARASA SOTO, P., "Los peligros de la pobreza, los valores del liberalismo y las soluciones asistenciales burguesas", en VVAA, Antiguo Régimen y liberalismo: homenaje a Miguel Artola, Vol. 2, Madrid, Alianza, 1994, pp. 421-440.

362 Ordenanza General para el reemplazo del Ejército de 3 de febrero de 1823, arts. $55-73,77$ y 81. 
serviría en el Ejército hasta que el procesado fuese absuelto o hubiese cumplido su condena. La entrega de los quintos, su medición y reconocimiento (solo para aquellos cuyo defecto o enfermedad no fuesen visibles) se realizarían por parte del comisionado, acompañado de dos médicos, uno nombrado por la Diputación y otro por el oficial comandante de la caja, y un representante de la Diputación, y todos aquellos que quisieran acudir al acto ${ }^{363}$.

Hecha la entrega de los reclutas en caja, el representante de la Diputación debería preguntarles si existiese alguna queja o reclamación que presentar ante la institución provincial por la actuación de los Ayuntamientos. Aquellos que deseasen reclamar comparecerían ante la Diputación, que escucharía sus motivos y pruebas, examinaría documentos, justificaciones y el certificado de las diligencias practicadas por el Ayuntamiento, para resolver definitivamente lo que corresponda ${ }^{364}$.

La Ordenanza de 1823 reglamentó la sustitución: la presentación de sustitutos quedó permitida, aunque solo podría ser individual y con el cumplimiento de una serie de requisitos: presentar el sustituto en el plazo máximo de un mes desde el día en que fueron declarados soldados; reemplazar a los sustitutos si éstos desertasen durante los dos primeros años de servicio y, por último, una serie de condiciones que el sustituto debería cumplir: superar las pruebas médicas, no estar casado, tener entre dieciocho y treinta años, tener la talla, robustez y aptitud para el servicio (estos requisitos quedan a juicio del comandante de la caja) y presentar un certificado del Ayuntamiento donde residiese que certificase su buena conducta, el

\footnotetext{
363 Ordenanza General para el reemplazo del Ejército de 3 de febrero de 1823, arts. 85-94 y 98.

364 Ordenanza General para el reemplazo del Ejército de 3 de febrero de 1823, arts. 95 y 96.
} 
no estar procesado criminalmente $y$ el no haber sufrido penas infamantes ${ }^{365}$.

Finalizaba la Ordenanza de 3 de febrero de 1823 con unas breves referencias sobre la lucha contra el prófugo. Aquellos prófugos que fuesen aprehendidos, además de las penas que establecía el Código Penal, sufrirían un incremento de un tercio sobre su prestación ordinaria y se harían cargo de los gastos que hubiese ocasionado su captura. Se consideraron prófugos aquellos que no se presentasen a los actos de llamamiento y declaración de soldados o al acto de entrega en caja. Serían considerados, sin embargo, desertores los que se fugasen una vez entregados en caja. Para que un huido fuese declarado prófugo, el Ayuntamiento debería instruir un expediente que se entregaría a su padre o pariente más cercano donde se hiciese constar su ausencia. Un familiar o vecino honrado del municipio actuaría como defensor del prófugo y presentaría ante el Ayuntamiento las justificaciones precisas. En el caso de existir cómplices en la fuga, el consistorio lo comunicaría al tribunal competente, y si el prófugo fuese capturado 0 se presentase voluntariamente, el expediente pasaría a la Diputación Provincial, que podría confirmar o revocar la decisión del Ayuntamiento. Una vez presentado el prófugo, su suplente quedaría libre de sus obligaciones militares, a no ser que el huido fuese considerado no apto para el servicio. Si el prófugo no tuviese suplente por no haber obtenido la suerte del soldado, sería entregado en caja para que cumpla el servicio militar. Si el prófugo fuese capturado por algún mozo alistado, éste quedaría libre de sus obligaciones en ese reemplazo. Se premia así a aquellos que colaborasen en la captura de un huido ${ }^{366}$.

\footnotetext{
365 Ordenanza General para el reemplazo del Ejército de 3 de febrero de 1823, arts. 100-104.

366 Ordenanza General para el reemplazo del Ejército de 3 de febrero de 1823, arts. 105-119.
} 
Aplicación y añadidos de las normas: la limitada vigencia ante el regreso del Absolutismo

Evidentemente, la situación de excepcionalidad por la que pasaba el país impidió la aplicación práctica de estas normativas liberales. El fin del Trienio y el inicio de la Década Ominosa (18231833), con Fernando VII de nuevo como monarca absoluto, trajo consigo la derogación de estas leyes ${ }^{367}$ y el regreso a la Ordenanza de 1800 como texto básico para regular el reclutamiento, además del intento, a la postre fracasado, de crear un grupo armado de Voluntarios Realistas ${ }^{368}$. Se restablecieron las exenciones previstas en la Ordenanza de 1800, "y se crearon otras nuevas para premiar los servicios prestados: [...] restituyó a los nobles la posibilidad de redimirse por dinero, y eximió a los voluntarios realistas, permitió presentar sustitutos a estudiantes de universidad y seminarios, oficiales de correos y empleados de la Real Hacienda $[\ldots]^{\prime \prime 369}$. La situación empezaría a cambiar con la muerte de Fernando y la llegada al trono de la niña Isabel II.

\footnotetext{
367 "Muy pocos resultados se obtuvieron con estas últimas disposiciones, que cerraban los dos primeros ciclos de la normativa castrense del liberalismo, al dictarse en un clima de oposición generalizada hacia una forma de gobierno que no había sido capaz de hacer participar a las masas populares en sus afanes modernizadores de la sociedad. Cuatro quintas en menos de tres años, y un total de casi 85000 papeletas de soldados encantaradas, no ayudaron a propagar las ventajas de la libertad por unas aldeas que, a cambio de la supresión de los diezmos y desestancar la sal, vieron crecer los impuestos y desaparecer la asistencia monacal" (PUELL DE LA VILLA, F., El soldado desconocido: de la leva a la "mili" (1700-1912), p. 187).

${ }^{368}$ Real Orden sobre la formación de cuerpos de Voluntarios Realistas, Gaceta núm. 12 de 12/06/1823.

369 FEIJÓO GÓMEZ, A., Quintas y protesta social en el siglo XIX español, pp. 262 y 263.
} 


\section{3.- El fin de los sistemas de reclutamiento del Antiguo Régimen: La Ley de 1837}

A partir de la muerte de Fernando VII, en 1833, creció enormemente el número de leyes, normas y disposiciones reguladoras del reclutamiento. Ello obliga a que el historiador deba "desarrollar una notable capacidad selectiva para poder discriminar las que eran coyunturales de la que iban a crear doctrina"370.

Una de las normativas que iban a marcar el futuro de los reemplazos en España sería la Ley de 1837, al constituirse en el eje fundamental de la legislación sobre quintas durante la siguiente década y media del siglo XIX.

La Ley para el Reemplazo del Ejército de 2 de noviembre de 1837 constituye uno de los textos legislativos más relevantes de todo el siglo XIX, ya que supuso una reforma de todo lo relacionado con el reclutamiento en España, y se constituyó en el punto de referencia para leyes posteriores aparecidas a lo largo del siglo XIX. Esta ley "[...] derogó todas las disposiciones anteriores sobre reclutamiento, concedió a las Cortes por derecho constitucional, la fijación del contingente y reemplazo anual, y reglamentó las operaciones del reemplazo $[\ldots]^{\prime \prime 371}$.

Con la Ley de 1837 se cierran definitivamente las puertas a los obsoletos e incluso caóticos sistemas de reclutamiento propios del Antiguo Régimen y se pusieron las bases de una nueva forma de alistamiento militar acorde con la ideología liberal, ya que la Ley de 1837 presenta rasgos de una evidente modernidad:

\footnotetext{
370 PUELL DE LA VILLA, F., El soldado desconocido: de la leva a la "mili" (17001912), p. 187.

${ }^{371}$ CRESPO-FRANCÉS Y VALERO, J.A., A las armas: Reclutamiento y servicio militar en España desde sus orígenes hasta nuestros días, p. 252.
} 
"[...] tratamiento estadístico de la distribución de los cupos, regulación anual de las operaciones del alistamiento y sorteo, y creación de órganos especializados en la administración y control del reclutamiento. Su operativa ha subsistido prácticamente inalterada hasta que, hace muy pocos años, la informática aplicada a las operaciones de reclutamiento permitió arrinconar los bombos de alambre y las bolas de madera numeradas. Sin embargo, todavía nos son familiares $y$ permanecen en vigor algunas de las rutinas implantadas entonces: el alistamiento de todos los mozos al alcanzar una determinada edad, el sorteo simultáneo en todo el territorio nacional y las cajas de reclutamiento Provinciales ${ }^{372 " .}$

Esta norma, además, se convirtió en el modelo a seguir, repetido en mayor o menor medida hasta la gran reforma del reclutamiento de 1912:

"A partir de 1837, la renovación anual de la Ley de Reclutamiento será casi automática hasta fin de siglo, con las reformas anuales orientadas a la mejora del mecanismo y a cubrir los vacíos legales ${ }^{\prime \prime 373}$.

Los periódicos seleccionados para conocer la situación de la opinión pública respecto al reclutamiento han sido El Eco del Comercio $^{374}$ y El Español ${ }^{375}$, si bien la prensa del momento se centró

372 PUELL DE LA VILLA, F., El soldado desconocido: de la leva a la "mili" (17001912), p. 190.

373 CRESPO-FRANCÉS Y VALERO, J.A., A las armas: Reclutamiento y servicio militar en España desde sus orígenes hasta nuestros días, p. 252.

374 "Con la muerte de Fernando VII y el final del absolutismo, y la asunción de la Regente María Cristina del título de Reina Gobernadora por la minoría de edad de Isabel II, se iniciará la transición hacia el Estado liberal al mismo tiempo que se produce un "nacimiento" de la prensa española al estilo de la europea que, en su tratamiento formal y carácter político, durará todo el siglo XIX. El Eco del comercio será el modelo más destacado de esa prensa informativa y política que, en este caso, se convertirá en el más cualificado órgano del liberalismo avanzado a través del cual se formará el Partido Progresista.

$[\ldots]$ 
más en el esfuerzo bélico frente al rebelde carlista y en las operaciones militares que en la forma de nutrir de efectivos al Ejército, cuestión tratada de una forma marginal. Sí que reflejó en sus páginas El Español los debates en Cortes sobre los distintos artículos de la ley, pero sin inmiscuirse en su contenido ${ }^{376}$.

[El Eco del Comercio] no dejará de aparecer ningún día, aunque a lo largo de su dilatada existencia -tres lustros- dejará de salir los domingos o los lunes. Será un periódico de gran tamaño (que variará a partir del uno de julio y seis de noviembre de 1837 y de uno de diciembre de 1846), de tipografía pequeña, de cuatro páginas y a varias columnas (a 2, 3, 4 y hasta 5 ). [...].

A lo largo de su vida será el periódico de la oposición ministerial por antonomasia. [...] Además de la de Madrid, publicó una edición de provincias, así como un suplemento de ocho páginas de carácter literario y político-satírico, desde el 16 de mayo de 1844 al cuatro de mayo de 1845, que editaba los jueves y los sábados.

[...] Con su desaparición, será El clamor público (1844-1864) quien mantenga la antorcha de la defensa y difusión de las ideas políticas de la revolución burguesa [...]" (http://www.bne.es/es/Catalogos/HemerotecaDigital).

${ }^{375}$ Con la asunción de la Regencia de María Cristina por la minoría de edad de Isabel II y el proceso de transición al Estado liberal, el periodismo español va a dar un salto cualitativo de madurez que lo situará a nivel europeo. Si los liberales progresistas habían fundado su gran diario -Eco del comercio- en 1834 en torno a Fermín Caballero, entre otros, un año después Andrés Borrego (1802-1891) hará lo propio impulsando el gran diario del liberalismo moderado y reformador, que comenzará a editarse el uno de noviembre de 1835. [...] sobre todo será el vértice del periodismo "monárquico-constitucional".

Un diario de cuatro páginas de gran formato (que irá variando), con tipografía pequeña, a tres, a cinco y hasta seis columnas, que innovará además la publicidad y con una "ordenación rigurosa de los contenidos", tal como señala Gómez Aparicio, que se constituirá en el modelo de la prensa informativo-política a lo largo de todo el siglo XIX, que también había adoptado en el campo del liberalismo progresista el Eco del comercio. Ofrecerá una amplia y cuidada información política nacional e internacional a través de redactores propios y las crónicas de sus corresponsales en París, Londres y Lisboa y en las diversas provincias españolas. Insertará diariamente un artículo editorial así como otros de fondo y de colaboración. No faltarán nunca las cartas de los lectores y revistas de prensa nacional y extranjera. Tendrá secciones como Actos del gobierno, Extractos de periódicos, Espectáculos, Cortes, Bolsa, Correspondencia, Tribunales, Variedades, etc. Introducirá asimismo el folletín y dará también amplitud a la información económica y comercial, con el movimiento portuario, los precios de los mercados nacional e internacional, los fondos públicos, etc. Borrego, un liberal conservador inteligente, no reaccionario y rara avis de la política española, tal como señala Seoane, dará un tono democrático al periódico incorporando a su redacción a una joven generación de periodistas españoles de un amplio espectro ideológico [...]. Ante el carácter independiente que Borrego pretende dar al periódico, si al principio apoya a Álvarez Mendizábal, pronto se mostrará contrario a su política y hará suya la crítica de Flórez Estrada a la desamortización. La Revolución de la Granja con la imposición de la Constitución de 1812 a la Reina Regente, llevará a Borrego a dimitir como director del diario el 15 de agosto de 1836, coincidiendo también con un cambio en el accionariado de la empresa y con su nombramiento como embajador en Londres por el ministerio de Francisco Javier Istúriz [...]" (http://www.bne.es/es/Catalogos/HemerotecaDigital). ${ }^{376}$ Ver el periódico El Español, durante el mes de octubre de 1837. 
La lucha contra el Carlismo como Contexto histórico

La nueva ley se enmarcó en el contexto de la primera guerra carlista $^{377}$ y de las necesidades de la Reina Regente y sus gobiernos para hacer frente al pretendiente rebelde de la Corona y canalizar los esfuerzos de un país agotado tras años de lucha e inmerso en una cruenta guerra civil ${ }^{378}$ que movilizaba a buena parte de la población española ${ }^{379}$. Supuso, además, el triunfo definitivo del Liberalismo en materia de reclutamiento y su adaptación a los nuevos conceptos liberales ${ }^{380}$.

El origen jurídico de los conflictos carlistas se remonta al comienzo del gobierno de la Casa de Borbón sobre España, cuando, asegurado el trono por las victorias militares y por el acuerdo diplomático ratificado en el Tratado de Utrech de 1713, Felipe V

\footnotetext{
377 Ver la siguiente bibliografía sobre el carlismo: BULLÓN DE MENDOZA GÓMEZ DE VALUGUERA, A., La primera guerra carlista, Madrid, Universidad Complutense de Madrid, 1992; CANALES, C. y CARRASCO, J. C., La primera guerra carlista, Madrid, Grupo Medusa, 2000.

378 Así narra el Eco del Comercio las tropelías cometidas por las fuerzas rebeldes: "Cuando entran las fuerzas rebeldes en un pueblo las casas de los conocidos por liberales son saqueadas e incendiadas, sus dueños bárbaramente sacrificados y no hay violencia y tropelía que no se cometa con los que se creen de opiniones poco en armonía con el espíritu de despotismo y de devastación. Por el contrario, cuando entran en sus poblaciones las tropas leales, los notoriamente desafectos, y enemigos nuestros, gozan de la mas completa seguridad, y pueden sin ningún peligro presentarse en público [...]" (El Eco del Comercio, 06/10/1837, p. 2).

379 Puell de la Villa aduce estos motivos para explicar la necesidad de una nueva legislación: "Los siete años de la Guerra Carlista se caracterizaron por la completa movilización de la población española. Sólo en el lado liberal se decretaron nueve quintas que llamaron a filas a un total de 370.000 hombres -compárese esta cifra con los aproximadamente 75.000 quintados durante todo el siglo XVIII, o los 250.000 de la Guerra de la Independencia-. El alistamiento de tan grandes contingentes puso de relieve la necesidad de reformar y mejorar las normas por las que se regía el reclutamiento. Por otra parte, la revolución de las ideas, de principios y de instituciones, que el cambio político producido en la nación habían ocasionado, reclamaban cada vez con mayor urgencia la reforma de aquella legislación. Además, las disposiciones dictadas durante los primeros años de la guerra sacaron a la luz el caos normativo existente, al tropezarse continuamente los encargados de su aplicación con preceptos en parte vigentes y en parte obsoletos" (PUELL DE LA VILLA, F., El soldado desconocido: de la leva a la "mili" (1700-1912), p. 188).

380 CRESPO-FRANCÉS Y VALERO, J.A., A las armas: Reclutamiento y servicio militar en España desde sus orígenes hasta nuestros días, p. 250.
} 
implantó, mediante auto acordado, la vigencia de la ley sálica, habitual en el trono francés, en materia de sucesión. Esto suponía que el varón tenía preferencia sobre la mujer a la hora de heredar el trono, con independencia del grado de parentesco de uno y otro respecto del monarca muerto. El auto acordado de 1713 iba a ser derogado por la Pragmática Sanción de 1789, que devolvía el sistema sucesorio español a su forma tradicional, establecida en el código de las Partidas en el siglo XIII, y que implicaba un sistema denominada semisálico, ya que daba preferencia al varón sobre la mujer, pero solo en el caso de que ambos tuvieran el mismo grado de parentesco respecto del rey muerto -es decir, que fueran hermanos-. Sin embargo, el estallido de la Revolución Francesa ese mismo año hizo que la Pragmática Sanción no llegara a publicarse, lo cual provocó que, al morir Fernando VII en 1833, se arrojaran serias dudas sobre su validez legal. A ellas se aferró don Carlos, hermano del rey muerto, para defender la vigencia de la ley sálica a través del auto acordado de 1713, que le otorgaría el trono al fallecer Fernando VII como pariente varón más cercano, pese a existir una hija del rey, la princesa Isabel.

Con este problema sucesorio en el horizonte, ya en octubre de 1832, vivo todavía el acérrimo absolutista Fernando VII y a instancias de su esposa María Cristina, se formó un gobierno encabezado por Cea Bermúdez que tenía como objetivo atraerse a los liberales más templados, lejos de los radicalismos del Trienio. El estallido del conflicto carlista consolidó esta tendencia y provocó la formación de nuevos gobiernos con presencia liberal que perseguían el triunfo en la guerra. El Liberalismo pudo así penetrar en las instituciones e instancias de poder y dejar su intensa impronta en materia legislativa.

En los primeros años del reinado de la niña Isabel, y con su madre como conductora de la política de la Corona, se inició el 
proceso para la aprobación de una ley de reclutamiento de inspiración liberal. Indica José Antonio Crespo-Francés que "Fernando VII y después María Cristina, dejaron las cuestiones militares en manos del Ejército, y ni siquiera el Estatuto Real de 1834 (elaborado por Martínez de la Rosa) recuperó la legislación gaditana en este sentido" ${ }^{\prime 381}$. Este Estatuto, que comenzó aspirando a alcanzar el rango de constitución, finalmente no fue tal ya que se ocupaba tan solo de una parte de los aspectos que debe cubrir un texto constitucional: las relaciones entre la Corona y las Cortes de la nación.

En 1834, en un contexto bélico, y ante la necesidad de cubrir las bajas y los puestos abandonados en el Ejército por los licenciados, algunos de los cuales continuaban prestando sus servicios como voluntarios a cambio de un real diario con los consecuentes gastos para la Hacienda pública, se presentó, discutió y aprobó en el Estamento de Procuradores, a propuesta del gobierno, una ley de reclutamiento de 25.000 hombres. El Secretario de Estado encargado de su presentación justificó esta normativa en la inexistencia de una ley que organizase definitivamente el reemplazo.

A la espera de su aprobación, y para evitar confusiones, el reemplazo se realizaría en 1835 siguiendo "[...] el método acostumbrado. Esto es con el objeto de hacerla con más facilidad por parte del Gobierno, y con menos molestia de los pueblos; pues es cosa sabida que estos ejecutan con menos repugnancia aquello a que ya están acostumbrados que lo que se les propone como nuevo, aún cuando sea más sencillo" ${ }^{\prime 382}$. Conscientes de las perentorias necesidades del Ejército, apenas encontró rechazo entre los procuradores el proyecto gubernativo, aunque sí que se emplazó al Gobierno para una rápida presentación de una definitiva ley de

\footnotetext{
${ }^{381}$ CRESPO-FRANCÉS Y VALERO, J.A., A las armas: Reclutamiento y servicio militar en España desde sus orígenes hasta nuestros días, p. 251.

382 Discurso del Secretario de Estado, Diario de Sesiones de las Cortes, 12/11/1834, n० 77, p. 695.
} 
reclutamiento que terminase con los males que provocaba el sistema de reclutamiento vigente:

"[Mi propósito] ha sido [...] el que se reclame cuanto antes del Gobierno la ley que él mismo ha indicado sobre que el reemplazo sea anual, y sobre que se remedien cuanto antes las infinitas vejaciones, los extraordinarios perjuicios que produce en los pueblos el monstruosísimo sistema actual. [...]. Indisputablemente el actual sistema de reemplazos causa perjuicios cuya enormidad se concibe con solo enunciarlos, no pudiendo por tanto el Estamento dudar de la necesidad de remediarlos" ${ }^{\prime \prime 383}$.

Los males denunciados por el procurador Belda eran diversos: en primer lugar la edad, ya que se consideraba a los soldados de treinta y seis años, edad máxima para ser reclutado, demasiado maduros como para poder reintegrarse fácilmente en la sociedad una vez finalizada la prestación. Propuso por ello dicho Procurador una edad de entre los diecisiete y los veintiún años para entrar en el sorteo. En segundo lugar, propuso limitar el número de exenciones, tanto individuales como territoriales, a excepción de Navarra y las Provincias Vascongadas, por la situación en que se encontraban en relación con el carlismo. Y, por último, planteó una reducción en la talla mínima exigida para el servicio ${ }^{384}$.

Otros procuradores criticaron la distribución de los cupos en función del obsoleto censo de 1797 y exenciones territoriales injustificadas como la madrileña ${ }^{385}$, si bien sus propuestas no fueron tomadas en cuenta con la justificación de la urgencia de la quinta y

383 Discurso del Sr. Belda, Diario de Sesiones de las Cortes, 25/11/1834, no 87, p. 801.

384 Discurso del Sr. Belda, Diario de Sesiones de las Cortes, 25/11/1834, no 87, p. 802.

385 Discurso del Sr. Marqués de Torremejía, Diario de Sesiones de las Cortes, 25/11/1834, no 87 , p. 805. 
una mejor y más justa regulación en una posterior, y más meditada, legislación.

No sería hasta el motín de los Sargentos de la Granja de San Ildefonso, en agosto de 1836, que supuso el acceso de los liberales radicales al poder, cuando se recuperaría la legislación gaditana y del Trienio Liberal en materia castrense, lo que condujo a un mayor control de la política militar y de la propia institución por parte del poder civil. Sin embargo, su vigencia fue efímera al aprobarse una nueva Constitución para regular el funcionamiento del Estado y una nueva Ordenanza sobre el reemplazo de efectivos en el Ejército, ambas en 1837.

En 1837 tuvieron lugar unas Cortes Constituyentes para elaborar una nueva constitución, que sería aprobada ese mismo año. Sin embargo, ese no fue el único fruto legal de las Cortes Constituyentes, que elaboraron una serie de disposiciones legales de gran importancia, como las leyes que respaldaban y daban continuidad al proceso de desamortización iniciado en 1833 por Mendizábal sobre los bienes, fundamentalmente, de las Órdenes Religiosas, o la ley que suprimía los mayorazgos, institución que había jugado un factor clave en la sociedad española desde la Edad Media, ya que al privar de toda herencia a los hijos menores, supuso un impulso vital para instituciones que brindaban una salida profesional a estos hijos sin herencia, tales como la Iglesia y el Estado.

La Constitución de 1837, impulsada por los progresistas durante el gobierno de Calatrava, y vigente hasta 1845, señaló en su artículo 45 que era el monarca el encargado de ejecutar las leyes, pero además "[...] su autoridad se extiende a todo cuanto conduce a la conservación del orden público en lo interior y a la seguridad del 
Estado con lo exterior, conforme a la Constitución y a las leyes"386. Se intenta por lo tanto que el poder civil recupere su autoridad en materia castrense. Además, la nueva Carta Magna indicaba que sería el Rey, a propuesta de las Cortes, quien fijara el contingente militar anual $^{387}$.

Como no podía ser de otra forma con unas Cortes y un Gobierno con predominio liberal-progresista, se establecía en la Constitución que todos los españoles estaban obligados a empuñar las armas para defender a la patria cuando fuera necesario y fueran llamados por la ley ${ }^{388}$. Sin embargo, no señalaba nada sobre el modelo y los métodos de reclutamiento, cuya reglamentación se dejó para legislaciones posteriores.

La adopción de los nuevos conceptos liberales en el desarrollo de la norma

La Ley de 1837 es un texto amplio, compuesto por 17 capítulos y 114 artículos, redactado por el Gobierno del progresista Calatrava pero discutido y aprobado por las Cortes el 31 de octubre de 1837 durante el Gobierno del moderado Eusebio Bardají Azara, y sancionado por la Reina Regente María Cristina de Borbón el 2 de noviembre del mismo año ${ }^{389}$.

\footnotetext{
${ }^{386}$ Constitución de 18 de junio de 1837, art. 45.

387 Constitución de 18 de junio de 1837, art. 76.

388 Constitución de 18 de junio de 1837, art. 6.

389 Ley de Reemplazos de 2 de noviembre de 1837, Gaceta Núm. 1129 de 01/01/1838. En adelante, Ley de Reemplazos de 2 de noviembre de 1837.
} 
a) Elaboración del padrón de vecinos: documento básico para el reparto de los cupos

Se inicia la norma con un primer capítulo centrado en la elaboración y destino del padrón de vecinos. Continúa, por tanto, siendo el padrón el primer paso a realizar en el proceso de reclutamiento y un documento fundamental para fijar el reparto de los cupos. Su importancia estribaba en que estos cupos se distribuían de forma proporcional al número de almas con las que contaba cada población.

El padrón se confeccionaría anualmente durante el mes de enero con todos los habitantes del pueblo, hombre y mujeres de todas las edades 390 , así como los ausentes por cualquier motivo o residentes temporales en otra localidad: criados domésticos, labradores, estudiantes, aprendices, etc. ${ }^{391}$. Con el objeto de evitar errores que propiciasen la no inclusión de algunos jóvenes en el

\footnotetext{
390 El Diputado Sr. Fontán criticó que se elaborase un padrón con un objetivo exclusivamente militar, ya que los gastos y complicaciones que éste suponía para las autoridades municipales eran excesivos, proponiendo una ley de empadronamiento que regulase esta cuestión: "Señores, que se empadronen todos los individuos que componen la Nación, es muy justo; pero que en la ley de reemplazos se exija el empadronamiento incluyendo todas las edades y sexos [...] es un exordio que va muy lejos de la cuestión y objeto á que se dirige un proyecto de ley de reemplazos. ¿Cuál es el objeto de ésta? Conocer todos los mozos hábiles para llevar las armas en el servicio del Ejército; y esto basta para conocer que la edad y el sexo deben ser los que se necesitan para este servicio. Debe, sí, haber otra ley de empadronamientos, la cual diga cómo deben hacerse estos y en qué época de cada año: esto deberá ser objeto de un proyecto de ley que el Gobierno debe presentar [...]; pero entre tanto, ¿han de tomar las armas las mujeres? ¿Las han de tomar los niños y los viejos, que han de ser objeto de este empadronamiento? ¿Saben los Sres. Diputados lo que cuesta un empadronamiento minucioso? ¿Se han de estar haciendo continuamente para mortificar á las autoridades municipales, exigiendo todos los datos que tienen relación con el objeto que se propone? [...] Debe haber esos empadronamientos generales de la Nación, debe conocerse cuanto más aproximadamente sea posible; en eso estoy conforme; pero no en ley de reemplazos, que tiene un objeto particular" (Discurso del Sr. Fontán, Diario de Sesiones de las Cortes, 13/10/1837, no 338, p. 6619).

${ }^{391}$ Ley de Reemplazos de 2 de noviembre de 1837, arts. 1 y 2.
} 
censo, la ley también especificaba a quienes se consideraba que dependían del pueblo ${ }^{392}$.

Para facilitar la confección del padrón en municipios con un significativo número de habitantes, los Ayuntamientos, con aprobación de las Diputaciones provinciales, podrían dividir la localidad en distritos, cada uno de 150 habitantes aproximadamente. Cada distrito se consideraría independiente para todas las operaciones de reemplazo, tendría su padrón particular y una autoridad del Ayuntamiento encargada de su elaboración. Si un distrito estuviese formado por varias poblaciones dispersas, en cada una de ellas se realizarían de forma independiente el padrón y las restantes operaciones para el reemplazo ${ }^{393}$.

Una vez elaborados los padrones, se obtendría de ellos un extracto firmado por los miembros del Ayuntamiento y el secretario que indicase el número total de habitantes de la población en cuestión para ser remitido a la Diputación provincial en los primeros ocho días del mes de febrero. Las personas que firmasen el extracto serían responsables de su concordancia con los datos del padrón ${ }^{394}$. Los fraudes en la elaboración del padrón (se llegó a constatar una supuesta disminución de la población española en dos millones de

392 "Se entiende que dependen del pueblo:

10.- Los que tengan habitación o casa abierta y propia o arrendada en el mismo pueblo con verdadera vecindad, aunque residan temporalmente en otra y tengan también en él casa abierta.

$2^{\circ}$.- Los que estén sujetos a la potestad de su padre, vecino del pueblo.

30.- Los hijos solteros de madre viuda, también vecina, que no tengan por sí habitación o casa abierta, propia o arrendada.

40.- Los que sin hallarse en alguno de los tres casos precedentes no lleven un año de residencia fuera del pueblo de que son naturales, o donde fueron últimamente vecinos sus padres; contando este año desde $1^{\circ}$ de Enero del anterior al en que se hace el padrón.

50.- Los que aún cuando lleven más de un año de residencia fuera del pueblo no prueben con certificación del Ayuntamiento de aquel en que residen, que han de ser comprendidos en su alistamiento.

60.- Los que hallándose en las mismas circunstancias de más de un año de residencia fuera del pueblo, hayan manifestado su ánimo de continuar perteneciendo a él, lo que deberán hacer en lo sucesivo en el mes de Enero de cada año; [...]" (Ley de Reemplazos de 2 de noviembre de 1837, art. 2).

${ }^{393}$ Ley de Reemplazos de 2 de noviembre de 1837, arts. 4 y 5.

${ }^{394}$ Ley de Reemplazos de 2 de noviembre de 1837, arts. 6, 7 y 8. 
habitantes entre un año y otro), originaron distintas propuestas con el objeto de una correcta realización de esta tarea en los años sucesivos, sin bien las distintas iniciativas en Cortes fueron finalmente rechazadas ${ }^{395}$.

Finaliza este primer capítulo señalando que, en los primeros días del mes de febrero, se formaría el alistamiento con todos "[...] los españoles solteros y viudos sin hijos que el día 30 de abril inclusive del año en que se hace el alistamiento se hallen en la edad de dieciocho años cumplidos, hasta veinticinco también cumplidos" ${ }^{396}$. Quedarían por tanto fuera del alistamiento los foráneos inscritos en la matrícula de extranjeros de algún consulado. Aclara la orden que deberían estar incluidos en el alistamiento los casados y ordenados in sacris mayores de veintidós años pero no los menores de esa edad ${ }^{397}$. Por tanto, la edad obligatoria para participar en el sorteo sería entre los dieciocho y los veinticinco años, una franja menor que en las leyes anteriores, ya que no incluía a todos los mozos entre los diecisiete y treinta y seis años. Además, "[...] al distribuirse los mozos en cinco grupos de edades para el sorteo, el cupo se solía cubrir con los de dieciocho y diecinueve años" ${ }^{398}$.

Aún así, hubo diputados que criticaron esta franja de edad al considerarla excesiva, y estimaron suficiente para cubrir las necesidades del Ejército el margen comprendido entre los dieciocho y veintidós años de edad:

395 Diario de Sesiones de las Cortes, 25/05/1842, no 124 pp. 3433-3436 y 21/06/1842, no 129 pp. 3627-3633.

${ }^{396}$ Ley de Reemplazos de 2 de noviembre de 1837, art. 9.

397 Esta circunstancia causó polémica en el seno de las Cortes al pronosticarse una avalancha de matrimonios antes de cumplir la edad de veintidós años, con el único objeto de evitar la prestación, llegando el Sr. García Blanco a proponer la prohibición del matrimonio antes de los veintidós años de edad, Diario de Sesiones de las Cortes, 17/10/1837, no 342, pp. 6694 y 6695.

398 PUELL DE LA VILLA, F., El soldado desconocido: de la leva a la "mili" (17001912), p. 190. 
"Yo he meditado este asunto desde que la Comisión se empezó a ocupar de la formación de este proyecto de ley, y tengo manifestado a alguno de sus individuos que no es necesario sujetar a los españoles á esta obligación hasta la edad de 25 años, aun cuando nos hallamos en el caso en que estamos hoy de tener sobre las armas un Ejército muy numeroso. Calculada nuestra población aproximadamente, aun cuando nos equivoquemos en un millón o dos, $y$ hechas as correspondientes bajas en razón de enfermedades, defectos físicos y demás que hacen al hombre incapaz do soportar las fatigas del servicio militar, siempre resultara que en las edades de 18, 19, 20, 21 anos, y si Se quiere 22, habrá un numero más que suficiente para ocurrir a las necesidades del reemplazo de nuestro Ejército. ¿Á qué, pues, tener a tantos españoles como estarán comprendidos en las edades de 23, 24 y 25 en la incertidumbre y pendientes, digámoslo así, para tomar estado y dedicarse a las respectivas carreras, de esta ley por ir mucho más allá, de lo que se necesita? Yo he reflexionado muy detenidamente, señores, sobre el total de nuestras fuerzas militares, comparándolas con nuestra población, y según mis cálculos creo que bastarán las edades de los tres años primeros para tener nuestro Ejército permanente bien servido y provisto, aun en circunstancias do guerra, y mucho más en el estado normal, en tiempo de paz"399.

b) Formación del alistamiento para el reemplazo

Se centra el segundo capítulo en la formación del alistamiento por localidades de todos los mozos comprendidos entre los márgenes de edad anteriormente citados. Se iniciaba en el mes de febrero en función de los padrones por localidades que se habían elaborado.

Los jóvenes estarían clasificados en función de su edad, y este documento, elaborado en el Ayuntamiento a puerta abierta y firmado por los capitulares y el secretario del consistorio, debería ser público

399 Discurso del Sr. Fontán, Diario de Sesiones de las Cortes, 13/10/1837, n 338, p. 6620. 
el primero de mayo ${ }^{400}$. Para asegurar una mayor formalidad en su elaboración, y hasta que empezasen a funcionar los registros civiles, asistiría al acto el párroco del pueblo u otros eclesiásticos que pudiesen aportar información de interés respecto a las edades de los mozos. Para ello irían acompañados de los libros parroquiales que considerasen necesarios $^{401}$. De nuevo se muestra la importancia que se concedía y la autoridad conferida en la España de la época al grupo eclesial a pesar de haberse eliminado las diferencias estamentales. Copias del documento de alistamiento serían expuestas en lugares públicos durante, al menos, tres días ${ }^{402}$.

c) Reclamaciones y rectificación del alistamiento

Los capítulos tres y cuatro de la ley se encargaron de regular todo lo concerniente a las reclamaciones respecto al alistamiento, presentadas ante el Ayuntamiento o la Diputación provincial.

Sería el primer día festivo del mes de marzo, y previo anuncio público, la fecha elegida para la lectura del alistamiento y su posible rectificación en función de las reclamaciones presentadas por los jóvenes, sus padres o parientes, tanto en lo que se refiere a su propia exclusión como a la inclusión en el mismo de otros mozos que debieran estar o a la rectificación de las edades propia o de otros. En el caso de no poder resolver la totalidad de las reclamaciones

\footnotetext{
400 Ley de Reemplazos de 2 de noviembre de 1837, arts. 11, 12 y 13.

${ }^{401}$ Ley de Reemplazos de 2 de noviembre de 1837, art. 12.

402 Ley de Reemplazos de 2 de noviembre de 1837, art. 14. Señalar que la publicidad otorgada a los actos del reclutamiento con el objeto de dotar una mayor legalidad a todo el proceso, también se podía convertir en una forma de rechazo popular hacia el reclutamiento militar: "Esta determinación [la de hacer públicas copias del documento de alistamiento] era aprovechada por algunas personas para expresar su protesta contra la quinta; circunstancia que se manifestaba, especialmente, al arrancar las hojas de los alistamientos e incluso hacerlas desaparecer del lugar donde habían sido ubicadas." (JIMÉNEZ GUERRERO, J., El reclutamiento militar en el siglo XIX: las quintas en Málaga (1837-1868), p. 81).
} 
presentadas durante ese día, se continuaría con esta tarea en los días festivos siguientes del mes de marzo ${ }^{403}$.

Los miembros del Ayuntamiento atenderían las reclamaciones y tendrían en cuenta las pruebas presentadas, tomando una decisión mediante votación. Todo lo acaecido en este acto de reclamaciones se recogería en un acta firmada por los miembros del consistorio. En el caso de que no se pudiese resolver una reclamación por deber desplazarse las autoridades municipales a otros pueblos, o porque se debieran traer documentos demostrativos de otros lugares, se indicaría en el acta, imponiéndose un plazo de tiempo "prudente" para aportar las pruebas y resolver dichas reclamaciones, no pudiéndose presentar nueva documentación una vez superado el plazo señalado ${ }^{404}$.

Quienes no estuviesen de acuerdo con la decisión del Ayuntamiento tendrían la posibilidad de reclamar ante una instancia superior, la Diputación provincial. Para ello deberían entregar ante la máxima autoridad de la provincia un certificado expedido por el consistorio donde se indiquen los motivos de la queja en un plazo máximo de diez días. La Diputación podía realizar las investigaciones que considerara pertinentes para resolver el expediente, y su decisión era inapelable.

En el caso de existir disputa entre dos pueblos de una misma provincia por incluir en el alistamiento a un mismo joven, sería la Diputación la encargada de revisar los expedientes y tomar una decisión final. Si la misma situación se produjese entre dos pueblos de distintas provincias, ambas Diputaciones deberían ponerse de acuerdo y, en caso de no hacerlo, sería el gobierno central quien debería tomar la decisión final ${ }^{405}$.

\footnotetext{
403 Ley de Reemplazos de 2 de noviembre de 1837, arts. 15 y 18.

404 Ley de Reemplazos de 2 de noviembre de 1837, arts. 16 y 17.

${ }^{405}$ Ley de Reemplazos de 2 de noviembre de 1837, arts. 19, 20, 21 y 22.
} 
d) Un sorteo por franjas de edad

El capítulo quinto se centra en el laborioso proceso del sorteo. Para ello, una vez que se hubiese rectificado el alistamiento, se obtendrían del mismo varios listados con los mozos comprendidos en las mismas edades: dieciocho y diecinueve, veinte, veintiuno, veintidós, veintitrés y veinticuatro años. El sorteo se celebraría en todos los pueblos de España el primer domingo del mes de abril a las siete de la mañana, y continuaría en los días siguientes si fuese necesario ${ }^{406}$.

La existencia de exenciones territoriales, concretamente en el País Vasco, ya fue reflejada por los periódicos del momento, si bien se minimizaron las consecuencias de tal exención:

"Los fueros de Vizcaya encierran una pequeña parte, y más pequeña de lo que generalmente se cree, de verdaderos privilegios. El principal es que en Vizcaya no hay quintas, y de aquí se ha sacado la falsa consecuencia de que aquí no se pagaba la contribución de sangre. Falsa y muy falsa consecuencia, porque en primer lugar los vizcaínos en tiempos de guerra acuden al llamamiento del Señor, y siempre han derramado la sangre con el valor que la historia lo tiene consignado. En segundo lugar, aunque es cierto que en tiempo de paz no ha contribuido el Señorío [...], también lo es que ha prestado el servicio con dinero, lo que hace desaparecer toda sombre de privilegio. Esta es una verdad, pero todo el mundo decía: en Vizcaya no hay quintas, $y$ escudado en este pretesto (sic) el despotismo exclamó: es una monstruosidad, los vizcaínos no pagan la contribución de sangre, este odioso privilegio debe desaparecer ${ }^{\prime 407}$.

Los sorteos se realizarían, en presencia de los interesados y de los miembros del Ayuntamiento, en función de las edades,

${ }^{406}$ Ley de Reemplazos de 2 de noviembre de 1837, arts. 23 Y 24.

407 El Español, 15/10/1837, no 713, p. 3. 
comenzando con los mozos entre dieciocho y diecinueve años. Los nombres de los jóvenes se escribirían en papeletas iguales, mientras que en otras papeletas, también iguales, se redactarían tantos números como mozos participaran en el sorteo. Las papeletas se introducirían en bolas, y éstas en "globos", uno para los nombres y otro para los números. Una vez introducidas las papeletas en sus respectivos globos y movidos éstos, dos niños menores de diez años serían los encargados de extraer, una a una, las bolas de ambos globos. El síndico leería la papeleta que contenga el nombre en voz alta, mientras que el presidente del Ayuntamiento haría lo mismo con la papeleta que contenga el número. Estas papeletas se mostrarían a los restantes miembros del consistorio y a todos aquellos que estuviesen interesados. Una vez celebrado el sorteo de los jóvenes entre dieciocho y diecinueve años, se realizarían los correspondientes a los veinte y veintiuno, veintidós, veintitrés, veinticuatro y veinticinco, un total de seis sorteos ${ }^{408}$.

Se puede observar la importancia que se concede a las autoridades locales en el acto del sorteo, siendo además responsables de su correcta celebración ${ }^{409}$. Sería además el secretario el encargado de redactar el acta "[...] con el mayor cuidado, pureza y diligencia $[\ldots] "$, y en ella se incluirían los nombres de los mozos cuyas papeletas hubiesen ido saliendo y el número que hubiese correspondido a cada uno ${ }^{410}$. El acta debía señalar expresamente si no se hubiese realizado algún sorteo por no haber ninguno o haber sólo un mozo comprendido entre esa franja de edades, y tendrían que ser leídas en público y firmadas por todos los miembros del Ayuntamiento y el secretario ${ }^{411}$.

\footnotetext{
408 Ley de Reemplazos de 2 de noviembre de 1837, arts. 25, 26, 27, 28 y 31.

${ }^{409}$ Ley de Reemplazos de 2 de noviembre de 1837, art. 29.

410 Ley de Reemplazos de 2 de noviembre de 1837, art. 30.

${ }^{411}$ Ley de Reemplazos de 2 de noviembre de 1837, arts. 32 y 33.
} 
En el caso de que un recurso presentado ante la Diputación hubiese prosperado, descenderían un número todos aquellos jóvenes que siguiesen al individuo excluido, sin celebrarse un nuevo sorteo. Sí que se repetiría en el caso contrario, cuando un individuo en un principio excluido del alistamiento finalmente sí lo estuviese. Sin embargo, este sorteo tendría unas características peculiares, ya que se incluirían en un globo tantos números como jóvenes participantes, y en otro la papeleta con el nombre del recién incluido junto a otras en blanco hasta completar el mismo número de papeletas que el otro globo. Extraídas las papeletas, al mozo nuevo le correspondería el número que hubiese coincidido cuando salía su nombre. Entre él y el mozo que hubiese sacado el mismo número en el primer sorteo se celebraría otro nuevo con dos globos, uno con las dos papeletas de los nombres y otro con dos papeletas: una con el número que les había correspondido y otra con el siguiente. Una vez extraídas las papeletas, uno quedaría con el número inicial, mientras el otro tendría el número siguiente, avanzando un puesto en la lista los mozos sorteados a partir del número extraído ${ }^{412}$.

e) Actuación de las Diputaciones Provinciales

El capítulo sexto regula la actuación de una institución nacida al amparo de las reformas liberales y que ejerció un papel fundamental en la ejecución del proceso de reclutamiento, siendo éste una de sus principales competencias, nos referimos a las Diputaciones provinciales $^{413}$. Uno de los principales cometidos de esta recién

\footnotetext{
412 Ley de Reemplazos de 2 de noviembre de 1837, arts. 35, 36, 37 y 38.

413 GONZÁleZ CASANOVA, J. A., Historia política de las Diputaciones desde 1812 hasta 1985, Madrid, Mancomunidad General de Diputaciones de Régimen Común, 1986; SANTANA MOLINA, M. y BERMÚDEZ AZNAR, A., La Diputación Provincial en la España decimonónica, Madrid, Ministerio de Administraciones Públicas, 1989.
} 
creada institución era, precisamente, vigilar todo el proceso para evitar fraudes y engaños.

Las Diputaciones eran las encargadas de que los Ayuntamiento les remitieran el extracto con la población de cada localidad y, al mismo tiempo, de elaborar un estado que manifestase el número de vecinos de cada pueblo y de la provincia en su totalidad. Este estado circularía por los pueblos de la provincia para comprobar posibles errores y, una vez enviado a las Cortes, sería el documento sobre el que se realizase el reparto de los cupos a cubrir por cada provincia ${ }^{414}$.

Las Diputaciones, además, velaban por el respeto a la legalidad en todo el proceso y podían recibir denuncias de posibles fraudes por parte de Ayuntamientos y particulares. Ante cualquier denuncia presentada, las Diputaciones estaban obligadas a abrir un expediente que aclarase los hechos $y$, en el caso de descubrirse irregularidades por parte de las autoridades locales en lo que se refiere a la ocultación de población para lograr una reducción en el número de quintos a entregar, las Diputaciones podrían imponer diversas penas $^{415}$ : económicas ${ }^{416}$, denuncia ante los tribunales de justicia, 0 incluso que el pueblo defraudador tuviese que aportar a filas un mayor número de mozos de los que le corresponderían en función de

\footnotetext{
${ }^{414}$ Ley de Reemplazos de 2 de noviembre de 1837, art. 40.

415 El Procurador Sr. Díez instó a la Cámara a transformar este artículo e imponer penas a las autoridades locales sólo cuando éstas hubiesen obrado de mala fe, "[...] porque es muy posible, señores, que un Ayuntamiento al formar su padrón incurra en equivocaciones involuntarias, y aquí la Comisión prejuzga un hecho que puede ser inocente. [...] Solo debe imponerse la pena cuando la ocultación sea voluntaria, sea maliciosa, sea fraudulenta" (Discurso del Sr. Díez, Diario de Sesiones de las Cortes, 18/10/1837, no 343, p. 6714).

416 La Ley no especificó la cuantía de las multas, lo que fue criticado por el Procurador Madoz, así como el hecho de que las Diputaciones tengan jurisdicción en esta materia y no un tribunal competente: "Las Diputaciones Provinciales (se dice en el artículo) impondrán al que de lugar á ello multas proporcionadas. Yo creo que esta es una expresión demasiado vaga y general. Yo estoy por que se debe fijar un máximum y un mínimum, como se hace en todas las leyes; porque no fijar este máximum y mínimum, es dar lugar á que las Diputaciones Provinciales obren de un modo arbitrario, de lo cual resultaría que se hiciese odiosa la ley, como se hacían las dadas en tiempo del despotismo, porque en ellas no había regla y la voluntad del que mandaba era la medida" (Discurso del Sr. Madoz, Diario de Sesiones de las Cortes, 18/10/1837, no 343, p. 6721).
} 
su población ${ }^{417}$, situación ésta que encontró la oposición de numerosos procuradores por considerar culpables del fraude a los miembros del consistorio y no a la población en general, acusada así de complicidad en el delito ${ }^{418}$, a lo que respondió la comisión encargada de la elaboración de la ley de la siguiente forma:

"Hay otra razón poderosísima mayor para que el pueblo pague, $y$ es que por fuerza el pueblo es cómplice: los interesados tienen que ser cómplices con el Ayuntamiento. ¿No tienen las listas al público? ¿No las ven todos los vecinos? Pues en verdad que los vecinos notarán si hay o no fraude (porque no se trata de un descuido de uno o dos sujetos (sic), y el artículo. usa de la palabra fraude para hacer ver que solo puede recaer sobre un número considerable de personas, ó sobre las ocultaciones que todos los que me escuchan saben cuán comunes son en España, y tanto, que en alguna provincia tengo datos para decir que llegan á ser de una tercera parte de su población. El pueblo sabe que cuanto menor sea el número de almas que figure, tanto menor será el cupo que les toque habiendo de repartir en proporción y de aquí es que (y puede decirse que sucede un millón de veces) se les llega a ofrecer a los Ayuntamiento que se les pagarán las multas que puedan imponérseles por el fraude, si se descubre, y se obliga á ello mancomunadamente el vecindario, que conmina á los que quieren decir la verdad. [...] Póngase al pueblo el único correctivo acaso capaz de evitar tal fraude. [...] Porque al joven a quien haya tocado la suerte, resentido y viendo que de todos modos ha de llevar las armas, es muy fácil que diga: señores, en mi pueblo se ocultaron tantos, que así se descubra el fraude, y quo una vez descubierto, no vuelva el pueblo á hacerlo, para no dar lo quo tanto le cuesta"1419.

A pesar de esta regulación a la que fue sometida la actuación de las Diputaciones, las denuncias sobre las mismas fueron

\footnotetext{
${ }^{417}$ Ley de Reemplazos de 2 de noviembre de 1837, arts. 41, 42, 43 y 44.

418 Diario de Sesiones de las Cortes, 18/10/1837, no 343, pp. 6715-6720.

419 Discurso del Sr. Fernández Baeza, Diario de Sesiones de las Cortes, 18/10/1837, no 343, p. 6715.
} 
habituales, lo que obligaría a promover posteriormente nuevos textos legales que impidieran el fraude por parte de la institución provincial.

f) Reparto de los cupos y la novedad del sorteo de quebrados

Atiende el capítulo octavo a una cuestión delicada como es el reparto de los cupos. De nuevo serían las Diputaciones las encargadas de realizar dicha tarea, ocho días después de haber recibido el decreto de reemplazo por parte de las Cortes, en función de la población de cada localidad ${ }^{420}$. Por tanto, tal y como ya recogía la Constitución de 1837 en su artículo 76, sería el Parlamento el encargado de emitir anualmente la orden de reemplazo y de fijar el número de reclutas necesarios.

Sin embargo, las dificultades para asignar un número concreto de quintos que hubieran de cumplir la prestación militar a cada pueblo ${ }^{421}$ en función de su población, se resolvió con un reparto de cupos por enteros y décimas (diez décimas era un soldado),

\footnotetext{
${ }^{420}$ Ley de Reemplazos de 2 de noviembre de 1837, arts. 45.

421 La utilización del término "pueblo" fue criticada por el Procurador Mouré al considerarlo un concepto confuso en diversas regiones del país: "Si tomo la palabra en contra, es solamente por saber qué es lo que entiende la Comisión por pueblo; porque en casi toda Galicia, Asturias, Santander y otras provincias donde la población está muy diseminada, no se sabe qué es lo que constituye un pueblo. Debo hacer presente á las Cortes que antes se hacían allí las quintas.de dos modos: la que se hacia para la Milicia Provincial era por parroquias, que es el modo más justo, más equitativo; y el otro método que se empleaba para la quinta del reemplazo del Ejército se hacia por jurisdicciones, las cuales comprendían varias parroquias que formaban un Ayuntamiento. Por consiguiente, no haciendo una explicación de lo que se quiere significar con la palabra pueblo, nos exponemos a que haya confusión en el modo de entender la ley. Si por pueblo se entiende lo que está bajo la jurisdicción de un Ayuntamiento, á veces componen esta jurisdicción 20 ó 30 parroquias diseminadas. Así, yo soy de parecer que se exprese si por pueblo se ha de entender la parroquia, ó lo que comprende la jurisdicción de cada Ayuntamiento" (Discurso del Sr. Mouré, Diario de Sesiones de las Cortes, 19/10/1837, no 344, p. 6733).
} 
"[...] de manera que se señale a cada pueblo los mozos que deba dar y las décimas que le toquen sortear con otros según las fracciones que resulten, o por las almas que les sobren después de las que corresponden al número de enteros, o porque no tenga las suficientes para dar uno de estos ${ }^{\prime 422}$.

Este complejo proceso ${ }^{423}$, regulado por la normativa entre sus artículos 46-52, es explicado por Enrique Martínez Ruiz de la siguiente forma:

"El sorteo de ese reparto se hará por enteros y décimos, según las fracciones que resulten; esas fracciones tendrán que completarse entre los distintos pueblos hasta formar enteros. Si algún pueblo no pudiese dar un entero, su población se reunirá con la de otro u otros para completarlo. Para ver el orden en que irán aportando sus décimos, se introducirán en un globo diez papeletas con los nombres de los pueblos, poniendo por cada uno tantas papeletas cuantas décimos le corresponden, y en otro globo diez papeletas numeradas del uno al diez. El pueblo que resulte con el número uno dará el soldado que tendrá 18 o 19 años; si no, se cogerá el pueblo siguiente, y si tampoco lo hay, del siguiente, y si ninguno tuviere de esa edad, se cogerá de la siguiente, y así sucesivamente" ${ }^{\prime 424}$.

Los resultados del reparto de los cupos se formalizaría en un documento donde, en dos columnas, se indicase el número de habitantes de cada municipio y el número que quintos que le había

\footnotetext{
422 Ley de Reemplazos de 2 de noviembre de 1837, art. 46.

423 "Llama poderosamente la atención el hecho de que todavía se le siga denominando "sorteo de quebrados" en el título del capítulo correspondiente y sin embargo en el articulado posterior ya aparezca reflejado el término "décimas" con el que será reconocido a partir de este momento." (JIMÉNEZ GUERRERO, J., El reclutamiento militar en el siglo XIX: las quintas en Málaga (1837-1868), p. 115).

424 MARTÍNEZ RUIZ, E., "Desertores y prófugos en la primera mitad del siglo XIX", p. 624.
} 
correspondido a cada uno de ellos. Este resultado se comunicaría por parte de la Diputación con la mayor brevedad a todos los pueblos ${ }^{425}$.

g) Llamamiento, declaración, reconocimiento y posibles exenciones de los soldados

El capítulo octavo, uno de los más extensos de toda la ley, se inicia con la cuestión del llamamiento, declaración y reconocimiento de los nuevos reclutas ${ }^{426}$. Todos los mozos alistados serían citados por edictos el primer día festivo que se celebre desde que el Ayuntamiento hubiese recibido el reparto de los cupos. Además de un anuncio general, se citaría personalmente mediante una papeleta a los mozos titulares o suplentes y, en su defecto, a su padre, madre, pariente más cercano o amo en el caso de los criados domésticos ${ }^{427}$.

Reunido el Ayuntamiento el día que se hubiese señalado, se procedería a tomar declaración y a tallar a los mozos. A este acto tendrían la obligación de acudir el cuádruple de mozos con los que la localidad tenía que contribuir a la quinta en cuestión. Se pretendía con ello evitar nuevos llamamientos que retrasasen todo el proceso.

El Ilamamiento comenzaría con el joven que, entre la franja de edad de dieciocho y diecinueve años, hubiese obtenido el primer número en el sorteo. Posteriormente se procedería a su medida por parte de una persona designada por el Ayuntamiento. En el caso de que no alcanzase la marca de cinco pies menos una pulgada $(1,597$

\footnotetext{
425 Ley de Reemplazos de 2 de noviembre de 1837, arts. 53 y 54.

426 "[...] no cabe duda de que la aprobación de la normativa legal que entró en vigor en 1837 aportó sustanciales reformas en la mecánica del reclutamiento significando, de facto, una serie de mejoras en los distintos actos que constituían la realización de la quinta." (JIMÉNEZ GUERRERO, J., El reclutamiento militar en el siglo XIX: las quintas en Málaga (1837-1868), p. 134).

${ }^{427}$ Ley de Reemplazos de 2 de noviembre de 1837, arts. 55 y 56.
} 
m. $)^{428}$ sin calzado, sería considerado falto de talla, se anotaría, y se llamaría al número siguiente. Si el joven fuese considerado óptimo de talla, se le examinarían otras cuestiones corporales necesarias para ser considerado apto. El mozo considerado apto podría exponer, en este mismo acto, los motivos que alegase para ser excluido del servicio y presentar la documentación que considerase necesaria para hacer ver su reclamación. Correspondía al Ayuntamiento, a través de una votación en la que participen la totalidad de sus miembros, tomar una decisión al respecto y declarar al mozo soldado o excluido ${ }^{429}$.

Una vez tallado y examinado el mozo con el primer número entre los dieciocho y diecinueve años, se procedería de igual forma con los números siguientes, hasta completar el cupo asignado a la población en cuestión. En el caso de no poder completar el número de reclutas con esta franja de edad, se continuaría con la lista correspondiente a los veinte años y así sucesivamente. Si algún recluta hubiese fallecido después del alistamiento, su puesto quedaría vacante y pasaría al número siguiente. Se procedería de la misma forma para la selección de los soldados suplentes, siguiendo siempre la numeración y la edad ${ }^{430}$. Durante este acto de llamamiento y declaración de los mozos sería el momento de presentar las alegaciones pertinentes ante el Ayuntamiento para acogerse a alguna de las exenciones ${ }^{431}$.

En el caso de que un joven alegase como inutilidad para el servicio una enfermad notoria o defecto físico visible, y que efectivamente así lo fuese, se le declararía excluido. Sin embargo, esta circunstancia también podía dar lugar a conflictos. En el caso de

\footnotetext{
${ }^{428}$ Señalar que la altura mínima exigida para entrar a formar parte del Ejército fue variando anualmente en función del decreto de reemplazo elaborado. En esta ocasión, el Diputado Mouré solicitó su rebaja en dos pulgadas, pero su propuesta fue rechazada. Discurso del Sr. Mouré, Diario de Sesiones de las Cortes, 19/10/1837, no 344, p. 6737.

${ }^{429}$ Ley de Reemplazos de 2 de noviembre de 1837, arts. 58 y 59.

${ }^{430}$ Ley de Reemplazos de 2 de noviembre de 1837, arts. 68, 69 y 71.

${ }^{431}$ FEIJÓo GÓMEZ, A., Quintas y protesta social en el siglo XIX español, p. 263.
} 
que hubiese dudas respecto a la enfermedad o defecto del mozo, los facultativos designados por el Ayuntamiento serían los encargados de realizar los reconocimientos médicos necesarios y efectuar una declaración jurada con su veredicto. Se señala en la ley que no es motivo de exclusión el haberlo estado en otros reemplazos, pues los motivos de inutilidad física debían "[...] atender al tiempo y estado actual" $^{432}$. Esta declaración sanitaria se incluirá en el acta, pero a la postre sería el Ayuntamiento, previo examen del reconocimiento médico, el que tomaría la última decisión.

Para evitar dudas, se especificaron los motivos que llevarían a la exclusión de un mozo, a saber: inutilidad física, aunque no se incluía una relación de exenciones físicas; los jóvenes en edad de quinta incluidos en las listas de "hombres de mar"433; los ya licenciados, redimidos y aquellos que hubiesen presentado a un sustituto; aquellos que llevasen dos años prestando servicio en la Milicia Provincial ${ }^{434}$ o que ejerciesen fuera de su provincia; el hijo único que mantuviese a su padre pobre o sexagenario impedido; el hijo único que mantuviese a su madre viuda y pobre; el hijo único que mantuviese a su madre pobre pero no viuda al estar el padre cumpliendo pena de presidio o trabajos públicos; el nieto único que mantuviese a sus abuelos pobres; el hermano de huérfano de padre y madre que le tuviese bajo su protección y no hubiese cumplido los 16 años; y el mozo que tuviese a un hermano sirviendo en el Ejército, ya sea de forma voluntaria o forzosa ${ }^{435}$. Este último tipo de exenciones,

\footnotetext{
432 Ley de Reemplazos de 2 de noviembre de 1837, arts. 61 y 62.

433 De nuevo se señala la importancia de las profesiones vinculadas a la Armada y al sector marítimo.

${ }^{434}$ Sobre la Milicia Provincial ver ECHANIZ ITUIÑO, M. A., La Milicia Nacional: fuerza popular del liberalismo español, 1974, Memoria de Licenciatura inédita, Universidad de Deusto; PÉREZ GARZÓN, J. S., Milicia Nacional y revolución burguesa, el prototipo madrileño, 1808-1874, Madrid, Instituto Jerónimo Zurita, 1978; OÑATE ALGUERÓ, P., Servir al Rey: la milicia provincial (1734-1846), Madrid, Ministerio de Defensa, 2001; HERRERO MATÉ, G., Liberalismo y Milicia Nacional en Pamplona durante el siglo XIX, Pamplona, Universidad Pública de Navarra, 2003.

${ }^{435}$ Ley de Reemplazos de 2 de noviembre de 1837, art. 63. El debate en Cortes respecto a la última excepción originó la enmienda, a la postre tenida en cuenta, de
} 
las familiares, "[...] siempre estuvieron envueltas en todo tipo de problemas, entre otras cosas, por la posibilidad de falsear la documentación y por la dificultad de fijar los límites de pobreza para acceder a esta exención" ${ }^{436}$.

Aunque no se cite expresamente, también se consideraron excluidos de la prestación del servicio los extranjeros. Sin embargo, esta circunstancia provocó actuaciones fraudulentas al solicitar los cónsules el fuero de extranjería para numerosos jóvenes.

Si comparamos esta legislación con la Ordenanza de 1800, observamos que el número de exenciones es menor ${ }^{437}$. Por una parte, ya no existen las exenciones por motivos de sangre, tanto clero como nobleza están obligados a empuñar las armas en el caso de recibir la suerte del soldado. Se habían eliminado, gracias a la

numerosos diputados, que consideraban que esta exención se debía conceder independientemente de si el soldado había sido reclutado de forma voluntaria o forzosa: "Al padre que tiene un hijo en el ejercito porque le ha cabido la suerte de quinto, y que por consiguiente ha sido sacado á la fuerza, se le concede el derecho de librar otro hijo; y con más razón creo yo que debe concederse este derecho al padre que tenga un hijo sirviendo voluntariamei;te en el Ejército ; porque este padre, en el mismo hecho de haber dado 6 su hijo el consentimiento para que se aliste voluntariamente, merece que se tenga con 61 más consideración que con el que ha cedido su hijo á la fuerza porque la ley se lo ha arrancado" (Discurso del Sr. Fontán, Diario de Sesiones de las Cortes, 20/10/1837, no 345, p. 6759).

${ }^{436}$ FEIJóo GÓMEZ, A., Quintas y protesta social en el siglo XIX español, p. 264.

437 La propia Comisión que elaboró la Ley reconoce su intención de reducir al mínimo el número de exenciones: "[...] ha sido la Comisión tan parca en proponer excepciones, para no perjudicar á unos por favorecer á otros, y también por no disminuir el número de los que entran en el alistamiento, aumentando el de los exentos, y para disminuir al propio tiempo la aversión que hasta ahora se ha tenido á las quintas y al servicio militar. Desde que empezó la guerra de la Independencia se han hecho tantas quintas y tantos alistamientos, que han dado lugar á una observación constante, y es, que cada orden ó decreto ó ley mandando una quinta ha sido recibido con más ó menos repugnancia, y ejecutado con más ó menos facilidad, según han sido mayores o menores las excepciones que se concedían en la ley ó decreto. Tan grandes, pues, y de tanta consecuencia han sido las miras de la Comisión al limitar el número de excepciones; pero sobre todas, la de que no se debía faltar á un principio constitucional. En la Constitución se dice que todos los españoles están obligados á defender la Patria cuando son llamados por la ley. Esta es un a obligación igual, una obligación que cada uno de los que se honran con el nombre de español tiene que cumplir, y obligación de que no se debe excluir al que esté ligado con él sino por causas muy poderosas, como las que ha tenido la Comisión, más bien bajo el aspecto de conveniencia y de beneficio público, que para favorecer á intereses particulares. La Comisión, pues, ha llevado las excepciones hasta el punto que podía llevarlas" (Discurso del Sr. Gómez Becerra, Diario de Sesiones de las Cortes, 20/10/1837, no 345, p. 6751). 
penetración del liberalismo y al predominio burgués, las desigualdades estamentales y se había implantado la igualdad de todos los ciudadanos ante la ley, también en lo que se refiere a la prestación del servicio de armas. Sin embargo, esta teórica igualdad jurídica es puesta en cuestión por la redención en metálico y la sustitución $^{438}$.

De la misma forma fueron menores las exenciones reconocidas por motivos laborales, con la única excepción de "los hombres de mar" y los que hubiesen prestado servicio, al menos durante dos años o en una provincia distinta a la de procedencia del recluta, en otro cuerpo armado, la Milicia Provincial. Las más habituales son las exenciones por impedimentos físicos o motivos familiares, casi todas porque el joven sin hermanos ${ }^{439}$ tuviese a su cargo a algún pariente pobre al que mantiene (padres o abuelos), pero son muy escasas a nivel cuantitativo. Más polémicas fueron las exenciones gracias al pago de una suma de dinero o a la presentación de un sustituto ${ }^{440}$. A esta segunda cuestión dedicó la ley un capítulo íntegro que posteriormente será analizado.

\footnotetext{
438 "De esta forma, las clases privilegiadas que habían perdido sus exenciones, seguían pudiendo quedar libres del servicio militar a través de aquella otra vía, y lo que en abstracto parecía una avance en la democratización del sistema de reclutamiento, en la práctica suponía una modificación mínima, ya que en su inmensa mayoría, las personas que podían pagar la redención en metálico eran, a "grosso modo", las mismas que antes quedaban exceptuadas. En cualquier caso, para la gran masa de la población española, incapaz de reunir las sumas exigidas, la ampliación del campo de la redención carecía de significado real" (FERNÁNDEZ RODRÍGUEZ, M. y MARTÍNEZ PEÑAS, L., "Problemática social en la legislación de reclutamiento decimonónica: exenciones, sustitución y redención", p. 326).

439 " 1 a.- No se entiende por hijo único el que tiene otro hermano varón mayor de 16 años, y no impedido para trabajar, aunque sea casado, eclesiástico, viudo o emancipado.

$2^{a}$.- Tampoco se entiende nieto único aquel cuyo abuelo o abuela tenga otro hijo o nieto varón mayor de 16 años y no impedido para trabajar, cualquiera que sea su estado" (Ley de Reemplazos de 2 de noviembre de 1837, art. 65).

440 "Las exenciones quedaban limitadas a catorce, todas ellas contenidas en el artículo $63^{\circ}$ de la Ley, despareciendo, como se ha dicho, todas las relativas a la pertenencia a la nobleza, a la Iglesia o a determinadas profesiones, manteniéndose las basadas en cuestiones sociales -hijos de viuda, aquellos que mantengan a parientes impedidos, etc.- que pasarían a formar, entonces y en adelante, el núcleo básico del sistema de exenciones" (FERNÁNDEZ RODRÍGUEZ, M. y MARTÍNEZ, L., "Problemática social en la legislación de reclutamiento decimonónica: exenciones, sustitución y redención", p. 325).
} 
Por lo que respecta a la redención en metálico, la Ley de $1837^{441}$ reconoció esta posibilidad, ya que se consideraron excluidos del servicio "[...] los que hayan redimido el servicio militar por el pecuniario en los términos y por el tiempo que lo hayan permitido las leyes, ordenanzas y reales decretos" ${ }^{\prime 42}$. No se especifica más al respecto en la normativa, y serían disposiciones posteriores las que regulen la cantidad y el medio a ingresar para gozar de esta exención. Fueron las necesidades económicas de la Hacienda pública las que impulsaron definitivamente la posibilidad de la redención en metálico, ya que la guerra civil había dejado las arcas del Estado en una situación cercana a la bancarrota. Sin embargo, la polémica estaba servida:

"La medida [fin de las exenciones estamentales] no podía dejar de levantar oposición en sectores tan importantes como la nobleza o la Iglesia: para paliar y prevenir las posibles reacciones adversas por parte de sectores con una gran fuerza económica y política que, previsiblemente, se opondrían a ver recortados de forma drástica sus privilegios, se incluyó en el texto de la ley una concepción mucho más amplia de la redención en metálico, habilitando su disponibilidad para cualquier persona que fuera capaz de satisfacer el precio estipulado por evitar la inclusión en el sorteo a filas" ${ }^{\prime 443}$.

De igual forma, se regulan en este capítulo los posibles fraudes cometidos por los mozos para evitar el alistamiento y se establecen una serie de penas en función de cada situación: en el supuesto de un mozo al que le hubiese tocado la suerte del soldado y tratase de

\footnotetext{
${ }^{441}$ Esta es la primera ley que vino a reconocer la redención en metálico, pero no la primera normativa, ya que esta posibilidad ya se recogió para los hidalgos en 1817 durante el reinado de Fernando VII, y que ya analizamos en su momento, Real Instrucción Adicional de noviembre de 1817.

442 Ley de Reemplazos de 2 de noviembre de 1837, art. 63.

${ }^{443}$ FERNÁNDEZ RODRÍGUEZ, M. y MARTÍNEZ PEÑAS, L., "Problemática social en la legislación de reclutamiento decimonónica: exenciones, sustitución y redención", p. 325.
} 
incumplir la ley, se le impondría un recargo en la prestación del servicio militar de seis meses a dos $\operatorname{años}^{444}$, y en el caso de no haberle tocado, la pena se incrementaría de cuatro a seis años ${ }^{445}$.

También se hace referencia a los posibles casos de daños físicos autoinflingidos y automutilaciones que pudiesen realizar los mozos para evitar la prestación ${ }^{446}$. Fue esta ley de 1837 la primera en intentar hacer frente a esta práctica ilegal que parecía cada vez más habitual si hacemos caso a los discursos de los diputados en Cortes $^{447}$. Para aquellos mozos que se les descubriese autolesionándose, las penas oscilarían entre los dos y cuatro años de trabajo en obras públicas ${ }^{448}$.

h) Conducción de los reclutas a su destino

Una vez finalizado el proceso de llamamiento, declaración y talla de los mozos, la norma regula, en sus capítulos noveno y décimo, la conducción de los reclutas a su destino, en este caso a la capital de provincia en primer lugar y a continuación a la caja de

444 Este recargo fue considerado muy leve por los Diputados Sr. Mouré y Sr. Sancho, que solicitaron un endurecimiento de las penas, Discurso del Sr. Mouré, Diario de Sesiones de las Cortes, 22/10/1837, no 347, p. 67971 y Discurso del Sr. Sancho, Diario de Sesiones de las Cortes, 22/10/1837, no 347, p. 6799.

${ }^{445}$ Ley de Reemplazos de 2 de noviembre de 1837, arts. 66.

446 "Es difícil establecer, de una manera fidedigna, el momento en el que aparece la inutilización física provocada por el mozo como medio de evadir la recluta. Sin embargo, consideramos que no resulta aventurado deducir que su práctica es paralela a la obligatoriedad de prestación del servicio de armas" (JIMÉNEZ GUERRERO, J., El reclutamiento militar en el siglo XIX: las quintas en Málaga (1837-1868), p. 335).

447 "Señores, son muchos los que se inutilizan por no sujetarse al servicio [...] cortándose los dedos y arrancándose los dientes, y la pena que aquí se impone no es la suficiente, mucho menos cuando el pueblo no está obligado á cubrir el reemplazo" (Discurso del Sr. Fontán, Diario de Sesiones de las Cortes, 22/10/1837, no 347, p. 6801).

${ }^{448}$ Ley de Reemplazos de 2 de noviembre de 1837, art. 67. De nuevo encontramos diputados que solicitaron penas más duras para atajar este tipo de delitos, así como un endurecimiento de los destinos, como por ejemplo, la Armada. Discurso del Sr. Infante, Diario de Sesiones de las Cortes, 22/10/1837, no 347, p. 6800 y Discurso del Sr. Fontán, Diario de Sesiones de las Cortes, 22/10/1837, no 347, p. 6802. 
quintos. La caja de quintos sería establecida por el capitán general en la capital de la provincia y sería dirigida por un oficial de su confianza, que se encargaría de todo lo relacionado con el destino y entrega de los reclutas. También se abre la posibilidad al establecimiento de cajas subalternas o dependientes de la principal ${ }^{449}$.

Este trayecto inicial incluiría a soldados y suplentes y se debería realizar con la mayor rapidez posible, cubriendo un recorrido mínimo de cinco leguas por jornada, y lo harían acompañados de un comisionado designado por el Ayuntamiento. A los soldados y suplentes se les entregaría, a cargo de las arcas municipales, dos reales diarios durante el tiempo que durase el traslado hasta la capital de provincia y se produzca la entrega efectiva en la caja de reclutas. Los suplentes que regresasen a su localidad también recibirían los dos reales diarios en su viaje de vuelta. Estos gastos serían cubiertos por el comandante de la caja de quintos, que haría el pago correspondiente al comisionado municipal para que los reingresase en la hacienda local ${ }^{450}$.

Este viaje también sería realizado, para ser medido o examinado, por aquellos mozos excluidos por el Ayuntamiento pero cuya no inclusión hubiese recibido la protesta de algún recluta. Los dos reales diarios que también se le debían pagar serían abonados por el "reclamante" y serán recuperados en el caso de ser cierta su reclamación. En caso contrario, el mismo reclamante debería hacer frente a "[...] la indemnización de los daños y perjuicios [...]"451.

Una vez que se encontrasen los reclutas titulares y los suplentes en la capital de provincia, el comisionado municipal haría entrega de los mismos en la caja de quintos, procediéndose al reconocimiento y medición de los reclutas. A este acto también

\footnotetext{
449 Ley de Reemplazos de 2 de noviembre de 1837, art. 87.

450 Ley de Reemplazos de 2 de noviembre de 1837, arts. 73, 74 y 75.

451 Ley de Reemplazos de 2 de noviembre de 1837, art. 76.
} 
asistirían dos miembros de la Diputación provincial para verificar su legalidad ${ }^{452}$.

Sorprendentemente, "[...] se daba el caso de que un joven que había sido declarado soldado [y por tanto apto en el Ayuntamiento], al ingresar en el Regimiento era desechado por inútil [... $]^{\prime 453}$. Por lo tanto, los nuevos reclutas estaban todavía a tiempo de ser reconocidos como no aptos en el momento que se les hacía el reconocimiento médico previo a su entrada en la Milicia ${ }^{454}$. Para el caso de individuos que alegasen para su exclusión del Ejército alguna enfermedad o defecto "no visible", el reconocimiento lo realizarían dos médicos, uno designado por la Diputación y otro por el oficial comandante de la caja, y a mayores un tercero, también nombrado por la institución provincial, en el supuesto de que el juicio sanitario de ambos fuese discordante. Sobre su actuación y opinión médica deberían emitir un certificado con destino a la Diputación ${ }^{455}$.

No se escapa al texto el atender a las obligaciones de los reclutas suplentes: cubrir la baja de aquel soldado titular que hubiese fallecido, que hubiese sido desechado por "inutilidad física" o falta de talla, o que se encontrase huido o preso por haber cometido algún delito. En este último caso, el suplente cubriría la baja del titular que le correspondiese hasta que el procesado hubiese cumplido su condena o hubiese sido declarado absuelto. Cuando este hecho se hubiese producido, el suplente podría regresar a su localidad, a no ser que el condenado lo fuese por pena "infamante", que obligaría al

\footnotetext{
452 Ley de Reemplazos de 2 de noviembre de 1837, arts. 79 y 80.

453 JIMÉNEZ GUERRERO, J., El reclutamiento militar en el siglo XIX: las quintas en Málaga (1837-1868), p. 181.

454 "La existencia de fraudes en los reconocimientos médicos seguía produciéndose. Y no sólo para declarar como inútil a alguien que no lo fuera, sino también enviando a filas a individuos que eran notoriamente enfermos, lo que conllevaba que una vez remitidos a la Caja de Reclutas tuviesen que ser devueltos a sus casas (JIMÉNEZ GUERRERO, J., El reclutamiento militar en el siglo XIX: las quintas en Málaga (1837-1868), p. 311).

455 "En esta certificación se han de expresar la enfermedad, sus circunstancias y el juicio de los facultativos sobre la utilidad o inutilidad del individuo" (Ley de Reemplazos de 2 de noviembre de 1837, art. 81).
} 
suplente a continuar en el Ejército por tener el titular prohibido su ingreso ${ }^{456}$.

Hecha la entrega en la caja de reclutas, se abre otra pequeña vía de reclamación ante la Diputación en los capítulos XI y XIII. Los diputados provinciales que hubiesen asistido al acto debían preguntar a los soldados por los posibles agravios que hubiesen recibido por parte del Ayuntamiento, y tomar nota formal de las reclamaciones. Estos diputados escucharían a los propios reclutas, testigos y al oficial de la caja, examinarían los documentos presentados por los interesados y las propias diligencias de los Ayuntamientos, para, en un acto público, resolver lo que correspondiese de una forma definitiva ${ }^{457}$. Se concede de esta forma facultad a las Diputaciones para imponer multas a los alcaldes, Ayuntamientos, secretarios de estos, facultativos u otras personas que hubiesen faltado a la observancia y exacta ejecución de esta ordenanza, o hayan dilatado o entorpecido los expedientes o diligencias que deban practicarse" ${ }^{458}$. Además, debían las Diputaciones denunciar los hechos delictivos ante los tribunales competentes "[...] cuando aparezca soborno, cohecho u otro delito o culpa que exija la imposición de pena corporal, de privación o suspensión de oficio o del ejercicio de alguna profesión $[\ldots]^{\prime \prime 459}$.

A pesar de esta regulación, la actuación de las Diputaciones sería objeto de numerosas denuncias por fraude, lo que obligaría a las autoridades gubernativas a emitir una nueva legislación en los años cuarenta que regulase definitivamente su actuación para evitar engaños y delitos.

\footnotetext{
456 Ley de Reemplazos de 2 de noviembre de 1837 , arts. 77 y 82 .

457 Ley de Reemplazos de 2 de noviembre de 1837, arts. 84 y 85.

458 Ley de Reemplazos de 2 de noviembre de 1837, art. 86.

459 Ley de Reemplazos de 2 de noviembre de 1837, art. 88.
} 
i) La sustitución: el primer reconocimiento legal de esta polémica figura

El capítulo XIV está consagrado de forma íntegra a uno de los aspectos más polémicos de cualquier legislación relativa al reclutamiento, el proceso de sustitución. Dice el artículo 89 que "el servicio militar podrá desempeñarse por medio de sustitutos, pero esta sustitución ha de ser individual $[\ldots]^{\prime 460}$. Sin embargo, sí se contempla al final del capítulo la posibilidad "[de una] sustitución general de todos los quintos de una provincia en los términos que sean más convenientes y cuando lo exijan las circunstancias particulares ${ }^{\prime 461}$. Por lo tanto, la sustitución individual estaría permitida, y en circunstancias excepcionales el Gobierno sí podría ordenar la sustitución global de todos los mozos de una provincia ${ }^{462}$.

Con la Ley de 1837 se regula definitivamente la posibilidad de la sustitución y, "[...] por ende, de abonar en metálico las prestación del servicio militar [lo que] conllevaba otorgar a las clases más poderosas desde el punto de vista económico, la facultad legal de eludir el ingreso a filas [...]. El privilegio estaba servido" ${ }^{463}$.

Los sustitutos se habían de presentar en la caja de quintos o en el cuerpo al que hubiesen sido destinados en el plazo máximo de un mes desde que fueron declarados oficialmente como soldados. Dos diputados provinciales asistirían a este acto para vigilar el proceso y remitir el informe correspondiente a la Diputación ${ }^{464}$.

\footnotetext{
${ }^{460}$ Ley de Reemplazos de 2 de noviembre de 1837, art. 89.

${ }^{461}$ Ley de Reemplazos de 2 de noviembre de 1837, art. 96.

462 Sorprende que la sustitución apenas encontró rechazo por parte de ningún diputado en Cortes, todo lo contrario, recibió un apoyo generalizado, Diario de Sesiones de las Cortes, 25/10/1837, no 350, pp. 6855-6857.

463 JIMÉNEZ GUERRERO, J., El reclutamiento militar en el siglo XIX: las quintas en Málaga (1837-1868), p. 355.

${ }^{464}$ Ley de Reemplazos de 2 de noviembre de 1837 , arts. 90 y 91.
} 
Además de instituir la posibilidad de la sustitución, la ley reguló quienes podrían ejercer como sustituto: mozos solteros o viudos sin hijos sorteables de la misma provincia menores de veinticinco años y licenciados del Ejército o milicianos provinciales, también solteros y menores de treinta años, o viudos mayores de treinta años con buena nota en su licencia y que no estuviesen sometidos a un proceso judicial $^{465}$.

Por otra parte, señalar que los sustituidos serían responsables de aquellos que ocupasen su lugar ${ }^{466} \mathrm{y}$, en el caso de que éstos desertasen antes de completarse su primer año de incorporación a filas, el sustituido tendría la obligación de incorporarse al Ejército como recluta. Además, "[...] las condiciones [de la sustitución] se acuerdan entre ambas partes, pudiendo ser gratuita o pagada" ${ }^{467}$.

\section{j) La suavización en las penas impuestas a los prófugos}

El capítulo número $\mathrm{XV}$ entiende de todo lo relacionado con la figura del prófugo, cuando se consideraba a un individuo como tal y qué penas se les había de imponer en caso de ser capturados $^{468}$. Muy claro es el art. 98 al establecer que individuos serían considerados prófugos:

"10.- los que no se presentaren personalmente en los días señalados para el llamamiento de los mozos y su declaración de

\footnotetext{
465 Ley de Reemplazos de 2 de noviembre de 1837, arts. 92, 93 y 94.

466 Ley de Reemplazos de 2 de noviembre de 1837, art. 94.

467 MARTÍNEZ RUIZ, E., "Desertores y prófugos en la primera mitad del siglo XIX", p. 627.

468 "Por lo que respecta al control y captura de los delincuentes podemos pensar que a la altura del año 1837 el Estado no contaba con suficientes elementos para reprimir un delito muy extendido y común; por eso es comprensible que tuviera que echar mano de los particulares para que lo auxiliaran en esa tarea con la promesa de una contrapartida que difícilmente se sentirían tentados a rechazar" (GONZÁLEZ ASENJO, A. J., "La resistencia al servicio militar en Galicia", p. 223).
} 
soldados, hallándose en el pueblo o distancia de diez leguas o menos, ni acrediten causa justa para no herbece presentado. 20.- Los que declarados soldados o suplentes no se presenten cuando se les cite para ser conducidos a la capital, o concurran prontamente a ella, de modo que puedan ser entregados en la caja antes de que se retire el Comisionado al efecto" ${ }^{\prime 469}$.

También serían considerados desertores los quintos que se hubiesen fugado una vez entregados en la caja provincial ${ }^{470}$.

En el supuesto de que un joven declarado soldado hubiese huido y no cumpliese con sus deberes con la nación y el Ejército, el Ayuntamiento tendría la obligación de tramitar un expediente, en un plazo máximo de cinco días, haciendo constar la ausencia del mozo, que sería entregado a familiares cercanos o, en el caso de que éstos se negasen, a algún vecino del pueblo, para que ejerciesen de defensores y justificasen la actuación del prófugo ${ }^{471}$. Una vez escuchadas sus justificaciones, el consistorio podría declarar al joven prófugo o no.

Si fuese declarado prófugo y cuando fuese detenido, el expediente pasaría a manos de la Diputación provincial ${ }^{472}$, mientras que el recluta se vería obligado a prestar el servicio militar, si fuese considerado apto, durante uno o dos años más de los prescritos en la orden, a juicio del Ayuntamiento y de la Diputación provincial en segunda instancia ${ }^{473}$. También se vería obligado a hacer frente a los gastos que generasen su búsqueda y conducción a la caja de reclutas, "[...] al resarcimiento de los daños y perjuicios que sufra el suplente $[\ldots]^{\prime \prime}$ y al pago de una multa de cinco a treinta duros a juicio de la Diputación ${ }^{44}$. Además, una vez aprehendido el prófugo, el

\footnotetext{
469 Ley de Reemplazos de 2 de noviembre de 1837, art. 98.

470 Ley de Reemplazos de 2 de noviembre de 1837, art. 101.

471 Ley de Reemplazos de 2 de noviembre de 1837, art. 102.

472 Ley de Reemplazos de 2 de noviembre de 1837, art. 105.

473 Ley de Reemplazos de 2 de noviembre de 1837, arts. 97, 106 y 107.

${ }^{474}$ Ley de Reemplazos de 2 de noviembre de 1837, arts. 103 y 111.
} 
suplente quedaría libre de su prestación ${ }^{475}$, mientras que el joven que hubiese colaborado en su captura "[quedaría] libre de la suerte que tenga en aquel reemplazo $[\ldots]^{\prime \prime 476}$.

Las penas se extienden hacia aquellos que hubiesen colaborado en la ocultación u huida del prófugo. En este caso el Ayuntamiento estaría obligado a enviar un certificado, señalando la actitud de los cómplices, a los tribunales competentes, para que éstos iniciasen la causa pertinente ${ }^{477}$.

Se observa, en comparación con normativas anteriores, una rebaja en las penas impuestas a los prófugos capturados, si bien en 1845 se endurecerán las condenas al decretarse que los prófugos apresados deberían realizar el servicio militar en Ultramar ${ }^{478}$.

La larga aplicación temporal demuestra la importancia de la ley

Finaliza la ley de 1837 con dos capítulos, XVI y XVII, que pretenden, por una parte, evitar fraudes en la aplicación del servicio de armas y, por otra, abrir la puerta a los reemplazos extraordinarios.

El primer objetivo se intenta alcanzar prohibiendo a los jóvenes mayores de dieciocho años ocupar ningún empleo ni cargo público sin acreditar que ya habían sido alistados y que habían servido como reclutas al Ejército, por si mismos o a través de un sustituto, o que hubiesen sido declarados exentos ${ }^{479}$.

Por lo que respecta a los reemplazos extraordinarios, se declaró que serían las Cortes las encargadas de convocarlos, siguiendo las

\footnotetext{
475 Ley de Reemplazos de 2 de noviembre de 1837, art. 108.

476 Ley de Reemplazos de 2 de noviembre de 1837, art. 110.

477 Ley de Reemplazos de 2 de noviembre de 1837, art. 104.

478 Real Orden de 08/07/1845, Gaceta de Madrid, núm. 3955, 13/07/1845.

479 Ley de Reemplazos de 2 de noviembre de 1837, art. 112.
} 
mismas reglas establecidas en esta ley "[...] a no ser que las Cortes, cuando los decreten, dispongan que se ejecuten de otro modo" ${ }^{480}$.

Con esta nueva norma quedó sin efecto la Ordenanza de 1800, que regulaba el alistamiento de los quintos, y sus disposiciones adicionales. Por tanto, quedó derogado todo el sistema legislativo anterior:

"Desde que se publique la presente ordenanza, quedan derogadas y sin efecto la de 27 de octubre de 1800, la instrucción adicional de 1819, y todas las demás disposiciones dadas hasta ahora sobre el modo de ejecutar los reemplazos"1481.

La nueva normativa de 1837 tuvo una aplicación de catorce años, hasta 1851. A lo largo de ese tiempo aparecieron nuevos textos legales de menor relevancia que desarrollaron, perfilaron, aclararon o mejoraron diversos aspectos de la norma original y que asimismo trataron de prevenir los fraudes.

A partir de la publicación de la Ley de 1837, fueron las Cortes quienes, anualmente, aprobaban el cupo anual que se consideraba necesario cubrir:

"La media de los cupos solicitados, a partir del final de la Guerra Carlista, se estableció en 25.000 hombres anuales, aunque muy irregularmente distribuidos: hubo años (1845 y 1847) en los que no se cumplía el trámite, y por lo tanto no se procedía al alistamiento, $y$ otros en los que se doblaba -como en 1844- o inclusive se triplicaba la media: en 1848 se pidieron 75.000 soldados, llamando a filas a los mozos desde los dieciocho a los veintidós años ${ }^{\prime 482}$.

\footnotetext{
${ }^{480}$ Ley de Reemplazos de 2 de noviembre de 1837, art. 113.

481 Ley de Reemplazos de 2 de noviembre de 1837, art. 114.

482 PUELL DE LA VILLA, F., El soldado desconocido: de la leva a la "mili" (17001912), p. 191.
} 
La solicitud de nuevos reclutas por parte del Gobierno con el objeto de terminar con la resistencia carlista, normalmente no originaba rechazo en el seno de las Cortes,

"sólo algunas voces discordantes se atrevieron a tachar de irracional una quinta de 40.000 hombres como la de 1838, cuando no había los medios para garantizar la subsistencia de los soldados ya enrolados [...], y acusaron de ineptitud y desorganización al gobierno y a los militares que dirigían un Ejército de 27.000 hombres incapaz de doblegar a 50.000 guerrilleros acorralados ${ }^{\prime 483}$.

Esta irregular distribución anual en la solicitud de mozos originó importantes desigualdades que fueron denunciadas por algunos diputados:

"Pero del modo que se dice ahora en el proyecto de que estos 25.000 hombres sirvan por ocho años, no puede establecerse esa igualdad, porque siendo un reemplazo tan considerable, resultará que el año que viene tal vez no habrá reemplazo, ni al siguiente tampoco y los jóvenes que en ese tiempo cumplan 18619 años quedarán libres, cuando los de esta edad en esto año sufren el peso de la contribución. [...] Tenemos, pues, que los 25.000 hombres pedidos no son cantidad proporcional a la base de un buen Ejército que debe ser reemplazado anualmente, y que hace también que la obligación de servir d la Nación con las armas pose desigualmente sobre los españoles, pues como es sabido que los que tienen más obligación por la ley de reemplazos son los de 18 años, menos los de 19, menos los de 20 y así sucesivamente hasta 25, los jóvenes que en los años inmediatos vayan cumpliendo la primera edad quedarán beneficiados respecto de loa que ahora la han cumplido, porque los reemplazos no serían tan considerables, y habrá de consiguiente desigualdad, que

${ }^{483}$ FEIJÓo GÓMEZ, A., Quintas y protesta social en el siglo XIX español, p. 147. 
producirá injusticia, lo cual debe evitarse, pues una ley mal concebida conduce siempre á semejantes extremos ${ }^{\prime 484}$.

La utilización de censos antiguos para realizar el repartimiento de los cupos también fue denunciada por diputados que lo consideraban injusto al no reflejar la realidad demográfica provincial:

"[...] hay que tener presente que la base que hasta aquí ha servido para el reparto de los cupos entre las provincias [el censo de 1836] es defectuosísima, pues todo el mundo sabe que los censos de población son muy inexactos, y que unas provincias quedan con ellos perjudicadas $y$ otras beneficiadas ${ }^{\prime 485}$.

A lo largo de los años cuarenta, los líderes políticos y militares del momento modificaron o ampliaron ligeramente algunos aspectos de la legislación en materia de reclutamiento:

"Espartero [...] unificó los reemplazos del Ejército y las Milicias Provinciales, y estableció la duración del servicio activo en cinco años para los soldados de Infantería, a cambio de servir tres años más en las Milicias Provinciales. Narváez se limito a mejorar la disciplina, a introducir algunas mejoras en la alimentación y el alojamiento de los soldados, e incrementar, en la medida de lo posible, el potencia del Ejército" $^{\prime 486}$.

El vacío legal que la Ley de 1837 había dejado en el campo de las exenciones por inutilidad física, al no concretar cuales y en qué grado se consideraban eximentes para el servicio militar, trató de ser

${ }^{484}$ Discurso del Sr. Fontán, Diario de Sesiones de las Cortes, 18/05/1842, no 118 , p. 3266.

${ }^{485}$ Discurso del Sr. Castilla, Diario de Sesiones de las Cortes, 20/11/1843, no 29, p. 253.

${ }^{486}$ FEIJÓo GÓMEZ, A., Quintas y protesta social en el siglo XIX español, p. 263. 
corregido cinco años después. Esta circunstancia había disparado los fraudes por parte de los Ayuntamientos:

"En el análisis de la situación creada se afirmaba que el Ejército había recibido como útiles, en las tres primeras quintas, a un elevado número de jóvenes a los que fue necesario licenciar a los pocos días, por poseer defectos físicos visibles. Lógicamente esta circunstancia se había planteado porque desde los propios Ayuntamiento se tenía consciencia de que al declarar como soldados a jóvenes inútiles, en la práctica los rebajaban del cupo asignado a la localidad. Estos jóvenes, al ser reconocidos en el Ejército, se les devolvía a la sociedad civil, no teniendo la localidad el deber de reemplazarlos por otros mozos ${ }^{\prime 487}$.

A pesar de la publicación de un reglamento en septiembre de 1842 al que se pudiesen acoger los facultativos médicos que participasen en los reconocimientos médicos de los reclutas, en la práctica éste quedó incompleto al no ofrecer una catalogación de todas las tipologías de enfermedades que eximían del servicio ${ }^{488}$.

Por lo que respecta a la cuestión de la exclusión del servicio de los súbditos extranjeros, los numerosos fraudes cometidos en este sentido obligaron a la elaboración de una real orden que aclarase los requisitos que debía cumplir un joven para ser reconocido como foráneo. Así, se estableció que "[...] por regla general debe considerarse como extranjero, y eximirse como tales del servicio militar de mar y tierra, a los extranjeros matriculados en sus respectivos consulados y los hijos de éstos, y faltos de aquel requisito siempre que sean menores de edad y vivan bajo la patria potestad"189.

\footnotetext{
487 JIMÉNEZ GUERRERO, J., El reclutamiento militar en el siglo XIX: las quintas en Málaga (1837-1868), p. 313.

488 Real Orden de 13 de Julio de 1842 sobre reglamento para la declaración de exenciones físicas en el servicio militar, no 43.

${ }^{489}$ Real Orden de 26 de Mayo de 1849, no 74, de 28/05/1849.
} 
Sería la cuestión de la sustitución, por el impacto social que generaba, la que más aclaraciones y reformas tuvo a lo largo del tiempo a través de diversas disposiciones legales aprobadas por las autoridades militares ${ }^{490}$. Así, una circular del ministerio de Gobernación fechada en mayo de 1838 estableció que, de forma obligatoria, los sustitutos presentados a cambio de otro recluta, tenían que ser mozos o viudos sin hijos entre los veinticinco y los treinta años ${ }^{491}$. También en el Parlamento la cuestión de la sustitución, e incluso la necesidad de las propias quintas, encontró furibundas críticas por parte de algunos diputados:

\section{"La contribución de sangre, Señora, as la más injusto y} opresiva al pueblo pobre, quo ve condenados sus hijos á tomar forzosamente las armas, al paso quo los ricos se libran per el dinero y que en nada contribuye para tan pesada carga el hombre opulento que no tiene hijos. Imitemos a otra Nación libre donde no se conoce este terrible tributo, y demos a los pueblos el mayor consuelo posible, y a V. M, la incomparable satisfacción de oír: en el reinado de Isabel II se acabaron las quintas. [...]. No hay razón, en efecto, para que un hombre que no tiene 4.000 reales haya de ser forzosamente soldado, y el que los tenga pueda eximirse do esta gavela. En esto no

\footnotetext{
490 "Esta compra de sustitutos o las exenciones mediante pago al Estado de una determinada cantidad tiene una repercusión gravísima en el terreno social, pues contribuiría a marcar aún más la diferencia de clases: los pobres agricultores y labradores veían impotentes como el Gobierno, a través del Ejército, les arrancaban a sus hijos para sumergirlos en unas guerras lejanas, mientras los hijos de los caciques y señoritos adinerados seguían pavoneándose por el pueblo. Allá en la lejanía, los hijos de la tierra derramaban su sangre y allí se quedaban definitivamente porque sus padres no tenían el dinero suficiente para pagar su exención. Es fácil imaginar el ambiente enrarecido que en los pueblos se iba formando a medida que iban notificando las bajas a los Ayuntamiento. El campesino veía que era muy duro el precio que tenía que pagar en esa guerra, precio que se endurecía aún más cuando veía los hijos de los caciques a quienes la guerra sólo costaba unos duros [...]. Fue ésta una distinción social, creada por obra y gracia del sentido económico del liberalismo, que se fue radicalizando [...]. Demasiado brutal para la sencillez del obrero, quien para retener a su hijo no dudaba en empeñar cuanto tuviese, hipotecar su finca o cualquier otro remedio a su alcance; el resultado era mantener y agravar la enrarecida atmósfera que en los pueblos andaluces y castellanos se respiraba." (MARTÍNEZ RUIZ, E., "Desertores y prófugos en la primera mitad del siglo XIX", p. 630).

${ }^{491}$ Real Orden de 02/05/1838, Gaceta de Madrid, núm. 1271 de 15/05/1838.
} 
encuentro igualdad, no encuentro libertad, no encuentro el régimen liberal por que tanto anhelamos; y es bajo todos aspectos injusto $y$ repugnante para mi que el hijo de un rico, solo cuando le guste la profesión haya de entrar en el servicio militar en la clase de oficial, y el infeliz, por más que le repugne, por más que sea cobarde, por más que la guerra que se haga sea contraria a sus ideas, haya de ir por fuerza a empuñar las armas "492.

Sería el diputado Orense quien encabezó las críticas progresistas a las quintas durante la década de los cuarenta, tildadas de injustas y onerosas para la Hacienda pública y para la economía del país, reclamando por ello su abolición, su sustitución por un ejército de voluntarios y una reducción en su tamaño en tiempos de paz ${ }^{493}$, aunque no sería el único en criticar el sistema:

"Perpiñá, por ejemplo, rechazó el depósito de 5000 rs. exigido a los sustitutos, ya que ello encarecía tanto la sustitución que la convertía en patrimonio de los ricos, y propuso un sistema de reclutamiento mixto a base de quintas y reenganches voluntarios, con una contribución sobre los que hubiesen de entrar en quintas, quienes la pagarían con gusto con tal de librarse del servicio, y que, al mismo tiempo, serviría para hacer frente a los gastos ocasionados por los enganchados voluntarios ${ }^{\prime 494}$.

\footnotetext{
492 Discurso del Sr. Orense, Diario de Sesiones de las Cortes, 06/11/1844, no 24, pp. 293 y 294.

${ }^{493}$ La opinión moderada al respecto de las quintas quedó bien clara en palabras del Diputado Luján: "Yo no llamo a la quinta una contribución onerosa, pesada, ominosa; [...] yo llamo a la quinta la obligación sagrada que tienen todos los ciudadanos de acudir a la defensa de la Patria cuando la ley les llama; y bajo este punto de vista, creo que la quinta es una de las grandes conquistas que han hecho los pueblos modernos en la constitución de sus libertades" (Discurso del Sr. Luján, Diario de Sesiones de las Cortes, 24/01/1849, n 19, p. 339).

494 FEIJÓO GÓMEZ, A., Quintas y protesta social en el siglo XIX español, p. 148; Discurso del Sr. Perpiñá, Diario de Sesiones de las Cortes, 06/11/1844, no 24, pp. 298 y 299; Discurso del Sr. Marqués de Albaida, Diario de Sesiones de las Cortes, 22/12/1847, no 30, pp. 554-556 y 558 y 559; Discurso del Sr. Mendizábal, Diario de Sesiones de las Cortes, 22/12/1847, n० 30, pp. 564-566.
} 
Pero sería un real decreto fechado en abril de 1844, publicado siendo Presidente del Gobierno Narváez, el que se apruebe con el objeto de acabar con la multitud de actuaciones fraudulentas que se habían observado y evitar la entrada de reclutas indeseables en el seno de la institución armada ${ }^{495}$. En él, se señala que la presentación de un sustituto se debía realizar en la sede de la Diputación provincial, con toda la documentación necesaria, por parte del propio sustituto o de sus padres o tutores debidamente acreditados. Para que este documento tuviese validez, el sustituido debía presentar en un banco público, como fianza especial, una suma de 5.000 reales. Además, la documentación que justificase la aptitud legal de los sustitutos debía ser enviada para su examen, por parte de la Diputación provincial, al juez de primera instancia del partido que correspondiese a la localidad de origen del sustituto ${ }^{496}$.

Para asegurar que el sustituto cumplía con todas las condiciones para su ingreso en el Ejército, se le sometería en la Diputación provincial a un reconocimiento riguroso en el que estarían presentes el comandante general de la provincia y el comandante de la caja. Este examen lo realizarían dos profesores del Cuerpo de Sanidad Militar, que debían certificar el buen estado de salud del sustituto "[...] con expresión circunstanciada de su estado de sanidad en general, y en particular del de los órganos, miembros o parte de aquellos, cuyas faltas o lesiones causan inutilidad para el servicio, 0

\footnotetext{
495 "Seis años de una dolorosa experiencia han hecho conocer en toda su extensión y deformidad las consecuencias de las malas artes y criminales manejos con que el interés individual y la inmoralidad de codiciosos especuladores han abusado de la Ley que permite la sustitución en el servicio militar, produciendo la desgracia de muchas familias y llevando a las filas del Ejército a hombres inútiles y sin las cualidades que para el servicio militar se requieren, a pesar de los documentos con que justificaban tenerlas, cuya falsedad ha sido posteriormente reconocida. El Gobierno de S.M. considera que la sustitución es una necesidad social en el estado presente de las costumbres, de la civilización y de la cultura de los pueblos, pero no es posible dejarla abandonada como hasta ahora a la sencillez de la Ley vigente, ni permitir que continúe siendo un manantial de escándalos monstruosos, y de gravísimos males no menos perniciosos al Ejército que a las familias interesadas en ello" (Real Decreto de 25/04/1844, Gaceta de Madrid, núm. 3512, 26/03/1844).

${ }^{496}$ Real Decreto de 25/04/1844, Gaceta de Madrid, núm. 3512, 26/04/1844, arts. 1-3.
} 
hacen dudosa dicha aptitud, en cuyo último caso no se admitirá el sustituto" ${ }^{497}$. En el caso de no haber acuerdo entre ambos, sería un tercer médico del mismo cuerpo el encargado de tomar la decisión final $^{498}$. Se declaró además a estos facultativos responsables de sus dictámenes en el caso de que el sustituto fuese posteriormente declarado inútil para el servicio, en cuyo caso podían ser suspendidos de empleo y sueldo, además de las penas y multas que les pudiese imponer la Justicia. ${ }^{499}$

Por otra parte, ningún sustituto sería admitido en la caja o cuerpo donde tuviese que servir si antes no se había depositado en la tesorería de la Diputación provincial el precio de la sustitución, impuesto en 5.000 reales. Por primera vez en la legislación se pone precio a la sustitución. El sustituto recibiría esta cantidad una vez que hubiese finalizado el tiempo de servicio, circunstancia que tenía que demostrar "[...] provisto de los documentos oportunos que le expida el inspector general de su arma para legitimar la identidad de su persona y su derecho a percibir aquella, sin cuyos requisitos no le será entregada"500. Por supuesto, aquel sustituto que desertase del servicio perdería el derecho a percibir el precio de su sustitución ${ }^{501}$. En el supuesto de que falleciese antes de cumplir su servicio completo, su dinero correspondiente pasaría a manos de quien el sustituto hubiese indicado en su testamento ${ }^{502}$.

En el caso de que el sustituto desertase durante el primer año de la prestación y el sustituido tuviese que ocupar su plaza en el

\footnotetext{
497 Real Decreto de 25/04/1844, Gaceta de Madrid, núm. 3512, 26/04/1844, art. 5. ${ }^{498}$ Real Decreto de 25/04/1844, Gaceta de Madrid, núm. 3512, 26/04/1844, art. 7. ${ }^{499}$ Real Decreto de 25/04/1844, Gaceta de Madrid, núm. 3512, 26/04/1844, arts. 7 y 8.

${ }^{500}$ Real Decreto de 25/04/1844, Gaceta de Madrid, núm. 3512, 26/04/1844, arts. 9 y 10.

${ }^{501}$ Real Decreto de 25/04/1844, Gaceta de Madrid, núm. 3512, 26/04/1844, art. 13.

${ }^{502}$ Real Decreto de 25/04/1844, Gaceta de Madrid, núm. 3512, 26/04/1844, art. 17.
} 
Ejército, el depósito entregado sería devuelto ${ }^{503}$. Sin embargo, quedarían exentos de ocupar su plaza aunque hubiese huido su sustituto las siguientes excepciones ${ }^{504}$ :

"10. - A los sustituidos que sean casados.

20.- A los hijos únicos de padres que no tengan otro varón mayor de 14 años, o que si lo tuviesen sea ordenado in sacris.

30. - Al hijo único de viuda y al nieto de abuelo o abuela sin otros hijos ni nietos mayores de aquella edad.

40.- Al huérfano único sin más hermanos mayores de la misma.

50.- Al que tenga otro hermano único sirviendo en el Ejército o en la marina militar, aunque sea en clase de oficial soltero por llamamiento o convocatoria legal, o por empeño voluntario que hubiese contraído un año antes del de aquella quinta.

60.- A los matriculados en alguna de las Universidades o colegios de medicina, cirugía o farmacia y demás establecimientos literarios de pública enseñanza, incorporados a cualquiera de las del Reino, que acreditaren en debida forma haber estudiado y ganado al menos tres cursos escolásticos, con notas que justifiquen su activa y eficaz aplicación y ventajosas disposiciones para el estudio de las ciencias.

70. - A los alumnos de la Academia de las nobles artes de San Fernando que cuenten los mismos años de estudio en ellas con igual aplicación, ventajoso concepto y resultados".

Llama este decreto a la presentación de voluntarios para cubrir la plaza por el tiempo que les faltaba de cumplir a los sustitutos que hubiesen desertado. Para incitar al voluntariado a estos jóvenes se les ofrecía una gratificación de 700 reales anuales ${ }^{505}$. Este fondo se

503 Real Decreto de 25/04/1844, Gaceta de Madrid, núm. 3512, 26/04/1844, art. 11.

504 Real Decreto de 25/04/1844, Gaceta de Madrid, núm. 3512, 26/04/1844, art. 12.

${ }^{505}$ Real Decreto de 25/04/1844, Gaceta de Madrid, núm. 3512, 26/04/1844, arts. 14 y 15. 
obtendría "[...] del depósito hecho a favor del sustituto desertor a quien el voluntario hubiese reemplazado"506. El sobrante de estos depósitos quedaría en manos del ministerio de Guerra, que los podría emplear en la adquisición de nuevos sustitutos ${ }^{507}$.

En lo que se refiere al Ejército de Ultramar, en 1843 se dispuso que esta sección de la institución armada, sin duda la de mayores dificultades para nutrir de efectivos,

"[...] debía ser reemplazado preferentemente con voluntarios enganchados por ochos años, y aceptó como voluntarios a quintos que así lo deseasen, soldados ya alistados en diferentes Armas y Cuerpos, y españoles de dieciocho a treinta años, solteros o viudos sin hijos, con cinco pies de altura mínima, y que no fuesen viciosos, insalubres, e insubordinados; pero el reemplazo se completaría con destinados forzosos de entre los condenados por prófugos y desertores. Por primera vez se fijó edad, talla y condiciones particulares, además de una prima de 8-11 duros, para el reemplazo ultramarino"1508.

Otro real decreto que vino a desarrollar la Ley de 1837 es aquel que hacía referencia a la actuación de las Diputaciones provinciales, muchas de las cuales habían mostrado una actitud considerada onerosa para el Estado ${ }^{509}$. Para limitar sus funciones, se declaró que

\footnotetext{
${ }^{506}$ Real Decreto de 25/04/1844, Gaceta de Madrid, núm. 3512, 26/04/1844, art. 15.

507 Real Decreto de 25/04/1844, Gaceta de Madrid, núm. 3512, 26/04/1844, art. 16.

508 FEIJÓo GÓMEZ, A., Quintas y protesta social en el siglo XIX español, p. 229; Real Decreto de 5 de Junio de 1843.

509 "Entre los gravámenes que pesan sobre los pueblos en la contribución de sangre, la que más inmediatamente afecta los intereses y prosperidad de las familias, y las que por lo mismo necesita de la más constante inspección y vigilancia del Gobierno, a fin de que el servicio se haga con regularidad, y se eviten los perjuicios a que la mala inteligencia de la Ley de Reemplazos puede dar margen.

En desacuerdo sin embargo con este principio algunas Diputaciones Provinciales se han arrogado la facultad de resolver definitivamente acerca de las reclamaciones en materia de quintas, fundándose para ello en los artículos 21 y 85 de la ordenanza vigente, cuya aplicación han considerado aquellos cuerpos como reservada exclusivamente a su conocimiento y decisión. Con este motivo son muchos los
} 
las decisiones de las Diputaciones fuesen ejecutivas tal y como indicaba la ley, "[lo que] no excluye la facultad que corresponde al Gobierno de admitir los recursos extraordinarios que le dirijan las partes interesadas contra las providencias de aquellas Corporaciones en materia de reemplazos" ${ }^{15}$. Además, reservó para el Gobierno la revisión y anulación de los acuerdos tomados por las Diputaciones que atentasen contra la ley ${ }^{511}$.

También se tuvieron que aclarar a través de normas posteriores a la de 1837 distintas cuestiones relacionadas con la conducción del recluta a la caja de quintos: el comandante de la caja sólo debía socorrerlos y prestarlos ayuda hasta el día que saliesen de la caja con destino a su regimiento, y no posteriormente. A partir de este momento, "[...] corresponde la asistencia de los quintos a las compañías de depósito o comisionados encargados de su saca o conducción, y de quienes han de recibir su prestación diariamente por cuenta de sus respectivos cuerpos" ${ }^{\prime 12}$.

Otra real orden prohibió a los capitanes generales conceder licencias, ni siquiera de un día, a los quintos de las cajas, con el objeto de evitar deserciones ${ }^{513}$, mientras que la lucha contra la figura del prófugo se acrecentó a través del endurecimiento de las penas para los huidos que hubiesen sido capturados ${ }^{514}$. También se intentó

\footnotetext{
agravios que, por ligereza en los acuerdos o equivocada interpretación de la Ley, han sufrido los particulares interesados en sus efectos, y graves al propio tiempo los perjuicios que ha experimentado el servicio público" (Real Decreto de 25/04/1844, Gaceta de Madrid, núm. 3512, 26/04/1844).

${ }^{510}$ Real Decreto de 25/04/1844, Gaceta de Madrid, núm. 3512, 26/04/1844, art. 1.

${ }^{511}$ Real Decreto de 25/04/1844, Gaceta de Madrid, núm. 3512, 26/04/1844, art. 2.

${ }^{512}$ Real Orden de 27/10/1843, Gaceta de Madrid, núm. 3331, 31/10/1843.

${ }^{513}$ Real Orden de 17/06/1844, Gaceta de Madrid, núm. 3568, 21/06/1844.

514 "Las diversas Reales órdenes que desde la publicación de la Ordenanza se han expedido imponiendo penas a los desertores sin haber conseguido hacer desaparecer este delito que destruye y desmoraliza los Ejércitos, han demostrado la ineficacia de nuestra legislación militar en esta parte; y deseando la Reina (Q.D.G.) que se consolide cada vez más la disciplina en las filas del Ejército, destruyendo los medios que puedan barrenarla, se ha dignado resolver que la pena señalada por la Real Orden de 8 de Enero de 1815 a los desertores de primera sin circunstancia agravante sea en lo sucesivo la de servir en uno de los Cuerpos de Ultramar el tiempo de su empeño, más el que el individuo hubiese estado desertando por vía
} 
aligerar el proceso de reclamaciones contra la decisión de la autoridad provincial. Cuando un mozo quisiese acudir a una instancia superior, sería el jefe político de la provincia (actual delegado del Gobierno), el encargado de instruir un expediente, donde incluyese toda la documentación necesaria para su resolución, que remitiría al ministerio de la Guerra, quien tomaría una decisión final ${ }^{515}$.

A lo largo de estos años también se concedió alguna exención a nuevos grupos, en este caso de religiosos, si bien muy minoritarios ${ }^{516}$.

Una de las cuestiones que recibió un mayor interés por parte de las autoridades militares fue la de la deserción. Los prófugos se incrementaban en el momento de concentrarse para ser conducidos a la caja de reclutas y, cuando una huida era verificada, las fuerzas de seguridad del Estado iniciaban la búsqueda del desertor para incorporarlo a su destino. Una de las primeras medidas tomadas contra la figura del prófugo fue el endurecimiento de las penas para los huidos ${ }^{517}$.

Para evitar la persecución y el apresamiento por parte de la Guardia Civil, una de las opciones que "[...] utilizaban los reclutas para verse libres de semejante acusación, proscripción y persecución consiguientes era marcharse al extranjero o a las provincias de

de recargo, haciéndose extensiva esta disposición a los prófugos de las quintas." (Real Orden de 08/07/1845, Gaceta de Madrid, núm. 3955, 13/07/1845).

${ }^{515}$ Real Orden de 04/03/1848, Gaceta de Madrid, núm. 4921, 05/03/1848.

516 "Se declaran exentos del servicio militar los novicios y profesos de los Colegios de misioneros de Filipinas establecidos en Valladolid, Ocaña y Monteagudo" (Real Orden de 18/03/1848, Gaceta de Madrid, núm. 4936, 20/03/1848).

517 "Las diversas Reales órdenes que desde la publicación de la Ordenanza se han expedido imponiendo penas a los desertores sin haber conseguido hacer desaparecer este delito que destruye y desmoraliza los Ejércitos, han demostrado la ineficacia de nuestra legislación militar en esta parte; y deseando la Reina (Q.D.G.) que se consolide cada vez más la disciplina en las filas del Ejército, destruyendo los medios que puedan barrenarla, se ha dignado resolver que la pena señalada por la Real Orden de 8 de Enero de 1815 a los desertores de primera sin circunstancia agravante sea en lo sucesivo la de servir en uno de los Cuerpos de Ultramar el tiempo de su empeño, más el que el individuo hubiese estado desertando por vía de recargo, haciéndose extensiva esta disposición a los prófugos de las quintas" (Real Orden de 08/07/1845, Gaceta de Madrid, núm. 3955, 13/07/1845). 
Ultramar, justificando su ausencia al no presentarse de esta manera"1818. Este recurso, cada vez más utilizado, justificó la publicación de un Decreto Real en 1846 que prohibía la expedición de pasaportes para ningún hombre entre los dieciséis y veinticinco años de edad, a no ser que demostrasen su exención del servicio o el resultado del sorteo correspondiente a su quinta ${ }^{519}$.

La posibilidad de la redención económica, recogida por la Ley de 1837 pero sin fijar su montante, se introdujo con fuerza en el debate en Cortes al ser solicitada su aprobación por algunos diputados desde 1846. Como argumento fundamental para su defensa esgrimieron la inmoralidad de aquellos que traficaban con hombres, es decir, de la sustitución, y la necesidad de que un hombre se pudiese redimir "[...] por el pago de una cantidad dada, sea la que quiera, [...], para que el gobierno con ella reenganche los soldados cumplidos, la destine al material de guerra o la emplee en lo que crea más conveniente en ese ramo"520. Es decir, aún teniendo en cuenta la impopularidad que esta medida pudiese tener, las necesidades económicas del Estado se situaban por encima del rechazo popular. Sin embargo, a pesar del apoyo del partido Moderado hacia la redención en metálico ${ }^{521}$, por el momento la misma no fue aprobada.

518 MARTÍNEZ RUIZ, E., "Desertores y prófugos en la primera mitad del siglo XIX", p. 629.

519 Real Decreto de 26 de febrero de 1846, Gaceta de Madrid, n. 34, de $1 / 03 / 1846$.

520 Discurso del Sr. Martín, Diario de Sesiones de las Cortes, 24/01/1849, no 19, pp. 324-325.

521 "Si hay uno que por medio de su fortuna puede librar á su hijo del servicio, y hay otro que es pobre, que no puede, esto sucede en todas las condiciones de la vida, porque el que tiene dinero no se moja, come mejor, se divierte más, pasea en coche y disfruta de todas las ventajas que proporciona el dinero. [...] Aunque la ley sea igual para todos, cada uno tiene que conformarse con la condición social que le tocó por su fortuna ó por su nacimiento" (Discurso del Sr. Duque de Valencia, Presidente del Gobierno, Diario de Sesiones de las Cortes, 24/01/1849, no 19, p 346). 



\section{4.- Un proyecto modernizador que se convirtió en referente para los años posteriores: El Proyecto de ley de 1850}

El 14 de noviembre de 1849 se presentó ante las Cortes un nuevo proyecto de ley de reemplazos con el objeto de modernizar las operaciones de reclutamiento; si bien el proyecto, aprobado por el Senado el 29 de enero de 1850, no se convirtió en realidad hasta el año 1856 por las dificultades y vaivenes políticos del momento, sí que lo hicieron, a través de reales decretos, algunas de las reformas en él diseñadas. Esta circunstancia, junto a la convocatoria de quintas en función de este proyecto de Ley hasta $1856^{522}$, justifica la necesidad de su análisis.

Este proyecto trató de normalizar y reglar todo lo relacionado con las distintas fases del reemplazo, en especial lo referido a las exenciones, "[...] remitiendo las consideraciones generales (afectados, duración, organización del Ejército) a la Constitución $[\ldots]^{\prime \prime 523}$. Se convirtió, junto con las leyes de 1856 y 1885 , en el referente más claro a seguir para el sistema de quintas durante la segunda mitad del siglo XIX.

\footnotetext{
522 "Pero el Gobierno, que conoce que ha de pasar algún tiempo antes que el proyecto de ley de reemplazos, pendiente en el Congreso, reciba la sanción de la Corona; persuadido como lo está de que tal como ha salido del Senado lleva grandes ventajas a la ley vigente, la cual por otra parte se halla desvirtuada hasta cierto punto; y convencido de que es llegada la época de preparar la transición entre lo que hoy existe y el nuevo sistema que ha de ponerse en ejecución, cree conveniente bajo todos conceptos, que por esta vez se ejecuten las operaciones del reemplazo con sujeción al proyecto que el Senado tiene aprobado, sin que por ello sea visto prejuzgar las cuestiones, cuya resolución definitiva introduzca acaso algunas alteraciones en la ley" (Proyecto de ley, presentado por el Sr. ministro de la Gobernación, llamando al servicio de las armas 35.000 hombres correspondientes al alistamiento de 1851, Gaceta Núm. 54, de 21/02/1851, p. 1053). Ver también Real Orden de 21 de Junio de 1851 para el reemplazo de 25.000 hombres, con arreglo a lo dispuesto en el proyecto de ley aprobado por el Senado el 29 de enero de 1850, Gaceta Núm. 6187 de 22/06/1851.

${ }^{523}$ FEIJÓO GÓMEZ, A., Quintas y protesta social en el siglo XIX español, p. 215.
} 


\begin{abstract}
Nuestro análisis se verá completado acudiendo a dos publicaciones periódicas de gran interés, como son El Clamor Público ${ }^{524}$ y La Época ${ }^{525}$.
\end{abstract}

\title{
La influencia moderada en un contexto político de predominio del Ejército
}

Se enmarca el proyecto de ley objeto de estudio en la Década Moderada (1844-54), cuando la reina Isabel II concedió la primacía en el poder al partido Moderado y a la omnipresente figura de su líder, el general Narváez, quedando marginados los progresistas.

El 4 de mayo de 1844 asumía el poder el general Ramón María Narváez ${ }^{526}$, que, exiliado en París durante los años de gobierno del

\footnotetext{
524 "Periódico progresista fundado en 1844 por Fernando Corradi, era de carácter agresivo y polemista, muy enfrentado a los gobiernos moderados. Cuando el progresismo alcanzó el poder, en 1854, decayó la influencia de este periódico, que pasó a órgano de la Unión Liberal, y su lugar lo ocuparía Las Novedades.

En contraste con la prensa posterior de finales de siglo, los periódicos de mediada la centuria son poco vistosos y sacan escaso juego de la tipografía. Sus noticias son fundamentalmente políticas, buscando la "formación" frente a la "información", no hay demasiados anuncios y el folletín ocupa un lugar destacado en la parte inferior" (http://www.bne.es/es/Catalogos/HemerotecaDigital).

525 "Diario vespertino fundado por Diego Coello y Quesada (182-1897) el uno de abril de 1849, a principios del siglo veinte será ya el decano de la prensa diaria política madrileña, extinguiéndose su vida a escasos días del golpe de Estado de julio de 1936. Será el diario por antonomasia de la monarquía, que se convertirá en prototipo de periódico aristocrático y conservador. Nace, desde una posición moderada, como reacción al semiabsolutismo del ministerio de Juan Bravo Murillo. Evoluciona a una oposición centrista y saluda alborozado el triunfo de 1854 del general Francisco Serrano, pero se mostrará contrario al bienio esparterista. Desde 1856 será el órgano de Unión Liberal, pero se separará de la misma a causa de los acontecimientos de la noche de San Gil, en abril de 1865, para apoyar a los gobiernos del general Ramón María Narváez y de Luis González Bravo, aunque después combatirá a este. Caracterizado por su fidelidad al trono isabelino, aceptará la Gloriosa en 1868 y tras algunas dudas y el fracaso de la candidatura de la nueva monarquía de Antonio María de Orleans, duque de Montpensier, Antonio Cánovas del Castillo lo ganará para la causa alfonsina, convirtiéndose en el estandarte periodístico de la Restauración durante el Sexenio Democrático" (http://www.bne.es/es/Catalogos/HemerotecaDigital).

${ }^{526}$ PÉREZ ALONSO, J. Ramón María Narváez: biografía de un hombre de estado. El desmontaje de la falsa leyenda del "Espadón de Loja", Historia constitucional: Revista Electrónica de Historia Constitucional, 14 (2013), Madrid; PABÓN Y SUÁREZ
} 
general Baldomero Espartero, había de constituirse en incontestable dominador de la política española en los años posteriores, y fue bajo su dominio cuando se elaboró la Constitución de 1845, que reservaba a la Corona un importante papel en la elaboración de las leyes, de tal forma que el poder legislativo quedaba constituido como una potestad compartida por la reina y por las Cortes -de las cuales, el Senado era elegido íntegramente por la Corona, sin restricción alguna sobre el número de miembros-, algo que consolidó aún más el poder del partido Moderado, basado en el apoyo entonces incondicional de la joven Isabel II a la formación.

Estamos en unos años donde el predominio del Ejército y sus grandes figuras en la vida política fue abrumador, y los cambios en el signo del Gobierno venían dados por los pronunciamientos militares $^{527}$. Este recurso al Ejército por parte de los moderados como herramienta represiva, y los recursos económicos que absorbía el mantenimiento de una milicia tan numerosa, fueron criticadas por el diario progresista El Clamor Público:

"Hé aquí el secreto de su eficacia. La situación alarmante de la Hacienda, espejo en que se reflejan siempre los extravíos de los gobiernos reaccionarios, ha venido á demostrar prácticamente que no puede abusarse de la fuerza á espensas (sic) de los derechos y garantías individuales, sin causar un déficit escandaloso entre los gastos y los ingresos, sin esponerse (sic) á la bancarota (sic). Los poderes fundados en la compresión y en la desconfianza, necesitan para sostenerse ejércitos numerosos, grandes centros administrativos, legiones de empleados, falanges de esbirros $y$ otros

DE URBINA, J., SECO SERRANO, C, Narváez y su época, Madrid, Espasa Calpe, 1983.

527 CEPEDA GÓMEZ, J., Los pronunciamientos en la España del siglo XIX, Madrid, Arco Libros, 1999; CEPEDA GÓMEZ, J., El ejército español en la política española; HEADRICK, D. R., Ejército y política en España (1866-1898); FERNÁNDEZ BASTARRECHE, F., Los espadones románticos, Madrid, Síntesis, 2007. 
medios costosos que absorben las rentas públicas, esquilman al contribuyente, esterilizan el trabajo, y ahogan la producción"1528.

De ahí que el citado periódico apoyase una drástica reducción del Ejército:

"Otros quizás replicarán que si este año se paga empeñándose en 709 millones el que viene no podrá salirse del conflicto y la ruina será segura. Esto es, desgraciadamente, muy cierto. La insolvencia nos amenaza lo mismo este año que el venidero, y para salir del apuro solo hay un camino: variar radicalmente de sistema político $y$ económico: cimentar el orden en la libertad: suprimir muchos soldados, muchas oficinas, muchos gastos inútiles que hoy hace necesarios la política de compresión: aumentar los ingresos quitando trabas al comercio y aboliendo contribuciones que destruyen la riqueza y esterilizan el trabajo" ${ }^{\prime 529}$.

Sería el duque de Valencia el principal valedor de una serie de reformas $^{530}$ para modernizar la institución castrense y los propios métodos de reclutamiento:

"A comienzos de 1847 [...], el Duque de Valencia ordenó a los consejos Provinciales y a los capitanes generales $y$ directores generales de las Armas, que evaluasen la normativa existente sobre el reclutamiento militar y que le remitiesen sendos informes sobre los aspectos concretos de la misma que convenía enmendar o suprimir,

${ }^{528}$ El Clamor Público, 12/12/1849, no 1966, p. 1.

${ }^{529}$ El Clamor Público, 12/12/1849, no 1966, p. 2.

530 La proximidad en la aprobación de una ley de reclutamiento que primase el voluntariado fue recogida por la prensa progresista: "-LEY DE REEMPLAZO-. Hablase de una reforma en la ley de reemplazos que piensan proponer algunos generales diputados y que consiste en abrir anualmente un alistamiento voluntario, ofreciendo ciertas ventajas á los que así ingresen en el ejército, y disminuyendo en proporción las quintas" (El Clamor Público, 18/12/1849, nº 1972, p. 3). 
alentándoles también a que le presentaran cualquier "adición" que la pudiera mejorar" ${ }^{\prime 531}$.

Siguiendo estos informes, el ministro de la Gobernación ${ }^{532}$, Luis José Sartorius y Tapia, Conde de San Luis ${ }^{533}$, elevó a las Cortes, el 12 de noviembre de 1849, este proyecto de ley para que fuese debatido por el Senado.

Sin embargo, la compleja situación política interfirió en el proceso de aprobación. La dimisión de Narváez - que volvería al gobierno poco después para sofocar los efectos hispánicos de la oleada revolucionaria europea de 1848- y la disolución de las Cortes impidieron la aprobación de la norma, por lo que "[...] Bravo Murillo $^{534}$ optó por dar al problema una solución de urgencia, al convertir el trámite constitucional para la aprobación de la quinta de 1851 en una disposición articulada con rango de ley $[\ldots]^{\prime \prime 535}$.

El proyecto de ley de 1850 tiene como base legislativa la Constitución de 1845, ley fundamental impulsada por Narváez como Presidente del Gobierno y expresión constitucional del doctrinarismo español. Según este texto, la figura del Rey es sagrada e inviolable, y "[...] su autoridad se extiende a todo cuanto conduce a la conservación del orden público en lo interior, y a la seguridad del Estado en lo exterior, conforme a la Constitución y a las leyes ${ }^{\prime 536}$. El

531 PUELL DE LA VILLA, F., El soldado desconocido: de la leva a la "mili" (17001912), p. 191.

532 Se observa la importancia y las múltiples competencias que el ministerio de la Gobernación tiene en cuestiones militares, sobre todo en las relacionadas con el reclutamiento, quedando al margen el ministerio de la Guerra en el planteamiento de una nueva ley.

533 Nacido en la Isla de León, hoy de San Fernando, en marzo de 1820, ejerció como abogado, periodista, mecenas y político, ocupando un sinfín de altos cargos: embajador, diputado, Presidente del Congreso, Ministro y Presidente del Gobierno (Diccionario Biográfico Español, edición digital, RAH, http://www.rah.es/cdeb.htm).

534 Sobre este político moderado, ver PRO RUIZ, J., Bravo Murillo: política de orden en la España liberal, Madrid, Síntesis, 2006.

535 PUELL DE LA VILLA, F., El soldado desconocido: de la leva a la "mili" (17001912), p. 191.

${ }^{536}$ Constitución de la Monarquía Española de 1845, título VI, art. 43. 
monarca es además el encargado de declarar la guerra y la paz ${ }^{537}$, y "[de] disponer de la fuerza armada, distribuyéndola como más convenga" ${ }^{138}$. El artículo 79 de la Constitución recoge un apartado de gran interés para nuestro estudio, ya que señala, al igual que hacía la Constitución de Cádiz, que serían las Cortes, a propuesta del Rey, las encargadas de fijar, anualmente, la fuerza militar necesaria para el país $^{539}$. Son amplios los poderes en materia militar que se conceden por tanto a la Corona, pero nada se especifica respecto al reclutamiento, que se dejó al criterio gubernamental ${ }^{540}$.

La búsqueda de la unificación legislativa no exenta de polémica en el desarrollo de la norma

El proyecto de ley de reemplazo del Ejército aprobado por el Senado el 29 de enero de 1850 está constituido por 17 capítulos, una disposición final, otra transitoria con un total de 153 artículos $^{541}$. Se trata de un texto amplio, minucioso y exhaustivo, presentado por el ministerio de la Gobernación ${ }^{542}$, que generó una gran polémica durante su debate en el Senado ${ }^{543}$. Además, tal y como sucede con

\footnotetext{
${ }^{537}$ Constitución de la Monarquía Española de 1845, título VI, art. 45, 40.

538 Constitución de la Monarquía Española de 1845, título VI, art. 45, 50.

539 Constitución de la Monarquía Española de 1845, título XIII, art. 79.

540 FEIJÓo GÓMEZ, A., Quintas y protesta social en el siglo XIX español, p. 210.

541 Proyecto de Ley presentado a las Cortes por el Sr. Ministro de la Gobernación del Reino en la sesión del Senado del día 14 de noviembre de 1849, Gaceta núm. 5588 de 17/11/1849. En adelante Proyecto de Ley, Gaceta núm. 5588 de $17 / 11 / 1849$.

542 El carácter mixto de la ley fue remarcado por el senador Marqués de Valgornera: "Se ha dicho, señores, que esta ley es civil, administrativa, que pertenece al Ministerio de la Gobernación. Esto es exacto; pero aunque la ley haya sido presentada por ese Ministerio, es una ley esencialmente mixta, es una ley que interesa al contribuyente que presta su sangre, y al Ejército que recibe el beneficio: es una ley que por los medios es administrativa, y por los fines es militar, esencialmente militar: de ella depende la buena composición del Ejército, su subordinación y su disciplina" (Discurso del Sr. Marqués de Valgornera, Diario de Sesiones del Senado, no 31, 28/01/1850, p. 404).

543 Los tres puntos de mayor debate en el seno del Senado fueron la celebración de una quinta anual de 25.000 hombres, las edades de los mozos que debían ingresar en el Ejército y la cuestión de la sustitución-redención.
} 
legislaciones previas, declaró nulas todas las disposiciones anteriores en materia de reclutamiento y, específicamente, la Ley de $1837^{544}$. El fin de la norma de 1837 fue defendida desde la prensa monárquica por amparar numerosos errores e injusticias en el proceso, alabando la actitud del Gobierno al querer cambiarla:

"Pero si esto no es conveniente hoy, necesario y aún urgente era revisar la ordenanza vigente de reemplazos á fin de hacer desaparecer las desigualdades, los errores y la injusticia en sus disposiciones que la experiencia ha demostrado.

Publicada esa ordenanza en 1837, mas de doscientas leyes, reales decretos y órdenes posteriores aumentan, explican y aun contradicen su contenido, en términos de hacer la legislación de quintas mas extensa y complicada que la legislación civil ó criminal de otras naciones.

Esta confusión, las parcialidades de los pueblos, y la precipitación con que los consejos provinciales examinan los expedientes de quintas formados por los Ayuntamiento, son causa hay de muchos errores y de no pocas injusticias en la declaración de soldados. Las Diputaciones provinciales, reunidas apresuradamente para repartir entre los pueblos el cupo de la provincia sin un censo exacto de la población, y sin otros datos ó antecedentes confundidos en los archivos ó en las oficinas de los gobiernos políticos, suelen hacer aun este reparto por el censo de muchos años antes, no teniendo para nada en cuenta la alteración de almas ocurrida desde entonces. La contribución de sangre, ya de por si harto gravosa, venia á hacerse asi insoportable, y el anuncio de ella estremecía a los pueblos y llevaba la consternación á las familias.

Urgía, como hemos dicho, revisar esa legislación, y eso es lo que ha hecho el gobierno con una solicitud y con un aplomo que le honra $[\ldots]^{1545}$.

544 Proyecto de Ley presentado a las Cortes por el Sr. Ministro de la Gobernación del Reino en la sesión del Senado del día 14 de noviembre de 1849, Gaceta núm. 5590 de 19/11/1849, art. 149. En adelante Proyecto de Ley, Gaceta núm. 5590 de $19 / 11 / 1849$.

${ }^{545}$ La Época, 16/11/1849, no 206, p. 2. 
Se inició el texto legislativo con un extenso preámbulo justificativo, ya que las disposiciones anteriores habían conducido a una falta de homogeneidad y precisión que habían complicado y oscurecido en exceso todo el proceso de reclutamiento y habían incrementado las dudas y consultas de las distintas autoridades. Se achaca, por tanto, a la confusión generada por las normas anteriores la necesidad de una nueva legislación que simplifique, ordene y precise las operaciones de reclutamiento. Reproducimos tal justificación pese a su amplitud por su notable interés:

"Frecuentemente aplicada vino la experiencia en auxilio de las teorías, y de ensayo en ensayo, cuando fueron ya bien conocidos sus efectos, a la Ordenanza de 1800 y la Instrucción de 1819 sucedió la Ley de reemplazos de 1837, en la actualidad vigente. [...].

Más justa y previsora [la ley de 1837], organizando oportunamente el servicio de las armas al poner coto a una parte de las anteriores arbitrariedades, dictó también reglas eficaces para facilitar todas las operaciones del reemplazo y conducirle a su término sin dilaciones inútiles, sin el desorden y confusión que lastimaban derechos y producir justas e interminables reclamaciones. Metódica en las materias, generalmente atinada en los preceptos, desacuerdo sería sin duda sustituirla con otra distinta en los métodos, en las aplicaciones, en el espíritu y las tendencias; pero desacuerdo sería también conservarla tal cual existe cuando la experiencia constante de doce años ha venido a demostrar, no ya las mejoras de que es susceptible, sino la necesidad de modificar algunas de sus disposiciones.

Precisamente porque éstas se han apreciado en su justo valor, porque la observación y la experiencia pusieron de manifiesto cuanto hay en ellas de inexplicable o inconveniente, porque no todas pueden admitirse sin graves dificultades, se dictaron sucesivamente las numerosas aclaraciones, que multiplicando los preceptos, si no hicieron más oscura y difícil la legislación de reemplazos, la presenta por lo menos como formada de fragmentos dispersos y sin aquella unidad y precisión, sin aquel enlace en las partes componentes, sin la homogeneidad y sencillez que reclaman su misma importancia y los 
conflictos de las autoridades y corporaciones encargadas de aplicarla. Su reforma es ya una consecuencia forzosa de sus vicisitudes y variantes; de las multiplicadas aclaraciones que produjo sucesivamente; de la dificultad de consultarlas aisladas y perdidas en la voluminosa colección de decretos expedidos hasta el día.

Pero el Ministro que suscribe, al emprender esta refundición de la Ley vigente de reemplazos, fue solo innovador para hacerla más comprensible y de fácil ejecución; para perfeccionarla y satisfacer las justas reclamaciones de los que con arreglo a ella son llamados al servicio de las armas. Después de una larga serie de reemplazos y de los infinitos expedientes y consultas a que dieron ocasión, bien apreciados sus efectos en la práctica, no podían ocultarse al Gobierno las mejoras de que esta legislación es susceptible [...] ${ }^{1546}$.

El capítulo primero instituye unos principios generales que habían de regir todo el articulado del proyecto. Así, se establece que la fuerza militar española estaría integrada por dos tipos efectivos: los voluntarios por una parte y los jóvenes que obtuviesen la suerte del soldado en los sorteos celebrados anualmente por otra ${ }^{547}$ : aunque se abría la puerta al voluntariado, el escaso número de candidatos

${ }^{546}$ Proyecto de Ley, Gaceta núm. 5588 de 17/11/1849.

547 La celebración de una quinta anual, periódica y fija, sin tener en cuenta las necesidades del momento y sin ser necesaria la aprobación de las Cortes constituye una de las grandes novedades del proyecto, Proyecto de Ley, Gaceta núm. 5588 de $17 / 11 / 1849$, art. 1 . Esta novedad de gran trascendencia, inicialmente no recogida por el proyecto que el Gobierno entregó al Senado pero introducida por la Comisión que se encargó de su estudio, fue muy criticada en el Senado al ignorar los artículos constitucionales que otorgaban a las Cortes, a propuesta del Ejecutivo, la función de fijar el número de reclutas quintados: "La contradicción que existe entre el art. $5^{\circ}$ del proyecto de ley que se discute el art. 79 de la Constitución, está terminante. Basta leer una y otra disposición. En el art. $5^{\circ}$ del proyecto de ley se fija una prestación al servicio anual de 25.000 hombres, que han de ingresar desde luego [...] en las filas del Ejército. ¿Y qué dice el art. 79 de la Constitución? Que las Cortes cada año, a propuesta del Rey, han de fijar la fuerza permanente del Ejército y armada. Pues si ahora prefijamos esa fuerza en 25.000 hombre anuales, ¿qué les queda que hacer a las Cortes venideras? [...] ¿Cómo se concilia esto con lo que se previene en esta ley, de que han de ingresar 25.000 hombres?. [...] La Constitución, en mi concepto, queda enteramente violada en su art. 79 [...]. Las necesidades del país, tanto para su defensa exterior como para la conservación del orden público, son transitorias; en un año pueden ser unas, y otro otras diferentes, y a nadie mejor que las Cortes corresponde calcular los sacrificios que esas necesidades exigen al país, respecto a una contribución tan costosa como es la personal" (Discurso del Sr. Sáinz Andino, Diario de Sesiones del Senado, no 26, 21/01/1850, p. 343). 
que por propia voluntad ingresaba en el Ejército obligaba a la celebración de un sorteo para quintar a 25.000 soldados anualmente ${ }^{548}$. Para formar parte de la fuerza armada como soldado voluntario se exigirían una edad y unas condiciones que se establecerían en un reglamento diseñado para ello ${ }^{549}$.

El ámbito geográfico para el alistamiento no era todo el territorio de la Monarquía, ya que se excluían los territorios coloniales y el archipiélago Canario. Además de todos los españoles que residiesen en las provincias peninsulares y balear, participarían en el alistamiento y el subsiguiente sorteo aquellos que residiesen en el extranjero ${ }^{550}$. Quedaba pendiente la cuestión de los foráneos residentes en España, excluidos del reemplazo, que sería regulada en 1852 a través de un real decreto, y que analizaremos en el apartado "añadidos a la norma".

No se establece por otra parte un número fijo de años que los reclutas deberían prestar servicio, aunque nunca excedería de los ocho. Se remite asimismo a los llamamientos que se celebraría anualmente para establecer el total de los mozos a ingresar a filas, un máximo de $25.000^{551}$, la duración exacta de la prestación y el

\footnotetext{
${ }^{548}$ El ministro de la Guerra, criticado por permitir la celebración de una quinta anual sin tener en cuenta el mandato constitucional que otorgaba al Gobierno y a la Cortes la competencia de fijar el número de reclutas a ingresar en el Ejército, acudió a la incertidumbre que sufrían los mozos por no saber en qué año se iba a celebrar quinta y cuantos soldados se iban a solicitar para justificar el establecimiento de una quinta anual con una cuota de reclutas fija, sin esperar a la decisión del Gobierno, que solo podría solicitar mayor número de soldados en circunstancias extraordinarias: "[...] Para ello hay razones muy poderosas: [...] ¿Qué cosa hay más aflictiva que la incertidumbre en que hoy están los mozos y sus familias? ¿y como se sale de esta incertidumbre sino sabiendo los mozos fijamente que en una época determinada está su suerte corrida? Cuando no hay otra regularización, y cuando se pide cada año una quinta, una mayor, otra menor, una en enero, otra en julio, entonces los mozos sorteables están en continua incertidumbre y ansiedad, sin poder disponer de sí mismos ni ayudar a los cálculos de sus familias" (Discurso del Sr. Ministro de la Guerra, Diario de Sesiones del Senado, no 24, 18/01/1850, p. 317).

549 Proyecto de Ley, Gaceta núm. 5588 de 17/11/1849, art. 2.

550 Proyecto de Ley, Gaceta núm. 5588 de 17/11/1849, arts. 3 y 4.

551 En el debate del Senado hubo senadores que consideraron esta cifra insuficiente, y reclamaron su elevación hasta los 30.000 reclutas anuales, mientras que otros la consideraron excesiva tanto para tiempos de paz como de guerra ante
} 
reparto de los mozos por provincias en función de las necesidades del momento 552 .

Por lo que hace referencia a las edades de los mozos, se termina con esa franja tan amplia que establecía la Ley de 1837, entre los dieciocho y los veinticuatro años, y con la diversidad de sorteos en función del año de nacimiento, y se estableció que serían jóvenes sorteados aquellos que tuviesen veinte años cumplidos o veintiuno no cumplidos ${ }^{553}$. Se incluirían además los jóvenes entre veintiuno y veinticinco años ${ }^{554}$ que no hubieran sido alistados en años anteriores. Este retraso en la edad de acceso al servicio militar fue criticado en el Senado por suponer un freno a la natalidad:

las escasas posibilidades que el país tenía de ser invadido y la mejora económica que, para el país, tendría una reducción el tamaño del Ejército, y reclamaron por ello su rebaja hasta los 20.000 mozos anuales, Discursos del Sr. Sanz, del Sr. Sancho, del Sr. Conde Valmaseda y del Sr. Ministro de la Guerra, Diario de Sesiones del Senado, no 25, 19/01/1850, pp. 322-331.

552 Proyecto de Ley, Gaceta núm. 5588 de 17/11/1849, art. 5.

553 El retraso en la edad de acceso al servicio militar fue criticado por el moderado Manuel Pavía, Marqués de Novaliches, comparando el servicio militar prusiano, sin posibilidad de redención y sustitución, con el español, y por el Sr. Armendáriz, por ajustarse mejor los jóvenes de menor edad a la disciplina y obediencia militar: "[...] es necesario que se varíe uno de los artículos de esta ley, y es el que deben ser soldados la edad de 20 años. Yo señalaría la edad de 18 años para no hacer variación [...]. La de 20 años es buena para Prusia, que es donde todos son soldados. [...]" (Discursos del Sr. Marqués de Novaliches y del Sr. Armendáriz, Diario de Sesiones del Senado, no 23, 17/01/1850, pp. 295 y 298).

${ }^{554}$ El incremento en la edad de acceso al Ejército hasta una edad mínima de veinte años fue justificado por el Conde de Lucena en la alta mortalidad que presentaban los reclutas más jóvenes en los primeros meses de su ingreso en el Ejército: "las grandes bajas del Ejército son precisamente ocasionadas por entrar a servir a esa edad. Vienen, señores, sin formar, sin perder los hábitos de sus padres. [...]. La Comisión, al señalar los 20 años para entrar en el servicio, cree hacer un bien a la humanidad en general, y el particular al Ejército"; y por el Sr. Huet por motivos físicos, disciplinarios y económicos: "Entonces el hombre está más desarrollado en sus fuerzas físicas e intelectuales, tiene más hábitos de obediencia, más apego a su familia, que conviene que conserve para después, y ha concluido el aprendizaje de su oficio, todo lo cual no sucede a los 18 años. A los 20 va a al servicio en disposición de poder volver a su casa [...] capaz de ser útil con la profesión que aprendió, con robustez y con fuerza; y nada de esto sucede hoy, pues viniendo al servicio a los 18 años pueblan los hospitales, causan notables bajas en las filas [...] y se causan graves gastos en el Erario público" (Discursos del Sr. Conde de Lucena y Sr. Huet, Diario de Sesiones del Senado, no 23, 17/01/1850, p. 296 y 301). 
"Tenemos, que a los que están en la edad de 18 y 19 años se les dificulta el casarse. Pues bien: entran en la edad de 20 años y están sujetos al servicio militar por ocho; son 25.000 hombres de esta edad los que anualmente salen del Ejército; luego quiere decir, que en ocho años 200.000 no pueden contraer matrimonio, porque siendo soldados se les prohíbe, y al salir del servicio, a la edad de 28 años, los que por fortuna no han perecido, se encuentran sin medios de subsistencia después de las penalidades que sufrieron, y sin tener a qué dedicarse para adquirirlos. ¿Se ha considerado esta medida por los individuos de la Comisión $?^{555 "}$

La prensa más conservadora sin embargo alabó este significativo cambio justificándolo en la falta de robustez suficiente de los mozos a los dieciocho años para sufrir las penalidades de la vida militar 556 .

En el caso de que un municipio no pudiese cubrir el cupo que se le había asignado con los mozos de veinte años, se vería obligado a acudir a los jóvenes de veintiuno que hubiesen participado en el sorteo del año anterior ${ }^{557}$.

Como finalización de este primer capítulo donde se establecían las bases del reclutamiento, se expresó claramente que la sustitución de mozos para el cumplimiento del servicio militar quedaba admitida,

555 Discurso del Sr. Mata Vigil, Diario de Sesiones del Senado, no 27, 22/01/1850, p. 354.

556 "Si en algunos puntos de la península á esta edad se halla desarrollada la naturaleza y las fuerzas de los jóvenes, no sucede lo mismo en otros muchos, y de todos modos, muy pocos tienen la suficiente robustez para soportar sin quebranto las fatigas del servicio militar. Esto es lo que se ha demostrado en la discusión del proyecto de ley, aunque ya era una verdad innegable para cuantos tienen un conocimiento en materia de quintas. Por otra parte, con esta disposición no solo se evitará el que se altere y padezca la salud del soldado llenándose los hospitales de quintos, sino qel que al retirarse del servicio se hallen sin oficio alguno que á los veinte años podían ya tener aprendido y ejercitado, después de haber sufrido el perjuicio de haber ido á él sin corresponderles rigurosamente porque otro ú otros jóvenes no habían adquirido, al tiempo de hacérsela declaración de soldados, el suficiente desarrollo para serlo, pero que lo tendrían tal vez un mes después de hecha esta declaración" (La Época, 01/02/1850, no 279, p. 1).

557 Proyecto de Ley, Gaceta núm. 5588 de 17/11/1849, arts. 6 y 7. 
sin existir además oposición ninguna en el seno del Senado, y se remitió al último capítulo, el XVIII, para conocer su regulación ${ }^{558}$.

a) Elaboración del padrón de vecinos: herramienta necesaria para conocer el número de posibles reclutas

Señalados los principios globales que habían de regir el reclutamiento, en los capítulos I, II y III se hacía referencia a la elaboración del padrón de vecinos, competencia de la administración municipal. De nuevo el padrón aparece como documento previo y fundamental para conocer el número de posibles reclutas con los que se cuenta y como un instrumento básico en la distribución de los cupos. De ahí la incisiva regulación que se establece para su elaboración. Para evitar posibles dudas, indica el texto que con la expresión "pueblo" se entiende a los distritos municipales compuestos de una o más localidades y en los que debe haber un padrón propio, así como a las posibles secciones en los que se divide un municipio 559 .

Para facilitar esta tarea fundamental para la conscripción, se permitió a los municipios mayores de 5.000 habitantes, previa autorización del jefe político de la provincia, dividir su territorio en secciones $^{560}$ de al menos 5.000 almas cada una ${ }^{561}$. Cada sección

\footnotetext{
558 Proyecto de Ley, Gaceta núm. 5588 de 17/11/1849, art. 8.

559 Proyecto de Ley, Gaceta núm. 5588 de 17/11/1849, art. 11.

560 "[...] lo más conveniente a toda población grande, es el dividir los Ayuntamiento todo lo posible, a fin de que se haga el sorteo con la mayor claridad y exactitud en una Nación como la nuestra, en donde aún no tenemos un buen censo" (Discurso del Sr. Huet, Diario de Sesiones del Senado, no 28, 24/01/1850, p. 374).

561 "La complejidad de las operaciones de la quinta así como el volumen de trabajo al que se veía sometido la Comisión encargada de elaborar el padrón de cada distrito aconsejó esta merma en el número de individuos que tenía que componer cada una de las divisiones administrativas pasando, en tan sólo una decena de años, de quince mil a cinco mil, lo que ciertamente conllevaba una rapidez en la ejecución no sólo de los padrones respectivos, sino de las demás operaciones del reemplazo" (JIMÉNEZ GUERRERO, J., El reclutamiento militar en el siglo XIX: las quintas en Málaga (1837-1868), p. 35).
} 
tendría un padrón particular e independiente elaborado por una Comisión compuesta por al menos tres concejales del Ayuntamiento designados por el alcalde ${ }^{562}$. Aquellos distritos municipales compuestos por poblaciones dispersas se considerarían como una única realidad para la confección del padrón y las operaciones de alistamiento y sorteo ${ }^{563}$.

El padrón de vecinos se elaboraría anualmente en todos los pueblos durante los primeros días del mes de enero e incluiría "[...] a todas las personas de ambos sexos que en él tengan su residencia, o en los caseríos, huertos, haciendas o cualquier otra estancia de su término, con inclusión de los que se hallen accidentalmente ausentes, cualquiera que sea el motivo de la ausencia y el punto donde se encuentren dentro o fuera del Reino" ${ }^{264}$.

Con el objetivo de acabar con los fraudes y evitar la no inclusión en el padrón de jóvenes ausentes, los artículos 13 y 14 buscaron aclarar posibles situaciones confusas para las autoridades municipales encargadas de elaborarlo. Así, se estableció que, en el caso de un mozo se encontrase durante el mes de enero en otra localidad del Reino o en el extranjero, sería incluido en el padrón si hubiese residido en el lugar donde se realizase el mismo en los dos años anteriores al primero de enero durante al menos dos meses cada $a n ̃ 0^{565}$. Se insiste además en que se consideraba residencia en una localidad la estancia del joven o de sus padres allí donde ejercían una profesión de continuo o donde residiesen de forma habitual manteniéndose con el producto de sus bienes. Una ausencia temporal y breve no se consideraba motivo de exclusión en el padrón para un mozo. Tampoco se consideraría interrumpida la residencia del joven en una localidad cuando se encontrase ausente por haberse

\footnotetext{
562 Proyecto de Ley, Gaceta núm. 5588 de 17/11/1849, art. 9.

563 Proyecto de Ley, Gaceta núm. 5588 de 17/11/1849, art. 10.

564 Proyecto de Ley, Gaceta núm. 5588 de 17/11/1849, art. 12.

565 Proyecto de Ley, Gaceta núm. 5588 de 17/11/1849, art. 13.
} 
desplazado a otra población por motivos de estudio o para el aprendizaje de un oficio, siempre que regresase a su localidad de origen al finalizar los mismos. $Y$ en los casos de que el padre o madre del mozo se encontrase "demente", sufriera condena de presidio, residiese temporalmente fuera de las provincias peninsulares o del archipiélago Balear o se desconociese su paradero, serían incluidos igualmente en el padrón de vecinos de su localidad habitual de residencia ${ }^{566}$.

b) Formación, reclamaciones y rectificación del alistamiento para el reemplazo: la posibilidad de recurrir el documento

Los capítulos IV, V y VI se centran en la formación del alistamiento, su rectificación y las posibles reclamaciones que se presenten al mismo ${ }^{567}$. El alistamiento se formaría anualmente durante los primeros días del mes de febrero en función del padrón general, y en él se incluiría a todos los jóvenes de veinte años y a aquellos entre veintiuno y veinticinco que no hubiesen formado parte del alistamiento en años anteriores. En este documento se incluirían todos los mozos que residiesen habitualmente en el municipio, ellos mismos o sus padres, y también aquellos que hubiesen residido en él durante los dos años previos al alistamiento ${ }^{568}$. La edad de los mozos es la mayor novedad del alistamiento, ya que el resto de los trámites de esta fase apenas sufre variaciones respecto a la Ley de 1837.

Para otorgar una mayor solemnidad al acto y evitar conflictos, al mismo deberían asistir todos los concejales del Ayuntamiento y los eclesiásticos que se designasen "[...] a fin de suministrar las noticias

${ }^{566}$ Proyecto de Ley, Gaceta núm. 5588 de 17/11/1849, art. 14.

567 "Con la aprobación de la nueva ley de quintas de 1850 se introdujeron una serie de cambios, tanto estructurales como formales, en lo que a realización de alistamientos se refiere" (JIMÉNEZ GUERRERO, J., El reclutamiento militar en el siglo XIX: las quintas en Málaga (1837-1868), p. 82).

568 Proyecto de Ley, Gaceta núm. 5588 de 17/11/1849, art. 15. 
que se les pidan, exhibiendo en caso necesario los libros parroquiales 569 . La autoridad eclesiástica repite como garante de la limpieza y la legalidad del evento. Además, el documento debería ser firmado por todos los cargos municipales asistentes al acto y el secretario del Ayuntamiento ${ }^{570}$. Para otorgar una mayor publicidad y credibilidad al acto, éste se celebraría a puerta abierta en dependencias municipales y se ordenó la fijación de copias del alistamiento en lugares públicos para el conocimiento de la ciudadanía durante al menos diez días ${ }^{571}$, una semana más que el plazo establecido por la Ley de 1837.

El capítulo $\mathrm{V}$ entiende de todo lo relacionado con las reclamaciones y la rectificación del alistamiento, otro de los aspectos más novedosos de la nueva legislación, ya que por primera vez se estableció la posibilidad de reclamar tal documento. Tal rectificación se llevaría a cabo el primer domingo del mes de marzo previo anuncio público por parte de las autoridades municipales. Las reclamaciones serían presentadas por los propios interesados o por sus padres o parientes, y podrían hacer referencia a la inclusión indebida o a la exclusión improcedente de algún alistado. Los miembros del consistorio atenderían las reclamaciones teniendo en cuenta las pruebas que se presentasen, y deberían fallar una decisión que aparecería reflejada en un acta junto a todas las reclamaciones presentadas. A los interesados se les expediría un certificado donde constasen las reclamaciones y la decisión tomada por parte del Ayuntamiento. En el supuesto de que todas las reclamaciones no se pudiesen resolver en una única sesión por tener las autoridades que desplazarse a otras localidades o porque se necesitase aportar documentación como prueba proveniente de lugares alejados, el propio consistorio establecerá un plazo límite para la presentación de

\footnotetext{
569 Proyecto de Ley, Gaceta núm. 5588 de 17/11/1849, art. 16.

570 Proyecto de Ley, Gaceta núm. 5588 de 17/11/1849, art. 17.

571 Proyecto de Ley, Gaceta núm. 5588 de 17/11/1849, arts. 18 y 19.
} 
los documentos oportunos para la reclamación, no pudiéndose presentar fuera del plazo señalado. Además, este proceso de rectificación del alistamiento continuaría, si no pudiese concluirse por falta de tiempo el primer domingo del mes de marzo, en los siguientes días festivos hasta su finalización, siempre previo anuncio en cada sesión del día en que se debería celebrar la siguiente ${ }^{572}$.

En su capítulo VI contempló la ley la posibilidad de recurrir la decisión adoptada por el Ayuntamiento. Para ello, los interesados tendrían que elevar una reclamación por escrito ante la propia autoridad municipal en un plazo máximo de tres días desde que el consistorio hiciese pública su decisión al respecto. Se expediría al interesado como aval de su reclamación un certificado expedido por la autoridad local. En un plazo de diez días, el reclamante debería personarse ante el consejo Provincial con el certificado emitido. Sería esta institución la encargada de tomar una decisión, quedando para los recurrentes, como última posibilidad en su reclamación, la alegación ante el ministerio de la Gobernación, "máximo órgano resolutorio en materia de quintas, y cuya resolución era inapelable" ${ }^{\prime \prime 73}$.

Sería esta misma institución provincial, en el caso de que los Ayuntamientos respectivos de una misma provincia no se pusiesen de acuerdo 574 , la que decidiría al alistamiento de qué localidad pertenecería un joven que hubiese sido incluido en dos o más pueblos siguiendo estos criterios de prioridad:

"10.- Al alistamiento del pueblo en que el padre del mozo haya tenido su residencia durante los dos años anteriores al del alistamiento.

\footnotetext{
572 Proyecto de Ley, Gaceta núm. 5588 de 17/11/1849, arts. 20, 21, 23 y 24.

573 JIMÉNEZ GUERRERO, J., El reclutamiento militar en el siglo XIX: las quintas en Málaga (1837-1868), p. 83.

${ }^{574}$ Proyecto de Ley, Gaceta núm. 5588 de 17/11/1849, art. 31.
} 
20. - Al alistamiento del pueblo en que el mozo haya tenido su residencia durante los dos años anteriores al del alistamiento.

30.- Al alistamiento del pueblo en que el padre del mozo tenga su residencia desde $1^{\circ}$ de enero del año del alistamiento o la haya tenido en este día.

40.- Al alistamiento del pueblo en que el mozo tenga su residencia desde $1^{\circ}$ de enero del año del alistamiento o la haya tenido en este día.

50. - Al alistamiento del pueblo de que sea natural el mozo"1575.

Si el joven víctima de un doble alistamiento lo fuese en dos municipios de dos provincias distintas, serían sus respectivos consejos provinciales los encargados de ponerse de acuerdo y decidir a qué alistamiento pertenecía; en el caso de no hacerlo, los expedientes serían remitidos al ministerio de la Gobernación para que tomase una última decisión. Si el sorteo se celebrase con anterioridad al fallo, sería el propio mozo quien decidiese en qué pueblo deseaba ser alistado ${ }^{576}$.

c) Un sorteo gestionado por los Ayuntamientos

De forma similar a la legislación de 1837, un capítulo completo del proyecto, el VII, regula todo lo relacionado con el sorteo, acto público que se debería celebrar anualmente, con los interesados presentes, el primer domingo del mes de abril a las siete de la mañana aunque existiesen recursos sin resolver acerca del alistamiento. En el caso de no finalizar ese mismo día, el sorteo continuaría la jornada siguiente ${ }^{577}$.

\footnotetext{
575 Proyecto de Ley, Gaceta núm. 5588 de 17/11/1849, art. 31.

576 Proyecto de Ley, Gaceta núm. 5588 de 17/11/1849, art. 31.

577 Proyecto de Ley, Gaceta núm. 5588 de 17/11/1849, arts. 32 y 33.
} 
Para la ejecución del sorteo se escribirían, en papeletas iguales, el nombre de los mozos alistados, y en otras papeletas, también iguales, tantos números como jóvenes hubiesen formado parte del alistamiento $^{578}$. Las papeletas serían introducidas en bolas, y éstas en dos globos, uno para nombres y otro para números, que serían leídas de forma previa a su introducción por parte del presidente del Ayuntamiento y del síndico ${ }^{579}$.

Una vez introducidas en sus respectivos globos, las bolas se removerían convenientemente y serían extraídas una a una por dos niños menores de diez años, uno por globo, que las entregarían al presidente y al síndico, encargados de leer en voz alta los nombres de los mozos que fuesen saliendo el primero y los números correspondientes el segundo, además de mostrarlas a los interesados. El secretario por su parte debería extender un acta con los nombres de los nuevos reclutas ${ }^{580}$.

Con el objeto de evitar actuaciones ilegales por parte de las autoridades locales, se señala que los Ayuntamientos serían responsables de que el sorteo se celebrase cumpliendo la legalidad, debiendo firmar el acta todos los concejales del consistorio, además del propio secretario. Se indica incluso que el propio ministerio de la Gobernación intervendría y decidiría sobre las reclamaciones o quejas presentadas ante posibles irregularidades o equivocaciones cometidas durante el sorteo, debiéndose celebrar un nuevo sorteo solamente como último recurso. Es más, en el supuesto de que alguna reclamación presentada ante el ministerio prosperase, ese individuo quedaría exento de acudir a filas, pero no se celebraría un nuevo sorteo $^{581}$. En el caso de que se tuviese que incluir en el alistamiento a algún individuo por una reclamación presentada, se realizaría un

\footnotetext{
578 Proyecto de Ley, Gaceta núm. 5588 de 17/11/1849, art. 34.

579 Proyecto de Ley, Gaceta núm. 5588 de 17/11/1849, art. 35.

580 Proyecto de Ley, Gaceta núm. 5588 de 17/11/1849, art. 36 y 38.

581 Proyecto de Ley, Gaceta núm. 5588 de 17/11/1849, art. 37, 38, 40, y 17.
} 
sorteo "supletorio" similar al primero pero con un globo con tantos números como mozos participaron en el primer sorteo, mientras que en "en otro globo se incluirá una papeleta con el nombre del que entre nuevamente y otras en blanco hasta completar un número igual al de las papeletas del primer globo" ${ }^{582}$.

d) El reparto del contingente: las DDiputaciones provinciales pierden protagonismo

Se centra el octavo capítulo en todo lo concerniente al reparto de los mozos sorteados ${ }^{583}$. La base para realizarlo sería la copia del acta del sorteo que el alcalde debía enviar, en un plazo máximo de tres días desde la celebración del sorteo y firmada por todos los concejales del Ayuntamiento y el secretario municipal, al jefe político de la provincia, quien a su vez conservaría una copia y enviaría otra al ministerio de la Gobernación antes de finalizar el mes de abril. Por primera vez en todo el proceso una autoridad de nombramiento gubernativo interviene en el mismo. Si estas copias no hubiesen llegado al ministerio antes de producirse el llamamiento para el reemplazo, el reparto del contingente se realizaría en función de aquel que hubiese regido el año anterior ${ }^{584}$.

En este documento vendrían especificados los nombres de los mozos que hubiesen recibido la suerte del soldado. La lucha contra las irregularidades cometidas, muy habituales según se desprende de las continuas amenazas emitidas contra las autoridades locales, conducen a la instrucción de una causa criminal y al establecimiento

\footnotetext{
582 Proyecto de Ley, Gaceta núm. 5588 de 17/11/1849, arts. 42-45.

583 "Las nuevas disposiciones legislativas en materia de quintas de 1850 y 1856 reformaron aspectos puntuales, relativos al desarrollo y circunstancias específicas en la declaración de soldados y suplentes. Estas medidas completaban un vacío legal, cuando no corregían disfunciones" (JIMÉNEZ GUERRERO, J., El reclutamiento militar en el siglo XIX: las quintas en Málaga (1837-1868), p. 157).

${ }^{584}$ Proyecto de Ley, Gaceta núm. 5588 de 17/11/1849, art. 52.
} 
de multas de 6.000 reales para aquellos miembros del consistorio que no hubiesen actuado correctamente ${ }^{585}$ y hubiesen omitido a alguno de los mozos sorteados ${ }^{586}$. Se impone pena de presidio en el caso de que los jóvenes omitidos superasen los cinco ${ }^{587}$.

De momento, y a diferencia de la legislación de 1837, las Diputaciones provinciales todavía no han intervenido en el proceso y han perdido protagonismo respecto a la normativa anterior. Tal y como recoge la Constitución de 1845, es el Parlamento quien fija el contingente militar anual necesario para cubrir las necesidades defensivas del país y su reparto por provincias en función de su población 588 pero, según esta nueva ley de reclutamiento, "las Diputaciones Provinciales repartirán el contingente señalado a sus provincias respectivas entre los pueblos de las mismas en proporción al número de mozos sorteados que tenga cada pueblo"589 y no en función del censo de la población como se hacía en la Ley de 1837. Además, si lo comparamos con la legislación de 1837, con la nueva norma la intervención y las competencias de las Diputaciones en materia de reclutamiento se han reducido notablemente.

Quedaba por regular la cuestión de las décimas, competencia esta vez sí de las Diputaciones provinciales. Eran ellas las encargadas

585 "Es necesario castigara no solo la mala fe, sino hasta la negligencia en que incurra aquel a quien corresponde formar estas copias o extender estos documentos. [...]. Se impondrá la pena, si de las diligencias resulta que puede haber fraude; pero entretanto importa castigar hasta la negligencia" (Discurso del Sr. Huet, Diario de Sesiones del Senado, no 29, 25/01/1850, p. 381).

${ }^{586}$ El diputado Sr. Conde de Torre-Marín consideró demasiado duras las penas que se establecían cuando podría, en ocasiones, de tratarse de simples errores humanos cometidos por los miembros del Ayuntamiento: "En este artículo se impone nada menos que la pena de un proceso criminal a los individuos del Ayuntamiento que hayan cometido la omisión del nombre de un mozo en las listas de los sorteados que el Ayuntamiento pasa al Consejo Provincial. Es necesario que el Senado tenga presente que será excesivo el número de las personas comprendidas en estas listas [...], lo cual explica la facilidad con que involuntariamente puede haber, por descuido u olvido, una omisión. Y por esto, señores, ¿se ha de proceder criminalmente contra los individuos de un Ayuntamiento? Es un castigo muy severo" (Discurso del Sr. Conde de Torre-Marín, Diario de Sesiones del Senado, no 28, 24/01/1850, p. 376).

587 Proyecto de Ley, Gaceta núm. 5588 de 17/11/1849, arts. 46 y 47.

588 Proyecto de Ley, Gaceta núm. 5588 de 17/11/1849, art. 48.

589 Proyecto de Ley, Gaceta núm. 5588 de 17/11/1849, art. 49. 
de realizar el repartimiento y de informar a cada pueblo del número de mozos que les ha tocado en el cupo, así como de "[...] la décima o décimas de soldado que haya de sortear con otro u otros pueblos, bien por los mozos que le sobren después del repartido el cupo, bien porque no tenga mozos suficientes para dar un soldado" 590 .

Una vez realizado el señalamiento de décimas, la Diputación procedería a realizar el sorteo de los quebrados entre los pueblos que hubiesen sido designados, "[...] procurando que el sorteo se haga con cada diez décimas para dar un soldado, y que los pueblos reunidos en cada combinación sean en lo posible los que menos disten entre sí"591. Este acto se celebraría a puerta abierta y con un anuncio público previo de 24 horas. Para realizar este sorteo se introducirían en un globo diez papeletas con los nombres de los pueblos afectados, cada localidad con tantas papeletas como décimas tuviese que contribuir. En otro globo se introducirían otras diez papeletas con los números del uno al diez. Serían dos vocales de la Diputación los encargados de extraer las papeletas, debiendo contribuir con un soldado a mayores aquella localidad que obtuviese el número uno, siempre que quede en este pueblo algún mozo útil de entre los comprendidos en el alistamiento. Si no fuese así, daría el soldado el número dos y así sucesivamente. Si ninguno de los pueblos tuviese un mozo útil, se acudiría al alistamiento del año anterior o, en su defecto, de dos años anteriores. Si tras recurrir a estas dos promociones no hubiese ningún mozo útil capacitado para el oficio de soldado y no se pudiese completar el cupo, estas plazas en cuestión quedarían sin cubrir ${ }^{592}$.

El resultado del repartimiento y de este sorteo de décimas se formalizaría en un documento a tres columnas: en una de ellas aparecería el número de mozos sorteados en cada pueblo, en otra el

\footnotetext{
590 Proyecto de Ley, Gaceta núm. 5588 de 17/11/1849, art. 50.

591 Proyecto de Ley, Gaceta núm. 5588 de 17/11/1849, art. 54.

592 Proyecto de Ley, Gaceta núm. 5588 de 17/11/1849, arts. 55, 56, 59 y 60.
} 
número de décimas asignadas a cada uno de ellos y en una tercera el número total de soldados que cada localidad debía afrontar en función del reparto. Este sería el documento que se enviaría a los distintos Ayuntamientos para poner en su conocimiento el número de soldados que debían aportar ${ }^{593}$.

e) Exenciones: la confirmación de la redención como alternativa a la sustitución

Todo el capítulo IX se dedica a especificar las posibles exenciones que se podían alegar para evitar el servicio militar. Las motivaciones son diversas. En primer lugar los motivos físicos, y en concreto no alcanzar la talla mínima exigida, estableciéndose la misma altura mínima que en la legislación de 1837, 1,596 m.:

"Los que no tengan la talla de cinco pies, ocho pulgadas y nueve líneas del marco de Burgos, que equivalen a los cuatro pies y once pulgadas que fijaba la Ordenanza de $1837^{\prime 594}$.

También se incluyen en el capítulo de exenciones aquellos declarados inútiles por enfermedad o defecto físico. En el caso de defecto físico visible o dolencia notoria, el propio Ayuntamiento podía examinar y declarar la exención de un mozo. Si fuese necesario, la autoridad municipal podría decidir en función del examen médico que realizase un facultativo. Si el joven se encontrase fuera de la península o en las provincias de Ultramar, podría ser reconocido en 
su lugar de residencia, tanto para examinar su enfermedad como para ser tallado 595 .

Además de las motivaciones físicas, existe un segundo tipo de justificaciones de interés económico o estratégico para el país que eximían del servicio militar: aquellos que formasen parte de la matrícula de mar desde la edad de dieciocho años, a cambio de quedar sujetos durante una campaña en los buques de la Armada en el primer llamamiento que se realizase en el distrito marítimo que le correspondiese; los carpinteros inscritos en las brigadas de arsenales; los que ya formasen parte del Ejército o de la Armada, ya sea en la oficialidad o en la clase de tropa; los trabajadores de las minas de Almadén y de sus fundiciones, siempre que no abandonasen su oficio con anterioridad a los treinta años, lo que constituye una novedad si lo comparamos con la Ley de $1837^{596}$.

Una tercera tipología de eximentes son aquellos relacionados con la situación profesional y la capacidad económica del afectado: los profesores y novicios de Escuelas Pías y Misiones de Filipinas ${ }^{597}$; los ya licenciados en el Ejército; los redimidos a través de un sustituto o una retribución pecuniaria ${ }^{598}$ y los ordenados in sacris ${ }^{599}$.

\footnotetext{
595 Proyecto de Ley, Gaceta núm. 5588 de 17/11/1849, arts. 62 20, 75 y 83.

596 Proyecto de Ley, Gaceta núm. 5588 de 17/11/1849, art. 64, 10, 20, $3^{\circ}$ y $6^{\circ}$. El senador Sr. Cabanillas se mostró en contra de exigir esta edad mínima para los mineros de Almadén en virtud de la importancia y la extrema dureza de su trabajo: "¿Conque un hombre que ha pasado las penalidades que acabo de manifestar, un hombre que ha estado prestando un servicio tan importante [...], un hombre que perjudicando a su salud ha estado en continuo riesgo de perder su vida, si a los 28 años o a los 29 [...] se separa de las minas y fundición, ha de tomar un fusil? Esto lo considero injusto $y$, por tanto, lo ataco, y niego mi insignificante voto. A los mineros de Almadén, en lugar de mimarlos con la consideración que exigen sus servicios, se les hace peor condición que a los demás" (Discurso del Sr. Cabanillas, Diario de Sesiones del Senado, no 29, 25/01/1850, p. 385).

597 Proyecto de Ley, Gaceta núm. 5588 de 17/11/1849, art. 64, 40 y $5^{\circ}$.

598 "En 1851, la ley de Narváez-Bravo Murillo autorizó la redención, principalmente como recurso alternativo que el Estado ofrecía a la sociedad para protegerla de los abusos de las sociedades de sustitución. Éstas se habían extendido por todo el territorio peninsular, con especial incidencia en las zonas donde la pequeña propiedad rural permitía a los campesinos avalar con su tierra, sus cosechas y sus ganados el préstamos que necesitaban para soslayar la suerte de sus hijos" (PUELL DE LA VILLA, F., El soldado desconocido: de la leva a la "mili" (1700-1912), p. 199).
} 
Es el artículo 65. 20 es el que concede cobertura legal a la sustitución y a la redención en metálico ${ }^{600}$ :

"No están obligados a servir aún cuando no interpongan su reclamación al tiempo de hacerse el llamamiento y declaración de soldados [...] 20.- Los que hayan redimido la suerte de soldado por medio de sustituto o por una retribución pecuniaria"601.

A la sustitución dedica la ley un capítulo completo, el XVII, que será analizado con posterioridad. Sin embargo, lo más novedoso está en la cuestión de la redención en metálico. Tal y como indica Puell de la Villa,

"Lo nuevo era que, por primera vez en un texto legal, se democratizaba el trueque de la contribución de sangre por un tributo económico cuya cuantía estaba al alcance de buena parte de la clase media"602.

Además, poco después de la publicación del proyecto de ley del Senado, verían la luz sucesivos documentos legislativos Ilamando a filas a 35.000 hombres correspondientes al sorteo y alistamiento de los años 1850 y 1851, que vinieron a regular la cuestión de la redención en metálico, estimada en 6.000 reales a ingresar en el Banco Español de San Fernando, y el destino de ese dinero, que debería ser empleado de forma obligatoria en la contratación de sustitutos $^{603}$.

\footnotetext{
${ }^{599}$ Proyecto de Ley, Gaceta núm. 5588 de 17/11/1849, art. 65, 10, 20, 30 y 40.

${ }^{600}$ FERNÁNDEZ RODRÍGUEZ, M. y MARTÍNEZ PEÑAS, L., "Problemática social en la legislación de reclutamiento decimonónica: exenciones, sustitución y redención", p. 326.

${ }^{601}$ Proyecto de Ley, Gaceta núm. 5588 de 17/11/1849, art. 65, 20.

602 PUELL DE LA VILLA, F., Historia del Ejército en España, p. 87.

${ }^{603}$ Real Decreto de 21 de Febrero de 1851, Gaceta núm. 6068 de 23/02/1851; Dictamen de 4 de Abril de 1851 sobre el Proyecto de Ley llamando al servicio de las
} 
Llama la atención como la prensa afín a la Monarquía justificó la redención y la sustitución por motivos humanitarios, alabándose asimismo la figura del voluntariado:

"Ínterin no se varíe radicalmente el sistema del enganche del ejército, verificándose por enganche voluntario de jóvenes robustos, de soldados por vocación, necesario y conveniente es admitir la sustitución para no privar á la sociedad de un miembro útil en otra carrera, para no llenar el ejército de jóvenes sin la robustez y las fuerzas necesarias para el servicio militar, y que habituados á una vida exenta de fatigas, no podrían resistir las de aquel. No es este en rigor un privilegio de clase, una exención a favor de las fortunas, sino un deber de humanidad, una ley imperiosa del servicio militar, que sin chocar con la igualdad y la justicia en la distribución de las cargas públicas, busca y prefiere un soldado fuerte, vigoroso, útil al ejército que languidecería ó sucumbiría en él, mediante cierto sacrificio pecuniario de este ó personal de otro"604.

Un cuarto tipo de exenciones son aquellas vinculadas a las circunstancias personales del recluta, las cuales se ven notablemente reducidas respecto a la legislación anterior ${ }^{605}$. También destaca la pormenorización que se realiza, descendiendo a una diversidad de condiciones muy particulares ${ }^{606}$ : hijo único o expósito que mantuviese a su padre pobre cuando éste se encuentre impedido o

armas a 35.000 hombres, Gaceta núm. 6111 de 07/04/1851; Real Orden de 21 de Junio de 1851, Gaceta núm. 6185 de 22/06/1851; Real Decreto de 2 de Julio de 1851, dictando instrucciones para la aplicación de los artículos del Proyecto de Ley aprobado por S.M. el 18 de junio de 1851, Gaceta núm. 6188 de 23/06/1851.

${ }^{604}$ La Época, 01/02/1850, no 279, p. 1

605 JIMÉNEZ GUERRERO, J., El reclutamiento militar en el siglo XIX: las quintas en Málaga (1837-1868), p. 277.

${ }^{606}$ Así justificó el Sr. Huet, miembro de la Comisión que elaboró el proyecto de ley de reemplazos, ante los miembros del Senado la existencia de este tipo de exenciones "humanitarias: Señores, la ley de reemplazo debe estar basada en principios de humanidad, y nadie podrá acusar al proyecto que se discute de que no es humano; pero la ley no debe ser humana para unos e inhumana para otros; las excepciones, por consiguiente, no deben ser en daño ni perjuicio de unos y en provecho exclusivo de otros" (Discurso del Sr. Huet, Diario de Sesiones del Senado, no $29,25 / 01 / 1850$, p. 387). 
sea sexagenario o a su madre viuda y pobre o cuyo cónyuge sea impedido o sexagenario; hijo único, incluidos los ilegítimos, o expósito que mantuviese a su madre pobre cuando su esposo se encontrase en prisión o en paradero desconocido desde hacía diez años (el mozo se incorporaría a filas en el momento que su padre recuperase la libertad o se tuviesen noticias suyas si se encuentra desaparecido, cesando en sus funciones el recluta suplente correspondiente; el nieto único que mantuviese a sus abuelos cuando el varón fuese sexagenario o impedido y la mujer viuda ${ }^{607}$; el hermano de un huérfano pobre menor de diecisiete años, o mayor de esa edad si es impedido, cuya manutención dependiese del futuro soldado608; el joven que ya tuviese otro u otros hermanos sirviendo en el Ejército como mozo sorteado o que hubiesen muerto en acciones de guerra, independientemente del nivel económico del padre o madre, siempre que no quede "[...] al referido padre otro hijo varón mayor de diecisiete años y no impedido para trabajar". Aclara este artículo 66 que no se consideraban a efectos de esta última exención los desertores, sustitutos, redimidos pecuniariamente, voluntarios, alumnos de academias militares y oficiales del Ejército de cualquier graduación ${ }^{609}$.

En el caso de que dos hermanos obtuviesen la suerte del soldado en un mismo reemplazo, serviría en el Ejército aquel que primero hubiese sido declarado soldado, quedando eximido el segundo. Sin embargo, "los mozos comprendidos en esta excepción

607 Proyecto de Ley, Gaceta núm. 5588 de 17/11/1849, art. 66, 10, 20, 30, 40, $5^{\circ}$ y 90.

${ }^{608}$ Señala este artículo 66 que "[...] se considerarán igualmente huérfanos para los efectos de esta excepción:

10.- Los que tengan padre si éste además de ser pobre se halla en edad sexagenaria, o impedido para trabajar, o sufriendo una condena que no haya de cumplir dentro de seis meses, o ausente por espacio de dos años, ignorándose desde entonces su paradero con certeza, a juicio del Ayuntamiento, o del Consejo Provincial en su caso.

20.- Los que careciendo de padre tengan madre si esta es viuda y pobre" (Proyecto de Ley, Gaceta núm. 5588 de 17/11/1849, art. 66, 10).

${ }^{609}$ Proyecto de Ley, Gaceta núm. 5588 de 17/11/1849, art. 66, 110. 
ingresarán en las filas y permanecerán en ellas hasta que justifiquen que su hermano o hermanos se hallaban en el Ejército precisamente en el día fijado para la declaración de soldados, y sólo quedarán libres cuando se llene este requisito, llamándose entonces en su lugar al suplente a quien corresponda" ${ }^{610}$.

La diversidad de situaciones explicitadas en el artículo 66 obligó a aclarar qué se entendía por hijo único, nieto único y qué nivel de pobreza sería considerado para eximir a un mozo del servicio militar. Así, se consideró que una familia tenía un hijo o nieto único cuando éste no tuviese más hermanos 0 , si los tuviese, fuesen menores de diecisiete años, impedidos, soldados, penados, viudos con hijos, casados o eclesiásticos que no pudiesen mantener a sus padres ${ }^{611}$. Además, "se reputará muerto el hijo, nieto o hermano que se halle ausente por espacio de más de 10 años consecutivos, y cuyo paradero se ignore desde entonces con certeza, a juicio del Ayuntamiento o del Consejo Provincial en su caso" ${ }^{\prime 612}$. Se consideró asimismo que el impedimento físico de un padre o abuelo para eximir al hijo o nieto del servicio había de ser una enfermedad habitual o un defecto físico que le impidiese su propia subsistencia. $Y$ aunque el padre o abuelo poseyese algunos bienes, no debería ingresar en el Ejército el hijo o nieto sin cuyo trabajo sus familiares se viesen privados del producto de esos bienes o no pudiesen subsistir sin el auxilio que les prestaba el mozo ${ }^{613}$.

La ley aclaró que no quedarían libres de la prestación los jóvenes que hubiesen sido condenados a penas de prisión en el plazo que media entre el sorteo y el llamamiento de los soldados ${ }^{614}$, con el

\footnotetext{
${ }^{610}$ Proyecto de Ley, Gaceta núm. 5588 de 17/11/1849, art. 66, 110.

${ }^{611}$ Proyecto de Ley, Gaceta núm. 5588 de 17/11/1849, art. 67, $1^{\text {a }}$ y $2^{\mathrm{a}}$.

${ }^{612}$ Proyecto de Ley, Gaceta núm. 5588 de 17/11/1849, art. 67, 3a.

613 Proyecto de Ley, Gaceta núm. 5588 de 17/11/1849, art. 67, 40, $5^{a}$ y $6^{a}$.

${ }^{614}$ Proyecto de Ley presentado a las Cortes por el Sr. Ministro de la Gobernación del Reino en la sesión del Senado del día 14 de noviembre de 1849, Gaceta núm. 5589 de 18/11/1849, art. 86. En adelante Proyecto de Ley, Gaceta núm. 5589 de $18 / 11 / 1849$.
} 
objetivo de evitar desincentivar el cometimiento de delitos que permitiesen eludir el servicio militar. Si la condena fuese anterior a la declaración como soldados, se contemplaron los siguientes supuestos $^{615}$ :

"1a.- Si la pena impuesta al mozo es la de suspensión de cargo público, derecho político, profesión u oficio, la de sujeción a la vigilancia de la autoridad, la de destierro, la de confinamiento mayor o menor, o la de inhabilitación de cualquier clase, ingresará a cuenta del cupo del pueblo en que haya sido declarado soldado; y tan luego como recaiga esta declaración, en la caja de la provincia a que corresponda el punto designado para destierro o confinamiento, o donde el mozo esté sujeto a la vigilancia referida, o donde resida.

2a. - Si la pena es de relegación, el mozo ingresará en el cuerpo de Ultramar a que le destine el Gobierno y a cuenta del cupo del pueblo en que haya sido declarado soldado.

3a.- Si la pena es de arresto menor o mayor, prisión o presidio correccional o menor, ingresará el mozo en las filas a servir en el tiempo de su empeño así que extinga la condena, si no cuenta entonces la edad de 30 años cumplidos.

No se llamará al suplente para cubrir la plaza del mozo condenado a cualquiera de las penas mencionadas en esta disposición, ni mientras el penado sufre la condena, ni cuando después de haberlo extinguido deja de ingresar en las filas por tener más de 30 años, aún cuando resulte para el Ejército la pérdida de un soldado.

4a.- Si la pena es de prisión o presidio mayor, condena o reclusión temporal o perpetua o extrañamiento, no ingresará en las

\footnotetext{
${ }^{615}$ El envío de reclusos a las filas del Ejército causó un intenso debate en el Senado entre los partidarios de su inclusión y envío a los destinos coloniales, Ceuta en concreto, ya que el no hacerlo podría constituirse en un incentivo para delinquir, y los que rechazaban esta idea ante la posibilidad de que el Ejército viese dañada su disciplina, imagen y dedicación: "[...] es mejor privarse de enviar al Ejército penados [...] de este género, que no exponernos a que un cuerpo correccional [el cuerpo del Norte de África] se contamine con la admisión en sus filas de estos criminales. [...] El servicio de las armas es un servicio penoso, si, pero que debe tener prestigio, y éste se le da con solo el hecho de no admitir que los penados por delitos comunes puedan prestarlo" (Discurso del Sr. Miquel Polo, Diario de Sesiones del Senado, no 30, 26/01/1850, p. 394).
} 
filas el penado, y se llamará desde luego en su lugar al suplente a quien corresponda" 616 .

f) Llamamiento y declaración de soldados y suplentes

Una vez que el Ayuntamiento hubiese recibido la documentación donde se señalaba el cupo que le había correspondido, se inicia la fase de llamamiento y declaración de los reclutas. Las autoridades municipales deberían publicar este reparto y citar mediante edictos a todos los mozos que hubiesen participado en el sorteo para tomar dicha declaración en un mismo día festivo ${ }^{617}$. Además de este anuncio general, y de forma más específica, se citaría personalmente a los jóvenes que hubiesen obtenido los primeros números y a los inmediatos. Si algún mozo no pudiese asistir, lo haría en su representación "[...] su padre o madre, curador, pariente más cercano, amo u otra persona de quien dependen"618. Esta citación se haría mediante papeletas dobles, una destinada al recluta y otra que se uniría al expediente después de haber sido firmado por el joven o su representante ${ }^{619}$.

Cuando se hubiese reunido el Ayuntamiento en la fecha señalada, se procedería a la declaración y tallaje ${ }^{620}$ de los mozos por parte de un sargento o comandante designado por el gobernador militar. En su defecto, sería una "[...] una persona inteligente que el

616 Proyecto de Ley, Gaceta núm. 5589 de 18/11/1849, art. 87.

617 Proyecto de Ley, Gaceta núm. 5588 de 17/11/1849, art. 69.

${ }^{618}$ Proyecto de Ley, Gaceta núm. 5589 de 18/11/1849, art. 70.

619 Proyecto de Ley, Gaceta núm. 5589 de 18/11/1849, art. 70.

620 "En el proyecto de ley que aprueba el Senado en enero de 1850 se detecta, con toda evidencia, una nueva regulación del sistema de tallaje de los mozos. Esta circunstancia obedecía al excesivo número que quedaban declarados exentos por no alcanzar la talla mínima exigida, siendo notoria la sospecha de la existencia de fraudes bien entre los talladores o entre los mozos quienes, a veces, llegaban a adoptar posturas ridículas con el objetivo de ver menguada su estatura" (JIMÉNEZ GUERRERO, J., El reclutamiento militar en el siglo XIX: las quintas en Málaga (1837-1868), p. 157). 
Ayuntamiento habrá designado al efecto". Por tanto, esta operación pasa a ser controlada directamente por el Ejército. Además, se especifica la conveniencia de que estuviese presente en el acto un oficial nombrado por el gobernador militar para controlar la exactitud de las mediciones.

El primero en ser tallado sería aquel que hubiese obtenido el número uno en el sorteo; en el caso de no llegar a la talla establecida se anotaría como corto y se llamaría al siguiente, y si lo alcanzase también se apuntaría y se procedería a continuación al examen de las otras personas que fuesen necesarias para cubrir el cupo, así como de tantos suplentes como soldados requeridos al municipio ${ }^{621}$.

En este mismo acto el mozo o la persona que lo representase expondría los motivos alegados para ser eximido del servicio, admitiéndose las justificaciones y documentos que se presentasen, ya sean por parte del interesado o de los que le contradijesen. En el propio acto el Ayuntamiento debería decidir si declarar apto o excluido al mozo. El consistorio podría conceder un plazo de tiempo para la presentación de pruebas, y también podría solicitar un examen médico ${ }^{622}$. Se observa la trascendencia y el significativo papel otorgado a las autoridades municipales, que son las que deciden sobre la aptitud de los reclutas, si bien se podía recurrir a instancias superiores.

Una vez que se hubiese tomado declaración a los soldados que habían de cubrir el cupo solicitado a una localidad, se procedería de la misma forma con los suplentes ${ }^{623}$, y en el supuesto de que no se pudiese completar el número de soldados y suplentes pedidos, se procedería a llamar a los mozos sorteados del año anterior que no hubiesen sido destinados al servicio, "[...] siguiendo el orden de los

\footnotetext{
621 Proyecto de Ley, Gaceta núm. 5589 de 18/11/1849, arts. 72, 77 y 78.

622 Proyecto de Ley, Gaceta núm. 5589 de 18/11/1849, arts. 73, 74 y 75.

623 Proyecto de Ley, Gaceta núm. 5589 de 18/11/1849, art. 78.
} 
números que hubiesen sacado en el sorteo de aquel año"624. En el caso de que tampoco se pudiese completar el cupo de soldados y suplentes, se acudiría al segundo año inmediato anterior. Sin embargo, "quedará sin cubrir el cupo de un pueblo y exento éste de toda responsabilidad si no bastasen a completarle los mozos que hubiesen sido comprendidos en el sorteo del año del reemplazo y en los de los dos anteriores" ${ }^{\prime 625}$. En este supuesto el jefe político de la provincia debería examinar las actas del alistamiento y declaración de los soldados, y si algún mozo fuese omitido del proceso de forma injustificada, se procedería a su alistamiento y sorteo. Además, si el jefe político considerase que las excepciones declaradas no se ajustaban a la ley, debería remitirlas para su examen al consejo provincial, encargado de tomar una decisión final ${ }^{626}$.

Cuando cada Ayuntamiento hubiese completado el cupo asignado, debería fijar un plazo para la presentación de los reclutas, siendo éste mayor para aquellos soldados que residan a más de cincuenta leguas de distancia de la localidad donde esté establecido el consistorio. Cuando finalice este plazo y se desconociese el paradero de algún mozo o hubiese sido declarado prófugo, se llamaría al suplente y se iniciarían las diligencias oportunas para la captura del huido. Los mozos que residiesen fuera de la provincia donde hubiesen sido sorteados, podrían ingresar en la caja de la provincia donde residiesen, aunque pertenezcan al cupo de su lugar de origen ${ }^{627}$.

Se dedican los últimos artículos de este capítulo $X$ a regular la situación de los soldados suplentes. En primer lugar, su llamamiento y declaración se realizaría en el Ayuntamiento. También tenían estos mozos el derecho de reclamar las decisiones de las autoridades municipales cuando se considerasen agraviados ante el consejo

\footnotetext{
624 Proyecto de Ley, Gaceta núm. 5589 de 18/11/1849, art. 79.

625 Proyecto de Ley, Gaceta núm. 5589 de 18/11/1849, art. 80.

626 Proyecto de Ley, Gaceta núm. 5589 de 18/11/1849, art. 80.

627 Proyecto de Ley, Gaceta núm. 5589 de 18/11/1849, arts. 84 y 85.
} 
provincial, y en este supuesto el alcalde del municipio estaría obligado a hacer constar en el expediente de declaración de los soldados cuantas reclamaciones se presenten, entregando a los interesados su respectivo certificado donde constase su nombre y el motivo de la protesta ${ }^{628}$.

También reguló la ley el modo de actuación respecto al suplente en el caso de que el mozo "propietario" de la plaza de recluta hubiese ingresado en el Ejército por haber sido capturado o por cualquier otro motivo. En este caso el suplente sería dado de baja, entendiéndose por el suplente "[...] el mozo que sacó el número más alto en el sorteo del año respectivo entre todos los llamados para cubrir el cupo del pueblo" ${ }^{\prime 629}$. Si el suplente falleciese prestando servicio, el "propietario" no se vería liberado de su obligación de cubrir su plaza ${ }^{630}$.

g) Conducción y entrega de los reclutas en la caja de la provincia

Regulan los capítulos XI y XII los modos de proceder por parte de las autoridades encargadas de trasladar y entregar a los soldados y suplentes desde su lugar de residencia hasta la capital de provincia para ser ingresados en la caja de reclutas. La partida se debía realizar en función de la lejanía entre ambos puntos, a razón de cinco leguas diarias, y de la fecha establecida por el jefe político ${ }^{631}$ para el ingreso de los reclutas. Será un comisionado del Ayuntamiento sin intereses

\footnotetext{
${ }^{628}$ Proyecto de Ley, Gaceta núm. 5589 de 18/11/1849, arts. 91-93.

${ }^{629}$ Proyecto de Ley, Gaceta núm. 5589 de 18/11/1849, art. 89.

630 Proyecto de Ley, Gaceta núm. 5589 de 18/11/1849, art. 90.

631 "Se trataba de conseguir la mayor brevedad posible en la entrega de los cupos y evitar los problemas que con la normativa anterior se producían, en especial, los retrasos en el cumplimiento de la norma, toda vez que cada pueblo tenía asignado un día propio para entregar su cuota de soldados" (JIMÉNEZ GUERRERO, J., El reclutamiento militar en el siglo XIX: las quintas en Málaga (1837-1868), p. 181).
} 
en el reemplazo quien acompañaría a los mozos. A cambio, recibiría una ayuda de costa establecida a juicio de la corporación y a cargo de los fondos municipales. Cada soldado y cada suplente recibiría asimismo del erario local dos reales diarios desde el día en que se inicie la marcha hasta su ingreso en la caja o su regreso al municipio. Estos pagos serían abonados al comisionado por el comandante de la caja para reintegrarlo en los fondos municipales. También recibirían dos reales diarios aquellos mozos excluidos por el Ayuntamiento que se desplazasen a la capital de provincia para ser medidos o reconocidos por un médico por haberse presentado una reclamación contra sus alegaciones para la exención ${ }^{632}$.

La actuación de las autoridades municipales en el proceso finaliza con este comisionado, que debería realizar el viaje acompañado con un certificado literal de todas las diligencias practicadas por el consistorio en los actos de alistamiento y declaración de los soldados. También debería llevar los documentos de filiación de los soldados y suplentes, un certificado con su nombre $y$ otro con el de los mozos reclamados y reclamantes ${ }^{633}$.

Una vez en la capital de provincia, los reclutas ingresarían en la caja establecida por el capitán general del distrito, a cuyo cargo se encontraría un oficial nombrado a tal efecto ${ }^{634}$. Dicha entrega la realizaría el comisionado del Ayuntamiento en presencia de un consejero provincial nombrado por el jefe político de la provincia y un jefe oficial designado por el capitán general. A este acto podrían asistir los suplentes o cualquier interesado, y podrían presenciar la medida, el reconocimiento médico y todos los trámites que jalonaban

\footnotetext{
632 Proyecto de Ley, Gaceta núm. 5589 de 18/11/1849, arts. 94-97.

633 Proyecto de Ley, Gaceta núm. 5589 de 18/11/1849, art. 98.

634 Proyecto de Ley, Gaceta núm. 5589 de 18/11/1849, art. 99.
} 
el recibimiento de los quintos ${ }^{635}$. El comisionado local recibiría además un certificado que testimonie la entrega de los quintos ${ }^{636}$.

En el supuesto de que existiesen dudas sobre la talla o estado de salud de algún mozo, sería reconocido por un facultativo o un tallador designado por el comisionado, y en función de su dictamen, y siempre que estuviese de acuerdo el resto de facultativos 0 talladores, los comisionados, el quinto reconocido y los demás suplentes o personas interesadas, se procedería a su ingreso o exclusión de la caja. Si no existiese acuerdo, se daría cuenta al consejo provincial para que decidiese. Si algún quinto no fuese admitido por falta de talla o problemas físicos, se entregaría al suplente que corresponda. Si algún mozo declarado soldado o suplente no se presentase a este acto de entrega y residiese a menos de diez leguas de la capital de provincia, automáticamente sería declarado prófugo y se iniciaría su búsqueda y persecución. Si residiese a más de diez leguas, no sería declarado prófugo si se presentase dentro del plazo de tiempo "prudencial" establecido por el Ayuntamiento. Estas prevenciones quedarían sin efecto en el caso de que el mozo acreditase legalmente ante el consistorio o el consejo provincial la causa que le impidió presentarse en la caja ${ }^{637}$.

\footnotetext{
635 "También constituye una aportación novedosa el hecho de que se recoja en la legislación la posibilidad que asistía a cualquier mozo de "enviar" a la capital a otro quinto para que fuese medido o reconocido, cuando tuviese sospecha de que durante la declaración de soldados y suplentes no se había actuado con legalidad" (JIMÉNEZ GUERRERO, J., El reclutamiento militar en el siglo XIX: las quintas en Málaga (1837-1868), p. 181).

${ }^{636}$ Proyecto de Ley, Gaceta núm. 5589 de 18/11/1849, art. 100.

637 Proyecto de Ley, Gaceta núm. 5589 de 18/11/1849, arts. 101-105.
} 
h) La lucha contra el prófugo y contra el fraude en su captura

Incluye el capítulo XII las medidas establecidas para luchar contra esta figura delictiva. La declaración de un recluta como prófugo y el recargo en el tiempo de servicio que se le establecía como pena exigía la tramitación de un expediente por parte del Ayuntamiento. En concreto, sería el síndico municipal el encargado de su elaboración y de entregarlo a su padre o pariente más cercano con el objeto de proceder a su defensa. Si estos familiares rechazasen el encargo, "se nombrará de oficio un vecino honrado en calidad de defensor"638. El propio Ayuntamiento escucharía las justificaciones que se presentasen y remitiría, en un plazo máximo de cinco días, el expediente al consejo provincial ${ }^{639}$.

Sería el consistorio el encargado de determinar cuando un huido era declarado prófugo $y$, en el caso de serlo, de imponer una multa por los gastos que provocase su captura. Sin embargo, y a diferencia de la legislación de 1837, solo serían considerados como prófugos aquellos que no acudiesen a su presentación en el acto de entrega sin causa justificada una vez que hubiesen sido declarados soldados. Tal y como indica el profesor Jiménez Guerrero,

"Esta circunstancia generó, a la par que una notable disminución en el número de los que legalmente eran prófugos, el descenso de las aprehensiones que se efectuaban. De hecho, esta norma legal trataba de poner coto a una práctica utilizada por algunos jóvenes, en el sentido de no presentarse al acto de la declaración para ser considerados como prófugos y ser presentados como tales por algún aprehensor que previamente había acordado con él una suma

${ }^{638}$ Proyecto de Ley, Gaceta núm. 5589 de 18/11/1849, art. 106.

${ }^{639}$ Proyecto de Ley, Gaceta núm. 5589 de 18/11/1849, art. 107. 
económica, con lo que éste quedaba libre de prestar el servicio militar ${ }^{\prime 640}$.

Además de los costes por su captura, el prófugo debería abonar al suplente que ha ocupado su puesto la cantidad de 1.000 reales anuales. Cuando un prófugo fuese apresado, sería destinado a las guarniciones africanas con un recargo en el servicio de entre uno y cuatro años a juicio del consejo provincial ${ }^{641}$. Dicha institución confirmaría o revocaría la determinación del Ayuntamiento, disponiendo la entrega del individuo a la caja de quintos o al cuerpo donde sirviese su suplente. Tal y como indicaba el artículo 89, el suplente que corresponda quedaría inmediatamente libre una vez que el prófugo haya sido entregado en la caja o en un cuerpo del Ejército. En el supuesto de que el prófugo no debiese ingresar a filas por inutilidad física o por no haber obtenido la suerte del soldado, se le impondría una multa de 500 a 2.000 reales a juicio del consejo provincial. Si careciese de los recursos necesarios, se le impondría pena de prisión ${ }^{642}$.

En el caso de que existiesen indicios de complicidad de terceras personas con el prófugo, el Ayuntamiento lo haría constar en el expediente instruido. Las multas impuestas para estos colaboradores oscilan entre los 500 y los 2.000 reales y, en el caso de no poder satisfacerla, se le impondrían penas de prisión según establece el Código Penal ${ }^{643}$. Se vuelve a mostrar la importancia y la capacidad de decisión que tienen las autoridades civiles, tanto municipales como provinciales, a la hora de intervenir en el proceso de reclutamiento,

640 JIMÉNEZ GUERRERO, J., El reclutamiento militar en el siglo XIX: las quintas en Málaga (1837-1868), p. 212.

${ }^{641}$ Esta pena fue considerada excesiva y demasiado severa por el senador Miquel Polo ante la posibilidad de que algunos mozos que hubiesen actuado con poca reflexión y sin malicia fuesen enviados a las plazas africanas (Discurso del Sr. Miquel Polo, Diario de Sesiones del Senado, no 30, 26/01/1850, p. 398).

${ }^{642}$ Proyecto de Ley, Gaceta núm. 5589 de 18/11/1849, arts. 106, 108, 111 y 114.

${ }^{643}$ Proyecto de Ley, Gaceta núm. 5589 de 18/11/1849, art. 109. 
pudiendo incluso imponer penas a los prófugos capturados y a sus colaboradores.

También se premió, al igual que en la Ley de 1837, la colaboración ciudadana en la captura del prófugo. Así, si el colaborador fuese un recluta destinado a filas, o su padre o hermano, se rebajaría su prestación "[...] el tiempo que se imponga de recargo al prófugo sin perjuicio de que sea dado de baja el suplente" ${ }^{\prime 644}$. Si el aprehensor de un prófugo no fuese familiar de un recluta, se le premiaría económicamente con una cantidad que se prevé fijar en un reglamento posterior, siempre y cuando el huido fuese considerado apto para el servicio. Si no lo fuese, se obviaría cualquier gratificación para evitar fraudes, y el prófugo no apto debería abonar los gastos que hubiesen ocasionado su captura y 6.000 reales de multa destinados a su suplente ${ }^{645}$.

Una última medida ya contemplada en la legislación de 1837 para evitar la huida al extranjero de mozos en edad militar, es la prohibición de conceder pasaporte a los jóvenes entre dieciséis y veintitrés años si no presentan un certificado que asegurase el cumplimiento de sus obligaciones con el Ejército y el depósito de una fianza que el proyecto de ley no especifica, dinero que perdería en caso de no presentarse en la caja de quintos si hubiese recibido la suerte del soldado. Dicha suma sería empleada por el ministerio de Guerra en cubrir su vacante, aunque no se llamaría a su suplente ${ }^{646}$.

\footnotetext{
644 Proyecto de Ley, Gaceta núm. 5589 de 18/11/1849, art. 115.

645 Proyecto de Ley, Gaceta núm. 5589 de 18/11/1849, arts. 116 y 117.

646 Proyecto de Ley, Gaceta núm. 5589 de 18/11/1849, art. 118.
} 
i) Las reclamaciones ante el consejo provincial y el ministerio de la Gobernación

Los capítulos XIV y XV atienden a las posibles reclamaciones presentadas ante la institución provincial, una de las grandes protagonistas, junto a los Ayuntamientos, en los distintos actos del reclutamiento. Para ello, y como una de las grandes novedades del texto legislativo analizado, los mozos entregados en la caja de quintos que se considerasen agraviados por el consistorio se lo harían saber a los comisionados encargados de vigilar la entrega designados por el Jefe Político de la provincia y por el capitán general. Éstos tomarían nota formal de su reclamación y se lo pasarían al consejo provincial $^{647}$. Se celebraría un acto público donde los interesados u otras personas en su nombre podrían exponer los motivos del agravio, mientras que el consejo examinaría cualquier documento o prueba presentada y las diligencias sobre la declaración de los soldados elaboradas por los Ayuntamientos, para proceder posteriormente a dictar la resolución oportuna, sin perjuicio del recurso que los interesados podrían presentar ante el ministerio de la Gobernación. El mismo consejo podría practicar las diligencias que considerase oportunas y establecer un plazo, lo más breve posible, para presentar documentos justificativos ${ }^{648}$.

Si la queja presentada estuviese relacionada con la talla o la aptitud física del interesado, participarían en la toma de decisiones, con voz y voto, dos jefes oficiales del Ejército, dos peritos o dos facultativos, todos ellos designados por el capitán general, mientras que por el consejo provincial sólo votarían los dos consejeros más antiguos. En el caso de existir empate en las votaciones, sería el jefe político quien debería tomar la última decisión. La decisión tomada en 
esta materia, aptitud física o talla del soldado, por el consejo provincial sería definitiva y no admitirá recurso ante el ministerio de la Gobernación ${ }^{649}$.

Sí que podrían recurrir ante el ministerio aquellos mozos que se considerasen agraviados por la decisión tomada por el consejo provincial en lo que respecta "[...] a la exclusión del alistamiento y a la inclusión en el mismo de otros mozos o de la suya propia [... $]^{\prime 650}$. Dichas reclamaciones deberían ser presentadas ante el jefe político de la provincia en un plazo máximo de ocho días desde la resolución del consejo provincial. Una vez que el jefe político tuviese en su mano la reclamación, procedería a instruir un expediente donde adjuntaría los informes de Ayuntamientos y consejo provincial, los acuerdos tomados por ambas corporaciones y las pruebas y documentos presentados, para ser enviado al ministerio de la Gobernación encargado de tomar una decisión final ${ }^{651}$.

j) Disposiciones penales: las causas criminales frente a las prácticas irregulares

Se centra el capítulo XVI en las causas criminales que los tribunales ordinarios podrían iniciar contra todas aquellas actuaciones irregulares que se cometiesen durante el proceso de reclutamiento, ya sea por parte de los reclutas o de las instituciones encargadas de organización y ejecución. Así, se establece que se iniciaría causa penal contra aquellos mozos sospechosos de haberse automutilado 0 inutilizado voluntariamente para evadir el servicio, endureciéndose notablemente las penas. En el caso de confirmarse su delito, serían destinados a ocupaciones compatibles con su situación física en las

\footnotetext{
649 Proyecto de Ley, Gaceta núm. 5589 de 18/11/1849, art. 121-124.

${ }^{650}$ Proyecto de Ley, Gaceta núm. 5589 de 18/11/1849, art. 127.

${ }^{651}$ Proyecto de Ley, Gaceta núm. 5589 de 18/11/1849, arts. 128-30.
} 
guarniciones africanas por el tiempo ordinario del servicio más dos años como castigo. Si su inutilidad física le impidiese la realización de cualquier oficio, sería condenado a diez años de presidio en las citadas posesiones africanas. Sus cómplices o encubridores también recibirían penas de cárcel $^{652}$. El puesto que quedase vacante por la inutilidad física de un autolesionado sería ocupado por su suplente solamente hasta que se demuestre que dicha lesión hubiese sido provocada653. La dureza de estas sanciones "[...] implica la existencia y, en cierta medida, el arraigo de esta práctica" ${ }^{654}$.

También se regularon las actuaciones de los tribunales ordinarios contra aquellos que hubiesen cometido otro tipo de fraudes con el objeto de evadirse del servicio. Cuando se probase la culpabilidad en este sentido de un joven, el tribunal ordinario podría imponer penas de cárcel al acusado, quien además debería pagar una indemnización al suplente que hubiese cubierto su puesto ${ }^{655}$. Los tribunales también deberían iniciar un proceso contra aquellas autoridades que hubiesen cometido irregularidades en las operaciones de reemplazo, sin perjuicio de las multas económicas que alcaldes y jefes políticos pudiesen imponer ${ }^{656}$.

\footnotetext{
652 El diputado Sr. Cabello criticó que se asimilasen los conceptos cómplice y encubridor por los siguientes motivos: "No debe confundirse, y mucho menos en el caso del presente artículo, al encubridor con el cómplice. ¿Cómo ha de aplicarse al padre, madre, o pariente próximo de un mozo que se haya mutilado para librarse del servicio, la misma pena que al que haya contribuido a cometer el delito? ¿Se querrá obligar a la madre a que acuse al hijo, y que sea ella la que le lleve al presidio por diez años? Pues qué, ¿no será bastante pena para una madre o para un padre, el ver a un hijo que se ha mutilado, quizá algún miembro necesario para el trabajo, en el que estriba su subsistencia, sino que se le ha de obligar a pasar también por esa acción altamente inmoral? Esto no es justo. Aquí se trata por una parte de cómplices, que son los que auxilian la Comisión del delito, y por otra los encubridores, que son los que albergan al que ha cometido el delito. Los padres nunca son cómplices, pero sí frecuentemente encubridores [...]. ¿Cómo ha de quererse privar, ni mucho menos castigar a un padre por albergar, por encubrir a su hijo?" (Discurso del Sr. Cabello, Diario de Sesiones del Senado, no 32, 29/01/1850, p. 425).

653 Proyecto de Ley, Gaceta núm. 5589 de 18/11/1849, art. 131.

654 JIMÉNEZ GUERRERO, J., El reclutamiento militar en el siglo XIX: las quintas en Málaga (1837-1868), p. 337.

${ }^{655}$ Proyecto de Ley, Gaceta núm. 5589 de 18/11/1849, art. 132.

${ }^{656}$ Proyecto de Ley, Gaceta núm. 5589 de 18/11/1849, arts. 133 y 135.
} 
k) El problema de la especulación con la sustitución y el reconocimiento de la redención en metálico

El último capítulo de este proyecto de ley atiende a todo lo relacionado con la delicada cuestión de la sustitución ${ }^{657}$, declarándose como objetivo básico del mismo acabar con la cantidad de delitos y la inmoralidad que, hasta entonces, las sustituciones habían provocado, implantándose para ello una redención de 6.000 reales que simplificase y facilitase la sustitución ${ }^{658}$. En primer lugar, se aclara que la sustitución es un acto legalmente permitido ${ }^{659}$, aunque ésta tenía que ser individual y nunca podría ser grupal, si bien el gobierno, en función de las circunstancias, podría admitir una sustitución general de quintos de una localidad o provincia ${ }^{660}$. Tal circunstancia fue criticada con dureza desde El Eco del Comercio, que si bien apoyó

\footnotetext{
${ }^{657}$ Esta polémica cuestión centró parte importante de los debates en el Senado, no ya porque hubiese senadores que la rechazasen por motivos de injusticia social, ya que las virtudes de su existencia fueron considerablemente unánimes, sino más bien por la existencia de senadores, caso del Sr. Armendáriz, que apostaban por facilitar las sustituciones, Discurso del Sr. Armendáriz, Diario de Sesiones del Senado, no 23, 17/01/1850, p. 301.

658 "Si logramos establecer una ley por la cual evitemos una multitud de delitos como los que demuestra la multitud de procesos que por mi mano pasan, y en que se multiplican las condenas de presidio para los sustitutos y para las empresas que buscan en la inmoralidad el lucro; si evitamos estos males, repito, habremos hecho un bien de grandísima importancia. Después del daño que causan las sustituciones, tal y como hoy se ejecutan, a la moralidad pública, téngase presenta que mayores males causa en el Ejército. Es tal el daño que aún en las filas del Ejército causan las empresas de sustitución, que hay batallones enteros en que los sustitutos no han recibido el precio justo que debieran recibir por su contrato, que no pueden recibirlo; y que hay sustituido, por el contrario, que tiene que pagar tres veces el precio de la sustitución. [...]. Por todas estas consideraciones, el proyecto de ley simplifica y facilita, por tanto, por medio de la entrega de 6.000 reales (Discurso Sr. Huet, Diario de Sesiones del Senado, no 23, 17/01/1850, p. 302).

659 "Los moderados introdujeron la redención en la ley de Bravo Murillo, y así el Ejército tendría la opción de elegir a los hombres que debían reemplazar a los que pagaban por no hacer el servicio militar. Sin embargo, no se arriesgaron a eliminar de ella el recurso a la sustitución, tal vez por desconfiar de los resultados del nuevo sistema [...]" (PUELL DE LA VILLA, F., El soldado desconocido: de la leva a la "mili" (1700-1912), p. 201).

660 Proyecto de Ley, Gaceta núm. 5589 de 18/11/1849, art. 128, y Proyecto de Ley presentado a las Cortes por el Sr. Ministro de la Gobernación del Reino en la sesión del Senado del día 14 de noviembre de 1849, Gaceta núm. 5590 de 19/11/1849, art. 136. En adelante Proyecto de Ley, Gaceta núm. 5590 de 19/11/1849.
} 
la posibilidad de la sustitución, rechazó la sustitución por provincias a juicio del Gobierno, circunstancia ésta tachada de inconstitucional:

"[...] no debemos dejar sin refutación la doctrina emitida sobre el último punto por el señor Infante. Este digno senador apoyó el artículo del proyecto que permite al gobierno que admita á su arbitrio la sustitución en materia de quintas á tales ó cuales provincias.

Sin entrar en la cuestión de si debe o no admitirse la sustitución, que desde luego la creemos conveniente y necesaria, nos parece que no se debe dejar al arbitrio del gobierno la facultad de conceder á una ó determinadas provincias el redimir sus quintos por este medio. Semejante facultad es un arma de que el gobierno puede llegar á hacer un funestísimo uso, no solo en materia de quintas, favoreciendo unas provincias con perjuicio de otras, sino en las elecciones. Si conviene admitir la sustitución, consígnese el principio para todas las provincias da España, dejándolas en libertad de cubrir su contingente de hombres como mejor les convenga.

Si es inconveniente la sustitución por provincias, no se hagan escepciones (sic), siempre odiosas para el que no es esceptuado (sic). El principio constitucional de igualdad ante la ley, que el señor Infante debe tener muy presente, se conculca y destruye concediendo tan omnímoda prerrogativa de gobierno.

En este punto, tanto como en el fijar la conscripción anual, el Senado ha votado dos artículos contrarios en nuestro concepto a todos los principios del derecho público y opuestos al espíritu y letra de la Constitución del Estado"661.

La sustitución individual podría realizarse mediante tres medios:

- Cambiando el número entre el mozo que quiera sustituirse y cualquiera que hubiese sido sorteado en una misma localidad, ya sea en el año correspondiente al reemplazo o en los dos anteriores.

${ }^{661}$ El Clamor Público, 31/01/1850, no 1713, p. 2. 
- Por medio de mozos que no hubiesen obtenido la suerte del soldado en los sorteos celebrados y se encuentren entre los veintitrés y los treinta años.

- A través de licenciados en el Ejército menores de treinta años ${ }^{662}$.

Se les exigía a los sustitutos, además de una edad limitada, ciertas condiciones para ser admitidos en el Ejército: ser solteros o viudos sin hijos, aptitud física adecuada para el servicio, poseer un certificado del alcalde de su localidad de residencia que acredite su buena conducta y el no estar procesado judicialmente ni haber sufrido penas de prisión, así como un certificado, en el caso de ser menor de edad, con el consentimiento de su padre o madre para engancharse como sustituto. Toda esta documentación debería ser remitida al juez de primera instancia del lugar de procedencia del sustituto para su correspondiente revisión. El consejo provincial también procedería a su examen y sería quien declarase o no apto al sustituto. El reconocimiento médico se llevaría a cabo por parte de facultativos designados por el capitán general, y esta autoridad también tendría que admitir como apto a un sustituto ${ }^{663}$.

Además, para ser admitido como sustituto se debería acreditar la consignación, ya sea por él mismo o por el sustituido, la cantidad de 6.000 reales en metálico en la depositaría de fondos provinciales o en un banco público ${ }^{664}$. Esta cantidad entregada, no denominada específicamente como redención en metálico ${ }^{665}$, se consideró una

\footnotetext{
662 Proyecto de Ley, Gaceta núm. 5590 de 19/11/1849, art. 137.

663 Proyecto de Ley, Gaceta núm. 5590 de 19/11/1849, arts. 138 y 147.

${ }^{664}$ Algunos diputados como Ros de Olano criticaron una cantidad que consideraron excesiva para buena parte de las provincias españolas, si bien constituía un gasto más asumible en las zonas más prósperas del territorio nacional, Madrid y Barcelona, Discurso Sr. Ros de Olano, Diario de Sesiones del Senado, no 24, 18/01/1850, pp. 314 y 315.

665 "En vez de comprar la redención del servicio para su hijo, una familia podía contratar un sustituto que había de servir en su puesto. El procedimiento era arriesgado, pues podía ocurrir que el sustituto desertara o fuese a su vez llamado a filas, en cuyo caso el primero tendría que ir al ejército. El precio y el número de
} 
garantía de la permanencia del sustituto en filas hasta la finalización de su prestación, momento en el que podría cobrarla. Esta fianza podría ser sustituida por "[...] una escritura pública en que el otorgante se obligue a entregar la cantidad señalada para depósito hipotecando al seguro de esta obligación bienes propios que consistan en fincas rústicas o urbanas y cuyo valor sea al menos el duplo del depósito $[\ldots]^{\prime \prime 666}$. No se exigiría fianza en el caso del mozo que sustituye a un hermano ${ }^{667}$. Tal y como indican los profesores Fernández Rodríguez y Martínez Peñas al respecto de esta garantía:

"De este modo, la sustitución adquiría caracteres comunes con la redención en metálico, ya que lo importante de la cantidad a consignar con frecuencia dejaba esta figura fuera del alcance económico de las capas más menesterosas de la sociedad, más aún si tenemos en cuenta que el artículo 140 elevaba la cantidad a depositar hasta los diez mil reales para el caso de que la presentación del sustituto no la realizara él mismo o su familia más directa" ${ }^{\prime 668}$.

Para evitar fraudes y acabar con la inmoralidad de las empresas que comerciaban con sustitutos 669 , y en el supuesto de que la

sustitutos variaba considerablemente según el momento y de una región a otra. Las zonas más pobres (Galicia y León, por ejemplo) pedían pocas redenciones, pero facilitaban muchos sustitutos. Las regiones más ricas, como Cataluña, Valencia, Madrid, proporcionaban pocos sustitutos, pero adquirían muchas redenciones y contrataban sustitutos de otras regiones" (HEADRICK, D. R., Ejército y política en España (1866-1898), p. 102).

${ }^{666}$ Proyecto de Ley, Gaceta núm. 5590 de 19/11/1849, arts. 139 y 143.

667 Proyecto de Ley, Gaceta núm. 5590 de 19/11/1849, art. 145.

${ }^{668}$ FERNÁNDEZ RODRÍGUEZ, M. y MARTÍNEZ PEÑAS, L., "Problemática social en la legislación de reclutamiento decimonónica: exenciones, sustitución y redención", p. 325.

669 "[...] se han formado compañías que han esquilmado los pueblos y han engañado completamente, no sólo a los que han depositado su dinero para asegurar su redención en caso de caberles la suerte de soldados, sino hasta a los mismos hombres que mandaban servir en el Ejército. Citaré cien ejemplos de esto: podré citar compañías enteras que habiendo sacado anticipadamente de los padres de familia o de los individuos comprendidos en los sorteos cantidades respetables para asegurar la sustitución caso de salir soldados, han buscado con este dinero los hombres, les han dado una cantidad muy módica al entrar en el servicio ya han 
presentación del sustituto se hiciese por una persona que no fuese el mozo sustituido, debería poseer un poder que acreditase su condición y debería depositar en un banco público la cantidad de 10.000 reales como fianza especial que "[...] garantice la responsabilidad que contra dicha persona pueda declararse por el uso del poder que le fue conferido" ${ }^{670}$. Además, se declaró que el sustituido nunca sería responsable de los actos o de la deserción de un sustituto, quien en este caso perdería su derecho a cobrar la cantidad depositada sino regresase a su plaza en un plazo máximo de un mes, cantidad que quedaría en manos del Estado para ser invertida en cubrir la baja del sustituto desertor ${ }^{671}$.

Los sustitutos deberían ser presentados en el plazo máximo de un mes desde el día en que fue declarado soldado el sustituido, mientras que la documentación requerida anteriormente señalada podría ser entregada en el plazo máximo de un mes desde la presentación del sustituto ${ }^{672}$.

quebrado después" (Discurso del Sr. Marqués de Vallgornera, Diario de Sesiones del Senado, no 31, 28/01/1850, p. 408).

${ }^{670}$ Proyecto de Ley, Gaceta núm. 5590 de 19/11/1849, art. 140.

671 Proyecto de Ley, Gaceta núm. 5590 de 19/11/1849, arts. 141 y 142 . El Gobierno se mostró convencido de que la obligación de presentar 6.000 reales como garantía de la sustitución supondría el fin de las compañías especuladoras: "La Comisión ha dicho: es imposible dejar la sustitución como estaba antes; porque se había por medio de contratistas que eran una sentina de maldades, un foco de falsificación y escándalo, que por colmo de él han venido a acabar de defraudar a los mismos con quienes se habían confabulado y comprometido. Pues bien, desde que el Gobierno diga que por 6.000 reales se puede redimir el servicio, han muerto esas sociedades; es imposible que nadie pueda ya especular con eso delante del Gobierno, porque el padre que tenga proporción de redimir la suerte de su hijo por 6.000 reales con plena seguridad, no ha de preferir el dar 4.000 reales a una Sociedad, corriendo con los azares y riesgos a que se expone el que tal hiciere" (Discurso del Sr. Marqués de Cabello, Diario de Sesiones del Senado, no 31, 28/01/1850, p. 431).

672 Proyecto de Ley, Gaceta núm. 5590 de 19/11/1849, art. 146. 
La convocatoria de quintas en función de este proyecto nunca aprobado es el añadido a la norma

El proyecto de ley tuvo una aplicación limitada, y no se convirtió en realidad hasta 1856 con la aprobación de una nueva ley que introdujo ligeras modificaciones. Sí que tuvieron aplicación algunas de sus reformas a través de reales decretos $u$ otras disposiciones legislativas, e incluso los reemplazos de 1851, 1852, 1853, 1854 y 1855 se realizaron en función de su articulado ${ }^{673}$, justificándose tal disposición de la siguiente forma:

"La regularidad en el reemplazo del Ejército, ya para el mejor orden en un servicio tan importante, ya para que esta carga que tanto afecta a la generalidad de los pueblos se reparta más equitativamente, exige la renovación periódica de un número determinado de hombres.

Movido el Gobierno por esta consideración, y resuelto, mientras circunstancias muy imperiosas no le obliguen a obrar de otra manera, a que no haya sorteo ni alistamiento en el año próximo, considera indispensable que en el actual se llamen a las armas a 35.000 hombres.

Pero el Gobierno, que conoce que ha de pasar algún tiempo antes de que el proyecto de Ley de Reemplazos, pendiente en el Congreso, reciba la sanción de la Corona, persuadido, como lo está, de que tal como ha salido del Senado lleva grandes ventajas a la Ley vigente, la cual por otra parte se halla desvirtuada hasta cierto punto;

673 Real Decreto autorizando al Ministro de la Gobernación del Reino para que presente a las Cortes un Proyecto de Ley llamando a las armas treinta y cinco mil hombres correspondientes al alistamiento del presente año, Gaceta núm. 6068 de 23/01/1851; Dictamen sobre el proyecto de Ley llamando al servicio de las armas 35.000 hombres, Gaceta núm. 6111 de 7/04/1851; Real Orden de 21 de Junio de 1851 para el reemplazo de 25.000 hombres, con arreglo a lo dispuesto en el proyecto de Ley aprobado por el Senado el 29 de enero de 1850, Gaceta Núm. 6187 de 22/06/1851; Real Decreto de 6 de Marzo de 1852, Gaceta Núm. 6469 de 09/03/1852; Real Decreto de 31 de Diciembre de 1852, Gaceta Núm. 8 de 08/01/1853; Real Decreto de 30 de Marzo de 1853, Gaceta Núm. 90 de 31/03/1853; Real Decreto de 3 de Enero de 1854, Gaceta Núm. 370 de 05/01/1854; Real Decreto de 7 de Febrero de 1855, Gaceta Núm. 768 de 08/02/1855. 
y convencido de que es llegada la época de preparar la transición entre lo que hoy existe $y$ el nuevo sistema que ha de ponerse en ejecución, cree conveniente bajo todos los conceptos que por esta vez se ejecuten las operaciones del reemplazo con sujeción al proyecto que el Senado tiene aprobado, sin que por ello sea visto, prejuzga las cuestiones, cuya resolución definitiva introduzca acaso algunas alteraciones en la Ley ${ }^{\prime 674}$.

La convocatoria de quintas en función de una "casi-ley" originó un largo debate en el Parlamento durante el mes de marzo de 1851 y encontró duras críticas por parte de algunos diputados pertenecientes al propio partido Moderado en el poder, y también entre miembros del Progresista, ante el carácter excepcional que suponía el acudir a un texto solamente aprobado por la Cámara Alta ${ }^{675}$. A ello se unen las críticas al excesivo número de reclutas solicitados ${ }^{676}$, llegándose incluso a criticar la existencia de ejércitos permanentes ${ }^{677}$, al incremento en el tiempo del servicio militar ${ }^{678}$, y a la sustitución, no

674 Real Decreto autorizando al Ministro de la Gobernación del Reino para que presente a las Cortes un Proyecto de Ley llamando a las armas treinta y cinco mil hombres correspondientes al alistamiento del presente año, Gaceta núm. 6068 de 23/01/1851.

675 Discurso del Sr. Roca de Togores, Diario de Sesiones de las Cortes, no 65, $12 / 03 / 1851$, p. 1266.

676 Discurso del Sr. Madoz, Diario de Sesiones de las Cortes, no 65, 13/03/1851, pp. 1305-1312.

677 "Los ejércitos numerosos son una prueba evidente de lo atrasados qua estamos en la verdadera civilización, porque por mas qua decantemos la civilización europea, no se concibe como unas Naciones realmente civilizadas, tengan necesidad de sostener millones de hombres sobre las armas; yo veo por lo tanto quo los Ejércitos permanentes son un mal. Se me dirá quo es mal necesario, pero yo creo que podría ponerse muy en duda esta necesidad" (Discurso del Sr. Jaén, Diario de Sesiones de las Cortes, no 71, 20/03/1851, p. 1438).

678 "Señores, hoy que un soldado se forma en dos meses lo mas tarde en cualquiera de los institutos del Ejército, ¿como se condena a un soldado a servir ocho años, sin tener en cuenta quo después de estos ocho años venga a su casa a la edad de 29, mas olvidado quo lo estaría si el plazo fuese mas corto, de las afecciones de familia, de localidad y do todas las demás que después de venir del servicio a residir en su país le han de hacer mas afecto al trabajo? Señores, esta es una cuestión de gravedad, porque es de riqueza y hasta de moralidad. El soldado, después que sirve ocho anos y vuelve a su hogar a la edad de 29 años, no puede conservar las afecciones y amor al trabajo quo tendría si volviese a una edad mas temprana y con menos tiempo de servicio en el Ejército" (Discurso del Sr. Pasarón y Lastra, Diario de Sesiones de las Cortes, no 69, 17/03/1851, p. 1379). 
ya por motivos de injusticia social, sino por la disciplina que la juventud podría conocer durante el servicio de las armas y por el mantenimiento que supondría de las "inmorales" sociedades especuladoras $^{679}$ que se dedicaban a gestionar la sustitución de los reclutas:

"Una de las grandes razones quo se dan en apoyo de la sustitución, es quo se cortan las carreras a que se halla dedicada la juventud; pues al que le toca la suerte de soldado, interrumpe sus estudios, con lo cual se trastornan las ideas quo la familia había concebido; tal vez se corta un enlace; y por ultimo, que muchos ciudadanos pueden ser mas útiles al Estado en cualquiera otra posición quo en el servicio de las armas. Yo creo quo un ciudadano es mas útil en el servicio de las armas quo en otra cualquiera carrera del Estado, porque la carrera militar enseña dos cocas importantísimas, quo son: a obedecer y a mandar, lo cual dispone al hombre a todos los grados de la sociedad, y le da una educación moral interesantísima, quo por desgracia escasea bastante entre nosotros ${ }^{\prime 680}$.

En cuanto a la redención y la sustitución, las críticas incidieron en la injusticia social que la primera suponía y en la conversión del

\footnotetext{
679 "Una consecuencia natural del reclutamiento por sorteo y del sistema de las redenciones fue el auge de las empresas capitalistas que se beneficiaron de esta situación. Tales fueron los bancos y las sociedades financieras que prestaban dinero por las redenciones a unos intereses que iban del 36 al 60\% anual. Lo mismo ocurría con las agencias que proporcionaban sustitutos. Sin embargo, las más importantes fueron las sociedades de seguros contra las quintas. En cualquier momento, durante los primeros años de la vida de su hijo, cualquier familia podía contratar contra la posibilidad de que aquél fuese llamado a filas. La prima variaba naturalmente conforme a la fecha de contratación y al tipo de riesgo a cubrir con la póliza. Sólo las pólizas más caras [...] garantizaban la redención. Las más baratas daban al asegurado la oportunidad de participar en otro sorteo en el que los ganadores quedaban exentos y los perdedores recibían premios de consolación.

Estos sistemas de seguros gozaron de gran popularidad a principios de los años sesenta. Las sociedades fueron fundadas por miembros de la aristocracia y financieros, incluso en algunas ocasiones por funcionarios o eclesiásticos" (HEADRICK, D. R., Ejército y política en España (1866-1898), p. 102).

680 Discurso del Sr. Roca de Togores, Diario de Sesiones de las Cortes, no 65, 12/03/1851, p. 1269.
} 
Estado en una gigantesca empresa de sustitución, además de las desigualdades territoriales que se originarían en cuanto a la aportación de soldados que las distintas provincias españolas harían al Ejército en función de su nivel de riqueza, y que podrían contribuir en el futuro a la expansión del socialismo:

"Veríamos a las Provincias Vascongadas y a la industriosa Cataluña, que por cierto está en posesión de no pagar nunca el cupo de hombres quo la corresponde, no dar ni un soldado para las armas, y los Ejércitos se compondrían en su totalidad de los desgraciados manchegos, de los pobres castellanos, de los desventurados murcianos, de los malhadados andaluces, $y$ algunos que otros extremeños y de otras provincias. [...]. Si la redención se admite, lo quo sucederá es quo los pueblos de provincias acomodadas se eximirán del servicio militar, y vendrán a, cubrir las bajas del Ejército solamente los de las provincias pobres, y se desarrollara entonces en el Ejército el espíritu de que el servicio militar, que hasta ahora ha sido odioso, esta reservado para los pobres y nada mas que para los pobres. Entonces sí que vendremos al verdadero socialismo, pero socialismo armado, regimentado, al cual no será posible resistir"681.

Buena parte de los diputados defensores de la redención criticaron en cambio la sustitución, por excluirse mutuamente ${ }^{682}$ y por considerar que hacía el juego a las compañías de especuladores que, como mercaderes de hombres, tanto daño causaban por su tráfico de

681 Discurso del Sr. Roca de Togores, Diario de Sesiones de las Cortes, no 65, $12 / 03 / 1851$, p. 1270.

682 "¿Cual sería, señores, el efecto de establecer al mismo tiempo la sustitución y la redención? [...]. Concediéndose a los quintos do 1850 la sustitución y la redención, el efecto inmediato de la redención es la baja de los sustitutos, porque la redención tiene un número fijo en la cantidad de 6.000 rs., tiene un beneficio inmenso, quo es el de quitar la responsabilidad que pesa sobre el sustituto dos años, y el beneficio de volver de un solo golpe la paz y la tranquilidad a las familias. Por de pronto tendríamos que la sustitución bajaría, porque no podría haber sustituto alguno a quien no diera mas de 6.000 rs., y porque nadie querría tener una espada pendiente sobre su cabeza, si aquel mozo que contrataba para sustituirle no quería cumplir" (Discurso del Sr. Conde de Fabraquer, Diario de Sesiones de las Cortes, n ${ }^{\circ}$ 70, 18/03/1851, p. 1405). 
reclutas $^{683}$. Otros diputados, sin embargo, defendieron la sustitución como un derecho adquirido por la población y por considerarla el único medio que tendían los más humildes para librarse del servicio de armas, ya que la redención, en realidad no un derecho sino una gracia concedida por el Gobierno, resultaba inalcanzable para sus modestas economías ${ }^{684}$. También hubo diputados que defendieron la redención sólo en circunstancias excepcionales relacionadas con las dificultades económicas del Estado, mostrándose en contra de la misma en los años "normales". A ello se unen las dudas sobre la utilización del dinero recaudado en financiar los enganches de voluntarios por parte del Gobierno o su empleo en otros menesteres ${ }^{685}$.

Tampoco faltaron las críticas progresistas a la desigualdad y la falta de homogeneidad nacional que suponía que la Provincias Vascongadas no contribuyesen con hombres al mantenimiento del Ejército:

"Señores, siempre que se trata de las Provincial Vascongadas, bien para los tributos, bien para lo que, a mi modo de ver, es más importante; pues lo es el tener que ir en caso necesario a arrostrar la muerte, y no hay ley, rigurosamente hablando, quo pueda establecerlo cuando es por otro; siempre, repito, quo se trata de esto se ha de prescindir de las Provincial Vascongadas, y el cupo que a ellas lee toca no lo han de dar, lo quo hace que refluya en el contingente de las demás; y es muy duro que así sea cuando se trata de arrancar brazos a la agricultura y a las artes, de arrebatar del seno do su familia a un joven, porque en otras Provincial haya un abuso quo obligue a las demás a cubrir sus cupos. Esto, señores, no se puede pasar; y yo por mi parte siempre he hecho y hago aquí esa

683 Discurso del Sr. Conde de Fabraquer, Diario de Sesiones de las Cortes, no 69, 17/03/1851, p. 1887.

684 Discurso del Sr. Félix García, Diario de Sesiones de las Cortes, no 69, 17/03/1851, p. 1407.

685 Discurso del Sr. Mata y Alós, Diario de Sesiones de las Cortes, no 71, 17/03/1851, pp. 1426-1432. 
protesta, y la continuaré haciendo hasta quo ese abuso se remedie. Señores, siempre se alegan log fueros; pero ya otras veces se ha demostrado, y se puede demostrar, que respecto at servicio de las armas, ya que de tributos de otro género no tratamos ahora, no hay tales fueros [...]. Se dice, sin que yo lo crea, quo los vizcaínos, alaveses y guipuzcoanos, son opuestos al servicio de las armas; pues bien: justamente ahora se presenta una ley, en virtud de la cual pueden redimirse pagando su dinero como todos los demás. Háganlo en masa: acoja esto el Congreso; y si los pueblos vascongados no quieren servir, y prefieren redimirse de ese servicio pagando su dinero, que lo paguen como los demás"686.

El partido Moderado en el gobierno, de manos del diputado Conde de Fabraquer y del ministro de la Gobernación, justificó la convocatoria de la quinta de 1851 en función del proyecto de ley del Senado por contar con tres grandes ventajas ${ }^{687}$ en tres aspectos: el alistamiento de los jóvenes a partir de los veinte años ${ }^{688}$, y no de los dieciocho como se hacía en función de la Ley de 1837; el Ilamamiento de un contingente fijo anual de al menos 25.000 hombres, que además no significaba incumplir el precepto constitucional que otorgaba al Gobierno la competencia en el establecimiento del contingente militar en función de las necesidades del país; y la posibilidad de la sustitución y la redención a cambio de 6.000 reales,

686 Discurso del Sr. Sánchez Silva, Diario de Sesiones de las Cortes, no 72, 21/03/1851, pp. 1448 y 1451.

687 "[...] en primer lugar, mas equidad, mas justicia en la base del repartimiento; después la facultad de poder redimir la suerte; después la irresponsabilidad, el haberse quitado el aliciente que había en la declaración de prófugos para libertarse; en fin, señores, enumerar las. ventajas del proyecto del Senado sobre la ley vigente, seria tarea muy prolija" (Discurso del Sr. Ministro de la Gobernación, Diario de Sesiones de las Cortes, no 65, 12/03/1851, p. 1282).

688 "díganlo per mí el llanto de tantos padres de familia, quo ven arrancárseles de sus brazos los hijos apenas formados; díganlo per mí esas espantosas tablas de mortalidad quo se ven en los hospitales militares, donde jóvenes que apenas han podido recibir todo el desarrollo de su organización, van a morir tísicos y consumidos, sin poder servir a su Patria, y aumentando la aflicción y el desconsuelo de sus familias. A la edad de 20 años, en casi todas las provincias de España ha adquirido ya el cuerpo de los jóvenes su desarrollo natural, y al mismo tiempo se encuentra mucha ventaja en las tallas, porque es constante quo los jóvenes están creciendo aun hasta más de la edad de 20 años" (Discurso del Sr. Conde de Fabraquer, Diario de Sesiones de las Cortes, no 65, 12/03/1851, p. 1276). 
teniendo como grandes ventajas esta última el suponer el fin de los fraudes y de las compañías de especuladores, impedir la pérdida de los principales brazos y los más cualificados profesionales y estudiantes del país, así como su carácter democrático ${ }^{689}$, además de suponer una realidad que históricamente se había aceptado en búsqueda del beneficio del país:

"[...] en todas las épocas ha existido un medio expedito y franco para que ciertas y determinadas clases, pare que ciertos $y$ determinados hombres, que pueden prestar en su círculo y en su órbita grandes servicios y ventajas al país, se liberten del servicio militar ${ }^{\prime 690}$.

Para evitar posibles estallidos sociales ante el descontento que generaba la redención, desde el hemiciclo se solicitó que, para aplacar el impulso socialista, sería necesario dedicar las rentas obtenidas mediante la redención para financiar un empleo o una salida económica para los reclutas con menos recursos en el momento de su licenciamiento y el regreso a su hogar tras años de servicio $^{691}$.

También se aprobó, en ese mismo año de 1851, un reglamento que establecía las indisposiciones físicas o las enfermedades que

\footnotetext{
689 "Se dirá también contra la redención quo es una ley por la que van á ir al servicio de las armas solamente los pobres; señores, precisamente en esta ley lo quo me satisface de ella es quo es ley puramente democrática, que es igual para todos; lo mismo coge al hijo del Duque y del poderoso quo al más miserable, quo al último español; es verdad quo el uno podrá paga $r$ y el otro no; pero de esto, á quien habremos de culpar? Cúlpese a la naturaleza humana, a la desigualdad en todo, que es desigual en las estaciones, en los tiempos, en los terrenos, en la figura do los hombres, en su capacidad y en todo; y si establecemos ese principio de que la ley no es igual porque no todos tendrán dinero para redimirse, empocemos a dar por el pie a todas las cosas, á todas las instituciones nuestras" (Discurso del Sr. Conde de Fabraquer, Diario de Sesiones de las Cortes, no 65, 12/03/1851, p. 1276).

690 Discurso del Sr. Hurtado, Diario de Sesiones de las Cortes, no 67, 14/03/1851, p. 1330).

${ }^{691}$ Discurso del Sr. Coello, Diario de Sesiones de las Cortes, no 67, 14/03/1851, p. 1337).
} 
eximían a un mozo de la realización del servicio militar ${ }^{692}$. Se trata de un largo y meticuloso documento que especifica, clasificándolas en dos grupos, los distintos problemas físicos que impedían la realización del servicio, así como los trámites a realizar y las prevenciones que se tomaron para evitar fraudes. Tales enfermedades o defectos físicos habían de ser reconocidos explícitamente por un facultativo

"[...] atendiendo a la apreciación pericial que hicieren de lo que resulte del reconocimiento $y$ de un expediente justificativo de su efectiva existencia, de su índole y naturaleza, de su antigüedad o rebeldía, de su estado de permanencia o de cronicidad, o de su cualidad habitual o periódica según los casos ${ }^{1693}$.

Dicho expediente justificativo debía ser instruido de oficio por parte del alcalde de la localidad de residencia del interesado, y contendría la siguiente documentación:

Una instancia dirigida al alcalde solicitando la instrucción y entrega del expediente justificativo de inutilidad "[...] en la que manifestarán el defecto o enfermedad que crean tener o padecer desde que tiempo y porqué causas, el facultativo o facultativos que los asistan o hubieren asistido, y el nombre y circunstancias de dos testigos que puedan declarar la certeza de la existencia o padecimiento de aquella $[. . .]^{\prime 694}$.

Una declaración del facultativo o facultativos que hubiesen asistido al presunto enfermo que acredite la existencia y las condiciones de su inutilidad ${ }^{695}$. El reconocimiento médico sería

692 Reglamento para la declaración de las exenciones físicas del servicio militar, Gaceta núm. 6188 de 23/06/1851. En adelante Reglamento, Gaceta núm. 6188 de 23/06/1851.

${ }^{693}$ Reglamento, Gaceta núm. 6188 de 23/06/1851, art. 3.

${ }^{694}$ Reglamento, Gaceta núm. 6188 de 23/06/1851, art. 4.

695 "La declaración pericial de los facultativos expresará clara y terminantemente la época en que se encargaron de la asistencia del pretendido o presunto inútil, el defecto, achaque o enfermedad que tiene o padece, sus causas, invasión, síntomas, 
efectuado por médicos titulares de los establecimientos de beneficencia de los pueblos respectivos y, en ausencia de ellos, por aquellos que designase el Ayuntamiento de entre los residentes en su localidad, preferentemente jubilados de los cuerpos de profesores castrenses, de la armada, o del servicio de sanidad militar ${ }^{696}$.

Una declaración de seis testigos, cuatro de ellos jóvenes incluidos en el sorteo, elegidos por el alcalde y el síndico del Ayuntamiento, a quienes pudiese constar la certeza del defecto físico ${ }^{697}$.

Informe o certificación, si se estimase conveniente, del párroco respectivo acreditando las condiciones físicas del presunto impedido ${ }^{698}$.

curso, estado actual y medios empleados para su curación o remedio, deduciendo de todo la verdadera existencia y diagnóstico de aquélla y las condiciones de su antigüedad o de cronicidad o de su cualidad de habitual o periódica, o por el contrario, la falta de estas condiciones; y concluirá por indicar los hechos y circunstancias que en su juicio deban justificarse principalmente por las declaraciones de los testigos para la mayor comprobación de la pretendida o presunta inutilidad de aquellos" (Reglamento, Gaceta núm. 6188 de 23/06/1851, art. 4).

${ }^{696}$ Reglamento, Gaceta núm. 6188 de 23/06/1851, art. 5.

697 "Para la declaración de los testigos se deberá acreditar, además de los hechos y circunstancias que indiquen como de conveniente o necesaria justificación los facultativos de asistencia del pretendido o presunto inútil:

10.- Desde cuando lo conocen, y que trato o resoluciones han tenido o tienen con él.

20.- Cual haya sido en su concepto el estado habitual de su salud.

30.- Que defectos, achaques o enfermedades hayan oído o les conste que ha tenido o padecido anteriormente.

4.- Si saben que padece de a que alega o presume que tiene, o de otra, desde cuando, a que causas se atribuye, si adolece de ella con más o menos frecuencia o periodicidad, o de un modo continuo, permanente o habitual, y si sus padres, abuelos o hermanos han padecido o muerto de la misma o de alguna otra de igual o semejante naturaleza.

50.- Por último, si les consta la mayor o menor dificultad, imperfección o imposibilidad absoluta que tiene para dedicarse al desempeño o quehaceres de su oficio o profesión, o para ejercer algunos actos, funciones o movimientos determinados" (Reglamento, Gaceta núm. 6188 de 23/06/1851, art. 4).

698 "El informe o certificación del párroco respectivo, cuando se le pidiere, se limitará a manifestar el juicio que hubiere formado acerca de la falta o del mayor o menor grado de inteligencia del pretendido o presunto inútil, del estado normal o de alteración de sus funciones mentales, o de la falta, vicio o defecto del sentido de su oído, o del uso de la palabra" (Reglamento, Gaceta núm. 6188 de 23/06/1851, art. 4). 
Un informe elaborado por el síndico personero donde constase todo lo relacionado con la instrucción del expediente, los testigos y la certeza de los hechos narrados.

Un dictamen del alcalde justificando los motivos de su decisión ${ }^{699}$.

Un nuevo reconocimiento médico se realizaría para todos los reclutas, titulares, suplentes, sustitutos y prófugos capturados, en el momento de su ingreso en la caja aunque no alegasen ningún tipo de inutilidad física. Dicho examen médico lo realizarán dos facultativos, uno nombrado por el consejo provincial y otro por el comandante general militar de la provincia respectiva, a los que se uniría un tercero en el supuesto de pareceres contrapuestos entre los dos primeros $^{700}$. Su actuación quedó completamente regulada por el artículo 7, que estableció la obligatoriedad de "[...] practicar un detenido y escrupuloso reconocimiento del estado actual de todos sus órganos y funciones [de los mozos], por los medios de exploración

\footnotetext{
${ }^{699}$ Reglamento, Gaceta núm. 6188 de 23/06/1851, art. 4.

700 "La elección de los facultativos de nombramiento de los Consejos Provinciales, recaerá con preferencia entre los de número o efectivo de los establecimientos públicos y de beneficencia Provinciales y demás empleados con sueldo pagado de los fondos del presupuesto Provincial, y entre los retirados, jubilados, pensionados $\mathrm{u}$ honorarios de los antiguos cuerpos de profesores castrenses de la Armada o del actual de sanidad militar que se presten a desempeñar este servicio; y a falta de unos y otros, entre los civiles que no correspondan a ninguna de estas clases procurando en cuanto sea posible que sean a un tiempo médicos y cirujanos, distintos cada día cuanto más lo permitan las circunstancias de la población y el número disponible de los de unas y otras clases, y nombrados con la única anticipación que fuere necesaria.

Respecto a la elección de los facultativos del nombramiento del Comandante general militar de la provincia respectiva, esta Autoridad designará diariamente el profesor del cuerpo de sanidad militar que deba concurrir a los reconocimientos que ocurran de los dos que durante las operaciones del reemplazo tendrá a sus órdenes inmediatas con este objeto; y para la asistencia de la caja de quintos; nombrados por el Capitán general del distrito de entre los destinados en los cuerpos del Ejército y hospitales militares existentes en el mismo, y a falta de los necesarios de los unos y los otros, de entre los cesantes por excedentes y retirados o jubilados de los antiguos cuerpos de profesores castrenses y de la Armada, o del actual de sanidad militar, a quienes en tal caso se les considerará como empleados en Comisión activa del servicio mientras desempeñan dicho cargo" (Reglamento, Gaceta núm. 6188 de 23/06/1851, art. 6).
} 
que sean convenientes y aconseje emplear la ciencia o lo sugiera su experiencia y previsión"701.

En función de tal examen, los facultativos declararían al mozo apto para el servicio por no padecer ninguna enfermedad o defecto físico contenidos en el reglamento; no apto si padeciese una o más de las enfermedades recogidas en el mismo; o pendiente de la presentación de un expediente justificativo de su aptitud o inutilidad y de los resultados de una nueva revisión médica. Asimismo, los facultativos encargados de practicar los reconocimientos deberían emitir un certificado declarando la aptitud o inutilidad del mozo. Tal documento debería contener el nombre y empleo del médico, qué autoridad le ha nombrado, el nombre del joven reconocido, el cupo del pueblo al que pertenezca, el número que hubiese sacado en el sorteo, si hubiese alegado inutilidad física para la exención, si hubiese presentado expediente justificativo de su inutilidad, los resultados del reconocimiento, la denominación técnica del defecto o enfermedad y sus síntomas y la calificación de útil o inútil para el servicio. También se previno a estos facultativos sobre su responsabilidad en cuanto a la falta de observancia del reglamento y a la exactitud y veracidad de los hechos que declaren y verifiquen ${ }^{702}$. Sin embargo, nunca

"[...] se procederá a hacer efectiva la responsabilidad de unos y otros facultativos sin que en vista del correspondiente expediente de declaración de aptitud o de inutilidad para el servicio militar, y de los resultados de los demás medios de comprobación que crean convenientes, preceda el dictamen fundado y afirmativo de la Academia médico-quirúrgica del distrito, respecto a los facultativos civiles, y del Director y junta consultiva del cuerpo de sanidad militar respecto a los profesores del mismo"m03.

\footnotetext{
701 Reglamento, Gaceta núm. 6188 de 23/06/1851, art. 7.

702 Reglamento, Gaceta núm. 6188 de 23/06/1851, arts. 7, 9 y 10.

703 Reglamento, Gaceta núm. 6188 de 23/06/1851, art. 11.
} 
Además de regular la actuación de los facultativos médicos, la mayor parte del reglamento recoge un cuadro donde se señalan el conjunto de enfermedades, defectos o problemas físicos que se consideraron eximentes del servicio militar. Estas dolencias fueron clasificadas en dos clases y se subdividieron en órdenes:

Primera: "Causas de inutilidad que deben declararse por los facultativos, atendiendo solo a lo que resulte del acto del reconocimiento" ${ }^{704}$, que a su vez se dividieron en ocho órdenes:

Orden $1^{\circ}$.- defectos físicos y enfermedades correspondientes al sistema cerebro-espinal y de los nervios.

Orden $2^{\circ}$.- defectos físicos y enfermedades correspondientes al aparato de la visión.

Orden $3^{\circ}$.- defectos físicos y enfermedades correspondientes al órgano del oído.

Orden $4^{\circ}$.- defectos físicos y enfermedades correspondientes al aparato digestivo y sus anejos.

Orden 50.- defectos físicos y enfermedades correspondientes a los aparatos respiratorio y circulatorio y sus anejos.

Orden $6^{\circ}$.- defectos físicos y enfermedades correspondientes al aparato genito-urinario.

Orden 70.- defectos físicos y enfermedades correspondientes al sistema cutáneo y celular.

Orden $8^{\circ}$.- defectos físicos y enfermedades correspondientes al aparato locomotor.

Segunda: "causas de inutilidad que se declararán por los facultativos atendiendo a lo que resulte del acto de reconocimiento y

\footnotetext{
704 "Cuadro de los defectos físicos y enfermedades que inutilizan para el servicio militar a los mozos sorteados, quintos, suplentes, sustitutos y prófugos en los casos y con las condiciones que en él se expresan" (Reglamento, Gaceta núm. 6188 de 23/06/1851).
} 
de un expediente justificativo de su efectiva existencia, de su índole y naturaleza, de su antigüedad o rebeldía, de su estado de permanencia o de cronicidad, o de su cualidad de habitual o periódica según los casos"705, en este caso dividida en nueve órdenes:

Orden 10.- defectos físicos y enfermedades correspondientes al sistema cerebro-espinal y de los nervios.

Orden $2^{\circ}$.- defectos físicos y enfermedades correspondientes al aparato de la visión.

Orden $3^{\circ}$.- defectos físicos y enfermedades correspondientes al órgano del oído.

Orden $4^{\circ}$. - defectos físicos y enfermedades correspondientes al aparato digestivo y sus anejos.

Orden $5^{\circ}$.- defectos físicos y enfermedades correspondientes a los aparatos respiratorio y circulatorio y sus anejos.

Orden 60.- defectos físicos y enfermedades correspondientes al aparato genito-urinario.

Orden 70.- defectos físicos y enfermedades correspondientes al sistema cutáneo y celular.

Orden $8^{\circ}$.- defectos físicos y enfermedades correspondientes al sistema linfático y de los ganglios de este nombre.

Orden $99^{\circ}$.- defectos físicos y enfermedades correspondientes al aparato locomotor.

Ese mismo año de 1851, tal y como hemos señalado en el capítulo de exenciones, se aprobó un Real Decreto que fijó la redención en metálico en la cantidad de 6.000 reales a ingresar en el

\footnotetext{
705 "Cuadro de los defectos físicos y enfermedades que inutilizan para el servicio militar a los mozos sorteados, quintos, suplentes, sustitutos y prófugos en los casos y con las condiciones que en él se expresan", (Reglamento, Gaceta núm. 6188 de 23/06/1851).
} 
Banco de San Fernando, debiéndose utilizar ese montante para la contratación de voluntarios ${ }^{706}$.

Y por último, y aunque no se refiere específicamente al tema del reclutamiento, una disposición legal aprobada en noviembre de $1852^{707}$ muestra un gran interés para nuestra temática al regular la cuestión de la extranjería, los derechos y deberes de los foráneos que residiesen en territorio español. En materia de reclutamiento, el texto se limitó a señalar lo siguiente:

"[...] así a los domiciliados como a los transeúntes y sus hijos, cuando no hayan optado por la nacionalidad española, estarán exentos del servicio militar. Esta excepción no alcanza a los nietos cuando sus padres han nacido ya en territorio español aunque conserven la nacionalidad extranjera'm08.

${ }^{706}$ Real Decreto de 2 de Julio de 1851, dictando instrucciones para la aplicación de los artículos del Proyecto de Ley aprobado por S.M. el 18 de junio de 1851, Gaceta núm. 6188 de 23/06/1851.

707 Real Decreto de 17 de Noviembre de 1852, Gaceta de Madrid, no 245, de 19/11/1852.

708 Real Decreto de 17 de Noviembre de 1852, Gaceta de Madrid, no 245, de 19/11/1852. 


\section{5.- Una norma progresista con apoyo moderado: La Ley de 1856}

Tan sólo seis años después de ser discutido y sancionado por el Senado el Proyecto de ley de reemplazos de 1850, se aprobó un nuevo texto legislativo sobre la materia, la Ley de reemplazos de 30 de enero de $1856^{709}$, elaborado por un Gobierno progresista ${ }^{710}$ con el apoyo de los moderados. El proyecto logró su aprobación pese a las protestas y motines antiquintas ocurridos durante el Bienio Progresista $(1854-1856)^{711}$ y al largo debate en el seno del Parlamento, con duras críticas vertidas por las nuevas formaciones políticas que entraron en las Cortes en 1854, demócratas y republicanos, que enarbolaban como una de sus banderas ideológicas y programáticas la abolición de la contribución de sangre:

"[...] la palabra democracia, que parece no se quiere entender, que de día en día trata de oscurecerse, lo que quiere decir en este capitulo que trata de la contribución de sangre, es que la democracia no quiere quintas, es que las detesta, es que las condena; es que la, democracia, más consecuente que parte de los individuos del progreso, no las admite, ni las admitirá jamás, ni en la oposición ni en el poder ${ }^{712 "}$.

Lógicamente, la intención del proyecto era completar y mejorar el Proyecto de ley de 1850, y así lo demuestra la extrema

\footnotetext{
709 Ley de Reemplazos de 30 de enero de 1856, Gaceta núm. 1125 de 02/02/1856. En adelante, Ley de Reemplazos de 30 de enero de 1856.

710 "[...] El sistema de reclutamiento se reformó en 1837, 1850, 1856 y 1867. Las leyes que tuvieron mayor vigencia -las de 1837 y 1856 - fueron aprobadas por parlamentos de mayoría progresista, adalides desde entonces del reformismo militar, no sólo en el periodo isabelino, sino también durante el Sexenio y la Restauración" PUELL DE LA VILLA, F., Historia del Ejército en España, p. 84 y 85.

${ }^{711}$ FEIJÓo GÓMEZ, A., Quintas y protesta social en el siglo XIX español, p. 216.

712 Discurso del Sr. Ruiz Pons, Diario de sesiones de las Cortes, no 281, 29/10/1855, p. 7821.
} 
minuciosidad con que se regularon todas las operaciones relacionadas con el reclutamiento ${ }^{713}$. Otro objetivo era "[...] calmar los ánimos con una declaración de intenciones que pretendía utilizar la quinta sólo cuando el reemplazo voluntario no fuese posible"714.

Se trata, por tanto, de un texto legal que presenta importantes semejanzas respecto al Proyecto de ley de 1850, aunque aportando novedades de corte progresista ${ }^{715}$.

Para realizar el seguimiento del calado de la ley en la opinión pública, hemos seleccionado como periódicos a analizar La Esperanza ${ }^{716}$ y La Discusión ${ }^{717}$. El primero de ellos prácticamente se

713 "[La Ley de 1856 es] una de las más importantes del siglo XIX en España, ya que, con diversas modificaciones, constituyó el núcleo esencial del sistema español de reclutamiento en cinco décadas, las comprendidas entre su aprobación en 1856 y la publicación de la ley de 1896", FERNÁNDEZ RODRÍGUEZ, M. y MARTÍNEZ PEÑAS, L., "La problemática social a través de la legislación de reclutamiento: exenciones, sustitución y redención en metálico", p. 323.

${ }^{714}$ FEIJÓO GÓMEZ, A., Quintas y protesta social en el siglo XIX español, p. 216.

715 "Su mayor defecto, como sucedió en la Ordenanza de 1837 y el Proyecto de 1851 , consistió en que se convirtió en un Reglamento de reemplazo más que una Ley, aunque mejoró las anteriores sustancialmente, al incluir en su primer capítulo una serie de disposiciones generales sobre los afectados por la Ley, la voluntad del gobierno de cubrir el cupo de voluntarios, y contempló, por vez primera, una recompensa para los ciudadanos obligados a prestar servicio" (FEIJóo GÓMEZ, A., Quintas y protesta social en el siglo XIX español, p. 216).

716 "Con el subtítulo de "Periódico monárquico", es la más importante cabecera de la prensa absolutista española del siglo XIX, como órgano oficioso del carlismo. Con una larga vida, nace tras ser vencidas las tropas carlistas con el "abrazo" de Vergara, el 10 de octubre de 1844, en pleno proceso de incorporación de amplios sectores ultracatólicos a la legalidad isabelina emanada de la Constitución de 1845, al ejército, a la administración y al propio Partido Moderado, en ese momento en el poder, pero sin renunciar a sus principios ideológicos como combatiente del régimen liberal y parlamentario.

Se trata de un diario de la tarde (excepto domingos y festivos) que prácticamente se publicará sin interrupción, y desaparecerá, junto al resto de la prensa carlista y la cantonal tras el golpe de Estado del general Manuel Pavía y la nueva asunción del poder del general Francisco Serrano, con el que se finiquita el periodo revolucionario abierto el 18 de septiembre de 1868 y abre la puerta a la restauración borbónica un año después.

En 1850 y durante casi un quinquenio, La esperanza llegará incluso a ocupar el primer puesto en la circulación de la prensa de la época, y competirá como periódico reaccionario con El católico (1840-1857), aunque éste se centre más en cuestiones religiosas. Durante el bienio progresista, La esperanza tendrá que competir como principal ariete de la extrema derecha con una publicación más fanática como La regeneración (1855-1873) y lo hará también con El pensamiento español (1860-1873)", (http://www.bne.es/es/Catalogos/HemerotecaDigital).

717 "Periódico fundado y dirigido en sus primeros años por el célebre jurisconsulto y político José María Rivero [...] quien desde 1851 venía presidiendo el Partido 
limitó a reflejar las novedades y el texto íntegro de la nueva ley y de los debates en Cortes, alabando las cualidades militares del pueblo español y estando más enfrascado en los asuntos religiosos que en los propiamente militares, sin inmiscuirse en su discusión, ni a favor

Democrático, fundando en 1848 de una escisión del Partido Progresista. Al mismo se integrarán como redactores, colaboradores y articulistas los principales intelectuales, políticos y periodistas de la primera generación de demócratas y republicanos españoles. Aparece con el subtítulo "diario democrático", que mantendrá prácticamente inalterable a lo largo de su existencia, el dos de marzo de 1856 , tendiendo un puente entre la izquierda del antiguo partido progresista y el demócrata recién legalizado durante el bienio.

Sus primeras polémicas serán contra el jacobinismo de La soberanía nacional, que dos años antes había fundado el fuorierista Sixto Cámara (1825-1859). Sin renunciar al programa antidinástico del partido de 1849 no hará cuestión fundamental la forma de gobierno, y gracias a la moderación y habilidad de Rivero, a su postura transigente y contemporizadora, sobrevive al golpe contrarrevolucionario de 1856. [...]

Tras entrar Francisco Pi y Margall en su redacción en julio de 1857, polemizará con El pueblo, el periódico que en 1860 funda Eugenio García Rico y que más tarde dirigirá Manuel Gómez Marín, como portavoz de los escindidos republicanos unitarios. Cuando Pi releve a Rivero en la dirección el uno de abril de 1864, será portavoz del ala socialista y federal del partido, que se enfrentará a la individualista que representa La democracia que ese mismo año funda Emilio Castelar.

Al final del reinado isabelino, el antiguo secretario de Sixto Cámara, Bernardo García se hará cargo de la propiedad y dirección del diario, hasta que el 21 de junio de 1866 publica su último número de su primera época, al ser suspendido como los demás títulos demócratas y republicanos como consecuencia de la sublevación del Cuartel de San Gil.

[...] Estructurado en secciones, incluía el editorial diario y los artículos de fondo de carácter político y doctrinal, revista de prensa, crónica parlamentaria, noticias del extranjero y de provincias, que serán elaboradas a partir de despachos telegráficos, folletín con novelas de corte histórico y político, gacetilla de la capital, cotizaciones de las bolsas, observaciones meteorológicas, noticias de alcance, espectáculos y, al final, una abundante y vistosa publicidad comercial. Llegará a tener imprenta propia y empresa editorial.

Tras el triunfo de la septembrina, reaparece el seis de octubre de 1868 , iniciando su segunda época, en un momento en que los demócratas se dividirán entre los denominados "cimbrios" o filoprogresistas, que se agruparán en el Partido Radical [...] desde el que alcanzarán las altas magistraturas del primer Estado democrático español, y los republicanos y federalistas.

Como periódico republicano sin más, La discusión ejercerá una gran influencia durante el sexenio. [...]. En noviembre de 1870 forma parte de la pléyade de periódicos antiamadeistas madrileños, que suman casi una treintena, y durante la segunda Asamblea Federal de 1871 será el más destacado baluarte del republicanismo benévolo, frente al intransigente representado por La igualdad. [...] La discusión publicará el último número de su segunda época el 30 de diciembre de 1874. Iniciará la tercera a partir del 14 de junio de 1879, [...] plenamente adscrito al republicanismo federal [...], hasta que publique su último número el 11 de noviembre de 1887, habiendo mantenido cierta irregularidad en su aparición en sus últimos meses de vida" (http://www.bne.es/es/Catalogos/HemerotecaDigital). 
ni en contra ${ }^{718}$, mientras el segundo, a pesar de no ver la luz hasta poco después de la aprobación de la norma, mostró una actitud beligerante y contraria a las quintas, e incluso rechazó la existencia de un Ejército permanente para España, innecesario ante el histórico y suficientemente demostrado heroísmo del pueblo español y la mejora que supondría para el crecimiento de la economía nacional:

"La sesión de ayer en el Congreso fue importantísima. Pocas veces hemos visto mayor número de diputados en sus asientos, mayor elevación en el debate, y más profunda la atención de la Cámara. Verdad es que pocas veces han terciado en la discusión oradores tan distinguidos, y ha sido el asunto tan importante, tan trascendental bajo todos conceptos.

Entrando en la orden del día, se abrió discusión sobre el proyecto relativo al aumento de la fuerza del ejército activo hasta 100.000 hombres, y nuestro querido amigo el señor don Nicolás María Rivero, pidió la palabra en contra.

718 A modo de ejemplo utilizamos este fragmento: "La comisión parlamentaria encargada de informar sobre el proyecto de reemplazos, ha dado su dictamen, en un todo conforme con el gobierno. Según la nueva ley, la fuerza del ejército se reemplazará: primero, con los mozos de veinte á treinta años que sienten plaza de soldado, y que se enganchen ó reenganchen voluntariamente, mediante retribución pecuniaria; y segundo, con los mozos de veinte, veinte y uno y veinte y dos años que designa la suerte de entre los que fuesen alistados anualmente. Los mozos que sentasen plaza ó se reenganchen, quedarán sujetos á sorteo cuando les corresponda por la edad, $v$ sí les tocare la suerte, permanecerán en las filas cubriendo plaza por el cupo de su respectivo pueblo, sin derecho á la retribución. Fuera de este último caso, el Estado les abonará seis mil reales al terminar los ocho años de su empeño, o cuando se inutilizasen en acción de guerra.

En cuanto á los mozos á quienes hubiese cabido la suerte de soldados en las quintas, la retribución será de dos mil reales, en los mismos términos. Todos los años habrá un alistamiento y un sorteo, en los que se comprenderán: $1 .^{\circ}$, los mozos que tengan veinte años de edad y no hayan cumplido veinte y uno el día 30 de abril inclusive del año en que se verifica el alistamiento; y $2 .{ }^{\circ}$, los mozos que, teniendo veinte y un años, y sin haber cumplido veinte y cinco en el referido día 30 de abril, no fueran comprendidos por cualquier motivo en el alistamiento de alguno de los años anteriores. La duración del servicio será de ocho años, contados desde el dia de la admisión definitiva de los mozos en la caja de la respectiva provincia, y el alistamiento alcanzará á los mozos que tengan la edad expresada, aunque sean casados ó viudos con hijos. La sustitución del servicio militar continúa autorizada.

En el primer domingo del mes de abril se hará anualmente el sorteo general en todos los pueblos, sin detenerlo por recursos que se hallen pendientes acerca del alistamiento, ni por ningún otro motivo; y el acto del llamamiento y declaración da soldados empezará el primer día festivo del mes de abril más próximo á la terminación del sorteo" (La Esperanza, 25/10/1855, no 3380, p. 2). 
La Cámara guardó respetuoso silencio; todos fijaron sus miradas en el diputado demócrata, porque en todos estaba la esperanza, que no salió defraudada, de oír un discurso que correspondiera á la alteza del asunto, á la fama del orador, y á las proporciones que debería tomar el debate. [...].

El señor Rivero se opuso al proyecto que se discutía por considerarlo inútil, inoportuno y peligroso, tres cargos que probó y justificó fácilmente en su notable discurso. $Y$ decimos fácilmente, porque ésos cargos saltan á la vista aun del menos avisado. La fuerza de nuestro ejército activo es hoy, en circunstancias nórmales, de 84,000 hombres. El gobierno cree que estamos avocados (sic) a grandes sucesos; que lá guerra de Italia puede estenderse (sic) por toda Europa; que nuestra neutralidad no basta para ponernos á cubierto de la ambición de estranjero (sic) monarca, y en atención á lodo esto, pido un ejército activo de 100.000 hombres, es decir, 16.000 más de los que hoy tiene. La cifra, bien mirado, es casi insignificante; pero gastos aparte, ¿para qué necesita España de ejércitos tan nutridos en caso de una guerra internacional? ¿Se ha olvidado de nuestra historia? decía muy bien el señor Rivero ¿Se ha dado al olvido que esta nación se ha levantado como un solo hombre siempre que se ha querido arrojar sobro su cuello la coyunda extranjera'? No, y esto podemos decirlo á la faz del mundo para [...] las generaciones venideras: España, para defender su territorio, su sagrada inmunidad y su nombre, ese nombre escrito con caracteres de oro en las páginas de la historia, no necesita de ejércitos"1719.

\section{La impronta de Espartero marca el contexto histórico}

Tras una década de poder incontestado del Partido Moderado, el sistema político del reinado de Isabel II mostraba cada vez más síntomas de agotamiento, lo que provocó un cambio en el Gobierno, al abandonarle esta formación y convertirse en la fuerza dominante el Partido Progresista. La transición no fue por vías legales, sino consecuencia de la llamada "vicalvarada": la revuelta de las tropas

${ }^{719}$ La discusión, 05/05/1859, no 1000, p. 2. 
acantonadas en el cuartel de artillería de Vicálvaro. Tras la derrota inicial de los sublevados, liderados en las inmediaciones de Madrid por O 'Donnell, tuvo lugar su posterior unión a las tropas del general Serrano y la publicación de un programa de acción política -el manifiesto de Manzanares ${ }^{720}$, en el que afirmaban:

"Nosotros queremos la conservación del Trono, pero sin la camarilla que lo deshonra, queremos la práctica rigurosa de las leyes fundamentales mejorándolas, sobre todo, la electoral y la de imprenta $[\ldots]$, queremos que se respeten en los empleos militares y civiles la antigüedad y el merecimiento [...], queremos arrancar a los pueblos de la centralización que les devora, dándoles la independencia local necesaria para que se conserven y aumenten sus intereses propios, y como garantía de todo esto queremos y plantearemos bajo sólidas bases la Milicia Nacional. Tales son nuestros intentos, que expresamos francamente sin imponerlos por eso a la Nación. Las Juntas de gobierno que deben irse constituyendo en las Provincias libres, las Cortes generales que luego se reúnan, la misma Nación, en fin, fijará las bases definitivas de la regeneración liberal a que aspiramos. Nosotros tenemos consagradas a la voluntad nacional nuestras espadas y no las envainaremos hasta que ella esté cumplida".

El deterioro de la situación a lo largo del verano, cuando los incidentes se extendieron a las grandes ciudades y la revuelta llegó a Madrid y Barcelona, forzó a la reina a entregar el poder al general Espartero, que puso como condición para aceptarlo la convocatoria de Cortes Constituyentes para elaborar una nueva norma jurídica suprema. Pese a la escenificación del abrazo entre Espartero, como símbolo de la monarquía, y O’Donnell, como representación de los rebeldes, pronto la esperanza de estos de que Espartero respetara en parte del programa de la "vicalvarada" se fue desvaneciendo.

\footnotetext{
720 Sobre el documento, ver GADOW, R., "Cánovas, del Manifiesto de Manzanares a la Restauración, en QUESADA NIETO, D., Isabel II y la mujer en el siglo XIX, Madrid, MECD, 2010, pp. 189-215.
} 
Las Cortes Constituyentes elaboraron un proyecto que nunca llegaría a ver la luz, la tantas veces mencionada constitución "nonnata" de 1856, que, sin embargo, es una piedra esencial en la historia jurídica española, ya que no solo mostraba los primeros atisbos de tolerancia religiosa, sino que contenía, por vez primera, una declaración de derechos individuales, tales como la inviolabilidad del domicilio, la libertad de residencia o la libertad de circulación dentro del territorio nacional, derechos estos que constituirían la base de la posterior constitución, aprobada en 1869.

La situación política bajo el Gobierno progresista se deterioró rápidamente. La prohibición de las asociaciones obreras y numerosos conflictos entre trabajadores y propietarios de fábricas textiles acabó generando la huelga general de Cataluña, en el año 1855, que vino a agravarse cuando una crisis en los suministros alimenticios a las zonas urbanas, coincidente con un fuerte brote de cólera, dio lugar a una sucesión aparentemente interminable de motines del pan en múltiples ciudades por toda la geografía peninsular ${ }^{721}$.

Estos motines crearon una ruptura en el gobierno de Espartero, al enfrentarse el ministro de la Gobernación, Patricio de la Escosura, con el ministro de la Guerra, O Donnell, ya que aquel acusaba a este de haberse excedido en la represión de los motines, para lo que se había recurrido a tropas del ejército regular que habían sometido a consejos de guerra a civiles y habían llevado a cabo ejecuciones sumarias. La reina apoyó a O’Donnell, a quién inmediatamente nombró presidente del gobierno, poniendo fin a dos años de gobierno progresista.

La crispada situación política y lo irregular del momento en que se produjo la designación de O'Donnell, cuando las Cortes se encontraban disueltas por ser verano, provocó que se produjera una

${ }^{721}$ CARASA SOTO, P., "Isabel II y la cultura de la pobreza", en PÉREZ GARZÓN, S. (coord.), Isabel II: los espejos de la reina, Madrid, Marcial Pons, 2004, pp. 111140. 
fuerte resistencia al cambio de gobierno, que se tornó en violenta cuando parte de la milicia nacional y miles de civiles, particularmente en Barcelona, se echaron a las calles para levantar barricadas y defender la permanencia del general Espartero en el poder. Este, sin embargo, no quiso ponerse a la cabeza de los que se oponían a la orden regia, y se retiró de la vida política mientras el Ejército, siguiendo órdenes de O'Donnell, aplastaba a sangre y fuego la resistencia, provocando centenares de muertos en las calles, a los cuales siguieron más tarde cientos de fusilamientos sumarios ${ }^{722}$.

En el contexto previo a estos trágicos acontecimientos, en octubre de $1855^{723}$, el Gobierno progresista encabezado por Espartero $^{724}$, con Leopoldo $\mathrm{O}^{\prime}$ Donnell ${ }^{725}$ y José Mac-Crohon y Blake ${ }^{726}$ como sucesivos ministros de Guerra y principales adalides de la norma, y Julián Huelves ${ }^{727}$ y Patricio de la Escosura Morrogh ${ }^{728}$ como sucesivos ministros de Gobernación, presentaría ante el Parlamento un nuevo proyecto de ley para el reemplazo que sería aprobado por

\footnotetext{
722 La obra fundamental sobre estos sucesos es FONTANA, J., "La época del liberalismo", en FONTANA, J., y VILLARES, R., (coords.), Historia de España, vol. 6, Barcelona, Crítica/Marcial Pons, 2007.

723 "En 1854, cuando los progresistas volvieron al gobierno, se activó en el Congreso lo que ahora llamaríamos un lobby antiquintas, cuya primera actuación sería la presentación de un proyecto de ley solicitando la abolición de los sorteos. Las seis rúbricas de sus ponentes estuvieron avaladas por más de 5.000 firmas populares, recogidas en menos de dos semanas. La iniciativa popular respondía a las expectativas despertadas por el generalizado ambiente abolicionista, patente en las barricadas madrileñas previas a la Vicalvarada" (PUELL DE LA VILLA, F., Historia del Ejército en España, p. 87).

724 La biografía de Baldomero Espartero puede ser consultada en ROMANONES, CONDE DE, Espartero. El general del pueblo, Madrid, Espasa-Calpe, 1932; BERMEJO, F., Espartero, hacendado riojano, Logroño, Colección Logroño 24, Instituto de Estudios Riojanos, 2000; SHUBERT, A. "Baldomero Espartero (17931879). Del ídolo al olvido", en BURDIEL, I., PÉREZ LEDESMA M. (coords.), Liberales, agitadores y conspiradores. Biografías heterodoxas del siglo XIX, Madrid, Espasa Calpe, 2001; VILCHES, J, Progreso y Libertad. El Partido Progresista en la Revolución Liberal Española, Madrid, Alianza Editorial, 2001; BURDIEL, I., Isabel II. No se puede reinar inocentemente, Madrid, Espasa-Calpe, 2004.

725 Diccionario Biográfico Español, edición digital, RAH, http://www.rah.es/cdeb.htm ${ }^{726}$ Diccionario Biográfico Español, edición digital, RAH, http://www.rah.es/cdeb.htm 727 Diccionario Biográfico Español, edición digital, RAH, http://www.rah.es/cdeb.htm ${ }^{728}$ Diccionario Biográfico Español, edición digital, RAH, http://www.rah.es/cdeb.htm
} 
el Congreso a comienzos del año siguiente ${ }^{729}$. El texto constitucional en qué se basó la ley continuó siendo la Carta Magna de 1845, ya que la constitución elaborada durante el Bienio Progresista nunca llegó a ver la luz.

La plasmación de los ideales progresistas se produce en el desarrollo de la norma

El nuevo texto legal aprobado en 1856 estaba formado por un total de 162 artículos, más uno adicional y otro transitorio, encuadrados en 17 capítulos. Se trata de una norma exhaustiva, que desciende al más mínimo detalle a la hora de regular las operaciones de reemplazo, donde de nuevo las autoridades civiles llevan el peso de las mismas, y con una estructura similar al Proyecto de ley aprobado por el Senado en enero de 1850, aunque incluyendo algunas novedades reglamentarias significativas ${ }^{730}$.

Carece la ley de preámbulo justificativo o de un planteamiento de sus objetivos ${ }^{731}$, y directamente se inicia con un articulado

\footnotetext{
729 "Su trámite parlamentario fue breve y sin contratiempos -una vez aceptada por el Gobierno la enmienda que aseguraba a los quintos una gratificación de 2.000 reales en el momento de obtener su licencia-, y apareció en las páginas de la Gaceta el 30 de enero de 1856" (PUELL DE LA VILLA, F., El soldado desconocido: de la leva a la "mili" (1700-1912), p. 193).

730 PUELL DE LA VILLA, F., El soldado desconocido: de la leva a la "mili" (17001912), p. 193.

${ }^{731}$ Estos objetivos sí fueron explicitados por el ministro de la Gobernación en su discurso de presentación de la ley ante las Cortes, identificándolos con los principios revolucionarios del nuevo Gobierno en el poder a pesar de los escasos cambios que la nueva ley mostró respecto al proyecto de 1850: "La ordenanza para el reemplazo del Ejército, de 2 de Noviembre de 1837, mejoró notablemente la de 1800 y su adicional de 1819. El proyecto de ley aprobado por el Senado en 29 de Enero de 1850 introdujo en aquella muchas e importantes variaciones aconsejadas por la experiencia en el trascurso de doce años. Hoy presenta el Gobierno a las Cortes un nuevo proyecto; basado en la opinión de esta Asamblea, en armonía con los principios proclamados en la ultima revolución, y cumpliendo la oferta que tiene hecha. Es una exigencia de la época actual que se mitigue cuanto sea posible el sacrificio de los pueblos para cubrir las bajas del Ejército permanente, recurriendo al sistema de enganches voluntarios. Así se establece en el adjunto proyecto, según el cual, es la quinta un medio subsidiario de atender a tan importante servicio, quo
} 
regulador. Así, su primer capítulo se dedica a especificar quienes formarían parte de la fuerza militar española, siendo estos únicamente nacionales y no foráneos ${ }^{732}$, y a establecer unos principios básicos que habían de regir todo el proceso. $\mathrm{Y}$ aquí aparece la primera gran novedad respecto al Proyecto de ley de 1850, al cambiar las prioridades en los jóvenes que formarían parte del Ejército. Constituye también una novedad ideológica introducida por los progresistas en el poder, ya que en el primer artículo "[...] se podía advertir una cierta voluntad formal de los progresistas hacia la constitución de un Ejército sin quintas" ${ }^{\prime 33}$.

La nueva ideología en el Gobierno, a través de este texto legal, antepuso a "[...] los mozos de 20 a 30 años que sienten plaza de soldados y que se enganchen y reenganchen voluntariamente mediante retribución pecuniaria"734 a los jóvenes alistados anualmente mediante el sorteo, que sólo serían reclutados en el supuesto de no existir un suficiente número de soldados voluntarios $^{735}$. La quinta aparece por tanto como un instrumento meramente subsidiario, considerado por el partido Progresista triste y doloroso pero necesario, pero preferible a un simple Ejército de

debe ser al mismo tiempo remunerado, vista la repugnancia que a él tienen todas las clases de la sociedad. Se conceden, pues, 6.000 rs. a los que per el tiempo de ocho años sienten plaza de soldados voluntarios, y 2.000 a los quintos per sorteo que sirvan el mismo tiempo; y esta recompense se hace extensiva a los inutilizados y a los herederos de los fallecidos en funciones de guerra o per sus resultas, come si cumpliesen el tiempo de su empeño" (Discurso del Sr. ministro de la Gobernación, Diario de sesiones de las Cortes, no 127, 13/04/1855, p. 3753).

${ }^{732}$ Ley de Reemplazos de 30 de enero de 1856, art. 8.

733 PUELL DE LA VILLA, F., El soldado desconocido: de la leva a la "mili" (17001912), p. 193.

734 Ley de Reemplazos de 30 de enero de 1856, art. 1. La limitación en esta edad para los voluntarios fue criticada por el diputado García Gómez, que consideró más oportuno la consideración de "útil" o inútil" para el servicio voluntario que los límites de edad, Discurso del Sr. García Gómez, Diario de sesiones de las Cortes, no 228, 25/10/1855, p. 7638.

735 "El Sr. Ministro de la Guerra decía en estos bancos el año pasado: "Es posible que esta sea la última quinta, yo lo deseo [...]. Naturalmente, si hubiera bastantes voluntarios para cubrir el número de hombres qua las Cortes han decretado deben componer el Ejército, ¿que cosa más cómoda para el sr. Ministro de la Guerra, para el Gobierno y para la mayoría, que tener qua aspirar a poder excusar el sorteo? [...] No, no llegan los voluntarios al número suficiente para formar el Ejército" (Discurso del Sr. Escosura, Diario de sesiones de las Cortes, no 231, 29/10/1855, p. 7727). 
mercenarios sin patria ni hogar ${ }^{736}$. Este recurso a la quinta fue criticado duramente por el partido Demócrata, contrario a los ejércitos permanentes excepto en situación bélica y a las quintas por su injusticia inherente, por su inconstitucionalidad, por ser un impuesto que recaía principalmente en las clases menesterosas y por considerar que el partido Progresista en el poder estaba traicionando los principios que habían enarbolado en la revolución de 1854:

"Y creéis, Sres. Diputados, que he oído siquiera a uno que se llamara progresista $y$ no ofreciera decididamente $y$ con toda sinceridad que la contribución de sangre sería abolida?¿Hay algún periódico progresista que no haya sostenido que cuando llegara su partido al poder serian abolidas las quintas, el monopolio de la sal y del papel sellado y el estanco del tabaco? ¿Y que se ha hecho de todo esto? Cuando se trató de quintal el año anterior, para que pudiera pasar, se nos dijo que acaso aquella sería la última y que este sistema sería sustituido por el enganche voluntario. La contribución de quintas es el terror pintado en los semblantes de todos aquellos que temen pueda tocarles la suerte; y así es que apenas se publica en los periódicos del Gobierno, se ve a todos atribulados, porque todos temen que pueda tocarles la suerte terrible cuando lleguen a meter la mano en el cántaro fatal. Hasta esto aumenta el horror de la contribución, pues lo más interesante que tiene el hombre en la sociedad, sus hijos, los ve expuestos a los caprichos de la suerte, y tiene que contemplar con frente serena, fijos sus ojos sobre el fatal

\footnotetext{
736 "Está consignado en la ley un principio, cual es el de la abolición de las quintas, si bien se ha impuesto la obligación al pueblo de verificar el reemplazo por medio de la suerte para asegurar el servicio de la milicia. Algo se ha reconocido en este punto, y en su consecuencia, necesario es que sea una verdad ahora el reemplazo y las garantías concedidas al pueblo; es menester hacer todos los esfuerzos posibles para sacar todas las ventajas que son consiguientes de este proyecto de ley" (Discurso del Sr. Labrador, Diario de sesiones de las Cortes, no 228, 25/10/1855, p. 7635). Ese sentimiento contrario a las quintas se observa entre los propios miembros de la Comisión que elaboró el proyecto de ley: "Quisiera que se evitaran [las quintas], quisiera que no existieran; pero en la necesidad de proveer al bien de la sociedad, cuando el enganche y el reenganche no satisfagan las exigencias del servicio, no hay más remedio que acudir a la quinta. Por manera que, si admito las quintas, es como un mal, pero como un mal necesario, inevitable" (Discurso del Sr. López Infantes, Diario de sesiones de las Cortes, no 228, 25/10/1855, p. 7637).
} 
cántaro que contiene las bolas del sorteo, si sale la terrible bola negra que le arrancara de sus brazos a su hijo querido"737.

Se aclara en el texto legislativo que los mozos que se enganchasen o reenganchasen voluntariamente a filas pero, por motivos de edad, debiesen participar en el sorteo y obtuviesen la suerte de soldado, perderían su condición de voluntarios, la retribución de 6.000 reales y las ventajas inherentes a su situación, aunque sí cobrarían el tiempo en que hubiesen servido voluntariamente y ese periodo de tiempo serviría además de cara a reducir la extensión del servicio obligatorio ${ }^{738}$. Al final de su servicio de ocho años, o en el caso de quedar inutilizados en acción de guerra, recibirían además una paga de 6.000 reales $^{739}$. El resto de los reclutas, es decir, los mozos que hubiesen obtenido la suerte del soldado en el sorteo, recibirían al finalizar la prestación una paga de 2.000 reales de vellón ${ }^{740}$, y así se tendría en cuenta en los

737 Discurso del Sr. Ruiz Pons, Diario de sesiones de las Cortes, no 231, 29/10/1855, p. 7722.

${ }^{738}$ Ley de Reemplazos de 30 de enero de 1856, art. 2. El diputado García Briz advirtió contra la posibilidad de que esta medida desalentase el voluntariado y propuso la exención del voluntario del sorteo de su pueblo respectivo: "En el art. $1^{\circ}$, señores, como primer elemento para sostener at Ejército permanente, se señala at enganche voluntario; a falta de él, y solo a falta de éste, entrará el sorteo, la quinta. La ley en su primer artículo establece el pensamiento de quo at Ejército se forme por medio del enganche voluntario; y sin embargo, en el artículo $2^{\circ}$ en su primera parte, precisamente lo que se hace es quitar todo estímulo al engancho voluntario, o al menos producirá ese efecto respecto de los mozos de 20 a 23 años, toda vez qua los deja sujetos a las resultas de los sorteos. De nada le servirá al mozo engancharse voluntariamente y adquirir por ese hecho un derecho a, la retribución de $6.000 \mathrm{rs}$., si en seguida, por tocarle la suerte, pierde at derecho y entra en la regla general de todos los sorteados. Yo diría, por el contrario, qua la manera de incitar a la juventud a que se enganchara voluntariamente y que no hubiera lunar al sorteo, sería qua los mozos en el mero hecho de engancharse tuvieran derecho a la gratificación de 6.000 reales" (Discurso del Sr. García Briz, Diario de sesiones de las Cortes, no 228, 25/10/1855, p. 7639).

739 Ley de Reemplazos de 30 de enero de 1856, art. 3.

740 El diputado García Gómez criticó la cantidad de 2.000 reales pagados al finalizar el servicio o por quedar el recluta inutilizado por considerarla insignificante e insuficiente: "Si lo que se propone la ley es que al dar esos 2.000 reales al cumplido o inutilizado pueda poner algún establecimiento al volver de su casa, es que le sirva de base para proporcionarse un modo de vivir seguro, no lo puede conseguir con esa cantidad tan insignificante: con 2.000 reales no puede 
presupuestos generales del Estado a través de los fondos de redención del servicio militar ${ }^{741}$. En el caso de fallecimiento, los familiares de los reclutas voluntarios o de los jóvenes sorteados tendrían derecho a percibir esas mismas cantidades ${ }^{742}$. Todas estas retribuciones "[...] se entienden sin perjuicio del haber, ventajas, premios y recompensas que corresponden a todos los individuos del Ejército, y que en la actualidad disfrutan o disfrutaren, con arreglo a las Ordenanzas militares, y demás disposiciones vigentes en el ramo de la Guerra"743.

Otro de los principios básicos que estableció la nueva ley es el ámbito geográfico de los jóvenes sobre los que recaería el alistamiento y sorteo, la duración del servicio y la edad de los reclutas. Así, serían los pueblos y ciudades peninsulares y del archipiélago balear los afectados, quedando excluido el territorio canario y el americano ${ }^{744}$. Participarían en el mismo todos los mozos cuyos padres o ellos mismos tuviesen o hubiesen tenido su residencia en el territorio peninsular o balear, aunque en el momento de proceder al alistamiento residiesen fuera del país. Respecto a la duración de la prestación, de forma similar al Proyecto de 1850, se estableció en los ocho años, con una reducción de dos años para aquellos que fuesen destinados a las provincias de Ultramar. $Y$ en cuanto a la edad, formarían parte de alistamiento los mozos de veinte años que no hayan cumplido veintiuno a fecha de 30 de abril, así como los jóvenes entre veintiuno y veinticinco que por cualquier motivo no hubiesen participado en los alistamientos y sorteos de años

establecerse un hombre ni aun mezquinamente en España [...]" (Discurso del Sr. García Gómez, Diario de sesiones de las Cortes, no 229, 26/10/1855, p. 7675).

${ }^{741}$ Ley de Reemplazos de 30 de enero de 1856, arts. 4 y 6.

742 Ley de Reemplazos de 30 de enero de 1856, art. 5.

743 Ley de Reemplazos de 30 de enero de 1856, art. 7.

744 Ley de Reemplazos de 30 de enero de 1856, art. 9. El diputado Labrador propuso, para reducir los costes y simplificar el proceso, que los sorteos no se celebrasen en cada municipio sino por distritos militares, siendo su propuesta rechazada por el Congreso, Discurso del Sr. Labrador, Diario de sesiones de las Cortes, no 229, 26/10/1855, p. 7677. 
anteriores. Se viene a limitar por lo tanto la edad de los mozos alistados $^{745}$.

Para cubrir el cupo encomendado a cada localidad, entrarían a servir en el Ejército los números que, por orden, hubiesen salido del sorteo. En el caso de no cubrir con estos mozos el cupo asignado, se recurriría a los alistados del año anterior o de dos años anteriores que no se encuentren en servicio, siempre que fuesen considerados aptos físicamente. Cuando no fuese suficiente con los tres alistamientos señalados, el cupo del pueblo en cuestión quedaría sin cubrir ${ }^{746}$.

Como últimos principios generales que habían de regular todo el proceso, señalar que la ley admitió expresamente la sustitución y se abrió la puerta a los reemplazos extraordinarios, cuyas reglas serían fijadas por una nueva ley, en el caso de que las circunstancias lo exigiesen $^{747}$. A diferencia del Proyecto de ley del Senado de 1850, no se estableció un cupo fijo anual de reclutas a ingresar en la fuerza armada, uno de sus aspectos más discutidos, sino

"[...] que el Gobierno ha creído quo esta contribución, como todas las demás, debe ser votada anualmente por las Cortes después que fije una ley la fuerza de que ha de constar el ejercito; y ha creído también quo el reparto de cada contingente no puede ser objeto de un

\footnotetext{
745 Ley de Reemplazos de 30 de enero de 1856, art. 10, 12 y 13.

746 Ley de Reemplazos de 30 de enero de 1856, art. 14. Esta circunstancia fue denunciada por el diputado Baeza ante las desigualdades que generaba entre los distintos municipios: "Es un hecho completamente sabido que algunos pueblos cubren su cupo con solo una parte de los mozos sorteados en el año a quo corresponde la quinta que se pide, mientras que otros no solo emplean los mozos sorteados en aquel año, sino que también recurren a los sorteos de los años anteriores; de manera que mientras un pueblo viene a pagar un 5 , un 10 , un 15 por 100 de contribución, otro pueblo no solo gaga un 100 por 100 de los mozos sorteables de aquel año, sino también un 100 por 100 de los correspondientes a cada uno de los años anteriores; de modo, señores, que no se puede dar un hecho de más notable desigualdad ni de más remarcada injusticia" (Discurso del Sr. Baeza, Diario de sesiones de las Cortes, no 231, 29/10/1855, p. 7719).

${ }^{747}$ Ley de Reemplazos de 30 de enero de 1856, arts. 15 y 16.
} 
decreto sino que ha de aprobarse a la vez que la ley para el reemplazo anual ${ }^{\prime \prime 7}$.

a) El reparto del contingente, competencia del Gobierno

El segundo capítulo de la norma atañe a todo lo relacionado con el reparto del contingente y a la cuestión de las décimas y su reparto. Si lo comparamos con el Proyecto de ley de 1850, se había producido un cambio en la estructura del texto, ya que dicho reparto era regulado con posterioridad a la elaboración del padrón, el alistamiento y el sorteo, y no en un estadio inicial como sucedía con la nueva Ley de 1856. Por lo demás, el contenido de ambas normas en esta cuestión es muy similar.

Tal reparto tenía que ser elaborado anualmente por el Gobierno a través de un proyecto de ley que había de presentar a las Cortes para su aprobación. En este mismo documento se señalaría el contingente con que cada provincia debía colaborar para el reemplazo del Ejército ${ }^{749}$. Dicho repartimiento se realizaría en función de la totalidad del número de mozos que, en cada provincia, hubiesen participado en el sorteo del año anterior, excluyendo a los fallecidos, los incluidos indebidamente en el alistamiento y los exceptuados del servicio $^{750}$. Deja de utilizarse como base del reparto la copia del acta

748 Discurso del Sr. ministro de la Gobernación, Diario de sesiones de las Cortes, no $127,13 / 04 / 1855$, p. 3753.

${ }^{749}$ Ley de Reemplazos de 30 de enero de 1856, art. 17.

750 Ley de Reemplazos de 30 de enero de 1856, art. 18. La base utilizada para realizar el reparto fue criticada por el diputado demócrata Figueras: "En la ley de quintas ha habido en la época constitucional un verdadero progreso. En la ley de 1837 se establecía por base del reparto et censo de vecindad, y este repartimiento era injusto. Pero en cambio estableció las series dentro de las cuales el soltero y el casado estaban expuestos a ir al servicio, y con esto se evitaron los matrimonios prematuros, causa frecuente de graves disturbios domésticos, y a menudo de grandes crímenes. Este fue ya un paso hacia el progreso. Vino la ley del año 51, y tomó por base el número de mozos sorteables del año anterior, y esto ya se acerca más a la equidad que el censo de vecindad. En la ley que ahora se propone, aunque toma la misma base, sin embargo dispone que se deduzcan para el reparto los que han sido incluidos indebidamente. [...]. Digo, señores, quo la base del reparto quo 
del sorteo elaborada por el alcalde y enviada al jefe político de la provincia tal y como establecía el Proyecto de 1850. El sorteo sería posterior al reparto y no anterior tal y como sucedía con la legislación previa $^{751}$.

Una vez que el Gobierno hubiese planteado y las Cortes aprobado la totalidad de los mozos necesarios para el reemplazo y el reparto del contingente por provincias, serían las Diputaciones provinciales, en un plazo de ocho días a contar desde el primero de febrero de cada año, las encargadas de "[...] repartir el cupo señalado en sus provincias respectivas entre los pueblos de las mismas en proporción al número de mozos sorteados que tuvo cada pueblo en el año anterior"752. Tal cupo se podría componer de soldados enteros solamente, enteros y décimas o décimas en exclusiva. Una vez sumados todos los soldados y décimas resultantes del reparto, y en el caso de faltar algunos soldados y décimas para completar el cupo de la provincia, se exigiría un décima más a los pueblos que hubiesen quedado con un mayor número de mozos sorteados una vez cubierto el cupo que les hubiese correspondido ${ }^{753}$.

Era la Diputación provincial por tanto la encargada de realizar este señalamiento de décimas, y sería esta misma institución la que realizase, a puerta abierta y con anuncio público de 24 horas de

\footnotetext{
ha adoptado la Comisión es altamente injusta." (Discurso del Sr. Figueras, Diario de sesiones de las Cortes, no 231, 29/10/1855, p. 7735).

751 "El resultado del sorteo y el reparto de cupos se publicaba el 15 de marzo, y los pueblos podían recurrir el resultado del mismo, aunque habitualmente no se discutía el resultado del sorteo, pero sí el repartimiento general, cuando entraban en conflicto dos o más pueblos que se consideraban agraviados mutuamente. Las quejas solían ser muy generales y se referían al hecho de que el repartimiento no consideraba la edad del vecindario para adjudicar los enteros y las décimas [...] o que la Ley no permitiese que algunas exenciones legales se considerasen a cuenta de cupo" (FEIJÓO GÓMEZ, A., Quintas y protesta social en el siglo XIX español, pp. 241 y 242 ).

${ }^{752}$ Ley de Reemplazos de 30 de enero de 1856, arts. 19-21.

753 "Serán considerados para este efecto como mozos sobrantes los de aquellos pueblos que no tengan los suficientes para dar una décima, y si al agregar la última o las últimas décimas resultasen dos o más pueblos con igual número de mozo sobrantes, la suerte decidirá cual o cuales de ellos han de sufrir la agregación" (Ley de Reemplazos de 30 de enero de 1856, art. 22).
} 
anticipación ${ }^{754}$, el sorteo de los quebrados entre los pueblos designados "procurando que el sorteo se haga con cada 10 décimas para dar un soldado, y que los pueblos reunidos en cada combinación sean en lo posible los que menos disten entre sím ${ }^{\prime 755}$. Para la ejecución de este sorteo se introducían diez papeletas en un globo con los nombres de los pueblos "[...] poniendo por cada pueblo tantas papeletas cuantas sean las décimas con que debe contribuir, y en otro globo se introducirán 10 papeletas con los números desde 1 hasta 10"756. Una vez movidos los globos, dos vocales de la Diputación procedían a extraer y verificar las papeletas, dando el soldado el municipio que obtenga el número uno para las combinaciones de diez décimas. Si tal pueblo no tuviese mozo útil, sería el que haya obtenido el número dos y así sucesivamente. Si ninguno de los pueblos tuviese mozo útil, se acudiría al alistamiento de los dos años anteriores $y$, en el caso de tampoco existir, esas plazas quedarían sin cubrir. Para los sorteos que combinen 20, 30 o más décimas se seguirá el mismo proceso, con la diferencia de que ningún pueblo de los sorteados pudiese dar más de un soldado ${ }^{757}$.

El resultado del reparto y del sorteo de décimas debía ser publicado en un documento a tres columnas, donde se indicaría el número de mozos sorteados de cada pueblo, el total de soldados y décimas que le hubiese correspondido a cada localidad y, por último, el número de soldados que debía afrontar. Este documento también recogería una nota con los sorteos de décimas ejecutados, los pueblos participantes y el número que le hubiese correspondido a cada uno. Una vez formalizado el repartimiento por localidades, el gobernador de la provincia debía remitir al ministerio de la Gobernación dos ejemplares de este reparto ${ }^{758}$.

\footnotetext{
754 Ley de Reemplazos de 30 de enero de 1856, art. 29.

755 Ley de Reemplazos de 30 de enero de 1856, art. 23.

756 Ley de Reemplazos de 30 de enero de 1856, art. 24.

757 Ley de Reemplazos de 30 de enero de 1856, arts. 25, 26 y 28.

758 Ley de Reemplazos de 30 de enero de 1856, arts. 30 y 31.
} 
b) La elaboración del padrón de vecinos, una importante competencia municipal

Se centran los capítulos III y IV de la ley en las tareas de elaboración del padrón. De nuevo se configura este documento como un instrumento esencial y previo para el inicio de las tareas de reclutamiento. Al igual que en el Proyecto de 1850, se permitía a los municipios "de mucho vecindario" dividir su territorio en secciones, no sólo de cara a la confección del padrón, sino para todo lo relacionado con el reemplazo. Para poder realizar esta división del municipio necesitaba el visto bueno del gobernador de la provincia, y cada distrito contaría al menos con 5.000 habitantes, considerándose cada uno de ellos como una localidad autónoma para todas las operaciones relacionadas con el reclutamiento militar. Así, cada sección tendría su padrón particular y será elaborado por una comisión formada por tres individuos del Ayuntamiento, a poder ser concejales del consistorio o, en el caso de no haber suficiente número, antiguos concejales en orden de antigüedad ${ }^{759}$.

Los distritos municipales compuestos por poblaciones dispersas serían considerados como una única unidad administrativa para la elaboración del padrón y para todas las operaciones relacionadas con el reemplazo. En el caso de que la mayoría de los habitantes de una localidad, feligresía o caserío dependientes de alguna población principal y mayor de 500 habitantes solicitasen realizar todas las operaciones del reemplazo de forma separada, podrían hacerlo en el caso de recibir el consentimiento del gobernador de la provincia ${ }^{760}$.

\footnotetext{
759 Ley de Reemplazos de 30 de enero de 1856, art. 32. El diputado Sr. Garrido solicitó que fuese la Diputación Provincial, por su mayor conocimiento de la realidad de las localidades de su provincia, la encargada de dar el visto bueno para realizar esta división de un municipio en secciones y no el Gobierno, pero su propuesta fue rechazada por las Cortes, Discurso del Sr. Garrido, Diario de sesiones de las Cortes, no 231, 30/10/1855, pp. 7761 y 7762.

760 Ley de Reemplazos de 30 de enero de 1856, art. 33.
} 
Sería durante los primeros días del mes de enero cuando anualmente se debía confeccionar el padrón de vecinos que incluiría a todos los habitantes de ambos sexos que residiesen en cada término municipal, así como a los que se encontrasen accidental o temporalmente fuera del mismo. También serían incluidos en el padrón los jóvenes entre veinte y veinticuatro años que, a fecha de uno de enero, se encontrasen, ellos mismos o su progenitores, en otra localidad o en el extranjero y hubiesen residido en el municipio durante los dos años anteriores, aún cuando estuviesen sirviendo ya en el Ejército o en la armada. En ambos casos se indicaría en el padrón la ausencia del joven y el tiempo que duró su residencia o la de sus padres en el pueblo ${ }^{761}$.

Para evitar posibles dudas en lo que se refiere a la elaboración del padrón, la ley estableció una serie de reglas que habían de regir el proceso. Así, en primer lugar se aclaró el concepto de residencia y se estableció que

"se entiende por residencia la estancia del mozo o del padre, o de la madre en el pueblo donde cada uno de estos ejerce de continuo su profesión, arte u oficio, u otra cualquier manera de vivir conocida o bien adonde habitualmente permanece, manteniéndose con el producto de sus bienes" ${ }^{762}$.

No se consideraría interrumpida la residencia porque el mozo o sus padres se hubiesen ausentado temporalmente del término municipal, o porque el joven se hubiese desplazado eventualmente por motivos de estudio, o porque alguno de los progenitores se encontrase demente, en prisión o se ignorase su paradero. Por último, y como novedad respecto al Proyecto de 1850 , se aclara que

\footnotetext{
${ }^{761}$ Ley de Reemplazos de 30 de enero de 1856, art. 35 y 36.

762 Ley de Reemplazos de 30 de enero de 1856, art. 37.
} 
para el caso de los mozos huérfanos o expósitos ${ }^{763}$ se consideraría como residencia del padre aquel centro de beneficencia donde el niño fue criado o aquel lugar donde residiese la familia que hubiese acogido al joven. En el caso que un niño hubiese pasado por ambas situaciones, tendría prioridad el lugar de residencia de la familia de acogida $^{764}$.

c) Formación, reclamaciones y rectificación del alistamiento para el reemplazo: una clasificación inicial de los futuros reclutas

Todo lo relacionado con el alistamiento y su rectificación es recogido en tres capítulos sucesivos, V, VI y VII. Éste se elaboraría anualmente en cada localidad durante los primeros días del mes de febrero en función del padrón general y comprendería a todos los mozos entre veinte y veinticuatro años, cualquiera que sea su estado y aunque ya estuviesen sirviendo en el Ejército o en la Armada por cualquier concepto y en cualquiera de sus clases o categorías, clasificándolos por orden en función de los siguientes criterios ${ }^{765}$ :

"10.- Los mozos cuyos padres o madres a falta de éstos, hayan tenido su residencia durante los dos años anteriores en el pueblo en que se hace el alistamiento hasta el día 10 de Enero inclusive, aunque se hayan ausentado posteriormente.

20. - Los mozos cuyos padres o madres a falta de éstos, tengan su residencia desde el día $1^{\circ}$ de Enero en el pueblo donde se hace el alistamiento.

\footnotetext{
763 CARASA SOTO, P., "Perspectivas de la historiografía española en torno a los expósitos e ilegítimos, desde las actuales tendencias de la historia social", en SVEN REHER SULLIVAN, D. (coord.), Actas do III Congresso da ADEH (Associaçao Ibérica de Demografia Histórica), Vol. 3, Guimaraes, Afrontamento, 1996, pp. 87-105.

764 Ley de Reemplazos de 30 de enero de 1856, art. 37.

765 Esta clasificación supone una novedad con respecto al Proyecto de ley de 1850, que no recogía ninguna diferenciación para los jóvenes alistados.
} 
30. - Los mozos que hayan tenido su residencia de igual modo en los dos años anteriores, siempre que hayan permanecido en el pueblos dos meses, cuando menos, durante este tiempo.

40.- Los mozos que tengan su residencia desde $1^{\circ}$ de Enero en el pueblo en que se hace el alistamiento"766.

De la confección del alistamiento se encargarían, en una sesión a puerta abierta, los miembros del Ayuntamiento y los eclesiásticos por ellos designados, los cuales debían suministrar las noticias que se les requiriesen y mostrar los libros parroquiales en aquellos lugares donde no existiese registro civil, aunque su papel en el proceso de reemplazo queda por primera vez reducido al suministro de los datos requeridos $^{767}$. El documento sería firmado por estos individuos y el secretario municipal, y copias del mismo deberían ser mostradas en lugares públicos durante un plazo mínimo de diez días ${ }^{768}$.

Sería el primer domingo del mes de marzo, y los domingos siguientes si fuese necesario por falta de tiempo, cuando se debía proceder a la rectificación del alistamiento, y de este acto se encargaría el capítulo VI de la ley. A él acudirían todos los jóvenes alistados que deberían ser citados personalmente. Una vez leído el alistamiento, los interesados o sus padres, parientes, amos 0 apoderados presentarían las reclamaciones correspondientes. Como novedad, cuando un mozo reclamase su exclusión del alistamiento y

\footnotetext{
${ }^{766}$ Ley de Reemplazos de 30 de enero de 1856, art. 38.

767 "La Comisión apela a los libros parroquiales cuando no hay registro civil; de manera que en los puntos donde le haya, ni se llama al párroco ni se llevan sus libros. [...]. Hubo un tiempo, no muy distante, porque yo he conocido yo, en que el párroco era una parte esencial en los reemplazos, sin embargo de que los reemplazos es una cosa estricta, absoluta y completamente civil, profana y no eclesiástica. No obstante, al despotismo le convenía mucho halagar al clero y tenerle contento. Yo también quiero mucho al clero, pero lo quiero en su órbita; así que yo no le doy participación civil en nada; en lo espiritual, todo. Cuando en el artículo anterior se llama al párroco, no es para que autorice el acto, no hace falta; es para que vaya con los libros, vea como se tratan, como se abren, que no se quiten hojas, etc., etc.; y después coge su libro bajo el brazo y se va a su casa" (Discurso del Sr. López Infantes, Diario de sesiones de las Cortes, no 232, 30/10/1855, pp. 7763 y 7764 ).

${ }^{768}$ Ley de Reemplazos de 30 de enero de 1856, arts. 39-42.
} 
fuese pobre de solemnidad, el Ayuntamiento 0 la autoridad competente no le exigiría las costas de las diligencias que tuviesen que practicar para demostrar el error ${ }^{769}$.

El Ayuntamiento debía oír y examinar las reclamaciones presentadas, admitiendo pruebas a favor y en contra del interesado, procediendo a resolver por votación. Se recogería en un acta todo lo ocurrido y la decisión de la autoridad municipal, expidiendo un certificado con la resolución a todos los reclamantes. Cuando una reclamación no pudiese ser resuelta en el mismo acto por necesitarse documentación procedente de lugares lejanos, se haría constar así en acta, y el consistorio establecerá un plazo "prudente" para presentar tales justificaciones ${ }^{770}$.

Destacar que se incluye en este capítulo VI los supuestos para ser excluido del alistamiento y por tanto también del servicio militar, sin ser necesario que el interesado presentase una reclamación para ser excluido del alistamiento por parte del Ayuntamiento ${ }^{771}$ : licenciados en el Ejército, los que no llegasen a veinte años de edad y superasen los veinticinco, aquellos que en un reemplazo anterior hubiesen redimido su suerte por medio de un sustituto o de una retribución pecuniaria ${ }^{772}$, así como aquellos que justificasen que habían sido alistados en otros pueblos para el mismo reemplazo ${ }^{773}$.

Las decisiones tomadas por el Ayuntamiento podían ser reclamadas, y así se recoge en el capítulo VII de la ley, que apenas aporta novedades respecto al Proyecto de 1850. Estas reclamaciones se debían hacer por escrito ante el consistorio en un plazo máximo de tres días. Recibirían para ello los reclamantes un certificado redactado

\footnotetext{
769 Ley de Reemplazos de 30 de enero de 1856 , arts. 43 y 48.

${ }^{770}$ Ley de Reemplazos de 30 de enero de 1856, arts. 44 y 47.

${ }_{771}^{7}$ Ley de Reemplazos de 30 de enero de 1856, art. 46.

772 Por tanto, la redención en metálico y la presentación de un sustituto servía para eximirse del servicio militar no ya sólo para el reemplazo en cuestión, sino también para reemplazos sucesivos.

773 Ley de Reemplazos de 30 de enero de 1856, art. 45.
} 
por el síndico municipal señalando los motivos de su queja ${ }^{774}$, documento que debería presentar ante la Diputación provincial en un plazo máximo de quince días ${ }^{775}$. Es la institución provincial la encargada de resolver la reclamación, "[...] sin perjuicio de que los interesados puedan recurrir al ministerio de la Gobernación en el plazo y forma que esta ley establece para todas las reclamaciones que se hicieren al Gobierno"776.

Los últimos artículos del capítulo VII se centran en los problemas que podrían surgir en el supuesto de que un mozo sea incluido en el alistamiento de dos pueblos distintos. Cuando se produzca esta circunstancia, los Ayuntamientos deberían ponerse de acuerdo y, en caso contrario, sería la Diputación provincial la que tomará una decisión atendiendo a los siguientes criterios:

"10.- Al alistamiento del pueblo en que el padre, o a falta de éste la madre del mozo, haya tenido por más tiempo su residencia durante los dos años anteriores.

20.- Al alistamiento del pueblo o donde el padre, o a falta de éste la madre, tenga su residencia desde el $1^{\circ}$ de Enero, o la haya tenido en este día

30.- Al alistamiento del pueblo en que el mozo haya tenido por más tiempo su residencia los dos años anteriores.

40.- Al alistamiento del pueblo en que el mozo tenga su residencia desde $1^{\circ}$ de Enero, o la haya tenido en este mismo día.

\footnotetext{
774 Ley de Reemplazos de 30 de enero de 1856, art. 49.

775 Ley de Reemplazos de 30 de enero de 1856, art. 50. El diputado Ambrosio González solicitó que estas reclamaciones presentadas por los mozos que se considerasen agraviados se pudiesen presentar también de palabra ante el Ayuntamiento ante el elevado índice de analfabetismo que existía en España, Discurso del Sr. González, Diario de sesiones de las Cortes, no 232, 30/10/1855, p. 7764.

776 Ley de Reemplazos de 30 de enero de 1856, art. 52. Esta posibilidad de recurso ante el Gobierno fue rechazada por numerosos diputados: "yo tengo gran terror de que haya ere tribunal de alzada para los fallos de las Diputaciones Provinciales en esta materia, y que este tribunal sea el Gobierno, porque son infinitos y trascendentalísimos los abusos que se has cometido por una mala inteligencia de la ley" (Discurso del Sr. Lasala, Diario de sesiones de las Cortes, n 232, 30/10/1855, p. 7767).
} 
50. - Al alistamiento del pueblo de que el mozo sea natural'm77.

Si el doble alistamiento que hubiese sufrido un mozo se produjese en dos localidades de provincias diferentes, ambas Diputaciones provinciales deberían ponerse de acuerdo. Si no es así, se remitirían los expedientes al ministerio de Gobernación para que decidiese en un plazo máximo de ocho días ${ }^{778}$. El que un proceso eminentemente administrativo encontrase en tantas ocasiones la última palabra del Gobierno encontró recelos entre los diputados de la oposición, que solicitaban que fuese el Tribunal ContenciosoAdministrativo, y no el poder Ejecutivo, el encargado de tomar la última decisión en cuestiones como el doble alistamiento

"¿por qué no ir conservando en la escala y aplicación de la ley de quintas el carácter contencioso-administrativo? Pues que, señores, cuando ante la Diputación Provincial se ventila sobre la libertad del hombre, cuando se cuestiona sobre su inclusión o exclusión en la lista del sorteo, cuando se determinan los casos prácticos respecto del alistamiento, cuando van a resolverse principios tan grandes como la libertad del hombre y el sorteo, ino es esto do la competencia exclusive de lo contencioso- administrativo, en vez de ser de la competencia del Gobierno? [...]. El Gobierno ¿es competente para resolver casos de jurisdicción? El Gobierno ¿es competente para dirimir contiendas entre partes, de la una la Administración y de la otra el interesado? El Gobierno, ¿puede por si y ante si resolver y establecer jurisprudencia? El Gobierno ¿puede dirimir intereses opuestos, ora de las partes entre sí, ora de los pueblos entre sí, ora de las Diputaciones entre sí, ora, en fin, de particular a particular? Pues que, si las Diputaciones Provinciales por su origen, por su carácter, por sus funciones son un cuerpo que por la ley de quintas que nos ocupa desempeña funciones contencioso-administrativas [...] ¿es posible que esos fallos vengan a sacar su fuerza ejecutiva bajo el recinto del Gobierno? ¿no sabe el Sr. Escosura que el Tribunal

\footnotetext{
777 Ley de Reemplazos de 30 de enero de 1856, arts. 55 y 56.

${ }^{778}$ Ley de Reemplazos de 30 de enero de 1856, art. 57.
} 
Contencioso administrativo desempeña dos clases de funciones, tiene dos caracteres, ora como cuerpo consultivo, ora como cuerpo que resuelve las cuestiones que se someten a su fallo ${ }^{779 " .}$

d) El sorteo: la intervención estatal para evitar fraudes

El acto del sorteo recibió una atención prioritaria como demuestra la extensión del capítulo, el VIII, a él dedicado. No cambiar la fecha de celebración con respecto al Proyecto de 1850 y se mantiene el primer domingo del mes de abril a las siete de la mañana, y en los días sucesivos en caso de no finalizarse en el día concretado. Sí que constituye una novedad el que se especifique que la fecha se mantendría aunque existiesen recursos pendientes de resolver relacionados con el alistamiento. También constituye una novedad el que se señale que el sorteo se celebraría a puerta abierta en el Ayuntamiento tras la lectura pública del alistamiento, y que la institución municipal sería la responsable en el caso de que se cometiesen ilegalidades en el acto ${ }^{780}$.

La celebración del sorteo apenas muestra cambios con respecto al Proyecto de ley de 1850. Para su realización se debían introducir en bolas, previa lectura por parte del alcalde y de otro miembro de la municipalidad, las papeletas con los nombres de los mozos y en otras bolas tantos números como jóvenes hubiesen participado el alistamiento. Estas bolas serían introducidas posteriormente en globos $^{781}$. Serían dos niños menores de diez años, uno por cada globo, los encargados de extraer las bolas y entregarlas al regidor $y$ al presidente del consistorio, quienes debían leer las papeletas en voz alta una vez sacadas de sus respectivas bolas y mostradas a quienes

779 Discurso del Sr. Salmerón, Diario de sesiones de las Cortes, no 232, 30/10/1855, p. 7770.

${ }^{780}$ Ley de Reemplazos de 30 de enero de 1856, arts. 58, 59 y 61.

${ }^{781}$ Ley de Reemplazos de 30 de enero de 1856, art. 60. 
así lo deseasen. Sería el secretario el encargado de redactar el acta con el nombre de los mozos que fuesen saliendo y el número que le hubiese correspondido a cada uno de ellos, documento que sería firmado por él mismo y los restantes miembros del Ayuntamiento ${ }^{782}$. Dos copias del acta serían enviadas por todos los alcaldes al gobernador de la provincia respectivo en un plazo máximo de tres días, y allí constaría el nombre de los mozos sorteados con el número que les hubiese tocado. Además, para evitar actos fraudulentos,

"Los individuos que firmen estas copias serán responsables de su exactitud; e incurrirán mancomunadamente en la multa de 600 reales por cada uno de los mozos que se hubieren omitido. En este caso dispondrá además el Gobernador de la provincia que se instruyan las oportunas diligencias para averiguar el motivo de la omisión, y si resultase fraudulenta se procederá contra los culpables según establece la Ley"783.

En el caso de que se presentasen reclamaciones ante el gobierno por inexactitudes o equivocaciones cometidas durante el acto del sorteo, sería el ministerio de la Gobernación el encargado de resolver en la forma que prevenía la ley, pero en ningún caso se anularía el sorteo, a no ser que el dictamen del Tribunal ContenciosoAdministrativo o del Consejo de Estado considerase indispensable su anulación $^{784}$. La posible intervención de ambas instituciones para anular un sorteo constituye una novedad con respecto al Proyecto de 1850. El protagonismo concedido en la resolución de reclamaciones y la posible anulación de los sorteos al Gobierno en detrimento de Diputaciones y Ayuntamientos de nuevo encontró importantes recelos incluso algunos diputados miembros del partido Progresista, que consideraban esta medida como propia del partido Moderado y

\footnotetext{
782 Ley de Reemplazos de 30 de enero de 1856, arts. 61-63.

783 Ley de Reemplazos de 30 de enero de 1856, art. 70.

784 Ley de Reemplazos de 30 de enero de 1856, art. 64.
} 
defendían una categoría de inapelable para el fallo de las Diputaciones:

"Señores, me levanto a combatir el art. 66, porque en él se conculcan las doctrines del partido progresista. En efecto, señores, se quiere en este artículo que las reclamaciones las resuelva el Gobierno; se quiere más: se quiere que la nulidad de los sorteos la declare el Gobierno; se quiere, en una palabra, que el Gobierno resuelva definitivamente en negocios quo corresponde resolver a las Diputaciones Provinciales y a los Ayuntamiento. ¿Son estas las doctrinas del partido progresista, ni lo fueron nunca? No, señores; precisamente en esta materia los hombres más avanzados del progreso han convenido completamente en que en la cuestión de reclamaciones sobre quintas, así como en las referentes a contribuciones, resuelvan en definitiva solamente las Diputaciones Provinciales y los Ayuntamiento. Pues aquí precisamente se falta a esto; aquí se quiere que en definitiva lo resuelva el Gobierno. Vosotros, señores de la Comisión, ¿os atreveréis a llamaros progresistas después de redactar este artículo? No, señores; no lo sois. Si lo fuisteis alguna vez, habéis abjurado las doctrines del partido progresista, adoptando las del partido moderado, con la diferencia que el partido moderado tuvo la franqueza de decir claro to quo iba a hacer; con la diferencia quo el partido moderado tuvo un sistema malo o bueno, una cosa conocida, pero vosotros habéis querido presentar un monstruo ${ }^{785 "}$.

Solamente se admitiría la repetición del sorteo en el caso de que alguna de las dos instituciones mencionadas lo recomendase. En el supuesto de que se tuviese que excluir del alistamiento a algún individuo por una reclamación presentada y admitida por la Diputación provincial o el ministerio de la Gobernación, y que el sorteo ya se hubiese celebrado, "descenderán sucesivamente los nombres correspondientes a los números que sigan al del individuo

785 Discurso del Sr. Garrido, Diario de sesiones de las Cortes, no 239, 08/11/1855, p. 8004. 
excluido sin practicar un nuevo sorteo"786. Si, por el contrario, se debiese incluir a algún individuo en un principio excluido del alistamiento, se realizaría un sorteo supletorio ${ }^{787}$.

Una vez celebrado el sorteo, se debería citar mediante edictos y por medio de papeletas duplicadas, el primer día festivo del mes de abril, a los mozos sorteados, y también a los jóvenes alistados de los dos años anteriores, en el lugar que se designase a tal efecto con el objeto de proceder a los actos de llamamiento y declaración de los soldados. Una de las papeletas sería entregada al mozo alistado y la otra se unirá al expediente de reclutamiento ${ }^{788}$. Tal expediente constituye una novedad administrativa, inédita hasta entonces en la legislación, que permite un mayor control y claridad sobre todo el proceso y sus participantes $^{789}$.

\footnotetext{
${ }^{786}$ Ley de Reemplazos de 30 de enero de 1856, art. 65.

787 "Para ello se incluirán en un globo tantos números cuantos sean los mozos de la edad que entraron en el primer sorteo. En otro globo se incluirá una papeleta con el nombre del que entre nuevamente, y otras en blanco hasta completar un número igual al de las papeletas del primer globo. Extraídas estas papeletas, el número que corresponda a la que tiene el nombre del mozo nuevamente incluido será el que tenga este, y se ejecutará otro sorteo entre él y el mozo que hubiere sacado el mismo número en el sorteo primero Para ello se introducirán en un globo los nombres de los dos mozos y en otro dos papeletas; la una con el número que tengan dichos mozos y la otra con el número siguiente; esto es, si el número que tengan los mozos fuera el 12, una papeleta con este número y otra con el 13.

Verificada la extracción quedará designado por ella el mozo que ha de conservar el número que tenían antes los dos; el otro tendrá el que siga, y los otros mozos sorteados desde aquél número en adelante ascenderán respectivamente cada uno una unidad; de manera que en el caso propuesto, uno de los mozos quedará con el número 12 , el otro tendrá el número 13 , el que tenía el número 13 pasará al 14, el del 14 al 15 y así sucesivamente" (Ley de Reemplazos de 30 de enero de 1856, arts. 67-69).

788 Ley de Reemplazos de 30 de enero de 1856 , arts. 71 y 72.

${ }^{789}$ El diputado Sr. Jaén solicitó además ante las Cortes, sin éxito, que, "[...] si fuese posible,[...] se estableciese un artículo que dijese que los Ayuntamiento pudiesen nombrar procuradores de los mozos sorteables, o una cosa semejante, esto es, una persona de ciencia que estuviese al corriente de la ley y de las operaciones del sorteo, a fin de que pudiera ayudar a los infelices. [...].Creo quo si tuvieran facultades los Ayuntamiento para nombrar procuradores de los sorteables, éstos sabrían a quien habían de acudir en primer término para enterarse de lo quo ignoraran y conocer la ley" (Discurso del Sr. Jaén, Diario de sesiones de las Cortes, no $240,09 / 11 / 1855$, p. 8038).
} 
e) La reducción en el número de exenciones

Se centra el capítulo IX en las exenciones y exclusiones del servicio militar, en general muy similares a las leyes anteriores aunque inferiores en número, pudiéndose diferenciar la siguiente tipología:

1. Motivos físicos: no alcanzar la talla mínima de 1,596 metros ${ }^{790}$, límite similar al establecido en las dos legislaciones previas, y los considerados inútiles por enfermedad o defecto físico ${ }^{791}$. A diferencia del Proyecto de 1850, nada se señala respecto a las autoridades competentes en esta materia ni a los reconocimientos médicos necesarios para declarar tal exención. Además, tampoco recoge una minuciosa relación de alegaciones físicas.

2. Motivos laborales y de interés estratégico o económico para el país: los que se hallasen matriculados en la lista de hombres de mar desde los diecinueve años y los carpinteros de ribera inscritos en las brigadas de arsenales $^{792}$; los operarios de las minas de Almadén

\footnotetext{
790 Por primera vez se fija la talla mínima en metros. El diputado Sr. Porto propuso, para evitar fraudes, que la medición de los reclutas se realizase en postura horizontal, rechazado por el ministro de la Gobernación al considerarlo depresivo para la dignidad de la especie humana, Discursos del Sr. Porto y del ministro de la Gobernación, Diario de sesiones de las Cortes, no 244, 14/11/1855, pp. 8202 y 8203).

${ }^{791}$ Ley de Reemplazos de 30 de enero de 1856, art. 73.

792 Para gozar de esta exención, la Ley fija los siguientes límites y obligaciones: "Los matriculados y carpinteros de ribera que con arreglo a esta disposición dejen de ingresar en el Ejército quedarán sujetos a servir cuatro años en los buques de la Armada desde el primer llamamiento que se haga en su distrito marítimo o arsenal, según su clase respectiva, aún cuando entonces no les toque por turno.

[...]

Así los matriculados como carpinteros de ribera que dejen de pertenecer a las matrículas o brigadas respectivas antes de cumplir la edad de 30 años, quedarán igualmente obligados a extinguir en el Ejército el tiempo que les falte para completar cuatro años de servicio a bordo e los buques de guerra, u ocho en los arsenales.
} 
siempre que fuesen vecinos de la zona o forasteros que llevasen al menos dos años trabajando como mineros, independientemente de que se hubiese suspendido su asistencia a la mina por enfermedades relacionadas con la insalubridad de sus trabajos; los alumnos de academias y colegios militares; Ios religiosos y novicios de las Escuelas Pías y las misiones de Filipinas, siempre que no dejen de pertenecer a tales órdenes religiosas antes de los treinta años $^{793}$. Los motivos que explican la exención de estos dos grupos clericales se deben a que "[...] el Estado no deja de sacar ventajas, en unas por la educación y en otras, no porque vayan a redimir infieles, sino porque contribuyen a que los Estados de Filipinas se mantengan obedientes a la metrópoli"794. Sin embargo, los ordenados in sacris no gozarían de ninguna exención, situación novedosa que no encontró oposición en el seno de las Cortes.

3. Motivaciones de tipo personal, si bien no se realiza una pormenorización tan exhaustiva con el Proyecto de ley de 1850 . El nuevo texto declaró eximidos

Si la separación de las matrículas o brigadas procede de delito o falta cometida por los matriculados o carpinteros, y no cuentan la edad de 30 años, después de extinguida la pena que se les haya impuesto, completarán el tiempo de servicio que les falte del modo que esta Ley establece para los que han sido procesados y penados criminalmente. [...]" (Ley de Reemplazos de 30 de enero de 1856, art. 74, 10 y $\left.2^{\circ}\right)$.

793 Ley de Reemplazos de 30 de enero de 1856, art. 74, 30, 40, 50 y 60. La posibilidad de que algunos religiosos quedasen exentos por su condición clerical encontró voces críticas en el Congreso: "No encuentro razón [para la exención] en los religiosos profesos de las Escuelas Pías, porque está dedicada esta comunidad a la enseñanza primaria, y hay multitud de escuelas mal pagadas y a sus profesores no se les recompensa en proporción a su trabajo, y no creo justo quo se haga esa excepción en favor de una comunidad quo no tiene otra misión social que cumplir" (Discurso del Sr. Jaén, Diario de sesiones de las Cortes, no 242, 12/11/1855, p. 8145).

794 Discurso del Sr. López Infantes, Diario de sesiones de las Cortes, no 242, 12/11/1855, p. 8145 . 
del servicio a los hijos únicos y nietos únicos ${ }^{795}$ de familia pobre $^{796}$ con el objeto de "de no dejar a un padre sexagenario abandonado, a una madre viuda abandonada, a una abuela, a una hermana, a un hermano huérfano abandonado, [...] ya que la sociedad no puede, no debe ser indiferente a la desgracia"797. Para evitar dudas, se aclaró que se reputaría como hijo o nieto muerto a aquel que se encontrase ausente por un espacio mayor de siete años, que el impedimento físico del padre o abuelo que eximiese al mozo del servicio había de impedirle el trabajo corporal necesario para la subsistencia y que se consideraría pobre a una persona que, aunque posea algunos bienes, no pudiese subsistir

795 Se consideraría hijo o nieto único, aunque tenga uno o más hermanos, el individuo que se encuentre comprendido en los siguientes casos:

"- Menores de 17 años cumplidos.

- Impedidos para trabajar.

- Soldados que cubren plaza que les ha tocado en suerte.

- Penados que extinguen una condena de cadena o reclusión, o la de presidio o prisión que no baje de seis años.

- Viudos con uno o más hijos, o casados que no pueden mantener a su padre o a su madre" (Ley de Reemplazos de 30 de enero de 1856, art. 75, $1^{\text {a }}$ y $2^{\mathrm{a}}$ ).

796 El difuso límite para declarar pobre a una familia quedó a juicio de Ayuntamiento y Diputaciones provinciales, circunstancia ésta criticada con dureza por el diputado Rodríguez Pinilla: "Todos los días, señores, en nombre de clases respetables, se esta aquí invocando, hasta por ápices, el sostenimiento de ciertas prerrogativas, de ciertas fórmulas y hasta de ciertos abusos, si se quiere decir así; y cuando se trata de las clases mas desvalidas en cuestión tan importante como es la de la contribución de sangre; cuando se trata de las exenciones que son mas frecuentes ante los Ayuntamiento y Diputaciones Provinciales, y de la cuestión en que más se expone a esas mismas clases desvalidas a que sean víctimas de los amaños, de las pasiones ó del interés de los más poderosos, de los mas astutos ó de los mas hábiles, se dice que es impracticable señalar la regla, quo debe quedar al juicio discrecional de los Ayuntamiento y Diputaciones Provinciales. [...]. En todas las ordenanzas hasta el día se ha consignado esa especie de indicación genérica, vaga e incierta para las declaraciones de pobreza, dejándolo esto a cargo de las autoridades, Pues precisamente porque este defecto ha existido en las ordenanzas anteriores, y justamente porque todas ellas han producido esos males, se necesita reformar la ley [...]" (Discurso del Sr. Rodríguez Pinilla, Diario de sesiones de las Cortes, no 244, 14/11/1855, pp. 8199 y 8200).

797 Discurso del Sr. López Infantes, Diario de sesiones de las Cortes, no 243, 13/11/1855, p. 8168. 
con el producto de dichos bienes si no es con el auxilio del hijo, nieto o hermano que debía ingresar en el Ejército ${ }^{798}$.

Nada se señala en este apartado de exenciones de la sustitución ni la redención en metálico. No quedaron exentos del servicio los maestros de instrucción primaria, ya que

"[...] solo en algunas partes se concede el derecho de exención para los maestros, considerando como una misión importantísima la de instruir a los hijos del pueblo; pero admitir ahora una excepción general, cuando la instrucción primaria se va generalizando, sería introducir en la ley una desigualdad monstruosa entre los mismos hijos del pueblo ${ }^{799 "}$ ".

f) Llamamiento y declaración de soldados y suplentes: la supervisión de la Diputación provincial

El capítulo $X$ reguló el proceso de llamamiento y declaración de los soldados, acto que se debería celebrarse en el Ayuntamiento de cada localidad el primer día festivo del mes de abril. En el mismo se procedería, en presencia de los concurrentes, a la medición de los mozos por parte de los talladores, comenzando por aquel que hubiese obtenido el número uno en sorteo. En el caso de no alcanzar la talla exigida, así se debía anotar, y se procedería al llamamiento y tallaje de los siguientes jóvenes. $Y$ en el caso de alcanzar la talla, se procedería a examinar el resto de las cualidades exigidas para el servicio. Para vigilar la legalidad del acto, debía asistir al mismo cada día un sargento, en activo o en situación de reserva, nombrado a tal efecto por el gobernador militar. Si no hubiese un número suficiente de sargentos, el propio consistorio designaría a una "persona

\footnotetext{
798 Ley de Reemplazos de 30 de enero de 1856, art. 75, 3a, 4a y $5^{a}$.

799 Discurso del Sr. Figuerola, Diario de sesiones de las Cortes, no 253, 27/11/1855, p. 8577.
} 
inteligente" para practicar la talla, que, además, recibiría una gratificación de los fondos municipales. Con el objeto de procurar que el tallador cumpliese fielmente con su función, presenciaría el acto un oficial de la guarnición, en activo o en situación de reserva, nombrado por el gobernador militar, o un oficial retirado invitado expresamente por el Ayuntamiento 800 .

En este mismo acto, o en un plazo máximo establecido por el consistorio, los mozos o las personas que les representen podrían exponer los motivos que les eximían del servicio y aportar la documentación justificativa. Sería el propio Ayuntamiento, "[...] sin dejar el punto a decisión de la Diputación Provincial $[\ldots]^{\prime 801}$, quien tomaría la decisión de declarar a un mozo soldado o excluido previa presentación, por parte del joven, del certificado que justificase los motivos de su exención ${ }^{802}$. En el caso de inutilidad física o enfermedad notoria, si no existiese conformidad de los interesados, serían uno o más facultativos designados por el Ayuntamiento, previo pago de seis reales por cada reconocimiento médico a realizar procedentes de las arcas municipales, los encargados de examinar al mozo, procediendo los cargos municipales a decidir en función de su dictamen y del reglamento de exenciones físicas. Tal decisión se tomaría en presencia de los números siguientes del sorteo teniendo en cuenta el estado en que aparezca el quinto durante el acto de reconocimiento sin atender a la posible declaración de inutilidad que se hubiese decidido en reemplazos pasados. Se deja la puerta abierta a la reclamación ante la Diputación provincial en caso de desacuerdo con la decisión municipal. En este caso, los reclamantes deberían comunicárselo por escrito o por palabra al alcalde en un plazo máximo de dos días desde que el Ayuntamiento hubiese fijado su resolución definitiva. La máxima autoridad municipal debería emitir

\footnotetext{
800 Ley de Reemplazos de 30 de enero de 1856, art. 77, 78 y 97.

801 Ley de Reemplazos de 30 de enero de 1856, art. 79.

${ }^{802}$ Ley de Reemplazos de 30 de enero de 1856, arts. 79 y 80.
} 
un certificado a todos los reclamantes donde se señalase su nombre y el objeto de su reclamación ${ }^{803}$.

Una vez que se hubiese tomado declaración y tallado al número uno del sorteo, se procedería de igual forma con los números siguientes hasta cumplir con el cupo de soldados requeridos y con un número igual de suplentes. Si con ambas categorías no se cubriese el cupo, se recurriría a los mozos sorteados el año anterior o los dos años previos y que no hubiesen cumplido el servicio. A estos mozos también se les realizaría un examen físico y se les sometería a un juicio de exenciones en el caso de que fuese necesario, siguiendo los mismos trámites administrativos. Quedaría exenta de cubrir el cupo la localidad que, recurriendo al sorteo del año y al de las dos promociones anteriores, no alcanzase el número de reclutas requeridos. En este supuesto, y como novedad respecto al Proyecto de 1850, sería la Diputación provincial y no el gobernador de la provincia, la encargada de examinar las actas de alistamiento y declaración de los soldados para juzgar si se había cumplido o no con la legalidad, pudiendo revocar las exenciones que no se ajustasen a la ley, debiendo además informar al ministerio de la Gobernación de tales incidencias ${ }^{804}$.

A continuación la ley se dedica a regular supuestos concretos que pudiesen incidir en la presentación y examen de los reclutas. Así, si un joven que hubiese recibido la suerte de soldado se encontrase a menos de cincuenta leguas del pueblo al que perteneciese, el Ayuntamiento establecería un término prudente para su presentación, no entregando un suplente ni declarando prófugo al mozo en cuestión hasta la superación de esa fecha. Si se encontrase a más de cincuenta leguas, se desconociera su paradero o hubiese sido declarado prófugo, en esta ocasión sí que se debería entregar al

${ }^{803}$ Ley de Reemplazos de 30 de enero de 1856, arts. 81, 87, 89, 98 y 99.

${ }^{804}$ Ley de Reemplazos de 30 de enero de 1856, art. 83-86. 
suplente ${ }^{805}$, además de iniciar los trámites oportunos para lograr la presentación del prófugo. Cuando esta circunstancia sucediese y fuese presentado el titular, se procedería a dar de baja al suplente. $Y$ si el recluta se encontrase fuera de la provincia donde hubiesen sido sorteados, podrían ingresar en la caja de aquella provincia donde residiesen, aunque pertenecerían al cupo del pueblo donde hubiesen sido sorteados ${ }^{806}$.

Tampoco olvida la ley la necesidad de regular el ingreso en el Ejército de aquellos mozos sorteados que hubiesen sido condenados por los tribunales ${ }^{807}$. Si la condena se hubiese producido en el plazo que media entre el sorteo y la declaración como soldado y la pena establecida fuera de presidio, el recluta sería destinado a las guarniciones africanas. En cambio,

"si la pena impuesta fue la de inhabilitación de cualquier clase, confinamiento, destierro, sujeción a la vigilancia de la Autoridad, represión pública, suspensión de cargo público, derecho político, profesión u oficio, arresto, multa o caución, así como la de resarcimiento de gastos y pago de costas procesales, el mozo que la haya sufrido ingresará en cualquiera de los cuerpos del Ejército"808.

En el caso de que el joven estuviese cumpliendo penas de prisión mayor antes de su declaración como soldado o se encontrase procesado por causa criminal, el penado no ingresaría en filas y sí lo haría su suplente; si la pena fuese presidio menor o correccional, sería destinado a las guarniciones de África; si la pena fuese de relegación, el mozo ingresaría en el Ejército de Ultramar; y si la pena

805 La Ley también aclara que "se entenderá que dicho suplente es el mozo que sacó el número más alto en el sorteo del año respectivo entre todos los llamados para cubrir el cupo del pueblo" (Ley de Reemplazos de 30 de enero de 1856, art. 95).

${ }^{806}$ Ley de Reemplazos de 30 de enero de 1856, arts. 90 y 91.

807 FEIJÓo GÓMEZ, A., Quintas y protesta social en el siglo XIX español, p. 246.

${ }^{808}$ Ley de Reemplazos de 30 de enero de 1856, art. 92. 
fuese inhabilitación, destierro, sujeción a vigilancia, represión pública, suspensión de cargo u oficio o arresto mayor o menor, el recluta ingresaría en la caja de su provincia correspondiente ${ }^{809}$.

g) Conducción y entrega de los reclutas en la caja de la provincia: citación personal para evitar engaños

Son los capítulos XI y XII los que regulan esta cuestión. Se estableció que todos los mozos declarados soldados y suplentes, previa citación personal ${ }^{810}$, deberían presentarse en la capital de provincia el día que el gobernador hubiese establecido como la fecha en que cada localidad haría la entrega de su cupo en la caja de reclutas. Esta fecha vendría condicionada por la distancia existente entre el pueblo y la capital de provincia, teniendo en cuenta que se dispuso para el traslado la realización de cinco leguas por jornada. Se anuló por tanto la obligatoriedad que imponía la legislación anterior de reunir a todos los mozos el día 15 de mayo. Irían los reclutas acompañados en su desplazamiento por un comisionado designado por el Ayuntamiento que recibiría la cantidad económica que el consistorio estimase oportuna como pago a sus servicios ${ }^{811}$. Asimismo, todos los jóvenes recibirían la cantidad de dos reales diarios a contar desde el día que emprendiesen su marcha hasta su

\footnotetext{
${ }^{809}$ Ley de Reemplazos de 30 de enero de 1856, arts. 93 y 94.

810 "[...] para evitar reclamaciones posteriores en el sentido de alegar ignorancia para no haberse presentado a la entrega del cupo, se ordena que los avisos a los mozos encartados no sólo se efectuara por anuncio público sino que [...] se hiciera por citación personal" (JIMÉNEZ GUERRERO, J., El reclutamiento militar en el siglo XIX: las quintas en Málaga (1837-1868), p. 183).

811 "El Comisionado irá provisto de una certificación literal de todas las diligencias practicadas por el Ayuntamiento, tanto acerca del alistamiento como respecto al acto de la declaración de soldados. Llevará también las filiaciones de los soldados y suplentes, y una certificación en que conste el nombre de los mismos y el día de su salida para la Capital, expresando además los nombres de los reclamantes a quienes con arreglo a lo dispuesto en el artículo anterior, el Ayuntamiento haya considerado sin medios para pagar los socorros de los mozos reclamados" (Ley de Reemplazos de 30 de enero de 1856, art. 104).
} 
ingreso en la caja para los titulares y hasta el regreso a su localidad de residencia para los reclutas suplentes. Acompañarían al contingente aquellos mozos excluidos por el Ayuntamiento que tuviesen que ser medidos o reconocidos de nuevo por alguna reclamación presentada, así como los interesados en esta reclamación ${ }^{812}$.

La entrega de los reclutas en la caja de la provincia comenzaría el día 15 de mayo y antes de finalizar el mes el ingreso se debía haber producido. Serían los gobernadores provinciales, a propuesta de las Diputaciones, los encargados de fijar la fecha en que cada partido o pueblo debía realizar la entrega de sus contingentes ${ }^{813}$. Un oficial designado por el capitán general del distrito sería el encargado de recibir a los reclutas, mientras que sería el comisionado municipal, en presencia de un diputado provincial designado por la Diputación, el encargado de constatar la entrega, pudiendo asistir al acto cualquier interesado ${ }^{814}$. Estos mismos cargos presenciarían además la medición, el reconocimiento y todas las diligencias que se practicasen con los reclutas. El quinto sería admitido o rechazado en función de lo que resultase de estos reconocimientos. En caso de no existir acuerdo entre los facultativos, talladores ${ }^{815}$, comisionados y los propios interesados, se daría cuenta a la Diputación provincial para que resolviese lo oportuno ${ }^{816}$.

\footnotetext{
812 Ley de Reemplazos de 30 de enero de 1856, arts. 100-103.

813 Ley de Reemplazos de 30 de enero de 1856, art. 105.

814 "No siempre los Ayuntamiento cumplieron con los plazos requeridos, ni siempre completaron los cupos solicitados, por lo que las amonestaciones por parte de la Comisión Provincial, del Ministerio de Gobernación, y del Ejército, fueron frecuentes" (FEIJÓo GÓMEZ, A., Quintas y protesta social en el siglo XIX español, p. 250).

815 "Habrá dos Facultativos y dos talladores, nombrados uno por la Diputación Provincial y otro por la Autoridad superior militar de la provincia. Los designados por la máxima autoridad Provincial recibirán una gratificación de diez reales por cada reconocimiento los primeros y una gratificación "proporcionada" los segundos a cargo de los fondos municipales. En cambio, talladores y Facultativos castrenses no recibirán ninguna gratificación" (Ley de Reemplazos de 30 de enero de 1856, art. 108).

${ }^{816}$ Ley de Reemplazos de 30 de enero de 1856, arts. 106 y 107.
} 
h) La lucha contra el prófugo

La Ley de 1856 introdujo algunas novedades de interés en esta cuestión si la comparamos con el Proyecto de 1850. Así, se inicia el capítulo XIII aclarando a quien se consideraba prófugo:

"Son prófugos los mozos que, declarados soldados o suplentes por el Ayuntamiento respectivo, no se presenten personalmente a la entrega en la caja de la provincia el día señalado para este acto si se encuentran en el pueblo o a distancia de 10 leguas del mismo, ya sea al tiempo de la declaración de soldados, o ya cuando se les cite para ser conducidos a la Capital" ${ }^{817}$.

Si el mozo se encontrase a más de diez leguas de la localidad donde habían sido declarados soldados o suplentes, no serían considerados prófugos si se presentan en la caja de reclutas dentro del plazo prudencial que estableciese el Ayuntamiento. Además, también se estableció que cuando el soldado o suplente pudiese presentar ante el consistorio o la Diputación causa justa del por qué no se había presentado en la caja, tampoco sería considerado prófugo $^{818}$.

Para que un individuo fuese declarado prófugo se debía tramitar un expediente por parte del Ayuntamiento correspondiente, que además sería el encargado de declarar a un mozo como tal. Dicho expediente sería sobreseído si el mozo se presentase en la capital de provincia el día que se fuese a efectuar la entrega de los quintos en la caja. De tal presencia debería informar al Ayuntamiento el comisionado encargado del traslado de los reclutas. En el caso de no presentarse el joven, se comunicaría tal circunstancia al padre, a

\footnotetext{
${ }^{817}$ Ley de Reemplazos de 30 de enero de 1856, art. 109.

${ }^{818}$ Ley de Reemplazos de 30 de enero de 1856, arts. 110 y 111.
} 
algún pariente cercano del prófugo o, en su defecto, "a un vecino honrado en calidad de defensor", para que pudiesen presentar alegaciones. También se comunicaría al suplente tal ausencia ${ }^{819}$.

Las penas impuestas para el prófugo son diversas: en primer lugar pagaría al Ayuntamiento los gastos que ocasionasen su captura y conducción a la caja de reclutamiento. También debería abonar al suplente que hubiese cubierto su plaza la cantidad de 1.000 reales por cada año que hubiese ocupado su plaza. Además, el prófugo capturado sería destinado a las guarniciones africanas por el tiempo ordinario del servicio más un recargo de uno a tres años fijado por la Diputación provincial. Si el prófugo fuese declarado inútil para el servicio, deberá abonar una multa entre 50 y 2.000 reales establecida por la Diputación ${ }^{820}$. Si no pudiese asumirla, cumpliría penas de prisión.

Serían las administraciones provincial y local las encargadas de capturar y castigar al prófugo, quedando al margen las autoridades militares. Una vez aprehendido el joven huido, él mismo y el expediente instruido serían trasladados a la Diputación provincial, quien podría confirmar o revocar las disposiciones tomadas por el consistorio y debería llevar al mozo a la caja de quintos o conducirle al cuerpo donde sirviese el suplente. En el caso de que el prófugo fuese absuelto por el Ayuntamiento, la Diputación también podría revocar esta decisión tras analizar el expediente ${ }^{821}$.

Lógicamente el soldado suplente que cubriese la plaza del prófugo se vería compensado por sus servicios. Así, sería liberado de sus obligaciones y recibiría la contraprestación económica de 2.000 reales por cada año como soldado por parte del prófugo. En el caso

\footnotetext{
${ }^{819}$ Ley de Reemplazos de 30 de enero de 1856, arts. 113 y 114.

820 Ley de Reemplazos de 30 de enero de 1856, arts. 112, 114 y 121.

${ }^{821}$ Ley de Reemplazos de 30 de enero de 1856, arts. 116-118.
} 
de que éste no pudiese afrontarla, el Estado se haría cargo de la mitad de esa cantidad ${ }^{822}$.

Los cómplices en la fuga también recibirían su castigo correspondiente. Para ello el Ayuntamiento debería tramitar un expediente que sería enviado al juzgado ordinario para que procediese a la formación de la causa. En caso de demostrarse su culpabilidad, deberían abonar una sanción de entre 500 y 2.000 reales $y$, en el caso de no poder pagarla, sufrirían penas de prisión en función de lo que estableciese el Código Penal ${ }^{823}$. Al igual que los cómplices son castigados, los colaboradores en la captura del prófugo también recibirían su compensación. Así, si el prófugo fuese capturado por algún soldado que estuviese cumpliendo el servicio militar, o por su padre o hermanos, su tiempo de prestación sería rebajado de forma similar al recargo temporal que se estableciese como pena para el huido capturado, siempre que éste fuese considerado útil para el servicio ${ }^{824}$. El resto de ciudadanos que colaborasen en la captura recibirían la compensación de 400 reales que debería abonar el prófugo 0 , en caso de que éste no tenga capacidad económica para ello, el Estado ${ }^{825}$.

Por último, y de forma similar a legislaciones previas, pero con mayor precisión, se establecían medidas encaminadas a evitar la salida del país de jóvenes en edad militar. Así, se prohibió a los mozos entre diecisiete y veintitrés años cumplidos salir del Reino, ya

\footnotetext{
822 Ley de Reemplazos de 30 de enero de 1856 , arts. 119 y 120.

823 Ley de Reemplazos de 30 de enero de 1856, art. 115.

824 Las diferencias en las compensaciones en función de la utilidad o inutilidad del huido para el servicio militar encontraron dudas en el seno del Congreso: "Pues diré que este artículo es injusto, por cuanto no premia como debe al que coge a un prófugo, aunque no sea apto para servir; porque el que hace la aprehensión, las mimas incomodidades tiene y el mismo riesgo de resentimiento corre siendo apto el prófugo que no siéndolo. Es más: el art. 125 impone de 500 a 2.000 rs. al prófugo que resultare inútil. ¿Que inconveniente, pues, tiene la Comisión en que se dé al aprehensor la misma cantidad u otra poco menor cuando el prófugo es apto, que cuando no lo es?" (Discurso del Sr. Zorrilla, Diario de sesiones de las Cortes, no 247, 20/11/1855, p. 8360).

${ }^{825}$ Ley de Reemplazos de 30 de enero de 1856, arts. 121-124.
} 
sea en territorio peninsular o en las provincias de Ultramar, a no ser que ya hubiesen sido sorteados. En este supuesto, en todo caso, deberían abonar un depósito de 6.000 reales que serían empleados por el ministerio de Guerra en cubrir la vacante que dejase el joven que se encontrase en el extranjero y no se presentase a servir su plaza. No se exigiría fianza en cambio para los jóvenes que viajasen a Ultramar, aunque éstos deberían prestar sus servicios en las provincias americanas en el supuesto de que obtuviesen la suerte de soldado. No se exigiría, en cambio, ninguna cantidad para aquellos jóvenes que quisiesen salir del país y acreditasen

"haber quedado libres de toda responsabilidad, bien por no haber sido llamados al servicio en el año en que fueron sorteados, ni en el transcurso de los dos años inmediatos siguientes, bien por haber redimido o cubierto su plaza de soldado por cualquiera de los medios que permite esta Ley" ${ }^{\prime 826}$.

i) Las reclamaciones ante la Diputación provincial y el ministerio de la Gobernación

Versan los capítulos XIV y XV sobre la posibilidad que tenían los mozos de reclamar las decisiones tomadas por los Ayuntamientos. En esta ocasión no era el comisionado nombrado por el consistorio ${ }^{827}$, sino que eran el diputado provincial y el comandante de la caja que asistía a la entrega de los quintos, los encargados de preguntar a soldados y suplentes si deseaban presentar una reclamación ante la Diputación por posibles agravios cometidos por el consistorio en ese mismo acto de entrega. Se tomaría nota de tales reclamaciones y se pasaría el documento, firmado también por el comisionado municipal,

${ }^{826}$ Ley de Reemplazos de 30 de enero de 1856, art. 125.

${ }^{827}$ Así lo establecía el Proyecto de ley de 1850. 
a la institución provincial. Sería la Diputación la encargada de examinar tales reclamaciones, la documentación aportada y las diligencias realizadas por los Ayuntamientos, para poder así tomar una resolución adecuada. La Diputación también podría practicar las oportunas diligencias si así lo considerase oportuno y podría establecer un plazo para que los interesados aportasen la documentación que considerasen necesaria ${ }^{828}$.

A continuación la ley se dispone a regular los distintos motivos de reclamación:

1. Si la reclamación fuese presentada por cuestiones de talla

"la Diputación Provincial dispondrá un nuevo reconocimiento por dos peritos talladores que no hayan intervenido en el primero, $y$ de los cuales nombrará uno la Diputación y otro el comandante de la caja. Si hubiese discordancia de pareceres entre los talladores, la misma Diputación nombrará un tercero, y en uno y otro caso, con vista de los dictámenes periciales, declarará al quinto soldado o excluido" ${ }^{829}$.

2. Cuando la duda proviniese de la aptitud física de un quinto, se realizaría un nuevo reconocimiento por parte de dos facultativos distintos cada día que no hubiesen participado en el primero y que serían nombrados por la Diputación y por la autoridad militar superior de la provincia. En caso de no haber acuerdo en su decisión prevalecería el dictamen del segundo ${ }^{830}$.

\footnotetext{
828 Llama la atención que los propios interesados no pudiesen defender personalmente su reclamación por haber sido ya entregados en la caja de quintos, Ley de Reemplazos de 30 de enero de 1856, arts. 126 y 127.

829 Ley de Reemplazos de 30 de enero de 1856, art. 128.

${ }^{830}$ Ley de Reemplazos de 30 de enero de 1856, art. 129.
} 
Los acuerdos que tomasen las Diputaciones en estos dos supuestos serían inapelables y no existía la posibilidad de reclamar ante el ministerio de la Gobernación "a no ser en el caso de que los fallos de las Diputaciones hubiesen sido contrarios al dictamen de dos de los facultativos o talladores $[\ldots]^{\prime \prime 831}$.

La última atribución otorgada a la Diputación en materia de reclutamiento constituyó una novedad administrativa que perseguía una mayor control sobre todo el proceso: se estableció la obligación de la institución provincial de elaborar dos documentos similares donde se incluyese el número y los mozos sorteados en cada pueblo, el cupo que correspondiese a cada localidad, los exceptuados por falta de talla e inutilidad física y el motivo de la misma, así como la proporción habida entre aptos y no aptos. Esta documentación se remitiría a los ministerios de Guerra y Gobernación.

Como última posibilidad de reclamación, esta vez frente a la resolución de la Diputación, se podía acudir al ministerio de la Gobernación, organizador de todo el proceso de reclutamiento. Para ello se debería presentar un recurso ante el gobernador de la provincia en un plazo máximo de ocho días desde que resolviese la Diputación, ya sea por motivos de exclusión o inclusión errónea del interesado o de otros mozos o por las excepciones que se hubiesen alegado y que no hubiesen sido tenidas en cuenta ${ }^{832}$. Esta nueva reclamación no frenaría en ningún caso la ejecución de los acuerdos tomados por la Diputación.

\footnotetext{
831 Ley de Reemplazos de 30 de enero de 1856, art. 130. Esta posibilidad de reclamación fue defendida por el propio ministro de la Gobernación: "Las resoluciones de las Diputaciones Provinciales son ejecutivas; se lleva a efecto to que ellas acuerdan; pero por si se han equivocado, se establece esta apelación al Gobierno y al Tribunal Contencioso-administrativo" (Discurso del Sr. Ministro de la Gobernación, Diario de sesiones de las Cortes, no 249, 20/11/1855, p. 8421).

832 Señala la propia Ley que no se podrá presentar reclamación ante el Ministerio por motivos de aptitud física o talla de un mozo. Ley de Reemplazos de 30 de enero de 1856, art. 134.
} 
Una vez recibida la protesta, el gobernador debería instruir, en un plazo máximo de un mes, un expediente que debería incluir "[...] los informes del Ayuntamiento y de la Diputación Provincial, copias de los acuerdos de estas dos corporaciones y las pruebas y los documentos que para dictarlas lo remitirá al ministerio de la Gobernación" ${ }^{\prime 833}$. Sería el ministerio de la Gobernación, teniendo en cuenta el dictamen del Tribunal Contencioso-Administrativo, el que tomaría la resolución definitiva ${ }^{834}$.

j) La sustitución y la redención en metálico: el fondo de redención del servicio militar

Se centra el capítulo XVI, penúltimo de la ley, en una de las cuestiones más polémicas: la sustitución ${ }^{835}$. En este apartado las novedades implantadas con respecto a disposiciones anteriores son de enorme relevancia, ya que se reconoce de forma expresa la redención en metálico como una forma de sustitución. Además, también se reconoció la posibilidad de la sustitución grupal o redención en metálico para todos los mozos de una localidad por parte de Ayuntamientos y Diputaciones provinciales, así como la sustitución general de todos los quintos de una provincia por parte

\footnotetext{
${ }^{833}$ Ley de Reemplazos de 30 de enero de 1856, art. 135.

${ }^{834}$ Ley de Reemplazos de 30 de enero de 1856, art. 136.

835 La posibilidad de la sustitución fue defendida por el diputado progresista Escosura en un ardiente discurso como un privilegio de la civilización, además de rechazar la anatematización que el partido Progresista realizaba de las clases más pudientes: "Se dice que la sustitución es un privilegio en favor del dinero. No, no es por privilegio del dinero, sino por privilegio de la civilización, si es quo hay privilegio. iComo! Si no admitís el principio de la sustitución, arrancareis a los 20 años la juventud a la literatura, a las artes y a las ciencias. Si no admitís el principio de la sustitución, ¿donde tendremos hombres a propósito para las diferentes posiciones en el Estado? Buscad otro medio de sustituir, a ver si lo encontráis, distinto del dinero. No, desgraciadamente no le hay; porque el dinero, señores [...], el dinero no es más que la representación de todas las cosas de la vida" (Discurso del Sr. Escosura, Diario de sesiones de las Cortes, no 231, 29/10/1855, p. 7725).
} 
del Gobierno cuando las circunstancias así lo requiriesen ${ }^{836}$. También destaca la enorme meticulosidad con que se regularon las condiciones que debían tener los sustitutos, "al objeto de evitar los fraudes y abusos que se venían cometiendo" ${ }^{837}$.

Se reconocieron cuatro medios diferentes para realizar la sustitución del servicio militar para mejorar lo legislado en 1837 y en el Proyecto del Senado de $1851^{838}$ :

1. Por el cambio de número entre el joven que quiera sustituirse y cualquier otro mozo soltero o viudo sin hijos, previamente tallado y reconocido en la Diputación provincial ${ }^{839}$, que hubiese sido sorteado en la misma provincia en el año correspondiente al reemplazo 0 en los dos años inmediatamente anteriores. Además este joven debería tener entre veinte y veinticinco años de edad, no encontrarse procesado criminalmente, no ser considerado exento del servicio ni depender el mantenimiento de sus padres o abuelos de su propio trabajo. También debía poseer una escritura pública que explicitase el permiso de su padre o madre para realizar la sustitución. Además, "el sustituido por cambio de número quedará obligado a ingresar en las filas del Ejército si en los

\footnotetext{
${ }^{836}$ Ley de Reemplazos de 30 de enero de 1856, arts. 147 y 148.

837 PUELL DE LA VILLA, F., El soldado desconocido: de la leva a la "mili" (17001912), p. 193.

838 "Es indudable, señores, quo la sustitución como se venía practicando por la ley de 1837 y aun por el proyecto de ley discutido en el Senado, quo varió ese sistema, es un mal grande para el Ejército y es un mal grande para el país. Para el Ejército, porque lo priva, al cumplir el año de servicio, al concluir la responsabilidad del que ha puesto el sustituto, y al recibir este, por consiguiente, el total de la cantidad por la cual se obliga a la sustitución, priva, repito, al Ejército de muchos hombres, pues pasado ese tiempo de responsabilidad son muy comunes, son muy generales las deserciones de los sustitutos" (Discurso del Sr. Ministro de Guerra, Diario de sesiones de las Cortes, no 250, 23/11/1855, p. 8460).

${ }^{839}$ Ley de Reemplazos de 30 de enero de 1856, art. 138.
} 
reemplazos sucesivos alcanzase al sustituto esta obligación" ${ }^{840}$.

2. "Por soldados licenciados del Ejército que no pasen de 32 años, aptos para el servicio y sin mala nota en su licencia"841. Para ello debían demostrar su edad a través de la partida de bautismo ${ }^{842}$.

3. Por cualquier mozo entre veintitrés y treinta años soltero o viudo sin hijos. Para ello debería acreditar tener esa edad $y$, en el caso de ser menor de veinticinco años, una licencia paterna que especificase su voluntad. Asimismo, deberían ser tallados y reconocidos por parte de la Diputación provincial ${ }^{843}$.

4. Mediante la redención en metálico, es decir, por medio de la entrega a otro mozo de la cantidad de 6.000 reales $^{844}$. Esta cantidad sería depositada, en un plazo máximo de dos meses desde que el mozo fue declarado soldado, en la Caja General de Depósitos de Madrid o en las tesorerías de la Hacienda pública de las distintas provincias, mientras que el sustituido debería acreditar tal ingreso ante la Diputación provincial mediante una carta de pago o documento acreditativo $^{845}$.

El texto realiza otra serie de prevenciones para consolidar la figura de la sustitución. Así, en el caso de que el sustituto desertase durante el primer año de servicio, sería el propio sustituido quien

840 Ley de Reemplazos de 30 de enero de 1856, arts. 137, 139 y 143.

${ }^{841}$ Ley de Reemplazos de 30 de enero de 1856, art. 137.

842 Ley de Reemplazos de 30 de enero de 1856, arts. 137 y 140.

843 Ley de Reemplazos de 30 de enero de 1856, arts. 137, 141 y 142.

${ }^{844}$ El diputado Carlos María de la Torre propuso que la redención no se valorase para toda la población en 6.000 reales, sino que fuese proporcional a la riqueza de cada familia, convirtiéndose de esta forma en un instrumento realmente igualitario, Discurso del Sr. De la Torre, Diario de sesiones de las Cortes, no 229, 26/10/1855, p. 7669.

${ }^{845}$ Ley de Reemplazos de 30 de enero de 1856, arts. 137, 149 y 150. 
debe reemplazarle en su puesto, si bien se admite la posibilidad de que se redima mediante la entrega de 6.000 reales $^{846}$.

También se recoge el destino de las cantidades entregadas por los redimidos, que obligatoriamente serían invertidas por el ministerio de Guerra en cubrir las bajas de estos jóvenes ${ }^{847}$ mediante reenganchados del Ejército 0 voluntarios que recibirían una gratificación de 6.000 reales $^{848}$. Por tanto, el destino exclusivo de la redención debía ser el enganche de voluntarios o el reenganche de veteranos del Ejército.

Como última novedad de la ley en el apartado de sustituciones destacar la obligación que se impuso al Gobierno de informar anualmente a las Cortes de las cantidades recaudadas a través de las redenciones y su destino, del número de mozos que se habían liberado del servicio, del número de reenganchados y voluntarios sustitutos, así como del número de plazas que habían quedado sin cubrir. Además, en el año 1859 se creaba el Consejo de Redención y Enganche del Servicio Militar ${ }^{849}$ para la gestión de los fondos recibidos

\footnotetext{
${ }^{846}$ Ley de Reemplazos de 30 de enero de 1856, art. 146.

847 "Para este fin, la suma total que importen las cantidades entregadas por los mozos será destinada única y exclusivamente al objeto de cubrir las bajas, de tal modo que resulte asegurada su precisa inversión" (Ley de Reemplazos de 30 de enero de 1856, art. 153).

848 Ley de Reemplazos de 30 de enero de 1856 , arts. 154 y 155 . Tal y como señala Puell de la Villa, "durante los cinco primeros años del primer gobierno de la Unión Liberal, se regularizó el llamamiento anual y, coincidiendo con la declaración de guerra a Marruecos, se creó el fondo de redenciones del servicio militar para poner en vigor le referido artículo 155 de 1856, encargando su gestión a un consejo específicamente dedicado a esta labor" (PUELL DE LA VILLA, F., El soldado desconocido: de la leva a la "mili" (1700-1912), p. 193).

849 "El consejo de Gobierno y Administración del fondo de redención y enganches para el servicio militar tiene su antecedente más directo en 1828 en el Depósito de Bandera y Enganche cuyo propósito era reclutar hombres para el servicio en Ultramar. La evolución del organismo lo lleva, treinta años después, a instaurar el denominado, con carácter general, Consejo de Redención y Enganches, organismo bajo la tutela del Tribunal de Cuentas del Reino y dependencia orgánica del Ministerio de Guerra (GARCÍA GARCÍA, A., y SEMPERE DOMENECH, M., "Conflicto y quintas. resistencia al servicio militar obligatorio: exenciones, exclusiones, redenciones y sustituciones en la Murcia del siglo XIX", en La era Isabelina y la revolución 1843 - 1875: Actas de las XIII Jornadas Nacionales de Historia Militar, Sevilla, Cátedra General Castaños, 2009, pp. 337-356).
} 
por la redención del servicio ${ }^{850}$. El objetivo de esos fondos debía ser la de contratar soldados voluntarios

"[...] pero, finalmente, se dedicaron a comprar títulos de la Deuda Pública; aunque los más frecuente, fue que acabaran englobados en los Presupuestos estatales. Puesto que los contingentes de tropa se fijaban anualmente según necesidades, no fue raro que en momentos de crisis económica particularmente aguda se llegara a incrementar, falsamente, las necesidades de reclutamiento para así aumentar las redenciones $y$, por lo tanto, los ingresos pecuniarios ${ }^{\prime 851}$.

k) Disposiciones penales: el castigo frente a las irregularidades

El último capítulo de la ley se centró en las causas criminales que los tribunales ordinarios podían iniciar para castigar las irregularidades que se hubiesen cometido durante el proceso de reclutamiento. Así, serían juzgados aquellos mozos que se hubiesen automutilado o inutilizado voluntariamente para eludir el servicio. Demostrado este delito, los culpables serían destinados a las guarniciones africanas durante diez años, sin posibilidad de retribución o licencia temporal. Sus coautores o encubridores serían condenados a presidio mayor en función de lo establecido en el Código Penal ${ }^{852}$.

También se iniciaría causa criminal contra el joven que hubiese actuado de forma fraudulenta para eximirse del servicio en cualquiera de las fases del proceso. Juzgado mediante el Código Penal, y una vez demostrada su culpabilidad, debería cumplir íntegro el servicio militar una vez que hubiese cumplido su pena de prisión. Además,

850 Ley de Reemplazos de 30 de enero de 1856, arts. 156 y 157.

851 FERNÁNDEZ VARGAS, V., "El servicio militar en el siglo XIX. Una percepción social", p. 105.

${ }^{852}$ Ley de Reemplazos de 30 de enero de 1856, art. 158. 
debería abonar al suplente que hubiese cubierto su plaza la cantidad de 1.000 reales por cada año cumplido en el Ejército, recluta que además quedaría liberado de sus obligaciones militares ${ }^{853}$.

Además de las multas que alcaldes y gobernadores pudiesen imponer, se iniciaría proceso criminal contra aquellos que hubiesen cometido delito durante la ejecución de las operaciones de reemplazo ${ }^{854}$. Los condenados por este motivo, además de penas de prisión, deberían resarcir por daños y perjuicios a aquellos jóvenes que, por su actuación fraudulenta, hubiesen tenido que cumplir el servicio militar ${ }^{855}$.

Larga vigencia y escasos cambios en la aplicación de la norma

Nos encontramos ante una de las leyes básicas en materia de reclutamiento de todo el siglo XIX, ya que se constituyó en una norma de referencia para toda la segunda mitad de la centuria, y las modificaciones introducidas en ella a lo largo de sus catorce años de vigencia fueron ciertamente limitadas ${ }^{856}$, a pesar del predominio en el Gobierno de un nuevo partido, la Unión Liberal, dirigido por el militar Leopoldo O'Donnell, Presidente del Gobierno en varias ocasiones

\footnotetext{
853 Ley de Reemplazos de 30 de enero de 1856, art. 159.

854 "Los Ayuntamiento, por negligencia o voluntariamente, no siempre cumplían las disposiciones dictadas para el reemplazo, lo que provocó quejas por parte de las Comisiones Provinciales de reclutamiento [...]. En unos casos la desidia y la negligencia, y en otros la voluntariedad de los Ayuntamiento, provocó irregularidades que adulteraron el resultado de las operaciones de reemplazo, al obligar a la Comisión Provincial a declarar soldados a suplentes, a rectificar juicios de exención, o a realizar juicios de adivinación para entender las actas y estadillos no acordes con los modelos distribuidos, o emborronados con rectificaciones y falseados con omisiones" (FEIJÓO GÓMEZ, A., Quintas y protesta social en el siglo XIX español, pp. 237 y 238).

${ }^{855}$ Ley de Reemplazos de 30 de enero de 1856, arts. 160-162.

856 Tan sólo algunos Reales Decretos que convocaban el reemplazo anual introdujeron, por motivos excepcionales, algunas modificaciones en los plazos establecidos por la Ley aprobada en 1856. Sirva de ejemplo el Real Decreto de 25 de Abril de 1857 llamando al reemplazo a 50.000 hombres, Gaceta Núm. 1573 de 26/04/1857.
} 
entre 1856 y 1866 . Señalar que, al poco tiempo de la aprobación de la norma, una de las medidas progresistas que contiene la misma fue suprimida, ya que se reimplantó la exención del servicio para los individuos pertenecientes a la Congregación de San Vicente de Paúl como reconocimiento a sus actividades misioneras en Ultramar ${ }^{857}$ y para todos los ordenados in sacris posteriormente, que volvían a recuperar así este privilegio ${ }^{858}$.

Fueron diversas las iniciativas parlamentarias principalmente presentadas por los representantes del partido Demócrata a lo largo de los últimos años de la década de los cincuenta y los años sesenta que pidieron la reducción del contingente solicitado por el Gobierno en Cortes al considerarlo excesivo para las necesidades defensivas y de mantenimiento del orden público del país ${ }^{859}$, incrementado notablemente en 1859 al elevar desde los 84.000 hasta los 100.000 hombres los miembros del Ejército activo y justificado por la participación española en expediciones en Marruecos, México y la Cochinchina, por el estallido de la guerra entre Francia y Piamonte frente a Prusia con la inestabilidad que el conflicto traía al viejo continente ${ }^{860}$, así como por la necesidad de asegurar el dominio sobre las colonias cubana, puertorriqueña y filipina, amenazadas por el imperialismo norteamericano:

"Nosotros creemos, sin embargo, que pudiendo venir a una solución pacífica la cuestión de Méjico, que pudiendo, si obramos con resolución y energía, imponer a los moros que vienen a perturbar la tranquilidad de Melilla, y en cierta manera a rebajar la dignidad del pueblo español, teniendo como tenemos una reserva respetable para

\footnotetext{
${ }^{857}$ Real Orden de 14 de Enero de 1857, Gaceta Núm. 1347 de 15/01/1857.

858 Real Orden de 30 de Agosto de 1857, Gaceta Núm. 1700 de 31/08/1857.

859 Discurso del Sr. González de la Vega, Diario de sesiones de las Cortes, no 25 , 03/06/1857, pp. 373 y 374 y Discurso del Sr. Santa Cruz, Diario de sesiones de las Cortes, no 25, 10/04/1858, pp. 1049-1052.

860 Ley de 18 de mayo de 1859 autorizando al Gobierno para aumentar hasta 100.000 hombres la fuerza del Ejército activo, y para abrir los créditos que sean precisos a dicho aumento, Diario de Sesiones de las Cortes, no 124 de 24/05/1859.
} 
las atenciones extraordinarias, podemos muy bien cubrir el servicio ordinario con 70.000 hombres"

La prensa afín a los demócratas mostró una postura similar, contraria al incremento del contingente, si bien el miedo a las medidas represivas limitaron sus críticas:

"Poco importaría que nos denunciase el gobierno de la unión liberal, con tal que llegara nuestro periódico á manos de nuestros correligionarios. Pero ya que el secuestro hace esto imposible, es preciso que renunciemos por ahora á escribir crónicas parlamentarias.

Hemos oído ayer tarde al Sr. Saavedra Meneses; hémosle oído decir, combatiendo el voto particular del Sr. Fagés, que es tan escasa la fuerza del ejército permanente, que, durante los últimos sucesos, el gobierno tuvo necesidad de aprovecharse de una de las columnas que persiguieron al batallón de Almansa, para que fuera también en persecución de las partidas que se levantaron en Cataluña. Nosotros pudiéramos contestar satisfactoriamente á este argumento, hecho por el señor Saavedra Meneses, queriendo probar que no es escesiva (sic) la cifra de 85.000 hombres que pide el gobierno; pero se nos denunciaría y se recogerían los ejemplares de LA DISCUSIÓN para que no fueran á provincias. ¿Por qué no ha dispuesto el general O'Donnell de los regimientos que tenía en Madrid, en Valladolid y otros puntos? Solo lo saben los habitantes de estas poblaciones ${ }^{\prime 1862}$.

En otras ocasiones, los artículos de opinión resultaban radicalmente contrarios a este incremento, poniéndose en cuestión todo el sistema militar español ante el daño que se ejercía sobre el país en su globalidad y la inutilidad del servicio, así como el perjuicio causado a los jóvenes y sus familias, siempre pobres, ya que la población con mayores recursos se podía redimir en metálico. A cambio se defendía el voluntariado, e incluso el fin de los ejércitos,

${ }^{861}$ Discurso del Sr. Madoz, Diario de sesiones de las Cortes, no 27, 05/01/1858, p. 588.

862 La discusión, 27/03/1866, no 3144, p. 2. 


\section{normalmente contrarios al sistema democrático. Reproducimos a continuación un largo artículo periodístico donde se recogían todas estas variables:}

"El proyecto de ley de reemplazo del ejército tiene por objeto arrancar del seno de la familia á 35.000 jóvenes, pobres todos, que entran en la edad de instruirse y de ser útiles á su familia y al progreso de la nación, para obligarles á ser soldados en tiempo de paz, con lo cual dejarán de producir, dejarán de instruirse [...]. Oye la lectura el Sr. Aparici, y comienza calificándolo de justo y de laudable, «pues tiende á proteger á los pobres.» No sabemos dónde encuentra esas deducciones tan peregrinas el ingenio del diputado valenciano. Proteger á los pobres es condenar á 35.000 de ellos á un servicio innecesario, tan innecesario que se convierte en ocio estéril; impedir así su desarrollo moral é intelectual, y en su consecuencia obligar á los demás pobres no incluidos en esta condena, á mantenerlos durante largos años. Estamos seguros dé que el Sr. Aparici no deseará ni ha leseado nunca para él protección semejante.

Digamos de paso que también el general O'Donnell la echó da filántropo ponderando las comodidades que se proporcionan al soldado: absurdo que raya la impiedad, pues cualquier joven de los que tienen que servir en el ejército, si tiene vocación de soldado, podría serlo con solo querer, y si no la tiene, podría adquirir libremente lo que consume y mucho más, empleando en tareas útiles á la sociedad el tiempo que pasa en los cuarteles ó á la puerta de pacificas moradas.

El Sr. Aparici, á pesar de esa laudable protección, se horroriza al pensar en las desgraciadas madres á quienes les arrancan de los brazos al hijo de sus entrañas; madres siempre pobres, porque los ricos pueden eximirse del servicio; las ve llorando, desesperadas, sin consuelo, en perdurable zozobra, renunciando al intimo cariño, al porvenir que soñaban para sus hijos...

En la tribuna pública había una madre que escuchaba anhelante las palabras del Sr. Aparici; que parecía ver su retrato en la pintura de aquel animado cuadro, y aquella madre lloraba y sollozaba silenciosa, y silenciosa oía decir que el proyecto era justo y laudable. Nosotros no estábamos bastante cerca de aquella desgraciada para oiría; pero mil 
veces se estremeció nuestro corazón al contemplarla, porque aquel semblante lastimo y aquel llanto decía á voces: ihijo de mis entrañas! Nosotros, en ocasionas semejantes, no podemos ocuparnos de si es bien ó mal que el gobierno y la comisión supriman las remuneraciones de 2.000 rs. á los cumplidos é inutilizados. Inutilizados son todos los que contra su vocación, contra su voluntad, contra la equidad (que aconseja favorecer al desvalido antes que al bien acomodado), tienen que pasar los seis años mejores de su vida fuera del hogar, del centro de su desenvolvimiento y de las condiciones favorables á los demás ciudadanos. iDichoso el Sr. Aparici que á lo menos encuentra á cada paso un recuerdo vivo, un monumento en pié de aquellos dichosos tiempos en que él habría sida un siervo glorioso de algún glorioso señor!

Así dice S. S.: «la suerte del soldado español es hoy mas que nunca buena y holgada.» Sí; para el irracional la hartura de la servidumbre es el supremo contento; para el que tiene conciencia de hombre, para nosotros, cuanto mas elevado es el ser en la escala de la creación, mas dolorosa le es la violencia, menos le satisfacen las miserias materiales que se le ofrecen en compensación de la santa libertad.

$[\ldots]$.

Alegraos, no lloréis: en vez de libertad, y de raciocinio, y de opinión, y de privilegios, como el Sr. Aparici, tendréis la dicha de ganar gloria en el servicio y comer el pan de la holganza forzosa. iEl Sr. Aparici es como siempre confusión

de confusiones! [...]. Necesitamos, dice S. S., necesitamos ejército: ¿para qué? Cataluña, la provincia mas calumniada de aviesa y de poco patriótica, de egoísta y de enemiga del orden, ¿cómo se mostró en la guerra de África? »Se trataba, no de intereses materiales, sino de la honra de la nación, y la autoridad militar superior de Cataluña dijo al gobierno: «Si necesitáis todas las fuerzas militares de mi mando para alcanzar satisfacción del agravio, llevadlas: [...] Allí sobraron los pobres soldados llevados al ejército por medio de las quintas, y allí pulularon los que voluntariamente ofrecieron su sangre para las batallas. Y iglorioso é inolvidable ejemplo! Aquellos voluntarios enaltecieron como siempre sus nombres y el de su patria común, y una vez más demostraron la falsedad del pretesto (sic) con que se perpetúa la contribución de sangre. 
El Sr. Aparici ino se daban a un hombre joven para proporcionarle algún modo de vivir, después de seis años de servicio forzoso! Si el Sr. Aparici cree esta compensación bastante, ¿qué es la que deberla ganar él que tiene una carrera libremente elegida, qué tiene el privilegio de la elección y de la elegibilidad? Basta de Sr. Aparici, que llama justo al gobierno de la unión liberal, y ama instituciones opuestas á las que el Congreso representa, y quiere libertad como á él le gusta, y ama tanto á los pobres, que es un dolor verle dispuesto á conceder 50,000 hombres al gobierno.

$[\ldots]$.

El Sr. Polo cree indigno de este siglo que se gasten sumas fabulosas en sostener ejércitos; pero añade: la situación lo exige: ¿LA hemos creado nosotros? No. ¿Bastará repetir simplemente que los principios sustentados por el Sr. Polo son los que crean situaciones que solo por la fuerza pueden sostenerse? Francia, devorada por el ejército, ¿se propone acaso la libertad del pueblo francés? El extraordinario ejército de Austria, ¿se ha creado acaso para hacer frente á exigencias democráticas? ¿Por qué es menor el ejército donde hay mas libertad? $[\ldots]^{\prime \prime 863}$.

También hubo en el Parlamento peticiones para la abolición del sistema de quintas ${ }^{864}$ o de algunas de sus injusticias ${ }^{865}$ y solicitudes para la reducción del contingente, pero "después de 1856 la oposición

${ }^{863}$ La discusión, 31/01/1862, no 1875, pp. 1 y 2.

864 "El mozo desde que es quintado y declarado soldado, pierde los naturales hábitos de obediencia y sumisión ala familia; no es ya el amigo del amigo; se obra una variación completa en él; hay una trasformación: por manera que pierde los lazos de sumisión a la familia, de la cual se cree emancipado, y no adquiere los de la disciplina militar, porque no ha entrado en el servicio, y nos encontraremos con 25.000 hombres diseminados por el país, en una situación excepcional y que no diré lleguen a ser un foco de perturbación, pero si podrán dar lugar a serios disturbios, espacialmente en los pueblos de cierta clase" (Discurso del Sr. González de la Vega, Diario de sesiones de las Cortes, no 25, 10/04/1858, p. 1056).

865 "Señores, por una rutina inconcebible, que cada día es más inconcebible cuantos más años pasan, y cuanto más nos vamos separando de cierta antigualla o corruptela que no tiene más fundamento que la ignorancia, se están exceptuando de este reparto las Provincias Vascongadas, y no pagan este contingente de guerra, que deben pagar según demostraré. [...]. ¿de donde se ha sacado esta vulgaridad de que las provincias no están obligadas a servir a la Patria con las armas en la mano? Es una ignorancia que no puede hallarse fundada en justicia alguna, sino en la costumbre, apoyada en lo que se hizo algún tiempo antes" (Discurso del Sr. Sánchez Silva, Diario de sesiones de las Cortes, no 25, 03/06/1857, pp. 367 y 368). 
a las quintas desde la tribuna parlamentaria se atenuó bastante, limitándose a las discrepancias con el Gobierno sobre la aplicación de la Ley y las atribuciones del Ejecutivo"866. Sería el año 1859 uno de los más intensos en lo que al debate en el Parlamento sobre quintas se refiere, con el discurso emitido por el demócrata Nicolás María Rivero, quien, a diferencia de los progresistas quienes en esta ocasión sí que apoyaron al Gobierno, rechazó la petición del Ejecutivo de elevar hasta los 100.000 reclutas los miembros del Ejército activo, y consideró el proyecto como inútil por no encontrarse España a las puertas de una guerra ${ }^{867}$, inoportuno por la difícil situación que atravesaba el país, excesivo en cuanto al número de soldados solicitados, peligroso para las instituciones liberales ${ }^{868}$ ante el creciente poder de los militares y el predominio del Ejército ${ }^{869}$, y perjudicial para el desarrollo económico español. Planteaba Rivero por el contrario "[...] un Ejército similar al de Estados Unidos y Suiza, reducido, formado por voluntarios, y con reservas milicianas, así como una contribución especial recaudada por los Ayuntamiento y Diputaciones para financiar este Ejército"${ }^{\prime 870}$. La respuesta por parte

\footnotetext{
${ }^{866}$ FEIJÓo GÓMEZ, A., Quintas y protesta social en el siglo XIX español, p. 152.

867 "¿qué nos amenaza a nosotros que estamos perfectamente aislados, que no sufrimos, y lo tenemos acreditado, el yugo extranjero; que cuando se trata de nuestra independencia somos completamente invencibles, como lo ha declarado no un cualquiera, sino después de una larga experiencia y de una serie no interrumpida de triunfos el mismo Napoleón el Grande? No es esta, pues, una ocasión oportuna para armarse [...]" (Discurso del Sr. Rivero, Diario de sesiones de las Cortes, no 109, 04/05/1859, p. 2985).

868 "Y ¿donde está este Gobierno? ¿Ha nacido por ventura a consecuencia del mecanismo parlamentario; ha sido producto del juego regular de los partidos, ha silo llamado eléctricamente, por decirlo así, a causa de la opinión pronunciada en su favor por todos los verdaderos representantes que time en el país? No: un simple decreto le ha creado: pues otro decreto puede sepultarlo. ¿Ha hecho algo este Gobierno, pregunto yo, para asegurar la obra de los Gobiernos parlamentarios, de manera que se pueda decir que en el instante en que él cesase, podría continuar por más tiempo asegurada la libertad de las instituciones? (Discurso del Sr. Rivero, Diario de sesiones de las Cortes, no 109, 04/05/1859, p. 2985).

869 "Durante el gobierno absoluto nos gobernaban los clérigos y los frailes; durante el gobierno constitucional nos gobiernan los militares [...]. ¿Quien no sabe que esta clase de gobiernos ha sido siempre contraria a la libertad le los pueblos? Estos gobiernos no tienen mis que la Ordenanza y la espada, y con ellas miden a su antojo los destinos del país" (Discurso del Sr. Rivero, Diario de sesiones de las Cortes, no 138, 11/10/1859, p. 3905).

${ }^{870}$ FEIJÓO GÓMEZ, A., Quintas y protesta social en el siglo XIX español, p. 152.
} 
de aquellos que eran favorables a incrementar el contingente del Ejército se centró en la misión civilizadora que a España le estaba reservada en territorio marroquí, siendo necesario un Ejército poderoso y disciplinado de quintos para tener éxito en tal empresa:

"Al decir que España ansía llevar sus armas a África, decimos una cosa obvia, sencilla y que se ha establecido hace tiempo como axioma común en la opinión de las gentes; decimos quo en África hay un pueblo por civilizar, que estamos constantemente amenazados por sus tribus, y que estamos llamados por la Providencia a llevar allí la luz de la civilización y a extenderla por todo el Imperio. Pues que, ¿podemos desconocer, señores Diputados, quo desde mucho tiempo a esta parte no se consideran como guerras verdaderamente justas en su objeto mas que aquellas que hacen los pueblos civilizados para extender la esfera de la civilización por todas partes? Que ¿acaso no somos nosotros uno de los pueblos llamados por su proximidad al continente africano para llevar allí con nuestras armas nuestra civilización? ¿Y no nos dan también derecho todos los días para extender nuestra civilización con las armas los agravios que la barbarie de aquellas poblaciones nos infieren? No hay, pues, contradicción, no puede haberla entre la opinión qua ansía la guerra de África y at espíritu de justicia qua deseamos todos asista al Gobierno al tiempo de llevarla a cabo"1871.

Asimismo, se aprobaron nuevas normas para evitar los fraudes y las falsificaciones de documentos en la cuestión de las sustituciones, y a partir de 1858 se exigió a las autoridades provinciales, gobernador civil y Diputación, un mayor control y una mayor rigurosidad en la revisión de la documentación que debían presentar los sustitutos ${ }^{872}$. También se reguló la actuación de las agencias de sustitución del servicio militar "[ante] la necesidad de contener y prevenir los abusos que la inmoralidad y la mala fe habían

871 Discurso del Sr. González Bravo, Diario de sesiones de las Cortes, no 138, 11/10/1859, pp. 3911 y 1912.

${ }^{872}$ Real Orden de 24 de Mayo de 1858, Gaceta Núm. 142 de 30/05/1858. 
introducido"873. Las empresas dedicadas a este negocio tendrían la obligación de presentar una instancia, junto a sus estatutos, ante el gobernador civil, y su creación debía ser oficialmente reconocida por el Gobierno, que además tendría la facultad de suprimirlas. Deberían asimismo ingresar en la Caja General de Depósitos o en la tesorería de la Hacienda pública de la provincia "una cantidad equivalente a la suma de 4.000 reales por cada sustituto que haya ingresado en la Caja de la mencionada provincia en la quinta inmediatamente anterior para el Reemplazo del Ejército activo"874.

Sin duda uno de los añadidos a la Ley de 1856 de mayor relevancia se estableció con la aprobación de la Ley de 17 de noviembre de $1859^{875}$ que creó el Fondo de Redenciones y Enganches y su consejo ${ }^{876}$, además de elevar el coste de las mismas a 8.000 reales $^{877}$ para esa quinta y para las sucesivas. Puell de la Villa justifica la aprobación de esta ley y la elevación del precio de la redención de la siguiente forma:

"Por la ley de reemplazos de 1856, O’Donnell se había comprometido a invertir los 6.000 reales, que el Tesoro recibía de cada redimido, exclusivamente en el enganche o reenganche de un voluntario que cubriera su vacante. La boyante marcha de la economía nacional durante el quinquenio unionista y la creación de compañías de seguros que redimían a los socios de que salían

\footnotetext{
${ }^{873}$ Real Orden de 24 de Mayo de 1858, Gaceta Núm. 142 de 30/05/1858.

${ }^{874}$ Real Orden de 24 de Mayo de 1858, Gaceta Núm. 142 de 30/05/1858.

875 Ley de 17 de noviembre de 1859, Gaceta, Núm. 145 de 20/11/1859.

876 "En la década de los sesenta, a pesar de la oposición manifestada en la prensa democrática y republicana, la redención y sustitución incrementaron su campo de acción y obtuvieron el apoyo de gobiernos, burguesía financiera con intereses en compañías de seguros y agencias dedicadas a la contratación de sustitutos, y clases altas y medias con capacidad económica para evitar el trance del servicio militar a sus hijos. Se extendió el derecho de redención por 8.000 rs. A los mozos de segunda y tercera edad, se puso en marcha el Consejo de Redención y Enganches, se produjeron las primeras desviaciones de fondos hacia la Hacienda Pública, se generalizó el negocio de la redención y la sustitución, y existió una completa interrelación entre bancos, sociedades de seguros de quintos, agencias de negocios, y burguesía financiera" (FEIJÓO GÓMEZ, A., Quintas y protesta social en el siglo XIX español, pp. 271 y 272).

${ }^{877}$ Real Orden de 20 de Abril de 1860, Gaceta Núm. 126 de 05/05/1860.
} 
sorteados por una pequeña cuota mensual, disparó la cifra de los que podían permitirse paga la exención de sus hijos, hasta llegar a liberarse la cuarta parte del cupo en 1859. Por el contrario y debido a la misma causa, el número de voluntarios fue reduciéndose y sólo la mitad de las vacantes de aquéllos se llegaban a cubrir" ${ }^{878}$.

También resultó muy significativa la Ley de 1 de marzo de 1861 que ordenó el reemplazo de 35.000 hombres, ya que derogó los artículos 4, 5, 6 y 7 de la Ley de 1856, "acabando así con la remuneración de 2.000 reales que recibían los soldados procedentes del sorteo"879 al finalizar el servicio militar, levantando numerosas críticas en los sillones parlamentarios ${ }^{880}$. Además, la Ley de 1 de Marzo de 1862 rebajó la talla mínima que permitía la exención a $1,560 \mathrm{~m}^{881}$. Habría que esperar hasta el reemplazo de 1862 para que se modernizasen o modificasen parcialmente algunos de los artículos de la Ley de 1856: la cantidad a cobrar por el recluta suplente que hubiese ingresado en filas sería de 250 reales anuales, mientras que los colaboradores en la captura del prófugo recibirían la cantidad de 400 reales $^{882}$.

878 PUELL DE LA VILLA, F., El soldado desconocido: de la leva a la "mili" (17001912), p. 201.

${ }^{879}$ FEIJÓO GÓMEZ, A., Quintas y protesta social en el siglo XIX español, p. 217.

880 "¿quien duda que esa llamada contribución que el pueblo en su enérgico lenguaje califica de "contribución de sangre" es con extremo dolorosa? ¿Quién duda que debe mejorarse mas y mas la condición del soldado, y procurar recompensar a los que hayan servido bien a la patria, para que poco a poco lo que es servicio se convierta en carrera, y andando los tiempos se componga, en su mayor parte al menos, de voluntarios el Ejército español? [...].Reconociendo yo que el Ministerio actual ha hecho mucho en favor del Ejército, no extrañéis que me oponga a la supresión de los 2.000 rs. que concedía una ley a los soldados cumplidos. Y no miro tal recompensa como paga; breve paga sería de largos trabajos; la defiendo solo como levísima compensación de perjuicios sufridos por la carrera truncada, por el oficio o arte abandonados; compensación levísima, pero merced a la cual, el cumplido pudiera dedicarse a alguna industria, a cultivar mejor el campo arrendado" (Discurso del Sr. Aparici y Guijarro, Diario de sesiones de las Cortes, no $49,30 / 01 / 1862$, p. 832.

${ }^{881}$ Ley de 15 de Diciembre de 1860, Gaceta Núm. 58 de 17/12/1860.

${ }^{882}$ Real Decreto de 1 de Marzo de 1862, Gaceta Núm. 62 de 03/03/1862. 
Durante la década de 1860 asistimos a un debate anual en Cortes entre los defensores de la política del Gobierno ${ }^{883}$ y el reclutamiento obligatorio y la oposición progresista que recogió tímidamente el sentir popular de rechazo a las quintas ${ }^{884}$, y con mayor motivo cuando la situación internacional y en concreto europea se había normalizado ${ }^{885}$. A ello había que unir la favorable situación geográfica de España ${ }^{886}$, el excesivo militarismo que afectaba al país y las dificultades que la pérdida de brazos jóvenes supondría para la economía ${ }^{887}$, además de los enormes recursos que,

${ }^{883}$ Los incrementos en el contingente solicitado solían justificarse anualmente por parte de moderados y unionistas en el Gobierno en la inestabilidad de la política internacional y el contexto colonial, en el ser España uno de los países europeos que proporcionalmente a su población menos contribuía al reclutamiento del Ejército, pero también en la cuestión social y la conservación del orden público: "Tenemos ante todo, señores, la cuestión social. No hay que engañarse. Aquí, dentro de la sociedad misma, hay una fuerza armada contra el poder publico que trata de subvertir la sociedad. Todos lo sabemos, y es inútil que haga aquí denegaciones sobre este particular. Todo el mundo sabe que se conspira; todo el mundo sabe el punto adonde se quiere ir; todo el mundo sabe que se trata de atacar, no ya solamente el orden público, sino la Monarquía y la dinastía; y ante esa situación, los que estamos en la Comisión, y cualquier propietario independiente, y cualquier persona interesada en la conservación del orden público, ¿habrá de escatimar al Gobierno 6.000 hombres, que es a lo quo he dicho quo se reduce toda la cuestión? (Discurso del Sr. Cláros, Diario de sesiones de las Cortes, no $75,01 / 05 / 1862$, p. 1585).

884 "¿quien duda que esa llamada contribución que el pueblo en su enérgico lenguaje califica de "contribución de sangre" es con extremo dolorosa? ¿Quién duda que debe mejorarse mas y mas la condición del soldado, y procurar recompensar a los que hayan servido bien a la patria, para que poco a poco lo que es servicio se convierta en carrera, y andando los tiempos se componga, en su mayor parte al menos, de voluntarios el Ejército español?" (Discurso del Sr. Aparici y Guijarro, Diario de sesiones de las Cortes, no 49, 30/01/1862, p. 832).

885 "El estado general de Europa en este momento no es tan grave, no amenaza peligros para la patria. Organicemos pues nuestro Ejército para un tiempo normal de paz; fijémonos pues en las necesidades interiores para reducir cuanto sea posible el Ejército permanente" (Discurso del Sr. Fáges, Diario de sesiones de las Cortes, no 56, 24/03/1866, p. 786).

886 "Por nuestra situación occidental, por la disposición geográfica del territorio [...] no nos obliga ti sostener Ejércitos tan crecidos come las naciones quo están en el centro de Europa; como la Francia que tiene al Norte la Inglaterra; al Sur y separada per los Pirineos la España, que pudieran serle enemigas, y tiene por último la gran frontera del Rhin, en la quo tiene quo defenderse de toda Europa. De manera que Inglaterra y España son países que por su constitución geográfica no necesitan grandes Ejércitos (Discurso del Sr. Figuerola, Diario de sesiones de las Cortes, no 60, 05/04/1866, p. 864).

887 "¿podrá citarse una nación en Europa que necesite menos Ejército que España? Por razón de la población, ¿habrá, alguna nación en que con menos utilidad, mejor dicho, con más perjuicios se distraigan de la agricultura, de la industria y del comercio los hombres para dedicarlos a la guerra? En la relación que en España 
del presupuesto nacional, se destinaban al mantenimiento del Ejército $^{888}$. Incluso se llegó a cuestionar el papel de la institución armada respecto al mantenimiento del orden social ya que, por su composición predominantemente popular, se podía convertir en un elemento desestabilizador:

"En estos días se ha hablado mucho de si el Ejército es el elemento principal de desorden, que de allí salían todas las perturbaciones, iAh, señores! ¿Es esto acaso una triste $y$ exclusive condición de nuestro suelo? [...] No es únicamente en España donde el Ejército ha causado revoluciones; el Ejército ha tomado parte en la revolución en todas las naciones del mundo [...]. El Ejército padece los males sociales que en mayor o menor escala se padecen en la sociedad $[\ldots]^{\prime 1889}$.

También se puso en cuestión el papel sobredimensionado de España en el ámbito internacional, criticando las intervenciones exteriores en Marruecos, Santo Domingo y la Cochinchina, que habían supuesto un enorme esfuerzo económico sin obtener los resultados esperados:

"Paréceme, señores, quo después de los resultados obtenidos de todas esas expediciones que he indicado, el Gobierno de S. M. no

está la población con el estado de desarrollo de los elementos de prosperidad y de riqueza, ¿habrá alguna nación que necesite más de los brazos, y a que mas perjuicios puedan seguirse de distraerles los hombres de este objeto? Respecto a las fronteras, la nación que tiene la dicha de poseer fronteras naturalmente tan fuertes, por un lado el Pirineo, por otro la frontera portuguesa [...]; la nación, repito, que tiene estas fronteras, no necesita de una gran fuerza constante para guarnecerlas" (Discurso del Sr. Herrera, Diario de sesiones de las Cortes, no 58, $27 / 03 / 1866$, pp. 826 y 827 ).

888 "Pero vamos ya a apreciar los frutos que este fatal sistema produce en el presupuesto [...]. O el presupuesto queda subordinado al Ejército, o el Ejército subordinado al presupuesto; que las naciones son poderosas si tienen recursos, y no simplemente hombres para pelear [...]" (Discurso del Sr. Figuerola, Diario de sesiones de las Cortes, no 60, 05/04/1866, p. 867 y nº 61, 06/04/1866, pp. 885 y 886).

889 Discurso del Sr. Fáges, Diario de sesiones de las Cortes, no 56, 24/03/1866, pp. 793 y 794. 
creerá que estamos en el caso de seguir por ese camino, no lo creemos seguramente; comprende bien que por el contrario es ocasión de cambiar completamente de sistema; es tiempo de guerrear poco en el exterior, de zanjar lo más honrosamente que se puedan Jas cuestiones que han surgido o están pendientes, sin detrimento de la honra, pero zanjarlas lo más pronto que sea posible, y convertir las fuerzas de la nación a otra guerra más productiva, más digna de un pueblo civilizado: a la explotación de nuestro suelo y de todas las fuentes de nuestra riqueza. Este es el medio, este es el camino quo se debe seguir para alcanzar la respetabilidad y la grandeza de la nación en el exterior, y no forzar los recursos de la nación violentándolos, aumentando considerablemente la deuda, teniendo en desnivel terrible los presupuestos para aparentar una grandeza y fuerza quo no se tiene ${ }^{\prime \prime 890}$.

La respuesta del Gobierno unionista en este sentido se limitó a defender la neutralidad española en el ámbito exterior, situación que para lograrse necesitaba de potencial militar:

"Yo soy partidario de la neutralidad; creo que conviene a los intereses de la nación española, si desagraciadamente ocurriese algún hecho que alterase la paz do Europa, guardar la mas estricta neutralidad llevada hasta el ultimo punto, hasta que sea posible guardarla sin mengua de nuestro decoro, y cuando no sea posible echar en la balanza el peso de nuestro poder. ¿Pero olvidan los Sres. Diputados que para nada se necesita ser mas fuerte que para ser neutral'? Una nación neutral, pero al mismo tiempo débil, no puede ser otra cosa que el juguete de las partes contendientes. Si queremos ser neutrales, es preciso que seamos fuertes en nuestras posesiones de África, en nuestros arsenales, en nuestras plazas del Mediterráneo, para hacer comprender a los combatientes que estamos dispuestos a ser verdaderamente neutrales; pero que si uno de ellos nos ofende, echaremos nuestro peso para inclinar la balanza a favor de la otra

890 Discurso del Sr. Herrera, Diario de sesiones de las Cortes, no 58, 27/03/1866, p. 828. 
parte. Esto se necesita para ser neutral: lo demás corno he dicho antes es ser juguete, es ser ludibrio de los contendientes ${ }^{\prime 891 .}$

Por último, y como una de las más significativas novedades previas al Sexenio Democrático, destacar la Ley de 26 de Junio de 1867 que reformó algunos artículos de la legislación de 1856 y originó un intenso debate parlamentario. Así, estableció un llamamiento anual fijo de 40.000 hombres para el reemplazo sin necesidad de que el Gobierno consultase a las Cortes ${ }^{892}$. El Ministro de la Gobernación, González Bravo, justificó este Ilamamiento anual fijo por considerarlo positivo para el Ejército que dejaba atrás eventualidades pero también para los propios reclutas y sus familias que ya conocían de antemano los cupos que, en sus localidades, se iban a solicitar por parte del Gobierno:

"Ninguna reforma de cuantas caben en la legislación que hoy rige, ha de ser mas acertada por mas útil, mas conveniente y mas ventajosa, así para los pueblos como para el Ejército; y ninguna otra, sin embargo, ofrecerá para algunos mayores dudas, dificultades y recelos. Pero todos estos obstáculos desaparecerán tan pronto como se examine y estudie la cuestión con algún detenimiento [...].

La eventualidad de un contingente distinto en cada año, además de imposibilitar por completo el sistema con que ha de constituirse toda la fuerza armada, para la mejor, la mas completa, y al mismo tiempo la menos costosa defensa del Estado; demás de alterar, y como si fuese caprichosamente, las condiciones del Ejército, dejando con forzosa variedad un número de sus soldados veteranos o bisoños, impide de todo punto el establecimiento de un buen sistema, y

${ }^{891}$ Discurso del Sr. O 'Donnell, Diario de sesiones de las Cortes, no 58, 27/03/1866, p. 830.

892 "Serán llamados anualmente al servicio de las armas 40,000 hombres. La fuerza que en virtud de ese ingreso anual exceda de la permanente que cada año fijen las Cortes con arreglo al art. 79 de la Constitución, pasará a las reservas que establece la organización de la fuerza total del Ejército, en la forma y condiciones quo determina. (Ley de 26 de Junio de 1867 sobre modificación de algunos artículos y reforma general de la ley de reemplazos, Gaceta Núm. 1786 de 27/06/1867, art. 3). 
reserva y renueva en cada año dudas, cuestiones y resoluciones que son en todos conceptos embarazosas, perjudiciales [...]. Pues si la designación del cupo fijo y permanente conviene tan en gran manea al Ejército, es más provechosa todavía para los pueblos. No hay otro medio para disminuir en lo posible su forzoso gravamen de contribuir al reemplazo, que el de establecer la equidad más completa y absoluta, evitando la injusticia procedente de la desigualdad en el cumplimiento de esta obligación [...]. Todas esas irregularidades y perjuicios se precaven por medio del sistema contrario de un cupo o contingente fijo e inalterable, siempre que baste para constituir $y$ conservar la fuerza armada necesaria en todas sus partes y en todas las eventualidades posibles, y no imponga al mismo tiempo a los pueblos un gravamen que fuera en cierto modo insoportable. Quo el número de 40.000 mozos como contingente fijo repartible todos los anos entre los pueblos que contribuyen, es el que se necesita para constituir el ejercito activo y la reserva, de modo que satisfagan todas las necesidades del servicio público $y$ en todo el territorio de la Monarquía, se demuestra y comprueba en el proyecto de ley que simultáneamente con este se presenta. Con tal sistema los pueblos cubrirán en lo sucesivo esta penosa, pero indispensable obligación, con certeza de que no ha de ser agravada nunca, con la mayor regularidad y con la, igualdad, equidad y justicia consiguiente en la suerte de todos los que contribuyan. Lo que importa aquí, es examinar si pueden sobrellevar buenamente el gravamen pasta donde ahora se acrecienta, para conseguir esos mismos fines. El resultado de tal examen, por fortuna, demuestra la posibilidad de su ejecución con las condiciones indicadas ${ }^{893}$.

\section{La duración del servicio se mantuvo en ocho años, divididos en} cuatro en el Ejército activo y otros cuatro en la reserva ${ }^{894}$. Cumplido

\footnotetext{
893 Discurso del Sr. Ministro de la Gobernación, Diario de sesiones de las Cortes, apéndice al no 13,13/04/1867, pp. 1 y 2.

894 "Bajo el punto de vista civil, que los soldados sirvan solo cuatro años, es grandemente conveniente, come comprenderá el Congreso, porque de esta manera no pierden los mozos el hábito a los trabajos del campo, que es de los que esencialmente necesita este país. Y no será tampoco exactamente cierto que el número de cuatro años, que marca la ley de organización del Ejército, sea demasiadamente corto para hacer buenos soldados, cuando la Francia, nación eminentemente militar, se ocupa en estos momentos en rebajar el tiempo del empeño a cinco años, uno más que entre nosotros" (Discurso del Sr. Marqués de la
} 
el primer periodo, los reclutas recibirían permiso para regresar a sus domicilios o al de sus padres, pudiendo cambiar de residencia, dentro de las provincias peninsulares y Baleares, con el permiso previo del jefe militar de la provincia. También necesitaban el correspondiente permiso para contraer matrimonio. Si fuese solicitado su reingreso en el Ejército por Real Decreto y no lo cumpliesen, serían considerados prófugos a todos los efectos. Pasados los ocho años de servicio, obtendrían licencia absoluta ${ }^{895}$. Por último, concedió la ley una reducción de dos años en el servicio para los destinados a los territorios de Ultramar o a los buques de la armada ${ }^{896}$.

Las intenciones del Gobierno sobre la mejora en el sistema de reclutamiento ${ }^{897}$ fueron puestas en cuestión por parte de la oposición. En concreto el diputado Muzquiz, en un interesante discurso, después de defender la importancia del papel del Ejército ${ }^{898}$, atacó el sistema de quintas como método de reclutamiento al considerarlo

Merced, Diario de sesiones de las Cortes, no 21, 03/05/1867, p. 226). "Tengo la íntima convicción de que el soldado español en esos cuatro años adquiere suficiente instrucción: primero, porque el oficio se aprende pronto, y también es bastante tiempo para conservar el espíritu militar que no puede perder mientras esté en su casa, porque en esos cuatro años, el ejercicio y la práctica de la vida del soldado engendran en el hombre de campo bastante firmeza y consistencia de ese espíritu militar para que no pueda perderlo en los cuatro años qua va a su casa (Discurso del Sr. Fernández San Román, Diario de sesiones de las Cortes, no 21, 03/05/1867, p. 231).

895 "La duración del servicio, contada desde el día de la admisión de los mozos en la caja de la respectiva provincia, será de cuatro años en el Ejército activo y su primera reserva adherente al mismo, y de otros cuatro anos en la reserva segunda o sedentaria" (Ley de 26 de Junio de 1867 sobre modificación de algunos artículos y reforma general de la ley de reemplazos, Gaceta Núm. 1786 de 27/06/1867, art. 4).

${ }^{896}$ Ley de 26 de Junio de 1867 sobre modificación de algunos artículos y reforma general de la ley de reemplazo, Gaceta Núm. 1786 de 27/06/1867, art. 6.

897 "El gobierno aumentó el número de soldados reclamados anualmente y fijó una cifra anual de 40.000 quintos, cifra muy superior a las bajas producidas anualmente en un Ejército inferior a 100.000 hombres, pero que sirvió para incrementar los ingresos por redención" (FEIJÓO GÓMEZ, A., Quintas y protesta social en el siglo XIX español, p. 153).

898 "Son los Ejércitos apoyo firmísimo de las leyes, amparo del ciudadano, protección de la propiedad, muro de defensa del Estado, elemento de progreso, instrumento poderoso de civilización [...]" (Discurso del Sr. Muzquiz, Diario de sesiones de las Cortes, apéndice al no 18, 29/04/1867, pp. 162-173). 
anacrónico $^{899}$ al tener su origen en periodos históricos anteriores, injusto e inconstitucional al coartar la libertad humana y saltar el principio de igualdad ante la ley ${ }^{900}$, imprudente desde el punto de vista político ${ }^{901}$, impolítico y antisocial por todos los perjuicios sociales

899 "Señores, el sistema de quintas en el orden histórico es un anacronismo; en el orden filosófico es una injusticia, y en el orden político es una imprudencia [...]. Señores: vosotros en los que pusilánime espíritu logre ofuscar la luz el claro reflejo de la verdad, el tremendo imperio del progreso, temblad, temblad, si, porque aparte de la ignominia de haber abjurado de vuestro destino, la inexorable posteridad arrojará, sobre vuestras cabezas gota a, gota las lagrimas de madres cuyos hijos injustamente arrebatáis, la sangre que el despecho arranque a corazones cuyo porvenir burláis, el sudor copioso de rostros que llevan impreso con el divino el sello de la libertad" (Discurso del Sr. Muzquiz, Diario de sesiones de las Cortes, apéndice al no 18, 29/04/1867, pp. 162-173).

900 "Este anacronismo, señores, impide que se cumpla la Constitución, porque la Constitución, sin distinción alguna, establece para todos la obligación de servir a la patria con las armas en la mano, y las quintas, en cuanto a la suerte apelan, impiden el cumplimiento de ese deber que la Constitución impone [...]. La quinta determina el porvenir de los hombres contra su voluntad, contra su vocación e inclinaciones; afecta creer que el hombre viene del acaso, vive en el acaso, y el acaso determina su suerte futura [...]. Hacéis una injusticia, porque hacéis violencia a la voluntad al individuo; la libertad sucumbe. Decidme: ¿puede inventarse en el orden social mayor injusticia? Esta injusticia es mas patente y manifiesta, si se considera que se convierte en un privilegio a favor de la fortuna. Si la Constitución exigiese que todos los ciudadanos estuviesen constante y exclusivamente dedicados a la carrera militar, sería una injusticia por lo que acabo de decir. Pero dejarlo al arbitrio de la suerte es doble injusticia; se hace de la injusticia un privilegio, privilegio que se opone al precepto de igualdad ante la ley, que es uno de aquellos que no pueden negarse en ninguna sociedad [...]. Esta desigualdad ante la ley es más notoria aun con el sistema de las redenciones y de las sustituciones, mediante las que cualquier ciudadano, por una cantidad establecida por la ley o arbitrariamente convenida en una sociedad mercantil, puede burlar el cumplimiento de la ley fundamental de la sociedad [...]. Injusticia, si. Porque las quintas constituyen un privilegio a favor de los padres que tienen hijos, y en perjuicio de los que le nacieron varones; porque hacen de la misma suerte al que nada posee fuera de su trabajo, y al acaudalado capitalista o rico propietario para quien, además de la defensa de la sociedad, tiene el Ejército la misión de asegurar sus propiedades" (Discurso del Sr. Muzquiz, Diario de sesiones de las Cortes, apéndice al no 18, 29/04/1867, pp. 162-173).

901 "Toda injusticia conduce en el orden político a una catástrofe, porque es una imprudencia [...].Y ved ahí como el mismo razonamiento nos conduce a probar mi tercera proposición, de que el sistema de las quintas en el orden político es una imprudencia. En efecto, señores, suponer que el hombre haya de resignarse buenamente a un destino hacia el cual no siente inclinación, es suponer en la carencia absoluta de espíritu; es desmentir el carácter y dignidad de la humana naturaleza: concíbase tamaño sacrificio cuando, embrutecido el hombre, no piensa más que en satisfacer los instintos naturales [...] (Discurso del Sr. Muzquiz, Diario de sesiones de las Cortes, apéndice al no 18, 29/04/1867, pp. 162-173). 
que genera y por permitir la redención y la sustitución ${ }^{902, ~ y ~}$ antieconómico si valoramos la situación económica del país ${ }^{903}$.

Para hacer frente a la abolición del sistema de quintas y evitar la aversión popular hacia el Ejército, el diputado Muzquiz propuso, además de la reducción del contingente, la creación de un Ejército de voluntarios financiado a través de

\begin{abstract}
"[...] una nueva contribución, una capitación general que comprenda a todos los ciudadanos españoles mayores de 20 años, sin más excepción que los jornaleros mayores de 60 años y los que sirven en el Ejército activo y en la reserva; y una capitación no igual para todos, sino según las diversas clases de profesiones de los individuos que pagasen, quo se halle prevista en tarifas que oportunamente se formulen $[\ldots]^{\prime \prime 904}$.
\end{abstract}

También propuso Muzquiz la creación de una reserva de 50.000 hombres

"[...] a la cual concurran voluntariamente los que dedicados a las faenas ordinarias de la vida quieran formarla; no los hagáis conocer mas que aquellas ligeras penalidades que causan contento en

\footnotetext{
902 Es impolítico el sistema de quintas porque imprime el sello de servidumbre en el primero de los derechos del ciudadano, y servidumbre que se compra y vende. Es impolítico, porque suprime toda idea de amor entre las diversas clases sociales [...] Es impolítico, porque perturba la constitución económica del país, ahora dejando incumplidas urgentísimas necesidades, ahora distrayendo de su objeto fuerzas de actividad, de gran potencia social. Es impolítico, en fin, porque se opone al sentimiento general del pueblo [...]" (Discurso del Sr. Muzquiz, Diario de sesiones de las Cortes, apéndice al no 18, 29/04/1867, pp. 162-173).

903 Por ese sistema, o priváis al individuo que por espacio de ocho años usufructúe en su trabajo, o de lo contrario le obligáis a hacer el sacrificio de 8.000 rs. para cumplir su compromiso. Por poco quo apreciéis el trabajo, podéis asegurar que vale mas que los 8.000 rs. la cantidad en que le estimáis [...]. Bajo el punto de vista económico, ¿queréis que el Ejército no perjudique a la sociedad? Pues retribuirlo convenientemente [...]. No tengáis nunca trabajos gratuitos; pagar a todo el mundo el precio de su trabajo, y entonces habrá ganancia para la sociedad [...]" (Discurso del Sr. Muzquiz, Diario de sesiones de las Cortes, apéndice al no 18, 29/04/1867, pp. 162-173).

904 Discurso del Sr. Muzquiz, Diario de sesiones de las Cortes, apéndice al no 18, 29/04/1867, pp. 162-173.
} 
almas bien templadas; hacedles saborear las ilusiones inseparables a toda vida inquieta y airada en los principios, y entonces, señores, las reservas despertaran las vocaciones, la voz cundirá, cundirá el ejemplo, y las vocaciones lo seguirán, las reservas servirán de camino al enganche voluntario come única base del reemplazo. Las reservas, come yo las ideo, crearán cualidades morales de grande estima para el Ejército y para la sociedad en general, porque despertarán el sentimiento de la obediencia a las autoridades legitimas, el espíritu de compañerismo entre los convecinos, y un sincero amor a la patria, cuyos sentimientos extenderán sus individuos por toda la sociedad, con la cual han de vivir íntimamente unidos, y crearán las cualidades que debe tener el Ejército; quo hoy día son más preciadas las cualidades en el soldado quo su habilidad y destreza, como la imperturbabilidad ante el peligro, la serenidad ante la muerte, y la obediencia hasta la abnegación; y esto solo se consigue con hombres sometidos constantemente a la disciplina $[\ldots]^{905}$.

La propuesta de Muzquiz fue rechazada por el Congreso e incluso calificada como utópica ${ }^{906}$. Sin embargo, las críticas hacia el Gobierno y su reforma de la ley de reclutamiento continuaron, acusándolo desde las filas progresistas de falta de análisis y estudio de la temática del reemplazo ${ }^{907}$, solicitando la reducción del contingente anual ${ }^{908}$, una nueva ley que regulase todo el proceso y limitase la responsabilidad de los mozos a un solo sorteo a lo largo de su vida y no a ninguno posterior ${ }^{909}$, el reparto de los cupos en función de los mozos que existiesen cada año y no en función de años

\footnotetext{
905 Discurso del Sr. Muzquiz, Diario de sesiones de las Cortes, apéndice al no 18 , 29/04/1867, pp. 162-173.

906 Discurso del Sr. Amorós y Pastor, Diario de sesiones de las Cortes, no 19, 30/04/1867, p. 183.

907 Discurso del Sr. Amorós y Pastor, Diario de sesiones de las Cortes, no 19, 30/04/1867, p. 184.

908 Discurso del Sr. Reina, Diario de sesiones de las Cortes, no 19, 30/04/1867, p. 194.

909 "Por consiguiente, si se ha de reformar la ley, reformémosla, pero con previo estudio; busquemos para ello et mejor camino; puesto que tenemos tiempo para ensayar y para estudiar, ensayemos y estudiemos; vengamos después aquí y discutamos" (Discurso del Sr. Amorós y Pastor, Diario de sesiones de las Cortes, no $19,30 / 04 / 1867$, p. 187).
} 
anteriores ${ }^{910}$, el fin de la sustitución por inmoral, el establecimiento de una redención menor y que fuese posible pagar a plazos ante la situación económica por la que atravesaba el país ${ }^{911}$, el fin de una talla mínima para ser admitido en el Ejército ${ }^{912}$, el establecimiento de mayores controles en los reconocimientos médicos para evitar fraudes $^{913}$ y la admisión del matrimonio para los reservistas ${ }^{914}$. Todas estas propuestas fueron rechazadas por el Gobierno, que llegó a alabar las virtudes de la vida militar y la alegría que la misma ocasionaba entre los nuevos reclutas:

\begin{abstract}
"Cuantos señores han tratado la cuestión de quintas han empezado diciendo que es una contribución dolorosa, que causa grandes quebrantos a las familias, que es un verdadero sacrificio come si se tratara de ir a galeras, a trabajos forzados, a sufrir una condena. Pues qué, ¿no merece algo la carrera militar? Pues qué, ¿no va a sostener la paz y el hogar de esas familias, y a ser el apoyo de todo lo más sagrado que hay en la sociedad? ¿Por qué han de llorar otros lo que no llora el quinto? Yo lo que veo es que lo primero que hace el quinto es ponerse la escarapela y pasear las calles con la
\end{abstract}

910 "[...] yo deseo que la distribución se haga por el número de mozos que haya en cada año, y no por el de los años anteriores [...]" (Discurso del Sr. Izco, Diario de sesiones de las Cortes, no 19, 30/04/1867, pp. 201 y 202).

911 Discurso del Sr. Amorós y Pastor, Diario de sesiones de las Cortes, no 19, 30/04/1867, p. 186 y discurso del Sr. Garvía, Diario de sesiones de las Cortes, no 20,01/05/1867, p. 221.

912 "Yo he sido siempre enemigo de la talla, porque siempre me ha parecido arbitraria. Me ha parecido caprichoso que el mozo que tiene dos líneas mas tenga que abandonar a su padre, a su madre, su país, y llegue a sacrificar su vida, y que otro que porque ha tenido en esa ocasión la grandísima fortuna, que para otras empresas puede ser gran desgracia, de tener dos líneas menos, de no llegar a la talla, se quede con su familia, cumpliendo con todos los deberes de ciudadano en la apacible tranquilidad del hogar doméstico" (Discurso del Sr. Amorós y Pastor, Diario de sesiones de las Cortes, no 19, 30/04/1867, p. 187).

913 "Fuente de inmoralidad he dicho antes que es la sustitución; fuente de inmoralidad la talla, y la tercera fuente de inmoralidad [son] los reconocimientos facultativos [...] (Discurso del Sr. Amorós y Pastor, Diario de sesiones de las Cortes, no $19,30 / 04 / 1867$, p. 188).

914 Discurso del Sr. Izco, Diario de sesiones de las Cortes, no 19, 30/04/1867, p. 198. 
guitarra, dando muestras de una alegría que está en oposición con esos lamentos ${ }^{915 \prime \prime}$.

Así, no se revocó el llamamiento anual fijo de 40.000 hombres ${ }^{916}$, se mantuvo la sustitución por considerarla beneficiosa para las clases populares ${ }^{917}$, se consideraron los reconocimientos médicos como una cuestión menor que no debía recogerse en una ley de reemplazo ${ }^{918}$, continuó la prohibición de matrimonio para los soldados en activo y con autorización de los superiores militares para los reservistas ${ }^{919}$, no se limitó la responsabilidad de los mozos a un

915 Discurso del Sr. Fernández San Román, Diario de sesiones de las Cortes, no 21, 03/05/1867, p. 229.

916 "Señores: que el contingente fijo responde a una necesidad social y de gobierno, y que todos los hombres de gobierno y de administración no tienen más remedio que aceptarle, es una verdad que está al alcance [...]. El contingente fijo es útil al Ejército y es útil también a la sociedad. Es útil al Ejército y al Gobierno, en primer lugar, porque el Gobierno sabe ya el número de soldados con que puede contar para las eventualidades del porvenir, para la organización o distribución que piense dar a la fuerza armada, según las necesidades del servicio en la época de su gobierno o administración. El subordinar aquel servicio a que las Cortes aprueben un cupo o aprueben otro, ofrece los inconvenientes que los Sres. Diputados conocen: no puede decretarse nada con carácter de estabilidad, nada puede hacerse con carácter de permanencia, porque no solo se ignora si las Cortes acordaran el contingente en el número de hombres que el Gobierno juzgue necesario, si que tampoco puede tenerse seguridad en que le fijen en tiempo oportuno [...]. Es útil también al Ejército, porque de esta manera se combinan y puntualizan los plazos en que deben hacerse las operaciones para Ia quinta, de modo que la entrega de los mozos se haga en época oportuna, a fin de que recibiendo la instrucción conveniente, si han de ser un día buenos soldados, empiecen las fatigas propias de su estado en las estaciones de otoño o primavera, que son, según he oído a personas quo juzgo competentes, las más favorables para dar principio a esta clase de trabajos (Discurso del Sr. Garvía, Diario de sesiones de las Cortes, no 20, 01/05/1867, p. 209).

917 "[...] estamos en que desde luego se lleve a cabo esa supresión [de la sustitución]. Queremos que se limite, pero no que desaparezca desde luego; y no queremos que desaparezca, en beneficio de las clases pobres, que no puedan tener los medios necesarios para acudir a la redención en la forma que hoy se halla establecida. Queremos facilitar a estas clases un medio de sustitución, porque no sería justo que un hijo, un hermano o un sobrino, que estuviera estudiando o siendo el sostén de una familia, se viera obligado a servir por no tenor los medios de redimirse y tener, sin embargo, los medios de sustitución" (Discurso del Sr. Torres Valderrama, Diario de sesiones de las Cortes, no 19, 30/04/1867, p. 190).

918 Discurso del Sr. Torres Valderrama, Diario de sesiones de las Cortes, no 19, 30/04/1867, p. 191.

919 "Un Ejército de soldados casados, a quienes acompañara, digámoslo así, otro ejercito de mujeres, de hijos, de ayas y de nodrizas, con todo lo necesario para su manutención, con todos los inconvenientes que ello llevaría consigo, no le concibe ni le entiende la Comisión. Mientras los soldados forman parte del Ejército activo, 
único sorteo ${ }^{920}$, y se mantuvo la misma talla mínima para el servicio militar que la establecida en la legislación de 1856, 1.596 m. ${ }^{921}$.

está aceptado y convenido que no puedan casarse; pero como pasan a una vida sedentaria, como solo son llamados en caso de guerra o en un accidente imprevisto, se deja una prudente libertad para que puedan casarse; pero siempre con conocimiento de la autoridad militar, para evitar el inconveniente de ese Ejército de mujeres quo acompañaría a los soldados y que iria en pos de los Ejércitos" (Discurso del Sr. Torres Valderrama, Diario de sesiones de las Cortes, no $19,30 / 04 / 1867$, p. 199).

920 Discurso del Sr. Torres Valderrama, Diario de sesiones de las Cortes, no 20, 01/05/1867, pp. 207 y 208.

921 "El Ejército ha de responder, no solamente s una necesidad material, sino que también es preciso que tenga cierto lustre y esplendor, que es indudable que vaya acompañado con la representación personal de los individuos que lo forman. En mi sentir, y en el de la Comisión, no se puede rebajar la talla mucho, porque es preciso que se reemplacen con las quintas do cada año, no solamente los cazadores y la infantería de línea, donde podrían pasar quizás, especialmente en el primer instituto, los hombres de baja talla, sino que también ha de tomar su gente la artillería, la caballería y los ingenieros, institutos todos quo necesitan talla [...]. Recordad S. S. que en el Ejército que ha de representar la fuerza, se necesita, no solamente moral, sino muy especialmente material, y según una fórmula reconocida de física, fuerza es igual el producto a dos factores, masa y velocidad; y poca masa me parece puede dar un hombre de muy poca talla, para que en el producto se halle la fuerza necesaria en movimientos de ataque dado" (Discurso del Sr. Marqués de la Merced, Diario de sesiones de las Cortes, no 21, 03/05/1867, p. 226). 


\title{
2.6.- Una situación convulsa hace fracasar los intentos de cambio: La Ley de 1870
}

\author{
El estallido de la Revolución Gloriosa, el inicio del Sexenio
} Revolucionario y la llegada al poder de las nuevas autoridades democráticas trajeron aparejada una transformación de relieve en la legislación española, empezando por su ley constitucional, sin que las normas que regulaban el reclutamiento quedasen exentas de estos intensos cambios. La libertad de imprenta también favoreció la aparición de un sinfín de publicaciones periódicas de todo color político, de las que hemos seleccionado La Iberia ${ }^{922}$ y La Época ${ }^{923}$ para

922 "Periódico progresista fundado por Pedro Calvo Asensio, renovó el estilo del serio periodismo político existente hasta entonces haciéndolo más polémico y ameno. Bajo la dirección de Práxedes Mateo Sagasta alcanzó su máxima difusión, y desempeñó un importante papel en la preparación de la Revolución de 1868. Entre enero y septiembre de 1868 adoptó el título de La Nueva Iberia, y aquí fue donde publicó Carratalá, el 3 de julio, su artículo "La última palabra", uno de los más célebres de la historia de la prensa española, en el que adelanta los planes revolucionarios" (http://www.bne.es/es/Catalogos/HemerotecaDigital).

923 "Diario vespertino fundado por Diego Coello y Quesada [...] el uno de abril de 1849 , a principios del siglo veinte será ya el decano de la prensa diaria política madrileña, extinguiéndose su vida a escasos días del golpe de Estado de julio de 1936. Será el diario por antonomasia de la monarquía, que se convertirá en prototipo de periódico aristocrático y conservador. Nace, desde una posición moderada, como reacción al semiabsolutismo del ministerio de Juan Bravo Murillo. Evoluciona a una oposición centrista y saluda alborozado el triunfo de 1854 del general Francisco Serrano, pero se mostrará contrario al bienio esparterista. Desde 1856 será el órgano de Unión Liberal, pero se separará de la misma a causa de los acontecimientos de la noche de San Gil, en abril de 1865, para apoyar a los gobiernos del general Ramón María Narváez y de Luis González Bravo, aunque después combatirá a este. Caracterizado por su fidelidad al trono isabelino, aceptará la Gloriosa en 1868 y tras algunas dudas y el fracaso de la candidatura de la nueva monarquía de Antonio María de Orleans, duque de Montpensier, Antonio Cánovas del Castillo lo ganará para la causa alfonsina, convirtiéndose en el estandarte periodístico de la Restauración durante el Sexenio Democrático. [...].

Tras el magnicidio de Cánovas, en 1897, y ya en manos del segundo marqués, Alfredo Escobar Ramírez, el diario continuará siempre al lado del jefe del sector mayoritario del Partido Conservador, apoyando a Francisco Silvela $y$, posteriormente, a Antonio Maura, y tras su crisis de 1913 y un breve titubeo, y durante la primera guerra mundial y siempre con la pretensión de mantener unido al partido, apoyará a Eduardo Dato. Tras el magnicidio de este, en 1921, será el portavoz de José Sánchez Guerra, el hombre de confianza de Maura. Como defensor de una monarquía constitucional y parlamentaria y desde su posición liberal-conservadora, será diario opositor a la dictadura primoriverista, llegando a ser multado y suspendido en abril de 1926 (http://www.bne.es/es/Catalogos/HemerotecaDigital). 
profundizar en nuestro estudio, convirtiéndose las quintas y su evolución en una cuestión fundamental en el proceso revolucionario y en la prensa que a su calor surgió.

Las paradojas de una situación revolucionaria marcan el contexto histórico

El reinado de Isabel II había venido a consolidar el sistema de quintas como la opción prioritaria para asegurar el reemplazo del Ejército. Tal mecanismo, en sus orígenes igualitarios y de inspiración revolucionaria liberal, se había visto tergiversado a través de sucesivas legislaciones que habían introducido la desigualdad y los privilegios en el sistema. Así lo explica Puell de la Villa:

"La quinta, en su acepción liberal, nació para regular las espontáneas movilizaciones del pueblo en defensa de la libertad, haciendo especial hincapié en los aspectos igualitarios del llamamiento a las armas, una vez desaparecidas las exenciones estamentales, territoriales y funcionales que habían caracterizado a las quintas del absolutismo. Sin embargo, al comenzar progresivamente a ir calando el liberalismo en la masa del pueblo y paralelamente convertirse en propietarios rurales los artesanos y comerciantes de las minorías burguesas que dieron impulso a la revolución liberal, éstos favorecieron una privilegiada legislación de reclutamiento que les amparaba de prestar el servicio militar y aquéllos advirtieron la contradicción existente entre le dogma igualitario que predicaba la Constitución y la injusticia existente en la aplicación práctica de sus preceptos" $^{\prime 924}$.

Este rechazo a las quintas, a sus injusticias y al servicio militar fue canalizado por los primeros esbozos de partidos populares, a saber, republicanos, demócratas y socialistas, quienes ondearon la 924 PUELL DE LA VILLA, F., El soldado desconocido: de la leva a la "mili" (17001912), p. 170. 
bandera de su abolición como un elemento más de justicia social ${ }^{925}$. Las agitaciones violentas en contra del reclutamiento comenzaron a manifestarse desde la década de 1840 en toda España, y alcanzaron su máxima intensidad durante el Sexenio, periodo caracterizado por los intentos de regeneración y modernización de la estructura política y socioeconómica del país. Este rechazo popular suponía un descontento que las nuevas autoridades revolucionarias debían canalizar $^{926}$, ya que había sido precisamente el apoyo de las clases humildes una de las claves de su encumbramiento al poder ${ }^{927}$. Si atendemos a una perspectiva más amplia que abarque todo el Sexenio, diferencia Puell de la Villa tres fases en el tratamiento del reclutamiento durante este periodo:

"En la primera de ellas, dominada por los militares del Pacto de Ostende y los representantes de las clases acomodadas, imperó el pragmatismo sobre la ideología revolucionaria, manteniéndose en

925 Son numerosísimas las peticiones que, a lo largo de todo el Sexenio, instituciones locales, partidos políticos y particulares presentaron a las Cortes solicitando la abolición de las quintas.

926 "Uno de los objetivos a que expresamente se comprometieron los revolucionarios de 1868 fue el de abolir el sistema de reclutamiento por quintas. La creencia de que la revolución supondría la desaparición del servicio militar obligatorio y de que el ejército pasaría a ser organizado sobre la base de soldados profesionales, supuso un importante respaldo popular hacia los hombres de septiembre de 1868 que, por su profesión militar, conocían perfectamente el impacto que esta promesa tendría" (FRIEYRO DE LARA, B., De campesino a soldado. Las quintas en Granada (1868-1898), p. 17).

927 "[...] Será necesario esperar hasta 1869 para que se reproduzcan las agitaciones violentas en contra del reclutamiento. Pero es muy posible que, precisamente en la última década del reinado de Isabel II, se recrudeciera el odio de las clases populares hacia aquel injusto sistema como reacción a las sangrías de hombres en las expediciones ultramarinas de Conchinchina, Méjico y Santo Domingo, difíciles de justificar ante los familiares de los quintos enterradas en tan lejanas tierras. Quizás por esto, la bandera de la abolición de las quintas se convirtió en el principal señuelo utilizado por los diversos movimientos antidinásticos para ganarse adeptos entre las masas que las sufrían [...] Está fuera de toda duda que el grito de iAbajo las quinas! no fue la única causa para que el pueblo se sintiera rabiosamente enfrentado al régimen isabelino, y mucho menos desde que la crisis de 1866 dejó sin trabajo y sin jornal a un buen número de obreros del campo y la ciudad, pero sí sirvió para expresar su oposición al sistema y como aglutinante de una conciencia de clase que estaba comenzando a desarrollarse en el ocaso de este reinado". (PUELL DE LA VILLA, F., El soldado desconocido: de la leva a la "mili" (1700-1912), p. 172). 
líneas generales la normativa diseñada por Narváez y O Donnell ante la necesidad de reforzar el Ejército de Ultramar y hacer frente a las partidas carlistas en la Península. El período republicano pretendió hacer compatibles las corrientes pequeño-burguesas, partidarias de la profesionalización pausada y por etapas de la milicia, con las reivindicaciones de las masas populares, que exigían la inmediata abolición del servicio militar forzoso. Por último, Castelar, ante el panorama de un país que vivía convulsionado por tres guerras civiles, se desdijo de lo predicado a todo lo largo de su vida e implantó el servicio obligatorio, y Serrano, más consecuente con su trayectoria isabelina, se inclinó por el retorno a las quintas tradicionales" ${ }^{\prime 928}$.

En 1868 , casi todas las tendencias políticas ${ }^{929}$ y casi todos los líderes revolucionarios a la postre sentados en las Cortes Constituyentes apostaron por la abolición de las quintas ${ }^{930}$, si bien los sucesivos presidentes del Gobierno provisional, Prim, Topete y Serrano, pronto tuvieron que incumplir esta promesa ante las amenazas militares a las que el nuevo régimen se enfrentaba, recibiendo duras críticas de los republicanos, que iniciaron una campaña popular de recogida de firmas solicitando su abolición ${ }^{931}$. El

\footnotetext{
928 PUELL DE LA VILLA, F., El soldado desconocido: de la leva a la "mili" (17001912), p. 274.

929 Para la ideología y las características de los principales partidos políticos, tanto gubernamentales como republicanos, proletarios o confesionales durante el Sexenio, ver ARTOLA, M., Partidos y programas políticos: 1808-1936, Vol. 1, Los partidos políticos, pp. 279-321; FERNÁNDEZ MIRANDA CAMPOAMOR, C., "La verificación de poderes en el Sexenio Revolucionario", Revista de Derecho Político, Madrid, no 55-56, 2002, pp. 343-364; PEÑA GONZÁLEZ, J., "La cultura política en el Sexenio", Revista de Derecho Político, Madrid, no 55-56, 2002, pp. 33-106; PERFECTO GARCÍA, M. A., "El Sexenio Revolucionario y los inicios de la Restauración", en La historia contemporánea en España: primer Congreso de Historia Contemporánea de España, Salamanca, 1996; SERRANO GARCÍA, R., "La historiografía en torno al Sexenio: entre el fulgor del centenario y el despliegue de lo local", Ayer, no 44 (2001), Madrid, Marcial Pons, 2001; SERRANO GARCÍA, R. (coord.), Figuras de la "Gloriosa": aproximación biográfica al Sexenio Democrático, Valladolid, Universidad de Valladolid, Secretariado de Publicaciones e Intercambio Editorial, 2006.

930 "Todas las fracciones del Congreso, salva la, Unión liberal, la más hábil en este punto y sin compromiso alguno, habían mostrado su deseo de abolir las quintas y organizar el Ejército sobre nuevas bases", discurso del Sr. Cervera, Diario de Sesiones de las Cortes, 11/03/1870, n² 236, p. 6426.

${ }_{931}$ FEIJÓO GÓMEZ, A., Quintas y protesta social en el siglo XIX español, p. 156.
} 
primer diputado republicano que presentó una proposición para la abolición de las quintas fue Luis Blanc ${ }^{932}$, quien defendió tal medida en un ardiente discurso por razones de derecho, justicia y libertad:

"Así lo comprende el pueblo, y apenas vio rota por la revolución la mordaza que tanto tiempo venia sellando sus labios, se abrieron éstos para dar paso al unánime grito de: iabajo las quintas y matrículas de mar! Grito que vino á halagar á la juventud, grito que vino á dar vida á los ancianos, grito que vino á mitigar el dolor de las pobres madres, que vieron en la revolución el pañuelo con que iban á enjugarse las lágrimas de sangre que brotaban de su corazón al recuerdo de tan tiránica ley.

Los manifiestos de todas las juntas revolucionarias justifican mis palabras. En todos ellos, en todos absolutamente, se ofrece esta ventaja, esta reforma, que reclama el derecho, que reclama la justicia, que reclama la causa de la libertad. Nosotros, que debemos ser aquí rieles intérpretes de esa revolución; nosotros, que debemos defender aquí los derechos del pueblo soberano, faltaríamos á nuestro deber y desgarraríamos nuestra bandera si no arrojásemos de nuestro suelo ese azote de la pobre familia que no tiene un puñado de oro para comprar un soldado, ese puñal que taladra el corazón de las que nos han dado el ser, ese huracán que lleva la desolación y el luto á todas partes. Porque, no lo dudéis, Sres. Diputados, las quintas pesan sobre las familias pobres corno plancha de hierro que les quita poco á poco la respiración, después de una lenta y horrible agonía'933.

También acudió el diputado Blanc al sentimentalismo para criticar la contribución de sangre, además de vincularla y compararla con la esclavitud negra y criticarla por los perjuicios económicos que ocasionaba:

932 El proyecto fue diseñado por Fernando Garrido y defendido en la Cámara por Luis Blanc, FRIEYRO DE LARA, B., De campesino a soldado. Las quintas en Granada (1868-1898), p. 22.

933 Discurso del Sr. Blanc, Diario de Sesiones de las Cortes, 06/03/1869, no 20, p. 347. 
"La española gente nos mira: todos tienen puestos sus ojos en las Cortes Constituyentes: la región ibera lo espera todo de nosotros, y las madres esperan también que de esta Asamblea salga el bálsamo que ha de venir á aliviar sus pesares. Vedlas cómo nos miran con los ojos velados por el llanto: escuchad sus desgarradores acentos que taladran estos muros y que nos dice: "Diputados de las Cortes Constituyentes, no consintáis por más tiempo que se aparte al hijo de nuestro regazo, al hijo de nuestras entrañas, al amor de nuestros amores, a la vida del nuestra vida: no permitáis por más tiempo que ese hijo vaya a morir en hospitales descuidados ${ }^{934}$; no consintáis que ese hijo, al volver al pueblo que le vio nacer, á la voz de un jefe y al sonido de una corneta, clave acaso la fratricida bayoneta en el pecho de sus hermanos y de sus padres, tal vez, que quizá se han levantado á defender el derecho, la razón y la justicia".

«Diputados constituyentes, nos dicen las pobres madres, basta de iniquidad, basta de error; y ya que tanto pedís que quede abolida la esclavitud de los negros, pedid que en España quede también abolida la esclavitud de los blancos.»

Si el acento desgarrador de esas madres no fuese bastante á conmover vuestros corazones, mirad las huellas que por do quiera dejan las quintas; ved cómo roban sus mejores brazos á la industria, al comercio, á las artes, á la agricultura. Es más: ved cómo nos roban los miembros sanos de la sociedad para devolvérnoslos podridos; y si dudáis que esta es una verdad palmaria, ved si muchos de ellos vuelven á ocuparse en la profesión ó en el oficio que dejaron para tomar las armas: ved cómo, envueltos en la holganza, siguen la senda de la empleomanía, y algunos la del crimen que les conduce, primero á los presidios, y después al patíbulo'1935.

A cambio de un Ejército permanente tan numeroso como el que, a juicio de Blanc, tenía España en esos momentos, el diputado propuso la creación de los Voluntarios de la Libertad, grupo armado

934 Sobre el sistema hospitalario español en el siglo XIX, véase CARASA SOTO, P., y ENCISO RECIO, L. M., El sistema hospitalario español en el siglo XIX: de la asistencia benéfica al sistema sanitario actual, Valladolid, Secretariado de Publicaciones de la Universidad de Valladolid, 1985.

935 Discurso del Sr. Blanc, Diario de Sesiones de las Cortes, 06/03/1869, no 20, p. 348. 
formado exclusivamente por voluntarios defensores de la revolución septembrina al que consideró capaz de hacer frente a un ataque extranjero y a las maniobras carlista y borbónica. Llegó incluso a plantear la posibilidad de que, en caso de que la Cámara no aboliese las quintas, el pueblo se presentaría indignado en las puertas del hemiciclo, planteamiento éste que fue reprendido por el propio presidente de la Asamblea ${ }^{936}$.

Fueron Juan Prim, ministro de la Guerra, y Topete, ministro de Marina, los encargados de contestar al diputado aragonés. El primero confirmó su oposición y la del Gobierno en su conjunto a las impopulares quintas, actitud que sostuvo cuando estaba en la oposición pero también al ser nombrado ministro del Gobierno provisional ${ }^{937}$. Sin embargo, defendió en su discurso la existencia de los ejércitos permanentes, por su unidad, fuerza y cohesión, cualidades de las que carecían los batallones de voluntarios. Estando a favor de la abolición de quintas, Prim consideraba necesario encontrar un sistema que permitiese su sustitución para abastecer a un ejército permanente encargado de defender la libertad conquistada, amenazada por los carlistas y que los batallones de voluntarios serían incapaces de doblegar. A ello se unían los problemas derivados de la sublevación cubana. Por tanto, el ministro de la Guerra se mostró favorable a la supresión de las quintas, pero a largo plazo, ya que las amenazas a las que tenía que hacer frente la Revolución lo impedían a corto plazo ${ }^{938}$. A ello se unía, argumentaba el ministro, el incremento de los costes que suponía la creación de un ejército de voluntarios frente al formado por quintos en una situación

\footnotetext{
936 Discurso del Sr. Blanc, Diario de Sesiones de las Cortes, 06/03/1869, no 20, p. 348.

937 "Se entendía, por tanto, que las de ese año 1869 eran una medida transitoria en tanto se habilitaba el sistema por el cual habría de formarse el ejército permanente, aunque parecía bastante evidente que el sistema de voluntarios difícilmente reportaría la solución buscada" (FRIEYRO DE LARA, B., De campesino a soldado. Las quintas en Granada (1868-1898), p. 22).

938 Discurso del Sr. Marqués de los Castillejos, Diario de Sesiones de las Cortes, 06/03/1869, no 20, pp. 349-350.
} 
económica tan frágil como en la que se encontraban las arcas del Estado939. Parecidos argumentos utilizó el ministro de Marina para justificar el aplazamiento en la abolición de las quintas, haciendo especial énfasis en las escasa formación que, para el arte de la guerra, vendrían a demostrar los voluntarios enrolados en buques de la armada, además del incremento consiguiente que, la contratación de voluntarios, tendría aparejada en el presupuesto de defensa. Finalmente, la Cámara decidió que el proyecto de ley presentado por Luis Blanc pasase a la Comisión de Guerra, donde sería rechazado en su totalidad.

Argumentos similares fueron utilizados por la prensa afín al Gobierno ya que, sin bien no se mostraban favorables a las quintas, y así lo habían señalado durante sus años de oposición a la reina, sí que pedían un debate sosegado respecto a una cuestión tan importante, destacando la necesidad de ejércitos permanentes, y criticaban la actitud "imprudente" y poco meditada de los republicanos, mientras que alababan la actitud "elocuente" del ministro Prim:

"No fué de escaso interés la discusión promovida con motivo de la proposición presentada y defendida por el señor don Luis Blanc, pidiendo al Congreso la abolición de las quintas. No estuvo muy elocuente el diputado por Huesca, á pesar de que la proposición se prestaba á un buen discurso, y su principal argumento fué, al

\footnotetext{
939 "El soldado español cuesta hoy al Estado, mantenido, vestido, alojado, cuidado en sus enfermedades, en fin, con todo lo que necesita, le cuesta al Estado 3 rs. 78 céntimos diarios. Ya ven los Sres. Diputados que más barato no puede ser, y esto es debido á la buena administración y economía que hay en el Ejército: no creo que haya un jornalero de ninguna parte que pueda vivir con 3 rs. y 78 céntimos; y si vive, vive mal, mientras que el soldado vive bien. Con este tipo resulta que un Ejército de 80.000 hombres, por ejemplo, cuesta 110 millones, cifra redonda. Pero como no se puede creer ni se puede admitir que por 3 rs. 78 céntimos vengan á ser soldados, hay que buscar el tipo de jornales de diferentes provincias; y buscando este término medio, no creo que me excedo si digo que á esos soldados voluntarios habrá que darles seis reales y medio. Pues dándoles seis reales y medio costarían los mismos 80.000 hombres 189 millones, cifra redonda: es decir, 80 millones más para el presupuesto de la guerra" (Discurso del Sr. Marqués de Castillejos, Diario de Sesiones de las Cortes, 06/03/1869, no 20, p. 350).
} 
condenar las quintas y matrículas de mar, considerarlas como la esclavitud de los blancos.

Contestaron al diputado republicano los señores ministros de Guerra y de Marina. El general Prim pronunció un elocuente discurso, en el que hizo resaltar que él siempre, desde la oposición, había defendido la conveniencia de abolir las quintas, y que hoy, en el poder, no pensaba de distinta manera; poro que siendo absolutamente precisa la existencia de los ejércitos permanentes, muy particularmente en España, donde se necesita, tanto para la conservación de la integridad de su territorio en Cuba como, para defender la libertad en la Península, amenazada por los reaccionarios isabelinos y carlistas, que desearían, si pudieran, envolvernos en los horrores de una guerra civil, no podía prescindirse de una fuerza que tuviese todas las ventajas que dá la disciplina y la unidad, por lo que era conveniente estudiar mucho ésta cuestión, y no olvidar que se roza con la económica, puesto que un ejército de voluntarios igual al que hoy tiene España, costaría á la nación ochenta millones más.

Por esta razón, si los autores no retiraban la proposición, pedía que pasara a las secciones para el nombramiento de comisión. Así lo acordó el Congreso. Nosotros deseamos que la comisión se inspire en el mis alto patriotismo, y estudiando con calma tan interesante asunto, proponga lo que esté de acuerdo con las ideas liberales y con la más estricta y rigurosa justicia $[\ldots]^{\prime \prime 940}$.

La prensa monárquica, heredera del régimen anterior, y cercana al futuro conservadurismo, no escatimó críticas hacia los progresistas y su líder, el General Prim, quien fue acusado de maltratar al Ejército con sus propuestas:

"Por eso nos duele ver al ministro de la Guerra emplear con tanta frecuencia argumentos que son armas de doble filo $y$, respetándolas, no queremos insistir mas en este punto'1941.

${ }^{940}$ La Iberia, 07/03/1869, no 3810, p. 1.

${ }^{941}$ La Época, 06/06/1869, no 6602, p. 1. 
Las críticas por parte de la oposición parlamentaria, en especial republicana, se intensificaron en el momento en que el Gobierno tripartito (progresistas, unionistas y demócratas) presentó un proyecto de ley para reclutar, mediante quinta, a 25.000 hombres, tachándolo de traición a la revolución septembrina e incumplimiento de las promesas realizadas al pueblo levantado en armas, además de rechazar incluso la existencia de ejércitos permanentes por los perjuicios económicos que ocasionaba al país ${ }^{942}$ y mitigar el peligro militar que carlistas, isabelinos ${ }^{943}$ y rebeldes cubanos suponían para el nuevo régimen y defender a los Voluntarios de la Libertad como verdaderos defensores de la democracia y de sobra capacitados para mitigar las amenazas que ensombrecían la revolución ${ }^{944}$. Se intensificó asimismo de manera notable la protesta social:

942 "Pero tienen otro gran inconveniente los Ejércitos permanentes, y es la pérdida de muchos brazos para las faenas agrícolas y para toda clase de industrias. [...]. Por consiguiente, nosotros deseamos que los soldados estén en sus casas trabajando, porque de esta manera se desenvuelve la riqueza general (Discurso del Sr. Orense, Diario de Sesiones de las Cortes, 23/03/1869, no 34, pp. 675 y 676).

943 "Cuando los pueblos vean que se hacen reformas, no hay que temer ni a los carlistas ni a los isabelinos. El carlismo hace treinta años que duerme en paz; y no creo que tenga medios para salir de su sueño. [...]. De los isabelinos es de quienes hay más que recelar, porque como han estado con la leche en los labios hasta ahora, difícilmente se podrán acostumbrar a pasarse sin ella" (Discurso del Sr. Orense, Diario de Sesiones de las Cortes, 23/03/1869, no 34, p. 677).

944 "Señores Diputados, si en el mes de Octubre nos hubieran dicho que las Cortes Constituyentes, nacidas del sufragio universal, habían de venir á discutir si debiéramos tener o no más quintas, seguramente que el que eso hubiera dicho [...], hubiese sido tenido acaso por un demente ó por un hombre poco conocedor del espíritu de la revolución de Setiembre. En el programa de Cádiz, en los manifiestos de todas las juntas, en los manifiestos de todos los pueblos, en los manifiestos de cuantos tomaron parte en la revolución, en todos ellos estaba escrito el «Abajo las quintas» y los pueblos vieron en la bandera de la revolución la conclusión de esa contribución injusta, de esa contribución ominosa; conclusión que siempre había defendido el partido democrático.

Pero no solo esto es lo extraño, sino que á la voz de todas las juntas, que á la voz del pueblo, que á la voz de la revolución, viene á unirse la voz misma del Gobierno y de la Comisión que presenta el dictamen que nos ocupa, y nos dicen que las quintas son una contribución inicua, injusta y odiosa. Y sin embargo, después de convenir todos en ello, se nos viene hoy á hablar de la contribución de quintas. [...] El Gobierno y la mayoría han aceptado el programa democrático como el programa de su política; y no obstante, después de aceptarlo y proclamarlo, vienen todos los días, en todas sus decisiones, falseando ese mismo programa, y falsear ese programa es falsear la revolución de Setiembre" (Discurso del Sr. Soler, Diario de Sesiones de las Cortes, 22/03/1869, no 33, pp. 614-617). 
"La recluta de 25.000 hombres en marzo de 1869, a pesar de plantearse como una medida transitoria, provocó una vez más la movilización y la protesta social en los pueblos y ciudades españolas. El incumplimiento de la propaganda revolucionaria en cuanto a las quintas hizo que de las posturas individuales que llevan a los mozos a tratar de eludir ilegalmente el ingreso en filas, se pase a una oposición multitudinaria, insólita hasta entonces. [...]. La profunda crisis económica en los años previos a la Gloriosa resulta también un factor determinante en el apoyo popular a los hombres de 1869, y determina, además, la imposibilidad de afrontar el pago de las exenciones pecuniarias, que si ya era general a la inmensa mayoría de las familias españolas, desde 1866 lo era mucho más.

De esta forma se explica la generalización de los motines contra el reclutamiento durante el Sexenio Revolucionario, cuando los progresistas que llegan al Gobierno se olvidan de sus promesas ${ }^{\prime 945}$.

No pudo el Gobierno, en boca del presidente de la comisión, Romero Girón, negar esa promesa inicial de abolición de las quintas, pero justificó este nuevo reclutamiento en las necesidades militares del país y en el limitado número de reclutas, un total de 25.000, que había solicitado el Gobierno para su ingreso en el Ejército, insuficiente incluso para asegurar el reemplazo ${ }^{946}$. Los grupos parlamentarios conservadores y la prensa cercana a la monarquía isabelina no se mostraron críticos hacia los llamamientos, considerándolos necesarios para el Ejército y la defensa de la Patria, el orden y la estabilidad, además de una herramienta de justicia social. Es más, rechazaron las diatribas antiquintas del ministro Prim, defendiendo su honorabilidad:

"En la sesión de ayer el General Prim, ministro de la Guerra, no hizo más que un simulacro de defensa en la importantísima cuestión de la supresión de las quintas y matrículas de mar [...].

\footnotetext{
945 FRIEYRO DE LARA, B., De campesino a soldado. Las quintas en Granada (18681898), pp. 22-23.

946 Discurso del Sr. Romero Girón, Diario de Sesiones de las Cortes, 22/03/1869, no 33, pp. 617-618.
} 
Calificó las quintas de tributo injusto y onerosísimo. iInjusto! ¿por qué? ¿no es la obligación de defender la patria, de amparar los derechos de los ciudadanos, de mantener el orden social, uno de los grandes deberes a los que nace sujeto el hombre en sociedad?

Comprendemos, tratándose de las quintas, que se clame contra la sustitución, que se pretenda, como en Prusia y en otros países sucede, todo ciudadano está sujeto al servicio militar, sin admitir la exoneración ni la sustitución. Esto podría ser perjudicial en sus resultados, pero se funda en un principio de justicia. Mas condenar por injustas las quinas en absoluto, equivale a sostener que la sociedad no necesita defensa ni tiene derecho a exigir de los que disfrutan del beneficio que proporciona el menor sacrificio.

En cuanto á que las quintas son onerosas, es verdad, como lo es toda contribución. Pero está demostrado, que un ejército reclutado por el enganche voluntario lo es muchísimo mas. Si.se quiere que la contribución de sangre no pese sobre el país, será preciso suprimir el ejército permanente. Mientras este subsista, mientras haya bajo las banderas 80 ó 100,000 soldados, ya provengan de la conscripción, ya sean voluntarios, la supresión de las quintas no resolverá nada, porque siempre faltarán esos brazos á la agricultura y á la industria, y porque en vez do pagar la nación como 2 para el sostenimiento de las fuerzas defensivas, tendrá que pagar como 6".

$[\ldots]$.

Los republicanos serían lógicos si atacaran de frente la existencia en España de un ejército permanente; pero admitir este, como el Sr. Blánc lo admitía, y combatir las quintas es desdeñar el ejército salido de las lilas del pueblo, éspresion (sic) la mas pura del pueblo, medio dé fundir las diferencias sociales y de adelantar la educación popular por los ejércitos del antiguo régimen, compuestos de mercenarios y forzosamente hostiles a la libertad.

[...].

Esperábamos que en materia tan grave, de tanto interés ara el porvenir de la misma revolución, el gobierno habría contestado con prudencia, rechazando la proposición do la minoría republicana. Nuestra sorpresa fué penosa cuando oímos al general Prim que quería ser el que firmase la ley hecha en Cortes, extinguiendo la contribución de sangre, quo lo deseaba ardientemente, aunque debía recordar al 
país que la sustitución de las quintas por el ejército voluntario le impondrá nuevos sacrificios $[\ldots]^{1947}$.

Los republicanos por su parte, de manos del diputado García López, llegaron a ofrecer su apoyo para que el Gobierno solicitase un préstamo que le permitiese financiar el reclutamiento de 25.000 voluntarios y no traicionar así las promesas realizadas, al considerar las quintas como un tributo odioso e inhumano ${ }^{948}$. Las discusiones fueron elevándose de tono hasta llegar a las acusaciones personales entre los diputados republicanos y los ministros de Guerra, Fomento y Hacienda, rechazándose finalmente la propuesta republicana. Las críticas al Gobierno se repetirían en jornadas posteriores ${ }^{949}$, defendiendo algunos diputados demócratas el mayor interés que tenía para el país un ejército de voluntarios por encima del reclutamiento forzoso:

"Hay que tener en cuenta también la diferencia que hay entre los soldados voluntarios y los forzosos. Al soldado forzoso duele exigirle nada. Principiase por leérsele una ley que le es completamente extraña, que tal vez no sabe leer él, que acaso no entiende porque está escrita en idioma castellano, al cual, si no completamente, es bastante extraño [...]. Al soldado voluntario se le

${ }^{947}$ La Época, 07/03/1869, no 6517, p. 2.

948 "La minoría republicana, que comprende los deberes de todo Gobierno constituido; la minoría republicana, que aspira con el tiempo á ser Gobierno y que apreciaría en igual caso que no se le negarán todos los medios que la administración pública necesita para el servicio de la Nación no insiste en disputar al Poder ejecutivo el número de soldados que ha pedido por el art . $1^{\circ}$ que acabáis de aprobar; pero lo que la minoría republicana no puede consentir es que para cubrir ese número, directa o directamente, tengan que apelar los pueblos y las corporaciones Provinciales al sistema de reemplazo por sorteo : y por eso, nosotros, que, como he dicho, queremos, antes que todo, atender á las necesidades públicas, vamos á facilitar al Poder ejecutivo a marcha de su administración, y presentamos para ello una enmienda, por la cual os pedimos, Sres. Diputados, que se conceda al Poder ejecutivo un crédito de tanta cantidad como sea la necesaria para que busque y consiga con dicha suma el número de soldados que necesite el Ejército", (Discurso del Sr. García López, Diario de Sesiones de las Cortes, 22/03/1869, no 33, pp. 619-621).

949 Diario de Sesiones de las Cortes, 22/03/1869, no 33, pp. 622-629 y 23/03/1869, no 34, pp. 633-636. 
puede tratar de otra manera; se le puede exigir todo, porque celebra una especie de contrato, y el que celebra un contrato está obligado á su cumplimiento. Por eso al soldado voluntario debe exigírsele el cumplimiento de la Ordenanza y de la disciplina con todo rigor, cosa que no puede hacerse con el soldado forzoso. Esto probaría que si el Gobierno necesita 25.000 soldados forzosos, tal vez tuviera bastantes con un número menor de soldados voluntarios. ¿De qué se trata, pues? Se trata de si ha de hacerse o no el sorteo en España, y para este yo debo deciros lo que es la quinta. La quinta la han juzgado la Comisión y el Gobierno, la ha juzgado el país, la hemos juzgado todos: la quinta es una iniquidad. [...] desde el momento en que por el sorteo se sacan soldados forzosos y al mismo tiempo se deja abierta la puerta á la redención, el que dispone de un capital considerable puede redimir la suerte de sus hijos con mucho menos dinero del que le cuesta un caballo, como decía mi amigo el Sr. Castelar; y la quinta gravita entonces sobre las clases menos acomodadas, que no pueden disponer de ese capital $[\ldots]^{1950}$.

Las críticas emitidas por el republicano Castelar no se quedaron atrás, ya que no sólo rechazó las quintas por considerarlas como una contribución infame y propuso un reducido ejército de voluntarios ante los escasos peligros exteriores que amenazaban al país ${ }^{951}$, sino también la injusticia que suponía que algunas regiones estuvieran históricamente exentas de las mismas, así como la identificación que se realizaba entre soldado y centralismo borbónico:

"Notad, señores, que una parte, la más enérgica del país, las provincias Vascongadas, no tiene quintas: dejo á la consideración del

\footnotetext{
950 Discurso del Sr. Gil Berges, Diario de Sesiones de las Cortes, 23/03/1869, no 34, p. 641.

${ }^{951}$ El diputado Castelar también minimizó los peligros interiores que amenazaban al nuevo régimen revolucionario: "Los isabelinos no han podido sostener quince días á su reina; los carlistas están completamente perdidos en medio de la generación que lanzó á la otra rama por creerla demasiado reaccionaria y que no consentiría la nueva rama de Orleans, porque sería la antítesis con la democracia moderna" (Discurso del Sr. Castelar, Diario de Sesiones de las Cortes, 23/03/1869, no 34, p. 652).
} 
Congreso el pensar cuánto hay de irritante en esta grande injusticia. Notad también que otra parte del país sumamente batalladora, aquella en que el general Prim ha nacido, no tuvo las quintas [...] hasta el año 1845. El soldado era allí odiado, muy odiado, porque recordaban aquellos habitantes la terrible dominación de los Borbones. Por consiguiente, hay provincias, grandes provincias, que, ó no tienen todavía las quintas, o las han aceptado de una manera violenta y cediendo más bien á la fuerza del poder central que á su propia voluntad y á su propia conciencia. [...] Empecemos porque el primer domingo de Abril es un día nefasto en todas partes continuemos por esta triste iniquidad de la lotería fúnebre, por la cual se arranca el corazón á unos y los que se alegran tienen que alegrarse de la desgracia de sus hermanos: sigamos porque salen de su casa los jóvenes, en el momento en que son más necesarios á sus padres y en el momento en que las primeras pasiones del corazón se arraigan en la tierra, por lo cual sufren más tarde una nostalgia que suele matar á muchos soldados en toda España: continuemos por la injusticia irritantísima que hay aquí, en esa contribución anti-democrática, en esa contribución anti-humanitaria ( $y$ por eso decimos que es una contribución inicua), la injusticia de que la paga el pobre y no la paga el rico, cuando el pobre necesita más de sus hijos que el rico, porque los ha criado para que empapen con el sudor de su frente el campo y le dé sus frutos, para que trabajen en el taller y le den su sustento en el momento mismo en que las fuerzas de su alma, como las de su cuerpo, decaen ${ }^{\prime 952}$.

A ello se unía, continuaba Castelar, la resistencia que presentaban los jóvenes a cumplir el servicio, que les llevaba a realizar actos inmorales contra su propia integridad física, además de la humillación que suponía para los mozos la obligación de desnudarse en público para el reconocimiento, los fraudes que se cometían en estos actos y los elevados gastos que suponía el traslado

952 Discurso del Sr. Castelar, Diario de Sesiones de las Cortes, 23/03/1869, no 34, p. 647. 
de los quintos a la caja de reclutamiento ${ }^{953}$. No cesó el diputado republicano en recordar a los hombres del Gobierno las promesas incumplidas que, para el pueblo levantado en armas, suponía el mantenimiento de las quintas, promesa además realizada en los meses previos a la Revolución y defendida por los propios ministros en los días previos a la Septembrina:

"Pero, señores, colvidará mi amigo el general Prim (no lo olvida, porque el otro día lo ha recordado) que antes de la insurrección de Agosto dijo que era necesario, complemente necesario, abolir las quintas? ¿Olvidará mí amigo el Sr. Sagasta que él ha sostenido muchas veces en La Iberia la abolición de las quintas? ¿Olvidará que en una solemne discusión nos echaba en cara lo mismo que ahora nos ha echado en cara el Sr. Romero Girón, que el partido republicano había sido el que había introducido las quintas en Europa, lo cual, si fuera cierto, haría caer gran responsabilidad sobre el partido republicano? Pero además, señores, ¿cuál ha sido el mandato más expreso de la revolución? El de abolir las quintas. [...] Aquí sucede que durante el período revolucionario se promete mucho, y durante el período legal se cumple poco: aquí sucede que durante el período de oposición se promete mucho, y durante el período de Gobierno se cumple poco'p54.

\footnotetext{
953 "Yo he visto á un joven quemarse un ojo con una bujía para quedarse tuerto y no ir al Ejército; he visto á otros cortarse los dedos con el mismo objeto: $y$, señores, tengo que denunciarlo aquí, porque las Cámaras son un gran jurado: la verdad es que la operación de medir al quinto es uña operación deshonrosa para un ciudadano; la verdad es que después de aquella especie de tormento, después de aquella especie de martirio, se ataca innoblemente al pudor, toda vez que se obliga al mozo á que se desnude en presencia de las gentes; la verdad es que después de todo esto hay gastos enormes en la conducción de los quintos, y que hay inmoralidades horribles en los actos del reconocimiento, porque ha habido muchos de los interventores en las exenciones que se han hecho ricos dando por válidos á los inválidos y dando por inválidos á los válidos. [...]. Si nosotros nos oponemos á las quintas, nos oponemos en nombre de la razón, nos oponemos en nombre del derecho, nos oponernos en nombre de la revolución de Setiembre y nos oponemos en nombre de un interés eterno y permanente, en nombre de la moralidad pública" (Discurso del Sr. Castelar, Diario de Sesiones de las Cortes, 23/03/1869, no 34, p. 648).

954 Discurso del Sr. Castelar, Diario de Sesiones de las Cortes, 23/03/1869, no 34, pp. 648 y 649.
} 
De nuevo el ministro de la Guerra, Juan Prim, se vio en la obligación de responder a la oposición republicana acusándola de populista y confirmando su rechazo a las quintas, consideradas injustas e inconvenientes, aunque no infames, y su apuesta futura por un ejército de voluntarios, a semejanza del modelo inglés, señalando que la petición de 25.000 hombres para el reemplazo era solo una medida provisional de urgencia, acudiendo al ejército de voluntarios en cuanto fuese posible, ya que en aquellos momentos el voluntariado sería ineficaz frente a la fortaleza carlista ${ }^{955}$. Además, el ministro sí que concedió importancia los peligros militares que acechaban a España y a la revolución, tanto por parte de la reacción carlista como de los elementos populares desestabilizadores:

"¿No quieren dar importancia los señores de la minoría al partido carlista, que es enemigo de todo lo existente? ¿No quieren darle importancia al partido que podemos llamar reaccionario? ¿No quieren darle importancia tampoco á los elementos de anarquía y de desorden que desgraciadamente hay en España? iQué más quisiera el Gobierno que reducir el Ejército á una cifra insignificantei ¿Para qué necesitan los Ministros tener muchos soldados sino para defender la integridad del territorio, para defender las conquistas de la revolución y para consolidar la libertad? ${ }^{956 " .}$

La prensa progresista también criticó la actitud de los republicanos y de la prensa afín a ellos, reclamando sosiego en el proceso de abolición de las quintas ante las dificultades por las que atravesaba el país:

"Tenga entendido La Igualdad [diario republicano] y los que como ella piensan, que el Poder ejecutivo, el Ayuntamiento de Madrid,

\footnotetext{
955 Discurso del Sr. Ministro de la Guerra, Diario de Sesiones de las Cortes, 23/03/1869, no 34, pp. 652-656.

956 Discurso del Sr. Ministro de la Guerra, Diario de Sesiones de las Cortes, 23/03/1869, no 34, p. 654.
} 
la mayoría de las Cortes y todos los que de liberales nos preciamos, deseamos tanto como ella, cuando menos, la desaparición de las quintas: queremos otro sistema de reemplazo y tenemos la completa seguridad de que, por el camino de la prudencia, llegaremos a un resultado definitivo mucho más pronto que La Igualdad con sus continuas reclamaciones. Tenga entendido que nosotros, como el Gobierno y la mayoría de las Cortes Constituyentes, tenemos tanto interés como ella en que no se arranquen los hijos á las, madres, los brazos á las artes y las inteligencias a sus aspiraciones, y que lo conseguiremos sin hacer tanta bulla $[\ldots]^{\prime \prime 957}$.

La polémica regresó al seno de las Cortes cuando el Gobierno, de manos del ministro Prim, presentó, para los años 1869-1870, un proyecto de ley solicitando la incorporación de 80.000 hombres al Ejército, justificando tal disposición en la inestabilidad europea, en el problema cubano y en los intentos de desestabilización social. Negó además el propio Prim la dureza del servicio militar, que se había reducido notablemente desde la revolución ${ }^{958}$. Incluso la prensa conservadora defendió las bondades del servicio militar y asimiló el Ejército con una institución democrática:

"[El servicio militar en España] no dura en su período activo mas que cuatro años; que con las licencias semestrales quedan

\footnotetext{
957 La Iberia, 24/03/1869, no 3824, p. 1.

958 "Pero S. S. está en un error si cree que se derraman tantas lágrimas cada vez que Ilegan las quintas. Esto fue en otro tiempo, cuando los soldados iban á los regimientos como una especie de forzados, porque entonces realmente el servicio militar era muy penoso. Los soldados eran tratados con poca consideración en aquellos tiempos [...]: era un trato verdaderamente horrible y más que duro. Pero hoy ha cambiado de tal manera la condición del soldado, que puede tener la seguridad el [...] de que toda la aprensión que tiene la mayoría de los hombres el día que entran en el cuartel, en cuanto han pasado allí un mes, no solo están satisfechos en su gran mayoría de estar allí, sino que cuando les dan licencias semestrales no las quieren y prefieren quedarse en los regimientos. [...].Y la prueba de que el soldado tiene buen trato es que no quiere hacer uso de la licencia semestral cuando se la dan. Y otra prueba es también el número de reenganchados que hay, el cual constituye una de mis mayores esperanzas, de que solo por este medio llegará un día en que no se necesitará apelar á las quintas para el reemplazo del Ejército" (Discurso del Sr. Ministro de Guerra, Diario de Sesiones de las Cortes, 08/06/1869, no 94, pp. 2615 y 2616).
} 
reducidos á poco más de dos años; de que el soldado es alimentado y vestido mejor, comúnmente, que en su casa; de que no entrando en sorteo hasta los veinte años y pasando á la reserva á los veinte y cuatro, ha tenido todo el tiempo necesario para aprender un oficio, y no el que se necesita para olvidarlo; de que se les enseña en las academias del regimiento a leer, escribir y contar; de que adquiere hábitos de aseo y orden, y se familiariza con los adelantos de la cultura social; avivándose su espíritu y haciéndose útil para ocupaciones y puestos en que no hubiera podido soñar sino saliera de su aldea: todas estas consideraciones y muchas que hacen del ejército reclutado por la conscripción una gran institución democrática'1959.

Las críticas republicanas no se hicieron esperar, acusando al Gobierno nuevamente de traición a los principios revolucionarios, de dañar la economía nacional y llegaron a identificar incluso ejércitos permanentes con monarquía y tiranía y república federal con ausencia de guerras y desarrollo económico, además de sospechar de las inclinaciones borbónicas de buena parte de la oficialidad militar:

"Señores Diputados, si en lugar de haber votado la monarquía y de haber un gobierno monárquico desde antes que la monarquía se votara, hubiéramos tenido un gobierno con tendencias republicanas y con deseos de que se estableciese la república en España, en lugar de tener hoy que combatir un proyecto por el cual se piden 80.000 hombres de línea, tendríamos solamente una fuerza de 20 a 25.000, porque en las repúblicas democráticas federales no hay necesidad de soldados: en las repúblicas lo mismo grandes que pequeñas, apenas hay Ejércitos permanentes. Estas, sobre el Ejército permanente que existe en las monarquías, tienen la gran ventaja de que en su mayor parte los individuos están en los talleres, en el campo, desenvolviendo la riqueza y el dinero en el bolsillo de los contribuyentes. Así, pues, mientras que en las naciones organizadas con el sistema republicano bastan algunos millones para sostener las fuerzas públicas, pues éstas se hallan mientras no hay guerra en sus casas, en las naciones

${ }^{959}$ La Época, 24/03/1869, no 6704, p. 2. 
monárquicas, aun en las más pobres y arruinadas como España, se necesitan muchos cientos de millones para mantener el Ejército permanente, que, en caso de invasiones extranjeras, no basta, teniendo los pueblos que recurrir á la sangre generosa de sus hijos para defender su independencia'1960.

También se propuso desde las filas republicanas la reducción de la fuerza permanente del Ejército a 50.000 hombres una vez que hubiese finalizado la insurrección cubana ${ }^{961}$, al considerar las reacciones isabelina y carlista como no despreciables pero imposibles de triunfo tras el apoyo popular a la Revolución Septembrina ${ }^{962}$. Además, esta reducción del contingente sería enormemente positiva para el crecimiento económico del país y evitaría el hundimiento de la Revolución de $1868^{963}$.

Similares reproches se repitieron en el Parlamento con motivo de la presentación, por parte del Presidente del Gobierno y ministro de la Guerra Juan Prim, de un nuevo proyecto de ley que fijaba la

\footnotetext{
960 Discurso del Sr. Garrido, Diario de Sesiones de las Cortes, 01/06/1869, no 87, p. 2473.

${ }^{961}$ Discurso del Sr. Rebullida, Diario de Sesiones de las Cortes, 09/06/1869, no 95, p. 2625.

962 "No son de temer las facciones que puedan levantarse en nombre de ese pretendiente tradicional, aunque no las considero insignificantes; aunque no las considero tan escasas de fuerza que puedan mirarse con desprecio, pues el señor general Prim que ha hablado de ellas conoce perfectamente esos elementos ha luchado con ellos con mucha honra, con mucha gloria, justamente luchando con ellos ha obtenido los mejores timbres para su historia, sabe que son fuertes, sabe que tienen toda la valentía, toda la energía del pueblo español, aumentada además con la que les da el género de vida de los campos, que es en donde más prestigio tiene precisamente ese partido. No es, pues, tan despreciable; pero á pesar de esto, á pesar de que reconozco fuerza en los elementos reaccionarios que pueden venir á combatir esta situación, creo que no se necesita pasar de la cifra que nosotros hemos presentado para responder de todas las eventualidades que puedan surgir (Discurso del Sr. Rebullida, Diario de Sesiones de las Cortes, 09/06/1869, no 95, p. 2627).

963 "Porque no respondiendo a los deseos del país podéis estar seguros de que, si no le damos esa justa satisfacción, si no hacemos estas economías que el estado de la Nación exige, si no planteamos las reformas que representa la revolución de Setiembre, todos los partidos, vosotros y nosotros nos hundiremos; y después vendrá no sé si la reacción ú otra cosa, pero de fijo viene sobre todos esa masa de granito que, en forma de presupuesto, nos habéis presentado, que nos aplastará y hundirá para siempre" (Discurso del Sr. Rebullida, Diario de Sesiones de las Cortes, 09/06/1869, no 95, p. 2629).
} 
fuerza permanente del Ejército para los años 1870-1871 en 80.000 hombres ${ }^{964}$, justificado de la siguiente forma a pesar de no cumplir los propósitos iniciales del Ejecutivo:

"Al acudir pie nuevo á las Cortes en demanda de la fuerza militar para el año económico de 1870-71, cuando tan corto tiempo ha trascurrido y cuando los sucesos pasados justifican la previsión de los que pudieran ocurrir, el Ministro que suscribe se ve en el deber imperioso de no poder rebajar un solo hombre de la fuerza existente hoy, contrariando sus propósitos y sus miras de disminuir los gastos del Estado. Por otra parte, una rebaja considerable en la fuerza militar desorganizaría completamente el Ejército, sin conseguir por esto grandes economías, pues el Erario no podría dejar de atender á los beneméritos jefes, oficiales y clases de tropa que una y otra vez han derramado su sangre por defender las libertades y las resoluciones de las Cortes Constituyentes ${ }^{\prime \prime 665}$.

La respuesta de la oposición republicana de nuevo fue contundente 966 , al considerar excesivo el número miembros de la fuerza armada al no existir amenaza exterior ni interior y el coste que suponía su mantenimiento, y más teniendo en cuenta las circunstancias, económicas y de otra índole, por las que atravesaba el país, a lo que se unía un excesivo número de oficiales:

\footnotetext{
964 Proyecto de ley, presentado por el Sr. Presidente del Consejo de Ministros y Ministro de la Guerra, fijando la fuerza del Ejército permanente para 1870-71, Diario de Sesiones de las Cortes, 26/11/1869, apéndice $2^{\circ}$ al no 167, pp. 1 y 2.

965 Proyecto de ley, presentado por el Sr. Presidente del Consejo de Ministros y Ministro de la Guerra, fijando la fuerza del Ejército permanente para 1870-71, Diario de Sesiones de las Cortes, 26/11/1869, apéndice $2^{\circ}$ al nº 167, p. 1.

966 Por el contrario, el diario monárquico La Época volvió a mostrar su apoyo más absoluto a las quintas y a la existencia del Ejército permanente, ya que "[además] de ser necesario para mantener la independencia e integridad de la patria, lo es para conservar el orden en el interior y servir al Estado de brazo fuerte en el cumplimiento de su misión de garantizar a los ciudadanos el respeto de sus personas, propiedades y derechos (La Época, 11/12/1869, no 6791, p. 3).
} 
"Yo comprendo que en el ánimo de Doña Isabel de Borbón, sostenida únicamente por las bayonetas del Ejército, estuviera el mantener muchos soldados para continuar en el Trono; pero que un Gobierno que se llama liberal, un Gobierno que debe vivir con el apoyo de la opinión pública, un Gobierno que debe sostenerse únicamente con la fuerza que ella le dé, venga aquí á pedir 80.000 hombres, esto es lo que no podía esperar, y esto es lo que los liberales no podíamos de ninguna manera creer. Para tres cosas solamente puede pedir el Gobierno los 80.000 hombres, puesto que no está amenazada la independencia nacional: primera, para sostenerse en el poder; segunda, para sostener la importancia de la Nación en el extranjero; tercera, para sostener el orden público. Pues bien, para ninguna de estas tres cosas se necesitan los 80.000 hombres. [...].

Pero creer que con 80.000 hombres sobre las armas hemos de tener nosotros poder bastante para imponernos á la Europa, y hemos de ser más de lo que somos, me parece una aberración completa; [...]. Por consiguiente, para hacernos simpáticos a las demás naciones do Europa no necesitamos sino tener buenas leyes, buenas instituciones, buena industria, buen comercio.

Tampoco el Gobierno necesita el Ejército para sostener el orden público: el orden público lo sostiene la policía, que es á quien únicamente se debe encomendar este cuidado [...].

Yo comprendo bien que en las circunstancias difíciles en que se encuentra Cuba hubiera venido el Gobierno pidiendo fuerzas para someter á los insurrectos de aquella isla; si así hubiera sido, nosotros hubiéramos meditado lo que nos convenía hacer, y es probable que hubiéramos acordado dar al Gobierno las fuerzas necesarias para que mantuviera á aquella provincia unida á las demás de la Península en el regazo de la nacionalidad española. Pero cuando no se trata de Cuba; cuando se vienen á pedir 80.000 hombres de Ejército para que sirvan de apoyo al Gobierno, que únicamente para eso se piden, nosotros nos debemos oponer con toda nuestra resolución, no sólo por quitarle esa fuerza material al Gobierno, sino así lo exige el estado penosísimo de nuestro Tesoro y el fomento de nuestra riqueza"967.

967 Discurso del Sr. Soler, Diario de Sesiones de las Cortes, 10/12/1869, no 179, pp. 4623 y 4624. 
Los republicanos fueron más allá en sus reproches y defendieron el voluntariado, llegando a poner en cuestión los ejércitos permanentes al acusar al Gobierno de traicionar la promesa de abolir las quintas, de falsear las cifras del Ejército al no tener en cuenta como miembros de la fuerza armada a Guardia Civil y Carabineros, además de identificar monarquía con militarismo y fuerza armada968 al considerar al Ejército como un poder político con tendencias conspirativas utilizado por sus más importantes líderes para acceder y conservar el poder; un poder político voluble, cambiante y que podía poner en peligro las conquistas de la revolución:

"[...] y como es de todos los poderes el que tiene las armas, es el más fuerte, es el que impera, es la cabeza y el brazo al mismo tiempo. Por eso estamos acostumbrados a ver tradicionalmente que los jefes del Ejército son los jefes supremos de la Nación [...].

Así es que lo que hay en la Nación no es una Asamblea Constituyente que manda, siso una Asamblea constituyente unida como apéndice al Ejército que obedece á los generales Prim y Serrano. La fuerza militar impera; así es que los Diputados de la mayoría no conciben que se pueda dar un voto de censura al general Prim, y que sea un hombre civil el que aquí mande. iHasta tal punto es entre nosotros preponderante el elemento militar?

¿Y cómo se remedia esto? Haciendo que las Cortes voten 80.000 hombres para que estén á las órdenes del general que mande en el Ejército, y que, como ya he dicho antes que es la única fuerza armada que hay en la Nación, puesto que el pueblo ha sido desarmado casi en su totalidad, será el general que mande el Ejército el que impere en España [...].

Pues qué, ¿no hemos visto en 1866 y 1867 al Ejército sosteniendo al Gobierno de los Borbones, y luego, de repente, algunos cuerpos hacer un cambio de frente, y después de haber ido persiguiendo al general Prim, volverse contra los Borbones y sublevarse para derribar á aquellos? Y con estos antecedentes, ¿qué

968 Discurso del Sr. Díaz Quintero, Diario de Sesiones de las Cortes, 13/12/1869, no 181 , pp. 4680-4681. 
garantías pueden tener en el Ejército la revolución, la Nación española y la Asamblea que la representa? [...].

La situación revolucionaria creada en Setiembre, por todas las razones que he dicho, y por otras que no son de este lugar, está hoy amenazada, y esta amenaza no puede venir más que de los elementos armados, y estos elementos armados son el Ejército'969.

La respuesta a estas acusaciones por parte de la prensa progresista se centró en los mismos argumentos ya planteados en años anteriores de sosiego y prudencia e imposibilidad de abolir las quintas ante las circunstancias nacionales, esperando tal medida para el futuro:

"Los argumentos empleados la defensa de su pensamiento [republicano] los basaron en la idea de que los Gobiernos libres deben buscar su apoyo en la opinión pública, y no en la fuerza armada. Conformes estamos nosotros con este principio [...] al que caminan las sociedades modernas; pero en el estado actual de Europa, envuelta en complicaciones más ó menos graves, que cada una de las naciones quiere resolver en propio provecho, aun cuando su último resultado se vean precisadas á acudir al terreno siempre fatal de la fuerza, y en el estado particular en que se encuentra España después de una revolución que ha derrocado una dinastía y dado origen á pretendientes que con la fuerza quieren imponerse, si hemos de conservar la integridad del territorio y llevar á feliz término la Revolución, consolidando lo que la soberana voluntad del país, representada en las Cortes Constituyentes, acuerde, es absolutamente precisa la conservación do ese ejército, que, en último término, es todavía relativamente inferior en número á las fuerzas permanentes con que cuentan las demás naciones de Europa. El día que ésta se decida á desarmar, conociendo sus verdaderos intereses, qué no están en la guerra, sino en la paz será el día más feliz de nuestra vida, porque veremos cumplidos nuestros constantes deseos

969 Discurso del Sr. Garrido, Diario de Sesiones de las Cortes, 10/12/1869, no 179, pp. 4626-4628. 
de no tener más fuerza armada que la absolutamente precisa para sostener los cuadros generales del ejército. No estamos do acuerdo con que el ejército español haya sido siempre ni sea el único poder político existente que impone su omnímoda voluntad en todo y para todo. [...] El ejército español no manda, sino que obedece, y obedece ciegamente, porque tal es su deber $[\ldots]^{\text {t970 }}$.

Los reproches republicanos se extendieron a la pésima alimentación que sufrían los soldados, la elevadísima mortalidad en el seno del Ejército y al inmenso daño demográfico y económico que el "celibato" impuesto a los reclutas hasta su pase a la reserva ocasionaba al país, similar al producido por un excesivo número de clérigos, que venía a reducir el número de jóvenes en edad de $\operatorname{trabajar}^{971}$ :

"Yo diré que el Ejército permanente, tal como hoy existe, no le puedo aceptar, no le quiero; le considero como la ruina de las naciones modernas, la ruina de la Hacienda, la ruina de la juventud, la ruina de la población, la causa, en fin, de una infinidad de males' ${ }^{\prime 972}$.

La contradicción entre proyecto y norma final marca el desarrollo de la misma

Las nuevas circunstancias políticas impuestas por el triunfo revolucionario llevaron a la postre a la gestación de una nueva ley acorde con los principios reformistas propios de la etapa

\footnotetext{
970 La Iberia, 11/12/1869, no 4045, p. 1.

971 Discurso del Sr. Cervera, Diario de Sesiones de las Cortes, 16/03/1870, no 240, pp. 6503-6508.

972 Discurso del Sr. Cervera, Diario de Sesiones de las Cortes, 16/13/1870, no 240, p. 6509.
} 
recientemente abierta973. Las expectativas que la Revolución Septembrina había recibido por parte de los grupos populares eran, por tanto, enormes, y también lo fue la frustración que vivirían por no colmarse sus expectativas $^{974}$, entre ellas la abolición de las quintas ${ }^{975}$, ya que éstas se mantuvieron en la nueva legislación a pesar del intento frustrado de ponerlas fin del principal líder revolucionario, el general Prim, y posteriormente de las autoridades republicanas.

Como paso previo a la aprobación de una definitiva ley de reclutamiento durante el Sexenio, encontramos la propuesta, a la postre rechazada, presentada por partido Radical, en concreto por el Marqués de Sardoal, y que contó con el apoyo de importantes dirigentes partidarios de la restauración alfonsina como Cristino Martos o el propio Cánovas del Castillo. Este proyecto mantenía el servicio militar obligatorio entre los veinte y los veintiocho años de edad, con tres años en el servicio activo y otros cinco en la reserva y con la única posibilidad de reducir la prestación para aquellos reclutas que hubiesen estudiado, circunstancia ésta que deberían demostrar a través de la superación de un examen. También quedaba admitida la sustitución para individuos de una misma familia hasta tercer grado

\footnotetext{
973 En Marzo de 1869 se formó una Comisión, constituida por siete diputados, para tratar el tema de la abolición de las quintas y las matrículas de mar, Diario de Sesiones de las Cortes, 09/03/1869, no 22, p. 394.

974 Manifestación de este descontento serán las algaradas populares que estallaron como protesta a las quintas y que fueron analizadas por las Cortes. Un ejemplo de ello lo encontramos en Barcelona en abril de 1870, Diario de Sesiones de las Cortes, 07/04/1870, no 258, p. 7184.

975 Podemos seguir a través de la prensa estas muestras de descontento popular, en ocasiones de forma violenta: "[...] tomando pretesto (sic) del sorteo que en cumplimiento de la ley debía celebrarse para el reemplazo del ejército el domingo 5 del actual, habían promovido algunos descontentos desórdenes en los arrabales de Barcelona, y levantándose en armas los revoltosos en los pueblos inmediatos; pero que el Gobierno tenía tomadas cuantas medidas eran suficientes para sostener la tranquilidad y reducir á los rebeldes, y asegurado que fuese el orden, el Gobierno daría cuenta detallada á las Cortes de todo" (La Iberia, 08/04/1870, no 4142, p. 1).
} 
de consanguineidad. Nada se mencionaba sin embargo en el proyecto respecto a la redención en metálico ${ }^{976}$.

La Ley de 29 de marzo de 1870977, reguladora del reclutamiento durante el Sexenio, tiene como base el proyecto presentado a las Cortes el 8 de febrero de $1870^{978}$ por el General Prim, en esos momentos ministro de Defensa y Presidente del Gobierno, así como hombre fuerte del mismo tras su decisiva participación en la Revolución Septembrina ${ }^{979}$. Sin embargo, son numerosos, e incluso sorprendentes, los cambios que se pueden observar si analizamos comparativamente el proyecto y la ley finalmente aprobada, cambios que serán especialmente destacados a medida que analicemos en profundidad la norma. Para los republicanos, el mantenimiento de las quintas y la aprobación de una ley que venía a confirmarlas legislativamente ponían en peligro a la propia revolución y en cuestión la legitimidad del Gobierno, además de identificar República con el fin de la contribución de sangre:

"Ved, pues, que esta ley os enajena todas las simpatías y os deja como en un yermo en medio del país, lejos de todos los elementos revolucionarios, que habían hecho una bandera de guerra de la

\footnotetext{
976 Proposición de ley del Sr. Marqués de Sardoal, estableciendo nuevas bases para el servicio militar, Diario de Sesiones de las Cortes, 12/04/1869, apéndice $8^{\circ}$ al no 47 , pp. 1 y 2.

977 Ley de reemplazos de 30 de Marzo de 1870, Gaceta núm. 89 de 30/03/1870. En adelante, Ley de 30 de Marzo de 1870.

978 Proyecto de Ley de ocho de Febrero de 1870 presentado por el Sr. Ministro de la guerra sobre organización y reemplazo del Ejército, gaceta núm. 43 de 12/02/1870. En adelante Proyecto de Ley de ocho de Febrero de 1870.

979 La actitud de los diputados en el debate en Cortes sobre una norma tan importante fue criticada desde el diario La Época, además de mostrar su apoyo a las quintas a la espera de una futura, y lejana, posibilidad de nutrir al Ejército a través del voluntariado: "La cuestión de quintas, que en la actualidad se ventila, tiene sin duda verdadera importancia; poro ello es, que los debates adolecen de una languidez extraordinaria (sic), que el número de diputados presentes es cada día mas reducido, y que el país no se mueve ante la inminencia una nueva conscripción, por mas que algunos pretendan agitarle: la necesidad de sostener un ejército permanente está reconocida, y si él servicio forzoso se considera una pesada carga, todos lo aceptan como una necesidad ínterin lega el día remoto en verdad, en que el sistema de remplazo voluntario puedo plantearse con probabilidades de buen éxito (La Época, 18/03/1870, n 6880, p. 2).
} 
abolición de las quintas, y divorciados de las clases populares, que habían acariciado esta idea con preferencia a todas al grito salvador de la revolución de Setiembre. Pensad que si estáis ahí ha sido con la esperanza de que realizaríais la abolición de las quintas; mejor dicho, si estáis ahí no es solo con esa esperanza, es con esa condición, condición impuesta por la revolución y por los partidos a que pertenecéis. Si para hacer frente á peligros imaginarios preferís a los medios revolucionarios que se os brindan, el Ejército y la quinta llevada a cabo con la misma rudeza ¿qué digo con la misma? con mayor rudeza, mayor crueldad y mas extensión que en el antiguo régimen, ¿con qué autoridad, con qué prestigio, con qué simpatía, con qué confianza podéis continuar gobernando la Nación? ${ }^{980 " .}$

Los motivos que explican las radicales diferencias entre Proyecto y Ley aprobada radican en la propia situación de los nuevos Gobiernos revolucionarios, acosados simultáneamente en tres frentes bélicos: el alzamiento cubano de octubre del mismo año de 1868, el levantamiento carlista iniciado en la montaña pirenaica en octubre de 1869 y extendido con posterioridad a otras regiones del norte peninsular y, ya proclamada la I República, los levantamientos cantonalistas que sacudieron especialmente el Levante español. Tales circunstancias, y las necesidades de soldados que estos conflictos exigían al Ejército, impidieron la aprobación de una ley que pusiese fin a uno de los principales anhelos populares, la erradicación de las quintas: "[...] esta ley suponía la aceptación de la incapacidad de los gobernantes para cumplir las promesas que hicieran en su tiempo"981. La Constitución de 1869, aprobada por los revolucionarios en el poder, apenas aportó novedades respecto a los textos constitucionales previos en lo que se refiere al reclutamiento. Así, la Carta Magna de 1869 se limitaba a señalar que "todo español está obligado a defender la Patria con las armas cuando sea llamado por la

\footnotetext{
980 Discurso del Sr. Rebullida, Diario de Sesiones de las Cortes, 16/12/1870, no 240, p. 6520.

981 FRIEYRO DE LARA, B., De campesino a soldado. Las quintas en Granada (18681898), p. 23.
} 
ley", que era atribución del Rey declarar la guerra y ratificar la paz, debiendo dar cuenta documentada a las Cortes, y que era competencia de la cámara legislativa, a propuesta del Gobierno, fijar anualmente el contingente militar ${ }^{982}$. Por tanto,

"[La Constitución de 1869] se limitó a reproducir el archiconocido artículo sobre la obligatoriedad de todos los españoles de defender a la patria con las armas en la mano, lo que significaba dejar en manos del gobierno la decisión de llamar a filas el número de hombres que estimase conveniente y por el sistema que creyese oportuno, y tampoco aportó nada nuevo en lo referente al control del Ejército por parte del poder civil, ya que el abuso de la suspensión de garantías constitucionales (Prim fue el primero en utilizar este recurso) dejaba las manos libres al gobierno y al Ejército para actuar de espaldas a la Constitución" ${ }^{\prime 983}$.

A pesar del predominio de la ideología antiquintas entre buena parte de los revolucionarios septembrinos ${ }^{984}$ y del ambiente popular contrario al servicio militar obligatorio, los sucesivos Gobiernos

982 Constitución de 1 de Junio de 1869 , arts. 28 y 70.
983 FEIJÓO GÓMEZ, A., Quintas y protesta social en el siglo XIX español, pp. 210 y 211.

984 "Todos, ó la mayor parte al menos todos cuantos apoyan hoy el dictamen de la comisión puesto al debate sobre organización y reemplazo del ejército, están firmemente decididos á procurar la abolición de las quintas.

El partido á quien LA IBERIA representa en la prensa política, el gran partido progresista, ha hecho siempre, hace hoy y seguirá haciendo seguramente mañana esfuerzos supremos por variar el sistema de reemplazo, de acuerdo con las aspiraciones de los pueblos, cosa que se conseguirá más en breve con el concurso leal de todos los que estamos interesados en no dilatarlo con exageraciones perjudiciales. LA IBERIA, por su parte, no sólo es favorable á la abolición de las quintas,-y esto lo consiga siempre que tiene ocasión,- sino que la ansía ardientemente, porque quiere que sé conviertan en hechos prácticos todas las aspiraciones á que ha rendido culto durante su vida periodística.

Pero bueno es no confundir las cuestiones. Hoy no se discute en el Congreso la abolición ó no abolición de las quintas, sino la ley de organización y reemplazo del ejército, ley que, si estudian detenidamente y sin pasión los que con tanta dureza la combaten, no podrán menos de reconocer como un gran adelanto en el camino de la abolición, á la que,-de nuevo decimos, -llegaremos sí hay el juicio y la prudencia necesaria por parte de todos, y no se crean conflictos que hagan necesaria á cada momento la intervención de grandes masas de fuerza" (La Iberia, 12/03/1870, no 4120, p. 1). 
amadeístas de Serrano, Prim, Sagasta y Ruiz Zorrilla no tuvieron más remedio que continuar con los llamamientos al reemplazo y aplazar el debate sobre la abolición de las quintas:

"Desde que se promulgara esta ley de reclutamiento en 1870 y hasta la llegada tres años después de la Ia República, fueron llamados en España a filas un total de 115.000 jóvenes. Si la quinta de 1869 se había presentado como una medida transitoria, el llamamiento de 40.000 hombres a filas en 1870, una vez sancionada la ley de Prim, dejaba claro que no llegaría la abolición. [...]. Los sucesivos Ilamamientos, de 35.000 hombres en 1871 y nuevo 40.000 hombres en 1872 apenas dejaban espacio a la esperanza de que algún día la quinta fuese abolida. Este sistema, además, no era recriminado sólo por las clases más desfavorecidas económicamente. También las familias de clase media eran contrarias al ejército, ya que en el caso de que pudieran permitirse acceder a las exenciones económicas, perdían con ello una gran capacidad adquisitiva. Esto conlleva un acrecentamiento de popularidad en las filas republicano-federales y a la radicalización, con respecto a los años anteriores, de la protesta y las reivindicaciones populares ${ }^{\prime \prime 885}$.

Importantes cambios sí que se introducirán en la nueva ley sobre reclutamiento aprobada durante los meses de vigencia de la I República y que posteriormente analizaremos, a pesar de su escasa repercusión práctica.

La nueva ley de reclutamiento aprobada en pleno Sexenio muestra notables diferencias con respecto a los textos legislativos que, en materia de reemplazos, se aprobaron a lo largo del siglo XIX. Como primera novedad destacar que fue el ministerio de Guerra, y no el de Gobernación, el que presentó el proyecto para su debate en las Cortes. Cambió, por lo tanto, la autoridad encargada de su elaboración y presentación y correspondió al ministerio más

985 FRIEYRO DE LARA, B., De campesino a soldado. Las quintas en Granada (18681898), pp. 24-25. 
interesado en todas las cuestiones de la tropa y su reclutamiento la iniciativa legislativa. Fue el general Prim, Presidente del Gobierno y ministro de Guerra, quien presentó ante la Cámara el nuevo texto y el general Serrano, como Regente del Reino a la espera de la llegada del nuevo monarca Amadeo de Saboya, quien la sancionó tras su aprobación por las Cortes.

Cabe señalar que la estructura y la extensión del nuevo texto legal poco tienen que ver con las restantes legislaciones de reemplazo decimonónicas. Así, la nueva ley muestra un carácter enormemente reducido al resumirse en tan sólo diecinueve artículos encuadrados en dos capítulos. A ellos se unen dos disposiciones adicionales, cinco transitorias y otros seis artículos englobados en un último capítulo centrado en las exenciones del servicio militar. También es reseñable que la meticulosidad que recogían las leyes anteriores para regular hasta el más mínimo detalle todas las fases del proceso de reclutamiento no aparece en la nueva Ley de 1870. Se debe destacar, igualmente, que carece de preámbulo justificativo, algo que sí se encontraba presente en el proyecto presentado inicialmente por Prim. Esta introducción resultaba significativa, al mostrar las intenciones, objetivos y principios ideológicos en que se basaba el Presidente del Gobierno y ministro de Guerra, muchos de los cuales no fueron recogidos por el texto legislativo que finalmente se aprobó, pero que resulta conveniente analizar.

En primer lugar, señalar que, en el preámbulo del proyecto de ley, el propio Juan Prim ensalzó la Ley de enero de 1856 y a las autoridades progresistas que la elaboraron. El motivo era la consideración que se hacía de la quinta como un método subsidiario a la hora de nutrir de soldados al Ejército, primando la figura del voluntario, tanto enganchado como reenganchado. A ello se unía la retribución pecuniaria que recibirían tanto voluntarios como 
quintos $^{986}$. También alabó Prim la posibilidad de que el Gobierno decretase una sustitución general para todos los jóvenes de una provincia si las circunstancias así lo recomendasen. Estas tres medidas beneficiosas provocaron la sorpresa en el legislador ya que "[...] después de 14 años de una legislación tan beneficiosa en constante ejercicio no ha sido posible aproximarse siquiera a la abolición de las quintas" ${ }^{\prime 987}$, objetivo básico y declarado del militar catalán por los perjuicios sociales que las mismas ocasionaban.

También analizó Prim en su proyecto los enormes gastos que habían supuesto para el Estado las pagas concedidas a los voluntarios para el servicio ${ }^{988}$, afirmando además que la retribución en metálico no era suficiente para retener en el Ejército a los soldados. Constató Prim que esta retribución no había servido para la disminución progresiva de la quinta; es más, el ministro indicó que había sucedido todo lo contrario en los últimos años al crecer el número de quintos solicitados anualmente por el Estado.

Rechazó Prim tanto la quinta como la retribución pecuniaria del soldado voluntario (esta última, por insuficiente para nutrir al

\footnotetext{
986 "Y no sólo estableció la indicada Ley el principio de que las bajas se reemplazasen con voluntarios, sino que, convencidos aquellos legisladores que para tenerlos era preciso retribuirlos pecuniariamente, concedieron 6000 reales a los que sentasen plaza por ocho años y 2000 a los que, obligados a venir al Ejército por su suerte, sirviesen el mismo tiempo, haciendo extensiva esta recompensa a los inutilizados y a los herederos de los fallecidos en función de guerra o de sus resultas" (Proyecto de Ley de ocho de Febrero de 1870).

987 Proyecto de Ley de ocho de Febrero de 1870.

988 "Ante todo conviene notar que el premio de 2000 reales que la Ley de 1856 concedía a los que cumpliesen en el servicio 8 años imponía un sacrificio anual de 40 a 50 millones de reales, supuesto que por término medio se licencian anualmente de 20 a 25.000 hombres, sacrificio que alivió al presupuesto de la Guerra la Ley de $1^{0}$ de Marzo de 1862, que suprimió el expresado premio o gratificación.

No se crea que por esto la Ley de 1856 ha dejado de dar los resultados que se propusieron las Cortes de 1854, pues cuando el Gobierno, echó de ver las cuantiosas sumas que debían gastarse cada año por el concepto indicado, y tuvo que arbitrar medios para librarse de satisfacerlos, dejó en libertad a los que tuviesen derecho al premio de continuar en el servicio hasta cumplir los 8 años o de pasar a la reserva, disposición que dio por resultado el que la mayoría optase por pasar a la reserva renunciando voluntariamente al derecho al premio; con lo cual se redujo en definitiva el sacrificio total para el Tesoro a más de 40 millones de reales, que es lo que resulta pagado por esta causa hasta fin de 1869" (Proyecto de Ley de ocho de Febrero de 1870).
} 
Ejército), así como la redención en metálico, "contraria al espíritu de la época989". Ello le llevó a apostar por el servicio militar obligatorio por considerarlo el más justo y equitativo, sin posibilidad de redención ${ }^{990}$. Sí admitía, en cambio, la sustitución, por suponer un posible medio de vida para las clases más empobrecidas, aunque se resaltó la necesidad de una estricta regulación para evitar abusos ${ }^{991}$. La oposición republicana mostró su indignación en el Parlamento con los partidos gobernantes y sus dirigentes, en especial el General Prim, cuando fue presentado el nuevo proyecto de ley de reclutamiento, ya que además de suponer una traición a la revolución por no abolir las quintas y un ataque a la libertad, a las instituciones democráticas y a las aspiraciones populares, constituía un tipo de esclavitud similar a la ejercida en el continente americano con la población negra:

\footnotetext{
${ }^{989}$ Proyecto de Ley de ocho de Febrero de 1870.

990 "El Proyecto de Ley adjunto está, por lo tanto, basado en el servicio militar obligatorio, no solo por lo que respecta a la organización general del Ejército como en lo que se refiere al reemplazo. El sistema no es nuevo, pues en otras potencias militares de Europa y naciones modelos de pueblos libres y de instituciones democráticas han impuesto la obligación del servicio militar a todos los ciudadanos, sin que puedan librarse de él por dinero, así como la necesidad de mantener y elevar el espíritu militar suprimiendo los premios y remuneraciones pecuniarias" (Proyecto de Ley de ocho de Febrero de 1870).

991 "No se consentirá en lo sucesivo la redención a metálico, ni se retribuirá pecuniariamente el servicio en el Ejército como hasta aquí. Conservase, sin embargo, la sustitución como en otras naciones, toda vez que esta no será solo en beneficio exclusivo de determinadas clases, como acontece en el día con la redención por dinero. La sustitución personal está más al alcance de todos, y no es en daño de los demás ciudadanos llamados al servicio militar ni del Estado, puesto que con dicho sistema se cubre el servicio de un hombre por otro sin dejar vacantes en el Ejército como sucede con la redención. El principio absoluto de la igualdad en esta materia produciría en su aplicación graves dificultades, sin redundar en beneficio de las clases más desgraciadas, a las cuales en compensación se les conceden las excepciones de que tratan los artículos 76 y 77 de la vigente Ley de Quintas, que se conservan subsistentes, respetando la asistencia debida por los hijos a los ancianos e impedidos pobres y la de los huérfanos desvalidos prestada por sus hijos, nietos o hermanos, así como lo establecido a favor de los hijos de padres pobres que tienen algún hermano en el Ejército, y la que les exime del pago de derechos por las diligencias y reconocimientos que fuesen necesarios.

El Gobierno comprende, sin embargo, los abusos a que puede dar origen la sustitución en el servicio, y los reglamentos que se dicten para la ejecución de esta Ley los evitarán, estableciendo garantías para el Estado y para el ciudadano que se sustituya" (Proyecto de Ley de ocho de Febrero de 1870).
} 
"Pero, señores, icuál no ha sido el desengaño del país, cuál no ha sido el desencanto de todos los ciudadanos al ver que se olvidan todas aquellas promesas; al ver que se reniega de todos aquellos compromisos, y que sin tener en cuenta que hemos hecho una revolución para tener libertad, se pretende imponer la esclavitud á los blancos, que no son otra cosa las quintas, puesto que las quintas son á los blancos lo que el tráfico ignominioso que se hace con los hombres de color en América es a la esclavitud! [...].

Las quintas son el enemigo de la libertad; por medio de las quintas se sujeta al joven que se lleva al Ejército, á no poder tener derechos, á no poder manifestar sus ideas á no poder pertenecer á asociaciones, á no poder ir a los espectáculos públicos, a no poder ocupar siquiera un lugar distinguido, a tener que humillarse en las calles cuando pasa algún otro á su lado, que, por su categoría militar, es superior á él. [...]. La abolición de los quintas está en el corazón del pueblo, que se ha pronunciado contra ellas ${ }^{992}$.

Las quintas, además de injustas e inmorales y de incrementar las desigualdades de clase, vendrían a fomentar las rivalidades regionales y a poner en peligro la unidad nacional al quedar algunos territorios del país exentos de esta contribución:

"Las quintas establecen una verdadera rivalidad nacional; exceptúan y privilegian a algunas provincias. Las más varoniles de España son indudablemente las del Norte. Pues no tienen quintas. Cataluña, que es una población de comerciantes, de trabajadores y de guerreros, la más ilustre quizás de todas las que por las orillas del Mediterráneo se extienden, la más distinguida en el trabajo y la guerra, Cataluña no ha tenido quintas hasta el año 1845, y todavía no han podido arraigarse en aquel noble, en aquel valiente, en aquel liberalísimo pueblo. Así es que las provincias dicen: "nosotras, porque no hemos tenido la fortuna de salvar nuestros antiguos derechos

992 Discurso del Sr. Soler, Diario de Sesiones de las Cortes, 10/03/1870, no 235, p. 6383. 
como las Provincias Vascongadas; nosotras, en estos tiempos de justicia, en estos tiempos de igualdad, en estos tiempos de democracia, no tenemos lo que la Edad Media concedió á las antiguas provincias vascas". Pues bien: esto quebranta por completo la unidad nacional, en que deben estar como en la atmósfera todos los pueblos. Es necesario, pues, abolir en todos la odiosa contribución de sangre ${ }^{1993}$.

El rechazo tradicionalista en el Parlamento no vino por su oposición a las quintas, sino por considerar que habían sido introducidas ilegal y despóticamente en territorio navarro ${ }^{994}$. Una actitud más comprensiva y exaltadora de la labor del Ejército en el mantenimiento del orden frente a los radicalismos de la época la encontramos entre los conservadores de La Época, si bien las críticas hacia el proyecto de Prim continuaron vigentes, al considerar que se había incrementado la dureza en el sistema de reclutamiento, en especial por prohibir la redención e incrementar el coste de la sustitución:

"Sin el valor y la constancia de que el Ejército ha dado tan repetidas pruebas durante los últimos diecisiete meses, oponiendo un dique insuperable a las exageraciones de los partidos estremos (sic), el absolutismo o la demagogia triunfantes, habrían dado un golpe funesto a la libertad sensata y fecunda, aplazando por muchos años entre nosotros el desenvolvimiento de régimen constitucional. Natural era, pues, que las parcialidades do ideas mas avanzadas clamasen sin cesar contra la existencia de la fuerza armada permanente, que consideraban como el principal obstáculo á la realización de sús planes, y hay que convenir en que han hecho todos los esfuerzos imaginables para destruirlo. Su cruzada contra las quintas es muy reciente, y no dejó de serles ventajosa, pues al mismo tiempo que

\footnotetext{
993 Discurso del Sr. Castelar, Diario de Sesiones de las Cortes, 23/03/1870, no 246, p. 6769.

994 Discurso del Sr. Ochoa, Diario de Sesiones de las Cortes, 10/03/1870, no 235, p. 6389.
} 
consiguieron dejar reducido á mínimas proporciones el reemplazo de 1869, arrancaron al gobierno declaraciones impremeditadas que hizo entonces buscando una efímera popularidad y que hoy se encuentra en la imposibilidad de cumplir. «Esta quinta será la última,» se dijo desde el banco ministerial; mas á pesar de tan solemne promesa, antes de trascurrir un año, el ministro de la Guerra ha tenido que presentar á las Cortes un proyecto de reemplazo mas duro que el anterior, y pedir que se discuta coa urgencia á fin de que las operaciones preliminares del sorteo puedan principiarse en la misma época que so han venido verificando hasta aquí.

No censuraremos ciertamente al genera Prim por su conducta: esta es por el contrario digna de elogio, y no titubeamos en consignarlo así aun á riesgo de que nuestra aprobación se utilice por los radicales avanzados como un arma poderosa para combatir la ley.

Las esperanzas del nuevo proyecto, mas económico para el Tesoro y mas eficaz para cubrir el efectivo del ejército, es, sin embargo, muy duro, es la quinta agravada, justamente en los momentos en que se habían hecho concebir esperanzas de que iba á desaparecer. Estableciese el servicio militar obligatorio desde la edad de 20 años, siendo su duración de cuatro en el ejército activo, dos en la primera reserva y uno en la segunda. Los sorteos se verificarán como de costumbre en las épocas anteriormente señaladas y por el mismo sistema. La redención por dinero queda suprimida; pero se conserva la sustitución personal, que tiene la ventaja de que el servicio de un hombre se cubra con otra sin dejar vacante alguna [...].

Tenemos, pues, que el servicio militar por reclutamiento forzoso se mantiene en toda su fuerza haciéndolo ostensivo á todos los mozos de 20 años, pues aquellos á quienes la suerte favorezca y no entren en el ejército activo, deben ingresar en la segunda reserva. Limítense al mismo tiempo los medios de redimir la suerte, conservándose solo la sustitución personal, que se supone «estar mas al alcance de todos», pero que en realidad ofrece mayores dificultades á todas las clases. Las mas acomodadas encontrarán sustitutos á costa de mayores sacrificios que hasta aquí, y muchas familias que antes libraban á sus individuos del servicio, no podrán hacerlo por el 
escesivo (sic) costo del reemplazo, superior en muchas ocasiones á sus recursos ${ }^{\prime \prime 995}$.

La respuesta del Gobierno en la Cámara a las acusaciones vertidas se limitó a acusar a la minoría republicana de insensatez, a reafirmar la necesidad de los ejércitos permanentes y a mostrar su rechazo a las quintas para cuando la situación económica y política del país hiciese posible su eliminación ${ }^{996}$ y el establecimiento de un ejército de voluntarios retribuidos:

"De manera que yo deseaba, deseo y desearé la abolición, no solo de las quintas, es decir, del sorteo, sino la abolición de todo lo que haga relación a arrancar los brazos á las ciencias y las artes para llevar los hombres al servicio militar. Pero reconozco, y reconocí como la minoría republicana, la necesidad del Ejército permanente, y deseo que en una época normal, pacífica, y de seguridad, podamos reducirla $y$ cubrir sus bajas por enganches voluntarios $y$ por medio de una ligera contribución pecuniaria: idichosos nosotros el día que podamos reducir nuestro Ejército a 40 o 50.000 hombres; porque entonces creo yo que sin gran trabajo podremos obtener la abolición de las quintas que tanto deseamos; porque es mucho más fácil y posible encontrar un corto número de hombres pagando sus servicios altamente $[\ldots]^{\prime \prime 997}$.

995 La Época, 11/02/1870, no 6850, p. 2.

996 "El gobierno, la mayoría de sus ministros, la mayor parte de los diputados, habían manifestado su opinión contraria a las quintas en la década de los sesenta [...], pero las circunstancias políticas les obligaron a mantenerlas contra la voluntad popular [...]. España precisaba un Ejército permanente ante el conflicto de Ultramar, carlistas, revueltas internas, y ese Ejército no podía formarse de voluntarios, ya que no había suficientes" (FEIJÓo GÓMEZ, A., Quintas y protesta social en el siglo XIX español, p. 158).

997 Discurso del Sr. Eraso, Diario de Sesiones de las Cortes, 10/03/1870, n० 235, p. 6390. 
Tal y como veremos a continuación, fueron pocos los principios ideológicos y prácticos recogidos en el proyecto inicial que se mantuvieron en la ley final ${ }^{998}$.

a) El reemplazo: una obligatoriedad universal del servicio ensombrecida por las exenciones económicas

El título primero de la nueva ley recogió toda una serie de generalidades que habían de regir todo el proceso de reclutamiento. Nada indicaba el texto sobre la elaboración del padrón, la formación y rectificación del alistamiento, la celebración del sorteo, el llamamiento y declaración de los soldados, la conducción y entrega de los reclutas en la caja provincial, la lucha contra el prófugo o la posibilidad de reclamación ante las instituciones por ilegalidades cometidas en el proceso. Sí que se hacían, en cambio, breves referencias a las exenciones, la sustitución y la redención en metálico, pero sin proceder a una regulación exhaustiva. La inexistencia de grandes cambios con la nueva ley en el proceso de reclutamiento fue ya observada desde La Época, lo cual aplaudía fehacientemente por mantener las quintas y la conscripción ${ }^{999}$ a pesar de las promesas revolucionarias $^{1000}$ :

\footnotetext{
998 El propio Prim reconoció en el Parlamento el cambio en sus puntos de vista motivados, según el propio presidente del Gobierno, por las difíciles circunstancias por las que atravesaba el país: "He dicho sí, y lo he dicho en documentos públicos, y 10 he dicho desde el banco del Diputado, que desearía que desapareciese la contribución de sangre, siempre que hubiese un medio de reemplazar esa contribución, porque nunca he podido comprender que en los tiempos que corren podamos estar sin Ejército permanente. [...]. Ni en los documentos que ha publicado, ni en mis discursos en las Cortes, cuando he hablado de esta materia, ni tampoco en los manifiestos que he dirigido a los electores cuando me han presentado candidato, he dicho jamás, ni he ofrecido votar por la abolición de quintas de una manera absoluta, sino con la reserva de que lo haría en el caso de que se encontrara medio de reemplazar al Ejército de otra manera que por la quinta" (Discurso del Sr. Presidente del Gobierno, Diario de Sesiones de las Cortes, $17 / 03 / 1870, n^{\circ} 241$, p. 6554).

999 "En cambio el ejército permanente, esa otra institución propia de la monarquía, se ha salvado del naufragio que le amenazó y con él el reclutamiento por medio de
} 
"Si en todos los proyectos que la revolución inició tuviera que suceder lo mismo que en el de quintas, no introduciría aquella grandes novedades en la administración pública. Terminada en la sesión de anoche la discusión del proyecto de ley sobre aquella materia, vemos que queda la redención por dinero, queda la sustitución, quedan, en fin, las quintas ó el reemplazo del ejército como antes, con ligeras variantes. Añádase que las ordenanzas militares no han sido reformadas, que la fuerza permanente no ha sufrido reducción, y que el estado mayor general ha tenido un gran aumento durante los últimos diez y ocho meses, y se comprenderá que la política radical, con la que tanto se alborota, sabe ser prudente pon los fuertes, reservando toda su audacia y su espíritu innovador para las instituciones y clases cuya existencia no se halla garantizada por la fuerza"1001.

Comienza el texto señalando que el servicio militar era obligatorio para todos los españoles al cumplir los veinte años de edad"1002, aunque también se abría la puerta a los voluntarios "[...] que reúnan los requisitos y circunstancias que actualmente se exijan por las Leyes, Órdenes y Reglamentos"1003. No recogía el texto, por tanto, la exigencias que se planteaban al voluntariado para ingresar en filas y se remitía a las normas vigentes ${ }^{1004}$. Tan solo señaló que la

la conscripción, que la revolución sé había comprometido solemnemente á suprimir" (La Época, 31/02/1870, no 6893, p. 2).

1000 La Época, 30/02/1870, no 6892, p. 2.

1001 La Época, 24/03/1870, no 6886, p. 2.

1002 El diputado republicano Abarzuza defendió este reclutamiento obligatorio para todos los jóvenes españoles exclusivamente para aquellas situaciones en que la independencia e integridad nacionales estuviesen en peligro, quedando la cuestión del mantenimiento del orden público para las fuerzas policiales: "nosotros queremos que en caso de invasión extranjera, y de tener que defender la integridad del territorio y la nacionalidad, que se obligue a todo el mundo a defender la Patria. Pero cuando no sea así $[\ldots]$, quien debe estar encargado de sostener el orden público, es la policía (Discurso del Sr. Abarzuza, Diario de Sesiones de las Cortes, 16/03/1870, no 240, pp. 6529).

${ }^{1003}$ Ley de 30 de Marzo de 1870, arts. 1 y 2.

1004 "Nosotros adoptamos un sistema más conforme con el espíritu de igualdad y los principios establecidos en la Constitución, y decimos: "conservando el principio a que obedece la ley, que continúe el derecho de servir voluntariamente en el Ejército". El que voluntariamente quiera servir a la Patria por su lealtad y por su 
duración del voluntariado sería de al menos cuatro años ${ }^{1005}$. También se planteó la posibilidad de que los soldados en servicio activo que así lo deseasen podrían continuar en él durante un máximo de dos años ${ }^{1006}$.

Se puede observar como una de las ideas básicas de Prim en el proyecto que presentó ante el Parlamento, el evitar el voluntariado retribuido ${ }^{1007}$ por los costes que suponía para el Estado, fue ignorada en el texto final ${ }^{1008}$, y el propio ministro de Guerra aceptó la supresión de esta idea por considerarla peligrosa para un Estado democrático:

"[...] en un país que, como el nuestro, se rige por instituciones democráticas, es necesario que el Ejército responda a esa manera de ser; y crear un Ejército de voluntarios, es por una parte, crear un

elevado patriotismo, tiene abiertas las puertas del Ejército. Y ya no hay sorteo en el sentido que hasta aquí se ha dado á esta palabra. Ahora son soldados todos los españoles á la edad de 20 años. [...].Y al decir que son soldados todos los jóvenes de 20 años, no queremos decir que todos vengan a la vez a empuñar las armas. Esta sería una carga muy insoportable para el país, que no podría consignar en el presupuesto una cifra bastante para sostener ese número de soldados, y esto sería una conscripción" (Discurso del Sr. Eraso, Diario de Sesiones de las Cortes, $10 / 03 / 1870, n^{\circ} 235$, pp. 6392 y 6393).

${ }^{1005}$ Ley de 30 de Marzo de 1870, art. 3. El diputado Sorní planteó una enmienda a este artículo proponiendo un número ilimitado de años para los soldados que quisieran reengancharse, ya que lo contrario suponía una limitación para el voluntariado: "[...] pues si un soldado está sirviendo y quiere reengancharse por cinco, por seis, por ocho años, ¿por qué ha de impedirse? Lejos de poner limitación al reenganche, yo creo que debe favorecerse y facultar el que pueda reengancharse por todo el tiempo que se quiera. Estamos diciendo que no hay voluntarios, que no se presentan, que no los habrá, lo cual no es cierto, como demostrará en otra ocasión, y sin embargo, ponemos limitaciones y más limitaciones para el enganche y el reenganche. ¿No es esto una contradicción? Si hemos de tener voluntarios, si se han de admitir voluntarios, que lo sean por toda el tiempo que quieran (Discurso del Sr. Sorní, Diario de Sesiones de las Cortes, 17/03/1870, no 241, p. 6552).

1006 Ley de 30 de Marzo de 1870, art. 4.

1007 Así aparece indicado en su Proyecto de Ley: "Quedan suprimidos para lo sucesivo los premios de enganches, pluses, sobresueldos y demás remuneraciones pecuniarias que conceden a los que sirven voluntariamente en el Ejército las Leyes de 24 de Junio de 1867 y $1^{\circ}$ de marzo de 1868" (Proyecto de Ley de ocho de Febrero de 1870, art. 13).

1008 "Quedan subsistentes los premios de enganche y reenganche, pluses, sobresueldos y demás ventaja pecuniarias que conceden a los voluntarios del Ejército las Leyes de 24 de Junio de 1867 y $1^{\circ}$ de Marzo de 1869, entendiéndose que la cuota de redención se distribuirá en 6 años en vez de los 8 que aquella Ley previene" (Ley de 30 de Marzo de 1870, art. 11). 
privilegio odioso, y por otra, poner en manos del Gobierno un número de soldados devotos á sus personas, formando con ellos una especie de guardia pretoriana que pudiera en momentos dados ser un peligro para la libertad, lo cual no es hoy temible, pero pudiera serlo en otra ocasión. Así lo ha comprendido el Sr. Presidente del Consejo de Ministros, que ha consentido en retirar esta parte del proyecto del proyecto $^{\prime 1009}$.

Es más, el voluntariado quedó constituido como la primera opción para el reemplazo aunque, ante la imposibilidad de constituir un ejército suficiente a base exclusivamente de voluntarios ${ }^{1010}$, se mantuvo el servicio militar obligatorio para los jóvenes de veinte años si no fuese posible cubrir con voluntarios las necesidades de efectivos del Ejército ${ }^{1011}$. Y es aquí cuando se retoma el acto del sorteo, apenas regulado en cuanto a autoridades competentes y ejecución, limitándose la ley a señalar que

"[...] para los efectos de esta distribución por la suerte se entenderá que los números más bajos, desde el uno hasta el

\footnotetext{
1009 Discurso del Sr. Marqués de Sardoal, Diario de Sesiones de las Cortes, 11/03/1870, no 236, p. 6423.

1010 El diputado Cervera propuso mejorar la situación y trato a los reclutas para incrementar el número de voluntarios: "¿Queréis voluntarios en el Ejército? [...]. No les deis premio: dadles más paga, aumentadles el prest; que tengan lo suficiente para vivir con desahogo, para comer mejor, para evitar ciertas privaciones, como tienen que sufrir en filas con el mezquino sueldo que el Estado les asigna. Entonces tendréis voluntarios en el Ejército. Quitad una infinidad de actos, de esos que son puramente reglamentarios [...], quitad una porción de trabas, que, como oprimidos, tienen nuestros desgraciados soldados: modificad nuestras ordenanzas militares: que los soldados tengan un poco más de libertad, que respiren mejor, que disfruten de más luz, de más espacio; que no estén constantemente en los cuarteles [...]; cómo con esta mayor libertad, que les podéis consentir sin perjudicar en nada lo que atañe al servicio militar y a la disciplina [...]; entonces veréis, repito, cómo dándoles todo lo que sea compatible con la disciplina y con la subordinación; dejando al soldado que se explaye; modificando talas sus condiciones de existencia, su vida de cuartel, sus cantinas; educándole bien y tratándole con humanidad y cariño, encontráis voluntarios para el Ejército" (Discurso del Sr. Cervera, Diario de Sesiones de las Cortes, 16/13/1870, no 240, p. 6508).

1011 "Cuando los alistamientos voluntarios no basten a cubrir las bajas que resulten en el Ejército permanente, se destinará por la suerte el número de hombres que fijen las Cortes, sacados de los jóvenes de 20 años que con arreglo al artículo $1^{\circ}$ están obligados al servicio de las armas" (Ley de 30 de Marzo de 1870, art. 5).
} 
que se haya fijado proporcionalmente en cada distrito municipal

para cubrir el contingente señalado por las Cortes, son los que

deben ingresar en el Ejército permanente ${ }^{\prime 1012}$.

\section{La gran novedad del texto procede de la afectación que supone}

para todos los mozos de veinte años el servicio militar, ya que los que no tuviesen que incorporarse al servicio activo por haber obtenido números altos en el sorteo, pasarían a formar parte de la segunda reserva ${ }^{1013}$. La totalidad de los jóvenes españoles debería

1012 Ley de 30 de Marzo de 1870, art. 5.
1013 Ley de 30 de Marzo de 1870, art. 5. De nuevo las acusaciones hipocresía y contradicción hacia el presidente del Gobierno, y de traición a los principios revolucionarios y al propio pueblo y de violación de los derechos individuales recogidos en el texto constitucional recientemente aprobado se escucharon desde las bancadas republicanas: "pasma y admira ciertamente que cuando llevamos año y medio o cerca de dos años desde la revolución, vengamos contrariando todo el espíritu de aquella revolución. Aquella revolución, unánimemente, de uno a otro extremo de la Península, dijo: "Abajo las quintas". [...]. Yo no sé por qué el Gobierno y la mayoría de estas Cortes se han de empeñar en contrariar aquello que entonces aplaudieron, aquello que entonces halagaron, aquello en que entonces hicieron consentir al pueblo que no habla de volver a tener. [...] ¿Es esto corresponder a las esperanzas que se hicieron concebir a los pueblos en la revolución de Setiembre de 1868? Si no se había de cumplir lo que entonces se ofreció, ¿por qué se ofreció? ¿No comprende el Gobierno que pierde completamente su prestigio, que pierde su autoridad, que pierde el asentimiento y la benevolencia de los pueblos cuando no cumple con toda lealtad los compromisos que tiene contraídos?

iA pesar de todos sus ofrecimientos, á pesar de los ofrecimientos hechos por muchos de los Diputados de la mayoría, se quiere todavía y se insiste en que haya quintas! ¿Hay, por ventura, señores, un acto más odioso, un acto más repugnante que el de las quintas? ¿Y no sabéis, señores, que ese es un sistema que destruye, que barrena por completo la Constitución que vosotros mismos acabáis de hacer? [...]. Y, señores, ¿hay acto más bárbaro que el del sorteo, para ver a qué desgraciado mozo le cabe la desventura de que se le arranque del seno de la familia, del lado de sus padres, para llevarle contra su voluntad a un cuartel y hacerle tomar una profesión a la que no tiene gasto ni inclinación? Si no es aficionado a las armas, ¿por qué se le ha de obligar que siga precisamente el oficio de soldado, que él no quiere, que a él no le gusta, y al que no tiene afición alguna? Pues contra su voluntad, contra sus deseos, se le arranca del seno de su familia, se le arranca de su hogar, se le aparta da sus habituales ocupaciones; y como si fuera un esclavo, como si fuera un autómata, como si fuera una persona sobre la cual el Gobierno tuviera absoluto dominio, se le lleva al cuartel, se le pone en la mano un fusil, se le somete a las órdenes de sus jefes y se le condena a que haga todo lo quo lo manden, a que esté allí encerrado cuando se lo manden, a que salga cuando se le mande salir, a que haga, en fin, todo lo que tiene que hacer un soldado cuando no tiene gusto, ni deseo, ni afición, ni voluntad para seguir semejante carrera. ¿Es esto justo? No; esto es atroz, esto es atrocísimo" (Discurso del Sr. Sorní, Diario de Sesiones de las Cortes, 17/03/1870, n 241, pp. 6552 y 6553). 
por tanto formar parte del Ejército, lo que no quiere decir que no existiese quinta ni sorteo, que estuviésemos ante un servicio universal, ya que se celebraría un sorteo para determinar qué mozos serían afectados por el servicio activo, pasando el resto a la segunda reserva:

"Pues bien, dada la imposibilidad de formar un Ejército de voluntarios, y siendo innegable la necesidad de tener Ejército permanente, no hay más medio que apelar al sistema del sorteo. Admitida esa necesidad, había dos procedimientos: o declarar soldados a todos los españoles, o declarar soldados á una parte de ellos. La Comisión en su proyecto declara soldados á todos los españoles á la edad de 20 años; pero como no es posible que todos los mozos de 20 años útiles, que se calculan en 135.000, sirvan al mismo tiempo en el Ejército, porque las necesidades del Estado no lo exigen, es menester designar entre ellos los que hayan de formar la fuerza pública, ¿Y cómo habla de hacerse esa designación sino por medio de la suerte? ¿Qué procedimiento más equitativo? ${ }^{\prime 1014}$.

Esta circunstancia de que todos los mozos de veinte años se viesen afectados, de una forma u otra, por el servicio militar, también encontró la el rechazo y oposición republicanos:

"Proponéis que, en vez de durar el servicio seis años, solamente dure cuatro, y esta realmente es una ventaja. Pero en cambio queréis establecer, y esta es la otra, el perjuicio grandísimo de sujetar al servicio de las armas a todos los mozos de 20 años, en vez de llamar á los que obtuvieren los primeros números en el sorteo. De modo que si bien reducís dos años el servicio, venís a someter a él a todos los jóvenes, que es lo que ha de causar más disgustos al Gobierno. Tales son vuestras reformas; más de accidente que de ciencia.

1014 Discurso del Sr. Marqués de Sardoal, Diario de Sesiones de las Cortes, $11 / 03 / 1870$, no 236, p. 6422. 
Esto servirá de enseñanza á los pueblos que os veían antes predicar contra las quintas, porque con ellas al menos se quejaban todos hasta el día del sorteo; pero una vez verificado éste, los que no hablan caído soldados se quedaban, al fin, satisfechos y aun contentos, aunque les causara pena ver marchar al servicio á sus compañeros. Mas ahora, todos se han de quejar igualmente, lo mismo los que ingresen desde luego en el servicio activo, como los que pasen a la reserva, porque a todos amenaza la esclavitud ${ }^{\prime \prime 1015}$.

La propuesta planteada por los republicanos suponía la definitiva eliminación de las quintas y la constitución de un ejército formado exclusivamente por voluntarios previa aprobación, por parte de las Cortes, del número de reclutas necesarios y de la consignación presupuestaria necesaria que, anualmente, debería ser fijada para su contratación:

"[...] fijado el número de las fuerzas del Ejército permanente por medio de una ley, en el presupuesto debe fijarse la cantidad necesaria para tener el Ejército permanente que las Cortes fijen, compuesto de voluntarios, y de esa manera no hay necesidad, absolutamente ninguna, de sorteo. Si no aceptáis este medio, si establecéis el sorteo, es porque absolutamente queréis que lo haya, no es porque queráis evitarlo"1016.

Más llamativa fue la enmienda que los números más bajos del sorteo durante los años siguientes, es decir, los primeros en ser reclutados para el Ejército, fuesen ocupados por los jóvenes

1015 Discurso del Sr. Soler, Diario de Sesiones de las Cortes, 10/03/1870, n० 235, p. 6385.

1016 Discurso del Sr. Sorní, Diario de Sesiones de las Cortes, 17/03/1870, no 241, p. 6553. Ver también el discurso del Sr. Pi i Margall criticando duramente al Gobierno por su propuesta de mantener la quinta, el sorteo y la afectación que toda la juventud española tendría respecto al reclutamiento obligatorio a través de la segunda reserva, Discurso del Sr. Pi i Margall, Diario de Sesiones de las Cortes, 17/03/1870, no 241, pp. 6569-6572. 
analfabetos como forma de premiar e impulsar la instrucción en las primeras letras:

"[...] habiendo de ser dolorosamente una necesidad lo de la quinta, yo quisiera, y de eso trato y á eso tiende mi enmienda, utilizar esa necesidad y fundar en ella un medio de hacer un gran bien al país instruyéndole. Se ha dicho siempre que cuanto más ilustrado es un país, tanto más rico y más poderoso es. Aquí se ha dado un gran impulso a la instrucción primaria; se han establecido escuelas en todas las poblaciones; se ha declarado hasta obligatoria en alguna ocasión la enseñanza; sin embargo, la enseñanza desgraciadamente no se ha desarrollado; y comparado nuestro pueblo con los de las demás naciones, ocupa el último lugar respecto a ilustración. Es necesario, pues, buscar un medio para sacar a nuestro pueblo de ese lamentable estado; un medio que evite ese mal; y el más eficaz a mi entender, es el que he tenido la honra de someter a las Cortes en la enmienda que estoy ligeramente apoyando.

Se pide en ella que ya que no se pueda prescindir para el reemplazo del Ejército del medio de las quintas, en el año de 1872 hayan de ser soldados todos aquellos jóvenes que, habiendo llegado a la edad de 20 años, no sepan leer ni escribir, y que cuando en cualquier localidad hubiese que sacar más para el reemplazo y se proceda al sorteo, ellos ocupen el número más bajo, a fin de que llenen primero el cupo los que no sepan leer ni escribir. ¿Y no se cree que si llegara a adoptarse este medio habíamos de conseguir dentro de tres o cuatro años que no hubiese jóvenes en España que ignorasen leer ni escribir? Esto produciría un beneficio inmenso, pues toda la población masculina tendría la instrucción suficiente para comprender los derechos consignados en la Constitución que hemos tenido la honra de formar todos" ${ }^{\prime 1017}$.

1017 Discurso del Sr. Gil Virseda, Diario de Sesiones de las Cortes, 17/03/1870, no 241, p. 6561. 
A la postre, tal enmienda sería rechazada por el Parlamento con el argumento de que tal propuesta supondría un mayor agravio para las clases más humildes, habitualmente las menos instruidas ${ }^{1018}$.

En lo que se refiere a la duración del servicio, éste quedó reducido a seis años y dividido en dos fases: cuatro años de servicio activo (que se podían prolongar en caso de guerra) y otros dos en la primera reserva, periodo en que los reclutas podrían residir en sus casas $^{1019}$. Los que por la suerte del sorteo no hubiesen tenido que ingresar en filas y hubiesen sido destinados a la segunda reserva permanecerían seis años en ella ${ }^{1020}$. El diputado Díaz Quintero, considerando excesiva tal duración, propuso, además del reclutamiento universal, reducir el periodo de prestación a tan solo dos años, contando con una instrucción previa en la escuela de los reclutas desde la niñez. De esa forma, los soldados ya llegarían con la formación necesaria a su periodo de prestación, lo que además permitiría que toda la población, y no sólo los sorteados, cumpliesen con su obligación de servir a la patria con las armas en la mano:

\begin{abstract}
"Seamos, pues, todos militares, y yo propongo que desde la niñez vaya el hombre a la escuela, aprenda la táctica militar, los giros de pies, los movimientos y todo lo necesario: que cuando vaya a los institutos siga aprendiendo, y haya en todos una clase de gimnasia militar, y que cuando vaya a la Universidad continúe esta misma clase, y así seremos todos militares; y así, cuando el joven llegue a los 20 años y vaya al servicio estará instruido y bastará que sirva dos años, como en Prusia. [...].
\end{abstract}

\footnotetext{
1018 Discurso del Sr. Llano y Pérsi, Diario de Sesiones de las Cortes, 17/03/1870, no 241, pp. 6561-6563.

${ }^{1019}$ Esta reducción en la duración del servicio militar fue mostrada como todo un avance por la Comisión que elaboró el proyecto de ley: "[...] no hay ninguna nación, absolutamente ninguna, en que los soldados sirvan menos tiempo que en nuestra Patria según esta ley. Naciones hay que pueden considerarse como verdaderamente liberales, y sin embargo, en ellas están obligados los ciudadanos a servir diez y doce años, y en algunas partes hasta veinte y veinticinco años" (Discurso del Sr. Eraso, Diario de Sesiones de las Cortes, 21/03/1870, no 244, p. 6724).

${ }^{1020}$ Ley de 30 de Marzo de 1870, art. 6.
} 
Pues qué, ¿en dos años no se puede formar un soldado? iAh, señores, en mucho menos tiempo puede formarse! No parece sino que es una cosa tan difícil formar un buen soldado! En mucho menos tiempo, digo, se forma un soldado, cuando está preparado por una educación conveniente. [...].

Creo, pues, que podrá reducirse á dos años de servicio activo y otros dos años en la primera reserva y los otros dos en la segunda; pero haciendo servir á todos. ¿Por qué razón ese privilegio que hayan de servir unos $y$ otros no?"1021.

Por lo que respecta a las exenciones, el texto se limitó a declarar vigentes aquellas que se establecieron en los artículos 73, 74, 75, 76, 77 y 78 de la Ley de 1856, con las ligeras modificaciones introducidas en la Ley de 1 de Marzo de $1862^{1022}$, exenciones que quedarían recogidas en un futuro reglamento ${ }^{1023}$. Se mantuvo, por tanto, la talla mínima de 1,560 m. ${ }^{1024}$ para entrar en el Ejército y las exenciones de distinta tipología (físicas, personales, por interés económico o estratégico) recogidas en la legislación previa. La existencia misma de exenciones, debido a los fraudes que en torno a ellas se producían, encontró la oposición del diputado Díaz Quintero,

1021 Discurso del Sr. Díaz Quintero, Diario de Sesiones de las Cortes, 22/03/1870, no 245, pp. 6737-6738).

1022 Ley de 30 de Marzo de 1870, art. 8.

${ }^{1023}$ Ley de 30 de Marzo de 1870, disposición transitoria 2a.

1024 El diputado Cervera encontró esta rigidez en la talla exigida a los reclutas como un anacronismo en un tiempo en que los adelantes militares no exigen una estatura mínima: "[...] era menester que fuerais menos exigentes en la cuestión de la talla, que no sé la influencia que podrá ejercer en el servicio militar. ¿Es acaso para que todos los soldados se presenten bien en revista? Pues, por ventura, los jóvenes de menor talla que la marcada, ¿no sirven para soldados de fila? ¿Qué razón hay en el estado en que se halla el arte militar, con los adelantos que se han hecho en él, con las armas de precisión, para que no sean soldados los que tengan una talla menor? ¿Es que se quieren soldados gallardos para lucir vistosos uniformes en las revistas y formaciones? Pues hacéis una ley de quintas careciendo de todos estos preliminares, careciendo de todos estos datos, e imponéis un sacrificio inmenso, un sacrificio de sangre al país, y lo imponéis desigual sobre todas las poblaciones, porque no tenéis estadísticas bien hechas de las provincias, ni de las localidades, ni del número de jóvenes que hay en España; y mientras en una población dejáis muchos jóvenes sin entrar en sorteo, en otras no dejáis ninguno. Hacéis, pues, una ley injusta" (Discurso del Sr. Cervera, Diario de Sesiones de las Cortes, 16/03/1870, no 240, p. 6508). 
quien propuso que, aquellos considerados inútiles para el servicio militar, realizasen otro tipo de tareas al servicio del Estado:

"Las excepciones son una inmoralidad permanente que ha estado corroyendo al país, y no necesito decir a los Sres. Diputados, porque lo saben muy bien, a qué clase de escándalos dan lugar las excepciones: muchas veces sucede que se declara inútil a uno que no tiene enfermedad, y útil al que la tiene, sin más que porque el primero ha pagado algo. Pues bien, si con esta inmoralidad no acaban las Cortes Constituyentes, no sé quién la ha de estirpar. El que no sea útil para llevar el fusil, que sirva de ranchero o de escribiente, pero que vayan todos los españoles de 20 años a servir sin que se escape ninguno"1025.

La respuesta de los miembros de la comisión fue contundente al acusar el Sr. Díaz Quintero de falta de sensibilidad y de sentido humanitario:

"Según S. S., era necesario que todos, absolutamente todos los españoles, cojos, mancos, altos, bajos, enfermos, tuertos, locos, etc., entrasen necesariamente al servicio, sin que hubiera excepción de ninguna especie; en una palabra, quería S. S. que matáramos todos los sentimientos benéficos de nuestro corazón, porque S. S. sabe que las excepciones que quiere borrar y de las cuales nos ocuparemos más adelante, se han establecido en beneficio de la orfandad, de la pobreza, de la senectud; se han establecido en favor de las clases desheredadas de bienes de fortuna. Esto, por consiguiente, no cabe indicarlo, ni mucho menos admitirlo por parte de la Comisión"1026.

Los republicanos por su parte, rechazando íntegramente las quintas por su iniquidad, se dedicaron a combatir en las Cortes 1025 Discurso del Sr. Díaz Quintero, Diario de Sesiones de las Cortes, 22/03/1870, no 245, p. 6738.

1026 Discurso del Sr. Eraso, Diario de Sesiones de las Cortes, 22/03/1870, no 245, p. 6738. 
aquellos aspectos de la ley que consideraban más injustos. Así, se mostraron contrarios a exenciones que continuaban librando del servicio a miembros de la Iglesia ${ }^{1027}$ y a conceder un crédito absoluto a las declaraciones de los párrocos, ya que "[...] creer en la aptitud absoluta de los curas en estas materias, ajenas del todo á sus estudios y á su ministerio, es creer un absurdo; y creer á ciegas en su buena fe, declarándolos impecables, vale tanto como creer en brujas" $^{\prime 1028}$. Tampoco admitieron la exención por motivo de talla, ya que "[el suponer] que el hombre que no tiene cierta estatura, no posee el desarrollo necesario en las fuerzas físicas para el servicio de las armas y para resistir las fatigas que este servicio exige, lo cual es completamente infundado é inexacto" ${ }^{1029}, y$ es que el librar a un hombre del servicio por su estatura "[origina] en el orden moral [...] tan graves y funestas [...] consecuencias [...] en el seno de las sociedades que tienen la desgracia de conservar las quintas, que yo atribuyo a esta injusta excepción la mayor parte de las rencillas, de los odios, de las riñas y de los disturbios que se producen en nuestras aldeas $^{\prime \prime 1030}$.

Y en lo que se refiere a la sustitución y el cambio de número en el sorteo, el texto simplemente declaró su legalidad ${ }^{1031}$, manteniéndose lo establecido en leyes previas ${ }^{1032}$. Sí que constituyó

1027 Discurso del Sr. Cabello, Diario de Sesiones de las Cortes, 22/03/1870, no 245, p. 6741.

1028 Discurso del Sr. Rebullida, Diario de Sesiones de las Cortes, 22/03/1870, no 245, p. 6743.

1029 Discurso del Sr. Rebullida, Diario de Sesiones de las Cortes, 22/03/1870, no 245 , p. 6743.

1030 Discurso del Sr. Rebullida, Diario de Sesiones de las Cortes, 22/03/1870, no 245, p. 6743.

1031 "[...] la ley de Prim, consolidaba, además, el establecimiento de un sistema en el que las exenciones económicas eran permitidas, causa de vital importancia en el discurso de oposición popular al ejército" (FRIEYRO DE LARA, B., De campesino a soldado. Las quintas en Granada (1868-1898, pp. 23-24.).

1032 Con estos argumentos defendió el diputado Serrano Bedoya el mantenimiento de la sustitución: "La sustitución, pues, es un principio liberal, es un principio de igualdad, es un principio de equidad: hay un quinto que tiene medios de hacerse sustituir, y ese quinto, por no encontrarse con las condiciones necesarias, con la salud bastante robusta para soportar las fatigas de la guerra, busca a un pariente, a un amigo o a un conocido que vaya por él a sufrir esas penalidades, mediante 
una novedad que el sustituido pasase a la segunda reserva si el sustituto perteneciese a ella. La posibilidad de acudir a la sustitución encontró un fuerte rechazo por parte de la minoría republicana en Cortes, que consideraron esta eventualidad como una inmoralidad y una estafa, así como una violación de la igualdad ante la ley ${ }^{1033}$, llegando a asimilar la existencia de sustitutos y negociantes de los mismos con traficantes de esclavos:

"Se niega á los quintos el derecho de redimirse del servicio militar entregando cierta cantidad al Estado; pero en cambio se levanta la institución de los traficantes de carne humana en España, la del infame negrero en América, puesto que permitiéndose la sustitución, no han de faltar personas que se encarguen de reunir, como en un almacén, jóvenes que ofrecer a todos aquellos que por el dinero quieran redimirse del servicio militar. Es decir, que renunciando el Gobierno a ese monopolio, lo ha entregado en manos de los particulares ${ }^{\prime 1034}$.

Además, la eliminación de la sustitución supondría una reducción de los odios y enfrentamientos de clase ${ }^{1035}$, así como una

una retribución convenida entre los dos. ¿Que inconveniente hay, pues, en permitir que un ciudadano fuerte y con buenas condiciones físicas vaya al servicio militar en lugar de otro débil y enfermizo? La sustitución, pues, es un principio completamente liberal; un principio de igualdad, y el prohibirlo sería coartar la voluntad del individuo, sería ejercer una tiranía y nosotros no las admitimos" (Discurso del Sr. Serrano Bedoya, Diario de Sesiones de las Cortes, 16/03/1870, no 240, p. 6517).

1033 "[...] en un artículo constitucional se dice que todos los españoles están obligados a defender la Patria con las armas en la mano, y es evidente que si se admite la sustitución por dinero, esta obligación general no recaerá sobre todos los españoles, sino sobre aquellos que no tengan dinero para comprar un sustituto (Discurso del Sr. Eusebio Jimeno, Diario de Sesiones de las Cortes, 22/03/1870, no 245, p. 6746).

1034 Discurso del Sr. Soler, Diario de Sesiones de las Cortes, 10/03/1870, no 235, p. 6385.

1035 "[...] los ricos, mezclados con los pobres en los cuarteles, en los ejercicios y en las faenas propias de los militares, traería el grandísimo resultado que trae la civilización, que trae todo aquello que agrupa a los hombres, que trae todo aquello que favorece la fusión de las diversas clases de la sociedad. Mezclados en los cuarteles, en los campamentos, en todas partes las diversas clases de la sociedad, se dulcificarían las costumbres, desaparecerían esas antipatías de clase que hay y 
mejor aceptación popular de la quinta, ya que no sólo las clases pobres acudirían a filas, sino también las enriquecidas es que "a pesar de los males que trae para [la quinta para] los pueblos, la tolerarían con más facilidad si no supieran que cuando se sortean los que han de ir a defender la Patria, los pobres son los que salen a defenderla, mientras que los ricos [...] se quedan en sus casas" ${ }^{1036}$.

Algo similar sucedió con la redención en metálico, limitándose la norma a establecer su legalidad ${ }^{1037}$ sin introducirse en su regulación, "aunque manteniendo la firme intención de sustituir a los redimidos con reenganchados, enganchados y voluntarios paisanos"1038. De nuevo, la idea de Juan Prim, en esta ocasión apoyada por los republicanos $^{1039}$, sobre la abolición de la redención en metálico contenida en su proyecto inicial, quedó olvidada en la tramitación definitiva de la ley, ya que quedó legalizado ${ }^{1040}$, una vez pasado el trámite parlamentario, uno de los rechazos populares más clamorosos por su injusticia ${ }^{1041}$ :

que necesariamente ha de haber, puesto que las de arriba tratan mal a las de abajo, lo cual por sí solo daría un grandísimo resultado" (Discurso del Sr. Tutau, Diario de Sesiones de las Cortes, 22/03/1870, no 245, p. 6749).

1036 Discurso del Sr. Tutau, Diario de Sesiones de las Cortes, 22/03/1870, no 245, p. 6749.

${ }^{1037}$ Ley de 30 de Marzo de 1870, arts. 9 y 10.

1038 FEIJÓO GÓMEZ, A., Quintas y protesta social en el siglo XIX español, p. 272.

1039 "En una cosa solamente debo dirigir una palabra de gratitud [...] al Gobierno, que es quien la ha propuesto, y es en que haya concluido con la redención. La redención era una plaga que pesaba sobre las clases medias, era la ruina de las familias poco acomodadas, que hacían inmensos sacrificios para librar a un hijo de la suerte de soldado" (Discurso del Sr. Cervera, Diario de Sesiones de las Cortes, 16/03/1870, no 240, p. 6509).

1040 "Para paliar esta fuerte presión social, la ley establecía la posibilidad de que se redimieran a cupos enteros, y no solo que las familias más acaudaladas de la nación pudieran librar a sus hijos a través de un pago. [...]. Para ello los Ayuntamiento y Diputaciones de todo el país podían acudir a operaciones de crédito o repartir las cantidades a pagar entre los vecinos y residentes de cada distrito municipal (FRIEYRO DE LARA, B., De campesino a soldado. Las quintas en Granada (1868-1898), p. 24).

1041 El Proyecto de Ley de Prim expresamente prohibía la redención en metálico: "Queda abolida la redención a metálico" (Proyecto de Ley de ocho de Febrero de 1870 , art. 12). 
"Lo que prueba la injusticia de vuestra ley de quintas, lo que prueba su iniquidad, es que apeláis a las excepciones, a los enganches y reenganches, a la sustitución, no queriendo en manera alguna privar a la clase artística, a la clase científica, a las clases medias, a la clase rica, del medio de que por dinero, por esta causa o por la otra pueda desde luego desembarazarse de un servicio tan penoso, de un servicio tan cruel. ¿Y qué significa esto? Que buscáis el privilegio, que no buscáis la unidad, que no buscáis la igualdad que todos proclamáis; que semejante unidad y semejante igualdad no existe en esta ley, puesto que no puede pesarse con un puñado de oro la vida del más desdichado de los españoles"1042.

La prensa conservadora por su parte defendía, por motivos de beneficio para todas las clases sociales, la existencia de la redención en metálico:

"[...] la redención á metílico, considerada como un privilegio de los ricos, es altamente beneficiosa á los pobres, pues el que voluntariamente quiere alistarse en las filas del ejército, se asegura un bienestar al terminar honradamente su compromiso, y si tiene la desgracia de morir, lega una cantidad relevante importante á los autores de sus días, á sus hijos ó á su viuda"1043.

Esta circunstancia, la injusticia inherente a las quintas, no impidió que la prensa progresista defendiese su existencia y la de los ejércitos permanentes, al menos temporalmente por las necesidades de la Patria, mostrando una actitud crítica hacia los republicanos y sus falsas promesas:

"Que el sorteo es hoy una necesidad; que el ejército permanente es ahora imprescindible, porque lo reclaman los más altos intereses

1042 Discurso del Sr. Cervera, Diario de Sesiones de las Cortes, 16/03/1870, no 240, p. 6509.

1043 La Época, 25/10/1872, no 7335, p. 2. 
de la patria, de la Revolución, de la libertad, que tantas amarguras ha costado y que de tantos, tan implacables y vengativos enemigos se halla amenazada, Se lo han dicho al pueblo aquellos de sus representantes que más han sufrido por su redención y por su honra; se lo han dicho en la prensa los que por su santa causa se han visto perseguidos y expatriados, los que por su bien tantos y tan grandes sacrificios han hecho nuestros hombres de gobierno, los diputados, liberales que componen la mayoría de las Cortes, como cuantos amamos la libertad y trabajamos todas sus posibles conquistas, aspiran con fe sincera á la abolición de la contribución de sangre, porque el cumplimiento de esas aspiraciones será señal de que España ha llegado á merecer todas las bienandanzas de un pueblo que, como el nuestro, ha nacido para ser libre y grande. Pero en el seno de nuestra patria se agitan aun elementos que se hallan en lucha con los sagrados intereses cuyo depósito guardan fielmente el Gobierno y las Cortes; aquella libertad y aquella grandeza están todavía amenazadas de peligros que hay que prevenir, de enemigos contra los que hay que estar en guardia. Por eso la abolición de las quintas no puede ser obra de un instante, sino para aquellos que no son responsables de tan altos intereses; para aquellos que sólo oyen los gritos de la pasión ciega, y no dan lugar á los consejos de la señora razón, que previsora y prudentemente debe guiar hoy á los que rigen los destinos de la patria, anhelando que no se malogren las conquistas revolucionarias y llegué á realizarse pronto esa otra conquista á que todos aspiramos. Pues bien; si el cumplimiento de la ley de reemplazos es una necesidad del momento que sólo puede desconocer la ceguedad de la pasión ó el encono de los enemigos de la situación revolucionaria, hoy, que es el día del cumplimiento, cuando ha llegado la hora de acatar con la rectitud de ciudadanos dignos y honrados las decisiones de la Soberanía nacional, no nos creemos relevados del deber de dar al pueblo la voz de alerta contra las sugestiones da la pasión y contra las excitaciones y consejos de hecho $[\ldots]$.

No hay que llamarse á engaño: los liberales verdaderos de todos los partidos han llevado á todos los ámbitos de España su voz preventiva, sus leales y patrióticos consejos. Cuantos no dieren oídos á aquella voz, cuantos no escucharen consejos tan prudentes, y ciegos y desatentados se rebelaren contra la ley y produjeren 
desórdenes, llámense como se llamen, enemigos serían de la libertad, responsables de los conflictos que pudieran sobrevenir para esta noble patria, que tiene derecho á la lealtad y abnegación de todos sus hijos"1044.

b) La organización del Ejército

El título segundo de la ley recogía una serie de generalidades sobre la organización del Ejército. Así, se declaró que el Ejército se dividía en permanente ( $y$ este a su vez en activo y primera reserva o reserva activa) y reserva, siendo las Cortes las encargadas de fijar anualmente el número de hombres que deberían ingresar a filas ${ }^{1045}$. La primera reserva estaría constituida por los soldados que hubiesen cumplido cuatro años de servicio activo en el Ejército, gozando de licencia ilimitada para poder regresar a sus hogares ${ }^{1046}$. La segunda reserva se formaría "[...] con los jóvenes de 20 años que excedan del contingente anual fijado por las Cortes para cubrir las bajas del Ejército permanente"1047. Ambos grupos de reservistas veían plenamente reconocidos todos sus derechos ciudadanos y

\section{"[...] podrán contraer matrimonio sin autorización después del} primer año de servicio; cambiar de domicilio o de residencia y viajar por España y el extranjero, dando conocimiento previamente al jefe de la reserva a que pertenezcan"1048.

Finaliza la Ley de 1870 con una serie de artículos adicionales y transitorios. Los primeros expresamente se encargaban de declarar el mantenimiento "[de] las atribuciones que en la realización del servicio

\footnotetext{
1044 La Iberia, 03/04/1870, no 4138, p. 1.

1045 Ley de 30 de Marzo de 1870, arts. 13, 14 y 15.

1046 Ley de 30 de Marzo de 1870, art. 16.

1047 Ley de 30 de Marzo de 1870, art. 17.

1048 Ley de 30 de Marzo de 1870, art. 18.
} 
militar competen a Navarra, ni las excepciones que por sus fueros disfrutan las provincias Vascongadas" y de anunciar una futura ley que armonizase el servicio de la Armada con los principios recogidos en el texto ${ }^{1049}$.

En cuanto a las disposiciones transitorias, éstas anunciaron la futura publicación de una ley de retiros que estableciese las pensiones que podrían disfrutar los voluntarios en el momento de retirarse del servicio activo y de las órdenes y reglamentos que permitiesen la ejecución de la ley. Además declaró derogada la Ley de reemplazos de 30 de enero de 1856 y los textos que vinieron a reformarla ${ }^{1050}$.

Limitada aplicación de la norma e importantes novedades que la modificaron

La Ley sobre reemplazos de 1870 tuvo una aplicación ciertamente limitada en el tiempo, ya que no se mantuvo más allá del fin del Sexenio y fue derogada con la Restauración Borbónica. Sin embargo, en las sucesivas leyes anuales que llamaban al servicio de las armas sí aparecieron algunas novedades reseñables. Destacar, por ejemplo, que se confirmó la exención para las provincias Vascongadas en el reemplazo ${ }^{1051}$ y que, aunque fuese el ministerio de

\footnotetext{
1049 Ley de 30 de Marzo de 1870 , artículos adicionales $1^{\circ}$ y $2^{\circ}$.

1050 Ley de 30 de Marzo de 1870, disposiciones transitorias $1^{a}, 2^{a}, 4^{a}$ y $5^{a}$.

1051 Los republicanos también criticaban la injusticia e inmoralidad que suponía una ley inicua que contemplaba la exención del servicio para una parte del territorio nacional: "¿No sabéis que en España existen respecto a este punto dos clases de españoles? ¿No sabéis, señores de la mayoría, de algunas provincias que están exentas de la legislación de quintas? ¿No sabéis que esto prueba que hay aquí una gran injusticia? Sabéis todos que hay provincias, de opinión al parecer no liberal, pero que realmente están en la verdadera práctica de la libertad, las Provincias Vascongadas, no sujetas en función de sus fueros al servicio forzoso militar. [...]. Sabéis que tienen privilegio y gozan de prerrogativa en esta parte, en el servicio más duro, en el servicio más penoso, en el servicio que, si fuese igual, yo declaro justo, de defender al país. [...]. ¿por qué ha de haber provincias exentas de ese tributo que pesa sobre el resto del país?" (Discurso del Sr. Escuder, Diario de Sesiones de las Cortes, 13/06/1871, no 59, pp. 1608 y 1609).
} 
Guerra el que presentase la Ley última aprobada en 1870, era el de Gobernación el encargado de realizar el llamamiento y el repartimiento del cupo ${ }^{1052}$. En el momento de aprobarse anualmente la ley que Ilamaba al reemplazo, encontramos las justificaciones del Gobierno acudiendo a la provisionalidad de los llamamientos, a la imposibilidad económica que, para la Hacienda pública, tenía la implantación de un ejército formado exclusivamente por voluntarios, a la inestabilidad por la que atravesaba el país ocasionada por los problemas carlista, cubano, filipino, extremismos políticos e internacionalista obrero, y al compromiso futuro de abolir las quintas:

"Si fuese pacífica la situación de Europa y en nuestro país se agitasen menos las pasiones, ya sería posible disminuir la fuerza armada y llenar sucesivamente las filas no recurriendo más que al alistamiento voluntario, como el Gobierno de S.M. desea con toda vehemencia en beneficio de las familias y los pueblos. Más las circunstancias actuales sólo permiten mantener las ventajas ya introducidas en la ley general de quintas, disminuyendo el tiempo de servicio y autorizando para su redención todas las posibles facilidades.

$[\ldots]$.

El Gobierno confía en que la pacificación de la isla de Cuba y el restablecimiento del orden en la Península [...], harán posible en breve plazo la reducción del Ejército y su organización por métodos más fáciles y menos vejatorios para los pueblos"1053.

1052 Ley de 20 de Abril de 1870 llamando al reemplazo a 40.000 hombres, Gaceta núm. 16 de 26/04/1879, arts. 2 y 3; Ley de 27 de Mayo de 1872 sancionada por S.M. el rey, y publicada en el Congreso, llamando al servicio de las armas a 35.000 hombres para el reemplazo del Ejército, Gaceta Núm. 236, de 30/05/1872; Ley de 3 de Julio de 1871 sancionada por S.M. el rey, y publicada en el Congreso, fijando la fuerza del Ejército permanente para el año económico de 1872-1873, Gaceta de $5 / 07 / 1871$.

1053 Proyecto de ley, presentado por el Sr. Ministro de la Gobernación, Ilamando a las armas 35.000 hombres para el reemplazo del Ejército, Diario de Sesiones de las Cortes, 22/05/1871, apéndice $2^{\circ}$ al no 41. 
La prensa conservadora vendría a criticar estas "incumplibles" promesas de los revolucionarios que venían a traicionar uno de sus principales ideales programáticos:

"No resultará de lo discutido en el Congreso ninguna idea nueva, no se preparará ninguna solución; ni para lo presente se conseguirá mejora alguna, ni quedará sembrada ninguna doctrina para lo porvenir. Dos cosas solamente quedan demostradas; que los revolucionarios de setiembre han faltado a su propia programa, de lo cual están superadamente convictos y confesos; y que la actitud de los partidos políticos en España es siempre la de la guerra civil permanente, en la que las hostilidades pueden estar suspendidas, pero la paz no llegará á hacerse nunca para sustituir la lucha legal á los azarosos conflictos dé las armas"1054.

Un decreto de mayo de 1870 vendría a regular la declaración y entrega de soldados en la caja. En él se señala que serían las Diputaciones provinciales las encargadas de distribuir el cupo otorgado a su provincia entre sus pueblos, debiendo publicar tal reparto en el Boletín Oficial de la provincia antes del 12 de junio, mientras que la entrega de soldados en la caja se realizaría entre el 22 de junio y el 15 de julio en función de la lejanía del pueblo respecto a la capital provincial y a juicio del gobernador provincial ${ }^{1055}$.

También se repitieron año tras año las críticas republicanas ${ }^{1056}$ hacia un Ejército sobredimensionado y desproporcionado en cuanto al

\footnotetext{
1054 La Época, 14/06/1871, no 1319, p. 2.

1055 Decreto de 21 de Mayo de 1870, Gaceta núm. 144 de 24/05/1870, arts. 2, 6, 7.

1056 Los republicanos trataron de asimilar república federal con abolición de las quintas buscando nuevos apoyos a su proyecto de Estado: "Todos los ciudadanos españoles tienen derecho de insurrección contra la quinta. [...]. Contra la tiranía hay el derecho de sublevarse siempre, y nosotros [...] no podemos negar el derecho de sublevarse a los que nosotros tiranizamos. [...]. Nosotros [los republicanos] somos el único partido que puede mandar en España sin sacar quintas, sin sacar soldados armados sometidos a una ley bárbara, y ésta es una de las causas que constituye la necesidad del establecimiento de la república federal en España"
} 
número de soldados ante una amenaza carlista y alfonsina consideradas menores y escasamente peligrosas para el nuevo régimen ${ }^{1057}$; hacia la traición e incumplimiento de las promesas realizadas en los años previos a la revolución Gloriosa ${ }^{1058}$, el engaño y la violación de las libertades individuales y de la Constitución democrática de 1869 que, para el pueblo español, suponía el mantenimiento de las quintas por parte de los sucesivos gobiernos monárquicos tras el triunfo de la Revolución; así como hacia la inmoralidad y la injusticia del reclutamiento forzoso y la necesidad de su sustitución por un ejército de voluntarios retribuidos, que mostrará una mayor convicción y preparación que el ejército forzoso:

"Pero una decepción continua, que parece ya destinada a renovarse cada año, hace al fin comprende a los pueblos que nada, absolutamente nada tienen que esperar de los partidos que actualmente están en el poder. [...]. Por consiguiente, llamándose los pueblos de nuevo a engaño, no esperéis tener la popularidad que buscáis; estáis ya juzgados, el país se somete, pero a la fuerza $[\ldots]^{1059}$.

Desde los bancos republicanos se presentaron proyectos de ley y enmiendas legislativas solicitando la definitiva abolición de las

(Discurso del Sr. Garrido, Diario de Sesiones de las Cortes, 26/10/1872, no 37, pp. 863-865).

1057 "[...] está perfectamente demostrado que ni para combatir a los carlistas, ni para combatir a los alfonsinos, ni para combatir a los conservadores de la revolución, ni para combatir a los republicanos, necesita el Gobierno de 40.000 hombres" (Discurso del Sr. Sampere, Diario de Sesiones de las Cortes, 24/10/1872, no 35, p. 793).

1058 "Vosotros dejáis permanente la revolución de Setiembre, por no haber cumplido sus más importantes promesas; luego queréis que éstas se cumplan, no por las vías pacíficas y legales, sino por medio de otra nueva revolución; y por esto yo os advierto que seréis los responsables de todas cuantas veces se altere en España el orden público, de todas cuantas veces se hagan otras revoluciones, para que de una vez se cumplan todas las promesas de la revolución de Setiembre (Discurso del Sr. Corominas, Diario de Sesiones de las Cortes, 25/10/1872, nº 36, p. 845).

1059 Discurso del Sr. Escuder, Diario de Sesiones de las Cortes, 13/06/1871, no 59, p. 1608. 
quintas ${ }^{1060}$, la incorporación de Navarra, Provincias Vascongadas y Canarias al régimen general español en materia de reclutamiento por oponerse al principio de igualdad ante la ley ${ }^{1061}$, la posibilidad de que Ayuntamientos y Diputaciones pudiesen redimir el cupo que les hubiese sido otorgado por medio de sustitutos o en metálico ${ }^{1062}$, la posibilidad de pagar la redención en metálico de 4.000 reales en dos e incluso hasta en cuatro plazos ${ }^{1063}$, y se escucharon asimismo voces favorables a la eliminación del Ejército permanente ${ }^{1064}$ y su sustitución por un sistema de milicias provinciales ${ }^{1065}$ sin posibilidad de exención exceptuando las motivaciones físicas:

1060 "Los diputados que suscriben tienen el honor de presentar al Congreso la siguiente enmiendo al artículo $1^{\circ}$ del proyecto de ley llamando 40.000 hombres al servicio de las armas:

Artículo 10: quedan para siempre abolidas las quintas [...]" (Enmiendas del Sr. González Janer al dictamen de la Comisión sobre el proyecto de ley llamando al servicio de las armas 40.000 hombres, Diario de Sesiones de las Cortes, 17/10/1872, apéndice al no 29, p. 1).

1061 Sirva de ejemplo: "Siendo obligación de todos los españoles defender a la Patria con las armas en la mano cuando fueren llamados por la ley, Navarra, como todas las provincias del reino, está obligada en los casos de quintas o reemplazos ordinarios o extraordinarios del Ejército, a presentar el cupo que les corresponda [...]" (Discurso del Sr. Barberá, Diario de Sesiones de las Cortes, 28/10/1872, no 38 , p. 896).

1062 Enmienda presentada por el Sr. González Janer, Diario de Sesiones de las Cortes, 30/10/1872, no 40, p. 994.

${ }_{1063} \mathrm{Si}$ no queréis aceptar esta adición, probablemente haréis la ruina de muchas familias, las cuales por no ver a sus hijos ir al servicio, preferirán tomar esta cantidad a cualquier precio, cueste lo que cueste, y, naturalmente, al obrar así tendrán que reducirse a la miseria (Enmienda y discurso presentada por el Sr. Sicilia de Arenzana, Diario de Sesiones de las Cortes, 30/10/1872, no 40, p. 998).

1064 "La Nación española no necesita para defender su independencia y su integridad del Ejército permanente [...]. La Nación española no ha necesitado Ejércitos permanentes; cuando se ha visto en peligro o amenazada su independencia por Naciones extranjeras, tiene dados grandes rasgos de abnegación y de heroísmo. El pueblo español, en todas las épocas en que se ha visto amenazado por invasiones extranjeras, no ha necesitado de soldados; todos los españoles, con el mayor ardimiento, con el mayor entusiasmo, han acudido a formar el Ejército nacional, ese Ejército que no quiere más que a los hombres voluntarios, no a los hombres forzados" (Discurso del Sr. Lafuente, Diario de Sesiones de las Cortes, 30/10/1872, no 40, p. 970).

1065 El diputado republicano Sorní acusó al Gobierno radical de Ruiz Zorrilla de no establecer un sistema de milicias por el impulso que éste supondría a la causa republicana: "Era necesario para sofocar el espíritu republicano del país, con objeto de que cuando vinieran las Cortes Constituyentes fueran monárquicos los diputados, era necesario, repito, desarmar la Milicia Nacional en los principales puntos de España [...]. Lo que hay es que no se quiere Milicia, porque sólo de esa manera es como se puede establecer la Monarquía en España" (Discurso del Sr. 
"Así pues, lo que convendría hoy al país sería la abolición de todo el Ejército permanente, y que se estableciera un sistema de milicias Provinciales desde la edad de 20 a 24 años; un Ejército de reserva en el cual cada uno de los inscritos pueda cumplir el tiempo de su servicio en el punto de residencia, creando un batallón en cada cabeza de distrito"1066.

Llama la atención que también pusieran en cuestión los republicanos la capacidad del Ejército español para hacer frente a cualquier invasión externa:

"Decís que puede peligrar la independencia de la Patria. Pues qué, si la independencia de la Patria peligrara, ¿la salvaría el Ejército permanente que hay en España? No. iAy de nosotros si apareciera un Ejército prusiano en los Pirineos! El Ejército permanente, por digno, por valiente que fuera, sería abatido desde los Pirineos hasta Calpe. Los pueblos no se defienden con el Ejército permanente, sino con el amor a la independencia, con el amor a la Patria de esos mismos pueblos ${ }^{\prime 1067}$.

Para impulsar el voluntariado que a la postre permitiese la supresión de las quintas, el Presidente del Gobierno y ministro de la Guerra, Francisco Serrano, presentó un proyecto de ley que permitía a los menores de veinticinco años ingresar en el Ejército sin el correspondiente consentimiento paterno:

Sorní, Diario de Sesiones de las Cortes, 23/10/1872, no 34, pp. 772-773). Ver también la propuesta de solicitando la supresión del Ejército permanente y su sustitución por una Milicia Nacional de corte progresista, Discurso del Sr. Pascual y Casas, Diario de Sesiones de las Cortes, 30/10/1872, no 40, pp. 970-973.

1066 Discurso del Sr. Cisa, Diario de Sesiones de las Cortes, 17/10/1872, no 29, p. 634.

1067 Discurso del Sr. Pascual y Casas, Diario de Sesiones de las Cortes, 30/10/1872, no 40, p. 973. 
"La conveniencia de facilitar por todos los medios posibles el enganche en el Ejército está reconocida por todos los que desean, como el Ministro que suscribe, contribuir a llenar las filas con soldados voluntarios.

Una de las causas que dificultan el enganche, es el consentimiento paterno que se exige a los jóvenes menores de 25 años, dando lugar a que en multitud de casos los jefes de los cuerpos no puedan admitir el enganche a individuos que, sin embargo de reunir las mejores condiciones para el servicio de las armas, se presentan solicitando el ingreso en las filas sin el documento en que se acredita el expresado consentimiento"1068.

La contradicción existente entre la edad legal para poder votar y la de ingresar sin consentimiento paterno fue denunciado como antidemocrática por la oposición republicana:

"Para que ingresen en el Ejército, se procura la dispensa de los jóvenes de 20 años, y para ejercer el derecho electoral, para ejercer los derechos civiles no les es permitido esa dispensa. [...].

Enhorabuena que se fije la edad de 20 años, para que los españoles tengan la plenitud de sus derechos; enhorabuena que todos los españoles de 20 años puedan tener voto electoral; puedan emanciparse de la patria potestad en todos sus efectos, puedan casarse sin autorización, puedan ingresar, hasta si quieren, en las filas del Ejército; pero que esto no sea un privilegio arrancado por el departamento de Guerra, con fines inmorales, y en su exclusivo beneficio"1069.

Los Ayuntamientos, por su parte, deberían remitir al ministerio de la Gobernación un expediente de declaración de los soldados donde se incluyese el nombre y apellidos de los reclutas, su talla, el

1068 Proyecto de ley, presentado por el Sr. Ministro de la Guerra y Presidente del Consejo de Ministros, para que se pueda ingresar voluntariamente todo español sin el consentimiento paterno, apéndice 40, Gaceta núm. 40 de 20/05/1871.

1069 Discurso del Sr. Escuder, Diario de Sesiones de las Cortes, 13/07/1871, no 104, p. 2682. 
número que obtuviesen en el sorteo y las exenciones reconocidas ${ }^{1070}$. Para la entrega en la caja se habían de presentar en la capital provincial los mozos declarados soldados para el Ejército permanente y aquellos que iban a ser destinados a la segunda reserva. Todos ellos serían reconocidos por un facultativo médico antes de su ingreso ${ }^{1071}$.

a) El proyecto abolicionista de Ruiz Zorrilla en 1872

Previamente al advenimiento de la I República y a la ley aprobada por el nuevo régimen republicano, el Gobierno monárquico radical de Ruiz Zorrilla presentó, en septiembre de 1872 a través de su Presidente y ministro de la Gobernación, un proyecto de ley ${ }^{1072}$ que sería aprobado por el Parlamento pero finalmente no aplicado ante la proclamación del nuevo régimen republicano. Este proyecto recogía como principio básico la eliminación de las quintas, ya que tal sistema

"[...] ofrece tan odiosos caracteres; pesa con tan enorme desigualdad sobre las diferentes clases sociales; concede tan escandalosas ventajas a la riqueza; roba tantos brazos a la agricultura, a la industria, al comercio; cambia de tal manera la índole del hombre, haciéndole olvidar sus antiguos hábitos y perder sus anteriores aptitudes; le devuelve, en fin, al lugar de donde la arrancó, tan inhábil para el ejercicio de su profesión y tan inútil para el sostenimiento de su familia, que ni es extraña la universal execración lanzada contra el intolerable sistema de quintas, ni merecería perdón el Gobierno que blasonando de liberal mantuviese un instante más ese

1070 Decreto de 21 de Mayo de 1870, Gaceta núm. 144 de 24/05/1870, arts. 9 y 10. 1071 Decreto de 21 de Mayo de 1870, Gaceta núm. 144 de 24/05/1870, arts. 11, 12 y 13.

1072 Proyecto de ley de 27 de septiembre de 1872 sobre reemplazo del Ejército y abolición de las quintas, Diario de Sesiones de las Cortes, 27/09/1872, apéndice octavo al no 12, pp. 1-4. En adelante, Proyecto de ley de 27 de septiembre de 1872. 
cáncer, capaz de viciar nuestra sociedad y agotar nuestros mejores elementos de vida"1073.

La supresión de la quinta no suponía en absoluto el fin del servicio militar y de los reemplazos ${ }^{1074}$, ya que, ante la imposibilidad de formar un ejército exclusivamente con voluntarios, el reclutamiento sería obligatorio para todos los españoles de los veinte a los veintisiete años ${ }^{1075}$ como "[...] un medio práctico de determinar la sucesiva responsabilidad de cada individuo para los llamamientos a las distintas situaciones que pueden corresponderle, bien en el Ejército activo, bien en las diferentes reservas"1076. Quedarían asimismo suprimidas por razones de equidad y justicia la redención en metálico y la sustitución, así como cualquier tipo de exención por empleo, cargo público o posición social ${ }^{1077}$, y las filas del Ejército se verían reducidas ya que "la feliz posición de España, situada a un extremo del continente y alejada del teatro de las grandes luchas europeas, permite rebajar la cifra proporcional de su Ejército, reduciéndolo al número estrictamente indispensable para asegurar la absoluta neutralidad $[\ldots]^{1078}$.

Se admitía la posibilidad del enganche voluntario retribuido a razón de cincuenta céntimos de peseta diarios, pero el servicio sería obligatorio para todos los mozos durante siete años, tres en activo, dos en la primera reserva y otros dos en la segunda, excepto en tiempo de guerra, cuando todos los reclutas formarían parte activa del Ejército ${ }^{1079}$. Sin embargo, no todos los jóvenes considerados aptos acudirían al servicio activo, sino que, dependiendo de las

\footnotetext{
1073 Proyecto de ley de 27 de septiembre de 1872, p. 1.

1074 La oposición republicana utilizó mayoritariamente este argumento, acusando al Gobierno de hipocresía, para rechazar el Proyecto de ley, Discurso del Sr. Esteban Collantes Diario de Sesiones de las Cortes, 30/01/1873, no 99, pp. 2822-4

1075 Proyecto de ley de 27 de septiembre de 1872, arts. 1-3, p. 3.

1076 Proyecto de ley de 27 de septiembre de 1872, p. 2.

1077 Proyecto de ley de 27 de septiembre de 1872, arts. 3 y 4, p. 3.

1078 Proyecto de ley de 27 de septiembre de 1872, p. 2.

1079 Proyecto de ley de 27 de septiembre de 1872, arts. 6-8, 10, 17 y 29, pp. 2-4.
} 
necesidades militares evaluadas por el Gobierno y a propuesta de las Cortes, solamente ingresarían en el Ejército aquellos a los que hubiese correspondido por orden numérico correlativo. Este orden sería fijado en función del alfabetismo o analfabetismo del mozo. Por lo tanto, si bien se propuso el fin del sorteo como medio para determinar que jóvenes tendrían la obligación de ingresar en filas y el final de la redención y la sustitución, continuaría existiendo un criterio diferenciador, la capacidad de leer y escribir, que haría recaer el peso del reclutamiento sobre los estratos más bajos de la sociedad, con menos posibilidades de alfabetización por su situación económica ${ }^{1080}$.

El proyecto de ley también recogía la posibilidad de prórrogas de un máximo de dos años en tiempo de paz en la incorporación al servicio para aquellos jóvenes que, a juicio de la Diputación provincial respectiva, "[...] justifiquen estar dedicados a los estudios de una carrera científica o literaria, o al aprendizaje de un arte u oficio cuya interrupción pudiera serles perjudicial por estar próximos a terminarlo"1081. Además, El Ejecutivo fijaba como principio prioritario la formación en las primeras letras de los soldados, "[para lo cual] el Gobierno establecerá en los cuerpos del Ejército las escuelas y academias necesarias para difundir la instrucción en la clase de tropa"1082. Es más, aquellos soldados que no hubiesen aprendido a leer y escribir correctamente durante su tiempo de prestación, sufrirían un recargo en el servicio de seis meses ${ }^{1083}$.

Las críticas hacia este nuevo proyecto de ley procedieron del partido Republicano pero también del Moderado. Los conservadores, a través del diputado Esteban Collantes, se centraron en la hipocresía y falta de franqueza que suponía el declarar la abolición de las quintas al mismo tiempo que se mantenía el reclutamiento forzoso

\footnotetext{
1080 Proyecto de ley de 27 de septiembre de 1872, arts. 12, 13 y 15, p. 3 .

1081 Proyecto de ley de 27 de septiembre de 1872, arts. 20 y 21, pp. 3 y 4.

1082 Proyecto de ley de 27 de septiembre de 1872, art. 25, p. 4.

1083 Proyecto de ley de 27 de septiembre de 1872, art. 25, p. 4.
} 
para todos los españoles, que además supondría un gran daño para el país:

"El Gobierno dice muy seriamente en al art. $1^{\circ}$ del proyecto: "quedan abolidas las quintas"; pero en el $2^{\circ}$ dice: "serán soldados todos los españoles". Esto es igual, señores, a si este mecanismo hipócrita se llevara la ley de la abolición de la esclavitud, y se dijera: "Artículo 10: queda abolida la esclavitud. Art. 20: a todos los blancos de Puerto Rico y Cuba se les pintará de negro, y todos continuarán siendo esclavos ${ }^{\prime 1084}$.

Por ello, los diputados moderados apostaron por el mantenimiento de la quinta a pesar de la oposición popular a la misma, ya que la constitución de un Ejército formado exclusivamente por voluntarios se había demostrado como una quimera en España ${ }^{1085}$.

Los republicanos, "[aunque no lograron] ponerse de acuerdo en cuanto al voto a emitir, ya que unos aceptaron el servicio obligatorio para las reservas, otros cuestionaron la obligatoriedad del servicio incluso en la reserva, y los menos rechazaron la existencia de un Ejército permanente ${ }^{1086 \prime \prime}$, utilizaron parecidos argumentos que los moderados a la hora de rechazar el proyecto de ley, ya que a través de esto texto "[...] las quintas quedan, no con el nombre de quintas, sino con otro nombre: es el servicio forzoso" ${ }^{1087}$. Además, algunos diputados pusieron en cuestión la existencia de ejércitos permanentes

\footnotetext{
1084 Discurso del Sr. Esteban Collantes, Diario de Sesiones de las Cortes, 30/01/1873, no 99, pp. 2823-2824.

1085 Discurso del Sr. Esteban Collantes, Diario de Sesiones de las Cortes, 30/01/1873, no 99, p. 2833.

1086 FEIJóo GÓMEZ, A., Quintas y protesta social en el siglo XIX español, p. 163.

1087 Discurso del Sr. Garrido, Diario de Sesiones de las Cortes, 31/01/1873, no 100 , p. 2865.
} 
por suponer un peligro contra la libertad y la democracia ${ }^{1088}$. El tono del debate se agrió debido a una nueva llamada del Gobierno a cubrir una quinta de 40.000 hombres: "no parecía lógico que presentaba un proyecto de abolición del sistema de reclutamiento por quintas llamara en la misma fecha a un reemplazo más, que de nuevo volvía a presentarse supuestamente como el último"1089. El malestar popular lógicamente se vio incrementado ante las promesas abolicionistas incumplidas del partido Radical ${ }^{1090}$.

b) La norma republicana que suprimía las quintas: La Ley de 17 de Febrero de 1873

En febrero de 1873 la Asamblea Nacional republicana publicó un breve texto legislativo que venía a implantar los ideales republicanos en materia de reclutamiento y cuya vigencia fue de tan solo seis meses ${ }^{1091}$. Nos encontramos ante una disposición importante en cuanto a su contenido, pero de nula repercusión práctica y que no contó con debate en el seno del Parlamento y apenas discusión en la prensa. Acudiremos a dos periódicos de características distintas para observar el impacto político de la misma: La Época, cuyos principales rasgos ya fueron explicados en páginas anteriores, y La Discusión ${ }^{1092}$,

\footnotetext{
1088 "Los Ejércitos permanentes son condenados por la democracia moderna: el partido republicano los condena como peligrosos a la libertad" (Discurso del Sr. Garrido, Diario de Sesiones de las Cortes, 31/01/1873, no 100, p. 2877).

1089 FRIEYRO DE LARA, B., De campesino a soldado. Las quintas en Granada (18681898), p. 25.

1090 FRIEYRO DE LARA, B., De campesino a soldado. Las quintas en Granada (18681898), p. 26.

${ }^{1091}$ Ley de 17 de Febrero de 1873, dictando disposiciones relativas al reemplazo en el Ejército, Gaceta núm. 54 de 23/02/1873. En adelante, Ley de 17 de Febrero de 1873.

1092 "Periódico fundado y dirigido en sus primeros años por el célebre jurisconsulto y político José María Rivero (1814-1878), quien desde 1851 venía presidiendo el Partido Democrático, fundando en 1848 de una escisión del Partido Progresista. Al mismo se integrarán como redactores, colaboradores y articulistas los principales intelectuales, políticos y periodistas de la primera generación de demócratas y republicanos españoles. Aparece con el subtítulo "diario democrático", que mantendrá prácticamente inalterable a lo largo de su existencia, el dos de marzo de
} 
si bien los periódicos republicanos aceptaron sin discusión la nueva norma porque, a pesar de ser convocadas nuevas quintas en los meses venideros, por considerarlo una necesidad, aunque desagradable, imperiosa para el país y el sostenimiento de la República.

La Ley republicana de reclutamiento constituye un texto muy breve y conciso, aprobado siendo Presidente del Gobierno Estalisnao Figueras ${ }^{1093}$ y ministro de la Guerra Fernández de Córdoba ${ }^{1094}$, que recogió algunas generalidades de importancia sobre el proceso pero

1856, tendiendo un puente entre la izquierda del antiguo partido progresista y el demócrata recién legalizado durante el bienio.

Sus primeras polémicas serán contra el jacobinismo de La soberanía nacional, que dos años antes había fundado el fuorierista Sixto Cámara (1825-1859). Sin renunciar al programa antidinástico del partido de 1849 no hará cuestión fundamental la forma de gobierno, y gracias a la moderación y habilidad de Rivero, a su postura transigente y contemporizadora, sobrevive al golpe contrarrevolucionario de 1856. Al final del reinado isabelino, el antiguo secretario de Sixto Cámara, Bernardo García se hará cargo de la propiedad y dirección del diario, hasta que el 21 de junio de 1866 publica su último número de su primera época, al ser suspendido como los demás títulos demócratas y republicanos como consecuencia de la sublevación del Cuartel de San Gil.

Con ediciones de mañana y tarde y de provincias y la publicación de algunos suplementos esporádicos, y no apareciendo los lunes, La discusión se había convertido en el primer periódico de referencia nacional, con gran circulación y prestigio. [...]. Tras el triunfo de la septembrina, reaparece el seis de octubre de 1868, iniciando su segunda época, en un momento en que los demócratas se dividirán entre los denominados "cimbrios" o filoprogresistas, que se agruparán en el Partido Radical (José María Rivero, Cristino Martos, Manuel Becerra, etc.) desde el que alcanzarán las altas magistraturas del primer Estado democrático español, y los republicanos y federalistas. [...]. En noviembre de 1870 forma parte de la pléyade de periódicos antiamadeistas madrileños, que suman casi una treintena, y durante la segunda Asamblea Federal de 1871 será el más destacado baluarte del republicanismo benévolo, frente al intransigente representado por La igualdad. Protestará contra el golpe de Pavía de enero de 1874, y aunque se sume a las tesis de Emilio Castelar, este fundará su propio órgano: El orden. Con el golpe restaurador del general Arsenio Martínez Campos en Sagunto, La discusión publicará el último número de su segunda época el 30 de diciembre de 1874 [...]" (http://www.bne.es/es/Catalogos/HemerotecaDigital).

1093 DUARTE MONTSERRAT, A., "Stanislao Figueras y el quimérico liberalismo manso", en PÉREZ LEDESMA, M., y BURDIEL, I., Liberales eminentes, Madrid, Marcial Pons, 2008.

1094 Fernando Fernández de Córdoba, marqués de Mendigorría, militar y político, nació en Buenos Aires en 1809 y murió en Madrid en 1883. Se sublevó contra Espartero (1843) y prestó su apoyo a la reacción conservadora de Narváez. Fue ministro de la Guerra (1847), capitán general de Cataluña (1848), y Presidente del Gobierno en 1854. Participó en la Revolución Gloriosa de 1868 y se alistó en el Partido Radical de Ruiz Zorrilla. Fue ministro de la Guerra con Amadeo I y de la Primera República con Estalisnao Figueras, Diccionario Biográfico Español, edición digital, RAH, http://www.rah.es/cdeb.htm 
sin pormenorizar en sus distintas fases y operaciones. La inspiración de esta ley se encuentra en el proyecto de texto constitucional republicano de 1873 , nunca aprobado, que

"[...] presentó el servicio militar como un derecho de todos los ciudadanos y no como un deber. La reducción del Ejército activo, su profesionalización, y la organización de unas milicias populares, fueron los tres principios en los que se basó la estructura militar republicana"1095.

Estos principios fueron recogidos en la ley febrero de 1873, cuando los republicanos abolieron las quintas, si bien jamás se cumplieron al aprobarse en agosto de 1873 la movilización de 80.000 reservistas, "reconociendo de hecho la imposibilidad de un Ejército permanente de voluntarios por la inexistencia de éstos y de fondos para atraerlos"1096. Además, defendieron, desde sus órganos periodísticos, la inquebrantable adhesión de las fuerzas armadas al modelo político republicano:

"Otra de las cuestiones que más llaman la atención pública es la actitud del ejército, del cual se dice que no tiene disciplina. Esto no es exacto. Lo que hay es que nuestros valientes soldados, al grito de iviva Alfonso!, contestan con el de iviva la República! y á esto llaman insubordinación los reaccionarios ${ }^{\prime 1097}$.

Si pormenorizamos en el análisis de la ley, destacar que ésta inició su articulado dividiendo la fuerza militar española en ejército activo y reserva, declarando la abolición de la quinta y estableciendo

\footnotetext{
1095 FEIJÓO GÓMEZ, A., Quintas y protesta social en el siglo XIX español, p. 211. 1096 FEIJÓo GÓMEZ, A., Quintas y protesta social en el siglo XIX español, p. 218. 1097 La Discusión, 23/02/1873, no 1336, p. 1.
} 
únicamente un ejército de voluntarios en activo ${ }^{1098}$, exclusivamente españoles entre diecinueve y cuarenta años, remunerados a razón de una peseta diaria pagada semanal o mensualmente. Para la reserva en cambio sí que se mantuvo el reclutamiento obligatorio ${ }^{1099}$.

La prensa republicana mostró todo su apoyo al voluntariado, por considerarlo el método más justo de nutrir de tropas al Ejército, además del sistema más útil de cara a derrotar a los rebeldes carlistas:

"Con la movilización de grandes fuerzas de voluntarios, y la enérgica persecución que sufren los carlistas por parte del ejército, se conseguiría que la insurrección desapareciese en breve de las provincias que asola $y$ donde se sostiene merced al merodeo que

1098 Los grupos conservadores se mostraron atemorizados ante la posibilidad del fin del Ejército y el reparto de armas entre el proletariado, en un contexto además de guerra carlista: "Dentro de nuestros principios y de nuestro sistema de gobierno, el armamento de los ciudadanos es inútil y perjudicial bajo el aspecto económico como bajo el político; para mantener el orden y la paz pública en el interior, deben bastar la administración de justicia y los institutos armados, pero sabemos que los carlistas dominan en algunas provincias; que hay necesidad de reanimar el espíritu público y de escitar (sic) á los pueblos á que por si propios se defiendan; acostumbramos además aceptar en muchas cuestiones, y para qué nuestra crítica no sea estéril, el punto de vista y los compromisos ineludibles del adversario; y aplicando estas reglas de conducta al caso presente, diremos que no rechazaríamos lo que ha dado en llamarse "armamento del pueblo", si no viéramos, por una parte, que coincide con el desarme y desorganización del ejército; y por la otra, que por pueblo no se entiende mas que el proletariado. [...]. Si se prosigue desorganizando y desmoralizando por todos los medios imaginables al ejército, ya casi disuelto, y armando alas turbas proletarias, todos los buenos deseos del poder ejecutivo, todas las promesas de que la república no ha de sor el gobierno de un solo partido, le servirán para engañarse y engañamos", (La Época, 20/02/1873, p. 2, no 7449).

1099 Esta indefinición en la forma de nutrir la reserva encontró fuertes críticas: "Según el art. 12, compondrán la reserva todos los mozos que el día 1 de enero tengan veinte años cumplidos, y el art. 13 prescribe que cuando el número de soldados voluntarios no baste para completar la fuerza del ejército activo, se llamarán los de la reserva que sean indispensables. Ahora bien, ¿cómo se hace el indicado llamamiento? ¿qué regla» han de seguirse? La ley guarda sobre este punto importantísimo completo silencio, y ha de verse en grande apuro el gobierno á quien corresponda aplicarla por primera vez. Si moviliza toda la reserva, resultará un ejército activo doble ó triple del que las Cortes voten. Si apela al sorteo, volvemos á las quintas con todos sus detalles. Si llama á los mozos según la fecha de su nacimiento, se concederá á la mayoría de ellos un privilegio injustificable, dándose lugar por otra parte á muchos abusos. Gomo la ley es de origen radical y ahora tenemos una situación republicana, podría suceder que con arreglo á los principios del partido dominante, se resolviera la cuestión declarando abolido el servicio militar obligatorio (La Época, 20/02/1873, p. 2, no 7449). 
practica en los pueblos pequeños y que las tropas no pueden custodiar"$^{1100}$.

La duración de este servicio militar voluntario sería de un mínimo de dos años para los enganchados y de un año para los reenganchados. Se contempló la posibilidad de que los voluntarios pudiesen reengancharse indefinidamente al Ejército, teniendo opción tanto a ascensos en el escalafón militar como a premios por sus méritos. De igual forma tendrían derecho a una paga de invalidez en el supuesto de quedar inútiles para el servicio y tendrían preferencia para ocupar las plazas de porteros y ordenanzas que fuese necesario cubrir en cualquier administración pública. Asimismo podrían elegir el arma a la que deseasen ser destinados siempre y cuando existiesen vacantes en la misma. Se buscó de esta forma dotar de una mayor estabilidad al oficio de soldado para hacer así más atractivo el voluntariado. De la admisión de voluntarios a lo largo de todo el año se encargaría una comisión provincial formada por dos diputados provinciales, un jefe del Ejército y dos médicos, uno forense y otro militar. Sin embargo, sería el Gobierno el encargado de fijar, previa aprobación por las Cortes, la cantidad de reclutas voluntarios necesarios para completar la plantilla del Ejército ${ }^{1101}$.

En lo que respecta a la reserva, la ley señaló que se formaría todos los años con los mozos que el día 1 de enero tuviesen veinte años cumplidos. Su estado habitual sería pasivo y su duración sería de tres años, pero el Gobierno podría ordenar su movilización en caso de necesidad a través de un decreto o en el supuesto de que no existiese un número suficiente de voluntarios. De esta obligación quedarían eximidos los soldados voluntarios que hubiesen pertenecido al ejército activo. No se admitió la redención ni la sustitución para evadir la obligación de pasar de la reserva al ejército 
activo en caso de necesidad. Durante el primer año, los soldados de reserva recibirían la instrucción militar necesaria en la capital de provincia donde residiesen, mientras que en los dos años restantes solo tendrían obligaciones en caso de guerra y cuando las necesidades no pudiesen ser cubiertas con los mozos que se encontrasen en el primer año de reserva. No especificó más la ley respecto a su instrucción ni obligaciones ${ }^{1102}$. En cuanto a las exenciones, alistamiento, Ilamamiento, declaración de ingreso, lucha contra el prófugo y reclamaciones, se declaró vigente todo lo dispuesto en la Ley 30 de Enero de $1856^{1103}$.

Como ya hemos indicado anteriormente, la vigencia y aplicación práctica de esta ley fue muy limitada debido a la escasa duración de la I República. Además, la publicación de la disposición que llamaba al servicio a 80.000 hombres de la reserva, justificándose tal disposición en la ausencia de voluntarios suficientes y en la situación excepcional por la que atravesaba el país ${ }^{1104}$, además de la dramática situación de la Hacienda pública ${ }^{1105}$, significó el no ponerla en práctica ${ }^{1106}$ :

"Las dificultades económicas y la escasez de voluntarios en los cuerpos francos destinaron al fracaso la ley de abolición de la quinta de los republicanos y en el mes de agosto de 1873, con Salmerón en el poder, se pide a las Cortes Constituyentes la movilización de 80.000 reservistas, sin redención ni sustitución, con lo que, en la práctica, se restableció el ejército permanente ${ }^{\prime 1107}$.

\footnotetext{
1102 Ley de 17 de Febrero de 1873, arts. 12-17.

${ }^{1103}$ Ley de 17 de Febrero de 1873, disposición transitoria 4a.

1104 La propia prensa republicana apoyaba tal Ilamamiento: "Afortunadamente ayer al fin pudo aprobarse definitivamente, entre otras, la ley por la cual se llaman á las armas 80.000 hombres de la reserva. Con esto tendremos ejército" (La Discusión, $17 / 08 / 1873$, no 1518, p. 1).

1105 Discurso del Sr. Ministro de la Gobernación, Diario de Sesiones de las Cortes, 12/08/1873, no 64, p. 1392.

1106 Ley de 16 de agosto de 1873, decretada y sancionada por las Cortes Constituyentes, movilizando 80.000 hombres de los adscritos a la reserva, Diario de Sesiones de las Cortes, 16/08/1873, apéndice $2^{\circ}$ al no 68, p. 1.

1107 FRIEYRO DE LARA, B., De campesino a soldado. Las quintas en Granada (18681898), p. 28.
} 
Lógicamente su debate en Cortes ejemplificó un rotundo varapalo para los republicanos, que vieron como recibían las mismas acusaciones que hacía poco tiempo ellos mismos habían emitido de traición a la revolución y al pueblo e hipocresía por aprobar en el Gobierno aquello que con tanta dureza habían criticado desde la oposición:

"Recuerdo, como recordaréis todos, cual ha sido siempre el criterio del partido republicano, cuáles han sido sus ofertas de todo tiempo, cuales sus compromisos contraídos; y hoy veo con profundo sentimiento que esas ofertas se han olvidado, que a esos compromisos se ha faltado, y que en todo viene o intenta hacerse lo completamente opuesto a cuanto se hacía antes. [...]. Yo no creía, yo no podía creer, y aunque lo estoy viendo todavía lo dudo, que haya [...] hombres pertenecientes a un partido que apenas llegados al poder hagan precisamente todo lo contrario de cuanto tenían dicho y ofrecido"1108.

El desencanto que supuso para las masas la no eliminación de las quintas durante el periodo del Sexenio, "[...] junto a la radicalización de algunos sectores y la escalada de las ideologías socialista y anarquista, acabó con la lucha popular por la abolición de quintas, a favor de una lucha más genérica por la regeneración completa del sistema a través de la revolución violenta"1109.

En conclusión, podemos señalar el Sexenio como un periodo de grandes convulsiones políticas (cambios de régimen y de dirigentes) y militares (guerra Carlista, levantamiento en Cuba y sublevación cantonal), fracasada desde el punto de vista de la política militar, que además incumplió una de las principales promesas hechas a los grupos populares que apoyaron la Revolución, tal y como era la

1108 Discurso del Sr. Bartolomé y Santamaría, Diario de Sesiones de las Cortes, 12/08/1873, no 64, p. 1379.

${ }^{1109}$ FEIJÓO GÓMEZ, A., Quintas y protesta social en el siglo XIX español, p. 167. 


\title{
abolición de las quintas y el establecimiento de un ejército compuesto exclusivamente por voluntarios:
}

\begin{abstract}
"[...] La oposición popular ante la injusticia social reflejada en el sistema de reclutamiento, además del desengaño por el incumplimiento de las promesas realizadas antes de la Revolución del 68, generaron un continuo enfrentamiento social que se tradujo, no solo en altercados callejeros y amotinamientos populares, sino en un aumento del número de prófugos, y sobre todo en una progresiva ralentización del proceso anual del llamamiento y sorteo. Sin duda estas causas, reforzadas por la delicada situación planteada por los varios frentes bélicos abiertos por todo el país, fueron determinantes en el fracaso de la política militar llevada a cabo durante el Sexenio Revolucionario"1110.
\end{abstract}

1110 FRIEYRO DE LARA, B., De campesino a soldado. Las quintas en Granada (18681898), p. 32. 



\section{7.- El fin de las aspiraciones abolicionistas: La Ley de}

\section{7}

Finalizadas las convulsiones revolucionarias del Sexenio y de nuevo con los Borbones como dinastía gobernante, con Alfonso XII como nuevo Rey y Cánovas del Castillo como hombre fuerte del Gobierno, se imponía una vuelta al pasado, un regreso a las concepciones previas en materia de reclutamiento, lejos ya de las veleidades reformistas de los años previos ${ }^{1111}$. En los primeros meses de la Restauración alfonsina se volvieron a poner en vigor las leyes isabelinas y la Ley de $1870^{1112}$, a la espera de la aprobación de una nueva legislación que recogiese los principios doctrinales y prácticos de las nuevas autoridades monárquicas. Entre tanto,

"El Decreto de 10 de febrero de 1875 ordenó el reemplazo del Ejército entre los mozos que al 31 de diciembre de 1873 hubiesen cumplido diecinueve años y superasen los $1.560 \mathrm{~mm}$ de talla mínima, aunque la necesidad de incrementar el número de soldados para hacer frente a la guerra carlista y a la rebelión cubana obligó a reducir la talla mínima a $1.530 \mathrm{~mm}$. y a reclutar a los mozos que en 31 de diciembre de 1874 hubiesen cumplido dieciocho años $[\ldots]^{\prime 1113}$.

\footnotetext{
1111 "Ni Serrano ni los políticos de la Restauración se plantearon la abolición de las quintas, y durante los años 1874, 1875 y 1876, sucesivos decretos y Reales Ordenes regularon la quinta anual: el decreto de 10 de febrero de 1875 ordenó el reemplazo de 70.000 hombres según las instrucciones de la Ley de 1870 [...] y autorizando, de nuevo, la redención a metálico por 2.000 ptas. y la sustitución del cupo con reservistas si faltasen jóvenes de diecinueve años; la Real Orden de 29 de abril de 1875 solicitó la incorporación a filas de todos los que disfrutasen de licencias temporales por enfermedad, autorizando a los Gobernadores a emplear la Guardia Civil para buscarlos y entregarlos en su destino, o bien en los hospitales asignados" (FEIJÓO GÓMEZ, A., Quintas y protesta social en el siglo XIX español, p. 218).

1112 "En buena medida, con la llegada de Cánovas al poder se restablecen las líneas tradicionales de la quinta tal y como se entendía en la época isabelina" (FRIEYRO DE LARA, B., De campesino a soldado. Las quintas en Granada (1868-1898), p. 33).

${ }^{1113}$ FEIJÓo GÓMEZ, A., Quintas y protesta social en el siglo XIX español, p. 223.
} 
Señalar también que fue Cánovas quien, como paso previo a la aprobación de las leyes que a continuación analizaremos y una vez finalizada la guerra carlista, sometió a la aprobación de las Cortes la ley que ponía fin al privilegio de exención del servicio militar para los mozos del País Vasco, y así sería aprobado ${ }^{114}$.

Nos disponemos a analizar los nuevos textos legislativos implantados por las autoridades borbónicas, en concreto dos nuevas leyes de reclutamiento aprobadas de forma sucesiva, complementaria y con escaso margen de tiempo, un reglamento que desarrolló la primera y una ley, algo más tardía, que vino a reformar parcialmente la segunda. Se trata de la Ley de 10 de Enero de 1877 de Reemplazo del Ejército, del Reglamento que regula el ingreso, permanencia y baja de los mozos declarados soldados de 22 de Octubre de 1877, de la Ley de 28 de Agosto de 1878 de Reclutamiento y Reemplazo del Ejército, que además incluye un Reglamento de exenciones del servicio por causas de inutilidad física, y de la Ley de 8 de Enero de 1882 de Reclutamiento y Reemplazo, reformando la Ley de $1877^{1115}$.

Ambos textos vinieron a configurar las características del reclutamiento en los años de la Restauración, muy cercanas a la situación prerrevolucionaria, a imagen y semejanza del modelo prusiano, y alejadas ya de las veleidades abolicionistas del Sexenio:

1114 Ley de 21 de Julio de 1876 sobre quintas en las provincias Vascongadas, Gaceta núm. 207 de 25/07/1876.

1115 Ley de Reemplazos de 10 de Enero de 1877, Gaceta núm. 11 de 11/01/1877, en adelante Ley de Reemplazos de 10 de Enero de 1877; Reglamento para el ingreso, baja y permanencia en el Ejército de los mozos que sean declarados soldados con arreglo a la Ley de 10 de enero de 1877, Gaceta núm. 297 de 24/10/1877, en adelante, Reglamento de 24 de Octubre de 1877; Ley de Reclutamiento y Reemplazo del Ejército de 28 de Agosto de 1878, Gaceta núm. 253 de 10/09/1878, en adelante, Ley de Reclutamiento y Reemplazo de 28 de Agosto de 1878; Reglamento para la declaración de exenciones del Servicio en el Ejército y en la Marina por causa de inutilidad física, en delante, Reglamento de exenciones físicas de 28 de Agosto de 1878; Ley de Reclutamiento y Reemplazo de 8 de Enero de 1882, reformando la Ley de 1878, Gaceta núm. 45 de 14/02/1882. En adelante Ley de reclutamiento y Reemplazo de 8 de Enero de 1882, reformando la Ley de 1878. 
"Ajena la nueva clase política gobernante a las protestas populares, 1875 comienza con un llamamiento de 70.000 hombres para combatir en las guerras carlista y cubana, dejando claro cuan vanas eran las promesas de los que proclamaban la abolición de las quintas. Entonces, todos los partidos que firmaron la Constitución canovista se comprometieron con un sistema de reclutamiento que imitara al alemán [...], reclutando grandes contingentes en épocas de paz, pero con reemplazos más breves. Se busca una fórmula que no pusiera en peligro el erario público ni la eficacia de la instrucción militar; aunque con la particularidad que supuso el mantenimiento de las ya tradicionales exenciones económicas que favorecían tan solo a las clases privilegiadas"1116.

Las reacciones a las mismas serán analizadas a través del examen de los periódicos La Época, cuyas características ya fueron señaladas en el momento de analizar la Ley de 1873, y El Imparcial ${ }^{1117}$.

1116 FRIEYRO DE LARA, B., De campesino a soldado. Las quintas en Granada (18681898), p. 33.

1117 "Considerado como el periódico más influyente en España en el último tercio del siglo diecinueve y primeros años del veinte, es fundado por Eduardo Gasset y Artime (1832-1884), apareciendo su primer número el 16 de marzo de 1867, como diario vespertino [...] de carácter informativo alejado del doctrinarismo propio de los periódicos de partido y fuertemente ideologizados, que llegará a ser considerado como el principal periódico de los que iniciaron la gran transformación de la moderna prensa española.

Desde una zona templada, nace afín a la Unión Liberal y como opositor al gobierno del general Ramón María Narváez [...]. Desde sus columnas se gestará la coalición de liberales, progresistas, demócratas y antidinásticos que propiciarán la Septembrina, convirtiéndose en el órgano más influyente del Sexenio Democrático, como refleja el aumento de su tirada [...].

Con el diario de Gasset se va a acentuar el periodismo español de una forma considerable, en palabras de Asenjo y, según Seoane, se consolidará el periodismo noticioso y empresarial de calidad, mezcla de un cuidado aspecto informativo moderno y ambicioso, a medio camino entre la asepsia y los extremismos, y de una opinión democrática. Convertida su imprenta en centro de propaganda de la Septembrina, será el más firme apoyo de Amadeo I y reconocerá a la I República, al tiempo que inicia el desbancamiento de su rival, el ecléctico diario La correspondencia de España, que desde 1859 venía siendo el hegemónico. [...].

Hostil al principio a la Restauración, termina integrándose en un "realismo político", manteniendo su independencia desde una posición liberal amplia, según palabras de Seoane, y situándose frente al otro gran diario, el dinástico y canovista La época. Sin embargo, su integración plena en el sistema forzará a sus dos principales periodistas, Araús y Fernández Flórez, liderar una primera escisión que 
Nuevas funciones represivas otorgadas al Ejército como contexto histórico

Pocas etapas de la historia de España han estado más marcadas por la inestabilidad que los últimos meses del llamado Sexenio Revolucionario, periodo que coincide con la corta vida de la I República española: once meses en los que se sucedieron cuatro presidentes de gobierno para ser finalmente derrocado el sistema por el golpe de Estado del general Pavía, oficial de la guardia civil que forzó a Nicolás Salmerón a disolver las Cortes para crear, acto seguido, un gobierno de concentración nacional, del que fueron exceptuadas, no obstantes, algunas fuerzas políticas -caso de los cantonalistas y de los carlistas- y a cuyo frente se colocó el general Serrano, que terminó iniciando el proceso de reinstauración de la monarquía.

Con el regreso de la Corona, personificada en esta ocasión en el hijo de Isabel II, Alfonso XII, se abrió un nuevo periodo, la Restauración, caracterizado por la búsqueda de una estabilidad en los gobiernos que, hasta ese momento, había estado ausente en las siete décadas previas. La esencia del sistema fue el bipartidismo, dado que el panorama político quedó por completo bajo el dominio de dos formaciones, el Partido Liberal encabezado por Sagasta y el Partido Conservador, cuyo líder más notable era Cánovas del Castillo.

originará la fundación, en 1879, de El liberal, que competirá desde una posición ideológica republicana y más a la izquierda. Como gran órgano de opinión y una de las más importantes empresas periodísticas de la Restauración, El imparcial seguirá siendo uno de los diarios de mayor prestigio y circulación, dando la nota más intelectual de la prensa nacional. [...].

Durante la dictadura primorriverista el diario ya se encuentra en la más absoluta postración y agonía [...]. En abril d 1927, de nuevo, Rafael Gasset y su familia se deshacen del diario, y un año después será constituida Editorial Española, S.A., para la edición del periódico, siendo su propietario el Banco de la Construcción, desapareciendo en 1933, tras su dilatada, próspera e influyente existencia (http://www.bne.es/es/Catalogos/HemerotecaDigital). 
Fruto de este sistema -que recibió el nombre de turno pacífico, por la alternancia en el poder de ambas formaciones sin las rivalidades fratricidas que habían caracterizado los años anterioresfue la Constitución publicada en el año de 1876, que vino a sustituir a la extremadamente liberal de 1869. La Constitución de 1876, la norma de este rango que ha estado vigente durante más tiempo en la historia española -un total de cincuenta y cinco años- era más conservadora que su predecesora, y suponía un retroceso en determinados derecho, como en el caso de la libertad de culto, contenida en la Constitución de 1869, pero que la obra de 1876 restringía a aquellas creencias que no ofendieran a la moral y la religión católicas.

Si observamos la Restauración desde una perspectiva amplia, y analizamos de forma global la legislación que, en materia de reclutamiento, fueron implantando los sucesivos gobiernos monárquicos, ya fuesen conservadores o liberales, la primera conclusión que podemos obtener es la inexistencia de cambios de relevancia en los distintos textos legales sobre reclutamiento que se fueron aprobando hasta la implantación de la Ley de 1912. Es más, podemos decir que la base teórica y la regulación práctica del reclutamiento ya se encontraban establecidas en las distintas legislaciones aprobadas antes del Sexenio. Por tanto, los cambios observados son mínimos si tenemos en cuenta las leyes previas y posteriores al Sexenio, y la huella de la Revolución en materia de reemplazo no fue por lo tanto importante.

Finalizado el periodo revolucionario, la sociedad española de la Restauración presentó una triple perspectiva en cuanto a su visión del reclutamiento en función de sus intereses particulares:

"El mantenido por las clases altas y medias, que constituían su principal baluarte [del régimen canovista], el popular y el militar. Los 
acomodados estaban decididos a impedir cualquier ensayo de universalización del servicio, tras haber sufrido en sus carnes las consecuencias de la Ley de Castelar. El pueblo había llegado a identificar la abolición de las quintas con un aumento de la presión reclutadora y, en su mayoría, aceptó el retorno al sistema isabelino sin excesivas protestas. Los militares profesionales, muy inclinados hasta entonces al voluntariado, habían experimentado lo inviable de esta solución e intuido la eficacia del reclutamiento prusiano, por lo que en su práctica totalidad aceptaron como inevitable la constitución de un gran Ejército de masas, integrado por todos los jóvenes del país ${ }^{\prime 1118}$.

Si nos centramos en los textos legales del periodo restaurador previos a 1912, las novedades se centran en la reducción del tiempo del servicio militar y en el aumento del período que pasaban los soldados en situación de reserva ${ }^{1119}$. De nuevo Puell de la Villa diferencia dos etapas a este respecto:

"[...] una primera etapa, de predominio conservador, durante la cual se regularizó el sistema de reemplazos y se gestaron sus normas reglamentarias, y otra de mayoría liberal, caracterizada por un recrudecimiento de la cuestión en el parlamento, en la prensa y en la calle, sin que el debate abierto se plasmara en las páginas de la Gaceta" ${ }^{1120}$.

Una importante novedad a tener en cuenta para el reclutamiento militar durante la Restauración son las nuevas funciones otorgadas al Ejército tras la restauración de los

1118 PUELL DE LA VILLA, F., El soldado desconocido: de la leva a la "mili" (17001912), p. 283.

1119 PUELL DE LA VILLA, F., El soldado desconocido: de la leva a la "mili" (17001912), p. 284.

1120 PUELL DE LA VILLA, F., El soldado desconocido: de la leva a la "mili" (17001912), p. 284. 
Borbones $^{1121}$. Además de ser un instrumento para la guerra y guardián de los restos coloniales en Cuba y Marruecos, la institución bélica asumió el papel protagonista en la represión de los movimientos reivindicativos populares y de las incipientes organizaciones obreras: "El ejército constituía el bastión del gobierno, su más eficaz agente de represión contra su propio pueblo"1122. Por tanto, el Ejército se erigió en garante del orden social burgués y en el principal protagonista de la represión estatal ${ }^{1123}$. Otra nueva misión otorgada regularmente al Ejército y de forma más concreta, a los quintos, fue la de su utilización como mano de obra barata cuando estallaban conflictos laborales y escaseaban los trabajadores:

"Lo novedoso en este período fue que el propio Estado se convirtió en contratista e intermediario entre la tropa y los terratenientes o empresarios, afectados por conflictos laborales, e incluso autorizó el trabajo de individuos reclutados para la defensa de la Nación en el servicio de intereses particulares"1124.

Tampoco podremos conocer la evolución de la institución castrense española ni de sus sistemas de reclutamiento durante la Restauración sin tener en cuenta el impacto que, en toda Europa, tuvo el conflicto franco-prusiano de 1870, con la aplastante victoria del Ejército germano en Sedán y el hundimiento del Segundo Imperio francés. Fueron numerosas las conclusiones que se extrajeron de esta

1121 LLEIXÁ, J., Cien años de militarismo en España: funciones estatales confiadas al Ejército en la Restauración y el franquismo, Barcelona, Anagrama, 1986.

1122 HEADRICK, D. R., Ejército y política en España (1866-1898), p. 37.

1123 "La resistencia social a este tipo de medidas [redención y sustitución] es continua a lo largo de este período, aunque la fuerte represión policial y el establecimiento paulatino como defensor y garante del orden público, que caracterizará al período de la Restauración Borbónica, controlan los alborotos y amotinamientos callejeros que provocaba -en esta época en mucha menor medida que en el Sexenio- la llamada a quintas por todo el país" (FRIEYRO DE LARA, B., De campesino a soldado. Las quintas en Granada (1868-1898, p. 34).

1124 PUELL DE LA VILLA, F., El soldado desconocido: de la leva a la "mili" (17001912), p. 255. 
guerra, que encumbraba a la Alemania unificada de Bismarck como una de las grandes potencias europeas, especialmente en el ámbito militar. Una de ellas fue el achacar a las deficiencias en el sistema de reclutamiento la catástrofe militar del Ejército francés, así como una evidente admiración por los nuevos sistemas de movilización germanos:

"Había que imitar el modelo alemán; era preciso vivir preparados para la guerra; se imponía el paso de toda la juventud por los cuarteles, instruirla en el menor plazo de tiempo posible y mantenerla en reservas movilizables hasta alcanzar la madurez. Los presupuestos militares se triplicaron y el contingente llamado a filas se incrementó considerablemente. Las leyes de reclutamiento se germanizaron" ${ }^{1125}$.

España no iba a quedar al margen de estos vientos de cambio, pero con una peculiar interpretación por parte del partido Conservador de Cánovas, ya que las nuevas leyes de reclutamiento continuaron permitiendo que, aquellos cuya situación económica se lo permitiese, pudiesen no incorporarse a filas. La burguesía adinerada, que rechaza la universalización del servicio, continuó por tanto eximiéndose de la prestación a cambio del pago de una redención económica ${ }^{1126}$.

1125 PUELL DE LA VILLA, F., El soldado desconocido: de la leva a la "mili" (17001912), p. 272.

1126 "A partir de 1875, aunque ya se planteara con anterioridad, la política en materia de reclutamiento que pretenderá llevar a cabo el gobierno de la Restauración, será enfocada hacia la implantación en nuestro país del modelo alemán de reclutamiento de 1870. Dicho sistema, cuyo objetivo principal era mantener al país preparado en todo momento para la guerra, se basa en el establecimiento de una pequeña fuerza permanente y una copiosa reserva rápidamente movilizable a través del cumplimiento de un servicio activo corto pero más intenso. La principal diferencia que mantuvo el sistema español de reclutamiento fue el mantenimiento de las clásicas exenciones económicas que destruyen uno de los principios, el de la obligatoriedad del servicio militar, del modelo de Ejército prusiano que venía imponiéndose en el resto de Europa" (FRIEYRO DE LARA, B., El reclutamiento militar en la crisis de la Restauración: el caso riojano (1896-1923), p. 53). 
El modelo prusiano, a pesar de su difusión en toda Europa, quedaba en España pospuesto ante la oposición de las clases acomodadas; y ello a pesar de que la Constitución canovista de 1876 ya establecía "que todo español está obligado a defender a la Patria por las armas $[\ldots]^{\prime 1127}$. Los intentos y proyectos reformistas de algunos ministros pertenecientes al partido Liberal-Fusionista caerán en saco roto, y solo el desastre del 98 vino a cambiar, parcialmente, la visión que se tenía del reclutamiento.

Una vuelta al pasado siguiendo el modelo alemán a lo largo del desarrollo de la norma

La Ley de 1877, presentada por el ministro de la Guerra Francisco de Ceballos ${ }^{1128}$ en noviembre de $1876^{1129}$, y la Ley de 1878 , presentada en este caso por el ministro de la Gobernación Francisco Romero y Robledo ${ }^{1130}$, marcarán la política española de reclutamiento durante todo el periodo restaurador hasta las reformas de Canalejas de 1912. Sus injusticias, al no cambiar apenas los sistemas de reclutamiento heredados, fueron señaladas por la prensa del momento:

\footnotetext{
1127 Constitución de 30 de Junio de 1876, art. 3.

1128 Nacido en Torrelavega en 1814, ejerció como Capitán General de las Provincias Vascongadas y Cuba. Participó en los distintos conflictos militares que jalonaron la historia decimonónica española, así como en la revolución septembrina. Afiliado al partido Conservador de Cánovas y senador vitalicio, alcanzó el cargo de ministro de la Guerra en 1875, puesto que mantendría hasta 1879, Diccionario Biográfico Español, edición digital, RAH, http://www.rah.es/cdeb.htm

1129 Proyecto de ley, presentado por el Sr. Ministro de la Guerra, sobre organización y reemplazo del Ejército, Diario de sesiones de las Cortes, apéndice $1^{\circ}$ al no 127 , 20/11/1876, pp. 1-3.

1130 Originario de Antequera (Málaga), tuvo una muy dilatada carrera política iniciada con su participación en la revolución Gloriosa, para ocupar diversas y sucesivas carteras merced a su filiación al partido Conservador durante la Restauración: Gobernación, Ultramar y Gracia y Justicia. Conocido por sus manejos electorales como ministro, también alcanzó la presidencia del Congreso, Diccionario Biográfico Español, edición digital, RAH, http://www.rah.es/cdeb.htm
} 
"Y su esencia, ya lo hemos dicho, son los 100.000 hombres anualmente llamados á las filas, dejando en pié las irritantes desigualdades y las insostenibles desventajas del antiguo sistema de reemplazo y organización de nuestro"1131.

La prensa afecta al nuevo régimen restaurador se limitó por el contrario a reflejar el nuevo articulado de la ley ${ }^{1132}$ y a mostrar una actitud laudatoria respecto a su contenido sin inmiscuirse en sus puntos más polémicos:

"Importantísimo es el proyecto de ley sobre organización y reemplazo del ejército, que apareció ayer en la GACETA, para someterse á la aprobación de las Cortes. Y una de sus mejores condiciones es su carácter previsor, pues tiende, no a resolver como se ha hecho otras veces, la cuestión militar del momento, sino a crear para lo sucesivo un ejército instruido y numeroso, cuyo sostenimiento en tiempo de paz ni grave el presupuesto ni interrumpa los trabajos agrícolas, por estar la mayoría en sus casas, según el sistema seguido actualmente en las naciones militares mas adelantadas.

La organización de las reservas responde á las dos grandes necesidades de la época, en que hay que atender a dos problemas de naturaleza contraría, poro igualmente perentoria: la detener disponibles ejércitos de consideración, en época donde todos los pueblos europeos tienen también fuerzas permanentes numerosas $y$ temibles, y cuidar al mismo tiempo de que no se distraigan de las faenas agrícolas, industriales, ni del estudio, los trabajos mas útiles y un número considerable de inteligencias. No es una ley sistemática que se decide ciegamente por una de las tendencias estremas (sic) que se disputan la preferencia y el acierto en estas materias importantes. El principio de la institución no desaparece pero so limita con trabas que redundarán en beneficio de la ilustración. $Y$, sobre todo, tiende á evitar el vicio de que los reemplazos, destinados esclusivamente (sic) a cubrir las necesidades de la defensa nacional,

${ }^{1131}$ El Imparcial, 07/12/1876, p. 1.

1132 La Época, 21/11/1876, no 8780, p. 2. 
sean medios indirectos de proporcionar recursos de otro género con perjuicio de todas las clases sociales, pero especialmente las menesterosas"1133.

La Ley de 1877 es un texto breve, con una estructura muy distinta a las disposiciones legislativas aprobadas en fechas anteriores al Sexenio. Está compuesto por un total de 23 artículos y una disposición transitoria, sin dividirse los mismos en capítulos temáticos. Para la verdadera pormenorización de las distintas operaciones que atañen al reemplazo tendremos que esperar al reglamento aprobado en octubre de ese mismo año 1877 , limitándose esta ley a establecer las líneas generales que habían de regular todo el proceso.

Justificó el ministro Ceballos en el preámbulo del proyecto de ley la necesidad de una nueva norma que sustituyese a las del Sexenio, en la necesidad de legislación que permitiese tener "[...] pocos y buenos soldados en tiempos de paz, y muchos en el de guerra; y por eso se da con justísima razón una gran importancia a la sólida instrucción y disciplina de los primeros" ${ }^{1134}$.

En primer lugar destacar que la Ley de 1877 comenzó declarando la obligatoriedad del servicio para todos los españoles ${ }^{1135}$. Por lo tanto, en apariencia declaraba el servicio militar obligatorio.

1133 La Época, 22/11/1876, no 8781, pp. 1 y 2.

1134 Proyecto de ley, presentado por el Sr. Ministro de la Guerra, sobre organización y reemplazo del Ejército, Diario de sesiones de las Cortes, apéndice $1^{\circ}$ al no 127 , 20/11/1876, p. 1.

1135 Ya en 1876, una nueva norma vino a establecer la obligatoriedad de las quintas también en las Provincias Vascongadas: "Art. I'. Los deberes que la Constitución política ha impuesto siempre a todos los españoles de acudir al servicio de las armas cuando la Ley los llama, de contribuir en proporción a sus haberes a los gastos del Estado, se extenderán, como los derechos constitucionales se extienden, a los habitantes de las provincias de Vizcaya, Guipúzcoa y Álava, del mismo modo que a las demás de la Nación.

Art. $2^{\circ}$. Por virtud de lo dispuesto, en el artículo anterior, las tres provincias referidas quedan obligadas [...] a presentar, en los casos de quintas o reemplazos ordinarios y extraordinarios del Ejército, el cupo de hombres que les correspondan con arreglo a las Leyes" (Ley de 21 de Julio de 1876 sobre quintas en las provincias Vascongadas, Gaceta núm. 207 de 23/07/1876). 
Más allá de esta obviedad, a la postre no cumplida, señalar que la Ley de 1877 estructuró al Ejército en dos grandes conjuntos, permanente y reserva, debiendo los soldados designados en la quinta servir cuatro años en cada uno de ellos ${ }^{1136}$. La reserva podría ser movilizada a través de un real decreto del Consejo de Ministros ${ }^{1137}$. Aquellos que pasasen a formar parte de la reserva obtendrían "[...] licencia ilimitada a sus casas sin goce de haber alguno, pero quedando siempre dispuestos a presentarse cuando sean llamados" y además podrían desplazarse sin ninguna limitación dentro del país tras solicitar el permiso al jefe local respectivo. Además, aquellos reclutas en activo que no deseasen pasar a la reserva podrían hacerlo si cumpliesen los requisitos que fijasen los reglamentos ${ }^{1138}$.

Una vez establecida la estructura del Ejército, la ley se encargó de señalar que jóvenes formarían parte del mismo. Se integrarían en él aquellos mozos españoles ${ }^{1139}$, de veinte años o diez y nueve para cumplir veinte ese mismo año que obtuviesen la suerte de soldado en el sorteo a celebrar anualmente el primer domingo del mes de febrero en todos los pueblos y lugares de la península y el archipiélago Balear, no así Canarias. En función del cupo establecido, "ingresarán en el servicio activo los que sean necesarios, pasando los demás con licencia ilimitada a sus casas"1140. Nada se señala por

${ }^{1136}$ El diputado Sr. Salamanca presentó una enmienda solicitando la reducción del tiempo de prestación en el Ejército permanente de cuatro a tres años para aquellos reclutas que supiesen leer y a escribir como medio de fomentar la instrucción primaria entre los jóvenes, Discurso del Sr. Salamanca, Diario de sesiones de las Cortes, no 141, 07/12/1876, p. 3882.

1137 "La reserva que nosotros proponemos podrá llegar también a 200.000 hombres, y cuando esto suceda, que será cuando este proyecto lleve ocho años de practicarse, podrá contar el país con 400.000 hombres, aparte de la Guardia Civil, carabineros y batallones de marina, fuerza muy suficiente hoy para atender a nuestras necesidades interiores y para ocupar entre las Naciones de Europa el lugar honroso que a nuestra dignidad corresponde" (Discurso del Sr. Azcárraga, Diario de sesiones de las Cortes, no 141, 07/12/1876, p. 3872).

1138 Ley de Reemplazos de 10 de Enero de 1877, arts. 1-6, 8 y 9.

1139 Ley de Reemplazos de 10 de Enero de 1877, art. 15.

${ }^{1140}$ Ley de Reemplazos de 10 de Enero de 1877, art. 12. 
tanto de un ejército compuesto por voluntarios, ni por voluntarios y quintos si no hubiese suficientes jóvenes de la primera categoría ${ }^{1141}$.

Por lo que respecta al contingente de los ejércitos de Ultramar, éste se cubriría con voluntarios en primer lugar y por los mozos designados en el sorteo en el caso de no cubrirse el cupo establecido con voluntarios ${ }^{1142}$. Los reclutas destinados en los territorios ultramarinos solo cumplirían cuatro años de servicio activo, quedando exentos de servir en la reserva ${ }^{1143}$. Se intenta de este modo fomentar el voluntariado y atraer soldados hacia los territorios coloniales, el destino más inseguro y peligroso.

La estatura mínima exigida para el ingreso en el Ejército ascendió a $1.540 \mathrm{~m}$., si bien aquellos que alcanzasen 1,5 m. serían dados de alta en la reserva, debiéndose presentar al reconocimiento durante los cuatro años posteriores al sorteo. Si a lo largo de este periodo alcanzasen la talla requerida de $1.540 \mathrm{~m}$., pasarían a formar parte del ejército permanente ${ }^{1144}$.

También señaló la ley la posibilidad que tenía un recluta de acogerse a la sustitución, quedando a partir de este momento

\footnotetext{
${ }^{1141}$ Las quintas y el sorteo fueron defendidas por el diputado Alzugaray: "Yo creo que el sistema de quintas ha venido a ser una perfección en el camino del progreso en la parte que se refiere al servicio militar, porque los Gobiernos venían hallándose frente a frente con el problema de hacer compatible el precepto constitucional relativo a la obligación de todos los españoles de servir a la Patria con las armas en la mano, con la necesidad de mantener sobre las armas más que el número de soldados que se juzgaba indispensable y que estaba en armonía con las atenciones del Erario público [...]. Después de ensayarse todo tipo de sistemas, se vino al de quintas, que en rigor parecía el más equitativo y demostraba por parte de la Administración una gran parte de imparcialidad. Todos los jóvenes era imposible que fueran al servicio de las armas; habiendo de ir solo algunos, y la Administración, con su espíritu de imparcialidad, dejaba que la suerte, es decir, que las leyes providenciales, dijeran quienes eran los que habían de servir a la Patria con las armas en la mano [...]" (Discurso del Sr. Alzugaray, Diario de sesiones de las Cortes, no 141, 07/12/1876, p. 3879).

1142 "[...] se establece en nuestro proyecto de una manera definitiva y permanente el modo de cubrir las bajas del Ejército de Ultramar, haciéndose en el momento del Ilamamiento anual y evitando que el reemplazo del Ejército de Ultramar se limite al alistamiento de voluntarios y evitando también, y esto es peor, que haya que hacer frecuentes sorteos dentro de los cuerpos de la Península" (Discurso del Sr. Azcárraga, Diario de sesiones de las Cortes, no 141, 07/12/1876, p. 3872).

1143 Ley de Reemplazos de 10 de Enero de 1877, art. 13.

${ }^{1144}$ Ley de Reemplazos de 10 de Enero de 1877, art. 14.
} 
limitada a parientes de hasta un cuarto grado inclusive. No existía esta limitación en lo que se refiere a los sustituidos que fuesen destinados a Ultramar ${ }^{1145}$. También se admitía una de las grandes reclamaciones de las clases acomodadas, tal y como era la redención en metálico a cambio de 2.000 pesetas, quedando el redimido exento de cualquier responsabilidad, tanto del servicio activo como de la reserva ${ }^{1146}$. Para utilizar el beneficio de la redención se señaló que sería preciso "[...] que los que la pidan acrediten que siguen o que han terminado una carrera o ejercen una profesión u oficio"1147. El importe sería ingresado en efectivo en la caja del Consejo de Redenciones y Reenganches militares, quien anualmente rendiría cuentas de las cantidades percibidas e invertidas al Tribunal de Cuentas del Reino y al ministerio de la Guerra. Estas cantidades se destinarían obligatoriamente a los siguientes fines:

\begin{abstract}
"[...] primero, a obtener un número de enganchados y reenganchados que cubran las plazas de los redimidos; segundo, a satisfacer los compromisos que actualmente tiene contraídos dicho Consejo, según se prescribe en el artículo $5^{\circ}$ de la Ley de Presupuestos para el año económico de 1876 a 1877; y tercero, a satisfacer la parte de premio correspondiente al tiempo servido en activo al suplente cuyo número responsable en primer término redima su suerte en metálico" ${ }^{1148}$.
\end{abstract}

\footnotetext{
${ }^{1145}$ Ley de Reemplazos de 10 de Enero de 1877, art. 16.

1146 Uno de los argumentos utilizados en la defensa de la redención fue la dificultad que tendrían los jóvenes acomodados para adaptarse a la dura vida militar: "[...] no nos olvidemos de que la mayoría de los jóvenes educados en la abundancia y en las comodidades, no tienen en nuestro país las condiciones físicas necesarias para soportar la vida soldado sin que se resienta su salud, y vendrían por consiguiente a aumentar considerablemente la cifra de enfermos en los hospitales, con grave perjuicio del Tesoro, del servicio, y de los demás soldados, que con más robustez tendrían que suplirles" (Discurso del Sr. Azcárraga, Diario de sesiones de las Cortes, no 145, 13/12/1876, p. 4027).

${ }_{1147}$ Ley de Reemplazos de 10 de Enero de 1877, art. 17.

${ }^{1148}$ Ley de Reemplazos de 10 de Enero de 1877, art. 18.
} 
En el caso de existir un remanente económico sobrante, éste debería ser destinado a adquirir o mejorar el material de guerra o a otros capítulos relacionados con el servicio militar. Se abría la puerta por tanto a no dedicar todas las cantidades percibidas al pago de enganchados y reenganchados. No estableció la ley las condiciones que se exigirían a enganchados y reenganchados, limitándose a señalar que su edad mínima sería de dieciséis años ${ }^{1149}$.

Aún la prensa más templada se mostró enormemente crítica ante la injusticia que suponían redención y sustitución, apostando por una reducción e incluso exención del servicio en función de la instrucción, y no de la riqueza:

"El reemplazo se hará como antes, por los mozos á quienes la suerte designe con los números mas bajos y carezcan de 8.000 rs. para redimirse. La defensa del territorio continuará, pues, encomendada á las clases pobres, y ellas serán también las únicas sobre quienes recaerán los peligros de la guerra, ora la provoquen los partidos, ora revista carácter nacional. De esa manera entienden los conservadores que debe ser equitativamente interpretado el artículo de la Constitución que impone por igual á todos los ciudadanos el deber de defender la patria con las armas en la mano ¿Y cuando se establecen esos privilegios en favor de la riqueza? Precisamente en el momento que por, primera vez se piensa en organizar grandes fuerzas armadas ó disponibles para colocarnos al nivel de las domas potencias que nos precedieron en ese camino. Propónose el gobierno crear dos numerosas reservas, que con e I ejercito activo podrán ascender á cerca de 800.000 hombres, y lejos de caminar sus disposiciones á un reparto equitativo de las penalidades y molestias del servicio entre todas las clases, procura ante todo que los favorecidos de la fortuna se eximan de ellas, sin otra razón que la de tener dinero.

Tiene el servicio obligatorio grandes inconvenientes en la práctica, porque, ante todas cosas, aflige á las clases ilustradas

${ }^{1149}$ Ley de Reemplazos de 10 de Enero de 1877, arts. 19 y 20. 
mucho más que á las que no lo son; por eso precisamente se han establecido limitaciones que en lo posible equilibran la desigualdad con que pesa el .servicio militar sobre las distintas clases sociales; pero esas limitaciones no pueden ser sino temporales, y concedidas sólo á la ilustración. La mayor capacidad para el servicio, porque ningún obstáculo ni peligro hay en que los soldados instruidos y de mayor alcance intelectual permanezcan manos tiempo en las filas del ejército activo. La redención á metálico, además de ser irritante privilegio del dinero, viene á infligir mayores sacrificios á las clases pobres, las cuales han de cubrir forzosamente las plazas de los mozos redimidos ${ }^{\prime 1150}$.

Incluso la prensa afecta al régimen mostró una actitud similar respecto a la redención, criticando esta figura por las desigualdades que generaba, y apostando por la participación en el Ejército de las clases ilustradas por mejorar la calidad del mismo y rechazando en todo punto el voluntariado:

"Uno de los puntos mas vulnerables que á nuestro modo de ver ofrece este proyecto de reemplazo, es sin disputa alguna el de revestir aparentemente las condiciones del servicio obligatorio, pues no se concibe la existencia de tal sistema allí donde se autorizan el sorteo, la sustitución y la redención, como precedentes esenciales al reemplazo; siquiera estos precedentes difiere un tanto de los consignados en la ley de 30 de enero de 1856.

Por otra parte, el principio dé la redención tal y como aparece consagrado en el proyecto, entraña una desigualdad chocante cediendo a consideraciones del orden social, y una rémora constante para los progresos del ejército, examinado el caso bajo el punto de vista militar. Si el derecho de redimirse alcanza tul amplitud que pueden optar á él todos los que tengan una carrera, ocupación ú oficio, ¿A qué queda reducido el propósito de una perfecta organización, como no sea reunir en una masa informe todos los desechos de la sociedad, marcados con el estigma vergonzoso de la

${ }^{1150}$ El Imparcial, 09/12/1876, p. 1. 
vagancia ó con el sello sombrío de la miseria? ¿A qué queda reducido el precepto constitucional, que impone á todo español la obligación imperiosa de defender la patria con las armas en la mano?

$[\ldots]$.

Formando parte del ejército las clases ilustradas de la nación, el concierto do las grandes agrupaciones sociales será cada vez mas armónico, porque no puede menos de serlo tratándose de una profesión que tiene por base la defensa de la patria, ante cuyo sagrado altar ceden todas las preocupaciones, se estrechan todas las voluntades, y un sentimiento de noble emulación hace que el honor y la disciplina sean los únicos resortes que mueven la gran entidad destinada á tan altos y honrosos fines dentro de la esfera oficial. Pensar en otra solución que la del servicio obligatorio, teniendo á la vista los funestos procedentes del enganche voluntario, verdadera recluta de la vagancia y la mendicidad, es empeñarse en cerrar los ojos á la evidencia $[\ldots]^{\prime 1151}$.

Los agrios debates parlamentarios respecto al reclutamiento cesaron con la Restauración borbónica ${ }^{1152}$. Toda la Cámara estuvo de acuerdo en la necesidad de servicio militar y el sorteo. Las únicas voces moderadamente críticas en el Congreso hacia este proyecto de ley las encontramos no ya dirigidas como en los años revolucionarios hacia la prestación militar, los ejércitos permanentes y las quintas, sino dirigidas hacia dos cuestiones, sustitución y redención, "[...] que

\footnotetext{
${ }^{1151}$ La Época, 07/12/1876, no 8796, p. 2.

1152 "En el periodo 1875-1900 la cuestión de las quintas pasó a un segundo plano, reduciéndose los debates sobre las quintas a breves discursos en las fechas en que se discutió un nuevo proyecto de Ley de reemplazos [...], a pesar de que en la calle el tema mantuvo toda su vigencia, como no podría ser de otra manera en unas fechas en que las calamidades bélicas endurecieron la contribución de sangre, a pesar de que el control ejercido por el Estado sobre la prensa y la represión de manifestaciones y protestas, junto con la pérdida de protagonismo del republicanismo en las reivindicaciones populares, hicieron que la cuestión de quintas se oscureciese notablemente y fuese sustituida por reivindicaciones más generales que afectaban directamente a la estructuración social y económica. En las Cortes ya no se planteó el dilema quintas sí o quintas no, y mucho menos se cuestionó la existencia de un modelo u otro de Ejército en virtud del sistema de reemplazo. Los debates se limitaron a particularidades de la quinta, como la redención y la sustitución, y al interés del gobierno por mantener un amplio número de reclutas anualmente" (FEIJóo GÓMEZ, A., Quintas y protesta social en el siglo XIX español, p. 163).
} 
destruyen, que oscurecen la esencia del sistema en sí" $^{1153}$, ya que suponían un varapalo hacia la ilustración del Ejército al posibilitar la liberación del servicio de los grupos con mayores niveles de formación, las clases acaudaladas. Tal circunstancia podría provocar la formación de un ejército de menesterosos que pondría en peligro la tan ansiada estabilidad social. Además, la posibilidad de que los más pudientes no sirviesen en filas suponía un menosprecio hacia la institución armada y un incremento de los antagonismos de clase. Por ello, los diputados liberales Arcos y López Domínguez y el republicano Castelar ${ }^{1154}$ defendieron en la Cámara la adopción del servicio militar obligatorio universal siguiendo el modelo prusiano, sin posibilidad de sustitución ni redención en metálico ${ }^{1155}$, considerado como un ejemplo a seguir por su mejor organización e ilustración tras los éxitos obtenidos por las armas alemanas en territorios austriaco y francés. El servicio obligatorio sería la única forma de garantizar la eficacia en la movilización de las tropas para contar con un número suficiente de reclutas movilizados en un tiempo mínimo y para asegurar la igualdad total ante la ley ${ }^{1156}$. También solicitaron ambos diputados una mejor instrucción de la tropa para mejorar ya que "el sistema de servicio general obligatorio debe ser un elemento civilizador como base de la instrucción del pueblo, y mucho más en un país como el nuestro, por desgracia bien poco instruido"1157.

\footnotetext{
1153 Discurso del Sr. Los Arcos, Diario de sesiones de las Cortes, no 127, 06/12/1876, p. 3846.

1154 Discurso del Sr. Castelar, Diario de sesiones de las Cortes, no 145, 13/12/1876, pp. 4029-4032.

1155 Discurso del Sr. Los Arcos, Diario de sesiones de las Cortes, no 127, 06/12/1876, pp. 3846-3849.

1156 "Los Ejércitos dispuestos para entrar en campaña, han de constar en la actualidad de un número mucho más grande, mucho más importante que antiguamente; ¿y por qué? Porque ya no hay fronteras, porque los caminos de hierro, los medios de comunicación que hoy existen, el telégrafo, el vapor y la facilidad para mover las masas exponen a las Naciones a ver en pocos días invadidas sus fronteras por masas organizadas de 300.000 o 400.000 hombres, acaso por medio millón de soldados" (Discurso del Sr. López Domínguez, Diario de sesiones de las Cortes, no 141, 07/12/1876, p. 3865).

1157 Discurso del Sr. López Domínguez, Diario de sesiones de las Cortes, no 141, 07/12/1876, p. 3868.
} 
El diputado Pavía por su parte solicitó la supresión, no solamente de la sustitución y la redención, sino de cualquier tipo de exención, incluidas las de talla, por los numerosos beneficios que un servicio universal tendría desde el punto de vista militar, pero también desde una perspectiva puramente social:

"Visto el decaimiento del espíritu guerrero, del espíritu militar, la resistencia de todas las clases a venir al servicio militar y lo perjudicial de la redención, yo tengo la plena convicción de que para levantar este espíritu guerrero y este espíritu militar, que yo creo que es necesario en esta Nación, si hemos de entrar en el concierto europeo, es preciso que el servicio en el Ejército sea obligatorio, sea forzoso y sin ninguna excepción, ni siquiera la de talla, exceptuando únicamente los motivos de salud. [...]. Señores Diputados, entrando en el Ejército todos los jóvenes, sin excepción alguna, desaparecerían por completo esas diferencias odiosas de riquezas, esas diferencias de posición, e imprimiría al Ejército un espíritu militar, un espíritu honrado y un espíritu estudioso.

Las clases menesterosas vendrían sin mengua ni dolor al servicio militar; las clases acomodadas que no disponen de dinero tendrían el placer de poder entrar en un servicio sin ser depresivo y sin necesidad de sacrificios; y las clases ricas, puesto que todos eran iguales, vendrían con gusto. Esta juventud procedente de las diferentes clases sociales, esparciría por completo sus luces, su instrucción, su educación, y establecería una emulación grande y digna"1158.

El diputado Salamanca por su parte, siendo contrario a la exención económica del servicio militar, solicitó la reducción de la redención en metálico a tan solo 1.250 pesetas, si bien los redimidos quedarían liberados tan solo de los cuatro años en el ejército activo, pasando directamente a la reserva. De esta forma incluso los redimidos estarían obligados a servir a la Patria con las armas en la

1158 Discurso del Sr. Pavía, Diario de sesiones de las Cortes, no 141, 07/12/1876, p. 3877. 
mano en una coyuntura bélica, cumpliendo con esta forma con la obligatoriedad del servicio militar que recogía la ley ${ }^{1159}$.

También desde la prensa se escucharon algunas voces críticas hacia el nuevo proyecto de ley, proponiendo al Gobierno ciertas reformas que viniesen a mejorar su articulado:

"La Comisión que entiende en ese proyecto, y que ha emitido dictamen sobre él, se ha negado á alterar sus bases esenciales, á pesar de los grandes defectos que esas bases encierran, y de la energía con que algunos oradores los combatieron. Anteayer indicaba el Sr. López Domínguez, y ayer explanó, al mismo tiempo que esos defectos, las soluciones que pudieran remediarlos: el servicio obligatorio, el establecimiento de verdaderas reservas, de reservas útiles, un sistema de instrucción para todo el ejército, que comprenda desde la enseñanza elemental á la superior y la desaparición de todos esos preceptos de la ley de reemplazos, que no son compatibles con la idea de justicia y la regla de equidad á que han de subordinarse las leyes y los deberes impuestos á los ciudadanos. Como el Sr. López Domínguez conoce bien los vicios de que adolece la organización actual de la fuerza pública, como su pensamiento es militar y político, y aspira á que esa fuerza, en el concierto de todos los elementos sociales, ocupe un puesto levantado y realice una misión civilizadora, insistía ayer mucho en la conveniencia de difundir la instrucción en el ejército, asegurando que el soldado no es contrario á ella, y que debiera obligársele á que la adquiriera aprovechando los ocios del servicio militar, que en ciertas armas y en épocas de paz representan un espacio de tiempo no despreciable. Sería plausible que esta advertencia se recogiera y se tradujese en disposiciones inmediatas, no sólo por el ejército mismo, sino por la masa de los ciudadanos, que

1159 "Con la enmienda queda establecido que el servicio es obligatorio a todos los españoles, puesto que el individuo no puede redimirse más que por el tiempo del servicio en el Ejército activo, y ha de pasar cuatro años a la reserva; es decir, que es una redención por el tiempo de paz, y tiene la justicia de que en tiempo de guerra es obligatorio a todos, que es cuando el servicio militar es indudablemente más grave para las familias (Discurso del Sr. Salamanca, Diario de sesiones de las Cortes, no 145, 13/12/1876, p. 4016. 
al fin recabaría por completo en pro de los intereses generales del país la influencia de aquella idea"1160.

Por último, en lo que atañe a la Ley de 1877, señalar que el propio texto legislativo emplazó al ministerio de la Gobernación, de acuerdo con los de Guerra y Marina, a presentar ante las Cortes un nuevo proyecto de ley de reemplazos con el correspondiente cuadro de exenciones. Hasta la aprobación de la ley definitiva, regiría todo el proceso de reclutamiento la Ley de $1856^{1161}$. Como resumen del texto, El Imparcial nos dejó esta visión enormemente negativa, poniendo en cuestión incluso la constitucionalidad de la norma:

"Hecha ya la opinión en favor de los ejércitos numerosos y baratos, nutridos por la conscripción de todos los ciudadanos en determinada edad, parecía indudable que el primer paso dado en la reorganización de nuestro ejército había de llevarnos al planteamiento de un sistema que, haciendo efectivo, sin hipocresía, el precepto constitucional que á todos los españoles impone la defensa de la patria con las armas, creara un ejército permanente en las condiciones necesarias, $y$ reservas numerosas, instruidas $v$ bien dispuestas para hacer frente á los conflictos interiores y exteriores $[\ldots]$.

Pues nada se ha hecho para variar la viciosa organización de nuestro ejército. El proyecto sometido á la deliberación de las Cortes viene, por el contrario, á introducir nuevas confusiones, que sobre perjudicar los intereses puramente militares, y establecer prácticas, de dudoso constitucionalismo, grava considerablemente al país, sin ventaja alguna para la defensa nacional'1162.

${ }_{1160}^{1161}$ El Imparcial, 08/12/1876, p. 1.

1161 Ley de Reemplazos de 10 de Enero de 1877, art. 22.

1162 El Imparcial, 09/12/1876, p. 1. 
La consolidación del sistema en la aplicación y añadidos a la norma

$\checkmark$ La unificación de la variedad legislativa en el Reglamento de 1877 y Ley de 1878

Más allá de los principios generales que estableció la Ley de 1877, fueron el Reglamento de 22 de octubre de 1877 y la Ley de 28 de agosto de 1878 los textos que regularon todas las operaciones de reemplazo. La última ley vendría a ser el documento que unificó los dos textos anteriores y puso fin a la variedad legislativa, y fue aprobada tras la firma de la paz de Zanjón ${ }^{1163}$ que pacificaba la colonia cubana con el objeto de estabilizar la política de reclutamiento sin apenas introducir cambios en respecto a leyes anteriores ${ }^{1164}$. Su ratificación por parte del Congreso apenas encontró oposición parlamentaria y los debates en su seno fueron mínimos, al igual que su reflejo en la prensa, limitándose prácticamente a reflejar el articulado del texto, sin inmiscuirse en sus cuestiones más polémicas. Al igual que con la Ley de 1877, tan sólo la sustitución y la redención en metálico ocasionaron ciertas polémicas en Cortes.

La Ley de 1878 destacó por su amplitud, las más extensa de todo el siglo XIX, y pormenorización, ya que estaba compuesta por

1163 "Se trata de un momento idóneo para la regulación de las diversas normativas referentes al sistema de reclutamiento en España, recién firmada la Paz de Zanjón que establece el final de una guerra que llevaba diez años mermando los recursos del Tesoro y exigiendo un esfuerzo supremo a las familias de aquellos mozos que carecían de bienes materiales para eximirse del servicio de las armas" (FRIEYRO DE LARA, B., De campesino a soldado. Las quintas en Granada (18681898, p. 39).

1164 FRIEYRO DE LARA, B., El reclutamiento militar en la crisis de la Restauración: el caso riojano (1896-1923), p. 56. Previamente a la firma del tratado, el Parlamento aprobó un Proyecto de Ley que tenía por objeto incrementar el voluntariado en Cuba ofreciendo una exención del servicio para los que, voluntariamente, llevasen dos años sirviendo en la colonia caribeña, Proyecto de ley, aprobado por el Congreso, declarando exentos del servicio militar a los que lleven sirviendo dos años en los cuerpos de voluntarios de Cuba, Diario de sesiones de las Cortes, apéndice $5^{\circ}$ al no $120,11 / 11 / 1876$, p. 1. 
un total de 208 artículos agrupados en XVIII capítulos, a los que habría que unir el reglamento de exenciones físicas que se adjuntó a la ley. Su estructura, a diferencia de la Ley de 1877, fue muy similar a las aprobadas a lo largo de toda la centuria decimonónica. El reglamento por su parte estuvo estructurado en 120 artículos comprendidos en XII capítulos. Las similitudes entre ambos textos, aprobados con escaso margen de tiempo, nos ha llevado a unificar su análisis.

a) Principios generales: las limitaciones a la libertad de los jóvenes

Reglamento de 1877 y Ley de 1878 comenzaron declarando, en su primer capítulo, la obligatoriedad del servicio militar para todos los españoles ${ }^{1165}$ de veinte años de edad, con una duración de ocho años totales, cuatro en activo y cuatro en la reserva ${ }^{1166}$. El número total de mozos que habían de ingresar en el Ejército sería publicado anualmente a través de un real decreto expedido por el ministerio de la Gobernación a propuesta del ministerio de la Guerra en función de las necesidades de efectivos militares y de acuerdo con el Consejo de Ministros ${ }^{1167}$. De nuevo Gobernación y Guerra aparecen como los grandes protagonistas en la gestión de todo el proceso de reclutamiento, el primero en cuanto a la organización y ejecución del mismo, y el segundo como principal interesado en cuanto a la renovación de su plantilla.

\footnotetext{
1165 "Para servir en el Ejército en cualquiera clase se admitirán solamente españoles" (Ley de Reclutamiento y Reemplazo de 28 de Agosto de 1878, art. 13). 1166 Reglamento de 24 de Octubre de 1877, arts. 6 y 7; Ley de Reclutamiento y Reemplazo de 28 de Agosto de 1878, arts. 1, 2, 4, 5, 6 y 7.

1167 "Esta norma [...] supuso el definitivo retorno a la normalidad al consagrar un sistema de reclutamiento muy semejante al instaurado en las reformas de Narváez de 1867. Tal y como quedó redactada aparcó definitivamente la profesionalización de las clases de tropa, pues se consideró inviable, aparte de costoso, encontrar suficiente número de voluntarios [...]" (PUELL DE LA VILLA, F., El soldado desconocido: de la leva a la "mili" (1700-1912), p. 272).
} 
Al igual que en la Ley de 1877, se declaró que los jóvenes que no hubiesen obtenido la suerte del soldado en el sorteo, "[...] quedarán en sus hogares con licencia ilimitada, a disposición del Gobierno bajo la denominación de reclutas disponibles"1168. Se consolida por tanto esta nueva figura del reclutamiento, solamente movilizable en casos de emergencia, que sería mantenida en leyes posteriores.

Para asegurar la concurrencia al llamamiento para el servicio militar, la Ley de 1878 estableció la obligación, para todos los jóvenes a partir de dieciocho años, de solicitar su inscripción en las listas del Ayuntamiento donde residiese ${ }^{1169}$. Igual obligación tenían los padres de los mozos y "[...] los directores o administradores de los asilos o establecimientos de beneficencia en que se criaron o en que se hallaren los mozos huérfanos de padre y madre y los expósitos" ${ }^{\prime 1170}$. Si el mozo en cuestión hubiese omitido voluntariamente su participación en el alistamiento y sorteo "[...] serán puestos con el número correlativo de inscripción en cabeza de lista del primer llamamiento que se verifique después de descubierta la omisión, y destinados al servicio activo sin jugar suerte ni oírseles ninguna excepción, además de las penas en que puedan incurrir si hubiesen procurado su Comisión con fraude o engaño"1171. En caso de haber sido declarados inútiles para el servicio, serían multados con el pago de 50 a 200 pesetas, así como con el arresto de uno a tres meses de prisión. Ninguno de estos individuos podrían desempeñar cargo público u honorífico alguno ni ser ordenados in sacris si no justificaban, a través de un certificado emitido por el alcalde de su localidad o por el gobernador, que habían solicitado su inscripción en las listas y que habían cumplido sus obligaciones con el llamamiento.

\footnotetext{
${ }^{1168}$ Ley de Reclutamiento y Reemplazo de 28 de Agosto de 1878, art. 16. 1169 Ley de Reclutamiento y Reemplazo de 28 de Agosto de 1878, art. 21. 1170 Ley de Reclutamiento y Reemplazo de 28 de Agosto de 1878, art. 22. ${ }^{1171}$ Ley de Reclutamiento y Reemplazo de 28 de Agosto de 1878, art. 24.
} 
La Ley de 1878 también estableció límites a la libertad de movimientos de los mozos al prohibir a los jóvenes entre los quince y los treinta y cinco años de edad, a no ser que acreditasen estar libres de responsabilidades, el salir del reino ${ }^{1172}$. Y si un mozo que obtuviese la suerte de soldado se encontrase en el extranjero y no se presentase para el cumplimiento de su obligación, su plaza no sería cubierta por su suplente, sino que el ministerio de la Guerra debería cubrir su vacante con los fondos obtenidos de la redención en metálico ${ }^{1173}$.

Ya hemos señalado como el Ejército permanente quedó dividido en activo y reserva, y los propios soldados pertenecientes al servicio activo se dividieron a su vez en dos categorías: los que debían ingresar como soldados en los distintos cuerpos al formar parte del contingente anualmente fijado; y los que, por exceder de dicho contingente, gozarían de licencia ilimitada con el nombre de reclutas disponibles ${ }^{1174}$. Los soldados en situación de reserva gozarían por su parte de licencia ilimitada para regresar a sus casas, pero estarían, durante los cuatro años que durase este periodo, dispuestos a presentarse cuando fuesen llamados. Esta circunstancia podría quedar en suspenso en caso de guerra ${ }^{1175}$. Tanto soldados de reserva como reclutas disponibles podrían viajar, en función de sus intereses, por la península, sin más limitación que solicitar un pase al jefe de la reserva respectiva. Estos pases serían devueltos tras su regreso y no se les podría negar a no ser que el Gobierno los hubiese limitado por cuestiones bélicas. Sin embargo, el permiso para trasladarse al archipiélago Canario o a los territorios de Ultramar debería se analizado individualmente por el ministerio de Guerra,

\footnotetext{
1172 Ley de Reclutamiento y Reemplazo de 28 de Agosto de 1878 , arts. 24 y 25. 1173 Ley de Reclutamiento y Reemplazo de 28 de Agosto de 1878, arts. 26 y 27. 1174 Reglamento de 24 de Octubre de 1877, arts. 7-9.

${ }^{1175}$ Ley de Reclutamiento y Reemplazo de 28 de Agosto de 1878, arts. 7 y 8.
} 
"[...] siendo obligación del interesado acreditar cada dos meses su existencia, y dar conocimiento al capitán general del distrito en que resida a fin de que por esta Autoridad llegue el correspondiente justificante al jefe de su Cuerpo"1176.

Si el mozo marchase de su residencia sin la autorización necesaria, sufriría una condena de un máximo de dos meses de prisión, a no ser que cayese en el delito de deserción. En este delito caerían aquellos individuos de la reserva, reclutas disponibles, destinados a Ultramar y los que estuviesen en observación de mayor estatura, que no se presentasen cuando fuesen llamados por la autoridad militar competente ${ }^{1177}$. En el supuesto de que el mozo en la reserva quisiera desplazarse al extranjero, sería el ministerio de Guerra el único capacitado para conceder tal permiso a través de una real orden, previo análisis de las motivaciones del recluta ${ }^{1178}$.

Además de estas limitaciones a la movilidad de los reclutas, se impusieron otras que también atañían a su vida personal. Así, se prohibió a los reclutas en activo, disponibles o con licencia temporal o ilimitada contraer matrimonio. Sí se les permitió en cambio a los que pasasen a la reserva ${ }^{1179}$.

También se ofrecieron en este primer capítulo premios para aquellos que se licenciasen con buena nota. Así, encontrarían éstos reclutas una atención preferente, siempre que reuniesen las capacidades exigidas, para los siguientes puestos públicos:

"[...] peones camineros, carteros y peatones o conductores de la correspondencia pública, celadores y ordenanzas de telégrafos, guardas o sobreguardas de montes, individuos de los

\footnotetext{
${ }^{1176}$ Reglamento de 24 de Octubre de 1877, art. 10.

1177 Reglamento de 24 de Octubre de 1877, arts. 11 y 13.

1178 Reglamento de 24 de Octubre de 1877, art. 10.

1179 Reglamento de 24 de Octubre de 1877, art. 12; Ley de Reclutamiento y Reemplazo de 28 de Agosto de 1878, art. 9.
} 
resguardos de tabacos y administradores subalternos de Loterías, Alcaldes de las cárceles de distrito judicial, vigilantes o celadores de los ferrocarriles, ordenanzas, porteros y cualesquiera otros dependientes de las oficinas del Estado, Ayuntamiento, Diputaciones Provinciales, juzgados de primera instancia $y$ municipales"1180.

Además, las viudas de los reclutas, sus hijas e incluso sus hermanas en el caso de no existir las dos primeras categorías, tendrían derecho preferente sobre otras personas a la hora de desempeñar la expendeduría de loterías, siempre que acreditasen buena conducta y reuniesen los requisitos exigidos ${ }^{1181}$.

b) La diversidad de las exenciones

El Reglamento de 1877 dedicó escasos artículos a la cuestión de las exenciones en el cumplimiento del servicio militar, pero la Ley de 1878 se extendió en dos largos capítulos, noveno y décimo, a regular esta temática, incluyendo un cuadro de exenciones físicas al final de la norma ${ }^{1182}$. Como regla general, quedarían excluidos del servicio, aunque no lo solicitasen, la siguiente variedad de categorías:

"10.-Los comprendidos en alguna de las exenciones físicas que marque el reglamento y cuadro aprobado al efecto.

\footnotetext{
${ }^{1180}$ Reglamento de 24 de Octubre de 1877, arts. 14 y 15.

${ }_{1181}$ Reglamento de 24 de Octubre de 1877, art. 16.

1182 El objetivo sería reducir al máximo el número de exenciones legales: "Consecuencia natural [...] es la limitación de las excepciones legales a sólo aquellos casos en los que evidentemente las aconseja el buen servicio del Estado o la satisfacción de alguna necesidad apremiante de los particulares. Por esta razón se restringen prudentemente en los términos que dicta la experiencia, y se otorgan con carácter temporal, sujetándolas a revisión por espacio de cuatro años para evitar que un defecto pasajero de lugar a una exención absoluta [...]" (Proyecto de Ley, presentado por el Sr. Ministro de la Gobernación, sobre el reemplazo del Ejército, Diario de sesiones de las Cortes, apéndice $1^{\circ}$ al no 11, 01/03/1878, p. 1).
} 
20.- Los que exima la Ley de reemplazos por circunstancias de familias.

30. - Los redimidos a metálico.

40. - Los que no tengan la talla de un metro 500 milímetros.

50.- Los que se sustituyan con hombres exentos de responsabilidad en activo y reserva" ${ }^{\prime 183}$.

La primera categoría de exenciones sería aquella que hacía referencia a las motivaciones físicas. Aquellos mozos declarados evidentemente incurables quedarían libres de cualquier responsabilidad, pero aquellos que fuesen considerados inútiles por cualquier enfermedad o defecto físico no incluido en el cuadro de exenciones deberían presentarse ante la comisión provincial de reclutamiento durante tres años sucesivos para ser reconocidos médicamente. $\mathrm{Si}$ en alguno de estos reconocimientos fuesen declarados útiles, ingresarían en el servicio activo ${ }^{1184}$.

También serían exceptuados del servicio aquellos mozos que, en el momento de ser declarados soldados, se encontrasen sufriendo condena de cadena, reclusión o presidio mayor, siendo sus suplentes los que ocuparían su plaza. Cuando la pena que hubiesen recibido fuese menor, estos mozos serían destinados a los cuerpos de Ultramar o a las guarniciones fijas africanas. Tal y como indicaba la Ley de 10 de enero de 1877, también quedarían exentos del servicio los jóvenes que no alcanzasen la talla mínima de 1.540 m., si bien aquellos que superasen los $1.500 \mathrm{~m}$. pasarían a formar parte de la reserva, debiendo presentarse anualmente ante la Diputación provincial de su provincia respectiva para ser tallados. Si alcanzasen en alguno de los cuatro años siguientes al sorteo la talla mínima exigida, pasarían a formar parte activa del Ejército durante cuatro

1183 Reglamento de 24 de Octubre de 1877, arts. 1 y 2; Ley de Reclutamiento y Reemplazo de 28 de Agosto de 1878, art. 3; Ley de Reclutamiento y Reemplazo de 28 de Agosto de 1878, art. 91.

${ }^{1184}$ Ley de Reclutamiento y Reemplazo de 28 de Agosto de 1878, arts. 86 y 87. 
años $y$, en el caso de no hacerlo, recibirían licencia absoluta. Quedarían sin embargo exentos de incorporarse al servicio activo cuando los reclutas reservas fuesen llamados a las armas ${ }^{1185}$.

Además de estas excepciones por motivos físicos, quedaron excluidos del servicio, por interés estratégico o económico del país, las siguientes profesiones:

"10. - Los inscritos en la matrícula de mar.

20. - Los mineros de Almadén.

30. - Los religiosos profesos de las Escuelas Pías y Misioneros de Filipinas.

40.- Los alumnos de las Academias Militares.

50. - Los colonos agrícolas"1186.

Se justifica la exención de aquellos que se encontrasen inscritos en la matrícula de mar por su obligación de servir en los buques de la Armada, que se consideró sustituto del servicio militar en el Ejército $^{1187}$.

Por lo que respecta a los religiosos profesos de las Escuelas Pías y misioneros de Filipinas, quedarían exentos siempre que no abandonasen la orden religiosa antes de cumplir los treinta años de edad; y en lo que se refiere a los mineros de Almadén, éstos solo quedarían exentos si en el año anterior al reemplazo que les correspondiese, siendo oriundos de los pueblos de la zona, hubiesen cumplido un mínimo de cincuenta jornadas en trabajos subterráneos o en la fundición de minerales, o cien si eran forasteros y no abandonasen el trabajo en la mina antes de cumplir los treinta años. Lo mismo sucedía con los oficiales del Ejército y la Armada y los alumnos de academias y colegios militares, quedarían exentos

\footnotetext{
${ }^{1185}$ Reglamento de 24 de Octubre de 1877, arts. 3, 4, 72-75; Ley de Reclutamiento y Reemplazo de 28 de Agosto de 1878, art. 88.

${ }_{1186}$ Reglamento de 24 de Octubre de 1877, art. 5.

${ }^{1187}$ Ley de Reclutamiento y Reemplazo de 28 de Agosto de 1878, art. 89.
} 
siempre que no dejasen de pertenecer a estas instituciones antes de cumplir los treinta años de edad ${ }^{1188}$.

Una tercería categoría que eximía del servicio sería aquella que tenía en cuenta las motivaciones familiares, que incluía las siguientes situaciones:

"10.- El hijo único que mantenga a su padre pobre, siendo éste impedido o sexagenario.

20.- El hijo único que mantenga a su madre pobre, siendo ésta viuda o casada con persona también pobre y sexagenaria o impedida.

30. - El hijo único que mantenga a su madre pobre, si el marido de ésta, pobre también, se hallare sufriendo condena que no haya de cumplir dentro de un año.

40. - El hijo único que mantenga a su madre pobre, si su marido se halla ausente por más de diez años [...].

50.- El expósito que mantenga a la persona que lo crió y educó $[\ldots]$.

60. - El hijo único natural que mantenga a su madre pobre, que fuere célibe o viuda, habiéndole ésta criado y educado como tal hijo, o si siendo casada, el marido, también pobre, fuese sexagenario o impedido.

70. - El mozo que mantenga a su abuelo o abuela pobres, siendo aquél sexagenario o impedido y ésta viuda, con tal que dicho nieto sea huérfano de padre y madre y haya sido criado y educado por su abuelo o abuela indicados.

80. - El nieto único que reuniendo las circunstancias expresadas en el párrafo anterior, mantenga a su abuela pobre, si el marido de ésta fuera también pobre y sexagenario o impedido.

90.- El hermano único de uno o más huérfanos de padre $y$ madre, si los mantiene desde un año antes del llamamiento $y$ declaración de soldados, o desde que quedaron en la orfandad, siendo dichos hermanos pobres y menores de 17 años o impedidos [...].

100. - El hijo de padre que, no siendo pobre, tenga otro $u$ otros hijos sirviendo personalmente en los cuerpos del Ejército activo, por haberles cabido la suerte, si privado del hijo que pretende eximirse no

${ }^{1188}$ Ley de Reclutamiento y Reemplazo de 28 de Agosto de 1878, art. 90. 
quedase al padre otro varón de cualquier estado, mayor de 17 años, no impedido para trabajar $[\ldots]^{\prime 1189}$.

La ley también estableció qué se consideraba hijo único para evitar posibles dudas. Así, se señaló que se consideraría hijo único a aquel joven que, teniendo uno o más hermanos, éstos fuesen menores de diecisiete años, impedidos para trabajar, soldados en el Ejército o delincuentes que estuviesen cumpliendo penas de prisión, condena de cadena o de reclusión ${ }^{1190}$.

Todos los mozos incluidos en la categoría de exentos por circunstancias familiares quedaban obligados a presentarse a los actos de llamamiento y declaración de los soldados durante los tres reemplazos siguientes $y$, en el caso de haber cesado su excepción, ingresarían en el servicio activo o como reclutas disponibles según la suerte que les hubiese correspondido en su reemplazo ${ }^{1191}$.

Aclaró el texto legislativo que los jóvenes que hubiesen sido condenados o que estuviesen procesados por causa criminal en el lapso de tiempo que transcurría entre el sorteo y la entrega en caja no quedarían exentos del servicio. Se estableció que los mozos que en el momento de ser entregados en caja hubiesen sufrido condena de inhabilitación, confinamiento, destierro, vigilancia por la autoridad, suspensión de cargo público, derecho político, profesión u oficio, arresto o multa, ingresarían en el servicio activo como cualquier mozo que hubiese obtenido en el sorteo la suerte del soldado. Si la pena recibida fuese la prisión, el recluta sería destinado a las guarniciones del norte de África. Y si la condena fuese anterior a la celebración del sorteo que había decidido su suerte, el destino del recluta variaría en función de la pena. Si la pena era de cadena, reclusión o presidio mayor, el penado no ingresaría en filas, y se

1189 Ley de Reclutamiento y Reemplazo de 28 de Agosto de 1878, art. 92.

1190 Ley de Reclutamiento y Reemplazo de 28 de Agosto de 1878, art. 93.

${ }^{1191}$ Ley de Reclutamiento y Reemplazo de 28 de Agosto de 1878, art. 95. 
llamaría a filas al suplente que correspondiese, que sería dado de baja cuando el recluta titular hubiese cumplido su pena; si la pena impuesta fuese la de presidio mayor o menor, el destino del recluta condenado sería el norte de África; si la pena fuese simplemente de inhabilitación, confinamiento, destierro o multa, el mozo ingresaría con normalidad en la caja de reclutas correspondiente a la provincia de su localidad de residencia; y si la pena fuese de relegación, el joven ingresaría en los cuerpos de Ultramar. Si en el momento de ingresar en caja el recluta se encontrase procesado por causa criminal y a la espera de juicio, ocuparía su plaza el suplente, que quedaría liberado en el momento en que el recluta titular hubiese sido absuelto o que la pena a la que ha sido condenado no fuese la de presidio $^{1192}$.

c) La distribución del contingente: el ministerio de Guerra solicita y el de Gobernación dispone

El segundo capítulo del Reglamento de 1877 y el tercero de la Ley de 1878 señaló que correspondía al ministerio de Guerra establecer qué número de reclutas necesitaba anualmente para cubrir las bajas acumuladas en el Ejército, debiendo comunicárselo al de Gobernación para que éste realizase el reparto del contingente entre las distintas provincias. Este ministerio publicaría en la Gaceta de Madrid el cupo de hombres con el que había de contribuir cada provincia, mientras que correspondía al de Guerra distribuir el contingente fijado en cada provincia entre las siguientes armas: Infantería, Artillería, Caballería, Ingenieros y Batallones de Marina. Fuera de este reparto quedaban las brigadas sanitarias y los obreros de la administración militar, cuyas necesidades de efectivos no serían cubiertas con reclutas sino con soldados que hubiesen completado su

${ }^{1192}$ Ley de Reclutamiento y Reemplazo de 28 de Agosto de 1878, arts. 96-99. 
instrucción militar y que hubiesen terminado 0 se encontrasen estudiando Medicina o Farmacia para el caso de las brigadas militares, o que ejerciesen como panaderos u otros oficios propios del servicio en el caso de la administración militar ${ }^{1193}$.

Una vez repartido el cupo provincial por parte del ministerio de Gobernación, eran las comisiones provinciales de reclutamiento quienes deberían elaborar el reparto entre las distintas localidades "[...] en proporción al número de mozos sorteados que tenga cada pueblo en el año del reemplazo"1194. Este cupo podría componerse por enteros, enteros y décimas o exclusivamente décimas, situación que obviaba el Reglamento de 1877. El documento de repartimiento entre los pueblos de la provincia debería estar impreso, por parte del gobernador civil, los primeros días del mes de marzo, para ser enviado al ministerio de la Gobernación ${ }^{1195}$.

Asunto importante dentro del reparto del contingente era la cuestión del sorteo de décimas o quebrados, situación que no afectaba a un posible recluta directamente, sino al municipio que la suerte designase y que se verificaría a través de un sorteo a celebrar en la comisión provincial de reclutamiento. La Ley de 1878 aclaró qué localidades se verían afectadas por esta situación:

"Si sumados todos los soldados y décimas que resultaren del repartimiento [...] faltasen algunos soldados y décimas para completar el cupo de la provincia, se exigirá a razón de una décima por cada pueblo a los que hubiesen quedado con mayor fracción decimal, después de descontado el cupo que les haya correspondido. Se tomará en cuenta para este efecto la fracción que represente el cupo de aquellos pueblos que no tengan mozos suficientes para dar una

1193 Reglamento de 24 de Octubre de 1877, arts. 17-21; Ley de Reclutamiento y Reemplazo de 28 de Agosto de 1878, arts. 28-30.

1194 Ley de Reclutamiento y Reemplazo de 28 de Agosto de 1878, art. 31. Más tarde, estas comisiones de reclutamiento se convirtieron, a través de la ley de 21 de agosto de 1896, en las llamadas comisiones mixtas.

${ }^{1195}$ Ley de Reclutamiento y Reemplazo de 28 de Agosto de 1878, arts. 32 y 42. 
décima; y si al agregar la última o las últimas décimas resultasen dos o más pueblos con igual fracción sobrante, la suerte decidirá cual o cuales de ellos han de sufrir la agregación"1196.

Una vez hecho el señalamiento de décimas, la comisión provincial de reclutamiento procedería a sortear, a puerta abierta, los quebrados entre los pueblos designados. En los globos no se introducirían papeletas con el nombre de posibles soldados, sino de los pueblos que se encontrasen en esta situación, tantas papeletas cuantas sean las décimas con que debía contribuir cada localidad. El resultado del sorteo debería la comisión publicarlo en un documento con tres columnas: en una figurarían el número de mozos sorteados en cada pueblo, en otra el número de soldados y décimas que le había correspondido a cada uno y, en una última columna, los reclutas que cada localidad debiese afrontar ${ }^{1197}$.

Uno de los capítulos más importantes en la distribución del contingente es el referente al servicio en Ultramar. El capítulo VIII del Reglamento de 1877 se encargó de esta cuestión, si bien se limitó a señalar que las bajas en estos cuerpos se cubrirían con voluntarios y "[con] los individuos del Ejército activo que se designen, en la forma que se prevenga por disposiciones especiales"1198. Para fomentar el voluntariado se ofrecía a los allí destinados el cumplimiento exclusivo de cuatro años en el ejército activo, quedando dispensados del servicio en la reserva ${ }^{1199}$. En el caso de no poder completarse el cupo necesario con voluntarios, la Ley de 1878 estableció que se procedería a realizar un sorteo entre todos los individuos del servicio activo. El número de soldados del ejército de Ultramar sería fijado anualmente por una ley aprobada por las Cortes $y$, en el supuesto de encontrarse éstas cerradas y en situaciones de emergencia, el

\footnotetext{
${ }^{1196}$ Ley de Reclutamiento y Reemplazo de 28 de Agosto de 1878, art. 33.

1197 Ley de Reclutamiento y Reemplazo de 28 de Agosto de 1878, arts. 34-41.

1198 Reglamento de 24 de Octubre de 1877, art. 76.

${ }^{1199}$ Reglamento de 24 de Octubre de 1877, arts. 77 y 78.
} 
contingente ultramarino podrá ser fijado por el Gobierno a través de un decreto ley ${ }^{1200}$.

d) El alistamiento y su rectificación

El Reglamento de 1877 pasó por alto la fase del alistamiento, pero no así la Ley de 1878, que la dedicó un total de cinco capítulos, entre el cuarto y el octavo. El alistamiento se elaboraría anualmente en todos los pueblos de la península y Baleares, excluyéndose todavía al archipiélago Canario, e incluiría a todos los jóvenes cuyos padres tuviesen 0 hubiesen tenido residencia en cualquiera de ambos territorios aunque habitasen en otro punto del reino 0 en el extranjero en el momento de realizarse el alistamiento. En él se incluirían a todos los mozos de veinte años, pero también a los menores de treinta y cinco que por cualquier motivo no hubiesen sido incluidos en alistamientos anteriores, aunque fuesen casados o viudos con hijos ${ }^{1201}$.

Para realizar el alistamiento y otras fases del reemplazo se admitió la posibilidad de que los términos municipales con mucho vecindario, sí lo consideraba oportuno el gobernador de la provincia, pudiesen dividirse en secciones de al menos 10.000 almas cada una. Estas secciones serían consideradas como pueblos independientes a todos los efectos en las operaciones del reemplazo y serían controladas por una comisión integrada por al menos tres individuos del Ayuntamiento. Los términos municipales compuestos por su parte por poblaciones dispersas serían considerados como una sola localidad para la formación del alistamiento, siempre que estas poblaciones no excediesen de los 500 habitantes $^{1202}$.

1200 Ley de Reclutamiento y Reemplazo de 28 de Agosto de 1878, art. 20.

1201 Ley de Reclutamiento y Reemplazo de 28 de Agosto de 1878, arts. 31, 15 y 17. 1202 Ley de Reclutamiento y Reemplazo de 28 de Agosto de 1878, arts. 43-45. 
La formación del alistamiento se debería iniciar el día primero de noviembre cuando los alcaldes de todas las localidades deberían publicar un bando haciendo saber a la población de su término municipal que se iba a proceder a la formación del alistamiento y recordando a los jóvenes comprendidos en la edad militar la obligatoriedad de inscribirse en el mismo. Sería durante los primeros días del mes de diciembre cuando se elaboraría anualmente tal alistamiento. Para ello las autoridades municipales podrían acudir al padrón municipal, a los libros del Registro Civil y a los libros parroquiales. Este documento incluiría a todos los mozos de veinte años, cualquiera que fuese su estado e independientemente de que se encontrasen ausentes dentro o fuera del reino, y los clasificaría ${ }^{1203}$ en función del lugar de residencia del mismo mozo o de sus padres ${ }^{1204}$.

Este alistamiento debería incluir también a los jóvenes que ya estuviesen sirviendo en el Ejército por cualquier concepto, excepto el haber obtenido ya la suerte del soldado, y en cualquiera de sus clases, categorías, institutos y dependencias ${ }^{1205}$. No incluiría sin embargo a los ya licenciados en el Ejército, los que se hubiesen redimido en metálico o presentado un sustituto en el reemplazo anterior, los que no llegasen a la edad de diecinueve años o pasasen

1203 "10.- Los mozos cuyo padre o cuya madre, a falta de éste, hayan tenido su residencia durante los dos años anteriores hasta el día $1^{\circ}$ de diciembre inclusive en el pueblo en que se hace el alistamiento, aunque se hayan ausentado posteriormente.

20.- Los mozos cuyo padre o cuya madre, a falta de este tengan su residencia desde $1^{0}$ de diciembre en el pueblo donde se hace el alistamiento.

30.- Los mozos que hayan tenido su residencia de igual modo en los dos años anteriores, siempre que hubiesen permanecido en el pueblo dos meses, cuando menos, durante aquel tiempo.

$4^{\circ}$.- Los mozos que tengan su residencia desde $1^{\circ}$ de diciembre en el pueblo en que se hace el alistamiento.

50.- Los naturales del mismo pueblo" (Ley de Reclutamiento y Reemplazo de 28 de Agosto de 1878, art. 20).

1204 Llama la atención que "[se] considerarán comprendidos en la edad requerida para el alistamiento los mozos que, aparentando tenerla notoriamente, no acrediten con documentos lo contrario" (Ley de Reclutamiento y Reemplazo de 28 de Agosto de 1878 , art. 50).

${ }^{1205}$ Ley de Reclutamiento y Reemplazo de 28 de Agosto de 1878, arts. 46-49. 
de treinta y cinco y los que hubiesen sido alistados y sorteados en años anteriores ${ }^{1206}$. En el supuesto de que un pueblo no pudiese completar su cupo con los mozos comprendidos en el alistamiento quedaría exento de toda responsabilidad ${ }^{1207}$.

La Ley de 1878 también se ocupó de aclarar el concepto de residencia del mozo para evitar posibles dudas y fraudes al respecto:

"10.- Se entiende por residencia la estancia del mozo o del padre o de la madres en el pueblo donde cada uno de éstos ejerza de continuo su profesión, arte u oficio u otra cualquier manera de vivir conocida, o bien donde habitualmente permanece, manteniéndose con el producto de sus bienes.

20. - No se considerará interrumpida la residencia porque el mozo, el padre o la madre se haya ausentado temporalmente del pueblo o lugar en que vive.

30.- Tampoco se considerará interrumpida la residencia del mozo en un pueblo porque lo deje eventualmente para dedicarse a los estudios o al aprendizaje de algún arte u oficio, siempre que regrese durante sus vacaciones cuando estos estudios o aprendizaje hubiesen terminado"1208.

En el acto de formación del alistamiento deberían estar presentes todos los miembros del consistorio y los curas o párrocos que éstos designasen para suministrar los datos que se les solicitase. El documento, que debería mostrarse públicamente durante un plazo de diez días, sería firmado por los concejales y el secretario municipal $y$, en caso de que existiesen omisiones indebidas, serían éstos personajes los responsables de las mismas y serían castigados con una multa de cien a doscientas pesetas los primeros y de doscientas

${ }^{1206}$ Ley de Reclutamiento y Reemplazo de 28 de Agosto de 1878, art. 58. 1207 Ley de Reclutamiento y Reemplazo de 28 de Agosto de 1878, art. 18. 1208 Ley de Reclutamiento y Reemplazo de 28 de Agosto de 1878, art. 51. 
a trescientas el segundo por cada mozo que no hubiese sido incluido en el alistamiento sin causa justificada ${ }^{1209}$.

Existía la posibilidad de rectificar el alistamiento ante posibles errores $\mathrm{u}$ omisiones en el mismo. Las reclamaciones podrían ser presentadas por los interesados o sus padres, parientes reconocidos, amos o apoderados, el primer domingo del mes de enero previo anuncio público y citación personal de todos los jóvenes comprendidos en el alistamiento. Estas protestas podrían versar tanto de la inclusión errónea como de la exclusión indebida de algún mozo, y deberían ser escuchadas todas por los miembros del Ayuntamiento, admitiendo las pruebas que se presentasen, y tomando a continuación una decisión por votación por mayoría absoluta. Todo lo expuesto, un extracto de las pruebas presentadas y las resoluciones del Ayuntamiento debían ser recogidos en un acta.

El consistorio podría declarar excluido del alistamiento a un mozo que no cumpliese las condiciones para estar en el mismo aunque el propio interesado no hubiese presentado una reclamación. En el supuesto de que las pruebas presentadas por los reclamantes no pudiesen verificarse en el acto, el Ayuntamiento podría establecer un plazo prudencial de tiempo para su presentación, y así se recogería en el acta. Para no frenar las operaciones del reemplazo y hasta el cumplimiento del plazo establecido, se consideraría que no se había presentado alegación alguna y el recluta continuaría formando parte del proceso como uno más. Una vez superado el plazo prescrito, las reclamaciones se considerarían desestimadas. Si el acto de rectificación del alistamiento no pudiese concluirse el primer domingo del mes de enero, se continuará en los días festivos inmediatos y no festivos si fuese necesario hasta su conclusión. El día 31 de enero debería estar finalizada la rectificación, y las listas

${ }^{1209}$ Ley de Reclutamiento y Reemplazo de 28 de Agosto de 1878, arts. 52-54. 
corregidas deberían ser firmadas por los individuos del Ayuntamiento y el secretario ${ }^{1210}$.

También la nueva ley confirmó una posibilidad de reclamar la decisión tomada por el consistorio. Para ello deberían los reclamantes presentar su queja por escrito en un plazo máximo de quince días desde la resolución del Ayuntamiento ante la comisión provincial de reclutamiento. Este documento iría acompañado por un certificado elaborado por la máxima autoridad municipal, a no ser que se le niegue o retarde al interesado injustificadamente. La comisión provincial podría decidir al respecto instruir un expediente si así lo considerase oportuno. Su decisión sería ejecutiva sin perjuicio de que los interesados pudiesen recurrir, como última instancia, al ministerio de la Gobernación ${ }^{1211}$.

Esta misma comisión decidiría asimismo en los casos en que un mozo hubiese sido incluido en los alistamientos de dos o más localidades cuando los Ayuntamientos respectivos no se pusiesen de acuerdo, siguiendo los siguientes criterios de prioridad:

"10.- Al alistamiento del pueblo en el que el padre, o a falta de este la madre del mozo, haya tenido por más tiempo su residencia durante los dos años anteriores.

20.- Al alistamiento del pueblo en que el padre, o falta de este la madre, tenga su residencia desde $1^{\circ}$ de diciembre, o la haya tenido en este día.

30. - Al alistamiento del pueblo en que el mozo haya tenido por más tiempo su residencia durante los dos años anteriores.

40.- Al alistamiento del pueblo en que el mozo tenga su residencia desde $1^{\circ}$ de diciembre, o la haya tenido en este mismo día.

50. - Al alistamiento del pueblo de que el mozo sea natural"1212.

${ }^{1210}$ Ley de Reclutamiento y Reemplazo de 28 de Agosto de 1878, arts. 55-57 y 5962.

1211 Ley de Reclutamiento y Reemplazo de 28 de Agosto de 1878, arts. 63-66.

1212 Ley de Reclutamiento y Reemplazo de 28 de Agosto de 1878, art. 67. 
Si no consiguiesen tomar una resolución, remitirían el expediente al ministerio de la Gobernación para que decidiese en última instancia ${ }^{1213}$.

e) La exhaustiva regulación del sorteo

El Reglamento de 1877 apenas reguló la fase del sorteo, pero la Ley de 1878 sí que realizó un exhaustivo análisis de la misma, dedicando su capítulo VIII a esta cuestión.

Ingresarían en los cuerpos activos del Ejército y la Armada no todos los mozos que anualmente fuesen declarados soldados, sino exclusivamente el contingente previamente fijado por los ministerios de Gobernación y Guerra. Para designar a los mozos que anualmente formarían parte del contingente se celebraría en todos los pueblos de la península y de las Baleares un sorteo entre los jóvenes de veinte años o que cumpliesen veinte durante ese año. El sorteo se realizaría anualmente el primer día festivo del mes de febrero a las siete de la mañana en todos los municipios españoles, sin posibilidad de ser aplazado por la existencia de recursos pendientes acerca del alistamiento. Este sorteo se celebraría a puerta abierta ante los miembros del Ayuntamiento y los propios interesados. Para su celebración se escribiría el nombre de los jóvenes alistados en papeletas iguales, y en otras papeletas, también iguales, tantos números como mozos alistados hubiese. Las mismas se introducirían en bolas y éstas en dos globos, uno con nombres y otro con números. De su extracción, una vez removidos los globos, se encargarían dos niños menores de diez años, uno para cada globo. Las papeletas extraídas con los nombres serían entregadas a un concejal, que las

${ }^{1213}$ Ley de Reclutamiento y Reemplazo de 28 de Agosto de 1878, arts. 67-69. 
iría leyendo una por una, mientras que a continuación el presidente iría leyendo el número que hubiese obtenido cada joven. Estas papeletas serían mostradas a los restantes miembros del Ayuntamiento y a los interesados que así lo deseasen, y se conservarían unidas hasta que termine el sorteo. Se declararía además la responsabilidad en el cumplimiento de la legalidad del Ayuntamiento en este acto ${ }^{1214}$.

Para terminar el sorteo el secretario debería redactar un acta donde se anotase el nombre de los mozos que fuesen saliendo y el número que le hubiese correspondido a cada uno para, después de ser leída en público, ser firmada por los miembros del consistorio y por el propio secretario, fijándose copias de la misma en los sitios públicos habituales ${ }^{1215}$.

Ningún sorteo podría ser anulado a no ser que así lo decretase expresamente el ministerio de la Gobernación por considerar que no existía otra posibilidad para subsanar los errores que se hubiesen cometido. Se intenta de esta forma que las reclamaciones no frenasen todo el proceso. Si a consecuencia de las reclamaciones presentadas ante la comisión provincial o el ministerio de la Gobernación algún mozo quedase excluido del alistamiento, el sorteo no se repetiría, y descenderían los nombres correspondientes a los números que siguiesen al individuo excluido. Si por el contrario se debiese incluir a algún individuo, se ejecutaría un sorteo supletorio. En él también existirían dos globos, uno con tantos números cuantos mozos hubiesen participado en el primer sorteo, y otro con el nombre del recién incluido y tantas papeletas en blanco como papeletas introducidas en el primer globo ${ }^{1216}$. Extraídas las papeletas, "[...] el número que corresponda a la que tiene el nombre del mozo nuevamente incluido será el que tenga este, y se ejecutará otro

\footnotetext{
1214 Ley de Reclutamiento y Reemplazo de 28 de Agosto de 1878, arts. 70-74. 1215 Ley de Reclutamiento y Reemplazo de 28 de Agosto de 1878 , arts. 75 y 76. ${ }^{1216}$ Ley de Reclutamiento y Reemplazo de 28 de Agosto de 1878, arts. 77-79.
} 
sorteo entre él y el mozo que hubiese sacado el mismo número en el sorteo primero". En este nuevo sorteo se incluiría en dos papeletas el nombre de los dos mozos y, en otras dos papeletas, se escribiría el número que obtuvieron ambos y el siguiente, quedando designado a través de su extracción el joven que fuese a conservar el número que tuvieron los dos en su momento ${ }^{1217}$.

En un plazo máximo de tres días desde la celebración del sorteo, los alcaldes deberían remitir al gobernador de la provincia tres copias del acta del mismo, con el nombre de todos los jóvenes sorteados y del número que les hubiese tocado en suerte. El gobernador enviaría una de las copias a la comisión provincial y otra al ministerio de la Gobernación. Los individuos del Ayuntamiento que hubiesen firmado estas copias serían responsables de su exactitud, pudiendo ser sancionados con una multa de hasta 250 pesetas por cada joven que hubiesen incluido u obviado de forma errónea en el sorteo $^{1218}$.

Una vez finalizado el sorteo, se citaría personalmente a través de edictos a los mozos que hubiesen obtenido la suerte del soldado, a fin de que se presentasen al acto de llamamiento y declaración de los soldados, acto éste que se celebraría el segundo día festivo del mes de febrero. Además de este anuncio general, se citaría personalmente a los implicados para su presencia en dicho acto a través de tarjetas duplicadas emitidas por el Ejército. Una se le entregaría al recluta, mientras que la otra se uniría a su expediente ${ }^{1219}$.

1217 Ley de Reclutamiento y Reemplazo de 28 de Agosto de 1878, arts. 80-82.

1218 Ley de Reclutamiento y Reemplazo de 28 de Agosto de 1878, art. 83.

1219 Ley de Reclutamiento y Reemplazo de 28 de Agosto de 1878, arts. 84 y 85. 
f) Llamamiento y declaración de los soldados

De nuevo el Reglamento de 1877 pasó por alto esta fase del proceso de reclutamiento, pero no así la Ley de 1878, que dispuso que el acto de llamamiento y declaración de los soldados se realizaría el segundo día festivo del mes de febrero. Si no se finalizase durante esa jornada, se realizaría los días siguientes sin ser necesario que fuesen días festivos. Al acto deberían acudir, además de los jóvenes requeridos para su ingreso en el Ejército, los concejales del Ayuntamiento en cuestión, siempre que no fuesen parientes de hasta cuarto grado de alguno de los mozos sujetos al Ilamamiento. Reunido el consistorio, se procedería a tallar y a obtener declaración de los mozos empezando por aquel que obtuvo el número uno en el sorteo hasta completar el cupo asignado a la localidad. Si no alcanzase la talla de $1.540 \mathrm{~m}$., se anotaría como falto de talla y se procedería a llamar a los números siguientes. Los jóvenes que se negasen a ser tallados o que adoptasen posturas no naturales en el momento de tallarse, podrían ser multados por parte del alcalde con una sanción económica de entre 5 y 150 pesetas, quedando detenido hasta que fuese tallado, incluso por la fuerza, en los días sucesivos. En el caso de que el mozo alcance la talla requerida, así se anotaría y se procedería a examinar las otras cualidades necesarias para el servicio. Sería un sargento designado por el gobernador militar de la provincia el encargado de realizar el tallaje de los mozos. Si no hubiese sargentos suficientes, tallaría a los jóvenes una persona inteligente designada por el Ayuntamiento que recibiría una gratificación a cargo de los fondos municipales. Para vigilar todo el proceso y procurar que el tallador cumpliese fielmente con su cometido, asistiría a este acto un oficial de la guarnición o de la reserva designado por el gobernador militar. Si no fuese posible la 
asistencia de un oficial en activo, lo haría uno retirado que se presentase voluntario a petición del consistorio ${ }^{1220}$.

En este mismo acto de llamamiento y declaración, los mozos o la persona que los representase podría presentar los motivos que tuviese para ser considerado exento del servicio, recibiendo por parte del Ayuntamiento un certificado donde se recogiesen las motivaciones alegadas. Se admitirían para ello las justificaciones y documentos que se presentasen, y se establecería asimismo un plazo temporal máximo para su presentación en caso de no poder aportarse durante el mismo acto, cuya finalización sería anterior a la fecha señalada para el traslado de los reclutas a la capital de provincia. El mozo que pretendiese eximirse del servicio por falto de talla o defecto físico debería presentarse ante el Ayuntamiento para ser reconocido. Durante este mismo acto podría el consistorio declarar al mozo soldado o excluido. Para que un mozo fuese declarado exento por inutilidad física, todos los miembros del consistorio deberían estar de acuerdo. Si no fuese así, se recogería en el acta, se declararía provisionalmente soldado al mozo y se dejaría la decisión a la comisión provincial de reclutamiento. Siempre que se excluyese del servicio o no se considerase apto para el mismo a algún mozo, se llamaría a un suplente ${ }^{1221}$.

Una vez terminada la declaración de los soldados requeridos a un pueblo para el servicio activo, se procedería a tomar declaración de todos los demás mozos sorteados, que obtendrían licencia ilimitada con la categoría de reclutas disponibles. Si alguno de los mozos que hubiese obtenido la suerte del soldado se encontrase a una distancia de menos de $300 \mathrm{Km}$. del pueblo al que perteneciese, el Ayuntamiento le debía conceder un plazo prudente para su

1220 Ley de Reclutamiento y Reemplazo de 28 de Agosto de 1878, arts. 100-103, 109 y 122.

1221 Ley de Reclutamiento y Reemplazo de 28 de Agosto de 1878, arts. 104-108 y 116. 
presentación antes de ser declarado prófugo y presentar en su sustitución al suplente. Si el mozo se encontrase a más de $300 \mathrm{Km}$. de distancia, había sido declarado prófugo o se desconociese su paradero, se entregaría al soldado suplente y se iniciarían los trámites para su captura ${ }^{1222}$.

Terminado el acto de declaración y llamamiento de los mozos sorteados en el año del reemplazo, se procedería a realizar las mismas operaciones y a examinar la exención que había excluido del servicio a aquellos reclutas destinados a la reserva durante los tres reemplazos anteriores ${ }^{1223}$.

Las decisiones tomadas por el Ayuntamiento durante este acto serían inapelables si no se presentasen ante el alcalde reclamaciones por escrito o por palabra en los días anteriores de la marcha de los soldados a la capital de provincia. En caso de existir indicios de fraude, la comisión provincial de reclutamiento podría investigar al consistorio. El alcalde debería hacer constar en el expediente de declaración de los soldados las reclamaciones presentadas y debería entregar a los reclamantes el correspondiente certificado de haber presentado una reclamación donde se indicase su nombre y el objeto de la misma. La comisión provincial podría revisar las exenciones otorgadas por un Ayuntamiento cuando lo considerase oportuno ${ }^{1224}$.

g) El ingreso en el servicio y la conducción a la caja de reclutamiento

Los capítulos III y IV del Reglamento de 1877 y los capítulos XII y XIII de la Ley de 1878 atendieron al ingreso de los nuevos

1222 Ley de Reclutamiento y Reemplazo de 28 de Agosto de 1878, arts. 110, 117 y 118.

1223 Ley de Reclutamiento y Reemplazo de 28 de Agosto de 1878, art. 114.

1224 Ley de Reclutamiento y Reemplazo de 28 de Agosto de 1878, art. 115. 
soldados en la institución armada. Sería una Comisión Permanente, denominada caja de recluta y establecida en todas las capitales de provincia, la encargada de recibir a los mozos que habían sido declarados soldados. Formada por un comandante que actuaría como jefe de la caja, un capitán y dos sargentos o cabos del arma de Infantería, podría recibir la ayuda eventual de otros subalternos si así lo considerase necesario el capitán general o gobernador militar. Los cargos principales serían nombrados por el ministro de Guerra, y los subalternos por el director de Infantería ${ }^{1225}$.

Correspondería al ministerio de Gobernación por su parte la tarea de fijar las fechas en las que las distintas localidades debían entregar a los mozos que han sido declarados soldados, nunca antes del día 12 de marzo. El ministerio de Guerra obraría en consecuencia, debiendo declarar abiertas las cajas en la misma época en que los jóvenes debiesen ingresar en ella. En el acto de entrega de los mozos estarían presentes obligatoriamente un comisionado del Ayuntamiento de casa localidad, un diputado provincial designado por la Diputación y el comandante de la caja. El comisionado municipal, que acompañaría a los jóvenes durante su viaje a la capital de provincia, no podría tener interés en el reemplazo y sería gratificado con fondos municipales. Debería ir acompañado de una certificación literal de todas las diligencias practicadas por el Ayuntamiento en los actos de alistamiento y declaración de los soldados y de las reclamaciones presentadas, y recibiría un certificado con el nombre de los mozos que hubiese entregado. También los reclutas serían socorridos durante el trayecto y hasta su ingreso en caja con cincuenta céntimos de peseta diarios a cargo de la hacienda local. El mismo viaje harían aquellos jóvenes cuya exclusión del servicio hubiese provocado desacuerdos para ser medido y reconocido de nuevo y aquellos mozos que hubiesen presentado una reclamación.

1225 Reglamento de 24 de Octubre de 1877, arts. 22-29; Ley de Reclutamiento y Reemplazo de 28 de Agosto de 1878, art. 131. 
Podrían asistir al acto de entrega cualquier persona interesada en su legalidad ${ }^{1226}$.

En el momento de la entrega en caja, cada uno de los reclutas sería tallado y reconocido por talladores y facultativos en presencia de un diputado provincial, un vocal de la comisión de reclutamiento, el comandante de la caja y representantes del Ayuntamiento. En el acto deberían estar presentes dos talladores y dos facultativos médicos: un médico y un tallador nombrados por la comisión de reclutamiento y otros dos por el gobernador militar de la provincia. Los dos primeros recibirían gratificación de 2 pesetas y 50 céntimos por cada reconocimiento que practicasen, no así los castrenses, que no recibirían gratificación alguna. Para que un joven fuese admitido o desechado "[...] es necesario que los facultativos, los talladores, los Comisionados, el mozo reconocido y los demás suplentes y personas interesadas se hallen conformes en uno u otro extremo"1227. Si no existiese conformidad por parte de alguno de ellos, se informaría a la comisión de reclutamiento, quien debería tomar una decisión al respecto ${ }^{1228}$.

Una vez ingresados los reclutas en la caja, quedarían sujetos a la jurisdicción militar, mientras que sería el jefe de la caja quien procuraría que la distribución entre el Ejército y la Marina y entre todas sus armas se hiciese con equidad y justicia, quedando sujetos a los establecido por el ministerio de Guerra y a las órdenes del capitán general del distrito. Se intentaba así prevenir ante posibles fraudes en el reparto de los destinos. Sería el capitán general del distrito el encargado de inspeccionar la administración de la caja. En el mismo momento de la entrega, el recluta iría acompañado de un documento de filiación que incluiría el número que hubiese obtenido en el sorteo

${ }^{1226}$ Reglamento de 24 de Octubre de 1877, arts. 30 y 31; Ley de Reclutamiento y Reemplazo de 28 de Agosto de 1878, arts. 124-132.

1227 Reglamento de 24 de Octubre de 1877, art. 31.

1228 Reglamento de 24 de Octubre de 1877, art. 32; Ley de Reclutamiento y Reemplazo de 28 de Agosto de 1878, arts. 134-138. 
de localidad y que se debería conservar hasta su baja en el servicio $^{1229}$. Las causas de la baja podrían ser las siguientes:

"[...] fallecimiento, redención a metálico, sustitución, exención del servicio, destino a cuerpos activos o pase con licencia ilimitada a sus casas en concepto de disponibles" ${ }^{1230}$.

También se solicitaba en la norma a los encargados de administrar la caja que informasen a los nuevos soldados de sus obligaciones, que se les tratase justamente y se les abonase una paga de 50 céntimos de peseta diarios desde que salieron de su pueblo hasta que ingresaron en la caja, "[...] procurando hacerles lo menos violento posible el cambio que experimentan en su modo de vivir al ingresar en el Ejército"1231.

h) Las reclamaciones ante las comisiones provinciales de reclutamiento y contra sus fallos

Los capítulos XV y XVI de la Ley de 1878 regularon la posibilidad de presentar reclamaciones ante las comisiones provinciales de reclutamiento y en contra de los fallos de las mismas. Éstas deberían presentarse en el momento de la entrega de los reclutas en la caja ante su comandante, quien las pasaría a la comisión provincial. En un acto público comparecería ante la comisión el reclamante y todas las personas interesadas que así lo deseasen, para exponer sus razones y mostrar su documentación justificativa, dictando la resolución la comisión en ese mismo acto. Esta decisión sería publicada inmediatamente, sin perjuicio del recurso que los

\footnotetext{
1229 Reglamento de 24 de Octubre de 1877 , arts. 34-36 y 41.

1230 Reglamento de 24 de Octubre de 1877, art. 37.

${ }^{1231}$ Reglamento de 24 de Octubre de 1877, arts. 39 y 40.
} 
reclamantes pudiesen presentar ante el ministerio de la Gobernación ${ }^{1232}$. También existía la posibilidad de que la comisión concediese un plazo para la presentación de la documentación requerida y practicase durante el mismo las pertinentes diligencias para poder tomar una decisión. Sin embargo, "para que la concesión del término indicando no retarde la operación de la entrega, el mozo o mozos que hayan sido declarados soldados por el Ayuntamiento, ingresarán en la Caja con nota de recurso pendiente hasta que la Comisión Provincial resuelva"1233.

Una de las justificaciones posibles para eximirse del servicio que los nuevos reclutas podían presentar era el tener un hermano sirviendo en el Ejército. Cuando ocurriese esta circunstancia, el mozo debería indicar donde se encontraba sirviendo el hermano, para que la comisión, por conducto del gobernador de la provincia, pudiese reclamar al capitán general del distrito en que se encontrase el hermano soldado, o de la dirección general del arma a que esté destinado, la certificación de su permanencia en el Ejército. Una vez que la comisión hubiese recibido la certificación, se acordaría la exención del mozo y su pase a la reserva ${ }^{1234}$.

Cuando la reclamación se presentase acerca de la talla de un mozo, dos peritos talladores nombrados por la comisión, preferentemente sargentos del Ejército, deberían realizar un nuevo reconocimiento, declarando al joven, en función de su dictamen, soldado o excluido. Cuando la reclamación versase sobre la aptitud física de un mozo, tres facultativos le realizarían un nuevo reconocimiento médico. En función del reglamento de exenciones físicas, estos facultativos decidirían acerca de su inclusión o exclusión del servicio. Los acuerdos que tomasen las comisiones respecto a estas reclamaciones serían definitivos y no admitirían la posibilidad

1232 Ley de Reclutamiento y Reemplazo de 28 de Agosto de 1878, arts. 162-164.
1233 Ley de Reclutamiento y Reemplazo de 28 de Agosto de 1878, art. 165.
1234 Ley de Reclutamiento y Reemplazo de 28 de Agosto de 1878, arts. 166 y 167. 
de recurso ante el ministerio de la Gobernación, a no ser que los fallos de dichas comisiones hubiesen sido contrarios al dictamen de los facultativos o talladores. Las comisiones provinciales comunicarían a los Ayuntamientos sus dictámenes y no admitirían otras reclamaciones. Deberían además elaborar dos estados que incluyesen el número de mozos sorteados en cada pueblo, el cupo correspondiente a cada uno, el número de los que hubiesen ingresado en el servicio activo, en la clase de reclutas disponibles y en la reserva, así como de los excluidos por inutilidad física. Dos copias de ambos estados se remitirían a los ministerios de la Guerra y de Gobernación ${ }^{1235}$.

En ciertas circunstancias los fallos de las comisiones provinciales sí podrían ser recurridos ante el ministerio de la Gobernación, en lo que respecta tanto a la inclusión como a la exclusión indebida de algún joven en el alistamiento. No podrían apelarse los acuerdos que dictasen las comisiones confirmando los fallos de los Ayuntamientos ni podrían presentarse reclamaciones que versasen sobre la talla o aptitud física de algún mozo. Tales recursos se deberían presentar ante el gobernador civil de la provincia en un plazo máximo de quince días desde la resolución tomada por la comisión, y en ningún caso se suspendería la resolución que ésta hubiese tomado. El Gobernador debería proceder a instruir un expediente y solicitaría los informes pertinentes, junto a las pruebas presentadas, a los Ayuntamientos y a la comisión provincial, para ser remitidas al ministerio de la Gobernación en un plazo máximo de un mes. Tales reclamaciones serían resueltas definitivamente y sin posibilidad de recurso por el ministerio previa consulta al Consejo de Estado y a la Academia de Medicina de Madrid ${ }^{1236}$.

1235 Ley de Reclutamiento y Reemplazo de 28 de Agosto de 1878, arts. 168-173. ${ }^{1236}$ Ley de Reclutamiento y Reemplazo de 28 de Agosto de 1878, arts. 174-178. 
i) El ingreso en el servicio activo

El artículo 7 del Reglamento de 1877 dividió el Ejército permanente en servicio activo y reserva. El capítulo $\mathrm{V}$ de la ley se encargó de la primera sección. El soldado nuevo recibiría el alta en el servicio el día siguiente en que sea dado de baja de la caja de reclutas, y a partir de esa fecha se le abonarían todos los haberes que le correspondiesen. Junto a ellos, formarían parte del servicio activo los enganchados y reenganchados ${ }^{1237}$.

Como novedad destacar que por primera vez en el conjunto de leyes analizadas hasta ahora se establece que a las distintas armas e institutos del Ejército se les dotaría de un exceso de soldados instruidos en el arte de la guerra para cubrir las bajas que se produjesen durante ese año y para reforzarlos en el caso de que fuese necesario. Por tanto, por primera vez, se abre la posibilidad de que el Ejército esté formado por más soldados de los inicialmente necesarios con el objeto de cubrir bajas y posibles necesidades, aunque estos reclutas, si se considerasen prescindibles, podrían regresar con licencia a sus casas, ya sea temporal o ilimitada, y no cobrarían ningún tipo de haber durante ese periodo. Sería el Gobierno quien debía prever esta situación y establecer qué número de soldados excedentes se asignaban a cada cuerpo o institución militar. Además, el gobernador militar de la provincia de residencia de estos soldados que hubiesen recibido licencia, tendría la obligación de comunicárselo al jefe de la Guardia Civil, al de la respectiva reserva y al alcalde del pueblo que correspondiese con el fin de que pudiesen vigilar su comportamiento, y cuidar de su pronta incorporación si fuesen llamados a las filas ${ }^{1238}$.

1237 Reglamento de 24 de Octubre de 1877, arts. 42-45.

${ }^{1238}$ Reglamento de 24 de Octubre de 1877 , arts. 46-50 y 55. 
Por último, señalar a este respecto que no todos los soldados podrían gozar de licencias para poder regresar a sus casas por no ser considerados necesarios. Así, se especifica claramente quienes tienen prioridad en el goce de tales permisos y a quienes se les prohibía expresamente:

"Las licencias temporales o ilimitadas se concederán en los cuerpos, por regla general, a los individuos que lleven más tiempo en activo sin causa especial que los retenga en él.

No podrán disfrutarla los enganchados ni reenganchados, los que no tengan completa su instrucción, los que tengan débito en su ajuste, los que sufren recargo, ni los que estén sujetos a procedimientos judiciales; resultando así adjudicada esta situación de descanso por antigüedad, clasificación de buena conducta y comportamiento como premio a los mejores soldados"1239.

Los individuos que recibiesen estas licencias tendrían la obligación de devolver su armamento, municiones y prendas mayores de vestuario en el cuerpo del Ejército que abandonasen. Sin embargo, sí se les admitía la posibilidad de viajar y cambiar de residencia previa solicitud al gobernador militar de la provincia donde se encontrasen, debiendo dicha autoridad castrense comunicar a las autoridades provinciales y municipales el nuevo lugar de residencia del recluta ${ }^{1240}$.

En raras ocasiones estos soldados que recibían licencia para abandonar el servicio por existir excedentes de reclutas fueron llamados de nuevo a filas. Sin embargo, la ley aclaró sus obligaciones si se produjese esta situación. Si fuesen llamados para cubrir bajas naturales producidas en su cuerpo, el encargado de hacerlo sería su jefe respectivo. Si fuesen llamados por el aumento de la fuerza 
efectiva de los cuerpos, serían los primeros que tendrían la obligación de incorporarse. $\mathrm{Si}$ no se presentasen serían considerados desertores ${ }^{1241}$.

j) La nueva categoría del recluta disponible

Regula el capítulo VI todo lo relacionado con esta nueva figura dentro del Ejército denominado recluta disponible, una de las grandes novedades que contiene el reglamento y la ley analizados. Se trata de "[...] todos los mozos que exceden del cupo que anualmente se asigna a cada pueblo para cubrir las bajas de los Ejércitos de la península y Ultramar y de la Marina y constituyen la segunda clase del servicio activo"1242. Es decir, serían los reclutas que, habiendo obtenido la suerte del soldado en el sorteo, no serían todavía llamados a filas y cuya incorporación quedaba pendiente de las necesidades militares en función de las bajas que existiesen en el Ejército $^{1243}$.

Estos reclutas deberán ingresar en la caja al mismo tiempo que los declarados soldados pero, una vez hecho el ingreso, pasarían a formar parte de los batallones de reserva de Infantería de su respectiva localidad y no del servicio activo. Una relación nominal que incluyese "[...] el número que les haya cabido en suerte, su domicilio, oficio u ocupación, estatura, nombre y apellido de los padres y todos los datos que puedan conducir al completo conocimiento de dichos individuos, sus antecedentes y ulterior destino $[\ldots]$ " sería enviado a distintas autoridades militares: los jefes de los batallones de reserva, gobernador militar de la provincia y jefe local de la Guardia Civil, con el objetivo de facilitar la incorporación de estos reservas cuando

\footnotetext{
${ }^{1241}$ Reglamento de 24 de Octubre de 1877, art. 54.

1242 Reglamento de 24 de Octubre de 1877, art. 56.

1243 Ley de Reclutamiento y Reemplazo de 28 de Agosto de 1878, art. 19.
} 
fuese necesario ${ }^{1244}$. Se buscaba con este documento evitar la no incorporación de reclutas disponibles cuando fuesen llamados a filas.

Una vez que estos mozos hubiesen sido presentados en sus respectivas reservas de Infantería, hubiesen jurado fidelidad a la bandera, se les informase de las leyes penales y hubiesen sido instruidos, en el plazo máximo de un mes podrían recibir un pase para marchar a su localidad de residencia. Durante este mes de permanencia en los centros de reserva recibirían una ración de pan y 50 céntimos de peseta diarios. Además, el tiempo servido en esta situación se computaría como en activo ${ }^{1245}$.

Tal y como se indicaba en el artículo 10 del reglamento, estos reclutas disponibles podrían viajar y cambiar de residencia. Podrían ser llamados, a través de real decreto, al servicio activo cuando el ministerio de Guerra lo estimase conveniente, ya sea por necesidades bélicas o por alteraciones en el orden público. Cuando se realizasen estos llamamientos, se incorporarían estos reclutas a los centros de reserva o a cualquier otro lugar que determinase el Gobierno, siendo luego distribuidos en función de las instrucciones del ministerio. En el supuesto de no ser llamados todos los reclutas disponibles y solo lo sea una parte de ellos, ingresarían en primer lugar los de menor edad. Una vez incorporados al servicio activo, deberían permanecer en él los cuatro años que fijaba la ley, pasando posteriormente a la reserva ${ }^{1246}$.

\footnotetext{
${ }_{1244}$ Reglamento de 24 de Octubre de 1877, arts. 57 y 58.

1245 Reglamento de 24 de Octubre de 1877, arts. 60-63 y 65.

1246 Reglamento de 24 de Octubre de 1877, arts. 66-71.
} 
k) La sustitución y la redención en metálico: reconocimiento legal sin apenas oposición parlamentaria

El Reglamento de 1877 apenas hace referencia a estos temas, pero no así la Ley de 1878, a los que dedicó el amplio capítulo XVII. Las únicas voces discordantes en el Parlamento con este proyecto de ley vinieron a este respecto, ya que suponía introducir una desigualdad en el cumplimiento de las obligaciones con la Patria e incluso la ruina de aquellos que luchaban por alcanzarla:

"Aquí se ha hecho una ley original, porque aparece como una de sus bases que el servicio militar es obligatorio a todos los españoles, y sin embargo no lo es toda la vez que por otros de sus artículos puede redimirse totalmente con metálico o por medio de la sustitución, y temporalmente por el cambio de número: de modo que, mientras que como base se establece que todos los españoles está obligados a servir en el Ejército, sus artículos eximen de hacerlo al que posea 2.000 pesetas o menos, obligando solo al servicio al que carezca o no pueda disponer en día dado de ellas.

[...].

Que la redención tiene mucho de inmoral y que desiguala por completo el peso de la carga entre las clases de la sociedad, no he de decirlo yo; basta saber el precio de la redención para convencerse que es evidente que resulta un sacrificio exiguo para los potentados $y$ es quizá la ruina de los pequeños labradores, de la clase media y de log industriales, y sobre todo, que afecta a cada uno según el estado de su fortuna mar b menos, viniendo a ser imposible para los mas, y aun quizá en algunos casos para individuos de las mismas clases a que parece quiere favorecerse tan injustamente"1247.

Reglamento y ley analizados admitían la sustitución a través de un pariente de hasta cuarto grado, tal y como lo recogía la Ley de 10

1247 Discurso del Sr. Salamanca, Diario de sesiones de las Cortes, no 110, 20/07/1878, pp. 3176-3177. 
de enero de 1877. Sin embargo, y como novedad, también se abría la posibilidad de presentar un sustituto en situación de recluta disponible o en la reserva, aunque no por individuos que hubiesen sido destinados a Ultramar, tuviesen un recurso pendiente o hubiesen sido declarados útiles condicionales. El sustituido quedaba como responsable de la permanencia en filas del sustituto, y debería ocupar su puesto, personalmente o través de otro sustituto, si el sustituto desertase, teniendo también la posibilidad de redimirse en metálico ${ }^{1248}$.

En el supuesto de que el sustituto fuese familiar de hasta cuarto grado del sustituido, debería demostrar tal condición a través de partidas sacramentales o certificados del Registro Civil. Debería además ser soltero o viudo sin hijos, no estar procesado judicialmente, no pertenecer al Ejército activo ni a la reserva, y tener licencia de su padre si fuese menor de edad. Y si el sustituto fuese un licenciado en el Ejército, también tendría que cumplir con ciertos requisitos como el tener una edad comprendida entre los veintitrés y los treinta y cinco años, haberse licenciado con buena nota y estar dispuesto a servir en los cuerpos de Ultramar por un espacio de cuatro años. Se buscaba así incrementar el número de reclutas dispuestos a ser enviados a territorio ultramarino. Para que un sustituto fuese admitido era necesario además que previamente fuese tallado y examinado por la comisión provincial de reclutamiento, asegurando así la aptitud física del mozo. Sería esta institución la encargada de decidir sobre la admisión de un sustituto ${ }^{1249}$.

También se establecieron unos plazos para presentar al sustituto $^{1250}$. Ésta presentación se debía realizar en un plazo máximo

1248 Reglamento de 24 de Octubre de 1877, arts. 79-83 y 85; Ley de Reclutamiento y Reemplazo de 28 de Agosto de 1878, arts. 179 y 188.

1249 Ley de Reclutamiento y Reemplazo de 28 de Agosto de 1878, arts. 180-186.

1250 "Esta y otras normativas hasta fin de siglo parecían indicar un intento por entorpecer las sustituciones, debido, tal vez, a la oposición de intelectuales, tratadistas militares, población en general, y la mayoría de los militares 
de dos meses desde el día en que fuese declarado soldado el mozo que pretendía sustituirse y en un plazo máximo de un mes si le hubiese tocado como destino Ultramar ${ }^{1251}$.

El sustituto de un individuo destinado a Ultramar sería considerado voluntario para estos territorios sin posibilidad de redimirse en metálico. Además, no podría promover expediente de exención por causas personales sobrevenidas después de su ingreso a filas una vez que hubiese ingresado en el Ejército ${ }^{1252}$.

Si bien el Reglamento de 1877 no hacía referencia a la redención en metálico, la Ley de 1878 sí recogía y regulaba esta posibilidad, a través de la entrega de 2.000 pesetas "[y siempre que el mozo redimido] acredite que sigue o ha terminado una carrera o ejerce una profesión u oficio"1253. Con esta exigencia "[...] se intentaba blanquear la visión "económica-materialista" de las redenciones, para darle un aire de intelectualidad y de apoyo al trabajo, a la cultura y a los "estudios", ante los frecuentes ataques y quejas de las clases populares"1254. Previamente a la Ley de 1878 se aprobó una real orden que admitía para los profesores de Instrucción Primaria la posibilidad de redimirse a ellos mismos o a sus hijos en función de los salarios pendientes de pago por parte de Ayuntamientos y Diputaciones ${ }^{1255}$.

Para eximirse debería presentar el recluta ante la comisión provincial, en un plazo máximo de dos meses desde que fuese declarado soldado, una carta de pago que acreditase haber entregado la referida cantidad a la administración económica de la provincia. El destino exclusivo de esta cantidad sería el reemplazo del Ejército a

profesionales, que consideraban esta práctica como inmoral y antipatriótica" (FEIJÓO GÓMEZ, A., Quintas y protesta social en el siglo XIX español, p. 273).

${ }^{1251}$ Ley de Reclutamiento y Reemplazo de 28 de Agosto de 1878, art. 187.

1252 Reglamento de 24 de Octubre de 1877, art. 84.

1253 Ley de Reclutamiento y Reemplazo de 28 de Agosto de 1878, art. 179.

1254 MOLINA LUQUE, J. F., Quintas y servicio militar: aspectos sociológicos y antropológicos de la conscripción (Lleida, 1878-1960), p. 44.

${ }^{1255}$ Real Orden de 30 de Mayo de 1875. 
través de la contratación de voluntarios. Dicha Comisión expediría un certificado que a su vez acreditase tal redención absoluta del servicio $^{1256}$.

El mozo redimido que posteriormente fuese declarado exento por enfermedad o defecto físico tendría derecho a que le fuese devuelta la suma entregada. Sería el ministerio de la Gobernación quien tendría que decidir sobre tal devolución para luego comunicárselo al de Guerra ${ }^{1257}$. De nuevo este ministerio no militar quedaba como encargado de decidir en cuestiones tan relacionadas con el reclutamiento como era la redención en metálico. Las bajas ocasionadas por esta redención económica serían cubiertas por parte del ministerio de Guerra mediante dos vías:

"10.- Por individuos de la clase de tropa del Ejército que quieran reengancharse.

20.- Por cumplidos del Ejército o individuos de la clase de paisanos que quieran alistarse voluntariamente ${ }^{\prime 1258}$.

Las acusaciones por parte del diputado Salamanca hacia la redención se centraron, además de su injusticia, en su posible utilización por parte del Gobierno para la obtención de recursos económicos solicitando, en el llamamiento anual, un mayor número de soldados de los necesarios, con el objetivo de obtener mayores ganancias al incrementarse el número de redenciones y utilizar este beneficio, no en la contratación de enganchados y reenganchados, sino en otros fines distintos al establecido por la ley:

"Además, y para fomentar el producto de redenciones, se ha adoptado un sistema que si no es muy moral, si proporciona grandes

\footnotetext{
${ }^{1256}$ Ley de Reclutamiento y Reemplazo de 28 de Agosto de 1878, arts. 189 y 190. 1257 Ley de Reclutamiento y Reemplazo de 28 de Agosto de 1878, arts. 191-193. ${ }^{1258}$ Ley de Reclutamiento y Reemplazo de 28 de Agosto de 1878, art. 195.
} 
rendimientos, y este consiste en pedir en las quintas mayor fuerza con destino a cuerpos activos que la necesaria; se destinan, y como luego a cada uno se le marca la que según presupuesto ha de tener, licencian contingentes anteriores en el número necesario para que solo quede la fuerza reglamentaria en revista, y no hay necesidad de otro procedimiento para que log redimidos no graven en poco ni en mucho al Estado, disminuyendo la fuerza efectiva, ni para evitar cálculos que dan el mismo inmoral resultado.

[...].

Además, coma las sustituciones se han limitado hasta el punto de ser casi nulas, se demuestra que lo que se quiere es la redención a toda costa"1259.

I) La búsqueda de los voluntarios: enganchados y reenganchados

El capítulo $X$ se encargó de regular la actuación en ambas figuras de voluntariado, es decir, de aquellos que voluntariamente ingresasen o continuasen en el servicio activo del Ejército ${ }^{1260}$. La Ley de 10 de enero de 1877 exigía una edad mínima para enganchados y reenganchados de dieciséis años, y ésta se mantuvo en el reglamento, aunque añade que se exigiría "[...] la estatura, robustez y desarrollo correspondiente a ella"1261, y se remitía a futuras disposiciones que lo regulasen. La edad máxima para entrar o continuar voluntariamente en el servicio activo se situó en los treinta y cinco años para los enganchados, en los cuarenta y cinco para los reenganchados y en los cincuenta para los obreros de Artillería, Ingenieros, Administración y Sanidad Militar ${ }^{1262}$.

1259 Discurso del Sr. Salamanca, Diario de sesiones de las Cortes, no 110, 20/07/1878, pp. 3177-3178.

${ }_{1260}$ Reglamento de 24 de Octubre de 1877, arts. 86 y 87; Ley de Reclutamiento y Reemplazo de 28 de Agosto de 1878, art. 10.

1261 Reglamento de 24 de Octubre de 1877, art. 88.

1262 Reglamento de 24 de Octubre de 1877, art. 89. 
Las condiciones que se establecieron para enganchados y reenganchados fueron realmente duras, ya que no tendrían la posibilidad de gozar de una licencia ni de pasar a la reserva. Los premios que cobrasen procederían del producto recaudado a través de la redención en metálico. Por ello se estableció que el número de voluntarios en el Ejército debía ser igual que el número de redimidos. Una vez cubierta esta obligación, el dinero recaudado en este capítulo de redenciones podría ser destinado a mejorar y adquirir nuevo material de guerra, siendo obligatorio que el ministerio de Guerra informase anualmente de ello a las Cortes ${ }^{1263}$. Además, estos mozos enganchados voluntariamente al Ejército también quedarían sujetos al sorteo por razón de su edad y, en el caso de obtener la suerte del soldado, ingresarían en la caja como cualquier recluta, cesaría su retribución pecuniaria y comenzaría el cómputo de sus años de servicio activo sin tener en cuenta los servicios previamente prestados $^{1264}$.

m) La reserva y las asambleas: el objetivo es mantener la disciplina militar para aquellos que no se incorporasen al servicio activo

El capítulo XI del Reglamento de 1877 reguló la situación de los soldados que pasasen a la reserva tras sus cuatro años en situación de servicio activo o como soldados disponibles, y que no deseasen continuar en el servicio activo como reenganchados ${ }^{1265}$. Por su parte, el capítulo XII se encargó de una nueva institución surgida con esta ley, la denominada Asamblea. Se trata simplemente de las reuniones periódicas que, bianualmente y con una duración máxima de seis

${ }^{1263}$ Reglamento de 24 de Octubre de 1877, arts. 90 y 91; Ley de Reclutamiento y Reemplazo de 28 de Agosto de 1878, art. 12.

1264 Ley de Reclutamiento y Reemplazo de 28 de Agosto de 1878, art. 11.

1265 Reglamento de 24 de Octubre de 1877, arts. 92-94. 
semanas, los soldados de la reserva y los reclutas disponibles deberían celebrar con el objeto de mantener la disciplina militar y actualizar su instrucción. Estas Asambleas serían reguladas por el ministerio de la Guerra, quien determinaría su duración, la fecha a celebrar y sus actividades. Durante este periodo ambos tipos de reclutas recibirían los haberes correspondientes a su arma ${ }^{1266}$.

En el momento en que un soldado pasase a la reserva, y antes de ser conducido por ferrocarril allí donde se dirigiese, recibiría, por parte del jefe de la compañía donde hubiese estado destinado, la siguiente documentación:

"La filiación del interesado totalizada por la fecha de la baja.

Duplicada relación de las prendas menores, expresando el estado de su uso.

Libreta de ajustes cerrada igualmente en el día de su baja.

Abonaré de los alcances con que pasa de una a otras situación, de lo que se le dará conocimiento al interesado.

Y la fe de soltero"1267.

Una vez se encontrasen en su lugar de residencia, tenían estos reclutas la obligación de presentarse, con la documentación que les había sido asignada, al jefe de la reserva correspondiente, al jefe de la Guardia Civil más inmediato y al alcalde de su localidad para ser inscritos en las listas de reserva de su jurisdicción respectiva ${ }^{1268}$. Estos individuos de las tropas de reserva estarían sujetos a la ley civil ordinaria, con estas únicas excepciones:

"Por separación de su residencia sin la debida autorización.

Por deserción.

\footnotetext{
1266 Reglamento de 24 de Octubre de 1877, arts. 118-121.

1267 Reglamento de 24 de Octubre de 1877, art. 95.

1268 Reglamento de 24 de Octubre de 1877, art. 106.
} 
Por desobediencia en acto de servicio.

Por falta de respeto a sus jefes y oficiales.

Por formar parte en armas de reunión tumultuaria contra el orden público, y permanecer en ella contrariando las órdenes de la Autoridad o de la fuerza pública.

O por otros delitos esencialmente militares"1269.

Deberían estos individuos entregar en sus respectivos cuerpos el armamento y las prendas mayores del vestuario, quedándose únicamente con las menores, consideradas de su propiedad. Volverían a la vida civil, aunque tendrían la obligación de presentarse a las órdenes de su jefe militar cuando se les ordenase. Sólo podrían ser llamados en el caso de que las necesidades de efectivos no se cubriesen con los individuos del Ejército activo ni con los reclutas disponibles. En el caso de ser necesarios, serían llamados mediante real decreto acordado con el Consejo de Ministros ${ }^{1270}$.

Con el objeto de facilitar una movilización rápida por motivos bélicos, las distintas armas e institutos del Ejército deberían tener organizados convenientemente a los individuos de la reserva y llevar detalladamente un registro con el alta y baja de los mismos. Para ello los jefes de la reserva deberían elaborar una triple relación donde figurasen, por una parte, los individuos de la reserva, por otra, los reclutas disponibles $\mathrm{y}$, por último, los soldados que se encontrasen con licencia temporal o ilimitada. También los gobernadores militares, los jefes de la Guardia Civil y los alcaldes de las distintas localidades deberían tener conocimiento de esta triple relación para facilitar la movilización en el caso de ser necesario. El control se ve incrementado sobre estas tres figuras al verse obligados a pasar, durante la primera quincena del mes de abril, por una revista personal ante el comandante de la Guardia Civil del puesto más

${ }^{1269}$ Reglamento de 24 de Octubre de 1877, art. 110.

1270 Reglamento de 24 de Octubre de 1877, arts. 97-99 y 105. 
cercanos a su localidad de residencia, quien debería dar cuenta de la misma al jefe de la reserva respectiva, al gobernador militar de la provincia, al capitán general del distrito y éste, a su vez, al ministerio de la Guerra. En el caso de no presentarse a tal entrevista en el plazo de un mes, serían considerados desertores ${ }^{1271}$.

Gozarían los reclutas reservas mientras se encontrasen en esta situación de la siguiente ventaja laboral:

"Las Autoridades militares, los Jefes y demás Oficiales encargados de estas reservas especiales procurarán, siempre que sea posible, dar a sus individuos preferencia a toda clase de personas para emplearlos en los trabajos u ocupaciones que tengan a su cargo, como por ejemplo: los de ingenieros en obras de fortificación o edificios militares; los artilleros en los Parques Maestranzaso, Fábricas; las de Administración en las factorías de pan y depósitos de utensilio y los de Sanidad militar en los hospitales"1272.

Además, podrían pasar a formar parte de los cuerpos de la Guardia Civil si reuniesen las cualidades exigidas en su reglamento. Una vez que finalizasen su tiempo de servicio, se presentarían al Jefe de la reserva para recibir licencia absoluta. Si falleciesen en esta situación, sus herederos podrían cobrar los haberes que se le adeudasen presentando un documento que les identificase como tales $^{1273}$.

Por lo que respecta a los jefes y oficiales en situación de reserva, su principal misión sería auxiliar a las autoridades militares en el supuesto de una movilización rápida que hubiese decretado el Gobierno. Procurarían la movilización de los reclutas disponibles, pero

\footnotetext{
1271 Reglamento de 24 de Octubre de 1877, arts. 100, 103 y 104.

1272 Reglamento de 24 de Octubre de 1877, art. 101.

${ }^{1273}$ Reglamento de 24 de Octubre de 1877, arts. 107 y 112.
} 
también la de los individuos con licencia ilimitada o temporal y contribuirían al mantenimiento del orden público ${ }^{1274}$.

n) La lucha contra el prófugo: destino, Ultramar

El capítulo XIV de la Ley de 1878 reguló la lucha contra el prófugo, cuestión no tratada por el Reglamento de 1877. Se consideró prófugo a aquel joven que, sin presentar causa justa ante la comisión provincial de reclutamiento, no se presentase al acto de declaración de soldados, al momento señalado para ser conducidos a la capital provincial o, habiendo ya sido declarado soldado, no se presentase personalmente al acto de entrega en la caja de reclutas el día señalado para el mismo ${ }^{1275}$.

Una vez apresados, los prófugos serían destinados a los cuerpos de Ultramar con un recargo en el servicio de cuatro años. Si el prófugo no se presentase al acto de llamamiento y declaración de los soldados pero sí al acto de entrega en la caja de reclutamiento, el recargo impuesto en el servicio sería tan solo de cuatro meses. Si el mozo resultase inútil para el servicio, sufriría un arresto de dos a seis meses y una multa entre 150 y 500 pesetas fijada por la comisión provincial $^{1276}$.

Una vez constatada la falta de presentación de un prófugo, se deberían iniciar los trámites para su captura. Sería un regidor del Ayuntamiento, en un plazo máximo de seis días, el encargado de abrir el expediente correspondiente y de informar "[...] al padre, curador o pariente cercano del que se dice prófugo, a fin de que expongan sus descargos, y si no hubiese aquellas personas o no

\footnotetext{
${ }^{1274}$ Reglamento de 24 de Octubre de 1877, arts. 115-117.

1275 Ley de Reclutamiento y Reemplazo de 28 de Agosto de 1878, arts. 141-143.

1276 Ley de Reclutamiento y Reemplazo de 28 de Agosto de 1878, arts. 144, 145 y 157.
} 
quisieren tomar este cargo, se nombrará de oficio un vecino honrado en calidad de defensor"1277. Al mismo tiempo se informará al suplente correspondiente su obligación de incorporarse a filas. Si el Ayuntamiento obviase la realización de estos trámites, recibiría una multa de cincuenta a doscientas pesetas impuestas por el gobernador de la provincia. La cuarta parte de la misma sería satisfecha por el secretario $^{1278}$.

La importancia de la institución municipal en la lucha contra el prófugo se ve incrementada al ser el propio consistorio el encargado de declarar prófugo al joven huido, y además debería asumir los gastos que ocasionase su captura. El prófugo por su parte debería indemnizar a su suplente con trescientas pesetas anuales. También debería el Ayuntamiento informar al juzgado ordinario de la existencia de posibles cómplices, que recibirían una multa económica de entre cien y trescientas pesetas o asumirían penas de cárcel si no pueden satisfacer la sanción monetaria. Algo menor era la multa, de 50 a 200 pesetas, para los que hubiesen escondido o admitido a su servicio a un prófugo ${ }^{1279}$.

Cuando el prófugo fuese capturado, el Ayuntamiento debería presentarlo, junto con su expediente, ante la comisión provincial de reclutamiento. Esta comisión, escuchando al prófugo y analizando su expediente, podría confirmar o revocar la decisión del Ayuntamiento y dispondría su entrega en la caja de reclutas. En el caso de revocación, el recluta quedaría exento del recargo de cuatro años en el servicio, pero no de servir en los ejércitos de Ultramar, ni del pago de los gastos de su captura ni de la indemnización a su suplente, que quedaría libre de cualquier responsabilidad con la institución militar. Si el prófugo no pudiese satisfacer el pago establecido para el suplente, sería el Consejo de Redenciones y Enganches el encargado

\footnotetext{
1277 Ley de Reclutamiento y Reemplazo de 28 de Agosto de 1878, art. 146. 1278 Ley de Reclutamiento y Reemplazo de 28 de Agosto de 1878, art. 147. 1279 Ley de Reclutamiento y Reemplazo de 28 de Agosto de 1878, arts. 148-150.
} 
de recompensarle con la cantidad de 100 pesetas anuales. Tampoco podría el prófugo evitar su incorporación a filas mediante la presentación de un sustituto o la redención en metálico ${ }^{1280}$.

Aquellos que colaborasen con la detención del prófugo se verían asimismo recompensados. Si el aprehensor fuese un recluta o algún familiar suyo, se rebajaría su tiempo destinado al servicio el mismo número de años que recargo se le impusiese al prófugo capturado. En el caso de no ser familiar de un soldado, se le recompensaría con cincuenta pesetas a pagar por el joven capturado ${ }^{1281}$.

o) Disposiciones penales: la lucha contra los incumplimientos

Finaliza la Ley de 1878 con un capítulo que recogía una serie de disposiciones penales que castigaban los incumplimientos que se hiciesen de la misma y los delitos que se cometiesen para eludir el servicio. En primer lugar se señala que los delitos que se cometiesen contra la ley serían juzgados por la justicia ordinaria, y no militar, excluyendo además todo fuero o exención ${ }^{1282}$. Ningún grupo social quedaba por tanto al margen del cumplimiento de sus obligaciones con el Ejército, con la excepción de los redimidos y de los que presentasen un sustituto.

Las disposiciones penales atendían primero a aquellos que tratasen de eludir el servicio a través de la automutilación o que hubiesen colaborado con otros jóvenes para mutilarse. Además de las penas que imponía el Código Penal, esta ley estableció como castigo el envío del soldado, siempre que no hubiese quedado inutilizado, a las posesiones africanas durante diez años sin posibilidad de licencia temporal ni retribuciones. Si el recluta no pudiese incorporarse al

\footnotetext{
1280 Ley de Reclutamiento y Reemplazo de 28 de Agosto de 1878, arts. 151-156. ${ }^{1281}$ Ley de Reclutamiento y Reemplazo de 28 de Agosto de 1878, arts. 158-160. 1282 Ley de Reclutamiento y Reemplazo de 28 de Agosto de 1878, art. 197.
} 
servicio por el daño autoinfligido, sería sustituido por un suplente, que quedaría libre de sus obligaciones una vez que se demostrase la culpabilidad del autolesionado, recibiendo además una indemnización de trescientas pesetas anuales por parte del soldado titular ${ }^{1283}$.

También se impusieron castigos por los delitos 0 faltas cometidos durante la ejecución de las operaciones de reemplazo. Además de las penas establecidas con arreglo a lo dispuesto en el Código Penal, si el delito hubiese dado lugar a que se llamase al servicio activo a un mozo a quien no hubiese correspondido ingresar por exenciones otorgadas a otros jóvenes, éste, además de ser dado de baja del servicio, recibiría una indemnización de trescientas pesetas por cada año que, indebidamente, hubiese formado parte del Ejército como recluta. Si el mozo indebidamente exceptuado hubiese cometido un delito, cumpliría además su servicio en los territorios de Ultramar sin posibilidad de eximirse. A ello se unían las multas que las distintas autoridades administrativas pudiesen imponer por cualquier infracción que se cometiese durante las operaciones de reemplazo y que no constituyesen delito ${ }^{1284}$.

Por su parte, las autoridades administrativas culpables de la omisión fraudulenta de un mozo en el alistamiento y sorteo sufrirían penas de prisión correccional y serían multados con 2.000 pesetas por cada soldado que hubiese evitado, de forma indebida, el servicio activo. El pueblo donde se hubiese cometido la infracción debería además entregar al hombre u hombres que hubiesen dado de menos $^{1285}$.

Los facultativos médicos por su parte que actuasen de forma fraudulenta expidiendo falsos certificados de enfermedad también serían castigados por el Código Penal y deberían resarcir económicamente, por daños y perjuicios, al Estado o a la persona

\footnotetext{
1283 Ley de Reclutamiento y Reemplazo de 28 de Agosto de 1878, arts. 198-201.

1284 Ley de Reclutamiento y Reemplazo de 28 de Agosto de 1878, art. 202.

1285 Ley de Reclutamiento y Reemplazo de 28 de Agosto de 1878, art. 203.
} 
que, por su incorrecta actuación, se hubiese visto obligado a ingresar en el Ejército. Si el facultativo o cualquier funcionarios público aceptase alguna compensación económica o regalo, sería además inhabilitado temporalmente para el ejercicio de su profesión y castigado a través del Código Penal ${ }^{1286}$.

p) Reglamento de exenciones físicas: una mayor atención hacia las enfermedades psiquiátricas

Vinculado a la Ley de 1878, y publicado en la Gaceta el mismo día que el propio texto legislativo, encontramos este amplio reglamento que, con un total de 231 artículos, venía a regular las exenciones del servicio por cuestiones de enfermedad e inutilidad física. Este Reglamento "[...] presenta una terminología más específica [que las contempladas por la Ley de 1856] para describir las diferentes exenciones, eliminando las motivadas por dolencias ambiguas y prestando mayor atención a las exenciones derivadas de patologías psiquiátricas $[\ldots]^{1287}$.

Para la celebración del juicio de exenciones, los Ayuntamientos deberían anunciar públicamente el día y la hora de su celebración, mientras que los mozos llamados al servicio deberían alegar las causas de su presunta inutilidad física. Los Ayuntamientos asimismo deberían anotar en un acta, junto al nombre, edad, oficio, talla y el número que haya sacado en el sorteo el mozo, la causa física alegada para su exención, designada con su nombre vulgar y técnico ${ }^{1288}$.

Los Ayuntamientos sólo podrían declarar exentos del servicio por motivos físicos a los individuos que padeciesen defectos 0 enfermedades realmente graves y visibles, es decir, aquellos que

\footnotetext{
1286 Ley de Reclutamiento y Reemplazo de 28 de Agosto de 1878, arts. 204-208. 1287 FEIJÓO GÓMEZ, A., Quintas y protesta social en el siglo XIX español, p. 266. ${ }^{1288}$ Reglamento de exenciones físicas de 28 de Agosto de 1878, arts. 1-7.
} 
estuviesen incluidos en la primera clase del cuadro de inutilidades físicas que establecía este Reglamento ${ }^{1289}$. Sus decisiones solo serían ejecutivas cuando no se presentasen reclamaciones o quejas contra las mismas ${ }^{1290}$. Cuando la enfermedad alegada quedase fuera de esta primera clase, los Ayuntamientos se limitarían a consignar en el acta las alegaciones presentadas y a definir, en la medida de sus posibilidades, el defecto físico aludido. Otra misión del consistorio relacionada con las exenciones físicas consistía en oír las reclamaciones presentadas a este respecto por los jóvenes que considerasen injusta alguna exención otorgada, debiendo consignar en acta de tal protesta y la fecha de la misma. Una copia de las actas donde se indicase las enfermedades alegadas y las exenciones otorgadas sería entregadas a la comisión provincial de reclutamiento por parte del comisionado municipal que acompañase a los reclutas en el acto de entrega en caja ${ }^{1291}$.

Los acuerdos tomados por los Ayuntamientos sobre este particular podrían ser investigados por las comisiones Provinciales cuando tuviesen sospechas sobre su incorrección. Podrían para ello

\footnotetext{
1289 Son las siguientes:

"10.- Falta completa de ambos ojos.

20.- Ceguera completa, permanente e incurable, que dependa de vaciamiento o consunción de los globos de ambos ojos.

30. - Pérdida completa de las narices.

40.- Pérdida completa de ambas orejas.

50.- Pérdida completa de la lengua.

60.- Pérdida o falta de todos los dientes, colmillos y muelas.

70. - Mutilación de una o de ambas extremidades superiores que cuando menos consista en la pérdida de una mano.

80.- Jorobas o torceduras del espinazo monstruosas, acompañadas de corta estatura del individuo.

90.- Pérdida completa de los órganos genitales externos.

$10^{\circ}$.- Mutilación de una o de ambas extremidades inferiores que cuando menos consista en la pérdida de un pie.

110.- Cojera que dependa de la desigualdad de longitud de las extremidades inferiores, y consista cuando menos en 12 centímetros de diferencia" (Reglamento de exenciones físicas de 28 de Agosto de 1878, art. 8).

1290 Reglamento de exenciones físicas de 28 de Agosto de 1878, art. 16.

${ }^{1291}$ Reglamento de exenciones físicas de 28 de Agosto de 1878, arts. 8-15 y 19.
} 
llamar a los mozos que hubiesen sido ya declarados exentos por los Ayuntamiento para así confirmar o rectificar sus sospechas ${ }^{1292}$.

Además de las inutilidades físicas comprendidas en la primera categoría y declaradas por los Ayuntamientos, todas las demás serían analizadas por dos facultativos, uno civil nombrado por la comisión y otro castrense designado por la autoridad superior militar de la provincia, a través de los reconocimientos médicos oportunos durante el acto de entrega en la caja de reclutas en primera instancia o en la propia comisión provincial en el caso de una nueva protesta o reclamación. Por tanto se celebraría un nuevo juicio de exenciones al que podrían asistir comisarios regios o comisiones extraordinarias designadas por el ministerio de la Gobernación para vigilar el proceso. Una vez realizado el reconocimiento, los facultativos deberán emitir un certificado que exprese su resultado, los síntomas de la enfermedad alegada, su nombre técnico y vulgar si lo tuviese y la utilidad o inutilidad del mozo para el servicio ${ }^{1293}$. Si el defecto físico alegado no estuviese incluido en el cuadro de exenciones que acompaña al Reglamento "[pero] que por su cronicidad, permanencia y manifiesta incompatibilidad para el servicio constituya verdadera inutilidad, quedan autorizados para emitir su razonado juicio científico conceptuándolo inútil para el servicio [... $]^{1294}$.

Si existiese además una nueva reclamación sobre el informe médico redactado por estos facultativos, se procedería a realizar un nuevo reconocimiento por parte de otros dos médicos que no hubiesen participado en el primero, decidiéndose en función del dictamen de todos ellos ${ }^{1295}$.

El lugar y la fecha de celebración de estos reconocimientos médicos sería dispuesto por la comisión provincial, que además

1292 Reglamento de exenciones físicas de 28 de Agosto de 1878, art. 17.

1293 Reglamento de exenciones físicas de 28 de Agosto de 1878, arts. 20-27 y 4244.

1294 Reglamento de exenciones físicas de 28 de Agosto de 1878, art. 25.

${ }^{1295}$ Reglamento de exenciones físicas de 28 de Agosto de 1878, art. 28. 
debería proporcionar a los facultativos todos los útiles sanitarios pertinentes para su realización y un funcionario encargado de redactar los certificados correspondientes. Podrían asistir a tales reconocimientos todos los interesados en el mismo o dos representantes si el local donde se celebrase no tuviese un espacio suficiente como para permitir la presencia de todos ellos ${ }^{1296}$.

También existía la posibilidad de que un mozo fuese declarado útil provisionalmente para el servicio, es decir, que ingresaría en el mismo pero podría ser declarado exento en función de cómo evolucionase su enfermedad, las cuales están incluidas dentro de la clase tercera del cuadro de inutilidades. A estos reclutas los facultativos les deberían emitir un certificado donde se señalase tal circunstancia para ser entregado al comandante de la caja, quien lo deberá anotar en sus filiaciones respectivas. Una vez que esta tipología de reclutas ingresase en caja volverían a tener un reconocimiento médico pasados dos meses desde su ingreso por parte de dos facultativos nombrados por la comisión provincial. Si el mozo resultase útil, volverá a su antiguo puesto, si no fuese así, sería reemplazado por un recluta disponible $e^{1297}$.

Finaliza el articulado del reglamento declarando a los distintos facultativos que participasen en los reconocimientos responsables del exacto y fiel cumplimiento de sus funciones, pudiéndose abrir un expediente gubernativo si existiesen sospechas sobre su incorrección, investigación en la que participarían emitiendo un dictamen la Real Academia de Medicina de Madrid si el facultativo fuese civil y la Junta Superior Facultativa del Cuerpo de Sanidad del Ejército si el sanitario fuese castrense ${ }^{1298}$.

Por último, señalar que el reglamento recogió una exhaustiva relación de las enfermedades y defectos físicos que eximían del

\footnotetext{
${ }^{1296}$ Reglamento de exenciones físicas de 28 de Agosto de 1878, arts. 29-33.

1297 Reglamento de exenciones físicas de 28 de Agosto de 1878, arts. 34-40.

1298 Reglamento de exenciones físicas de 28 de Agosto de 1878, arts. 47 y 48.
} 
servicio militar, clasificándolas en clases y órdenes. Las primeras hacían referencia a la autoridad competente para declarar la exención, siendo dos: el Ayuntamiento la primera clase de defectos, la caja de reclutas o de la comisión provincial de reclutamiento la segunda y, por último, éstas últimas autoridades para el caso de los reclutas útiles condicionales, es decir, aptos para el servicio en función del reconocimiento que se hacía transcurridos dos meses desde el ingreso en la caja de reclutas. Y en cuanto a la tipología de las enfermedades eximentes, se establecieron un total de 17 órdenes, a saber:

"Defectos físicos, estados patológicos generales y enfermedades constitucionales.

Defectos físicos y enfermedades correspondientes al aparato nervioso cerebro-espinal.

Defectos físicos y enfermedades correspondientes al aparato de la visión.

Defectos físicos y enfermedades correspondientes al aparato de la audición.

Defectos físicos o enfermedades correspondientes al aparato digestivo y sus anejos.

Defectos Físicos y enfermedades correspondientes a los aparatos respiratorio, circulatorio y sus anejos.

Defectos físicos y enfermedades correspondientes al aparato genito-urinario.

Defectos físicos y enfermedades, correspondientes a los tejidos cutáneo y calcular.

Defectos físicos y enfermedades correspondientes al sistema linfático y a los ganglios de este nombre.

Defectos físicos y enfermedades correspondientes al aparato locomotor.

Inutilidades físicas que deberán ser comprobadas y declaradas dentro del Ejército y de la Armada para causar la exención del servicio de los soldados útiles condicionalmente. 
Defectos físicos y enfermedades correspondientes al aparato nervioso cerebro-espinal.

Defectos físicos y enfermedades correspondientes al aparato de la visión.

Defectos físicos y enfermedades correspondientes al aparato de la audición.

Defectos físicos y enfermedades correspondientes al aparato digestivo y sus anejos.

Defectos físicos y enfermedades correspondientes a los aparatos respiratorio, circulatorio y sus anejos.

Defectos físicos y enfermedades correspondientes al aparato genito-urinario.

Defectos físicos y enfermedades correspondientes al aparato locomotor ${ }^{\prime 1299}$.

$\checkmark$ Los límites a la sustitución y la reducción en la cuantía de la redención: Ley de Reclutamiento y Reemplazo de 8 de enero de 1882, reformando la Ley de 1878

Apenas tres años y medio después de quedar aprobados por las Cortes la Ley de 1878 y el reglamento de exenciones físicas a ella vinculado, una nueva ley, aprobada en enero de 1882 por parte del Gobierno liberal de Sagasta, vino a reformar parcialmente ambos textos legislativos y a incluir algunos nuevos principios programáticos del partido en el poder, que afectaron principalmente a la redención y a la sustitución, al ser reducida en su cuantía la primera y limitada a los hermanos la posibilidad de la segunda. De nuevo el debate en Cortes y la discusión en prensa sobre su articulado fueron mínimos.

El proyecto de ley fue presentado a las Cortes el 17 de noviembre de $1881^{1300}$ por parte del ministro de la Guerra Arsenio

\footnotetext{
${ }^{1299}$ Reglamento de exenciones físicas de 28 de Agosto de 1878, arts. 1-183.

1300 Proyecto de Ley de reforma de la actual organización del Ejército de 17 de Noviembre de 1881, Gaceta núm. 327 de 23/11/1881. En adelante, Proyecto de Ley de reforma del Ejército de 17 de Noviembre de 1881.
} 
Martínez Campos ${ }^{1301}$, que justificó de la siguiente forma la necesidad de tales cambios:

"Aunque sobre la base de la Ley de reemplazos de 28 de agosto de 1878 se ha dado un gran paso para organizar el Ejército a semejanza de lo que está adoptado en la mayoría de las naciones de Europa, la experiencia demuestra son necesarias algunas modificaciones que perfeccionen el sistema, y a este fin obedece al adjunto proyecto de ley.

El Ministro que suscribe, por no molestar la atención de las Cortes, se limitará a dar aquí una sucinta idea [...] para la mejor inteligencia de la proyectada reforma: España por su población, y teniendo en cuenta las fuerzas que podrían invadirla, ha de aspirar a un Ejército de 400.000 hombres instruidos que puedan presentarse en pocos días en primera línea.

Con la organización actual, aún permaneciendo en las filas los soldados de todas las armas plazos que no ha excedido desde 1875 acá de dos años y tres meses a tres años y cuatro meses, se ha conseguido tan solo una cifra de 376.353 hombres, de los cuales 108.355 son reclutas disponibles, pudiendo asegurarse que de los restantes no llegan a 180.000 los que han recibido instrucción.

Hay, pues, necesidad de aumentar la fuerza de los contingentes instruidos que pasan a la reserva y el número de años de permanencia en ésta"1302.

La justificación era clara y mostraba, según el ministro, las enseñanzas que se habían obtenido de los conflictos europeos: la necesidad de una rápida movilización militar, tal y como demostraba la guerra franco-prusiana, obligaba a aumentar el número de

${ }^{1301}$ Arsenio Martínez Campos es uno de los militares de mayor prestigio del siglo XIX español, especialmente por su participación en la Restauración de los Borbones y sus labores militares en Cuba. Ejerció como ministro de Guerra tanto en gobiernos conservadores como liberales, ya que formó parte de ambos partidos, y también alcanzó de forma efímera la presidencia del Gobierno de manos del partido Conservador, (Diccionario Biográfico Español, edición digital, RAH, http://www.rah.es/cdeb.htm)

1302 Proyecto de Ley de reforma del Ejército de 17 de Noviembre de 1881. 
soldados, ya instruidos para la guerra y en situación de reserva, dispuestos a empuñar las armas de una forma eficaz cuando fuesen requeridos. $Y$ para ello nada mejor que aumentar el periodo de tiempo en que los soldados se encontrasen en la situación de reserva, que además no incrementaría los gastos públicos que supondría un aumento excesivo del número de reclutas. El proyecto planteó para ello dividir la fuerza de tropa del Ejército en cuatro situaciones:

- Servicio activo con una duración de tres años.

- Reserva activa de tres años con licencia ilimitada para los soldados.

- Segunda reserva durante cuatro años.

- Batallones de depósito compuestos por reclutas disponibles y redimidos en metálico durante doce años ${ }^{1303}$.

Se esperaba con esta división la movilización rápida de un Ejército de 400.000 efectivos instruidos para la guerra en pocos días cuando la situación lo requiriese.

El proyecto de ley presentado por Martínez Campos vino acompañado por una amplia e interesante memoria justificativa de la necesidad de los cambios propuestos. En esta ocasión se aludió específicamente al conflicto franco-germano de 1870 y a la victoria de las armas alemanas como un cambio de rumbo en la organización de los ejércitos europeos y se insistió en la necesidad de que la institución castrense española se adaptase a estos cambios. La novedad reside en el incremento del número y la eficacia de los soldados instruidos en las armas en situación de reserva y no tanto

1303 Proyecto de Ley de reforma del Ejército de 17 de Noviembre de 1881. 
en activo, para poder ser rápidamente movilizados en caso de conflicto $^{1304}$.

Señaló el ministro de la Guerra en dicha memoria que el número de efectivos del Ejército español ascendía a 376.000 hombres, estando solo instruidos para la guerra la mitad de ellos, cifra del todo insuficiente. Los batallones de reserva españoles serían además incapaces de una rápida movilización, un mínimo tres meses, y "[...] en este periodo de tiempo la invasión habría tal vez adelantado tanto en el interior del Reino, que una gran parte del territorio estaría en poder del enemigo, y la otra haría sacrificios acaso tardíos y estériles para rechazar la agresión y conquistar el terreno perdido"1305.

1304 "En la actualidad, con el progresivo y extraordinario desarrollo que estos [los Ejércitos] han tenido en las naciones más importantes de Europa; en el deseo de cada una de sobrepujar a sus vecinas, no solo en la composición de aquélla, sino también en el número, y las dificultades económicas que han tocado para poder sostener sobre las armas en tiempo de paz las fuerzas que creían necesarias para atender a la defensa del territorio y representar en el concierto Europeo el papel que cada una creía estar llamada a llenar, han acudido a crear grandes reservas y no tener en filas más hombres que los estrictamente necesarios para que tuviesen tiempo de adquirir la instrucción y hábitos militares indispensables, y que a la vez fuesen los suficientes para llegar a la cifra que en caso de guerra había de alcanzar el total del Ejército. Si no tuviéramos reciente el ejemplo del poderoso esfuerzo que en el año 1870 hizo Alemania para poner en pie de guerra aquélla masa de hombres que casi oscureció las grandes invasiones de que nos habla la historia antigua, podríamos dudar de la posibilidad de poner en movimiento ordenadamente tan considerable número de hombres, y sobre todo de la eficacia de las reservas.

Desde muchos años atrás la organización del Ejército prusiano ha tenido grandes encomiadores, aunque no faltaban bastantes militares que creían carecía de muchas de las condiciones a que deben obedecer las organizaciones de los Ejércitos; pero después de la guerra franco-alemana, casi todos los gobiernos han procurado hacer aquellas reformas que estimaban más adaptables a las costumbres y modo de ser de sus respectivas naciones, imitando en lo posible el sistema adoptado en Prusia. Las guerras que asolaban a España, y la necesidad de ocurrir a las circunstancias del momento, nos impidieron seguir por el pronto impulso pero así que terminaron aquellas, entró el Gobierno en el movimiento general, y las leyes de reemplazo de 10 de enero de 1877 y 28 de agosto de 1878, con la creación posterior de los batallones y comisiones de reserva y depósito, marcaron un gran paso en este camino, que si desde luego no fue completo, se debió al pensamiento de no hacer innovaciones violentas que pudieran pugnar con nuestras costumbres y tal vez con nuestras preocupaciones, y sólo se trató de iniciar el sistema para ir desarrollándolo sucesivamente (Proyecto de Ley de reforma del Ejército de 17 de Noviembre de 1881).

${ }^{1305}$ Proyecto de Ley de reforma del Ejército de 17 de Noviembre de 1881. 
Además, Martínez Campos ponía en cuestión la aptitud para la guerra de los reclutas disponibles y las seis semanas de instrucción que, cada dos años, tenían éstos, ya que "[...] la educación y costumbres militares [...] no se adquieren más que con la vida en común de cuartel o campamento con soldados más antiguos y al cabo de cierto tiempo" ${ }^{1306}$.

Reivindicó el ministro por todos estos motivos la necesidad de reformar la Ley de reclutamiento de 1878 y la organización del propio Ejército y su reserva. Esta reforma se debería basar en los siguientes principios:

- El ejército puesto en pie de guerra en caso de agresión debía ser lo suficientemente numeroso.

- Todos los soldados que lo compongan deberían tener una instrucción adecuada para su cometido.

- La movilización debía ser rápida.

- En tiempos de paz el presupuesto de defensa no debía poner en peligro la situación del Erario público ni dañar, al tener ocupados a brazos jóvenes, la situación de la agricultura y la industria.

Para cumplir estos objetivos, tal y como indicamos anteriormente, Martínez Campos defendió en esta memoria la necesidad de completar un Ejército con 400.000 efectivos $^{1307}$ y la división de la fuerza indicada en los cuatro tipos que previamente hemos señalado: servicio activo, reserva activa, segunda reserva y batallones de depósito. Las dos primeras, que deberían llegar a la

\footnotetext{
${ }_{1306}$ Proyecto de Ley de reforma del Ejército de 17 de Noviembre de 1881.

1307 "[...] debemos procurar acercarnos a la cifra de 400.000, comprendiendo no solo el Ejército activo sino también la reserva; dicha fuerza puede aumentarse durante la guerra, porque cuando esta estalle, las necesidades de la defensa, el honor de la Nación, el entusiasmo que en un pueblo altivo y guerrero como el nuestro se ha de despertar, acallarán necesariamente las consideraciones del excesivo gasto y de la conveniencia de no esperar tantos brazos de la agricultura y de la industria" (Proyecto de Ley de reforma del Ejército de 17 de Noviembre de 1881).
} 
cifra de 400.000 efectivos, constituirían un solo ejército capaz de frenar una agresión, dando además tiempo para la instrucción de la segunda reserva que cubriría las bajas de los cuerpos en campaña e incluso pasarían a primera línea de combate si los acontecimientos bélicos así lo requiriesen. Esta tercera tipología de reclutas disponibles no debería bajar de 300.000 efectivos. Cuando esta situación se produjese "[...] se podrá decir que habremos puesto sobre las armas el máximum de hombres a que racionalmente puede aspirar España, pero será en un caso supremo, cuando se tenga que combatir por la independencia o la integridad de la patria"1308. Veía el ministro difícil superar esta cifra de soldados, muy inferior a las capacidades de movilización de las principales potencias europeas, atendiendo a los recursos del país.

La memoria justificativa, además del aumento en el número de reclutas en la reserva, insistió en la necesidad de mejorar la instrucción de los soldados, insuficiente hasta ahora según el ministro. La solución ideal sería prolongar el servicio militar hasta los ocho años, "[...] pero llenar esta condición y a la vez tener un Ejército numeroso, es imposible; no hay hacienda que pueda soportarlo, y sería gastar las fuerza vivas y los recursos de las naciones en la paz para que llegaran desangradas a la guerra"1309. Estas limitaciones llevaron al ministro a proponer un periodo de instrucción de tres años. Además de la formación militar en los cuarteles, los nuevos reclutas que aspirasen al puesto de alférez deberían ser formados en los conocimientos rudimentarios de lectura y escritura, y esta formación debería correr a cuenta del Estado "[...] sin que sus padres tengan que hacer costosos sacrificios pecuniarios que no les permite su corto sueldo"1310. Defendió para ello que los

\footnotetext{
1308 Proyecto de Ley de reforma del Ejército de 17 de Noviembre de 1881. 1309 Proyecto de Ley de reforma del Ejército de 17 de Noviembre de 1881. 1310 Proyecto de Ley de reforma del Ejército de 17 de Noviembre de 1881.
} 
aspirantes a oficial tendrían que ser formados en un centro común de enseñanza, en una Academia General Militar ${ }^{1311}$.

Concluyó Martínez Campos su memoria justificativa defendiendo la necesidad de estas reformas para situar a España en el lugar que le correspondía en el concierto de las naciones europeas $^{1312}$. La oposición parlamentaria al proyecto de nuevo fue mínima. Tan sólo el demócrata Canalejas encabezó una iniciativa contraria al mismo acusando al Gobierno liberal de reaccionario y de actuar con improvisación e impaciencia ${ }^{1313}$.

Una vez analizado el proyecto de ley y los motivos que justificaron las reformas planteadas, nos disponemos a revisar el propio articulado legislativo de la nueva Ley de Reclutamiento y Reemplazo de 8 de Enero de $1882^{1314}$, si bien nos centraremos exclusivamente en los aspectos que son reformados con la nueva disposición. Aunque la reforma había sido planteada por el ministerio de Guerra, fue el de Gobernación quien finalmente la implantó de manos de Venancio González ${ }^{1315}$.

Se inició el texto declarando la obligatoriedad del servicio militar, pero se incrementó la duración del mismo hasta los doce años, seis en el servicio activo y otros tantos en la segunda

\footnotetext{
1311 "Una vez establecida la Academia General, los oficiales del Ejército procederán de un centro común con lazos de indeleble compañerismo que solo se crean e la juventud; se establecerá un conjunto armónico entre todos los cuerpos y entre todas las clases del Ejército, basado en la instrucción, en el cariño, mutuo respeto y conciencia de sus deberes, con lo cual se levantará nuestro espíritu militar" (Proyecto de Ley de reforma del Ejército de 17 de Noviembre de 1881).

1312 Proyecto de Ley de reforma del Ejército de 17 de Noviembre de 1881.

1313 Discurso del Sr. Canalejas, Diario de sesiones de las Cortes, no 79, 24/12/1881, pp. 2109-2110.

${ }^{1314}$ Ley de reclutamiento y Reemplazo de 8 de Enero de 1882, reformando la Ley de 1878.

1315 Venancio González y Fernández dedicó buena parte de su vida a la carrera política como diputado desde 1863. Tras el Sexenio, en cuyas Cortes también participó, ejerció como ministro de la Gobernación en tres Gabinetes de Sagasta y como ministro de Hacienda con el mismo Presidente, Diccionario Biográfico Español, edición digital, RAH, http://www.rah.es/cdeb.htm
} 
reserva ${ }^{1316}$, si lo comparamos con las leyes de 1877 y 1878 . Además, se implantó una división en cinco tipos de reclutas que recogía, casi en su totalidad, el proyecto de Martínez Campos, y es aquí donde residió la principal novedad de la ley:

Servicio activo, con una duración de seis años, y subdividido en la siguiente tipología:

1. En activo.

2. Con licencia ilimitada o reserva activa.

3. Reclutas disponibles.

Reserva, con duración de otros seis años:

1. Segunda reserva.

2. Reemplazo de la reserva ${ }^{1317}$.

La forma de realizar el repartimiento apenas fue modificada. Tan solo se señaló que correspondía al ministerio de la Gobernación, a través de un real decreto, señalar con que contingente de reclutas debía contribuir cada provincia en función del número de mozos sorteados de la totalidad de sus pueblos. La talla mínima exigida fue elevada ligeramente hasta los 1,545 m. Aquellos que no alcanzasen esa estatura mínima pero superasen los $1,500 \mathrm{~m}$. serían destinados a los batallones de depósito durante tres años a la espera de tres sucesivos reconocimientos anuales que permitiesen comprobar si el joven había superado esa estatura. Si esta circunstancia se produjese, ingresarían en el servicio activo; si no fuese así, al cuarto año recibirían licencia absoluta ${ }^{1318}$. Se intentó de esta forma incrementar el número de soldados formados en el arte de la guerra dispuestos para una rápida movilización.

1316 Ley de reclutamiento y Reemplazo de 8 de Enero de 1882, reformando la Ley de 1878 , arts. 1 y 2.

1317 Ley de reclutamiento y Reemplazo de 8 de Enero de 1882, reformando la Ley de 1878 , art. 4

1318 Ley de reclutamiento y Reemplazo de 8 de Enero de 1882, reformando la Ley de 1878 , arts. 28,29 y 88. 
Del servicio activo formarían parte durante seis años los reclutas declarados soldados. Una vez cumplido este plazo, recibirían licencia ilimitada para regresar a sus hogares, aunque seguirían formando parte del Ejército como reclutas en la reserva. Existía la posibilidad de acortar el plazo de permanencia en el servicio activo hasta los tres años si así lo decidiese el ministerio de la Guerra por las necesidades militares del momento. Para aquellos que se viesen obligados a permanecer en el servicio activo durante los seis años preestablecidos, tendrían derecho a recibir una paga de 3 pesetas y 75 céntimos mensuales ${ }^{1319}$.

También se encargó la ley de acotar qué mozos serían considerados reclutas disponibles, y lo serían aquellos jóvenes sorteados, no exentos y útiles para el servicio, que no hubiesen ingresado en las filas del Ejército. Serían destinados a los batallones de depósito de sus provincias respectivas. Asimismo serían considerados reclutas disponibles aquellos mozos declarados inútiles por alguna enfermedad o defecto no incluido en el reglamento de exenciones y que no pudiesen formar parte del servicio activo. Durante tres llamamientos sucesivos serían de nuevo examinados, y en el caso de ser considerados útiles en cualquiera de los tres reconocimientos, ingresarían en el servicio activo. El tiempo que hubiesen pasado en los batallones de depósito les sería contabilizado para su prestación en la reserva, pero no en el servicio activo. Esta tipología de reclutas disponibles debería acudir a las asambleas que el Gobierno convocase para su instrucción. Su misión sería cubrir las bajas que se produjesen entre los miembros del servicio activo del Ejército. Estos reclutas disponibles, y también los jóvenes eximidos,

1319 Ley de reclutamiento y Reemplazo de 8 de Enero de 1882, reformando la Ley de 1878 , art. 5 . 
deberían acudir al llamamiento convocado por el Gobierno para cubrir las bajas habidas en caso de guerra ${ }^{1320}$.

La segunda reserva estaría compuesta por su parte por todos los reclutas que hubiesen cumplidos los seis años de servicio activo o como reclutas disponibles. Los individuos de ambas reservas, reserva en activo y segunda reserva, deberían acudir a las asambleas anuales que convocase el Gobierno y acudir a filas cuando fuesen llamados. Se intentó así mejorar la preparación de los reclutas que no formasen parte del servicio activo por si fuese necesaria su rápida movilización en caso de guerra. El pase de un individuo de la primera a la segunda reserva solo se podría suspender si estuviese declarado el estado de guerra. Además, podrían viajar libremente por la península y cambiar de residencia, dando conocimiento previamente a sus respectivos jefes. Estos derechos solo se podrían negar en caso de conflicto bélico o de alteración del orden público. Los reclutas disponibles no podrían viajar ni cambiar de domicilio durante el primer año que se encontrasen en tal situación. Los soldados en activo y los de la reserva activa no podrían contraer matrimonio, pero sí los de la segunda reserva ${ }^{1321}$.

Incluyó esta ley otras importantes reformas respecto a la aprobada en 1877. Así, se introdujo por primera vez al archipiélago Canario como territorio sometido a las operaciones de reemplazo, aunque solo podrían prestar sus servicios en tiempos de paz y serían destinados obligatoriamente a su territorio de residencia ${ }^{1322}$. Perdían por tanto su exención pero conservaron algunos privilegios.

El número de mozos que debía ingresar en el servicio activo sería concretado a través de un real decreto expedido por el

${ }^{1320}$ Ley de reclutamiento y Reemplazo de 8 de Enero de 1882, reformando la Ley de 1878 , arts. 6 y 7.

${ }^{1321}$ Ley de reclutamiento y Reemplazo de 8 de Enero de 1882, reformando la Ley de 1878, arts. 7-9.

1322 Ley de reclutamiento y Reemplazo de 8 de Enero de 1882, reformando la Ley de 1878 , arts. 14 y 15. 
ministerio de Gobernación a propuesta del de Guerra y de acuerdo con el Consejo de Ministros. El resto de mozos quedarían en sus casas formando batallones de depósito como reclutas disponibles. En tiempo de guerra o por determinadas circunstancias excepcionales, el Gobierno, a través de un decreto del ministerio de la Guerra, podría movilizar a todos los cuerpos que considerase necesario, independientemente de su pertenencia al servicio activo o a la reserva. Para cubrir las bajas y completar la fuerza del Ejército activo puesto en pie de guerra se llamaría a los reclutas disponibles. Si aún así fuese necesario cubrir más bajas, se movilizaría a toda o parte de la segunda reserva a través de una ley aprobada por las Cortes o a través de un decreto aprobado por el Consejo de Ministros si éstas estuviesen cerradas ${ }^{1323}$.

Otro aspecto novedoso de la ley es el que definía el medio de cubrir los cuerpos destinados a Ultramar. Estos ejércitos, cuya fuerza determinaría anualmente las Cortes, se reemplazarían a través de voluntarios pertenecientes a la fuerza armada o por antiguos soldados que no superasen los treinta y cinco años de edad. En el caso de no cubrirse las vacantes a través de voluntarios, se procedería a enviar a los reclutas que hubiesen sido designados a través de un sorteo. En el caso de guerra, el ministerio podría enviar los cuerpos que considerase más convenientes. Se deja al ministerio la capacidad de destinar a los destinos coloniales los cuerpos más preparados del Ejército español si así lo requiriesen las circunstancias bélicas. Los soldados destinados a Ultramar prestarían un servicio de únicamente cuatro años, permaneciendo otros cuatro en la reserva. Para fomentar la continuidad de los soldados en estos territorios, se ofreció a los reclutas allí destinados la posibilidad de continuar en territorio americano otros dos años en activo o en la reserva activa,

${ }^{1323}$ Ley de reclutamiento y Reemplazo de 8 de Enero de 1882, reformando la Ley de 1878 , arts. 16-19. 
recibiendo licencia absoluta al cumplir los seis años ${ }^{1324}$. A cambio por tanto de permanecer seis años en territorio colonial, se podían eximir de las obligaciones que, durante otros seis años, los soldados peninsulares tenían con el Ejército.

El artículo 25 de la Ley de 1878 fue también reformado con el objetivo de evitar la picaresca en las exenciones. Para ello se prohibió que fuesen ordenados in sacris aquellos que no acreditasen encontrarse libres de toda responsabilidad respecto al servicio militar. También se trató de limitar las exenciones por motivos familiares, es decir, para el mantenimiento de familiares por parte de hijos o nietos únicos, que recogía el artículo 92 de la Ley de 1878. Estos mozos estarían obligados a presentarse a los actos de llamamiento y declaración de los soldados durante los tres años siguientes a su reemplazo para demostrar que continuaba vigente el motivo de su exención. Si esta hubiese cesado, el joven ingresaría en la caja, dando de baja al joven que hubiese acudido en su lugar. Si continuase durante los tres reemplazos siguientes, estos mozos quedarían en la situación de reclutas disponibles, pudiendo ser movilizados en caso de guerra ${ }^{1325}$. De nuevo se incrementa el aporte de reclutas dispuestos a la movilización en el supuesto de conflicto bélico, tal y como recogían las indicaciones del ministro Martínez Campos.

También fueron cambiadas con la nueva ley las fechas en que se realizarían las distintas operaciones del reemplazo. El alistamiento se ejecutaría en los últimos días del mes noviembre o primeros de diciembre y se estableció el día 8 del último mes del año como fecha tope para realizar la rectificación del mismo, mientras que el sorteo se debería celebrar el último domingo del mes de diciembre. El acto

\footnotetext{
${ }^{1324}$ Ley de reclutamiento y Reemplazo de 8 de Enero de 1882, reformando la Ley de 1878 , art. 20.

1325 Ley de reclutamiento y Reemplazo de 8 de Enero de 1882, reformando la Ley de 1878 , arts. 25 y 95.
} 
de llamamiento y declaración de los soldados se realizaría por su parte el primer domingo del mes de enero ${ }^{1326}$.

La nueva ley trató también de aclarar qué jóvenes deberían estar presentes el día de la entrega en caja. Además de los mozos declarados soldados, tenían obligación de acudir al acto un número de suplentes igual al de soldados titulares, y cuya exención fuese dudosa; todos aquellos que pretendiesen exceptuarse del servicio y todos aquellos cuya exención temporal tuviese que ser sometida a revisión durante tres reemplazos. No deberían acudir sin embargo los reclutas disponibles ${ }^{1327}$.

Además de las diferentes situaciones por las que habrían de pasar los reclutas durante sus años de servicio, seguramente el aspecto más significativo de la ley sea la reducción de la cuota a pagar por parte de aquellos que quisieran redimirse en metálico ${ }^{1328}$. Esta redención baja de 2.000 a 1.500 pesetas, siendo por tanto mayor el número de reclutas con posibilidades de evitar el servicio activo. El mantenimiento de la redención fue explicado por "[...] los perjuicios que se irrogarían [con su supresión] a la industria, las ciencias y las artes al suprimir la redención y obligar a toda la juventud a ingresar en el Ejército, abandonando las aulas y sus profesiones de arte e industria"1329.

1326 Ley de reclutamiento y Reemplazo de 8 de Enero de 1882, reformando la Ley de 1878 , arts. 47, 54, 55, 61, 62, 70, 84 y 100.

1327 Ley de reclutamiento y Reemplazo de 8 de Enero de 1882, reformando la Ley de 1878 , art. 124.

1328 Las críticas de Canalejas de centraron en la redención, considerada como "[...] es una gran vergüenza para nuestra Patria, y no puede disculparse siquiera considerándole desde el punto de vista económico, porque los fondos, los recursos que produce la redención tienen una inversión que ha sido objeto de legitimas censuras y quo no se acomoda ciertamente a las exigencias ni a las necesidades del Ejército. Bien es verdad quo aun cuando desde el punto de vista económico pudiera legitimarse la redención, aun subsistiría la injusticia, y para nosotros, legisladores, importa mucho mas corregir una injusticia quo arbitrar un recurso" (Discurso del Sr. Canalejas, Diario de sesiones de las Cortes, no 79, 24/12/1881, p. 2110).

1329 Discurso del Sr. Dabán, Diario de sesiones de las Cortes, no 79, 24/12/1881, p. 2129). 
No se contradice sin embargo con el espíritu de la ley la obligación que tenían estos redimidos de ingresar en la institución castrense como reclutas disponibles, quedando exentos del servicio activo. Sólo deberían acudir a las asambleas de instrucción que practicasen los reclutas de su reemplazo y empuñar las armas exclusivamente en tiempos de guerra ${ }^{1330}$.

Por tanto, aumenta el número de jóvenes susceptibles de redimirse, pero su exención no era completa, ya que recibirían una educación castrense mínima como reclutas disponibles y deberían acudir al llamamiento en caso de conflicto bélico. De nuevo se volvió a incrementar al número de mozos dispuestos a empuñar las armas en situación de reserva, pero sin que el Estado tuviese que asumir los costes que supondría su incorporación al servicio activo. Supuso además una de las primeras limitaciones que se impuso a la redención en metálico ya que, aunque se redujo el dinero a pagar para gozar de la exención, el redimido mantenía ciertas obligaciones con la reserva del Ejército y no recibía una licencia absoluta ${ }^{1331}$.

También trató el texto legislativo de poner límites a una práctica socialmente discutida: se prohibió la sustitución a no ser que fuese entre hermanos, con la única excepción de los reclutas destinados a Ultramar, a quienes se permitía presentar un sustituto de su mismo reemplazo. Además, al igual que sucedía con los redimidos en metálico, la sustitución no suponía una desvinculación

1330 Ley de reclutamiento y Reemplazo de 8 de Enero de 1882, reformando la Ley de 1878 , art. 179.

${ }^{1331}$ Esta limitación en la redención fue asumida como un éxito y un avance en la igualdad por parte del ministro Martínez Campos: "Hoy, con este proyecto, creo que el Gobierno ha dado un gran paso, pues por él se impone al que se redime la obligación de servir a su Patria en caso de guerra, de acudir a las asambleas, ya como recluta disponible, ya en los batallones de reserva. Antes, sabe el Sr. Canalejas, que desde el momento en que un mozo se redimía, para él ya había concluido toda obligación, y hoy no sucede así, pues hoy se le redime únicamente de las molestias que se le pueden ocasionar con los años quo se le obligaría a permanecer en las filas, pero no se le redime de la obligación de servir a la Patria en casos dados (Discurso del Sr. Ministro de Guerra, Diario de sesiones de las Cortes, no 79, 24/12/1881, p. 2113). 
total del Ejército, ya que los sustituidos permanecerían como reclutas disponibles en los batallones de depósito ${ }^{1332}$.

Por último, señalar que la Ley de 1878 , las reformas en ella implantadas a través de la Ley 8 de enero de 1882 y el Reglamento de exenciones físicas de 1878, serían refundidos en nuevo texto legal ${ }^{1333}$ que mantendría una vigencia de tan solo tres años con la aprobación de una nueva Ley de reclutamiento en julio de 1885 .

1332 Ley de reclutamiento y Reemplazo de 8 de Enero de 1882, reformando la Ley de 1878 , arts. 3 y 180.

1333 Ley de Reemplazos de 10 de Enero de 1882, Gaceta núm. 45 de 14/02/1882. 



\section{8.- Un intento de frenar las críticas: La Ley de 1885}

Apenas pasados tres años desde la aprobación de la Ley de 1882 que venía a reformar el texto legislativo de 1878, nos encontramos con una nueva Ley de reclutamiento y reemplazo con fecha de 11 de julio de 1885 que introducía algunas importantes novedades en la regulación del proceso ${ }^{1334}$. El nuevo texto, aprobado por el partido Conservador de Cánovas en el Gobierno, venía a revisar el implantado por los liberales tres años antes. El origen de su aprobación debe buscarse en la necesidad de maquillar la legislación sobre el reemplazo frente a las críticas populares y también militares en contra de los privilegios existentes por motivos económicos y a favor de un servicio militar obligatorio para toda la población. Una nueva reforma de la ley se produjo en 1896, circunstancia que abordaremos más adelante ${ }^{1335}$. Con los cambios introducidos y el interés social sobre la materia, los debates en Cortes sobre quintas se vieron reducidos apenas a las fechas en que se discutía la cifra del contingente anual y a las cuestiones relacionadas con la sustitución y la redención en metálico. Acudiremos a los periódicos La Época, ya analizado en legislaciones previas y emblema conservador, y EI Globo ${ }^{1336}$, para completar el impacto de la nueva legislación.

1334 Ley de reclutamiento y reemplazo de 11 de Julio de 1885, Gaceta núm. 144 de 13/07/1885. En adelante, Ley de reclutamiento y reemplazo de 11 de Julio de 1885.

1335 Ley de 21 de Agosto de 1896, reformando la Ley de reclutamiento y reemplazo de 11 de Julio de 1885, Gaceta núm. 236 de 23/08/1896 y Reglamento para la ejecución de la Ley de reclutamiento y reemplazo del Ejército de 11 de julio de 1885 modificada por la de 21 de agosto de 1896, Gaceta núm. 361 de 26/12/1896. En adelante, Ley de 21 de Agosto de 1896 y Reglamento de 21 de Agosto de 1896. 1336 "Fundado por Emilio Castelar (1832-1899), será el principal órgano del posibilismo representado por el Partido Republicano conservador y unitario. Publica su número prospecto el 21 de marzo de 1875 y comienza su andadura a partir del uno de abril de ese año [...]. Va a tener una prolongada vida y durante sus dos primeros años estará dirigido por Pedro Avial y sus páginas estarán alejadas del debate político.

A partir de 1877 lo dirigirá Joaquín Martín de Olías (1842-1900), que había sido ya uno de sus principales redactores, [...] señalando bajo su cabecera que ya es un diario político, además de ilustrado, literario y científico. En números de cuatro 
La nueva división territorial militar española como contexto histórico

El año 1885 vino marcado por la temprana muerte del joven rey Alfonso XII. La puerta a la inestabilidad quedaba así abierta de par en par nuevamente, dado que el heredero al trono era el hijo aún no nato del rey difunto, lo cual suponía que se produciría una larga regencia, hasta que el príncipe tuviera edad suficiente para gobernar por sí mismo.

La sombra de la inestabilidad y de la fractura nacional impulsó a los líderes de los dos principales partidos políticos, Cánovas y Sagasta, a entrevistarse en El Pardo para llegar a un acuerdo que posibilitara, a través de una voluntad de común entendimiento que evitara la desintegración del sistema político en lo que, sin duda, se anunciaba como un periodo difícil para la Monarquía. Si llegó a

páginas y a cuatro columnas, resaltan sus excelentes y numerosos grabados y su estructura será la propia de los diarios de la época, con artículos políticos, secciones de noticias nacionales y extranjeras, despachos telegráficos de la agencia Fabra, así como las de espectáculos, cotizaciones de bolsa, etc. Incorpora también el folletín y su cuarta plana estará íntegramente dedicada a los anuncios comerciales.

Los cambios en su propiedad se van a ir sucediendo. En 1885 lo adquiere Eleuterio Maisonnave, que también lo dirigirá, y comenzará la época más brillante del diario, que ya en 1880 había alcanzado una circulación en torno a los 25.000 ejemplares, llegando a ser uno de los periódicos republicanos y anticlericales de mayor difusión entre un público amplio no necesariamente castelarino, a la vez que el partido republicano liberal había avanzado hacía su progresiva integración en el régimen de la Restauración, tal como señala Seoane. En 1890 lo adquirirá Alfredo Vicenti, que lo dirigirá también hasta 1895, pasando al año siguiente a ser propiedad del futuro conde de Romanones, Álvaro de Figueroa y Torres (1863-1950), una de las figuras más importantes del Partido Liberal de Práxedes Mateo Sagasta, quien pondrá en la dirección a José Franco Rodríguez.

Como diario liberal-demócrata, en el periodo finisecular se convertirá en cómodo refugio de la "aristocracia" de la generación del 98, según señala Gómez Aparicio, resaltando la incorporación a su redacción de Pío Baroja y Azorín. Y en 1902, Romanones lo vende al diputado catalán Emilio Ríus y Peniquet, quien asume la dirección [...]. El diario pasa a subtitularse "independiente", tira dos ediciones diarias, y desaparecen de sus páginas las ilustraciones. Su propiedad pasará a manos de Ivo Bosch y defenderá la política de Segismundo Moret (1833-1913), a la vez que su difusión irá bajando drásticamente, si en 1913 era de unos 8.000 ejemplares, en 1920, se calcula que estaba ya entre los mil y dos mil ejemplares. A partir de 1923 llegará a perder su frecuencia diaria [...]" (http://www.bne.es/es/Catalogos/HemerotecaDigital). 
firmarse o no el acuerdo por escrito -el pacto de El Pardo- es algo que todavía hoy es objeto de debate entre la historiografía. En cualquier caso, el entendimiento entre Cánovas y Sagasta propició uno de los pocos cambios de gobierno sin estridencias ni incidentes, cuando los conservadores perdieron el poder a favor de los liberales ${ }^{1337}$.

Este fue el contexto en que el proyecto de ley de reclutamiento fue presentado por el ministro de la Gobernación conservador Francisco Romero y Robledo ${ }^{1338}$. Los principios programáticos e ideológicos de los gobiernos conservadores respecto al reclutamiento apenas habían variado, y los motivos de la aprobación de una nueva ley, explicados en su preámbulo, residían zonas militares, se había adoptado para el territorio del Estado español ${ }^{1339}$. Sorprendentemente, la prensa republicana posibilista de Castelar no se introdujo en el análisis de la nueva norma, ni en sus proyectos de reforma posteriores, más allá de reflejar en sus páginas los debates parlamentarios, mientras que la prensa conservadora consideró necesaria la reforma en la legislación sobre reclutamiento por las limitaciones de la normativa previa, en especial en lo que se refiere a la formación del contingente:

"Un proyecto de gran importancia para el ejército está á punto de ser promulgado y puesto en práctica. Este proyecto, cuya necesidad era sentida hace tiempo, es el que aumenta el efectivo del

1337 Al respecto, ver ALEJANDRE, J.A., "El Pacto de El Pardo", Historia 16, 116 (1985), pp. 19-28; DARDÉ MORALES, C. y VARELA ORTEGA, J., "La Regencia y el Pacto de el Pardo", en ESPADAS BURGOS, M. (coord.), La época de la restauración: (1875-1902), Vol. 1, Madrid, Espasa Calpe, 1996, pp. 359-369.

${ }^{1338}$ Francisco Romero y Robledo, nacido en Antequera (Málaga) en 1838 y muerto en Madrid en 1906, abogado, político y ministro del Partido Conservador de Cánovas, ocupó diversas carteras ministeriales en sucesivas ocasiones, tales como Fomento, Gobernación, Ultramar y Gracia y Justicia. Fue además Presidente del Congreso de los Diputados entre 1903 y 1905, Diccionario Biográfico Español, edición digital, RAH, http://www.rah.es/cdeb.htm

1339 Real Decreto de 9 de Junio de 1882, Gaceta núm. 161 de 10/06/1882; Real Decreto de 13 de Diciembre de 1883, Gaceta núm. 348 de 14/12/1883. 
ejército, si bien manteniendo una parte con licencia temporal, a fin de que los gastos no excedan de los créditos consignados en los presupuestos sometidos á la aprobación de las Cortes. En el preámbulo del indicado proyecto se reconoce qué fue laudable el pensamiento que informó la legislación vigente; pero dado lo complejo del organismo militar, la experiencia de la práctica ha venido á demostrar que los resultados no responden á los gastos que ocasiona.

Obedece, como es sabido, la actual legislación, ál principio de mantener cortos efectivos sobre las armas y un considerable número de hombres instruidos en las reservas, para lo cual se elevan los contingentes llamados anualmente al servicio y sé dota con un cincuenta por ciento más de fuerza á los cuerpos de infantería durante tres meses del año, á fin de qué los nuevos reclutas puedan dedicarse en ese tiempo exclusivamente á la instrucción, y como consecuencia reduce á dos años y tres meses la permanencia en las filas, del soldado de infantería. La manera como se llevan á cabo las operaciones del reclutamiento y reemplazo anual, la desigual densidad de las zonas militares asignadas á los batallones dé infantería y otras varias causas que no creemos necesario indicar, por demasiado conocidas, producen en la práctica resultados que dejan mucho que desear. La incorporación á los Cuerpos de los contingentes que se les asignan, no se verifica de una vez, sino que median cuatro, seis $y$ hasta ocho semanas entre la llegada de la primera parte del contingente y la de la última, y por lo tanto no se consigue que la instrucción sea simultánea, como fué el pensamiento dé los autores de la ley, que en este punto importante queda defraudada. [...] Había, pues, que pensar en la reforma del sistema, y por eso ha sido tan bien recibido el proyecto de aumento de fuerza del ejército permanente presentado por el señor ministro de la Guerra [... $]^{1340}$.

Los escasos cambios que implicó la nueva ley explican la práctica inexistencia de oposición al proyecto presentado por el Senado ${ }^{1341}$. Tan solo el diputado militar liberal sr. Dabán mostró ciertos recelos hacia algunas de las reformas que implicaba la nueva

\footnotetext{
${ }^{1340}$ La Época, 11/06/1885, no 11818, p.1.

1341 Proyecto de ley, remitido por el Senado, sobre reclutamiento y reemplazo del Ejército, Diario de Sesiones de las Cortes, apéndice $4^{\circ}$ al no 168, 09/06/1895, pp. $1-23$.
} 
legislación, pero estando en líneas generales de acuerdo con el espíritu de la norma:

"En tal concepto, empiezo por confesar que con esta ley se da un gran paso respecto al reclutamiento del Ejército. Esta ley, comparada con las de 1882 y 1878, presenta ventajas inmensas sobre aquellas ${ }^{1342 "}$.

Como segundo motivo que explica la aprobación de la norma encontramos la necesidad de adaptación de las tareas del reemplazo a las nuevas cajas de reclutamiento, recién creadas y que venían a sustituir a las establecidas en las capitales provinciales civiles ${ }^{1343}$.

Esta nueva organización militar del territorio había traído consigo numerosos problemas a la hora de realizar las operaciones del reemplazo, "[...] toda vez que en la mayor parte de las cabezas de las nuevas zonas no existe corporación a quien poder confiar con probabilidades de acierto la resolución de las muchas cuestiones que suelen presentarse en el acto de la entrega de los reclutas, al que hoy va unido el fallo de cuantas reclamaciones se promueven acerca de las exenciones alegadas por los mismos"1344. La necesidad de

1342 Discurso del Sr. Dabán, Diario de Sesiones de las Cortes, no 176, 18/06/1895, p. 5138.

1343 "La Ley de 8 de enero de 1882, que reformó la de 28 de agosto de 1878 sobre reclutamiento y reemplazo del Ejército, inició la idea de dividir el territorio de la Península e Islas adyacentes en zonas militares, cada una de las cuales debía comprender los pueblos llamados a nutrir con sus contingentes unos mismos cuerpos activos, sus reservas y batallones de depósito correspondientes. Desarrollada esta idea en el Real Decreto expedido por el Ministerio de la Guerra con fecha 9 de junio del mismo año, que dio una nueva organización a los cuerpos del Ejército activo y de reserva, y aprobada en 10 de julio siguiente la demarcación territorial de las 140 zonas en que dichos cuerpos quedaron localizados, vino a establecerse en cada una de ellas por Real Decreto de 13 de diciembre de 1883 una Caja de recluta que reemplazase a los existentes anteriormente en las capitales de las provincias civiles y recibiese los mozos del llamamiento anual procedentes de los Ayuntamiento comprendidos en el territorio de la zona respectiva" (Ley de reclutamiento y reemplazo de 11 de Julio de 1885, Preámbulo).

${ }^{1344}$ Ley de reclutamiento y reemplazo de 11 de Julio de 1885, Preámbulo. 
superar estas dificultades obligaba a una pronta aprobación de una nueva ley que regulase el reclutamiento.

Un tercer objetivo especificado de la ley era reducir la complejidad administrativa que suponía, tal y como establecía la Ley de 8 de enero de 1882, la celebración de tres sorteos con los mozos sujetos al Ilamamiento, a saber:

- El primer sorteo en el Ayuntamiento de cada pueblo.

- El segundo en la caja de reclutas para designar a los mozos que, habiendo sido ya declarados soldados, serían destinados a Ultramar.

- Un tercero dentro de cada batallón de depósito para cubrir las bajas que se produjesen en el servicio activo.

Para evitar este inconveniente se decidió reducir los tres sorteos a uno solo, que se debería celebrar en la cabecera de cada zona militar, y en el que se fijaría definitivamente la suerte de los mozos sin tener en cuenta su lugar de procedencia. Además, previamente se debía fijar el cupo que cada zona, y no cada localidad, debía entregar, para evitar así las complicaciones y desigualdades que creaban el sorteo de décimas ${ }^{1345}$.

El preámbulo de la ley señaló por último otros dos objetivos menores que contenía su articulado: reducir el número de exenciones existentes, especialmente en el ámbito rural, y elevar el precio de la redención en metálico a 2.000 pesetas para aquellos soldados destinados a Ultramar ${ }^{1346}$.

Por último, señalar que una de las reformas más importantes que contuvo la nueva ley fue trasladar las competencias en materia de reclutamiento del ministerio de Gobernación al de la Guerra ${ }^{1347}$.

1345 Ley de reclutamiento y reemplazo de 11 de Julio de 1885, Preámbulo.

1346 Ley de reclutamiento y reemplazo de 11 de Julio de 1885, Preámbulo.

1347 "Como venía siendo tradicional desde que se implantó este precepto por las Cortes de Cádiz, el legislativo fijaba cada año la fuerza de que debía constar el 
Este texto legislativo, junto a la Ley de 1896, vinieron a militarizar definitivamente el reemplazo ${ }^{1348}$.

Desarrollo de una norma que apenas transformó la legalidad vigente

La ley, una de las más largas de todas las aprobadas a lo largo del siglo XIX y muy similar en su estructura a las puestas en vigor en 1778 y 1882 , se compone de un total de 179 artículos encuadrados en XVII capítulos, una disposición transitoria y un reglamento para la declaración de exenciones por motivos de inutilidad física ${ }^{1349}$.

a) Disposiciones generales: el teórico mantenimiento de los años de servicio militar

De nuevo se inició una ley en su primer capítulo declarando la obligatoriedad del servicio militar para todos los españoles con una duración de doce años al igual que establecía la legislación de enero de 1882. El servicio se dividió en activo y segunda reserva, manteniendo las mismas ideas que las planteadas por Martínez

Ejército permanente y por decreto se determinaba el cupo de hombres del reemplazo anual que se incorporaban a los cuarteles. Hasta entonces, la iniciativa del decreto era competencia de la cartera de Gobernación, quien también se responsabilizaba de la distribución territorial del contingente entre las distintas provincias españolas, con arreglo a su población respectiva. A continuación, las Diputaciones Provinciales señalaban el cupo de hombres que correspondía a cada pueblo; cupo que los Ayuntamiento sorteaban entre los alistados para que los números más bajos se incorporaran al cuartel. En virtud de la nueva ley, todo el proceso pasó a ser responsabilidad del ramo de Guerra. Su titular fijaba el contingente, lo repartía por zonas de reclutamiento y movilización y, en la cabecera de esta nueva unidad administrativa militar, su jefe presidía el sorteo de los mozos y declaraba soldados a los que hubiese correspondido (PUELL DE LA VILLA, F., El soldado desconocido: de la leva a la "mili" (1700-1912), pp. 287 y 288).

1348 FEIJÓo GÓMEZ, A., Quintas y protesta social en el siglo XIX español, p. 220.

1349 Reglamento para la declaración de exenciones del servicio en el Ejército y en la Marina por causa de inutilidad física. En adelante, Reglamento de exenciones físicas. 
Campos en su proyecto de ley, sin permitirse la posibilidad del voluntariado, opción ésta defendida desde La Época ${ }^{1350}$. El servicio activo incluía las siguientes situaciones:

- Servicio activo permanente.

- Licencia ilimitada o reserva activa.

- Reclutas en depósito o soldados condicionales.

Los soldados con licencia ilimitada o en reserva activa podrían ser llamados a filas cuando el Gobierno estimase conveniente, y así se haría en 1909 en los días previos a la Semana Trágica de Barcelona $^{1351}$.

La segunda reserva por su parte tendría una duración de seis años $^{1352}$. Los mozos declarados soldados útiles ingresarían en el servicio activo, permaneciendo en sus casas un máximo de un año hasta que fuesen llamados por las autoridades militares para su ingreso en caja. Los útiles condicionales, pendientes del fallo médico, ingresarían en caja cuando éste fuese positivo. Los reclutas que por sorteo fuesen destinados al servicio activo, permanecerían en él tres años hasta que recibiesen licencia ilimitada o pase a la reserva activa

1350 "Para remediar estos inconvenientes sería lo más obvio autorizar á los jefes de los Cuerpos para que admitieran voluntarios con objeto de cubrir las plazas de cabos, después de llenar los requisitos reglamentarios, limitando esta concesión á un numero determinado por Cuerpo, los cuales, además de engancharse por un tiempo que no bajara de cuatro años, deberían acreditar su buena conducta, cierta instrucción elemental y no ser menores do diez y ocho años, ni mayores de veinticuatro" (La Época, 13/06/1885, no 11820, p.1).

1351 Real Decreto de 10 de Julio de 1909 llamando a filas a los soldados de la reserva activa, Gaceta núm. 192 de 11/07/1909.

1352 La existencia de las reservas se vio como el método más optimo para mantener la formación militar de los reclutas sin causar un excesivo daño al Erario público: "Es principio reconocido en el sistema moderno la necesidad de tener numerosas reservas instruidas, es decir, compuestas de individuos que hayan pasado por las filas, sin que para ello sea preciso sostener un ejército permanente de fuerza superior á lo que los recursos del presupuesto consienten, y es, por otra parte, indispensable para la buena instrucción de todas las clases, que no se limiten á la dirección de unidades demasiado exiguas de fuerza á fin de no verse embarazados y sin saber desenvolverse el día en que aquéllas se eleven á las cifras señaladas para caso de guerra, esto es, en los momentos en que todas las clases deben utilizar los conocimientos y pericia que hayan adquirido durante la paz (La Época, 11/06/1885, no 11818, p.1). 
en momentos de paz para el país. En situaciones excepcionales o de guerra, el Gobierno podría suspender esta licencia ilimitada, aunque también las podría anticipar cuando la situación lo aconsejase ${ }^{1353}$. Se reservó por tanto el Ejecutivo la posibilidad de enviar a sus casas previamente a la finalización de su servicio activo a los reclutas cuando así se considerase necesario, habitualmente por motivos presupuestarios: "[...] se mantiene el largo periodo de cumplimiento del servicio militar en consonancia con los demás ejércitos europeos, pero se reduce en la práctica la permanencia de tiempo en filas"1354. Por el contrario, el Gobierno podría suspender el pase a la reserva de los soldados si una situación de excepcionalidad así lo requiriese.

De la situación de reserva activa formarían parte aquellos soldados que recibiesen licencia ilimitada para marchar a sus hogares. En esta situación permanecerían el tiempo necesario hasta cumplir los seis años del servicio activo. A la situación de reclutas en depósito pertenecerían, durante seis años y hasta su pase a la reserva, los mozos declarados definitivamente soldados que, por exceso de cupo, no tendrían que cubrir bajas en el servicio activo; los redimidos en metálico o sustituidos ${ }^{1355}$; y los eximidos por motivos familiares o falta de talla. Una vez transcurridos los seis años de servicio activo, reserva activa o reclutas en depósito, todos los soldados pasarían a la segunda reserva, siendo dados de alta en el batallón de su localidad de residencia hasta la extinción de sus obligaciones con la defensa de la patria. Este pase solo podría suspenderse si se encontrasen movilizados los cuerpos de la segunda reserva. Estos soldados en situación de reserva activa se deberían

1353 Ley de reclutamiento y reemplazo de 11 de Julio de 1885, arts. 1-4, 8 y 14. 1354 FRIEYRO DE LARA, B., De campesino a soldado. Las quintas en Granada (18681898), p. 40.

1355 La redención en metálico y la sustitución no suponían por tanto una exención absoluta del servicio. 
incorporar a sus cuerpos cuando así lo determinase el ministerio de la Guerra $^{1356}$.

Los reclutas de depósito por su parte deberían acudir a las asambleas de instrucción que estableciese el ministerio de la Guerra y se incorporarían a los cuerpos activos cuando así se considerase necesario. Los individuos pertenecientes a la segunda reserva también deberían acudir a las asambleas cuando así lo dispusiese el ministerio, sin que la duración de las mismas pudiese exceder un mes cada año. En el caso de ser necesaria su movilización por motivos bélicos, así se haría a través de una ley o un real decreto expedido por el ministerio de la Guerra de acuerdo con el Consejo de Ministros. Aquellos que no acudiesen a esta convocatoria serían considerados desertores $^{1357}$.

Los individuos en situación de reserva activa o de segunda reserva y los reclutas en depósito podrían viajar y establecerse por todo el territorio español, posesiones coloniales incluidas, previa licencia de sus respectivos jefes. Solo en caso de guerra o alteración del orden público podrían negarse estas licencias. Sí que tenían limitaciones a su movilidad los reclutas en depósito que cubriesen las bajas del servicio activo durante sus dos primeros años de servicio y los reclutas en caja, que solo podrían viajar dentro de su distrito militar y no podrían cambiar de residencia ${ }^{1358}$. Se intentaba así poner coto al fenómeno de los prófugos.

También la vida personal de los reclutas se vio limitada por la legislación, ya que soldados en servicio activo, en reserva activa, los sorteados que resultasen excedentes de cupo, los mozos en caja y los pendientes de la resolución de un recurso, no podrían contraer matrimonio ni ser ordenados religiosos, aunque sí podrían ocupar cargos públicos y desempeñar oficios, siempre que fuesen

1356 Ley de reclutamiento y reemplazo de 11 de Julio de 1885 , arts. 5-7.

1357 Ley de reclutamiento y reemplazo de 11 de Julio de 1885, art. 9.

${ }^{1358}$ Ley de reclutamiento y reemplazo de 11 de Julio de 1885, arts. 10 y 11. 
compatibles con sus deberes militares. Sí que podrían contraer matrimonio y ser ordenados los individuos de la segunda reserva y los reclutas de depósito ${ }^{1359}$.

Además de los reclutas alistados y sorteados, la ley también admitió la posibilidad de que soldados voluntarios, mayores de dieciocho años, formasen parte del Ejército. Sin embargo, estos voluntarios no fueron excluidos del acto del sorteo, y deberían servir en los cuerpos armados a los que hubiesen sido asignados en caso de haber recibido la suerte del soldado, cesando los haberes que cobraban en su condición de voluntarios. Tampoco verían reducido su tiempo de servicio forzoso al no ser contabilizado el tiempo que habían servido como soldados voluntarios. Los individuos de la recluta activa y los reclutas en depósito también podrían ser admitidos como reenganchados voluntarios para los cuerpos activos, aunque deberían extinguir sus obligaciones con los doce años de servicio obligatorio ${ }^{1360}$.

En lo que se refiere al reemplazo de los cuerpos de Ultramar, éste se realizaría preferentemente con voluntarios reenganchados que hubiesen estado allí destinados y con soldados licenciados menores de treinta años. Si con ambos tipos de reclutas no fuese suficiente, serían enviados los soldados de cada llamamiento anual designados por la suerte. En caso de guerra, el ministerio podría efectuar un sorteo extraordinario entre los cuerpos activos para enviar un nuevo contingente militar. Los individuos destinados a Ultramar gozarían de ciertas ventajas, como el ver reducido su tiempo de servicio hasta sólo cuatro años. Una vez pasados estos años regresarían a la península para formar parte de la segunda reserva hasta cumplir los ocho años prescritos. $Y$ en el caso de que, una vez cumplidos los cuatro años en Ultramar un recluta desease reengancharse, cumpliría otros dos años de servicio activo y recibiría

1359 Ley de reclutamiento y reemplazo de 11 de Julio de 1885 , arts. 12 y 13 .

${ }^{1360}$ Ley de reclutamiento y reemplazo de 11 de Julio de 1885, arts. 16 y 17. 
después licencia absoluta, lo que suponía una novedad respecto a las leyes de 1877,1878 y $1882^{1361}$. Las dificultades para enviar reclutas a los territorios coloniales motivaron estas ventajas concedidas a los mozos que voluntariamente deseasen desplazarse a este difícil destino, del que resultaba relativamente fácil no volver jamás.

Por lo que respecta a los mozos oriundos del archipiélago Canario, no se recuperó la exención de la que gozaban anteriormente, aunque se mantuvo el privilegio de ser destinados a los cuerpos establecidos en las islas y exclusivamente en tiempos de paz $^{1362}$.

Finaliza este primer capítulo de disposiciones generales con una serie de artículos que recogían uno de los principales objetivos de la ley, como era el de adaptar el reclutamiento a la división del territorio español en zonas militares ${ }^{1363}$. Así, se declaró que, a partir de la entrada en vigor de la nueva norma, el reclutamiento sería organizado en función de estas zonas militares, que "[...] satisfarán las necesidades del reemplazo de unos mismos cuerpos armados en la forma que determine el reglamento para la ejecución de la parte militar de esta Ley"1364. Destacar asimismo que la nueva norma ignoró la fase del sorteo, para cuya regulación se remitió a la Ley de 1882.

b) El alistamiento: la lucha contra el fraude

La Ley de 1885 se extiende, a través de un total de cinco capítulos, en la regulación del alistamiento. Éste debería verificarse en todos los pueblos de la península, Baleares y también Canarias, y

\footnotetext{
${ }^{1361}$ Ley de reclutamiento y reemplazo de 11 de Julio de 1885 , arts. 18 y 19.

1362 Ley de reclutamiento y reemplazo de 11 de Julio de 1885, art. 20.

1363 Ley de reclutamiento y reemplazo de 11 de Julio de 1885 , arts. 21 y 23 .

1364 Ley de reclutamiento y reemplazo de 11 de Julio de 1885, art. 22.
} 
de él formarían parte todos los mozos cuyos padres residiesen o hubiesen residido en territorio español aunque en el momento de elaborarse el alistamiento residiesen fuera del mismo. Incluiría a todos los jóvenes que cumpliesen diecinueve años entre el 1 de enero y el 31 de diciembre del año en cuestión, independientemente de ser casados o viudos con hijos ${ }^{1365}$. También incluiría a los individuos que, sin haber cumplidos los cuarenta años, cinco más por tanto si lo comparamos con la legislación anterior, no hubiesen sido comprendidos por algún motivo en el sorteo de años previos ${ }^{1366}$.

Para la elaboración del alistamiento se estableció, como obligatorio para todos los jóvenes españoles, su inscripción en las listas de los Ayuntamientos al alcanzar la edad de dieciocho años, ya fuese en el municipio donde residiesen sus padres o donde residiesen ellos mismos. Si los padres omitiesen esta obligación deberían afrontar una multa de entre 250 y 1.000 pesetas. Igual obligación e igual responsabilidad tenían los directores o administradores de los asilos o establecimientos de beneficencia y los jefes de establecimientos penales en que estuviesen acogidos o reclusos, al cumplir la edad e dieciocho años, los huérfanos de padre y madre y los expósitos ${ }^{1367}$.

Aquellos mozos que no hubiesen sido comprendidos en el alistamiento de su año correspondiente también recibirían su sanción: serían incluidos en el primer alistamiento que se verificase una vez descubierta la omisión, y serían clasificados como soldados sorteables independientemente de la exención que alegasen, designándoles además los primeros números del sorteo en el que no tomaron parte,

1365 La variación, en comparación a la Ley de 1877, de la edad en los mozos comprendidos en el alistamiento de cada año se explica fácilmente, y es que aquellos a quienes correspondiese la suerte del soldado no habían de prestar personalmente el servicio en los cuerpos armados hasta febrero del año siguiente, teniendo en cuenta los plazos ordinarios de la misma, en cuya época habrían cumplido ya los veinte años de edad.

1366 Ley de reclutamiento y reemplazo de 11 de Julio de 1885 , arts. 25 y 26.

${ }^{1367}$ Ley de reclutamiento y reemplazo de 11 de Julio de 1885, arts. 27-29. 
sin perjuicio de las penas en que pudiesen incurrir por fraude 0 engaño. En el caso de resultar inútiles para el servicio, sufrirían un arresto de uno a tres meses de prisión y se verían obligados a abonar una multa de 50 a 200 pesetas. También sería premiado quien denunciase la existencia y paradero de un mozo omitido del alistamiento y que resultase útil para el servicio. En este caso tendría el derecho de designar un mozo entre los comprendidos en el sorteo de aquél año, fuese o no hijo suyo, para que fuese excluido del servicio, siendo considerado redimido en metálico a todos los efectos $^{1368}$.

Para lograr que no se produjesen fraudes en la elaboración del alistamiento, y con el objeto de incrementar el control sobre el mismo, se prohibió a cualquier español de entre veinte y cuarenta años ocupar cargo alguno de nombramiento público sin presentar el documento que acreditase su edad y el hallarse libre del servicio militar $^{1369}$, o el estarlo prestando en la situación correspondiente. Sin practicar dicha formalidad,

"Tampoco podrán ser admitidos los indicados mozos de un modo permanente como funcionarios, obreros ni dependientes de ninguna de las Compañías de ferrocarriles y demás establecimientos, empresas o Sociedades autorizadas por el Estado, por la provincia o por el Municipio, bajo la responsabilidad e sus Gerentes o Administradores con sujeción a esta Ley.

Tampoco podrán ser admitidos de igual manera como capataces destajistas ni jornaleros o empleados de cualquier clase en ninguna de las obras que se hagan por gestión directa del Estado, de la provincia o del Municipio"1370.

\footnotetext{
1368 Ley de reclutamiento y reemplazo de 11 de Julio de 1885 , arts. 30 y 31 .

1369 Este documento debe ser expedido por el secretario de la comisión provincial de reclutamiento respectiva y visado por el presidente de la misma.

1370 Ley de reclutamiento y reemplazo de 11 de Julio de 1885, art. 32.
} 
También se pusieron limitaciones para aquellos que deseasen salir del país. Así, todo joven mayor de quince años tenía prohibido salir del territorio nacional sin acreditar que se hallaban libres de cualquier responsabilidad con sus obligaciones militares, además de consignar para tal efecto un depósito de 2.000 pesetas. Esta cantidad sería empleada para redimir en metálico a aquel mozo que, habiendo salido al extranjero, no regresase a España cuando hubiese obtenido la suerte del soldado, quedando tal personaje en la misma situación y con las mismas obligaciones que los redimidos en metálico. Esta cantidad no sería exigida a aquellos españoles que se trasladasen a Ultramar. Además, en caso de que un emigrante ultramarino fuese declarado soldado, se procuraría que prestase su servicio en su provincia americana de residencia ${ }^{1371}$.

Al igual que en la Ley de 28 de Agosto de 1878, el nuevo texto legal permitía a las poblaciones de mucho vecindario dividir su término municipal en secciones de al menos 10.000 personas para ejecutar todas las operaciones del reemplazo. Por el contrario, los términos municipales compuestos por poblaciones dispersas serían considerados como un solo pueblo para dichos trámites. Se considerarían independientes para tales operaciones del término municipal aquellas feligresías o caseríos dependientes de un municipio mayor pero que cuenten con más de 500 almas, siempre que lo solicitase el vecindario y fuese aprobado por el gobernador de la provincia ${ }^{1372}$.

La fecha para la elaboración del alistamiento cambia con respecto a la Ley de 1878: de los primeros días del mes de diciembre se pasa a los primeros del mes de enero, previa publicación de un bando municipal recordando a todos los mozos del municipio con dieciocho años cumplidos su obligación de inscribirse en el 
alistamiento $^{1373}$. Remarca la ley la obligación de incluir en el documento a los individuos que ya se encontrasen sirviendo en el Ejército por cualquier concepto y en cualquiera de sus clases y categorías. Llama la atención que la propia ley señaló que los mozos que aparentasen tener la edad para ser alistados, y no lo pudiesen demostrar documentalmente, serían incluidos en el alistamiento, situación que podía dar lugar a numerosos fraudes e injusticias ${ }^{1374}$.

Se mantuvieron los mismos criterios que en la Ley de 1878 para determinar cual se consideraba la residencia del mozo ${ }^{1375}$. El resto de trámites para la elaboración del alistamiento, a saber, autoridades presentes en el acto $y$ encargadas de firmar el documento y las sanciones que se les pudiesen imponer por fraude u omisión, quedaban exactamente igual que en la legislación $a_{\text {anterior }}{ }^{376}$. Sí cambia lógicamente la fecha de publicación del alistamiento, ya que también cambia la fecha de su elaboración. Con

1373 Ley de reclutamiento y reemplazo de 11 de Julio de 1885 , arts. 38-40.

1374 Ley de reclutamiento y reemplazo de 11 de Julio de 1885 , arts. 41 y 42 .

1375 "Primera: Se entiende por residencia la estancia de un mozo o del padre o de la madre en el pueblo donde cada uno de éstos ejerza de continuo su profesión, arte u oficio u otra cualquier manera de vivir conocida, o bien donde habitualmente permanece manteniéndose con el producto de sus bienes.

Segunda: No se considerará interrumpida la residencia porque el mozo, el padre o la madre se hayan ausentado temporalmente del pueblo o lugar en que viven.

Tercera: Tampoco se considera interrumpida la residencia del mozo en un pueblo porque lo deje eventualmente para dedicarse a los estudios o al aprendizaje de algún arte u oficio, siempre que regrese durante sus vacaciones, o cuando estos estudios o aprendizaje hubiese terminado.

Cuarta: Cuanto queda establecido respecto al padre del mozo, tendrá igualmente aplicación a su madre cuando el padre esté demente, cuando se halle sufriendo una condena en algún establecimiento penal, cuando resida fuera de las provincias de la península, Islas Baleares y Canarias, y por último, cuando se ignore su paradero.

Quinta: Se considerará como no existente la madre del mozo si se halla comprendida en alguno de los casos mencionados en la regla anterior.

Sexta: El asilo o establecimiento de beneficencia en que se criaron o en que se hallaren acogidos los mozos huérfanos de padre y madre, los expósitos, o el punto en que residan las personas que los hubiesen prohijados, se considerarán respecto a los mismos como la residencia de su padre para la formación del alistamiento y demás operaciones del reemplazo, pero cuando los mozos huérfanos o los expósitos se hallaren a la vez en los dos casos expresados, los Ayuntamiento y Comisiones Provinciales se atendrán al punto de la residencia de las personas que hubiesen prohijado a dichos mozos, y no al de los establecimientos de beneficencia, salvo el caso de haber muerto los prohijantes quedando en menor edad el prohijado" (Ley de reclutamiento y reemplazo de 11 de Julio de 1885, art. 43).

${ }^{1376}$ Ley de reclutamiento y reemplazo de 11 de Julio de 1885, arts. 44 y 45 . 
la nueva ley se impuso el 15 de enero como fecha tope para que las autoridades municipales expusiesen, en los lugares públicos habituales, copias del mismo ${ }^{1377}$.

Tampoco sufrió apenas modificaciones todo el proceso de rectificación del alistamiento. Éste se celebraría el último domingo del mes de enero, previa notificación personal a todos los jóvenes afectados, y en él se escucharían las reclamaciones del síndico municipal y de los propios interesados, que podrían versar tanto de la exclusión como de la inclusión indebida de algún mozo. Los miembros del Ayuntamiento deberían escuchar las reclamaciones presentadas y admitir las pruebas que se presentasen, tomando una decisión por mayoría absoluta. Reclamaciones, pruebas y resolución serían recogidas en un acta elaborada por el secretario. Si una reclamación fuese presentada por una persona reconocidamente pobre, no se le exigiría ningún pago por las diligencias que se practicasen ${ }^{1378}$.

A diferencia de la Ley de 1878, en esta ocasión sí se recogió un apartado específico señalando qué jóvenes quedarían excluidos, no ya del servicio, sino del alistamiento. En esta categoría se incluyeron: los que hubiesen servido voluntariamente en el Ejército sin retribución de enganche; los que en el reemplazo anterior hubiesen redimido su suerte de soldados por medio de un sustituto o de la redención en metálico; los que superasen la edad de cuarenta años; los que hubiesen sido alistados y sorteados irregularmente en los años anteriores; los que justificasen haber sido alistados en otro pueblo durante el mismo reemplazo; los trabajadores de las industrias de pesca y navegación, ya que éstos servirían en la Armada y no en el Ejército; y los pertenecientes al cuerpo de voluntarios de la marinería. Además, el propio Ayuntamiento podría declarar excluido del alistamiento a cualquier mozo que, formando parte de las categorías mencionadas, no lo reclamase. También

1377 Ley de reclutamiento y reemplazo de 11 de Julio de 1885, art. 46.

1378 Ley de reclutamiento y reemplazo de 11 de Julio de 1885, arts. 48 y 49. 
podría el consistorio establecer un plazo de tiempo prudente para que los mozos presentasen las pruebas necesarias que les excluyesen del alistamiento ${ }^{1379}$.

La rectificación del alistamiento podría continuar durante los días festivos y no festivos inmediatos al último domingo del mes de enero hasta su conclusión. El día anterior al segundo domingo de febrero los Ayuntamientos se reunirían para cerrar definitivamente las listas rectificadas, que deberían ser firmadas por los concejales, el secretario y el delegado de la autoridad militar si es que concurriese al acto. Todos los alistados serían citados personalmente para que acudiesen al sorteo que se celebraría el segundo domingo de febrero ${ }^{1380}$.

También se contempló la posibilidad de que los alistados reclamasen por su inclusión indebida ante la comisión provincial de reclutamiento. Para ello debían presentar una reclamación por escrito o por comparecencia ante el secretario municipal en un plazo máximo de tres días desde la publicación del alistamiento. Al reclamante se le expediría un certificado gratuito donde constase su queja y los motivos de ella, documento que debería presentar, antes de quince días, ante dicha comisión, que podría instruir un expediente si así lo considerase oportuno. Su decisión sería ejecutiva sin perjuicio de un posible recurso ante el ministerio de la Gobernación ${ }^{1381}$.

En lo que se refiere a la inclusión de un joven en dos o más alistamientos de distintos pueblos, la Ley de 1885 apenas difirió en la resolución de estos conflictos respecto a la de 1878 y se mantuvieron los mismos criterios de prioridad para que la comisión pudiese resolver. Si el equívoco se produjese entre pueblos de distintas provincias y sus Ayuntamientos y comisiones provinciales respectivas no se pusiesen de acuerdo, los expedientes serían remitidos al

\footnotetext{
1379 Ley de reclutamiento y reemplazo de 11 de Julio de 1885, arts. 50-52. 1380 Ley de reclutamiento y reemplazo de 11 de Julio de 1885, arts. 53-55. ${ }^{1381}$ Ley de reclutamiento y reemplazo de 11 de Julio de 1885, arts. 56-59.
} 
Consejo de Estado para que, en un plazo máximo de dos meses, propusiese al ministerio de la Gobernación la resolución que estimase oportuna $^{1382}$.

c) Exenciones: la diferenciación entre exenciones totales y parciales

La nueva ley recogió un aspecto novedoso en la cuestión de las exenciones, ya que diferenció entre las exenciones totales del servicio, a las que dedicó el capítulo VII, y las parciales, es decir, aquellas que permitían eludir el servicio en tiempos de paz, pero no en caso de guerra, a las que dedicó el capítulo VIII. Entre las primeras podemos destacar las siguientes:

- Exenciones físicas, ya sean por defectos físicos evidentemente incurables o por padecer enfermedades evidentes que los facultativos pudiesen comprobar $y$ declarar en un acto de reconocimiento médico ante la Comisión de Reclutamiento ${ }^{1383}$. Las primeras darían lugar a una exclusión total del servicio, mientras que las segundas sólo darían lugar a la exclusión temporal, quedando sujetos a revisión de la inutilidad en los tres llamamientos sucesivos. Incluimos aquí la exención por no alcanzar la estatura mínima, 1,500 mm. y no llegar a la de 1,545 mm. Los comprendidos en este margen de altura ingresarían en los respectivos depósitos con la obligación de presentarse para ser tallados, o bien reconocidos y aún observados, en la época de clasificación de cada uno de los tres llamamientos

\footnotetext{
1382 Ley de reclutamiento y reemplazo de 11 de Julio de 1885, arts. 60-62.

1383 Señalar que continuó vigente el Reglamento de exenciones físicas de 28 de Agosto de 1878, y que las enfermedades señaladas por la nueva Ley como motivos de exención se recogen en las clases $1^{\mathrm{a}}$ y $2^{\mathrm{a}}$ de dicho reglamento.
} 
sucesivos; y si al cuarto año no alcanzasen la estatura de un $1,545 \mathrm{~mm}$., o resultasen inútiles para el servicio, se les expediría el certificado declarando su exención. Si por el contrario alcanzasen en algunos de dichos años la estatura de un 1,545 mm. o fuesen conceptuados como útiles, se reformaría su clasificación declarándoles soldados sorteables, y se incorporarían con los mozos del primer llamamiento, abonándoseles el tiempo transcurrido para completar el plazo de seis años en situación activa, debiendo servir por lo menos un año en un cuerpo activo ${ }^{1384}$. El diputado Dabán propuso que, además de la altura, se tuviesen en cuenta a la hora de examinar las características óptimas de un mozo para entrar en el servicio, "[...] el peso y el perímetro del pecho como pruebas de robustez proporcionadas" ${ }^{1385}$. Tal propuesta no encontró el apoyo parlamentario suficiente.

- Los religiosos profesos de las Escuelas Pías, de las congregaciones destinadas exclusivamente a la enseñanza con autorización del Gobierno y de las misiones dependientes de los ministerios de Estado y Ultramar y los novicios de las mismas órdenes que llevasen seis meses de noviciado. Si tales religiosos abandonasen las referidas órdenes antes de cumplir los treinta y dos años quedarían sujetos a alistamiento ${ }^{1386}$.

- Los operarios de las minas de Almadén, que fuesen naturales de este pueblo 0 de los de Chillón, Almadenejos, Alamillo y Gargantiel, y que estuviesen matriculados en el establecimiento con destino a trabajos

${ }^{1384}$ Ley de reclutamiento y reemplazo de 11 de Julio de 1885 , arts. $63,1^{\circ}, 2^{\circ}$ y $3^{\circ}$ y 66,10 y 20.

1385 Discurso del Sr. Dabán, Diario de Sesiones de las Cortes, n 176, 18/06/1895, p. 5139.

${ }^{1386}$ Ley de reclutamiento y reemplazo de 11 de Julio de 1885 , art. 63, 40 y $5^{\circ}$. 
subterráneos o a los de fundición de minerales, siempre que hubiesen realizado por lo menos cincuenta jornadas de trabajos subterráneos en el año anterior al del reemplazo en que debían ser comprendidos ${ }^{1387}$.

- Los oficiales del Ejército o de la Armada y sus institutos, los alumnos de escuelas, academias y colegios militares, los maquinistas, ayudantes de máquina, practicantes de cirugía e individuos de todas las demás clases militares pertenecientes a los buques de la Armada ${ }^{1388}$.

- Los mozos que el día 1 de abril se hallasen sufriendo condena de cadena, reclusión, extrañamiento, presidio o prisión mayor o correccional que no debiesen extinguir antes de cumplir la edad de cuarenta años, o hubiesen sido condenados a esas penas por sentencia firme o se encontrasen procesados por causa criminal ${ }^{1389}$. En cambio, los mozos que en el día 1 de abril estuviesen sufriendo condena de confinamiento, inhabilitación de

1387 "Los que fueren excluidos del servicio militar por esta causa, quedarán obligados a presentar en el acto de la rectificación de cada uno de los alistamientos sucesivos, hasta que cumplan la edad de 32 años, certificación que acredite haber prestado el mencionado número de jornales en el año anterior, sin cuyo requisito serán nuevamente alistados y declarados soldados, a no ser que justifiquen haber dejado de asistir a las minas por enfermedades consiguientes a la insalubridad de sus trabajos, presentando certificado expedido por el Interventor y visado por el Superintendente de dichas minas con referencia al expediente instruido al efecto" (Ley de reclutamiento y reemplazo de 11 de Julio de 1885, art. 63, 60).

1388 "Los comprendidos en esta exclusión que antes de cumplir los 32 años de edad obtuvieren la licencia absoluta 0 dejaren de pertenecer respectivamente a cualquiera de las clases indicadas, quedarán sujetos a nuevo alistamiento y clasificación, abonándoseles en tal caso como servicio activo el que ya hubieren prestado desde la edad de 16 años cumplidos para extinguir los doce de su obligación" (Ley de reclutamiento y reemplazo de 11 de Julio de 1885, art. 63, 70). 1389 "Los que antes de cumplir esta edad extingan dichas penas se incorporarán al primer llamamiento que se verifique y serán clasificados con los mozos pertenecientes al mismo por no incurrir entonces en ellos ninguna causa de exención de las determinadas en esta Ley fuesen declarados soldados sorteables y les tocare cubrir plaza en las filas, serán destinados al batallón disciplinario de Melilla por el tiempo de su servicio activo, aquellos a quienes corresponda servir en la Península, y a la Brigada disciplinaria de la isla de Cuba los que por razón del número que hayan obtenido en el sorteo deban servir en Ultramar" (Ley de reclutamiento y reemplazo de 11 de Julio de 1885, art. 63, $8^{\circ}$ ) y Ley de reclutamiento y reemplazo de 11 de Julio de 1885 , art. 66, $3^{\circ}$. 
cualquier clase, destierro, sujeción a la vigilancia de la autoridad, suspensión de cargo público, derecho de sufragio, profesión u oficio, arresto mayor o menor, caución o multa, o hubiesen sido condenados con sentencia firme a dichas penas, serían clasificados como los demás mozos de su llamamiento, pudiendo ingresar en cualquiera de los cuerpos del Ejército si les correspondiese servir en activo. Los que se encontrasen por su parte sufriendo la pena de relegación serían también clasificados y destinados a los ejércitos de Ultramar si por las demás circunstancias fuesen declarados soldados y les correspondiese servir en activo. Su destino podría ser cualquier cuerpo del Ejército, excepto los que se hallasen sufriendo condena de cadena, reclusión, extrañamiento, presidio o prisión mayor o correccional que no debiesen extinguir antes de cumplir la edad de cuarenta años, que serían destinados al batallón disciplinario de Melilla por el tiempo de su servicio activo, aquellos a quienes correspondiese servir en la península, aquellos que perteneciesen a la brigada disciplinaria de la isla de Cuba y aquellos que, por razón del número que hubiesen obtenido en el sorteo, debiesen servir en Ultramar ${ }^{1390}$.

En lo que se refiere a las exenciones parciales, es decir, aquellas que permitían eludir el servicio en tiempos de paz pero no de guerra, serían incluidos en esta categoría los soldados condicionales que sólo debían prestar sus servicios en tiempos de conflicto y en los periodos de asamblea de instrucción. Se incluía en este apartado la siguiente tipología por motivos familiares:

${ }^{1390}$ Ley de reclutamiento y reemplazo de 11 de Julio de 1885, arts. 64 y 65 . 
"El hijo único que mantenga a su padre pobre, siendo éste impedido o sexagenario.

El hijo único que mantenga a su madre pobre, siendo ésta viuda, o casada con persona también pobre y sexagenaria o impedida.

El hijo único que mantenga a su madre pobre, si el marido de ésta, pobre también, se hallare sufriendo condena que no haya cumplido dentro de un año.

El hijo único que mantenga a su madre pobre, si su marido se halla ausente por más de 10 años, ignorándose absolutamente su paradero $[\ldots]$.

El expósito que mantenga a la persona que lo crió y educó, habiéndole conservado en su compañía desde la edad de 3 años sin retribución alguna [...].

El hijo único natural, reconocido en legal forma, que mantenga a su madre pobre que fuere célibe o viuda, habiéndole ésta criado y educado como tal hijo [...].

El nieto único que mantenga a su abuelo o abuela pobres, siendo aquél sexagenario o impedido, y ésta viuda, con tal que dicho nieto sea huérfano de padre y madre, y haya sido criado y educado por el abuelo o abuela indicados.

El nieto único que, reuniendo las circunstancias expresadas en el párrafo anterior, mantenga a su abuela pobre, si el marido de ésta fuera también pobre y sexagenario o impedido, o se hallare ausente por más de diez años, ignorándose su paradero.

El hermano único de uno o más huérfanos de padre y madre, si los mantiene desde un año antes de la clasificación y declaración de soldados, o desde que quedaron en la orfandad, siendo dichos hermanos pobres y menores de 17 años o impedidos para trabajar, cualquiera que sea su edad.

El hijo de padre que no siendo pobre tenga otro $u$ otros hijos sirviendo personalmente en los Cuerpos armados del Ejército por haberles cabido la suerte, si privado del hijo que pretende eximirse no quedase al padre otro varón de cualquier estado, mayor de 17 años, no impedido para trabajar [...]. Lo prescrito es esta disposición respecto al padre se entenderá también respecto a la madre casada 0 viuda"1391.

${ }^{1391}$ Ley de reclutamiento y reemplazo de 11 de Julio de 1885, art. 69. 
Para evitar dudas respecto a qué se consideraba hijo único, el texto legal imponía una serie de reglas para determinarlo. Así, se estableció que se consideraría como hijo o nieto único al mozo que, aún cuando tuviese más hermanos, éstos fuesen menores de diecisiete años cumplidos; impedidos para trabajar; soldados que en los cuerpos armados del Ejército cubriesen la plaza que les ha hubiese tocado en suerte; penados que extinguiesen una condena de cadena o reclusión o la de presidio o prisión que no bajase de seis años; y viudos con uno o más hijos, o casados que no pudiesen mantener a su padre o a su madre. No podría sin embargo reputarse como hijo único al mozo que tuviese un hermano eclesiástico por no estar éste impedido para el trabajo ${ }^{1392}$.

También se señaló que se reputaría como fallecido al hijo, nieto o hermano que se encontrase ausente por espacio de más de diez años consecutivos y cuyo paradero se ignorase desde entonces, y que serían considerados como huérfanos los hijos de padre pobre y sexagenario o impedido para trabajar, o que se hallase sufriendo una condena que no debiese cumplir antes de terminar el año en que se verificase la clasificación, o ausente por espacio de diez años. Además, para que el impedimento del padre o abuelo eximiese del servicio al hijo o nieto que los mantuviese, había de ser tal que, procediendo de enfermedad habitual o defecto físico, no les permitiese el trabajo corporal necesario para asegurar su subsistencia. Asimismo se aclaró que se consideraría pobre a una persona, aún cuando poseyese algunos bienes, si privada del auxilio del hijo, nieto o hermano que debía ingresar en las filas, no pudiese proporcionarse con el producto de dichos bienes los medios necesarios para su subsistencia. Por último, indicó la Ley que se entendería que un mozo mantenía a su padre, madre, abuelo, abuela,

1392 Ley de reclutamiento y reemplazo de 11 de Julio de 1885, art. 70, $1^{\circ}$. 
hermano o hermana, siempre que éstos no pudiesen subsistir si se les privaba del auxilio que les prestaba dicho mozo ${ }^{1393}$.

En lo que respecta a los jóvenes que tuviesen hermanos sirviendo en el Ejército, la ley aclaró que se consideraría como tal al hijo que hubiese muerto en labores relacionadas con el servicio o por heridas recibidas durante su desempeño, dentro de dos años contados desde la fecha de la lesión, y también por la fiebre amarilla, el tétanos, la fiebre biliosa grave de los países cálidos, la hepatitis aguda y la tisis, si se encontrase sirviendo en alguno de los ejércitos de Ultramar. En cambio, no se entendería que servían en el Ejército para conceder la excepción a los desertores, los sustitutos de otros mozos, si no lo son por su hermano, y los que hubiesen redimido el servicio por medio de sustitución o de retribución pecuniaria ${ }^{1394}$.

El juicio de exenciones se debía celebrar en cada pueblo en la fecha señalada por el gobernador de la provincia a propuesta de la comisión de reclutamiento, y siempre dentro de la primera quincena del mes de abril. Al juicio de exenciones se presentarían todos los mozos que hubiesen solicitado su exclusión temporal del servicio, los que hubiesen sufrido una reclamación por existir dudas sobre su falta de talla o su ineptitud física y todos aquellos que hubiesen reclamado ante la comisión un fallo del Ayuntamiento, así como los interesados en estas reclamaciones ${ }^{1395}$.

Cabe destacar la propuesta, a la postre rechazada, que el diputado Dabán realizó en el Congreso, en la que proponía que médicos e ingenieros, por la especial categoría de su profesión, quedasen eximidos en tiempos de paz aunque no en situación de guerra:

\footnotetext{
1393 Ley de reclutamiento y reemplazo de 11 de Julio de 1885 , art. $70,2^{\circ}-8^{\circ}$. 1394 Ley de reclutamiento y reemplazo de 11 de Julio de 1885, arts. 70, 90-110, 71 y 72.

${ }^{1395}$ Ley de reclutamiento y reemplazo de 11 de Julio de 1885, art. 102.
} 
"Aparte de los médicos, que en mi concepto es lo más esencial $y$ de primer orden en el Ejército, vienen luego los ingenieros en todas sus manifestaciones, vienen los industriales; $y$ yo entiendo que a todas estas clases que tienen una aplicación natural y lógica en todas las movilizaciones de los Ejércitos, sería conveniente eximirlas del servicio de soldado en tiempos normales, imponiéndoles en cambio el deber de servir dentro de las facultades de cada una de ellas, en las diferentes armas en las cuales tienen aplicación"1396.

d) Clasificación y declaración de los soldados

El capítulo IX de la ley reguló el acto de declaración de los reclutas, y se mantuvo para su realización la misma fecha que la Ley de 1878, establecida en el primer domingo del mes de febrero. Al acto deberían acudir todos los concejales del Ayuntamiento en cuestión, con la única excepción de aquellos que fuesen parientes de hasta cuarto grado de alguno de los mozos sujetos a llamamiento ${ }^{1397}$.

El desarrollo de este acto, una vez reunido el Ayuntamiento, era muy similar al establecido por la Ley de 28 de Agosto de 1878. Comenzaba con el tallaje del mozo que hubiese ocupado el primer lugar en el alistamiento, y se continuaría con los números sucesivos. Si su altura fuese inferior a los 1,500 mm., sería declarado excluido del servicio; si su talla se encontrase entre los 1,500 y los 1,540 $\mathrm{mm}$. , sería declarado excluido temporalmente a la espera de nuevos reconocimientos en los siguientes tres años; y si superase los 1,540 mm., se anotaría así a la espera del reconocimiento médico. Si el mozo no guardase su posición natural, el alcalde podría, después de tres apercibimientos, imponerle una multa de entre 5 y 50 pesetas, además de quedar detenido a la espera de una nueva medición. Esta

\footnotetext{
1396 Discurso del Sr. Dabán, Diario de Sesiones de las Cortes, no 176, 18/06/1895, pp. 5138 y 5139.

1397 Ley de reclutamiento y reemplazo de 11 de Julio de 1885, arts. 73, 74 y 83 y 84.
} 
tarea sería realizada, en presencia de un oficial de la guarnición, por un sargento, en activo, con licencia temporal o en la reserva, nombrado por el gobernador militar de la provincia o el comandante de armas. Si no hubiese un número suficiente de sargentos, se confiaría esta tarea a una persona inteligente designada por el Ayuntamiento que recibiría una paga a cargo de los fondos municipales. En este mismo acto los mozos, o las personas que les representasen, podrían presentar los motivos y pruebas que alegasen para su exención, recibiendo un certificado de los motivos aportados $^{1398}$.

Una vez tallados todos los mozos, el Ayuntamiento, como nueva tarea encomendada por la nueva ley que venía a incrementar su carga de trabajo en este campo, se dispondría a clasificar a los reclutas, tanto del reemplazo del año correspondiente como a los excluidos temporalmente de los tres reemplazos anteriores, dentro de las siguientes categorías ${ }^{1399}$ :

- Soldado sorteable, para aquellos que no alegasen o no acreditasen debidamente algún motivo legal para eximirse del servicio.

- Excluido totalmente del servicio militar.

- Pendiente de reconocimiento ante la comisión provincial, o pendiente de recurso, si por falta de prueba no pudiera otorgársele en el acto la exclusión o excepción que hubiese alegado.

- Soldado condicional o recluta en depósito.

Para la presentación de la documentación justificativa de una exención, el Ayuntamiento podría imponer un plazo de tiempo prudencial, no más allá del tercer domingo del mes de marzo, para

1398 Ley de reclutamiento y reemplazo de 11 de Julio de 1885, arts. 75-77.

${ }^{1399}$ Ley de reclutamiento y reemplazo de 11 de Julio de 1885 , arts. 78 y 81. 
que así el consistorio tuviese tiempo para decidir. Cuando esta documentación acreditase la pobreza de los padres o abuelos del mozo, las autoridades municipales, encargadas de su emisión, no les exigirían el pago de ninguna costa o derecho por su expedición ${ }^{1400}$.

En este acto de declaración, el Ayuntamiento podría declarar exento a un joven por defecto físico visible, pero en el caso de no existir conformidad entre todos los interesados, se haría constar en acta y se remitiría el expediente a la comisión provincial de reclutamiento para que tomase una decisión. Las decisiones tomadas por las autoridades municipales se considerarían ejecutorias, a no ser que existiese reclamación por escrito o por palabra ante el alcalde o que existiesen sospechas de fraude, en cuyo caso podrían ser revisadas por la comisión de reclutamiento. Las reclamaciones presentadas deberían unirse al expediente del soldado en cuestión, y hacerse públicas a través de edictos ${ }^{1401}$.

e) La lucha contra el prófugo: la reducción de la pena temporal

El capítulo XI de la Ley de 1885 atendió a la persecución de esta figura delictiva. El texto señaló que serían considerados prófugos aquellos jóvenes que no se hubiesen presentado al acto de declaración y clasificación de los soldados. Solamente se exceptuarían de esta regla general los siguientes mozos:

- Los que se encontrasen en prisión, que se deberían presentar ante el Ayuntamiento en cuanto alcanzasen la libertad.

- Los que estuviesen sirviendo en cualquiera de los cuerpos del Ejército, academia o colegio militar.

1400 Ley de reclutamiento y reemplazo de 11 de Julio de 1885, art. 79.

${ }^{1401}$ Ley de reclutamiento y reemplazo de 11 de Julio de 1885, art. 80, 82, 85 y 86. 
- Los que se encontrasen gravemente enfermos.

- Los religiosos profesos de las Escuelas Pías, de las congregaciones destinadas exclusivamente a la enseñanza con autorización del Gobierno y de las misiones dependientes de los ministerios de Estado y Ultramar y los novicios de las mismas órdenes.

- Los operarios de las minas de Almadén.

- Los oficiales del Ejército o de la Armada y sus institutos, los alumnos de escuelas, academias y colegios militares, los maquinistas, ayudantes de máquina, practicantes de cirugía e individuos de todas las demás clases militares pertenecientes a los buques de la Armada.

- Los que se encontrasen sufriendo condena de cadena, reclusión, extrañamiento, presidio o prisión mayor o correccional.

- Los que residiesen en las provincias de Ultramar o fuera del Reino ${ }^{1402}$.

La pena impuesta a los prófugos apresados sería un recargo de dos años en el tiempo de servicio, con destino además a las provincias de Ultramar. Se reduce, si lo comparamos con la Ley de 1878, la pena impuesta de cuatro a dos años, si bien el destino ultramarino seguía siendo el mismo ${ }^{1403}$.

1402 Ley de reclutamiento y reemplazo de 11 de Julio de 1885 , arts. 87 y 88 . Por Real Orden de 15 de Abril de 1886 se consideró ampliado por motivos extraordinarios el término legal para el juicio de exenciones ante la comisión provincial para los efectos de no firmar expedientes de prófugo a los mozos que no se presentaron con motivo de la invasión del cólera, Real Orden de 15 de Abril de 1886, Gaceta núm. 110 de 20/04/1886.

1403 "[...] la Ley de 1885 consiguió atajar los delitos de soborno, cohecho, negligencias, cometidos por administrativos y facultativos, al militar las operaciones de reemplazo y fiar su vigilancia a Comisarios Regios nombrados por el Gobierno. Estas disposiciones, acompañadas de un mejor despliegue de las fuerzas del orden (Guardia Civil y Carabineros) y una mayor coordinación entre distintas instituciones, permitieron incrementar el número de aprehendidos en los últimos años del siglo, aunque no consiguió aumentar el número de transgresores, al no 
Perderían además el derecho a sustituirse o redimirse, así como a cualquier exclusión o excepción que pudiera corresponderles. En el caso de que el prófugo se presentase voluntariamente ante la caja de reclutas, quedaría dispensado de los dos años de recargo, aunque su destino seguiría siendo Ultramar. Si el prófugo no debiese ingresar en el servicio porque resultase inútil para el mismo, sufriría un arresto de dos a seis meses y una multa de 150 a 500 pesetas, fijada por la comisión de reclutamiento. El Ayuntamiento seguía teniendo por una importancia capital en la lucha contra el prófugo y en su castigo, ya que era el encargado de declarar a un mozo prófugo o no, de iniciar el expediente para su captura, y de establecer el recargo en el tiempo de servicio que se le imponía por su delito. Los expedientes iniciados por el Ayuntamiento deberían estar finalizados antes del 10 de julio, y en caso contrario recibirían una multa por omisión, impuesta por la comisión provincial, de 50 a 500 pesetas. Asimismo los Ayuntamientos deberían informar a los juzgados ordinarios en el caso de existir sospechas de complicidad de terceras personas. Además de la pena que se les impusiese en función del Código Penal, recibirían una multa de entre 100 y 500 pesetas. Para el caso de los prófugos residentes en Ultramar, serían los gobernadores de la provincia los encargados de emitir la orden oportuna de captura del prófugo y de gestionar su ingreso en los cuerpos ultramarinos ${ }^{1404}$.

El expediente iniciado por el Ayuntamiento para gestionar la captura del prófugo sería enviado a la comisión provincial de reclutamiento, que podría confirmar o revocar la decisión de éste en vista del expediente y de la declaración del prófugo aprehendido. La revocación de tal fallo no eximía al prófugo del pago de los gastos

disuadir a los que optaban por la fuga o el soborno" (FEIJóo GÓMEZ, A., Quintas y protesta social en el siglo XIX español, p. 260).

${ }_{1404}$ Ley de reclutamiento y reemplazo de 11 de Julio de 1885, arts. 89-94, 97, 99 y 101. 
ocasionados por su captura ni le permitiría redimirse en metálico ni sustituirse, y se incorporaría de inmediato al servicio ${ }^{1405}$.

También se concedieron gratificaciones para aquellos que colaborasen en la captura de un prófugo. Así, si era un soldado o sus padres o hermanos quienes hubiesen prestado su ayuda, vería el recluta reducido su tiempo de prestación en el servicio activo en el mismo número de años de recargo que hubiese sufrido de sanción el huido. Si no lo fuere, recibiría una gratificación de 50 pesetas a abonar por el prófugo si éste fuese apto para el servicio. Nada recibiría en cambio si no fuese considerado apto ${ }^{1406}$.

f) Conducción e ingreso de los reclutas en la caja de la provincia

La Ley de 1885 dedicó sus capítulos XI y XIV al traslado y entrega de los mozos en la caja de reclutamiento. Todo el proceso de conducción e ingreso de los mozos a la caja de reclutas se iniciaría el primero de diciembre cuando, una vez resueltas las reclamaciones sobre el llamamiento, las comisiones de reclutamiento debían remitir, a los jefes de las cajas de reclutamiento, toda la documentación que hasta ese momento había salido del proceso, a saber: una relación por pueblos de los mozos de su zona que por encontrarse en el caso previsto en el art. 30 tuviesen designados los primeros números del sorteo; otra relación de los soldados útiles que correspondiesen a su zona; otra, también por pueblos, de los excluidos temporalmente del servicio militar; otra de los que hubieran sido declarados prófugos por los Ayuntamientos o por las comisiones provinciales; otra, que comprendiese a los mozos cuyos expedientes no se hubieran fallado; $\mathrm{y}$, por último, otra relación con los excluidos totalmente del servicio 
militar. En el momento en el que el jefe de la caja recibiese esta documentación, iniciaría todas las operaciones preliminares para la distribución de los mozos ${ }^{1407}$.

Estos mozos serían previamente citados personalmente para informarles de la fecha de su salida. Como encargado del traslado quedaba un comisionado municipal, que recibiría una cantidad proporcionada a su función del erario local. Para realizar convenientemente su labor, el comisionado iría acompañado de un certificado de todas las diligencias practicadas por el consistorio, así como de las reclamaciones que se hubiesen producido y de las pruebas presentadas. Llevaría también las filiaciones de los declarados soldados y una relación de los excluidos, dividida en grupos o secciones, según la clasificación que de ellos hubiese hecho el Ayuntamiento. Los mozos trasladados serían recompensados, al igual que en legislaciones previas, con una cantidad de 50 céntimos de peseta diarios, desde el día en que emprendiesen la marcha hasta su regreso al municipio o su ingreso en la caja, a razón de 30 kilómetros por jornada. También recibirían tal cantidad los jóvenes que se desplazasen a la capital por motivos de una reclamación, si ésta resultase justa. No recibiría ninguna cantidad por el contrario si la reclamación no fuese tenida en cuenta por la comisión, a no ser que el reclamante careciese de medios para satisfacer los gastos ${ }^{1408}$.

El ingreso definitivo de los mozos en la caja se produciría el segundo sábado del mes de diciembre, y se iniciaría por los reclutas del pueblo cabeza de comarca, finalizando por los más alejados del mismo. Tal ingreso se produciría por orden alfabético, en presencia del comisionado municipal y de todos aquellos que quisieran asistir. Este comisionado recibiría, de parte del jefe de la caja, el pase de los mozos declarados soldados, de los soldados condicionales y de los eximidos por cualquier motivo. Una vez efectuado el ingreso, los 
reclutas pasaban a depender de la jurisdicción militar y abandonaban la civil ${ }^{1409}$.

g) Las reclamaciones ante las comisiones provinciales de reclutamiento y contra sus fallos

Correspondió a los capítulos XII, XIII y XV la tarea de regular todo lo que competía a las reclamaciones presentadas ante las comisiones provinciales por las resoluciones tomadas por los Ayuntamientos y contra las decisiones tomadas por esta misma institución provincial.

Serían estas comisiones provinciales las competentes a la hora de resolver los recursos presentados contra las decisiones tomadas por los Ayuntamientos en todas las operaciones relacionadas con el reemplazo, así como de imponer las multas correspondientes a los infractores de la ley. La comparecencia de los reclamantes debería producirse en un acto público, donde presentarían los motivos de su queja y las pruebas que los avalasen. Correspondía a la comisión provincial tomar una decisión en función de la documentación presentada por los reclamantes y siempre teniendo en cuenta las diligencias practicadas por los Ayuntamientos. Las resoluciones tomadas deberían ser comunicadas a los interesados y a los alcaldes de los pueblos afectados. Para tomar una decisión, la comisión provincial podría practicar las diligencias necesarias y establecer un plazo máximo de un mes para que los interesados presentasen las pruebas oportunas y seis meses cuando las diligencias hubiesen de practicarse en las provincias ultramarinas ${ }^{1410}$.

1409 Ley de reclutamiento y reemplazo de 11 de Julio de 1885 , arts. 126-132.

${ }^{1410}$ Ley de reclutamiento y reemplazo de 11 de Julio de 1885, arts. 107-109. 
Cuando la reclamación presentada versase en la existencia de un hermano sirviendo en algún cuerpo del Ejército como soldado de reemplazo, debería la comisión solicitar al capitán general del distrito en que se encontrase destinado el hermano recluta un certificado donde constase su existencia en el Ejército y su destino. En el artículo 166 de la Ley de 1878 se prevenía que estas certificaciones se reclamasen por conducto de los gobernadores civiles. La nueva ley ignoró este paso buscando una mayor celeridad en las operaciones del reemplazo ${ }^{1411}$.

En el caso de que la reclamación presentada tratase sobre la talla de algún mozo, sería la autoridad militar la encargada de designar dos sargentos talladores para efectuar las mediciones pertinentes. Cuando los talladores no pudieren dar su dictamen de una manera terminante, por no guardar el mozo la debida posición natural, la comisión provincial le apercibiría hasta tres veces, y si no produjese resultado este apercibimiento, podría declararle con talla suficiente para el servicio, consignándolo en la filiación del interesado. Si la reclamación versase sobre la aptitud física de un mozo se practicaría un reconocimiento por dos facultativos que serían nombrados uno por la comisión provincial y otro por la autoridad militar superior de la provincia ${ }^{1412}$. Si no hubiera acuerdo entre ambos profesionales, la comisión provincial nombraría un tercero; si creyese el caso difícil, nombraría uno la comisión y otro la autoridad militar: en vista de los dictámenes de todos ellos debería decidir acerca de la aptitud del mozo, arreglándose a lo que determinase sobre el particular el reglamento de exenciones físicas. Todas las personas nombradas por la comisión, pero no por la autoridad castrense, para efectuar los trabajos de tallaje y reconocimiento

\footnotetext{
1411 Ley de reclutamiento y reemplazo de 11 de Julio de 1885, arts. 110 y 111 .

1412 El diputado Dabán propuso que ambos facultativos perteneciesen al Ejército y no fuesen designados por las Diputaciones ante los posibles abusos y fraudes que se pudiesen cometer, Discurso del Sr. Dabán, Diario de Sesiones de las Cortes, no $176,18 / 06 / 1895$, pp. 5140 y 5141.
} 
médico, recibirían una gratificación de 2 pesetas y 50 céntimos. Los acuerdos tomados por la comisión en estos dos tipos de reclamaciones serían definitivos y no admitirían recurso ante el ministerio de la Gobernación. Tampoco las cajas de recluta podrían resistir la admisión de jóvenes que hubiesen sido definitivamente declarados soldados por la comisión de reclutamiento ${ }^{1413}$.

Las resoluciones tomadas por las comisiones de reclutamiento respecto a la exclusión del alistamiento y a la inclusión en el mismo de otros mozos o de la suya propia y a las excepciones que se hubiesen alegado podrían en cambio ser recurridas ante el ministerio de la Gobernación. No podrían sin embargo reclamarse las decisiones tomadas por las comisiones que estuviesen de acuerdo con los fallos de los Ayuntamientos, y sólo se admitiría respecto de ellos el recurso de nulidad fundado en la infracción de alguna de las prescripciones de la ley. Tampoco podrían apelarse los fallos de las comisiones que versasen sobre la talla o la aptitud física de un mozo ${ }^{1414}$.

Los recursos a las decisiones de la comisión deberían presentarse ante esta institución ${ }^{1415}$ en un plazo máximo de quince días desde que fue tomada la resolución. En todo caso, estos recursos no suspenderían la aplicación de las resoluciones tomadas por la comisión, buscando de esta forma no frenar todo el proceso. Como novedad respecto a la legislación anterior, reseñar que se permitió a las autoridades militares, en representación del Ejército, presentar reclamaciones en todas las incidencias del reemplazo ante el ministerio de la Gobernación ${ }^{1416}$.

Sería el secretario de la comisión de reclutamiento el encargado de recibir estas reclamaciones y de expedir un certificado a su

\footnotetext{
${ }^{1413}$ Ley de reclutamiento y reemplazo de 11 de Julio de 1885, arts. 112-116.

1414 Ley de reclutamiento y reemplazo de 11 de Julio de 1885, art. 117.

1415 Se diferencia así de la Ley de 28 de Agosto de 1878 que establecía que los recursos dirigidos al ministerio de la Gobernación debían presentarse ante el gobernador civil de la provincia.

${ }^{1416}$ Ley de reclutamiento y reemplazo de 11 de Julio de 1885, arts. 117-119.
} 
interesado. Debería además la comisión instruir expediente con la mayor brevedad posible, pidiendo dentro de los tres días siguientes el informe del Ayuntamiento, así como las pruebas y los documentos presentados. El tiempo para la instrucción de estos expedientes no excedería de un mes, y serían enviados al secretario general del Consejo de Estado, a fin de que la sección de Gobernación del mismo lo elevase con su dictamen al ministerio de la Gobernación dentro del término de dos meses. Sería tal ministerio el encargado de tomar la decisión final. Podría el mismo ministerio revisar y anular las resoluciones por las que se hubiese infringido alguna disposición de la ley si de ellas resultase perjuicio al Estado, aunque no mediase reclamación ${ }^{1417}$.

Una vez efectuado el ingreso en caja, se efectuaría el sorteo para designar que jóvenes servirían en los cuerpos peninsulares y cuales servirán en Ultramar. Este sorteo sería público y presidido por una junta, responsable del cumplimiento de la legalidad, formada por el jefe de la caja, el juez de primera instancia del partido, el alcalde y el síndico del Ayuntamiento de la capital provincial y los jefes de los batallones de reserva y depósito. Al acto también acudirían los comisionados municipales ${ }^{1418}$.

La celebración del sorteo para designar a los soldados destinados a América seguía reglas muy simples: en un globo se introducirían las papeletas con el nombre de los reclutas y en otro tantas papeletas numeradas como número de soldados fuesen a ser enviados a Ultramar. Serían dos niños menores de diez años los encargados de sacar las papeletas, y los mozos que obtuviesen los números correlativos más bajos serían los destinados al continente americano. Si existiesen reclamaciones respecto a la celebración de este sorteo, será el ministerio de la Guerra el encargado de investigar los hechos y de tomar una resolución. El sorteo solo podría ser 
anulado por el Gobierno, asesorado por el consejo de Estado, cuando considerase absolutamente forzosa su repetición como único medio posible de subsanar las irregularidades cometidas en el mismo ${ }^{1419}$.

h) Unos criterios fijos para la distribución del contingente y el destino de los mozos sorteados

Una novedad importante que presentó la Ley de 1885 en cuanto a su estructura es que, además de ignorar la fase del sorteo, cuyo desarrollo quedó exactamente igual que el establecido por la Ley de Reclutamiento y Reemplazo de 28 de Agosto de 1878, fue el traslado de una de las fases iniciales en todo el proceso, la distribución del contingente, para el final de su articulado, en concreto para el capítulo XVI. Además de esta notable diferencia estructural de la ley, de mayor importancia resulta que la propia distribución del contingente se realizase después, y no antes como en las legislaciones previas, del acto del sorteo, en concreto el día 20 de febrero. Correspondía al ministerio de la Guerra realizar dicha distribución por zonas en función de las bajas habidas ese año en el seno de la fuerza armada. Para calcular el cupo con que cada zona debía contribuir al reemplazo, el ministerio debería tener en cuenta las siguientes variables ${ }^{1420}$ :

- El número de mozos sorteados que existiesen en cada caja.

- El número total de bajas que hubiesen de reemplazarse en los ejércitos de Ultramar.

- El número total de bajas que debían reemplazarse en el ejército peninsular. 
- El número de mozos que debería suministrar cada zona para asegurar el completar los cuerpos de Artillería, Caballería e Infantería que se nutriesen permanentemente de su recluta local.

- El total de los soldados que se necesitasen para tener completos en situación de paz las tropas de Infantería de Marina, Ingenieros, Administración y Sanidad Militar, establecimientos militares $u$ otras unidades orgánicas de carácter especial que auxiliasen con sus servicios a las armas de combate.

- El cupo que se señalase para cada zona debía guardar relación con el número de mozos sorteados en cada una de ellas.

Una vez señalado el cupo de cada zona, los soldados se distribuirían entre los distintos cuerpos y secciones del Ejército siguiendo los siguientes criterios:

"Primero: Se designará la parte numérica de mozos que debe ser destinada a Ultramar, componiéndose esta parte de las que hayan obtenido los números más bajos en el sorteo de cada Caja.

Segundo: Se señalará el número de mozos que hayan de ingresar en la Artillería.

Tercero: Igualmente el que debe ser alta en los Cuerpos de Caballería.

Cuarto: Después los que correspondan pasar a cubrir las bajas en los Batallones de Infantería.

Quinto: $Y$ el resto numérico del cupo señalado a cada zona se distribuirá asignando a los Cuerpos de Infantería de Marina, Ingenieros, Administración Militar, etc los reemplazos que necesiten para su efectivo completo, cuidándose de agregar en cada uno de estos sobrantes las mayores fracciones posibles para los cuerpos e 
Institutos que exijan menor aptitud especial para sus funciones técnico-militares ${ }^{\prime 1421}$.

Reseñar que fue la primera vez que, entre toda la legislación sobre el reemplazo del siglo XIX, una norma recogió los principios básicos que guiarían la distribución del contingente en función de unos criterios fijos. La ley también señaló que, aquellos mozos sorteados que no tuviesen que ingresar en los cuerpos armados por exceder el cupo señalado a su zona, quedarían como reclutas de depósito, sin recibir ninguna compensación económica, a la espera de ser llamados para su ingreso en el Ejército para cubrir las bajas que se produjesen en tiempos de paz. Estos reclutas, y los soldados de la reserva activa, podrían ser llamados al servicio activo y movilizados en circunstancias excepcionales a través de un decreto expedido por el ministerio de la Guerra. En el supuesto de no cubrirse las bajas con los reclutas excedentes de cupo, se podría acudir a los reclutas excedentes del sorteo anterior, a los mozos que se hubiesen redimido o sustituido $\mathrm{y}$, en última instancia, a las fuerzas de la segunda reserva ${ }^{1422}$. La sustitución y la redención no tenían por que eximir por tanto de incorporarse a filas en caso de conflicto bélico y si las circunstancias del Ejército así lo requiriesen, aunque este llamamiento nunca se produjo durante el periodo de vigencia de la normativa.

i) La sustitución y la redención en metálico: la creciente pérdida de privilegios ante la protesta social

El penúltimo capítulo de la ley reguló las cuestiones relacionadas con la sustitución y la redención en metálico, figuras

${ }^{1421}$ Ley de reclutamiento y reemplazo de 11 de Julio de 1885, art. 147.

1422 Ley de reclutamiento y reemplazo de 11 de Julio de 1885, arts. 148-150. 
que, a pesar de mantenerse, pierden parte de sus privilegios, ya que podían, los reclutas acogidos a cualquiera de ellas, ser llamados a filas en situaciones excepcionales. La ley estableció que las cantidades recaudadas por estos conceptos se debían invertir, íntegramente, en la retribución de voluntarios y reenganchados con premio $^{1423}$.

El precio de la redención se situó en 1.500 pesetas para los mozos que fuesen a ser destinados a los cuerpos peninsulares y se elevó, en comparación con la legislación previa, hasta las 2.000 para los de Ultramar. Estas cuotas permanecieron inalterables hasta 1912:

"Esta situación de estabilidad en el país se verá seriamente alterada conforme se acreciente el peligro de revueltas en Ultramar y se afiancen las exigencias de las clases desfavorecidas en la Península, lo que llevará en 1912 a la derogación de las prerrogativas tradicionales con respecto a las exenciones económicas. De hecho, las protestas populares originadas por la llamada a quintas no terminaron con el Sexenio, aunque aquella fuera la época más conflictiva. El recrudecimiento de la guerra en Ultramar y las masivas llamadas de mozos para cubrir el contingente del cada vez más diezmado ejército español en Cuba, provocaron la protesta social e incluso revueltas y amotinamientos $[\ldots]^{\prime 1424}$.

Los mozos redimidos quedarían en situación de reclutas de depósito y debían recibir instrucción militar. Por primera vez se realiza esta distinción económica en función del destino del recluta y los redimidos no quedaban completamente exentos del servicio, ya que existía una posibilidad, aunque remota, de ser llamados a filas en situaciones excepcionales ${ }^{1425}$. A diferencia de la Ley de 1878 , no se

${ }^{1423}$ Ley de reclutamiento y reemplazo de 11 de Julio de 1885, art. 157.

1424 FRIEYRO DE LARA, B., De campesino a soldado. Las quintas en Granada (18681898), p. 41.

1425 "Los redimidos y sustituidos nunca llegaron a ser convocados a los ejercicios de instrucción previstos en la legislación, y mucho menos serían enviados al frente, 
exigiría a los jóvenes redimidos el dedicarse a un oficio, arte o profesión, siendo suficiente con el pago de la redención. Este ingreso lo debería realizar el mozo sorteado, o cualquier persona en su nombre, en la Caja general de Depósitos o en cualquier delegación de Hacienda. El certificado que recibiría en el momento del ingreso debía ser presentado en su caja de reclutamiento en el plazo máximo de dos meses desde que se verificase el ingreso a filas del mozo para el caso de los cuerpos peninsulares y diez días antes del embarque en el caso de los cuerpos ultramarinos. El jefe de la caja le expediría un certificado que acreditase su condición de redimido ${ }^{1426}$.

Quedó contemplada también la posibilidad de que la cantidad aportada fuese devuelta en el supuesto de no llevarse a efecto la redención por cualquier circunstancia. Sería asimismo devuelta en el caso de que el recluta redimido quedase como excedente de cupo y por tanto no tuviese que ingresar en el servicio activo. La solicitud de devolución debería ser presentada por los interesados ante el ministerio de la Guerra, que decidiría lo que correspondiese, si bien sería el ministerio de la Gobernación el encargado de informar al de Hacienda de su obligación de devolver las cantidades ingresadas ${ }^{1427}$.

La posibilidad de devolver la redención fue vista por el diputado Daván como una posible herramienta de amaño y fraude electoral que el Gobierno podía utilizar para asegurar sus intereses:

"El señor presidente de la Comisión, que como he dicho es presidente del Consejo de redenciones, saber mejor que yo que por regla general, desde larga fecha, fluctuaba el número de devoluciones acordadas por el ministerio de Gobernación entre 60 y 80 . Pues bien, de un solo golpe [...], en un solo año han pasado a 200 y pico o 300, y

pero de esta forma se consiguieron acallar las protestas y se reforzó la pantalla legal que declaraba a todos los ciudadanos iguales ante la Ley" (PUELL DE LA VILLA, F., El soldado desconocido: de la leva a la "mili" (1700-1912), p. 288).

${ }_{1426}$ Ley de reclutamiento y reemplazo de 11 de Julio de 1885, arts. 151-153.

${ }^{1427}$ Ley de reclutamiento y reemplazo de 11 de Julio de 1885, art. 154-156. 
coincide, señores, con que todas esas reales órdenes concediendo este beneficio de la devolución del premio de la redención vienen a coincidir después del periodo electoral. De manera que unidas estas dos circunstancias, no me parece que es aventurado suponer que esto se ha convertido en otro de los manubrios electorales que se pueden manejar por el Gobierno [... $]^{1428}$.

También se introdujeron cambios legislativos para la sustitución ya que, a partir de esta ley, solo se permitió entre hermanos y en un plazo de dos meses ${ }^{1429}$, excepto para los destinados a Ultramar, "[que] podrán sustituirse con individuos de su misma zona en cualquiera situación o con licenciados del Ejército, entendiéndose siempre que el sustituto renuncia a todo derecho de exclusión o excepción, aún cuando esté pendiente de la resolución de cualquier recurso"1430. De nuevo se pusieron trabas legales a la figura de la sustitución, socialmente mal conceptuada.

Ambas tipologías de sustituto deberían ser reconocidos ante el comandante de la caja y coronel jefe de la respectiva zona y, en caso de resultar apto para el servicio, su expediente sería enviado al gobernador militar de la provincia para informarle sobre la aptitud legal del sustituto, su situación en el Ejército y la legitimidad de los documentos presentados. Sería esta autoridad militar la encargada de admitir o rechazar al sustituto, pudiendo hacer para ello las necesarias pesquisas. Por último, señalar que en el caso de que un

1428 Discurso del Sr. Dabán, Diario de Sesiones de las Cortes, n 176, 18/06/1895, p. 5143.

${ }^{1429}$ Además, estos hermanos y los sustitutos de Ultramar deberían tener la aptitud física necesaria, no superar los treinta y cinco años, no encontrarse prestando servicio en los cuerpos activos del Ejército, ser soltero o viudo sin hijos, no haber sido procesado criminalmente y tener licencia de sus padres si fuese menor de edad. También deberían acreditar, mediante partidas sacramentales o documentos del Registro Civil, el grado de parentesco con el individuo que pretende sustituir y su edad. Ley de reclutamiento y reemplazo de 11 de Julio de 1885, arts. 158 y 160-165. En 1896 se admitieron como sustitutos a los casados siempre que acreditasen el permiso de la mujer a través de una certificación, Real Orden de 12 de mayo de 1896, Gaceta núm. 147 de 26/05/1896.

${ }^{1430}$ Ley de reclutamiento y reemplazo de 11 de Julio de 1885, art. 159. 
sustituto desertase durante su primer año de servicio, debería el sustituido ingresar en su lugar, aunque conservaba la posibilidad de presentar a un nuevo sustituto o de redimirse en metálico ${ }^{1431}$.

j) Disposiciones penales: la sanción de los incumplimientos

Finaliza la ley con un capítulo, el XVII, que recogió una serie de disposiciones penales para sancionar los incumplimientos y delitos que se cometiesen al burlar la misma. Los delitos cometidos previamente al ingreso del mozo en caja serían juzgados por la justicia ordinaria con exclusión de todo fuero. Todos los delitos o faltas que no tuviesen carácter militar y que se cometiesen en la ejecución de las operaciones del reemplazo, serían castigados con arreglo al Código Penal y a las disposiciones de la ley. Si la irregularidad cometida no constituyese un delito 0 falta, las comisiones provinciales de reclutamiento podrían imponer sanciones económicas $^{1432}$.

A continuación se tipificaron los distintos delitos prescritos en caso de incumplimiento de la ley:

- El que se automutilase para eximirse del servicio sería castigado con penas de prisión correccional en sus grados medio y máximo (art. 436 del Código Penal).

- El que mutilase a otro con el mismo objetivo sería castigado con presidio correccional en sus grados mínimo y medio en función del art. 437 del Código Penal.

- Si el delito hubiese dado lugar a la indebida exclusión o excepción de un mozo, además de lo prescrito en el Código Penal, se le impondría una multa de 1.500

${ }^{1431}$ Ley de reclutamiento y reemplazo de 11 de Julio de 1885, arts. 163 y 166 .

${ }^{1432}$ Ley de reclutamiento y reemplazo de 11 de Julio de 1885, arts. 167 y 171. 
pesetas, siendo destinado a los cuerpos de Ultramar sin posibilidad de exención.

- Los culpables de la omisión fraudulenta de un mozo en el alistamiento y sorteo, incurrirían en la pena de prisión correccional y en una multa que podría llegar hasta las 1.500 pesetas por cada soldado que hubiese dado de menos, a consecuencia de la omisión, el pueblo donde ésta se hubiese cometido.

- El facultativo que con el fin de eximir a un mozo del servicio militar emitiese un certificado falso de enfermedad, o en el caso de que algún modo faltase a la verdad en sus declaraciones o certificaciones facultativas, sería castigado con arreglo al 323 del Código Penal: penas de arresto mayor en su grado máximo y multa de 125 a 1.250 pesetas. En todo caso quedaría obligado al resarcimiento de los daños y perjuicios que indebidamente hubiese causado a una tercera persona o al Estado por la baja indebida.

- El facultativo que recibiese alguna dádiva o presente en el cumplimiento de su labor, además de ser inhabilitado temporalmente para el ejercicio de su profesión, sería castigado a través del artículo 397 del Código Penal: prisión correccional en grado mínimo y medio.

- Los que con dádivas, presentes o promesas corrompiesen a los facultativos o funcionarios públicos, serían castigados con arreglo al artículo 402 del Código: prisión correccional en grado mínimo y medio.

- La fraudulenta presentación de un mozo en vez de otro, sería castigada con arreglo al artículo 483 del Código: presidio mayor y multa de 250 a 2.500 pesetas. 
- Cuando en virtud de delito cometido por las personas que interviniesen en las operaciones del reemplazo como funcionarios públicos o en calidad de peritos, resultase indebidamente exceptuado o excluido algún mozo, la multa a pagar por esta falta sería de 2.250 pesetas.

- Los que omitiesen, retrasasen o impidiesen el curso o efecto de las órdenes emanadas de autoridades competentes para el llamamiento e ingreso de los reclutas en caja; los que de algún modo dificultasen el cumplimiento de dichas órdenes en perjuicio de tercero o del servicio público, y los que no las notificasen individualmente a los interesados, teniendo el deber y la posibilidad de hacerlo, incurrirían en las penas de prisión correccional en sus grados mínimo y medio e inhabilitación especial temporal ${ }^{1433}$.

k) Reglamento de exenciones físicas: tipología inalterada de enfermedades con cambios en el procedimiento de actuación de las autoridades competentes

Vinculado a la Ley de 1885, encontramos un nuevo reglamento de exenciones físicas publicado en la Gaceta el mismo día que la norma. La tipología de las exenciones permaneció inalterable en comparación con el Reglamento de exenciones físicas de 28 de Agosto de 1878. Sí cambiaron algunos aspectos sobre el procedimiento y la forma de actuar de las autoridades competentes a la hora de declarar una exención. Estas novedades fueron recogidas en su articulado introductorio, que será objeto de nuestro análisis, dejando de lado el conjunto de enfermedades y defectos físicos

1433 La sanción a todos estos delitos es recogida en la Ley de reclutamiento $y$ reemplazo de 11 de Julio de 1885, arts. 171-179. 
eximentes por no haber cambiado y por haber sido ya analizados en profundidad con el reglamento anterior ${ }^{1434}$.

Se inició el reglamento declarando la exención del servicio militar para aquellos mozos que padeciesen alguno de los defectos o enfermedades del cuadro de inutilidades físicas que acompañaba al reglamento, aunque el tipo de exención variaba en función de la enfermedad padecida. Son varias las autoridades competentes para declarar una exención:

- Los Ayuntamientos declararían las exenciones para los mozos que padeciesen las enfermedades más graves y visibles, es decir, las incluidas en la clase primera del cuadro de exenciones físicas ${ }^{1435}$, sin necesidad de reconocimiento médico pero sí del acto del juicio de exenciones ${ }^{1436}$. Más allá de los defectos y enfermedades encuadrados en la primera clase, los Ayuntamientos no podrían declarar ninguna exención, y se limitarían exclusivamente a consignar en actas las alegaciones presentadas por los reclutas, designando los defectos o

${ }^{1434}$ Reglamento de exenciones físicas de 12 de Agosto de 1885, Gaceta núm. 144 de 13/07/1885. En adelante, Reglamento de exenciones físicas de 28 de Agosto de 1878.

1435 "10.- Falta completa de ambos ojos.

20.- Ceguera completa, permanente e incurable, que dependa de vaciamiento o consunción de los globos de ambos ojos.

30.- Pérdida completa de las narices.

40.- Pérdida completa de ambas orejas.

50.- Pérdida completa de la lengua.

60.- Pérdida o falta de todos los dientes, colmillos y muelas.

70. - Mutilación de una o de ambas extremidades superiores que cuando menos consista en la pérdida de una mano.

$8^{\circ}$.- Jorobas o torceduras del espinazo monstruosas, acompañadas de corta estatura del individuo.

90.- Pérdida completa de los órganos genitales externos.

$10^{\circ}$.- Mutilación de una o de ambas extremidades inferiores que cuando menos consista en la pérdida de un pie.

110.- Cojera que dependa de la desigualdad de longitud de las extremidades inferiores, y consista cuando menos en 12 centímetros de diferencia" (Reglamento de exenciones físicas de 12 de Agosto de 1885).

${ }^{1436}$ Reglamento de exenciones físicas de 12 de Agosto de 1885, arts. 1-8. 
enfermedades alegados, con sus denominaciones vulgares y con las técnicas ${ }^{1437}$.

- Las decisiones del Ayuntamiento al respecto de las exenciones físicas podían ser reclamadas ante la comisión provincial de reclutamiento, que analizaría y decidiría en un nuevo juicio de exenciones sobre estas protestas y sobre las exenciones encuadradas en la segunda y tercera clase del cuadro. Los interesados deberían presentar su reclamación, por escrito o por palabra, ante el alcalde de la localidad. Todas las reclamaciones se harían constar en un expediente que sería enviado a la comisión provincial, institución encargada de decidir. También podría intervenir cuando tuviese sospechas sobre la irregularidad de los acuerdos tomados y las exenciones otorgadas por los Ayuntamientos, incoando expediente gubernativo para exigir responsabilidades al consistorio en cuestión ${ }^{1438}$. El juicio de exenciones sobre los mozos que padeciesen alguna de las enfermedades encuadradas en la segunda y tercera clase del cuadro, se celebraría durante el mismo acto de entrega de los mozos en la caja de reclutamiento, previo reconocimiento médico de todos los jóvenes llamados a ingresar en el Ejército, hubiesen presentado o no solicitud de exención ${ }^{1439}$. En caso de protesta o

\footnotetext{
${ }^{1437}$ Reglamento de exenciones físicas de 12 de Agosto de 1885, arts. 9 y 10.

1438 Reglamento de exenciones físicas de 12 de Agosto de 1885, arts. 11-17.

1439 "Si el mozo reconocido fue eximido del servicio en reemplazos anteriores por causa de inutilidad física, [los facultativos] harán puntualmente designación de la inutilidad que motivó dicha exención.

Si el reconocimiento practicado en el acto no resultase defecto ni enfermedad de las que inutilizan para el servicio, harán constar esta circunstancia en el cuerpo del certificado $[. .$.$] , consignando enseguida su juicio científico de que el mozo en$ cuestión es útil para el servicio en el Ejército y en la Marina.

Si del reconocimiento practicado resultase en el acto la existencia de uno o más defectos, una o más enfermedades de las incluidas en las clases primera y segunda del cuadro de inutilidades que acompaña a este Reglamento, consignarán a continuación de aquellos datos los síntomas y signos que comprueben la indudable existencia del defecto o defectos, enfermedad o enfermedades alegados, el
} 
reclamación, un nuevo reconocimiento se practicaría en la comisión provincial ${ }^{1440}$. Estos reconocimientos serían practicados por dos facultativos, uno civil designado por la comisión y otro de los cuerpos de sanidad del Ejército o de la Armada nombrado por la autoridad militar superior de la provincia, a los que la comisión facilitaría el lugar para su celebración y todo el material médico imprescindible para el mismo ${ }^{1441}$. De los reconocimientos médicos practicados, la comisión podría declarar a un mozo apto o inútil para el servicio, pero también útil condicional si su enfermedad fuese pasajera y estuviese incluida en la tercera clase del cuadro de exenciones, a la espera de un nuevo reconocimiento médico. Los que se hallasen en el caso anterior serían observados durante dos meses en las cajas respectivas, pasando los que lo necesitasen a los hospitales militares, donde los hubiere, y en su defecto a los civiles. Las observaciones se practicarían en dichos establecimientos por los profesores de los mismos, y en las cajas por dos facultativos nombrados uno por la comisión provincial y otro por el

diagnóstico con la denominación técnica generalmente admitida en la ciencia, y con la vulgar, si la tuviere, y el orden y número de dichas clases en que se halle 0 hallen incluidos, expresando enseguida un juicio científico de que el mozo en cuestión es inútil para el servicio en el Ejército y en la Marina.

Si el defecto o defectos, enfermedad o enfermedades alegadas correspondiesen a la clase segunda del cuadro de inutilidades que acompaña a este Reglamento, los Médicos que hayan practicado el reconocimiento, harán constar en el certificado correspondiente dicha alegación, y los indicios, si los hubiere, que den o puedan dar probabilidad de la existencia del defecto o defectos; enfermedad o enfermedades alegados, consignando en segunda su juicio científico de que los mozos reconocidos deben ser declarados útiles condicionalmente para el servicio.

Si del acto del reconocimiento resultare que el mozo reconocido ante la caja de recluta o ante la Comisión Provincial tiene o padece defecto o enfermedad no incluidos en el cuadro de inutilidades que acompaña al presente reglamento, que por su cronicidad, permanencia y manifiesta incompatibilidad para el servicio constituya verdadera inutilidad, quedan autorizados para emitir su razonado juicio científico conceptuándolo inútil para el servicio [...]" (Reglamento de exenciones físicas de 12 de Agosto de 1885, art. 25).

1440 Reglamento de exenciones físicas de 12 de Agosto de 1885, arts. 18-24, 40 y 41.

${ }^{1441}$ Reglamento de exenciones físicas de 12 de Agosto de 1885, arts. 28-33. 
comandante militar, y del resultado se daría noticia a la comisión provincial. El nuevo reconocimiento se practicaría ante esta corporación por los facultativos nombrados por la misma, y por la autoridad militar, y declararían definitivamente acerca de la utilidad o inutilidad del mozo. Si el mozo resultase útil, volvería a la caja e ingresaría en el Ejército. Si, por el contrario, fuese declarado inútil, la comisión provincial haría enseguida el llamamiento y entrega del recluta disponible que debiese reemplazarle ${ }^{1442}$.

- El ministerio de la Gobernación podría decidir en última instancia en casos de supuesto fraude, escuchando previamente el juicio de la Real Academia de Medicina de Madrid o de la Junta superior facultativa de Sanidad Militar. Su participación abarcaba además la vigilancia e inspección de los juicios de exenciones, a través de comisarios regios 0 comisiones extraordinarias, nombrados para cerciorarse de la corrección en la celebración de los mismos ${ }^{1443}$.

El descontento social obliga a nuevos añadidos a la norma

a) Una mayor solicitud de soldados para Ultramar en las disposiciones aclaratorias de la ley

La nueva Ley aprobada en 1885 no supuso una definitiva estabilización legislativa en materia de reclutamiento, ya que, con el transcurso de los años desde su aprobación, originó diferentes

${ }_{1442}$ Reglamento de exenciones físicas de 12 de Agosto de 1885 , arts. 34-39.

1443 Reglamento de exenciones físicas de 12 de Agosto de 1885, arts. 42-48. 
disposiciones aclaratorias ${ }^{1444}$. En primer lugar, destacar que el territorio español fue divido en 111 zonas militares y 18 circunscripciones de reclutamiento ${ }^{1445}$ con el objetivo que acabar con las deficiencias que había provocado la división realizada en 1883 en 68 zonas $^{1446}$. En cada zona existiría una caja de reclutas a cargo de un teniente coronel de Infantería ${ }^{1447}$. También fueron numerosas las disposiciones que vinieron a conceder la exención del servicio para órdenes religiosas dedicadas a la enseñanza ${ }^{1448}$.

1444 "Señora: No desconoce V.M. que la aplicación de los preceptos de la vigente Ley de Reclutamiento y Reemplazo del Ejército, en el transcurso de poco mas de cinco años que lleva en práctica, ha motivado diferentes disposiciones aclaratorias $[\ldots]$.

Con posterioridad a estas innovaciones, ha sido preciso recurrir de continuo al Consejo de Estado, para resolver no pocos puntos que en la Ley quedaron sin una clara y concreta solución [...]" (Real Decreto de 27 de Septiembre de 1890, Gaceta núm. 273 de 30/09/1890).

${ }^{1445}$ Real Decreto de 16 de Diciembre de 1891, arts. 1, 37 y 38. Gaceta núm. 353 de $18 / 12 / 1891$ y 353 de 19/12/1891.

1446 "La creación de las zonas militares como subdivisión territorial a los efectos de reclutamiento, localización y organización de las reservas, a semejanza de lo que de muy antiguo se practicaba en otros Ejércitos, es una de las mejoras más trascendentales introducidas en el nuestro.

Todas las alteraciones que han modificado la primitiva división del territorio de la Península e Islas adyacentes que, con relación a los fines indicados, fijó el Decreto de 1883, obedecieron al plausible deseo de facilitar las complejas operaciones del reclutamiento; pro fuerza es reconocer que, a pesar de tan rectos propósitos, los 68 cuadros encargados, en la actualidad, de tan importante misión, resultan insuficientes para atender, como es debido, a los vastos y delicados asuntos que originan, en cada uno, los reclutas y reservistas que tienen a su cargo" (Real Decreto de 16 de Diciembre de 1891, Gaceta núm. 353 de 18/12/1891 y 353 de 19/12/1891).

1447 Real Decreto de 16 de Diciembre de 1891, art. 10, Gaceta núm. 353 de $18 / 12 / 1891$ y 353 de $19 / 12 / 1891$.

1448 Por Real Orden de 9 de Mayo de 1887 fueron declarados excluidos del servicio militar los misioneros de los Colegios de la Orden de San Francisco que existían en Cohegin, Vich, Sancti Spíritus, Valencia, Zarauz y Lucerna.

Por Real Orden de 17 de Octubre de 1889 fueron excluidos los jóvenes pertenecientes a la Orden de los Canónigos Regulares de San Agustín mientras la Congregación se destine exclusivamente a la enseñanza.

Por la Ley de 15 de marzo de 1890 se exceptuaron provisionalmente del servicio militar a los jóvenes de la Península que ingresaron en el Seminario Conciliar de Santiago de Cuba para cursar en él la carrera eclesiástica.

Por Real Orden de 10 de diciembre de 1890 se declaró la misma exención para los individuos de la Congregación de la Santa cruz y Pasión de Nuestro Señor.

Por Real orden de 15 de junio de 1894 se declaró que los novicios de la Orden de San Francisco de Sales quedaban exentos por estar dedicados a la enseñanza gratuita de los pobres y los niños.

Igual declaración se hizo por la Real Orden de 14 de enero y 17 de abril de 1895 respecto de los religiosos que pertenecen a las Congregaciones de María y de San 
Las críticas hacia las injusticias inherentes al sistema de reclutamiento no cesaron con el paso de los años, en especial en lo que hace referencia al excesivo número de mozos solicitados anualmente $^{1449}$, a las injusticias derivadas de la redención y al afán recaudatorio del Gobierno en sus Ilamamientos anuales de reclutas:

"El llamamiento de 55.000 hombres en estas circunstancias, no puede tener más objeto que el de exigir al pobre contribuyente que haga redenciones en número de 10, 116 12.000, para que recoja el Tesoro 15, 16620 millones de pesetas, que bien los ha de menester por cierto, pero no se deben arrancar de esta manera a las clases más necesitadas de la Nación: precisamente los padres que redimen, en su mayor parte, son los que agotan todos sus recursos con el objeto de conservar al mozo hábil para el trabajo en el seno de la familia; los que pueden holgadamente atender a las exigencias de la redención, son escasos en número. Si el Sr. Ministro de Hacienda tiene necesidad, que si la tiene, no ya de 15620 millones, sino de un centenar o más de millones, para enjugar el déficit del Tesoro, no es justo quo se pida un número de soldados superior al que, aplicando la ley estrictamente, se debe pedir ${ }^{\prime 1450}$.

El descenso en el número reclutas solicitados, y una reducción del contingente, fueron apoyados por los republicanos con diversos argumentos, como la mejora económica que supondría tal reducción, la prevalencia del derecho internacional y la tradicional neutralidad española, la óptima situación geográfica del territorio español, muy difícil de ser invadido, y la imposibilidad de que España, debido a su

Alfonso de Liborio domiciliada en Palma por dedicarse ambas exclusivamente a la enseñanza.

1449 "La especial situación que se vivía en Ultramar reclama un envío constante de hombres al frente, con lo que las Cortes decretan una y otra vez la llamada a reservistas y excedentes de cupo, así como alarga el tiempo de permanencia de los soldados en el frente colonial" (FRIEYRO DE LARA, B., De campesino a soldado. Las quintas en Granada (1868-1898), p. 41).

1450 Discurso del Sr. Pedregal, Diario de Sesiones de las Cortes, no 27, 17/02/1887, p. 675. 


\section{retraso económico y militar en comparación con otras potencias mundiales, participase en una conflagración generalizada:}

"El Ejército, pues, autor en muchas ocasiones de aquellas grandezas, ha de ser en todo caso participe de ellas, de sus prosperidades y de sus pobrezas, reflejo, en fin, de la situación de la Patria, cuyo honor y defensa le están encomendados. Claro es que quisiéramos tener el primer Ejército del mundo, por el número de los soldados, por su armamento y hasta por la estética, como quisiéramos ser los primeros en todo lo demás quo significara engrandecimiento del país; quisiéramos tener las mejores instituciones políticas, económicas y sociales; distinguirnos por el desarrollo extraordinario de nuestra industria, de nuestra agricultura y de nuestro comercio; quisiéramos que la Patria española fuera, en una palabra, la mas feliz y mas adelantada de la tierra; pero desgraciadamente estas son patrióticas aspiraciones quo por el momento distan mucho de la realidad, y la realidad nos da un pib forzado de que no se puede prescindir, que es, la situación del país, imponiéndose al Ejército como a las demás instituciones en que se desarrolla nuestra la vida nacional. [...].

Aparte de nuestra position geográfica y de las garantías que ofrece, porque presenta grandes dificultades un golpe de mano sobre nuestras costas, mayores aún sobre las fronteras pirenaica y de Portugal, tenemos el seguro del derecho internacional vigente, que no consiente tales cocas, si sabemos conservarnos en una absoluta neutralidad $[\ldots]$.

¿Cree S. S. quo podríamos hacer frente a una contingencia desgraciada con el efectivo de nuestro Ejército, aunque sea el quo propone el señor Ministro de la Guerra? ¿Cree quo podríamos tomar una parte directa en una conflagración general europea en condiciones de pesar algo en la balanza de los resultados? [...].

Todo el mundo ve que las fuerzas militares con que contarnos actualmente, nuestro material de guerra, todo lo quo es necesario para la guerra misma, es deficientísimo"1451.

${ }^{1451}$ Discurso del Sr. Muro, Diario de Sesiones de las Cortes, no 143, 18/06/1888, pp. 4331-4333. 
Incluso los propios conservadores pusieron en cuestión lo que consideraban un contingente excesivo solicitado por el Gobierno liberal, no por la situación económica del país, sino por la escasa necesidad que tenía el país, en esos momentos, de un amplio Ejército:

"Si yo entendiera que, cualquiera que fuese la situación triste y aflictiva de mi país, por altos motivos de patriotismo era necesario un supremo sacrificio, yo sé que no en vano se acudiría a esta Patria que ha abandonado no solo las riquezas, sino la tranquilidad y las vidas de sus hijos, por su propia defensa. Es, pues, la necesidad, no la situación económica, la que determina la cifra del Ejército.

$Y$ en este punto dirigía yo en otra ocasión, y ahora repito, una pregunta al Gobierno de S. M.: ¿Es que las necesidades del interior o las necesidades de la política exterior imponen un Ejército superior a aquel con el cual mantuvimos nuestra neutralidad frente a una lucha europea tremenda en el año 1870, y pudimos perfectamente sofocar en poco tiempo, mediante la iniciativa y el talento de un general ilustre, las perturbaciones interiores? ¿Entiende el Gobierno de S. M. que existe esa necesidad?"1452.

La inestabilidad legislativa en materia de reclutamiento queda patente si tenemos en cuenta la presentación y debate en Cortes de dos nuevos proyectos de reclutamiento en 1887 y 1891 que, aunque no fueron aprobados, muestran los deseos de cambio que, en esta materia, existían entre algunos sectores políticos y militares: el Proyecto de ley constitutiva del Ejército impulsado por el ministro de la Guerra Cassola, y el Proyecto de ley de reclutamiento presentado por el ministro del mismo ramo Azcárraga.

1452 Discurso del Sr. Gamazo, Diario de Sesiones de las Cortes, no 143, 18/06/1888, p. 4337. 
b) El intento de un servicio universal, excepto en Ultramar, según el Proyecto de reforma del General Cassola ${ }^{1453}$

El primer proyecto al que hemos hecho referencia, defendido por el ministro liberal Manuel Cassola ${ }^{1454}$ y con Canalejas como principal valedor, sin duda fue uno de los más polémicos y que más controversia originó, y se incluía en un proyecto de reforma más amplio, ya que afectaba a toda la estructura de la institución castrense ${ }^{1455}$, pero dedicando un capítulo específico al reclutamiento. Este proyecto, parcialmente recuperado por el Presidente del Gobierno Canalejas en 1911-1912, propuso el servicio militar obligatorio para todos los españoles de veinte años de edad siempre que cumpliesen los requisitos físicos y legales mínimos e independientemente de su situación socioeconómica ${ }^{1456}$. Se rechazó por tanto la posibilidad de redención en metálico y de sustitución ${ }^{1457}$

1453 Para conocer en profundidad el proyecto de Cassola en todas las esferas del Ejército, consultar PUELL DE LA VILLA, F., "El General Cassola, reformista militar de la Restauración", Revista de Historia Militar, 45 (1978), Madrid, Ministerio de Defensa.

${ }^{1454}$ Manuel Cassola Fernández (1838-1890), natural de Hellín, además de participar en diversas expediciones en el extranjero (México, Santo Domingo y Cuba) y en la tercera Guerra Carlista a lo largo de su carrera militar, fue ministro de la Guerra durante el Gobierno de Sagasta. Nombrado en 1897, dimitió tras la polémica y las disputas provocadas por su proyecto de Ley, Diccionario Biográfico Español, edición digital, RAH, http://www.rah.es/cdeb.htm

1455 Proyecto de Ley constitutiva del Ejército de 22 de Abril de 1887, Gaceta núm. 114 de 23/04/1887. En adelante, Proyecto de Ley constitutiva del Ejército de 22 de Abril de 1887.

${ }_{1456}$ Proyecto de Ley constitutiva del Ejército de 22 de Abril de 1887, arts. 13 y 21.

1457 La prensa conservadora precisamente justificó su rechazo al proyecto en los grandes quebrantos que, para el Erario público, supondría un servicio universal sin posibilidad de redención ni sustitución: "El establecimiento del servicio militar obligatorio es uno de los puntos culminantes de las reformas. [...] ¿ha llegado el momento de establecerlo en España? [...] No se varía en un instante la manera de ser de los pueblos. El Tesoro, además, habría de sufrir gravísimos quebrantos, y esto no lo han meditado los fusionistas, que parecen siempre arrastrados por una funesta tendencia á la bancarrota. La supresión de las redenciones á metálico implica una pérdida de 16 millones de pesetas al año, que no sabemos con qué ingresos se sustituirían [...]. En otras naciones existe el servicio obligatorio, pero, aparte de que en ellas hay costumbres públicas y una organización general que lo consiente sin rodamientos de ninguna clase, no se halla en ellas establecido sobre bases tan duras como las que el General Cassola propone, quizá con sobrado desconocimiento del país. La falta de cuarteles, la habitual dureza empleada por las 
para el servicio activo en la península por primera vez en una iniciativa legislativa presentada ante las Cortes ${ }^{1458}$. El servicio tendría una duración de doce años para los destinados en la península, divididos en las situaciones de servicio activo, primera y segunda reserva, y ocho para los enviados a Ultramar, cuatro en servicio activo y otros cuatro, ya en la península si así lo deseasen, en la segunda reserva ${ }^{1459}$.

La disposición más polémica del proyecto se encuentra en el rechazo expreso que se propuso para la sustitución y la redención en

clases y otros accidentes de la vida de cuartel, no pueden menos de hacerse insoportables á la juventud que ha pasado sus mejores años en las cátedras ó en las escuelas especiales para ver luego truncada de un golpe su carrera.

Estas reformas no pueden llevarse á la práctica sin la conveniente preparación lenta y sesudamente realizada, y sin fijar una organización que, como en Prusia acontece, permita á todos los ciudadanos llenar sus deberes para con la patria sin perjuicio de los intereses propios. Por el sistema que el General Cassola propone el servicio obligatorio, antes lleva á paisanizar el ejército que á militarizar el país, que es precisamente lo contrario do lo que esto sistema de reclutamiento significa en todas partes. Bajo su aspecto puramente económico, que no puede darse al olvido, la reforma es más ruinosa todavía. El presupuesto, además de perder ingresos en cantidad de 16 millones de pesetas al año, como hemos dicho, agotados los fondos de las Cajas especiales de redención y enganche, tendrá que sufragar las obligaciones pendientes por este concepto y-las que habrá de adquirir.

Así que la medida, sin satisfacer ninguna necesidad presente, aumenta á 20 millones el déficit calculado para el año venidero [...]. Mientras la tranquilidad pública permitía mantener reducido el contingente del ejército, la redención venía á constituir un impuesto de consideración, que introducía al Tesoro recursos muy apreciables, dada la penuria del Erario, sin privar por eso al ejército de los hombres que el servicio exigiese. Por último, no hay igualdad distributiva en la reforma desde el momento que, hasta los mismos reclutas que rediman ó sustituyan su servicio en Ultramar, tienen que prestarlo en la Península por el mismo tiempo y en las mismas condiciones que si no hubieran pagado las 2000 pesetas. [...]. Con las bases propuestas, ó es impracticable la idea, ó su realización será gravosa al Tesoro, y ni en uno ni en otro caso satisfará por completo las necesidades que tratan de remediarse. [...]" (La Época, 23/04/1887, no 12482, p. 1).

1458 "En el seno del Ejército, la opinión se escindió. La mayor parte de los generales se opusieron a un proyecto que, independientemente de los problemas corporativos que planteaba, suponía el inminente regreso de sus hijos y familiares en los cuarteles. La oficialidad de Infantería se alineó con Cassola [...], los influyentes oficiales del Estado Mayor y los elitistas artilleros e ingenieros lo rechazaron [...]. Durante las dos legislaturas en que se mantuvo abierta la cuestión, se publicaron numerosos folletos, generalmente anónimos, expresivos de las diferentes posturas adoptadas. En la prensa nacional, y particularmente en la madrileña, el tema no pasó desapercibido, pero fueron los diarios militares los que dedicaron amplísimos espacios a esta cuestión y donde las pasiones se desataron en infinidad de cartas al director, artículos firmados y, evidentemente, sueltos de la redacción y editoriales [...]" (PUELL DE LA VILLA, F., El soldado desconocido: de la leva a la "mili" (17001912), p. 289).

1459 Proyecto de Ley constitutiva del Ejército de 22 de Abril de 1887, art. 14. 
metálico, al considerarlo una iniquidad, excepto para los destinados a Ultramar, que sí que se podrían acoger a la redención a cambio del pago de 2.000 pesetas. Sin embargo, esta circunstancia no supondría una exención definitiva del servicio, ya que los redimidos y sustituidos sí que tendrían la obligación de prestar el servicio en territorio peninsular ${ }^{1460}$. Por tanto, sustitución y redención sólo servirían para evitar el servicio en Ultramar, pero los que se acogiesen a estos privilegios tendrían que formar parte de los cuerpos peninsulares en las mismas circunstancias que el resto de los reclutas. Los fondos obtenidos a través de sustituciones y redenciones serían empleados en recompensar a aquellos que solicitasen voluntariamente su destino a Ultramar ${ }^{1461}$.

Otra novedad que recogió el proyecto de ley relacionada con el reclutamiento sería la posibilidad, para aquellos jóvenes entre dieciocho y veinte años de edad, de ingresar en el servicio activo para así cumplir y extinguir antes su obligación respecto al servicio militar y ver reducido su tiempo de prestación obligatoria. Deberían cumplir con ciertas condiciones: superar un examen teórico y práctico sobre el servicio militar y presentar equipo, armamento y uniforme completos. Estos voluntarios servirían un año completo en los cuerpos activos, pasando al cumplirlo a la situación de primera reserva durante seis años ${ }^{1462}$.

En cuanto a las exenciones, éstas apenas sufrirían ninguna variación en su tipología: físicas, legales (oficiales del Ejército, alumnos de academias militares, religiosos y novicios de las Escuelas Pías y congregaciones dedicadas a la enseñanza, condenados a presidio) y familiares (mozos que mantengan a su familia desvalida o pobre $)^{1463}$.

\footnotetext{
1460 Proyecto de Ley constitutiva del Ejército de 22 de Abril de 1887, art. 15. 1461 Proyecto de Ley constitutiva del Ejército de 22 de Abril de 1887, art. 25. 1462 Proyecto de Ley constitutiva del Ejército de 22 de Abril de 1887, arts. 18 y 19. 1463 Proyecto de Ley constitutiva del Ejército de 22 de Abril de 1887, art. 21.
} 
La polémica generada en torno al proyecto de Cassola, los intereses de los grupos acomodados y la oposición conservadora ${ }^{1464}$ impidieron la aprobación de este texto que buscaba terminar con las injusticias sociales en materia de reclutamiento, pero su espíritu sería recogido años después, en la legislación de 1912.

c) El fin de la redención y la sustitución para los destinos peninsulares en el Proyecto de reforma del ministro Azcárraga

Las dudas surgidas en torno a la aplicación de la Ley de 1885 motivaron un nuevo proyecto de reforma de la ley, cuyas bases fueron presentadas por el ministro de la Guerra conservador Marcelo Azcárraga ${ }^{1465}$, e incluso se formó una junta formada por representantes de los ministerios de Gobernación, Marina, Ultramar y Guerra, encargada de su redacción ${ }^{1466}$. Este proyecto de ley, presentado a las Cortes pero nunca aprobado, contenía como principal novedad el fin definitivo de la sustitución y de la redención en metálico para los destinos peninsulares, pero admitía esta posibilidad para los reclutas destinados a Ultramar. Además se permitía a Ayuntamientos y Diputaciones redimir a todo el cupo

\footnotetext{
1464 "Romero Robledo rechazó esta solución y defendió la redención y la sustitución, ya que el servicio obligatorio para todos condenaría a la esclavitud a todos por igual, y ello provocaría la emigración de las familias ricas y de los estudiantes que no estuviesen dispuestos a interrumpir su carrera y, además, llevaría al Estado a la ruina, incapaz de mantener un Ejército tan numeroso" (FEIJóo GÓMEZ, A., Quintas y protesta social en el siglo XIX español, p. 165).

1465 Nacido en Manila en 1832, fue ministro de la Guerra con Cánovas del Castillo y Silvela, llegando a ocupar la presidencia del Gobierno hasta en tres ocasiones con mandatos breves. Murió en Madrid en 1915. Diccionario Biográfico Español, edición digital, RAH, http://www.rah.es/cdeb.htm

${ }^{1466}$ Real Decreto de 27 de Septiembre de 1890, Gaceta núm. 273 de 30/09/1890; Real Orden de 30 de Septiembre de 1890, Gaceta núm. 274 de310/10/1890; Proyecto de Ley de reclutamiento y reemplazo del Ejército de 13 de Julio de 1891, Gaceta núm. 195 de 14/07/1891, 196 de 15/07/1891, 197 de 16/07/1891, 198 de 17/07/1891, 199 de 18/07/1891, 200 de 19/07/1891, 201 de 20/07/1891, 202 de 21/07/1891, 203 de 22/07/1891, 204 de 23/07/1891, 205 de 24/07/1891, 206 de $25 / 07 / 1891$ y 207 de $26 / 07 / 1891$.
} 
destinado a Ultramar de su ámbito territorial. También proponía, al objeto de evitar las irregularidades cometidas por los Ayuntamientos, reducir al mínimo las competencias municipales en materia de exenciones e incrementar las concedidas a las comisiones de reclutamiento. Como tercer aspecto novedoso del proyecto destacamos la posibilidad de que un joven solicitase una prórroga temporal, de hasta un máximo de cuatro años consecutivos y nunca cuando el país se encontrase en guerra, para su ingreso en el servicio por motivos de estudios o razones laborales. Estas prórrogas serían concedidas por la comisión provincial de reclutamiento. Como última novedad destacar la propuesta que se realizó de crear milicias provinciales y cuerpos de veteranos, que serían puestos en pie de guerra en caso de agresión exterior ${ }^{1467}$.

d) La necesidad de efectivos para hacer frente a la guerra colonial en la Ley y Reglamento de 21 de agosto de 1896

Desde que se firmara la paz de Zanjón entre Martínez Campos y los independentistas, en 1878, en el que se establecía el compromiso mutuo de que Cuba fuera tratada como una provincia más de España y a los cubanos como españoles de pleno derecho, las disensiones sobre el cumplimiento de la paz habían sido constantes, en especial en lo relativo a la implementación de leyes electorales que favorecían claramente el peso político de los españoles nacidos en Europa frente al de los nacidos en la isla. Por ello, Zanjón trajo unos años de calma, pero no sirvió para zanjar de forma definitiva el

1467 Proyecto de Ley de reclutamiento y reemplazo del Ejército de 13 de Julio de 1891, Gaceta núm. 195 de 14/07/1891, 196 de 15/07/1891, 197 de 16/07/1891, 198 de 17/07/1891, 199 de 18/07/1891, 200 de 19/07/1891, 201 de 20/07/1891, 202 de 21/07/1891, 203 de 22/07/1891, 204 de 23/07/1891, 205 de 24/07/1891, 206 de 25/07/1891 y 207 de 26/07/1891. 
conflicto entre Cuba y el gobierno central de Madrid, alimentado cuidadosamente por la diplomacia y la inteligencia estadounidenses.

En 1893, consciente de que la situación podría agravarse en cualquier momento, Antonio Maura trató de conseguir la aprobación de una reforma descentralizadora que sirviera para crear un nuevo marco de convivencia entre Cuba y Madrid, pero el proyecto no logró ser llevado adelante, al ser considerado por la mayor parte del gobierno como demasiado radical.

En febrero de 1895 comenzó en Cuba un alzamiento, que a la postre se transformaría en guerra de independencia, respondiendo al llamamiento para ello efectuado por Martí desde su exilio norteamericano. El comienzo de de la rebelión fue bastante poco prometedor, ya que solo en la parte occidental de la isla tuvo verdadero impacto el alzamiento $y$, durante los meses entre febrero y octubre de aquel año, los alzados no llegaron a tomar ninguna ciudad cubana.

Sin embargo, la incapacidad del general Martínez Campos para acabar por completo con la rebelión, y los posteriores excesos del general Valeriano Weyler en la represión -que habían llegado precedidos de algunas acciones igualmente crueles por parte de los insurrectos, como la condena a muerte de todo nacido en la isla que sirviera bajo la bandera de España- entre 1896 y 1897, así como la paralización en el mismo mes de febrero de 1895 de una ley que pretendía descentralizar parte de la administración española, tal y como se solicitaba desde la isla ${ }^{1468}$, acabaron alimentando la hoguera hasta que el conflicto se convirtió en una verdadera guerra con elevadísimas tasas de mortandad entre los soldados peninsulares, motivada sobre todo por las enfermedades tropicales. El hecho de que muchos de los fallecidos fueran soldados de reemplazo y la

1468 Ver TARRAGÓ, R.E., "La guerra de 1895 en Cuba y sus consecuencias", en Arbor: ciencia, pensamiento y cultura, no 735 (2009), Ejemplar dedicado a: Los destinos inciertos: el exilio republicano español en América Latina, pp. 215-229. 
necesidad de mantener en marcha una guerra a miles de kilómetros del suelo peninsular, hizo que la cuestión del reclutamiento militar volviera a ser uno de los temas candentes de la política española.

La reforma definitiva de la Ley de 1885 se produjo en 1896 cuando un nuevo texto legislativo y un nuevo reglamento para su ejecución vinieron a completarla y reformarla parcialmente, impulsadas otra vez por el ministro de la Guerra Marcelo Azcárraga y con Cánovas como Presidente del Gobierno ${ }^{1469}$, en un contexto de crisis colonial con el frente cubano abierto ${ }^{1470}$, y con crecientes reticencias de los reclutas para ser trasladados a un frente con muy duras condiciones de vida:

"Es un círculo vicioso: la situación en Cuba obliga al Gobierno español (haciendo caso omiso de la verdadera capacidad de su ejército y de las especiales condiciones del frente cubano) a enviar la mayor cantidad de hombres posibles a Ultramar; pero también apremia a los reclutas a buscar vías de escape ante los sucesivos Ilamamientos. El Estado, por su parte, trata de incentivar el voluntariado y de frenar la corrupción entre los funcionarios encargados de las operaciones de la quinta y los propios reclutas alistados, quiénes, cada vez con más frecuencia, tratan de escapar de forma ilícita al llamamiento"1471.

1469 Ley de 21 de Agosto de 1896 y Reglamento de 21 de Agosto de 1896.

1470 Sobre la guerra hispano-cubana ver DE DIEGO, E., 1895: la guerra en Cuba y la España de la Restauración, Madrid, Editorial Complutense, 1996; FUSI AIZPURÚA, J. P., Antes del desastre: orígenes y antecedentes de la crisis del 98: Congreso Internacional, Madrid, Universidad Complutense de Madrid, 1996; DE DIEGO, E., Hacia el 98: la España de la Restauración y la crisis colonial (18951898), Madrid, Escuela Diplomática, 1997; ELORZA, A., y HERNÉNDEZ SANDOICA, E., La guerra de Cuba (1895-1898): historia política de una derrota colonial, Madrid, Alianza, 1998; TONE, J. T., Guerra y genocidio en Cuba: 1895-1808, Madrid, Turner, 2008; REY VICENTE, M. y CANALES TORRES, C., Breve historia de la guerra del 98, Navarra, Nowtilus, 2010.

1471 FRIEYRO DE LARA, B., De campesino a soldado. Las quintas en Granada (18681898), p. 42. 
El objetivo básico de la ley sería por tanto poder cubrir las necesidades del ejército ultramarino aumentando el número de voluntarios, reduciendo el número de prófugos y acabando con los delitos y corruptelas relacionados con el reemplazo: "corrupción relacionada con las declaraciones de enfermedades y defectos físicos, presentación de falsos prófugos, aceptación de sustitutos que no cumplían con los requisitos que la ley reclamaba, etcétera"1472. Azcárraga reconocía así la falacia del sistema de quintas y la corrupción generalizada del régimen de la Restauración. Sin embargo, "las raíces del problema eran tan profundas, la autocomplacencia de los privilegiados tan acentuada, que el Gobierno consideró suficiente, para poner fin a los abusos [...], la militarización de las comisiones investigadoras, la celebración del sorteo en los pueblos y el cese de las primas a los cazadores de prófugos" ${ }^{1473}$.

La ley por tanto no alteró apenas la organización del servicio ni del reemplazo, pero sí que recogió algunas novedades en las operaciones de la quinta ${ }^{1474}$ para evitar abusos y fraudes ${ }^{1475}$ :

- Para incrementar el control sobre las autoridades civiles encargadas del reemplazo, en particular de los Ayuntamientos, un delegado de la autoridad militar, con los mismos deberes y responsabilidades que los

\footnotetext{
1472 FRIEYRO DE LARA, B., El reclutamiento militar en la crisis de la Restauración: el caso riojano (1896-1923), p. 59.

1473 PUELL DE LA VILLA, F., El soldado desconocido: de la leva a la "mili" (17001912), p. 294.

1474 "Las últimas leyes de reclutamiento del siglo no cambiaron el espíritu de la legislación anterior, pero modificaron los mecanismos de reemplazo, y acortaron los plazos, hasta el punto de concebir el proceso de reclutamiento como una cadena de operaciones realizadas el año anterior al de ingreso en filas" (FEIJÓo GÓMEZ, A., Quintas y protesta social en el siglo XIX español, p. 273).

1475 Podemos encontrar ambos textos refundidos en Manual de la Ley de reclutamiento y reemplazo del Ejército de 11 de julio de 1885 refundida en un texto legal por Real Decreto de 2 de Octubre del mismo año acompañada de los Reglamentos de la Ley y Cuadro de exenciones físicas, anotada con numerosas citas de Reales Órdenes, advertencias y seguida de formularios, por Isidro de Molina Fernández-Moreno; abogado y Secretario de la Excma. Diputación Provincial de Cuenca. Gaceta núm. 297 de 23/10/1896, núm. 298 de 24/10/1896 y núm. 299 de $25 / 10 / 1896$.
} 
individuos del consistorio, asistiría a los actos de formación del alistamiento, clasificación de los soldados y sorteo. El Gobierno podría además nombrar comisarios regios a fin de que pudiesen inspeccionar todas las operaciones relativas al reclutamiento, tanto de las encomendadas a las corporaciones municipales y provinciales, como a las de las comisiones de reclutamiento, siempre que lo estimase oportuno, para cerciorarse de su exactitud y legalidad ${ }^{1476}$.

- Se estableció la siguiente clasificación para los mozos de cara al servicio militar: excluidos total o parcialmente del servicio, soldados, soldados condicionales y prófugos ${ }^{1477}$. El reglamento que ejecutó la ley estableció una serie de limitaciones a la libertad personal de los reclutas. Así, los mozos en caja no podrían contraer matrimonio, los mozos en activo hasta que no transcurriesen tres años desde su incorporación a filas y los soldados en depósito tendrían que esperar un año, mientras que los reclutas condicionales no sufrirían restricciones mientras durase su situación $^{1478}$.

- También se implantaron nuevas fechas para celebrar todos los actos del reclutamiento, a saber:

$$
\begin{aligned}
& \text { "10.- Alistamiento. - } 1^{0} \text { de enero y días subsiguientes. } \\
& \text { 20.- Rectificación del alistamiento.- Último domingo de }
\end{aligned}
$$
enero.

30.- Sorteo.- Segundo domingo de febrero.

\footnotetext{
1476 Ley de 21 de Agosto de 1896, arts. 1, 4 y 15.

1477 Ley de 21 de Agosto de 1896, art. 2.

1478 Ley de 21 de Agosto de 1896 y Reglamento de 21 de Agosto de 1896, arts. 8 y 10.
} 
40.- Clasificación y declaración de soldados.- Primer domingo de marzo, resolviéndose todas las incidencias durante dicho mes.

50.- Revisión ante las Comisiones Mixtas de Reclutamiento.- Del 10 de abril al 30 de junio.

60. - Ingreso en caja de los mozos. - $1^{\circ}$ de agosto.

70.- Señalamiento y distribución del contingente para el Ejército de la Península y el de Ultramar por el Ministerio de la Guerra.- $1^{\circ}$ de septiembre.

$8^{\circ}$.- Incorporación de los reclutas en las cajas para su destino a Cuerpo activo.- desde 10 de noviembre, cuando lo disponga el Ministerio de la Guerra, a menos que las necesidades del servicio exijan que se anticipen los plazos antes marcados $[\ldots]^{11479}$.

- Se introdujeron algunas novedades en el alistamiento de los jóvenes residentes en el extranjero: los hijos de españoles nacidos en la península, Baleares y Canarias y posesiones del norte de África que residiesen en los distritos de Ultramar, serían inscritos en el alistamiento del pueblo de residencia de sus padres, y si éstos se hallasen también en Ultramar, se haría la inscripción en el pueblo en que nacieron; los súbditos españoles nacidos en territorio nacional y residentes en el extranjero, serían alistados en los Ayuntamientos respectivos, sin responder ante los consulados del servicio militar; los súbditos españoles nacidos y residentes en el extranjero y cuyos padres hubiesen nacido y residiesen en el extranjero, solicitarían su inscripción en el alistamiento, presentándose a los cónsules del punto en que se encontrasen, los cuales remitirían una relación filiada de los mozos, por el ministerio de Estado, al Gobernador Civil de Madrid, para que dispusiese su inscripción en una

${ }^{1479}$ Ley de 21 de Agosto de 1896, art. 3. 
de las tenencias de alcaldía de esta capital, a menos que los interesados designasen la localidad en que preferían ser alistados. En los territorios africanos, las juntas de arbitrios vendrían a desempeñar el mismo papel que los Ayuntamientos peninsulares ${ }^{1480}$. Las oficinas consulares en aquellos territorios con población española muy numerosa, tales como Argelia o Marruecos, podrían practicar las operaciones del reemplazo si así se lo ordenase el Gobierno de la nación ${ }^{1481}$. Por primera vez se concedieron competencias en materia de reclutamiento a autoridades diplomáticas en el extranjero.

- El acto del sorteo no tendría por qué celebrarse en cada pueblo del territorio nacional sino que, con el objeto de simplificar el proceso, el Gobierno podría decretar su celebración en la cabecera de una o de algunas de las zonas militares, con asistencia de los comisionados de los Ayuntamientos. El sorteo podría suspenderse cuando se produjese algún hecho excepcional no previsto en la ley. En caso de suspensión se precintarían con el sello del Ayuntamiento los dos bombos, quedando además custodiados por agentes de la autoridad ${ }^{1482}$.

- En lo que respecta al acto de clasificación y declaración de los soldados, la ley no introdujo ninguna novedad, pero sí el reglamento que la desarrolló ya que, para evitar fraudes, se reguló con enorme precisión como había de ser el tallaje del mozo en el Ayuntamiento:

\footnotetext{
${ }^{1480}$ Reglamento de 21 de Agosto de 1896, arts. 27-29 y 38.

${ }^{1481}$ Ley de 21 de Agosto de 1896, art. 5.

1482 Ley de 21 de Agosto de 1896, art. 4 y Reglamento de 21 de Agosto de 1896, art. 47.
} 
"Para tallar el mozo se le colocará con los pies enteramente desnudos, haciéndole quitar la chaqueta o prenda equivalente, y la faja, si la llevase, consintiéndole solo en la cintura una correa o cinturón estrecho. Tomará en la talla la posición militar, teniendo los talones unidos, apoyándolos en la intersección del plano vertical de la talla con el horizontal de la base; los pies igualmente abiertos, formando un ángulo algo menor que el recto; las piernas tendidas, sin hacer fuerza en las rodillas; el peso del cuerpo a plomo sobre las caderas; recogido el vientre; el pecho hacia fuera; los hombros algo retirados; los brazos caídos naturalmente; derecha la cabeza sin violencia y apoyada en la talla; la barba un poco recogida y la vista al frente ${ }^{\prime 1483}$.

- En lo que se refiere a las exenciones, se fijó la cantidad económica cobrada por una persona para ser considerada pobre y poder alegar motivo de exención familiar: quedó establecido el umbral en menos de 75 céntimos de peseta diarios $^{1484}$. Se incrementó el número de exenciones concedidas a las órdenes religiosas, recogiendo la siguiente relación de órdenes exentas:

"10. - Venerable Orden de Canónicos de San Agustín.

20.- Congregación de la Santísima Cruz y Pasión de Nuestro Seños Jesucristo.

30.- Congregación de los Hijos del Inmaculado Corazón de María, establecida en las posesiones del Golfo de Guinea.

40.- Religiosos [...] de la Congregación de María.

60.- Órdenes religiosas dependientes del Ministerio de Ultramar, que son: Agustinos Descalzos (Recoletos), Agustinos Calzados, Dominicos, Franciscanos, Jesuitas, Carmelitas Descalzos y Trinitarios de Alcázar de San Juan.

70. - Congregación de San Vicente de Paúl.

1483 Reglamento de 21 de Agosto de 1896, art. 60.

${ }^{1484}$ Reglamento de 21 de Agosto de 1896, arts. 63-65. 
80. - Religiosos y novicios de la Compañía de Jesús.

90. - Colegios de la orden de San Francisco, establecidos en Cohegin, Vich, Sancti Spiritus (Valencia), Zarauz y Lucena, los cuales se sostendrán con sus propios recursos, sin auxilio del Estado, y cuyos Misioneros se comprometerán a servir toda su vida en las Misiones de Tierra Santa y de África [...].

100.- Religiosos [...] de la Congregación Instituto de Hermanos de las Escuelas Cristianas.

110.- Los mozos que de cualquier pueblo de la península vayan al Seminario conciliar de Santiago de Cuba a cursar la carrera eclesiástica $[\ldots]^{1 / 1485}$.

- Se mantuvo la competencia municipal de poder declarar exentos a aquellos mozos comprendidos en la primera clase de enfermedades o defectos físicos detallados en el cuadro de exenciones. Cuando la enfermedad o defecto físico fuese de otra naturaleza, se sometería al interesado al reconocimiento físico del médico municipal. Cuando el dictamen del médico fuese declarar al mozo impedido para el trabajo, quedaría el interesado sujeto a nuevo reconocimiento por los médicos de la comisión mixta, que tomarían la decisión pertinente ${ }^{1486}$.

- Todo prófugo aprehendido o presentado que ingresase en filas, se destinaría, cualquiera que fuese su número en el sorteo, al cupo para Ultramar del pueblo correspondiente, si perteneciese a alguno de los reemplazos que estaban sobre las armas ${ }^{1487}$. Y si perteneciese a reemplazos anteriores se abonaría al primer reemplazo que se verificase. Los prófugos que, sin haber acudido al acto de la clasificación y declaración de soldados, se presentasen para el ingreso en caja, no sufrirían recargo alguno y

${ }^{1485}$ Reglamento de 21 de Agosto de 1896, art. 50.

${ }_{1486}$ Reglamento de 21 de Agosto de 1896, art. 66.

${ }^{1487}$ El objetivo vuelve a ser completar el difícil cupo de Ultramar. 
servirían en la situación que su suerte hubiese determinado ${ }^{1488}$. Se suavizaron así las penas para los prófugos arrepentidos, con el objeto de estimular su presentación en la caja de reclutas aunque no se hubiesen presentado en los actos previos.

- Las comisiones provinciales de reclutamiento serían sustituidas por las comisiones mixtas de reclutamiento, que asumirían todas sus funciones, y estarían compuestas por autoridades civiles y militares: el gobernador de la provincia como presidente, el coronel jefe de la zona como vicepresidente, dos diputados provinciales como vocales, un jefe de la caja de recluta, un delegado de la autoridad militar competente, un médico civil, nombrado por la comisión provincial, un médico militar, nombrado por el comandante en jefe del Ejército y el secretario de la Diputación. Formaría también parte de la junta, con voz, aunque sin voto, como el secretario de la comisión, el síndico y un delegado del Ayuntamiento del pueblo cuya revisión se practique. Asumieron estas comisiones una nueva competencia según la nueva ley, como es la revisión de todos los expedientes de los mozos que en el acto de la clasificación y declaración de soldados por el Ayuntamiento fuesen considerados como excluidos temporal o totalmente del servicio militar, así como de los declarados soldados condicionales. Además, el certificado expedido a estos reclutas avalando tal condición no sería expedido por los Ayuntamientos, sino por la propia comisión. Se redujo a 45 días el tiempo que tenían estas comisiones para declarar una exención física en función del dictamen de los facultativos médicos y, si tal decisión

${ }^{1488}$ Ley de 21 de Agosto de 1896, art. 6. 
fuese tomada una vez que el mozo hubiese ingresado en caja, la resolución podría ser reclamada por el jefe del cuerpo al que perteneciese el reclamante ante el ministerio de la Guerra. Estos individuos declarados exentos pero ya ingresados en la caja, serían declarados soldados condicionales y continuarían prestando sus servicios en activo hasta que verificasen el ingreso en el mismo de los mozos del reemplazo inmediato, siendo entonces dados de baja en los cuerpos activos ${ }^{1489}$.

- El Reglamento de 1896 señaló que las decisiones de las comisiones mixtas serían definitivas, a no ser que éstas entrasen en contradicción con las tomadas por los Ayuntamientos, en cuyo caso la sección de Gobernación y Fomento del Consejo de Estado intervendría para proponer al Gobierno lo que estimase conveniente. Se mantuvo la posibilidad de recurrir ante el ministerio de la Gobernación las decisiones de la comisión mixta ${ }^{1490}$.

- Por primera vez incluyó una ley la posibilidad de que un voluntario del Ejército acudiese a la redención en metálico para librarse de la responsabilidad que contrajo, estableciéndose en 1.500 pesetas. Se admitió además voluntarios a partir de catorce años siempre que fuesen hijos de jefes y oficiales del Ejército. Los voluntarios que pasasen doce años sirviendo en la institución armada recibirían licencia absoluta ${ }^{1491}$.

- El Gobierno podría suspender la concesión de licencias absolutas a los soldados en caso de guerra 0 en situaciones extraordinarias. Las licencias ilimitadas se

1489 Ley de 21 de Agosto de 1896, arts. 8-12, Real Decreto de 5 de Enero de 1897, Gaceta núm. 6 de 06/01/1897, Real Orden de 5 de Febrero de 1897, Gaceta núm. 38 de 07/02/1897 y Reglamento de 21 de Agosto de 1896, arts. 97-113.

1490 Reglamento de 21 de Agosto de 1896, arts. 133, 139 y 140.

${ }^{1491}$ Reglamento de 21 de Agosto de 1896, arts. 182, 206 y 210. 
concederían a los individuos que llevasen más tiempo de servicio, preferentemente a aquellos que supiesen leer y escribir o sólo leer, especialmente si habían adquirido esta instrucción en sus años de prestación. No podrían disfrutar de dichas licencias los que no hubiesen completado su instrucción, los que sufriesen recargo en su tiempo de prestación o los que estuviesen sujetos a procedimientos judiciales ${ }^{1492}$. Un ejemplo de la concesión de estas licencias ilimitadas lo encontramos en 1904, cuando se expidió licencia ilimitada a todos los individuos de los regimientos y batallones de Infantería de la península y plazas del norte de África en el tercer año de servicio $^{1493}$.

- También se estableció la obligación para los individuos del Ejército en situación de reserva y depósito con licencia ilimitada de pasar revista anual ante las autoridades militares durante los meses de octubre y noviembre. Aquellos individuos que no se presentasen a este acto ingresarían en el servicio activo entre tres y seis meses para recibir la correspondiente instrucción militar ${ }^{1494}$. Se procuró así la existencia de unos reclutas instruidos en el arte de la guerra de cara a posibles conflictos aunque no perteneciesen al servicio activo.

- Por último, la ley señaló que los ministerios de Gobernación y Guerra publicarían las disposiciones necesarias que hiciesen cumplir su articulado, quedando

1492 Ley de 21 de Agosto de 1896, art. 13 y Reglamento de 21 de Agosto de 1896, arts. 229 y 230.

${ }^{1493}$ Real Orden Circular del Ministerio de la Guerra de 24 de Mayo de 1904, Gaceta núm. 147 de 26/05/1904.

${ }^{1494}$ Reglamento de 21 de Agosto de 1896, arts. 236-247. 
vigente la Ley de 11 de Julio de 1885 en aquellos artículos que no hubiesen sufrido alteración ${ }^{1495}$.

e) Añadidos posteriores a la Ley de 1896

En 1904, una nueva ley aprobada en Cortes vino a disponer la forma en que el ministerio de la Guerra había de realizar el reparto del contingente. Tal ministerio debería publicar el primero de septiembre de todos los años un real decreto donde

"[...] señalará por separado el contingente de los hombres con que cada zona de la Península ha de contribuir para el reemplazo en los Cuerpos del Ejército de Mar y Tierra, el contingente necesario de la zona de Baleares para los Cuerpos de aquel Archipiélago, y de los que sea preciso de las zonas de Canarias para las unidades de estas Islas. El estado que, según el citado artículo, ha de acompañar a dicho Real Decreto, se dividirá en tres; uno de las zonas de la Península; otro de la de Baleares y el tercero de las dos de Canarias, expresando estos dos últimos el número de reclutas que dará la Isla; consideradas para estos efectos como una sola la de Ibiza y Formentera, y como otra las de Gomera y Hierro"1496.

Ese mismo año de 1904, un real decreto vino a dividir el territorio de la Península en 116 circunscripciones a efectos del reclutamiento, reemplazo y movilización del Ejército. Dentro de cada una de ellas existiría una caja de recluta y un cuadro del batallón de segunda reserva, cuyas cabeceras estarían situadas en puntos colocados sobre las vías férreas. Estas 116 circunscripciones, administradas por un coronel de Infantería, se agruparían en 54

\footnotetext{
1495 Ley de 21 de Agosto de 1896, arts. 17 y 18.

1496 Ley de 17 de Julio de 1904 relativa al señalamiento del contingente de hombres con que han de contribuir las zonas de la Península, Baleares y Canarias para el reemplazo de los Cuerpos del Ejército, art. 1, Gaceta núm. 201 de 19/07/1904.
} 
zonas militares de reclutamiento y reserva para la administración, régimen y servicio interior de las unidades que en aquéllas se organizan. De las 47 provincias de la península, 41 se constituirían con una sola zona; las de Madrid, Sevilla, Valencia, Oviedo y Coruña tendrían dos zonas y la de Barcelona comprendería tres zonas. Cada zona estaría al mando de un coronel de Infantería ${ }^{1497}$.

A efectos administrativos, se consideró que pertenecían a la caja de reclutas los mozos en caja, reclutas con licencia ilimitada por exceso de fuerza, excluidos temporalmente del servicio, soldados condicionales y prófugos. En cada zona de reclutamiento y reserva habría un depósito al que pertenecerían los mozos excedentes de cupo, redimidos y sustituidos, y los que por razones de familia tuviesen confirmadas sus excepciones de prestar el servicio ordinario en activo ${ }^{1498}$.

Proyectos de reforma posteriores a las leyes de 1885 y 1896

Como apartado final del análisis sobre las leyes de 1885 y 1896 , destacamos una serie de proyectos de ley sobre reclutamiento y reemplazo, ninguno de ellos aprobados por diversas circunstancias.

\footnotetext{
1497 Real Decreto del Ministerio de la Guerra reorganizando las tropas del Ejército y servicio con ellas relacionado, arts. 31, 32 y 33, Gaceta núm. 315 de 12/11/1904. 1498 Real Decreto del Ministerio de la Guerra reorganizando las tropas del Ejército y servicio con ellas relacionado, arts. 36 y 37, Gaceta núm. 315 de 12/11/1904.
} 
Los intentos de cambio tras el Desastre del 98 en el Proyecto de reforma de 1902

El primero fue presentado ante las Cortes en febrero de 1902 por parte del ministro de la Guerra Valeriano Weyler ${ }^{1499}$, tan solo cuatro años después del desastre de Ultramar ${ }^{1500}$ y con un país necesitado de respuestas e iniciativas tras las pérdidas coloniales y con una institución militar completamente desprestigiada y objeto de numerosas críticas por parte de sectores civiles ${ }^{1501}$.

Hay que tener en cuenta además la convulsa situación sociopolítica por la que atravesaba el país y la posibilidad de un conflicto civil y de fuertes agitaciones sociales en el contexto depresivo del desastre del 98, argumento éste que ya fue utilizado

1499 Valeriano Weyler, nacido en Palma de Mallorca el 17 de Septiembre de 1838 y fallecido el 20 de Octubre de 1930, es uno de los militares españoles más prestigioso por sus tratados militares y su participación en la represión de la sublevación cubana. Fue Senador y Ministro de la Guerra hasta en tres ocasiones formando parte del Partido Conservador. Diccionario Biográfico Español, edición digital, RAH, http://www.rah.es/cdeb.htm

1500 "La guerra de Cuba determinó el futuro rumbo del reclutamiento. Los soldados enviados a ultramar se reclutaron exclusivamente entre las capas inferiores de la población, a fin de no indisponer al sistema con las clases que lo sustentaban, sin ningún empacho en contravenir la legislación vigente.

A medida que aumentaba el número de hombres que cruzaban el Atlántico y se conocían datos sobre las bajas de las tropas españolas, muchos intentaron evitar el embarque. El gobierno decidió acabar con la picaresca que permitía eludir el servicio mediante sobornos y tráficos de influencias, pero mantuvo la exención para los que podían pagarla. [...].

Después del 98, los "regeneracionistas" -conservadores y liberales- exigieron la urgente reforma de la legislación para que desaparecieran injustos privilegios. Sin embargo, pasaron todavía ocho años hasta que Canalejas fundó el Partido Demócrata, con el compromiso de universalizar el servicio, promesa que se hizo realidad en 1911" (PUELL DE LA VILLA, F. Historia del Ejército en España, pp. 139 y 140).

Ver también PAYNE, S. G., Los militares y la política en la España contemporánea, pp. 41-88.

Sobre el desastre del 98 ver SÁNCHEZ, J. P., La guerra cubano-hispano-americáine (1898), Rennes, Laboratoire Interdisciplinaire de Recherche sur les Amériques, 1995; NUÑEZ FLORENCIO, R., El ejército español en el desastre de 1898, Madrid, Arco Libros, 1997; RUBIO, J., El final de la era Cánovas: los preliminares del desastre de 1898, Madrid, Ministerio de Asuntos Exteriores, 2004.

1501 Real Decreto de 5 de Febrero de 1902 autorizando al Ministro de Guerra presentar ante las Cortes un Proyecto de Ley para el Reclutamiento y Reemplazo del Ejército, Gaceta núm. 57 de 27/02/1902. En adelante, Proyecto de Ley de Reclutamiento de 5 de Febrero de 1902. 
por los distintos gobiernos para justificar el incremento en las solicitudes anuales de tropas a pesar de la menor necesidad que se tenía de las mismas por la pérdida de las últimas colonias americanas y por las crecientes dificultades económicas ${ }^{1502}$ :

"Con orden y paz interior, unos cuantos años quizás puedan bastar para reponer a la Nación de sus dolorosos quebrantos, por el esfuerzo solo del perseverante trabajo. Sin paz y sin orden, ninguna fuerza individual ni social podrá desenvolverse realizando sus fines intelectuales, morales o económicos, que son los que han de redimirnos y regenerarnos. Hay, pues, que defender a toda costa el único bien que nos queda, puente de nuestra salvación presente y futura, y para esto imperiosamente necesitamos de tan numeroso Ejército. Porque si bien es verdad que hasta hoy el orden material no se ha visto seriamente turbado, el orden moral está profundamente herido, como no podía menos de estarlo después de las catástrofes y de los daños sufridos, y al amparo de este desorden los espíritus levantiscos, los legendarios soñadores podrían intentar el aprovechamiento de nuestras desventuras políticas, militares $y$ económicas, para dar vuelo y esperanzas de triunfo a las opuestas ideas radicales que han sido nuestra gran desgracia durante casi todo el siglo.

Es una hipótesis, quizá, pero que yo necesito hacer y que vosotros debéis admitirme: si a las desgracias pasadas agregásemos hoy una guerra civil, tal vez la Europa nos negara hasta el derecho a la vida como Nación.

Yo soy de los que entienden que, con haber sido tan grandes $y$ tan profundas las catástrofes actuales, todas ellas no representan el daño que significaría una guerra civil, corta o larga.

$Y$ contra este mal hay que prevenirse; tan grave daño hay que prevenirlo, aprovechando las lecciones del pasado. Contra todo intento de guerra interior hay que caer con mano dura, demostrar a

1502 "Que el país no puede soportar el gasto que ocasiona el sostenimiento de un Ejército permanente de 100.000 hombres, están en la conciencia de todos vosotros. [...]. Estoy perfectamente seguro de que nadie podrá sospechar, y mucho menos creer, que corra peligro alguno por tierra nuestra independencia; que nadie podrá temer que atente contra ella ninguna nación", Discurso del Sr. Cobián, Diario de Sesiones de las Cortes, no 37, 26/11/1902, pp.1484 y 1485. 
los perturbadores, por medio de una verdadera ocupación militar del territorio quo la necesite, que vamos no sólo a vencer la rebeldía, sino de no consentir el menor incremento"1503.

Antes de la presentación de los citados proyectos, y hasta la aprobación de la Ley de 1912, las críticas parlamentarias, especialmente desde los bancos republicanos, hacia el sistema de reclutamiento, en particular por su injusticia ante el mantenimiento de la redención en metálico ${ }^{1504}$, y hacia el Ejército de forma global por su ineficacia, fueron una constante a lo largo de los años posteriores al Desastre, solicitando como forma de ingreso en la fuerza armada o bien el servicio forzoso universal sin posibilidad de redención o bien un voluntariado reducido ante las escasas necesidades militares que tenía España ${ }^{1505}$. El rechazo de los sucesivos gobiernos conservadores al servicio militar obligatorio se argumentó en la imposibilidad que, para la precaria Hacienda pública española, tenía la incorporación de un número elevado de hombres al Ejército:

"Si el país no puede sostener más que 80.000 hombres y el reclutamiento de los de una edad da 2 millones de hombres, decidme, aunque se declara el servicio militar obligatorio, donde van a servir, si

\footnotetext{
1503 Discurso del Sr. Andrade, Diario de Sesiones de las Cortes, no 36, 14/07/1899, pp. 946 y 947.

1504 "iAh! Yo bien sé el secreto de este llamamiento excesivo. Basta con comparar el actual proyecto de presupuestos con los anteriores. Figuraban en los pasados presupuestos (no quisiera equivocarme) 8 millones en el capítulo de Rentas, como producto de la redención del servicio militar; y en este presupuesto figuran 12 millones. Es claro: a más llamamiento más redenciones, y mientras tanto, sigue el proyecto de servicio militar obligatorio durmiendo en el Senado, y mientras tanto seguirá la iniquidad de la redención del servicio militar, iniquidad igual a la del impuesto de consumos; porque repito lo que ya en otra ocasión he dicho: la contribución de consumos y la redención a metálico son dos bofetadas anuales que se dan al proletariado" (Discurso del Sr. Azcárate, Diario de Sesiones de las Cortes, no 42, 06/12/1905, p. 1049).

1505 Discurso del Sr. Palma, Diario de Sesiones de las Cortes, no 37, 15/07/1899, pp. 992-996; Discurso del Sr. Pi y Margall, Diario de Sesiones de las Cortes, no 38, 17/07/1899, pp. 1020-1022 y Discurso del Sr. Muro, Diario de Sesiones de las Cortes, no 38, 17/07/1899, pp. 1025-102.
} 
el país no tiene recursos para uniformarlos, para llevarlos a los cuarteles y para costear su permanencia en servicio activo"1506.

Los excesivos gastos que comportaba la administración del Ejército fueron criticados también desde la prensa republicana, aprovechando los problemas financieros para criticar la organización y gestión de las fuerzas armadas:

"Contra los militares, que tienen su vida al servicio de la Patria no hay animadversión en nuestro pensamiento. Lo hay contra la terquedad en mantener una organización que empobrece al país y que hasta ahora no ha logrado que sea capaz de llevarnos a la victoria $^{\prime 1507}$.

También los carlistas presentaron una fuerte oposición a la posibilidad de universalización del servicio, al considerarlo una carga más para el pueblo español: "A mi me parece que los españoles tenemos ya bastante que hacer sin que nos aumentaran las ocupaciones"1508.

El proyecto presentado por el ministro Weyler era un texto amplio, que no se limitó a recoger los principios generales que habían de regir los cambios que se proponían, sino que reguló de una forma exhaustiva y práctica todas las operaciones relacionadas con el reclutamiento.

A continuación destacamos las novedades más importantes que recogió el proyecto de ley:

1506 Discurso del Sr. Romero Robledo, Diario de Sesiones de las Cortes, no 27, 21/12/1900, p. 735.

${ }_{1507}$ El Globo, 26/06/1903, no 10055, p. 1.

1508 Discurso del Sr. Nocedal, Diario de Sesiones de las Cortes, no 119, 14/02/1902, p. 3458. 
- Se propuso variar la clasificación de los mozos en sus doce años de servicio, especificando con claridad las situaciones de licencia ilimitada, reclutas condicionales y reclutas en depósito. También se admitían reclutas voluntarios mayores de dieciocho años y se incrementarían las sanciones para aquellos que no hubiesen solicitado su inclusión en el alistamiento ${ }^{1509}$.

- Respecto a la redención en metálico, se planteó la supresión del depósito que debían abonar los mozos después de los quince años de edad. Además, en lugar de multar a los jóvenes que, antes de cumplir la edad obligatoria para inscribirse en el alistamiento, saliesen de España, se propuso imponer multas a las empresas nacionales de vías marítimas que admitiesen a bordo en sus embarcaciones individuos que no tuviesen el competente permiso de la Comisión mixta de reclutamiento. A estos individuos se les obligaría a presentarse en el consulado español donde fijasen su residencia, perdiendo, si así no lo hacían, todo derecho a alegar excepciones y declarándoles prófugos. Los redimidos en metálico no quedarían exentos completamente del servicio, sino que podrían ser llamados a filas en caso de guerra o alteración del orden público. Los redimidos además quedarían relevados de todo servicio excepto de la instrucción, para así tener un cuadro de oficiales instruido en reserva en caso de necesidad ${ }^{1510}$.

1509 Proyecto de Ley de Reclutamiento de 5 de Febrero de 1902, Preámbulo, arts. 2$9,16-19$ y arts. 29 y 30.

1510 Proyecto de Ley de Reclutamiento de 5 de Febrero de 1902, Preámbulo y art. 31. 
- Para evitar irregularidades y favorecer la pureza en todo lo concerniente al reemplazo, se propuso dividir los términos municipales densamente poblados en secciones con un máximo de 5.000 personas cada una. También se mejoraría la regulación para asegurar que los españoles residentes en el extranjero cumpliesen con sus obligaciones militares. Para ello los consulados verían incrementadas sus atribuciones en materia de reclutamiento ${ }^{1511}$.

- El proyecto de ley estableció como obligatorio el traslado a la capital provincial, aunque no debiesen ingresar en caja, de los mozos excluidos temporal o totalmente del servicio por defecto físico para ser reconocidos definitivamente $\mathrm{y}$ de los que hubiesen presentado $\mathrm{o}$ hubiesen recibido alguna reclamación ${ }^{1512}$.

- Se planteó la clasificación de las exclusiones del servicio militar en totales, temporales y condicionales. De la primera tipología formarían parte los jóvenes con enfermedades o defectos físicos evidentes; de la segunda, los mozos que sufriesen enfermedades que pudiesen superarse con el paso del tiempo y aquellos que se encontrasen procesados por causa criminal; y de la tercera aquellos que, transcurrido un tiempo, pudiesen perder la causa de su exclusión, oficiales del Ejército y la Armada y los mozos que se hallasen sufriendo condena si ésta fuese de prisión ${ }^{1513}$.

- Los soldados condicionales serían aquellos que gozasen de una exención por motivos relacionados con la pobreza

1511 Proyecto de Ley de Reclutamiento de 5 de Febrero de 1902, Preámbulo y arts. 24, 32 y 101.

1512 Proyecto de Ley de Reclutamiento de 5 de Febrero de 1902, art. 107.

1513 Proyecto de Ley de Reclutamiento de 5 de Febrero de 1902, Preámbulo y arts. 76-81. 
de su familia, pero serían mayores los requisitos exigidos para poder acceder a este tipo de exención ${ }^{1514}$.

- Se propuso la supresión de las exclusiones por corto de talla, religiosos profesos y novicios de las órdenes religiosas y por servicios prestados en las minas de Almadén. También desparecería la excepción de la que gozaban los colonos agrícolas "[...] y que a tantos abusos se ha prestado, y se concede, en determinadas condiciones, a los mozos que mantengan a su padrastro $o$ madrastra y a los huérfanos acogidos en la niñez que se encuentren en igual caso"1515. Tampoco conllevaría exención el matrimonio de un hermano celebrado el día antes del sorteo ${ }^{1516}$.

- Se planteó que la Secretaría de las comisiones mixtas de reclutamiento no fuese ocupadas por los secretarios de las Diputaciones provinciales si no por los jefes del Ejército que desempeñasen los cargos de oficiales mayores $^{1517}$.

- Se propuso crear el padrón militar para evitar exclusiones indebidas en el alistamiento, y de cuya gestión se ocuparían las comisiones mixtas de reclutamiento ${ }^{1518}$.

- El derecho de recurrir los fallos de las comisiones mixtas solo se admitiría para los supuestos de exenciones indebidas e inclusiones y exclusiones incorrectas de algún mozo. No podrían apelarse por el contrario los acuerdos dictados por las comisiones mixtas confirmando los fallos

1514 Proyecto de Ley de Reclutamiento de 5 de Febrero de 1902, Preámbulo y arts. 82-85.

1515 Proyecto de Ley de Reclutamiento de 5 de Febrero de 1902, Preámbulo.

1516 Proyecto de Ley de Reclutamiento de 5 de Febrero de 1902, Preámbulo y art. 97.

1517 Proyecto de Ley de Reclutamiento de 5 de Febrero de 1902, Preámbulo.

1518 Proyecto de Ley de Reclutamiento de 5 de Febrero de 1902, Preámbulo y arts. 112 y 113. 
de los Ayuntamientos ni cuestiones relacionadas con la aptitud física o la talla de un recluta. Se mantuvo la figura de los comisarios regios para vigilar todo el proceso de reclutamiento y revisar sus operaciones, tanto las encomendadas a las corporaciones municipales y provinciales como las asumidas por las comisiones mixtas $^{1519}$.

- Se planteó la posibilidad de implantar la concesión de prórrogas por estudio o trabajo, aunque los mozos que disfrutasen de las mismas deberían contribuir con un impuesto proporcional a su fortuna o a la de sus padres. Las prórrogas tendrían un plazo máximo de tres años consecutivos, serán concedidas por las comisiones mixtas y no podrían exceder el diez por ciento de los soldados declarados útiles. En caso de conflicto, el ministerio de la Guerra podría declarar finalizadas las prórrogas ${ }^{1520}$.

- Por primera vez, un proyecto de ley propuso el establecimiento de un sistema de cuotas para los mozos en situación de licencia ilimitada no llamados a filas, excluidos, exceptuados y padres de prófugos en función de su riqueza, quedando exentos los jóvenes declarados pobres y los acogidos en asilos de beneficencia ${ }^{1521}$.

- Con los fondos obtenidos a través de prórrogas, cuotas y multas impuestas, se constituiría un fondo especial llamado Tesoro de Guerra, destinado a la adquisición de

1519 Proyecto de Ley de Reclutamiento de 5 de Febrero de 1902, Preámbulo y arts. 125 y 130.

1520 Proyecto de Ley de Reclutamiento de 5 de Febrero de 1902, Preámbulo y arts. 143-159.

1521 Proyecto de Ley de Reclutamiento de 5 de Febrero de 1902, Preámbulo y arts. 184-199. 
armamento y material de guerra y gastos de instrucción y maniobras ${ }^{1522}$.

- Se mantendría la redención en metálico por un valor de 2.000 pesetas, aunque estos reclutas recibirían instrucción militar durante un mes en los tres primeros años de servicio. Sus plazas serían cubiertas por voluntarios, enganchados y reenganchados. El importe de la redención sólo se devolvería en caso de muerte del recluta antes de su incorporación a filas ${ }^{1523}$.

- Los reclutas con licencia ilimitada por exceso de cupo que no tuviesen que ingresar en los cuerpos armados permanecerían en sus casas sin paga alguna. Recibirían instrucción militar y serían llamados para cubrir las bajas naturales que en tiempo de paz ocurriesen en sus cuerpos; mientras que en tiempos de guerra, o cuando por circunstancias especiales fuese preciso el aumento de la fuerza armada, el ministro de la Guerra podría convocarlos, total o parcialmente, para maniobras o ejercicios militares por el tiempo que hubiesen de durar estas prácticas ${ }^{1524}$.

- Por último, también se planteó la reforma del cuadro de inutilidades físicas, dividiendo éstas en cinco clases: inutilidades que determinasen la exclusión definitiva del servicio; aquellas cuya declaración correspondiese a las comisiones, atendiéndose solo a lo que resultase del acto de reconocimiento; aquellas cuya exclusión había de proceder un reconocimiento y observación; exclusión temporal, que sería determinado las comisiones mixtas,

1522 Proyecto de Ley de Reclutamiento de 5 de Febrero de 1902, Preámbulo y art. 200.

1523 Proyecto de Ley de Reclutamiento de 5 de Febrero de 1902, arts. 201-206.

1524 Proyecto de Ley de Reclutamiento de 5 de Febrero de 1902, Preámbulo. 
atendiendo solo a lo que resultase del acto de reconocimiento; la exclusión decidida por lo que resultase del reconocimiento y la observación ${ }^{1525}$.

$\checkmark$ El primer planteamiento de las cuotas en el Proyecto de reforma de 1903

Un nuevo proyecto recogiendo las bases para la reforma de la ley de reclutamiento ${ }^{1526}$, tampoco aprobado, fue presentado ante las Cortes el 22 de Junio de 1903 por parte del ministro de la Guerra Arsenio Linares ${ }^{1527}$. Se trata de un texto que se limitó a plantear las bases y principios programáticos básicos que se debían discutir en la Cámara legislativa pero no descendió a una regulación exhaustiva de las operaciones de reclutamiento. Analizaremos del mismo tan sólo las novedades propuestas en función de leyes y proyectos anteriores.

Como primera novedad, destacar que se planteó la ampliación del servicio militar de doce a quince años de duración ${ }^{1528}$. El servicio activo duraría tres años, aunque en algunas situaciones, se podría reducir a uno. También podrían recibir licencia ilimitada reemplazos completos antes de cumplir los tres años de servicio activo si así lo consideraba necesario el Gobierno ${ }^{1529}$. Se planteó por primera vez en

\footnotetext{
1525 Proyecto de Ley de Reclutamiento de 5 de Febrero de 1902, Preámbulo.

1526 Real Decreto de 22 de Junio de 1903 autorizando al Ministro de la Guerra para que presente a las Cortes un Proyecto de Ley de bases para la reforma de la Ley de reclutamiento, Gaceta núm. 177 de 26/06/1903. En adelante, Proyecto de Ley de bases para la reforma de la Ley de reclutamiento de 22 de Junio de 1903.

1527 Arsenio Linares, nacido en Valencia en 1848 y muerto en Madrid en 1914, militar y político español, participó en las guerras carlistas y en los conflictos coloniales. Fue asimismo senador vitalicio y ministro de Guerra en sucesivos gobiernos conservadores, (Diccionario Biográfico Español, edición digital, RAH, http://www.rah.es/cdeb.htm).

1528 Proyecto de Ley de bases para la reforma de la Ley de reclutamiento de 22 de Junio de 1903, Base 1a, A.

1529 "Sin embargo, los que a su ingreso en Caja tuviesen concluida la carrera o profesión; si se hubieran distinguido notablemente en las artes, la industria o la agricultura, o hubieran alcanzado primer premio en concurso general de tiro; podrán al terminar el primer año obtener licencia ilimitada, y continuar en la misma
} 
un proyecto de ley de reclutamiento la posibilidad de ascenso para aquellos jóvenes con una carrera universitaria finalizada y especiales aptitudes militares, que recibirían el empleo de sargento al pasar a la primera reserva y el de alférez cuando lo hiciesen a la segunda ${ }^{1530}$. Se buscaría así mejorar la formación académica de la oficialidad.

En la base segunda del proyecto se atendió a la cuestión del reclutamiento en territorio extranjero, que sería competencia de los consulados autorizados por el Gobierno. Las atribuciones de estas instituciones se verían incrementadas hasta el punto de actuar del mismo modo que los Ayuntamientos peninsulares. Los españoles nacidos en el extranjero y residentes en una localidad donde no hubiese cónsul serían alistados en la ciudad de Madrid. Además, se planteó que para los mozos sin recursos que residan en el extranjero y deseasen presentarse para cumplir con sus obligaciones militares, los gastos que generase su repatriación serían financiados por el Estado ${ }^{1531}$.

Se planteó de nuevo, al igual que en el Proyecto de ley de 1902, la posibilidad de dividir las exclusiones del servicio militar en tres tipos: totales, temporales y condicionales ${ }^{1532}$.

También se propuso una clarificación exacta de las competencias de las comisiones mixtas de reclutamiento, que pasarían a ser las siguientes:

situación, perteneciendo a Cuerpo activo. También, antes de terminar el tercer año de servicio y después del segundo en filas, podrá acordarse por el Gobierno licencia ilimitada a reemplazos completos, por armas o por regiones, siempre dentro de esta situación, hasta finalizar el tiempo marcado a la misma" (Proyecto de Ley de bases para la reforma de la Ley de reclutamiento de 22 de Junio de 1903, Base 1a, $\left.B, 4^{\circ}\right)$.

1530 Proyecto de Ley de bases para la reforma de la Ley de reclutamiento de 22 de Junio de 1903, Base 1a, J.

${ }^{1531}$ Proyecto de Ley de bases para la reforma de la Ley de reclutamiento de 22 de Junio de 1903, Base 2a , A, B y C; Base 6a, E.

1532 Proyecto de Ley de bases para la reforma de la Ley de reclutamiento de 22 de Junio de 1903, Base 4a, A. 
"Entre los cometidos de la Comisión mixta figurará la resolución y fallo de expedientes de excluidos, exceptuados (comprendiendo en éstos a los que tuvieron la causa de excepción después de su ingreso en Caja y aún hallándose en la segunda situación) y prófugos, así como la concesión de prórrogas para el ingreso en filas, pago de cuotas y multas, y la formación del padrón militar ${ }^{\prime 1533}$.

Con el objeto de reducir los gastos de mantenimiento del personal militar, se planteó la posibilidad de que aquellos reclutas que se presentasen equipados reglamentariamente financiándolo con sus propios recursos y atendiesen a su propia manutención durante el tiempo que estuviesen en filas, podían ser destinados a un arma o cuerpo de su región de residencia y podían obtener autorización para pernoctar fuera del cuartel. También se propuso la posibilidad de que aquellos que se presentasen con su caballo equipado fuesen destinados al cuerpo de Caballería. Un último privilegio económico que se planteó fue la posibilidad de que, aquellos individuos que pagasen una cuota no menor de 250 pesetas, prestasen un servicio activo de tan solo seis meses durante los tres años de duración del mismo ${ }^{1534}$. Por lo tanto se planteó una posible supresión la redención en metálico y la sustitución ${ }^{1535}$, pero se mantenían ciertos privilegios para los más pudientes, que podrían ver reducido su periodo de permanencia en filas a través del pago de una cuota. Es la primera vez que un texto legislativo presentado ante las Cortes planteó esta posibilidad, la del soldado de cuota, definitivamente implantado con la Ley de 1912. Todos los recursos obtenidos por el cobro de prórrogas y cuotas pasarían a formar parte de los recursos ordinarios

\footnotetext{
1533 Proyecto de Ley de bases para la reforma de la Ley de reclutamiento de 22 de Junio de 1903, Base $8^{\mathrm{a}}$, A.

1534 Proyecto de Ley de bases para la reforma de la Ley de reclutamiento de 22 de Junio de 1903, Base 10a, A.

1535 Proyecto de Ley de bases para la reforma de la Ley de reclutamiento de 22 de Junio de 1903, Base $13^{a}$.
} 
del presupuesto del ministerio de la Guerra, no dedicándose en exclusividad, tal y como se planteaba en leyes anteriores, a la contratación de voluntarios ${ }^{1536}$.

De nuevo se planteó la eventualidad de que los mozos pudiesen disfrutar de prórrogas temporales a la hora de prestar el servicio, de un máximo de tres años consecutivos, por motivos de estudio o de trabajo. Las concesiones de estas prórrogas no podrían superar el diez por ciento de los mozos declarados útiles, y los reclutas tendrían que pagar un impuesto nunca superior a 100 pesetas anuales. Los prófugos, los excluidos condicionalmente que por su voluntad abandonasen la causa de exclusión, y aquellos que hubiesen recibido sentencia firme de un tribunal no podrían obtener prórrogas ${ }^{1537}$.

En tiempo de guerra o cuando fuese preciso aumentar la fuerza de los cuerpos,

"[...] el Ministerio de Guerra, de acuerdo con el Consejo de Ministros, podría, mediante Real decreto poner en pie de guerra todo o parte de los Cuerpos activos, llamando a filas a los soldados de primera reserva; pero siempre se tendrá en cuenta para el orden del Ilamamiento, cuando éste no sea del contingente total [...] el grado de Instrucción, el menor tiempo de servicio desde el ingreso en Caja y los números más bajos del sorteo en los reemplazos respectivos. Igual procedimiento se adoptará para los reclutas en revisión y en depósito"1538.

Como es lógico, y tras las pérdidas recientes de las últimas colonias americanas, el proyecto planteó por último derogar todas las

\footnotetext{
1536 Proyecto de Ley de bases para la reforma de la Ley de reclutamiento de 22 de Junio de 1903, Base $14^{a}$, A-G y $15^{a}$.

1537 Proyecto de Ley de bases para la reforma de la Ley de reclutamiento de 22 de Junio de 1903, Base 11a, A-J.

1538 Proyecto de Ley de bases para la reforma de la Ley de reclutamiento de 22 de Junio de 1903, Base 12a, L.
} 
disposiciones penales que conllevasen el envío a Ultramar de los reclutas $^{1539}$.

$\checkmark$ El intento de mejorar la instrucción según el Proyecto de reforma de 1906

Tres años después de este proyecto de ley, en noviembre de 1906 encontramos en las páginas de la Gaceta un nuevo proyecto de ley de bases para la reforma de la Ley de reclutamiento y reemplazo del Ejército ${ }^{1540}$. Presentado ante las Cortes por el ministro de la Guerra Agustín Luque ${ }^{1541}$, tampoco fue aprobado. En general, el texto no planteó nueva ideas, ya que, en su mayor parte, las reformas propuestas habían sido recogidas en los anteriores proyectos de reforma. Esta circunstancia, junto al objetivo declarado del proyecto, la mejora en la instrucción de los reclutas, fueron anunciadas en el mismo preámbulo:

"Más del 60 por 100 de los mozos declarados soldados pasa el tiempo de su servicio sin recibir instrucción ni vestir el uniforme militar, y de ello no puede culparse a la Ley de reclutamiento y Reemplazo, que acertadamente dispone que los reclutas en depósito acudan a maniobras y asambleas de instrucción. Otras pueden ser las causas que tienen en tal atraso al Ejército, y para obviarlas, haciendo general la instrucción militar, satisfaciendo el precepto legal, a los

1539 Proyecto de Ley de bases para la reforma de la Ley de reclutamiento de 22 de Junio de 1903, Base $16^{\mathrm{a}}$.

1540 Real Decreto de 15 de Noviembre de 1906 autorizando al Ministro de la Guerra para que presente a las Cortes un Proyecto de Ley de bases para la reforma de la Ley de reclutamiento, Gaceta núm. 323 de 19/11/1906. En adelante, Proyecto de Ley de bases para la reforma de la Ley de reclutamiento de 15 de Noviembre de 1906.

1541 Nacido en 1850 y muerto en 1934, desarrolló sus labores profesionales en España, Cuba y Melilla. Cercano al republicanismo, ocupó hasta en cuatro ocasiones la cartera de Guerra durante gobiernos liberales. Fue asimismo senador vitalicio y director de la Guardia Civil, (Diccionario Biográfico Español, edición digital, RAH, http://www.rah.es/cdeb.htm). 
deseos de la opinión y las necesidades del Ejército, presenta el Ministro que suscribe estas bases, obra, más que suya, de dignos antecesores en el cargo, que para remediar tan grave mal, previos luminosos estudios, de acuerdo en determinados puntos con el Ministerio de la Gobernación, oportunamente, en diversas épocas, traducidas en proyectos de Ley, los sometieron a la sabiduría de las Cortes. No son, pues, ideas nuevas las que se emiten ni, por lo general, es nuevo su desarrollo"1542.

Podemos destacar las siguientes novedades planteadas por el proyecto, escasas en número, pero de singular importancia:

- El servicio militar aumentaría su duración hasta los quince años $^{1543}$.

- Se propuso aumentar en un año el tiempo dedicado a la reserva activa ${ }^{1544}$. Sin embargo,

"[...] los que a su ingreso en Caja tuviesen concluida carrera o profesión; se hubieren distinguido notablemente en las artes, la industria o la agricultura, o hubieran alcanzado primer premio en concurso general de tiro, podrán al terminar el primer año obtener licencia ilimitada y continuar en la misma situación, perteneciendo a Cuerpo activo. También, antes de terminar el tercer año de servicio y después del segundo en filas, podrá concederse por el Gobierno licencia ilimitada a reemplazos completos, por Armas o por regiones, siempre dentro de esta situación, hasta finalizar el tiempo marcado a la misma"1545.

1542 Proyecto de Ley de bases para la reforma de la Ley de reclutamiento de 15 de Noviembre de 1906, Preámbulo.

1543 Proyecto de Ley de bases para la reforma de la Ley de reclutamiento de 15 de Noviembre de 1906, Base $1^{\text {a }}$, A.

1544 Proyecto de Ley de bases para la reforma de la Ley de reclutamiento de 15 de Noviembre de 1906, Preámbulo.

1545 Proyecto de Ley de bases para la reforma de la Ley de reclutamiento de 15 de Noviembre de 1906, Base 1a, B. 
- Se planteó eliminar la exención por corto de talla, con el objetivo de incrementar el número de soldados del Ejército en un once por ciento, justificándose tal supresión en que estos reclutas sí que podían ser llamados a filas en circunstancias excepcionales ${ }^{1546}$.

- Se propuso mejorar la instrucción de los reclutas con licencia ilimitada por exceder la fuerza necesaria, en vistas a su futura movilización por cualquier circunstancia ${ }^{1547}$.

- Se mantendría las posibilidad de las prórrogas durante tres años consecutivos por motivos de estudio y trabajo, debiendo estos reclutas abonar además una cantidad nunca superior a las 1.000 pesetas anuales ${ }^{1548}$.

- De nuevo un proyecto de ley planteó la supresión de la redención y la sustitución por considerarlas antipatrióticas, aunque permitía las cuotas ${ }^{1549}$. Si bien el proyecto no llegó a salir adelante, esta circunstancia, la supresión de la redención, fue implantada temporalmente tras los sucesos de la Semana Trágica de Barcelona en agosto de 1909, aunque fue reimplantada cuando la convulsión social se había frenado en el mes de

\footnotetext{
1546 Proyecto de Ley de bases para la reforma de la Ley de reclutamiento de 15 de Noviembre de 1906, Preámbulo y Base 6a, B.

1547 "Los mozos declarados soldados útiles que por exceder de la fuerza necesaria, quedan con licencia ilimitada. Estos, si no reciben instrucción, permanecerán en caja un año como reclutas disponibles, y transcurrido ese tiempo pasan al depósito de la zona como reclutas con licencia ilimitada por exceder del cupo, hasta que les corresponda el pase a la segunda reserva.

Si durante el año de permanencia en Caja o después en el depósito de la zona recibieran instrucción, serán destinados a Cuerpo en situación de licencia ilimitada por exceder del cupo, o en primera reserva si dicha instrucción la recibieran al finalizar el tercer año. Estos, durante los dos primeros años, cubrirán las bajas normales que ocurran en sus Cuerpos" (Proyecto de Ley de bases para la reforma de la Ley de reclutamiento de 15 de Noviembre de 1906, Base 1a, B).

1548 Proyecto de Ley de bases para la reforma de la Ley de reclutamiento de 15 de Noviembre de 1906, Base $11^{\mathrm{a}}$, A-J.

1549 Proyecto de Ley de bases para la reforma de la Ley de reclutamiento de 15 de Noviembre de 1906, Base $13^{\mathrm{a}}$ y Base $15^{\mathrm{a}}, \mathrm{A}-\mathrm{G}$.
} 
octubre ${ }^{1550}$. Aquellos reclutas que pagasen la cantidad de 1.500 pesetas podrían pernoctar fuera del cuartel y recibir permisos especiales para ausentarse temporalmente del servicio, mientras que aquellos soldados con mayores recursos económicos sí que podrían elegir el cuerpo donde recibirían la instrucción a través del pago de 1.500 pesetas $^{1551}$.

- Los recursos económicos obtenidos mediante cuotas, pagos por prórrogas y multas se deberían utilizar para mejorar la instrucción de los reclutas, y quedarían como recursos ordinarios del presupuesto del ministerio de la Guerra $^{1552}$.

- Se permitiría el voluntariado para los hijos de jefes y oficiales del Ejército mayores de catorce años con un sueldo de 1.500 pesetas anuales ${ }^{1553}$.

- También se propuso el ascenso a los cargos de sargento y alférez de aquellos soldados que hubiesen mostrado especiales aptitudes en el momento de su pase a la primera y segunda reserva ${ }^{1554}$.

- Se permitiría el viaje al extranjero para los mayores de quince años de edad sin necesidad de abonar un depósito monetario, aunque deberían presentarse ante su consulado respectivo cuando alcanzasen la edad militar.

${ }^{1550}$ Real Orden de 4 de Agosto suspendiendo toda redención a metálico del servicio militar, Gaceta núm. 217 de 05/08/1909, y Real Orden disponiendo el restablecimiento de la redención a metálico del servicio militar activo, Gaceta núm. 285 de 12/10/1909.

1551 Proyecto de Ley de bases para la reforma de la Ley de reclutamiento de 15 de Noviembre de 1906, Base $13^{a}$ y Base 14a, 1-9.

1552 Proyecto de Ley de bases para la reforma de la Ley de reclutamiento de 15 de Noviembre de 1906, Preámbulo y Base $16^{\mathrm{a}}$.

1553 Proyecto de Ley de bases para la reforma de la Ley de reclutamiento de 15 de Noviembre de 1906, Base $1^{\mathrm{a}}, \mathrm{H}$.

1554 Proyecto de Ley de bases para la reforma de la Ley de reclutamiento de 15 de Noviembre de 1906, Base 1a, L. 
De nuevo aparecían reguladas las competencias que, en materia de reclutamiento, tendrían los consulados en el extranjero ${ }^{1555}$.

- Asimismo se volvió a plantear la clasificación de las exclusiones del servicio en totales, temporales y condicionales $^{1556}$.

- El proyecto señaló, como última novedad, la necesidad de regular de una forma más precisa las competencias de las comisiones mixtas de reclutamiento ${ }^{1557}$, sin especificar cuales serían exactamente tales atribuciones.

1555 Proyecto de Ley de bases para la reforma de la Ley de reclutamiento de 15 de Noviembre de 1906, Base 2a, B y Base 6a, E.

1556 Proyecto de Ley de bases para la reforma de la Ley de reclutamiento de 15 de Noviembre de 1906, Base 4a, A.

1557 Proyecto de Ley de bases para la reforma de la Ley de reclutamiento de 15 de Noviembre de 1906, 8a, A y C. 



\section{9.- La teórica universalización del servicio militar:}

\section{La Ley de 1912}

Finalizamos nuestro análisis legislativo con la primera ley que, en materia de reclutamiento, fue aprobada a lo largo del siglo XX, y cuyos principios básicos se mantuvieron vigentes hasta las reformas de Azaña durante la II República. Previamente nos centraremos en los dos proyectos de ley que precedieron al texto final y que establecieron las bases para su redacción definitiva ${ }^{1558}$. Tendremos en cuenta para el análisis de esta importante ley dos publicaciones de características y criterios ideológicos muy distintos y enfrentados, como eran El Socialista ${ }^{1559}$ y El Siglo Futuro ${ }^{1560}$.

1558 Real Decreto de 2 de Abril de 1909 autorizando al Ministro de la Guerra para que presente en Cortes el adjunto Proyecto de Ley de Bases para el Reclutamiento y el Reemplazo del Ejército, Gaceta núm. 95 de 05/04/1909. En adelante, Proyecto de Ley de Bases para el Reclutamiento y el Reemplazo del Ejército de 2 de Abril de 1909. Real Decreto de 6 de Octubre de 1910 autorizando al Ministro de la Guerra para que presente en Cortes el adjunto Proyecto de Ley de Bases para el Reclutamiento y el Reemplazo del Ejército, Gaceta núm. 280 de 07/10/1910. En adelante, Proyecto de Ley de Bases para el Reclutamiento y el Reemplazo del Ejército de 6 de Octubre de 1910.

1559 Meter caracts.de el socialista, junto a la fuente de información.

1560 "Fundado por Cándido Nocedal (1821-1885), aparece el 19 de marzo de 1875 con el subtítulo de "diario católico" cuando la tercera guerra carlista (1872-1876) está en un momento enconado, pero no defenderá claramente esta causa hasta que, en 1879, aparezca El fénix, de Alejandro Pidal y Mon, y en $1881 \mathrm{La} f e$, el periódico de Vicente de Castro y Antonio Juan de Vildósola, con los que iniciará una enconada polémica en el seno del ultracatolicismo, que acabará años después en el cisma entre sus filas. Nocedal será en este tiempo jefe de prensa y representante en Madrid del pretendiente Carlos María de Borbón (1848-1909), pero el órgano oficial del carlismo lo ostentará el diario El correo catalán, que a partir de 1876 había fundado Luis María Llauder.

El diario, que no aparecerá en los días festivos, tendrá una larga vida que alcanza los 61 años, será de gran formato, que variará en el tiempo, así como las imprentas en la que será estampado y pasará de ser compuesto de cuatro a cinco columnas. Con editoriales y artículos doctrinales, políticos y religiosos y noticias nacionales y extranjeras, muchas de ellas recogidas de otros periódicos, como especie de revista de prensa, y otras procedentes de telegramas de la agencia Fabra. Contaba también con una sección oficial, otra religiosa, gacetillas y mientras duró la guerra carlista una propia sobre noticias de la misma. Al principio publicará un folletín de carácter religioso y moralista.

$[\ldots]$. 
La necesidad de terminar con las injusticias propias del sistema de quintas vino a impulsar el desarrollo de la ley y de los dos proyectos que la precedieron que a continuación vamos a analizar.

\author{
Esta necesidad tiene su origen en los sucesos ocurridos en el \\ Protectorado español en Marruecos y en Barcelona ${ }^{1561}$. Tuvieron que \\ producirse ambos desastres ${ }^{1562}$, con la muerte aparejada de cientos
}

Nocedal entablará una batalla doctrinal no sólo con los periódicos ya citados de su mismo carácter ideológico sino con los propios obispos españoles a los que tacha de veleidades liberales, lo que dará lugar a que La fe sea expulsada de las filas carlistas en 1881 a la vez que Pidal y Mon y su Unión Católica terminarán engrosando las filas del canovista Partido Conservador, ocupando su ala más a la derecha. A la muerte de Nocedal y después de un breve "directorio" carlista integrado por varios generales, Francisco Navarro Villoslada será nombrado jefe de Comunión Tradicionalista y su jefe de prensa, a la vez que Rafael Nocedal Romea hijo de don Cándido- tomará las riendas del diario y lejos de ir hacia un encuentro con sus correligionarios, radicalizará su ideología antiliberal llegando al enfrentamiento directo y personal con el Carlos VII, y junto a otros 23 periódicos de la misma naturaleza publicará el Manifiesto de la Prensa Tradicionalista, siendo acusado por el mismo pretendiente de "rebelde y excitador de la rebeldía" a su causa, decretando su expulsión del Partido Tradicionalista. Fruto de esta escisión, en 1889, nace el Partido Integrista, del que El siglo futuro será su órgano central de prensa. El diario nocedalista ocupará pues a través de su furibundo antiliberalismo neocatólico la extrema derecha política y seguirá atacando a sus irreconciliables periódicos enemigos dentro de las propias filas ultramontanas y a los mismos prelados españoles de la Restauración, a través de su máxima de que el liberalismo era "pecado".

[...]

Desde su militancia ultracatólica, su credo siguió siendo de un furibundo fundamentalismo antiliberal, el más reaccionario, fanático e intransigente del neocatolicismo, siendo tildado de "cavernícola [...]".

Ya a partir de los años veinte se había hecho evidente su obsesión apocalíptica de que los males de España eran fruto de la alianza entre la masonería y el judaísmo y el comunismo internacionales, así que aplaudirá la política antisemítica del nazismo, aunque no estuviera de acuerdo con la teoría de la superioridad de la raza aria en Europa. Editó su último número el 18 de julio de 1936, y con la sublevación militar sus talleres fueron confiscados por la CNT, de los que saldrá el periódico Castilla libre" (http://www.bne.es/es/Catalogos/HemerotecaDigital).

${ }^{1561 " D e s p u e ́ s ~ d e l ~ 98, ~ r e g e n e r a c i o n i s t a s, ~ c o n s e r v a d o r e s ~ y ~ l i b e r a l e s ~ s e ~ p r o n u n c i a r o n ~}$ de forma unánime por la urgente promulgación de una ley que hiciera desaparecer las injusticias de la legislación de quintas [...]. Sin embargo, corrieron ocho años para que Canalejas se comprometiera a universalizar el servicio y otros seis hasta que la promesa se hizo realidad. La reforma de 1912 nació a remolque de los acontecimientos de Barcelona y Melilla; la clase política tuvo que resignarse a su aprobación, no sin antes mitigar la abolición de la redención por medio de las cuotas; y tampoco colmó las aspiraciones populares, enfrentadas definitivamente con el servicio forzoso, cuando no con la propia existencia de la fuerza armada" (PUELL DE LA VILLA, F., El soldado desconocido: de la leva a la "mili" (1700-1912), pp. 273).

1562 Todos los años, en el momento de presentación ante las Cortes el real decreto llamando a filas a los mozos, se escuchaban críticas desde los bancos de la minoría republicana solicitando una reducción del contingente militar solicitado, 
de personas y la indignación popular consecuente, para que las inflexibles autoridades de la Restauración iniciasen la tan anhelada reforma que pusiese fin a las injusticias inherentes al sistema percibidas como socialmente inaceptables ${ }^{1563}$.

El estallido social cristalizó en parte por el descontento de los más desfavorecidos ante un sistema de reclutamiento que permitía a los más pudientes eludir el servicio militar, y se manifestó definitivamente tras los sucesos de la guerra marroquí de 1909, "[...] conocida generalmente como la guerra del Barranco del Lobo, por haber tenido lugar en el paraje melillense del mismo nombre uno de los mayores desastres del conflicto, que le costó al Ejército español de África más de mil bajas"1564, después de que las tropas españolas respondieran de forma errónea a diversos ataques sobre las concesiones mineras en la región. Estas injusticias eran reconocidas

principalmente por motivos económicos y sociales. Sirva de ejemplo este discurso del diputado Pérez Crespo: "Lo primero que debemos hacer, a mi juicio, antes de dotar de Ejército numeroso al país, es nutrir al país mismo le aquellas condiciones de vida indispensables para que pueda desarrollar sus otras esferas de actividad, porque si nosotros no constituimos una Nación aumentando su riqueza, contribuyendo por toda clase de medios á que la riqueza exista, no hay que soñar que, porque tengamos Ejército numeroso, la Nación española va a ser más rica; eso es un clarísimo error que han notado constantemente ilustres parlamentarios, rebatiendo en otras ocasiones un proyecto de ley parecido al que hoy se discute. Hagamos Nación" (Discurso del Sr. Pérez Crespo, Diario de sesiones de las Cortes, 22/11/1907, no 100, pág. 2817).

1563 "Las fórmulas de reclutamiento de comienzos del siglo XX mantuvieron la redención en metálico, con el consiguiente malestar social entre las clases menos afortunadas, que veían como, una y otra vez, eran los campesinos y el proletariado urbano quienes nutrían las filas de los Ejércitos españoles, en especial en los duros conflictos coloniales" (FERNÁNDEZ RODRÍGUEZ, M. y MARTÍNEZ PEÑAS, L., "La problemática social a través de la legislación de reclutamiento: exenciones, sustitución y redención en metálico", p. 324).

${ }^{1564}$ FERNÁNDEZ RODRÍGUEZ, M. y MARTÍNEZ PEÑAS, L., "La problemática social a través de la legislación de reclutamiento: exenciones, sustitución y redención en metálico", p. 325.

Sobre este conflicto colonial, ver MARTÍN CORRALES, E., Marruecos y el colonialismo español (1859-1912), Barcelona, Bellaterra, 2002; BALFOUR, S., Abrazo mortal: de la guerra colonial a la guerra civil en España y Marruecos (19091939), Barcelona, Península, 2002; LÓPEZ BARRANCO, J. J., El Rif en armas: la narrativa española sobre la guerra de Marruecos (1859-2005), Madrid, Marenostrum, 2005; MADARIAGA, M. R. de, En el Barranco del Lobo: las guerras de Marruecos, Madrid, Alianza, 2005; ALÍA MIRANDA, F. (coord.), La guerra de Marruecos y la España de su tiempo (1909-1927), Ciudad Real, Sociedad Don Quijote de conmemoraciones culturales Castilla la Mancha, 2009. 
desde los propios círculos de poder y suscitaban inseguridad en la élite parlamentaria por favorecer la extensión del socialismo:

"Los legisladores, los Diputados a Cortes y los Senadores que nos reunimos en estos recintos para discutir serena y tranquilamente cuántas y cuáles serán las fuerzas que en el año próximo integrarán el Ejército nacional, hemos de tener en cuenta la revolución que representa el avance del socialismo, en algunos pueblos elevado ya a las esferas del Poder, $y$ en otros pueblos actuando en los Cuerpos legislativos. Si así lo hacemos, ¿habremos de reconocer que hay algo que nos incomunica a los legisladores que estas cosas discutimos, con la viviente realidad, con la sociedad que ha de sufrir las consecuencias de aquellas leyes que nosotros votemos. $Y$ es que nosotros, indudablemente -no creo que nadie proteste de la palabra-, somos aquí unos buenos burgueses que estamos discutiendo leyes para que los infelices que no tienen la suerte que nosotros hemos tenido de poder salvarnos del cumplimiento del precepto legal constitucional de servir a la Patria con las armas, vayan a servirla"1565.

Los propios socialistas, desde sus órganos de prensa, se mostraban enormemente críticos con un Gobierno conservador que había llevado al país a una dolorosa derrota y a una lejana guerra que había conducido a la muerte de miles de proletarios:

"Los hechos, los tristes hechos ocurridos en el Rif, y que todos conocen, han venido a darnos la razón, por más que el Gobierno, tomando al país por tonto y mostrándose cínico, diga que, a pesar de lo sucedido, él no suscita la guerra en aquel país [...]. Por haber hecho precisamente esa política en Marruecos los gobernantes españoles, por mover tan solo a estos la idea de amparar los intereses de unos cuantos millonarios y conquistar algunos kilómetros de terreno que en nada beneficiarán a la nación, tenemos hoy que deplorar la muerte de

1565 Discurso del Sr. Salvatella, Diario de sesiones de las Cortes, 14/10/1910, no 88, p. 2962. 
los obreros que trabajaron en las minas, las bajas habidas en las fuerzas españolas, las producidas igualmente en el campo moro y las viviendas que a estos se les ha destruido.

Son ellos -nuestros gobernantes-, y no los moros, los responsables de lo que allí ha ocurrido días pasados y de lo que ocurra en lo sucesivo, y, por lo tanto, contra ellos irá nuestra crítica, nuestra indignación y nuestro odio"1566.

Como consecuencia directa de este desastre militar, encontramos la llamada a filas de 14.000 reclutas de la reserva activa a través del Real Decreto de 11 de julio de $1909^{1567}$, hombres ya licenciados que tenían que abandonar sus trabajos y familia, y que tuvo como contestación popular a la misma las protestas y la represión subsiguiente en la ciudad de Barcelona en los sucesos conocidos como la Semana Trágica ${ }^{1568}$. El descontento por la movilización de las Brigadas Mixtas de Madrid y de Barcelona, así como de otras unidades militares, se extendió por muchas ciudades, y los incidentes en las estaciones de trenes donde los llamados a filas eran concentrados para ser trasladados a África fueron numerosos, siendo los más importantes lo que tuvieron lugar en la madrileña estación del Mediodía y en la estación de Zaragoza.

Sin embargo, donde el descontento cristalizó en gravísimos disturbios fue en Barcelona, donde el descontento por la llamada a filas de los reservistas sirvió como combustible para una situación social ya de por sí explosiva, por los enfrentamientos entre obreros y propietarios, entre sindicatos y partidos de izquierdas con las oligarquía locales, el auge del pistolerismo de todo signo político y la

\footnotetext{
${ }^{1566}$ El Socialista, 16/07/1909, no 1219, p. 1.

1567 Real Decreto de 11 de julio de 1909, autorizando al Ministro de la Guerra para llamar a filas los soldados de la reserva activa que considere precisos, Gaceta núm. 696 de 11/07/1909.

1568 Ver COMELLAS, J. L., Del 98 a la Semana Trágica: crisis de conciencia y renovación política, Madrid, Biblioteca Nueva, 2002; MARÍN SILVESTRE, D., La Semana Trágica: la revuelta popular y la Escuela Moderna, Madrid, La Escuela de los libros, 2009.
} 
dura represión política e incluso militar llevada a cabo contra toda muestra de protesta. La prohibición de una reunión de Solidaridat Obrera que pensaba declarar la huelga general en Cataluña provocó la creación de un comité secreto de huelga, que trasladó el movimiento al margen de la legalidad. Desde el lunes 26 de julio de 1909 al domingo siguiente, los disturbios y la violencia se extendieron por toda la ciudad, provocando una reacción del gobierno que utilizó al ejército para aplastar las protestas.

Uno de los elementos que más indignaban, dentro del llamamiento a filas de los reservistas, era el mantenimiento de la redención en metálico ${ }^{1569}$, a pesar de la supuesta mejora en las condiciones de vida de los reclutas en los cuarteles que los diputados del partido Conservador defendieron en los años previos a la aprobación de la nueva ley, mejora que convertía al Ejército en la mejor escuela de patriotismo y disciplina:

"Ha habido también el argumento sentimental, por decirlo así, de la pérdida y el quebranto que se produce en los hogares con las redenciones. [...] Efectivamente, la redención es un quebranto grave para los hogares modestos; pero yo creo que en esto está S. S. aún bajo el influjo de la tradición bética del siglo pasado, en que tuvimos, según creo recordar, treinta y dos años de guerra casi seguidos, lo cual, naturalmente, dejó en los hogares una tradición de espanto y de tragedia con la marcha al Ejército del hijo que representaba las más floridas esperanzas de los padres; pero, afortunadamente, los tiempos han cambiado; llevamos años de paz, las contingencias internacionales no parece verosímil que alteren, al menos en mucho

\footnotetext{
1569 "Porque el caso es que aquí nadie quiere la guerra contra el infiel marroquí; pero allá vamos enviando elementos de combate y tomando posiciones [...]. No sabemos, naturalmente, en que parará todo ello, lo único cierto hasta ahora es que a África han sido enviados a defender una supuesta ofensa al honor nacional, mientras que los burgueses que han redimido a sus hijos del patriótico deber de empuñar las armas quedan aquí haciendo votos por que la suerte acompañe a nuestros soldados, para que ellos, los burgueses, puedan continuar la pacífica labor de explotar los trabajos de las minas rifeñas" (El Socialista, 16/07/1909, no 1219, p. 1).
} 
tiempo para nosotros, la normalidad, y aparte de eso, las condiciones de los Ejércitos modernos, del Ejército español inclusive- $y$ esto es tanto más meritorio en él, por cuanto tiene menos medios, menos recursos para ello-, las condiciones, digo, del servicio moderno en el Ejército español son bastante más dulces que lo eran antaño; el vestuario es irreprochable, está á la altura de los mejores; la alimentación ha mejorado mucho; la higiene en los cuarteles ha progresado tanto, que yo he de citar, porque me causó una impresión muy grande, un concienzudo informe del doctor Ovilo relacionado con la mortalidad del soldado en las campañas de Ultramar, pues he sentido un gran alivio al leer en estos días otro folleto de un distinguido médico militar en que da la gratísima noticia de que casi ha desaparecido la viruela de las guarniciones, hasta el punto de que hay año en que no se he registrado ni un solo caso; y el estado sanitario en general mejora tanto, que la proporción de la mortalidad entre la población en armas y la población civil, en núcleos proporcionados, es infinitamente más pequeña en los que visten uniforme que en las clases civiles. Por eso digo que hay una gran tradición de horror y de temor al servicio militar, y esa tradición no está justificada; y yo me lamento, y me he de lamentar siempre de que perdure en el seno de la clase media de la sociedad española esa educación sedentaria, mimosa, casi faldera, que mira con horror la vida militar, que la presenta como una vida llena de horrores y de quebrantos; y yo creo que toda esa educación, reforzada además con una enseñanza memorista y rutinaria, tiene encanijada física y moralmente a la clase media, y si no se corrige, preparará su bancarrota próxima en la dirección predominante que ahora tiene en los desenvolvimientos sociales.

$[\ldots]$.

Yo creo que el Ejército es una escuela insustituible en este momento, de abnegación, de deber, de disciplina, de fortaleza, de patriotismo, de muchas virtudes que en estos días, algunos muy tristes, suelen parecer en crisis ${ }^{1570}$.

1570 Discurso del Sr. Rovira, Diario de sesiones de las Cortes, 22/11/1907, no 100, pp. 2821 y 2822. 
La gravedad de los acontecimientos violentos en Barcelona, la salida del Gobierno de su Presidente Antonio Maura y la llegada al mismo de Canalejas impulsaron la definitiva aprobación de una nueva ley ${ }^{1571}$. Sin duda este nuevo texto tiene una enorme importancia histórica al universalizar el servicio militar, convertirlo en un deber personal e intransferible y abolir la redención y la sustitución, si bien se creó la figura del soldado de cuota, quien podría ver reducido su tiempo de servicio a cambio del pago de una cantidad en metálico, además de elegir destino y dormir fuera del cuartel. Lógicamente este privilegio económico volvería a provocar la indignación popular al verse como un privilegio de los $\operatorname{ricos}^{1572}$ en un Parlamento donde la presencia del socialista Pablo Iglesias y sus denuncias hacia las injusticias de la quinta vendrían a incrementar el acaloramiento de los debates $^{1573}$. La repuesta desde la prensa ultraconservadora a estas denuncias no se haría esperar, acusando al dirigente socialista y al conjunto de los partidos republicanos de antipatriotismo y conspiración:

1571 "Sabido es que Melilla y Barcelona le costaron el puesto a Maura y que, al aceptar Alfonso XIII la formularia dimisión que el líder conservador le presentó en la mañana del 21 de octubre, se abrió una profunda brecha en las relaciones entre ambos, hecho de enorme trascendencia para la futura estabilidad de la Monarquía. El rey encargó la formación de gobierno a Canalejas, quien llamó al general Luque a la cartera de Guerra. Este equipo dio impulso definitivo a la reforma del sistema de reemplazos. El presidente recogía el testigo de los septembristas y ambos el de Cassola" (PUELL DE LA VILLA, F., El soldado desconocido: de la leva a la "mili" (1700-1912), p. 300).

1572 FEIJÓO GÓMEZ, A., Quintas y protesta social en el siglo XIX español, p. 221.

1573 "Pero, ¿es que en las cuestiones económicas que se producen en las Naciones lleva la voz el proletariado, o la lleva la clase patronal o capitalista? ¿Es que en la cuestión de Melilla, en la cuestión de África, fue la clase proletaria la que pidió que se realizase esa campaña para ir a trabajar a aquella región, ó han sido los que no iban a ir allí, porque, después de todo, en nuestro país hay muchos sitios donde trabajar? ¿Es que en otros países, cuando ha habido guerras, las ha pedido el proletariado? No; las ha provocado la clase capitalista, que es la dueña del Poder. No tiene el proletariado influencia bastante para contener aquellas campañas de carácter económico, y es claro que estas guerras no se han podido verificar sin los brazos de la clase obrera, pero la resultante ha sido para la clase capitalista" (Discurso del Sr. Iglesias, Diario de sesiones de las Cortes, 14/10/1910, n 88, p. 2969. 
"Con esto y las amenazas de la huelga general, se propone el socialismo español cumplir los compromisos que ha contraído con gentes extranjeras, de combatir á nuestra Patria y al Ejército español, empezando por fomentar la derrota de nuestras armas en Marruecos [...]. Pues en conjunción con estos elementos antimilitaristas están los republicanos españoles, que aplauden y se disponen á secundar los compromisos del socialismo español con los enemigos de la Patria y del Ejército. En este antimilitarismo anárquicosocialista se sostienen los republicanos españoles, con otros elementos que se dicen monárquicos, y que si no aplauden con el descaro de los republicanos las declaraciones de Pablo Iglesias, las reciben sin protesta ni censura en sus periódicos $[\ldots]^{\prime 1574}$.

\section{Los proyectos previos}

Como paso previo al análisis de la Ley de 1912 debemos detenernos en los dos proyectos legislativos que la preceden y que establecieron ya los principios generales que recogió la misma. Sin embargo, ambos proyectos no llegaron ni siquiera a ser discutidos en el seno del Parlamento debido a los cambios de gobierno. El planteamiento de principios similares y una estructura con muchas similitudes en ambos nos ha llevado a unificar su análisis.

El primero de los proyectos de ley fue presentado en abril de 1909 por el ministro de la Guerra Arsenio Linares, mientras que el segundo lo fue en octubre de 1910 de manos de Ángel Aznar ${ }^{1575}$. Se

\footnotetext{
1574 El Siglo Futuro, 14/10/1910, p. 1.

1575 Arsenio Linares nació en Valencia y murió en Madrid (1848-1914). Militar español que, después de ocupar destinos en Filipinas, Madrid y Melilla, fue destinado a Cuba para mandar la brigada de operaciones de la provincia de Santiago. General de división por la acción de Seibabo, organizó la defensa de Santiago de Cuba, como gobernador de dicha plaza, cuando se inició el ataque norteamericano a las fortificaciones de la bahía. Colaborador de Cassola, en 1900, Silvela le nombró ministro de la Guerra. Ocupó la misma cartera en el segundo Gobierno Silvela (1902). Con Maura, durante su Gobierno largo (1907-1909), era ministro cuando estalló de nuevo el conflicto de Marruecos; dio su discutida orden de movilización de reservistas, que contribuyó a provocar los hechos de la Semana
} 
justificaron ambos proyectos ${ }^{1576}$ de ley en su preámbulo en la necesidad de contar con una reserva instruida en tiempos de paz para alcanzar así, en tiempos de guerra, los efectivos indispensables instruidos para la lucha y preparados para una rápida movilización ${ }^{1577}$. La duración del servicio en doce años impedía el cumplimiento de tal necesidad, ya que los reclutas recibían licencia absoluta transcurrido ese periodo de tiempo. Desde la prensa más conservadora y ultracatólica, se utilizó este proyecto de ley y la situación del Ejército para arremeter contra el Gobierno liberal, si bien se limitó fundamentalmente en sus columnas a reflejar las líneas esenciales de la nueva norma:

"Nuestro ejército, no obstante la excelencia del personal, por lo que afecta á organización completa con todo el material necesario, está reducido á una división que hemos llamado división modelo y de la que la prensa ha estado hablando un trimestre; nuestro poder

Trágica de Barcelona, Diccionario Biográfico Español, edición digital, RAH, http://www.rah.es/cdeb.htm

Ángel Aznar y Butigieg (1847-1924) nacido en Totana (Murcia), fue Jefe Militar de la Casa Real de Alfonso XIII, Capitán General de varias regiones españolas, Director de la Guardia Civil, Diputado a Cortes, Senador vitalicio y, por dos ocasiones, Ministro de la Guerra, Diccionario Biográfico Español, edición digital, RAH, http://www.rah.es/cdeb.htm

1576 "Satisfacer los justos anhelos de los que consideran sagrado deber de todos los ciudadanos útiles, sin distinción de clases sociales, la prestación personal del servicio militar, conseguir durante la paz, para cuantos hayan de acudir a las armas en momentos supremos la más perfecta instrucción y hábitos de disciplina, cualidades ambas, que avalaran por sí solas el vigor de un Ejército, y lograr dichas aspiraciones, salvando las dificultades económicas que limitan los efectivos de las fuerzas permanentes, han sido los principales propósitos del Ministro que suscribe, al redactar estas Bases, obra más que suya, de dignos antecesores, que con la mayor competencia y fortuna tradujeron sus trabajos en Proyectos de Ley, que en diferentes épocas en 1909 la última, fueron sometidos a la sabiduría de las Cortes. No son, pues, ideas nuevas las que se consignan, ni, en general, es nuevo el desarrollo de ellas, a excepción de algunas, muy pocas, modificaciones preceptivas, que se han considerado necesarias, para acomodar este proyecto al pensamiento militar y político del Gobierno" (Proyecto de Ley de Bases para el Reclutamiento y el Reemplazo del Ejército de 6 de Octubre de 1910, Preámbulo).

1577 Proyecto de Ley de Bases para el Reclutamiento y el Reemplazo del Ejército de 2 de Abril de 1909, Preámbulo; y Base $1^{\text {a }} \mathrm{A}, 1^{\circ}$ y $2^{\circ}$ y Proyecto de Ley de Bases para el Reclutamiento y el Reemplazo del Ejército de 6 de Octubre de 1910, Base $1^{\mathrm{a}} \mathrm{A}$. 
naval es nulo, y con el proyecto de escuadra del actual gobierno amenaza seguir siéndolo durante muchos años"1578.

También desde la prensa socialista se aprovecharon los acontecimientos marroquíes para poner en cuestión la estructura del Estado liberal, resaltando las protestas y la indignación populares en contra de la guerra:

"Las muchedumbres congregadas en ese día en capitales y pueblos se han manifestado decididamente hostiles a todo propósito bélico en el Magreb [...]. La campaña contra la guerra deber continuar incansablemente, tenazmente, mientras no se consiga el anhelo de todos de poner término al antiguo derroche de energías, hoy agravado, que viene haciéndose en África en nombre de unos pretendidos derechos históricos"1579.

En el caso de estallar una guerra, el Proyecto de 1909 criticó la imposibilidad de "disponer [...] de soldados bastantes para constituir un primer Ejército de operaciones de suficiente efectivo y formar otro de segunda línea, quedando todavía los hombres necesarios para cubrir bajas y atender a la defensa local del territorio"1580. Ante esta circunstancia, el ministerio de la Guerra propuso prolongar la duración del servicio militar hasta los dieciocho años y aumentar el número de individuos que adquiriesen la formación castrense, fijando para ello nuevas bases para el señalamiento de los cupos ${ }^{1581}$.

Además, sería necesaria la creación de una reserva territorial para proteger las plazas y ciudades importantes en caso de

\footnotetext{
1578 El Siglo Futuro, 06/04/1909, no 509, p. 1.

1579 El Socialista, 19/05/1911, no 1314, p. 1.

1580 Proyecto de Ley de Bases para el Reclutamiento y el Reemplazo del Ejército de 2 de Abril de 1909, Preámbulo.

1581 Proyecto de Ley de Bases para el Reclutamiento y el Reemplazo del Ejército de 2 de Abril de 1909, Base 6a A-J; y Proyecto de Ley de Bases para el Reclutamiento y el Reemplazo del Ejército de 6 de Octubre de 1910, Preámbulo y Base 7a A-N.
} 
peligro ${ }^{1582}$. Para incrementar el número de efectivos se planteó la posibilidad de que indígenas voluntarios del norte de África y del Golfo de Guinea formasen parte del Ejército ${ }^{1583}$. El número de voluntarios y reenganchados nunca podría superar el 25 por ciento del total de los efectivos ${ }^{1584}$.

El servicio militar quedaría dividido en las siguientes situaciones:

10.- Reclutas en caja (plazo variable).

20.- Servicio activo (3 años).

30.- Primera reserva (5 años).

40.- Segunda reserva (6 años).

50.- Reserva territorial (resto de los dieciocho años) ${ }^{1585}$.

En caso de guerra, el Gobierno podría ampliar estos plazos y retrasar la expedición de licencias absolutas. Los individuos de las distintas reservas tendrían la obligación anual de acudir a las asambleas, maniobras e instrucción que estableciesen las autoridades militares ${ }^{1586}$. Además, los individuos útiles que hubiesen obtenido la suerte del soldado en el sorteo se dividirían en dos categorías: los que tuviesen que ingresar en el servicio activo y los excedentes de

1582 Proyecto de Ley de Bases para el Reclutamiento y el Reemplazo del Ejército de 2 de Abril de 1909, Preámbulo y Base $2^{a}$ A.

1583 Proyecto de Ley de Bases para el Reclutamiento y el Reemplazo del Ejército de 2 de Abril de 1909, Base $1^{\text {a }}$ B; y Proyecto de Ley de Bases para el Reclutamiento y el Reemplazo del Ejército de 6 de Octubre de 1910, Preámbulo y Base $1^{\text {a }}$ A.

1584 Proyecto de Ley de Bases para el Reclutamiento y el Reemplazo del Ejército de 2 de Abril de 1909, Base $1^{\text {a }} \mathrm{I}$; y Proyecto de Ley de Bases para el Reclutamiento y el Reemplazo del Ejército de 6 de Octubre de 1910, Base $1^{a} \mathrm{H}$.

1585 Proyecto de Ley de Bases para el Reclutamiento y el Reemplazo del Ejército de 2 de Abril de 1909, Base 2a A-P; y Proyecto de Ley de Bases para el Reclutamiento y el Reemplazo del Ejército de 6 de Octubre de 1910, Base 2a A-I.

1586 Proyecto de Ley de Bases para el Reclutamiento y el Reemplazo del Ejército de 2 de Abril de 1909, Base $2^{a} \mathrm{~J}$ y $\mathrm{M}$; y Proyecto de Ley de Bases para el Reclutamiento y el Reemplazo del Ejército de 6 de Octubre de 1910, Base $2^{\text {a }}$ J-M. 
cupo, que quedarían obligados a incorporarse a los cuerpos armados cuando así se dispusiese en función de las necesidades militares ${ }^{1587}$.

En cuanto a las autoridades encargadas de dirigir y coordinar todo el proceso de reclutamiento, ambos proyectos de ley apenas plantearon novedades respecto a las legislaciones previas, ya que era la institución municipal quien controlaría las primeras fases del proceso, es decir, alistamiento, sorteo y clasificación de los mozos, mientras que una comisión mixta de reclutamiento presidida por el gobernador civil de la provincia sería la encargada de decidir acerca de los recursos promovidos en contra de los fallos de las autoridades municipales, conceder las prórrogas $y$, en general, vigilar del buen funcionamiento del proceso y de la buena actuación de las autoridades locales. Solamente cuando la ley hubiese sido violada podría intervenir el ministerio de la Gobernación a través de los comisarios regios que a tal efecto se designasen ${ }^{1588}$.

De nuevo los dos proyectos legislativos plantearon la posibilidad de que los reclutas se acogiesen a prórrogas, situación que sería recogida en la Ley de 1912. Estas prórrogas se podrían solicitar por un máximo de tres años por razones de estudio o por asuntos de índole económica. Serían las comisiones mixtas las encargadas de decidir a tal respecto, no pudiendo superar las prórrogas concedidas el total de un diez por ciento de los mozos declarados soldados. Las prórrogas serían suspendidas en caso de guerra ${ }^{1589}$.

Otra de las novedades más reseñables que recogían los proyectos fue la supresión de la redención en metálico, estando todos

1587 Proyecto de Ley de Bases para el Reclutamiento y el Reemplazo del Ejército de 6 de Octubre de 1910, Base $1^{\text {a }} \mathrm{G}$.

1588 Proyecto de Ley de Bases para el Reclutamiento y el Reemplazo del Ejército de 2 de Abril de 1909, Base 4a A-LL; y Proyecto de Ley de Bases para el Reclutamiento y el Reemplazo del Ejército de 6 de Octubre de 1910, Base 3a A-K y Base $5^{\mathrm{a}} \mathrm{A}-\mathrm{N}$.

1589 Proyecto de Ley de Bases para el Reclutamiento y el Reemplazo del Ejército de 2 de Abril de 1909, Base 5a A-M; y Proyecto de Ley de Bases para el Reclutamiento y el Reemplazo del Ejército de 6 de Octubre de 1910, Preámbulo y Base 6a A-M. 
los españoles obligados a servir en filas ${ }^{1590}$, aunque se plantearon nuevas medidas para que el Estado pudiese captar ingresos por distintos conceptos para atender a la instrucción, vestuario y equipo del contingente. También se propuso la distinta duración del servicio en función del grado de formación del recluta, reduciéndose el tiempo de prestación para aquellos que mostrasen mayores conocimientos y cuyo periodo de instrucción militar requiriese menos tiempo ${ }^{1591}$.

Aunque su suprimía la redención en metálico, de nuevo los proyectos de ley volvieron a contemplar la posibilidad de las cuotas $^{1592}$, definido así por el propio texto legislativo:

"Se da el nombre de cuota militar a un impuesto, pagadero por años completos, a partir del $1^{0}$ de febrero de cada año, que deben satisfacer aquellos mozos que, por causa legal, dejen de prestar una parte del servicio militar, o disfruten de prórrogas de incorporación a filas o algunas otras ventajas que estas bases determinan"1593.

1590 Proyecto de Ley de Bases para el Reclutamiento y el Reemplazo del Ejército de 2 de Abril de 1909, Base $1^{\text {a }} \mathrm{C}$ y $1^{\mathrm{a}} \mathrm{F}$; y Proyecto de Ley de Bases para el Reclutamiento y el Reemplazo del Ejército de 6 de Octubre de 1910, Preámbulo.

1591 "En la actualidad se hallan obligados a servir en idénticas condiciones los que carecen de la instrucción primaria elemental y los que poseen un título académico; el buen tirador y quien desconoce por completo el uso de las armas de combate; el rudo campesino exento de ilustración, y los que por su arte, profesión u oficio, gozan de ella en mayor o menor grado; y como esto no debe subsistir, puesto que la enseñanza militar de unos y otros exigirá muy diverso tiempo, se modifica la Ley actual en este punto, otorgando ventajas a los que demuestran mayores conocimientos; lo cual redundará seguramente en beneficio de la cultura general del país" (Proyecto de Ley de Bases para el Reclutamiento y el Reemplazo del Ejército de 2 de Abril de 1909, Preámbulo).

1592 "Este mecanismo era una fórmula de compromiso, ya implantada en otros Ejércitos europeos, para cohonestar el mandamiento constitucional -el deber de todos los ciudadanos a servir a la patria con las armas en la mano-, con determinados derechos adquiridos por jóvenes que hubieran iniciado una carrera universitaria o una actividad profesional o empresarial antes de ser llamados al servicio" (PUELL DE LA VILLA, F., El soldado desconocido: de la leva a la "mili" (1700-1912), pp. 298).

1593 Proyecto de Ley de Bases para el Reclutamiento y el Reemplazo del Ejército de 2 de Abril de 1909, Base 7a A. 
Estarían obligados a pagar este impuesto los mozos exceptuados del servicio, los padres o tutores de los prófugos, los que disfrutasen de prórroga y los pertenecientes al cupo de instrucción ${ }^{1594}$. Aquellos reclutas que abonasen una cuota de 500 pesetas y costeasen su equipo, podrían ver reducido su tiempo de prestación a los diez meses y elegir su destino militar; si pagasen 1.000 , su prestación se reduciría a cinco meses ${ }^{1595}$. Por lo tanto, aunque se finalizaría con la injusticia de la redención, permanecerían desigualdades como las cuotas. Podrían además gozar de licencias temporales o ilimitadas aquellos soldados que hubiesen destacado en las operaciones de tiro, los que se hubiesen distinguido de un modo notable en las artes, industria, agricultura o en cualquier otra profesión $^{1596}$.

Para reducir costes, los proyectos de ley propusieron la formación de cuadros y oficiales gratuitos que facilitasen la movilización del Ejército y que complementasen a los profesionales retribuidos. Estos cuadros deberían poseer una carrera universitaria o estar próximos a finalizarla, y sólo serían movilizados en caso de urgencia, volviendo a sus casas tan pronto como se retornase a la normalidad. Esta situación permitiría dotar a la institución castrense de mayor elasticidad, evitar un excedente de oficiales y reducir los gastos de la Hacienda pública ${ }^{1597}$.

También plantearon ambos proyectos de ley la necesidad de elevar más allá de los veintiún años la edad de ingreso en filas para

\footnotetext{
1594 Proyecto de Ley de Bases para el Reclutamiento y el Reemplazo del Ejército de 2 de Abril de 1909, Base 7a A-L.

1595 Proyecto de Ley de Bases para el Reclutamiento y el Reemplazo del Ejército de 2 de Abril de 1909, Base 7a N-U; y Proyecto de Ley de Bases para el Reclutamiento y el Reemplazo del Ejército de 6 de Octubre de 1910, Base 8a A-T.

1596 Proyecto de Ley de Bases para el Reclutamiento y el Reemplazo del Ejército de 2 de Abril de 1909, Base 7a LL y M; y Proyecto de Ley de Bases para el Reclutamiento y el Reemplazo del Ejército de 6 de Octubre de 1910, Preámbulo.

${ }^{1597}$ Proyecto de Ley de Bases para el Reclutamiento y el Reemplazo del Ejército de 2 de Abril de 1909, Preámbulo, Base 1a A, 30; y Base 9a A-LL y Proyecto de Ley de Bases para el Reclutamiento y el Reemplazo del Ejército de 6 de Octubre de 1910, Preámbulo y Base $10^{\mathrm{a}} \mathrm{A}-\mathrm{L}$.
} 
los soldados voluntarios, "teniendo presente que faltos muchos de éstos, a la edad en que hoy se admiten, de robustez y desarrollo físico suficientes y dedicados a ejercicios corporales que exigen el empleo de un vigor con que no cuentan, vienen a llenar los Hospitales militares, víctimas de la anemia y de otras afecciones, con aumento extraordinario de los inútiles, sin ventaja alguna para el Ejército y con dolorosas y sensibles pérdidas, tanto para las familias como para el Estado"1598. Para los reclutas ordinarios, la edad se mantendría en esos veintiún años ${ }^{1599}$.

Como última novedad, los proyectos de ley propusieron la modificación del cuadro de exenciones físicas y, en función de los exámenes médicos, la división de los reclutas no exentos en dos categorías: aptos plenamente para el servicio, y aquellos que, por alguna deficiencia física, sólo fuesen empleados en el Ejército para funciones auxiliares. Además, aquellos que fuesen eximidos por motivos físicos o exceptuados del servicio por constituir el sostén de su familia o por ser ordenados in sacris, se deberían someter durante los tres años siguientes al de su alistamiento a un proceso de revisión de las causas que determinaron su exclusión para, en el caso de haber cesado éstas, ingresar en los cuerpos armados. Los exceptuados por estos últimos motivos deberían además incorporarse a filas en caso de guerra ${ }^{1600}$. El Proyecto de ley de octubre de 1910 propuso una novedad respecto al de 1909: anular la exención para los eclesiásticos, "quienes tendrán en lo sucesivo la honrosa ocasión de contribuir a las necesidades del Ejército, no en funciones

1598 Proyecto de Ley de Bases para el Reclutamiento y el Reemplazo del Ejército de 2 de Abril de 1909, Preámbulo.

1599 Proyecto de Ley de Bases para el Reclutamiento y el Reemplazo del Ejército de 2 de Abril de 1909, Base $3^{a}$ A.

1600 Proyecto de Ley de Bases para el Reclutamiento y el Reemplazo del Ejército de 2 de Abril de 1909, Preámbulo, Base 2a D, Base $3^{a} \mathrm{M}, \mathrm{N}$ y N y Base 11 A y B; y Proyecto de Ley de Bases para el Reclutamiento y el Reemplazo del Ejército de 6 de Octubre de 1910, Preámbulo, Base $4^{a}$ A-H y Base 12 A-B. 
marciales, sino en las propias y muy importantes de su sagrado Ministerio"1601.

El servicio militar obligatorio marca el desarrollo de la norma

Nos introducimos en el análisis definitivo de la Ley de Reclutamiento y Reemplazo del Ejército de 19 de Enero de $1912^{1602}$, presentada, siguiendo en gran parte los principios doctrinales de los dos proyectos de ley analizados previamente, por el ministro de la Guerra Agustín Luque ${ }^{1603}$, y que vino a cambiar un sistema que había permanecido casi invariable desde la Ley de $1837^{1604}$. Sus principios doctrinales, según el propio ministro de la Guerra, serían la igualdad y equidad al universalizar el servicio, la justicia al suprimir la redención en metálico y la eficacia que supondría que, a pesar de mantenerse el sorteo, todos los jóvenes españoles recibiesen instrucción militar:

"La ley de Bases que discutimos llena cumplidamente el aspecto social y moral al que en primer término hemos de atender por equidad, por justicia y por compromiso del partido democrático liberal. Todos vendrán á las filas activas del Ejército; la redención á metálico ha pasado a la categoría de recuerdo triste, y los que por número se

${ }^{1601}$ Proyecto de Ley de Bases para el Reclutamiento y el Reemplazo del Ejército de 6 de Octubre de 1910, Preámbulo.

1602 Ley de reclutamiento y reemplazo de 12 de Enero de 1912, Gaceta núm. 21 de 21/01/1912. En adelante, Ley de reclutamiento y reemplazo de 19 de Enero de 1912.

1603 Agustín Luque (1850-1936). Se distinguió como militar en la campaña carlista, tomando parte después en algunos alzamientos republicanos. Como periodista defendió las reformas del general Cassola. Fue ministro de la Guerra en 1905, con Moret, volvió a serlo en 1906 y 1909 con el mismo Presidente, e implantó durante su gestión la Ley de Jurisdicciones. Ocupó la misma cartera con Canalejas (1911) y con Romanones (1912, 1915), Diccionario Biográfico Español, edición digital, RAH, http://www.rah.es/cdeb.htm

${ }_{1604}$ CRESPO-FRANCÉS Y VALERO, J.A., A las armas: Reclutamiento y servicio militar en España desde sus orígenes hasta nuestros días, p. 270. 
salven de prestar el servicio en primera situación activa, recibirán también instrucción militar"1605.

El partido Conservador se opuso al proyecto de ley no por la universalización del servicio que éste recogía, sino por carecer de la posibilidad de exención para aquellos mozos más útiles para la sociedad $^{1606}$, a lo que se unía una improvisación y una falta de tiempo para su correcta aplicación y una carencia de recursos económicos que impedía el establecimiento del servicio militar obligatorio:

1605 Discurso del Sr. Ministro de la Guerra, Diario de sesiones de las Cortes, 11/05/1911, no 32, p. 777.

${ }^{1606}$ El conservador Martín Sánchez realizó un nítido repaso de los distintos sistemas de reclutamiento existentes en Europa para argumentar su oposición al proyecto de Ley: "Existen hoy, puede decirse, que tres sistemas de reclutamiento en Europa, que son: el sistema voluntario, seguido por Inglaterra, que es caro y creo que malo; nosotros no podríamos implantarle aquí; el sistema seguido por Suiza, que consiste en instruir a todos los hombres útiles, careciendo de Ejército permanente. Cuando cumplen veinte años, pasan por los cuarteles dos o tres meses y se van a su casa, constituyendo lo que se llama la Nación armada; también este sistema creo yo que en España daría malos resultados, y la prueba de que no es muy bueno es que no lo tiene más Nación que Suiza. Y después viene el sistema general que, por denominarlo de alguna manera, le llamaremos sistema prusiano, porque es donde nació, que es el que han copiado casi todas las Naciones de Europa. Podía citar un cuarto sistema, que es el que sigue Bélgica, y que consiste en llamar al voluntariado a todos aquellos hombres que quieran servir, es decir, sistema inglés, y como no reúne más que 8.000 hombres por ese medio y necesita todos los años 14.000 , los otros 6.000 los recluta por el sistema de servicio militar obligatorio a la prusiana. Este proyecto de bases que estamos discutiendo obedece al sistema general seguido por casi todas las Naciones cle Europa y algunas Repúblicas de América, por considerar que es el mejor y el menos caro, porque económico entiendo yo que no es ninguno de los sistemas de reclutamiento. Veamos si este sistema de reclutamiento que queremos establecer en España es como el que se ha establecido en Alemania, en Austria, en Italia, en Rusia, etc., como el que se ha establecido en esas Naciones que han seguido el sistema alemán. [...]. Nosotros debemos hacer una ley de Reclutamiento, en la que por el sistema de selección eliminemos del servicio a cuantos podamos eliminar; debemos hacer algo parecido a lo que hacen Italia, Austria y otras Naciones, las cuales establecen una serie de eliminaciones en favor de los pequeños agricultores, de los maestros de escuela, etc., en virtud de las cuales se llama al servicio solamente a los que son necesarios y no se molesta a los demás. [...]. ¿Podrán venir todos? Yo sostengo que no hay posibilidad económica en el país, ni necesidades militares que exijan del país tan gran esfuerzo como el de mandar todos sus hombres durante más o menos tiempo a filas. Pues si no pueden venir todos, veamos quiénes son los que se han de quedar en sus casas". (Discurso del Sr. Martín Sánchez, Diario de sesiones de las Cortes, 10/05/1911, no 31, pp. 742-745 y 748). 
"En estas condiciones, ¿vamos a entrar nada menos que en un cambio de organización mediante el servicio militar obligatorio? En primer lugar, ces posible pasar de lo actual a lo que se intenta sin una preparación larga y muy costosa? Podrá decir la Comisión o el Sr. Ministro de la Guerra que hay dos años de plazo. ¿Es que dos años es tiempo suficiente? Señor Ministro, isi recientemente se han encontrado los reclutas que han sido llamados hace poco tiempo a sus respectivos cuerpos con que faltan utensilios, con que falta vestuario y con que no hay caballos en los cuerpos montados! [...].

Pues ¿y cuarteles? Si para llamar al servicio militar obligatorio es menester, como dice muy bien el proyecto de ley que discutimos, que haya cuarteles que reúnan condiciones de higiene, porque hay en España muchos que son antiguos conventos que se han utilizado para este fin, y en ellos se ha gastado mucho más que si se hubieran hecho de nuevo [...]; pero como serán más los soldados, las condiciones higiénicas serán peores por la mayor aglomeración; a eso me refiero [...]. Yo creo que habrá tantos excedentes como al presente, y entonces, ¿qué servicio militar obligatorio es ese? [...] Precisamente este es uno de los puntos que quiero tratar, Sr. Ministro, el de la imposibilidad en que estamos de poder realizar el servicio militar obligatorio, por la razón avasalladora de que no hay dinero, porque la Nación no es bastante rica para poder sostenerlo"1607.

El establecimiento del servicio obligatorio para todos los españoles traería, según una oposición conservadora no contraria a la globalidad del proyecto pero sí a algunos de sus principios, un engrandecimiento en el tamaño del Ejército realmente asombroso y difícil de mantener para un Estado como el español, siendo necesario por tanto el establecimiento de determinadas exenciones para el servicio militar:

"Nosotros tenemos, como he dicho antes, 135.000 hombres útiles; la ley dispone que estén tres años en servicio activo y cinco en

1607 Discurso del Sr. Llorens, Diario de sesiones de las Cortes, 11/05/1911, no 32, p. 780. 
la primera reserva; es decir, que son ocho contingentes; ocho contingentes de 135.000 hombres dan, para lo que nosotros llamamos primera línea, 1.080 .000 soldados. Y yo pregunto: ¿es que esta cifra no asusta ya? Ese millón y pico de soldados, ¿no significa por sí solo la imposibilidad material de que pueda cumplirse lo que dice la ley? Porque es exactamente lo mismo (y dispénseme la Cámara lo vulgar del ejemplo) que si una ley dispusiera que en este local y en un momento dado se reunieran 3.000 hombres. Como de pie no caben más que 1.030, aunque lo digan todas las leyes del mundo, es imposible que se reúnan 3.000. Y conste que no me refiero á los cuarteles que esos 1.080.000 hombres necesitan, porque ya sé que no se han de llamar de una vez, sino que han de venir de una manera sucesiva, y que en tiempo de guerra han de estar acampados; eso, aun cuando importante, es casi secundario al lado del equipo, de los vestuarios, de los fusiles, de los cañones, en una palabra, del material de guerra y de los medios económicos de que nosotros disponemos para poder instruir 1.080.000 soldados. La cifra solamente asusta. ¿Qué? ¿Es que hacemos una ley más para que no se cumpla? Esto es lo grave para el país: que hagamos leyes ya con el convencimiento íntimo de que no se pueden llevar a la práctica. Por eso es necesario que cuando lleguemos a la discusión de las bases hagamos todos lo posible para que esta ley sea viable y practicable, y que al día siguiente de votada o a los dos años se pueda plantear tal como quede, sin protesta de nadie, sin que vengamos a tener las protestas de que ha ido Fulano y no ha ido Zutano, y no se da más razón que la suerte $o$ el número, cuando en todas partes la suerte o el número es lo menos; lo más es la ley, que es la que excluye, y la que dice: ¿tú eres hijo único, o sostén de familia, o corto de talla? Pues no vas al servicio. Esa es una ley de equidad para todos, lo mismo para el hijo del banquero que para el hijo del menestral, con una sola diferencia, la de la tasa, porque, naturalmente, el hijo del banquero paga más que el hijo del menestral, que pagará menos o no pagará nada. Yo, más que igualdad, quiero equidad ante la ley para todas las clases $^{\prime 1608}$.

1608 Discurso del Sr. Martín Sánchez, Diario de sesiones de las Cortes, 10/05/1911, n० 31, p. 745. 
La prensa más conservadora también se opuso a esta universalización del servicio y especialmente a la supresión de la redención en metálico, proponiendo su mantenimiento de una forma proporcional:

"Con la condición de aplicar los ingresos obtenidos por tal concepto [la redención en metálico], en estas tres atenciones preferentemente, que no creo estuvieran reñidas con la monarquía ni con la república, ni mucho menos con la democracia.

Primera. Pensión vitalicia á los inutilizados en el servicio de las armas.

Segunda. Premio al reenganche.

Tercera. Premio al voluntario colonial.

En lugar de ese equívoco de las clases proletarias, á las que tengo el honor de pertenecer, del servicio militar permanente, personal y obligatorio, tal como lo entiende el pueblo, ¿no sería más práctico y ventajoso para todos - defensa nacional inclusive- que al llegar á los veinte años, después de establecida la redención proporcional, se distribuyeran los mozos en dos grandes

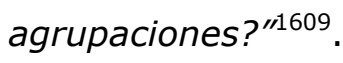

Además de las furibundas críticas hacia el servicio universal obligatorio, desde estos sectores reaccionarios se proponía el servicio voluntario:

"El servicio militar obligatorio, además de anticonstitucional, quebranta la ética, se burla de la ciencia, deforma la justicia, da vida al antimilitarismo, aviva odios y rencores, da un contingente horroroso de prófugos, desertores y suicidas y no produce los resultados apetecidos; pues los Ejércitos modernos, científicamente hablando, deben ser profesionales, dotados de medios y recursos materiales para estar constantemente en prácticas, educándose, en especialización.

${ }^{1609}$ El Siglo Futuro, 11/05/1911, no 1153, p. 2. 
Sí; el Ejército debe ser voluntario y profesional. El voluntario no va por fuerza, va porque quiere, y no abriga rencor contra una profesión que él mismo ha elegido"1610.

Por lo que a los republicanos se refiere, en concreto los reformistas del partido de Melquiades Álvarez, anunciaron un apoyo inicial al proyecto de ley, en especial en lo que atañía a la universalización del servicio y a la prohibición de la redención en metálico, pero también rechazaron algunos puntos del texto por considerarlo antidemocrático y que traicionaba el espíritu de la normativa al continuar con las desigualdades de clase en lo que respecta a la incorporación a filas, ya que apostaban por una instrucción militar obligatoria para todos los ciudadanos pero con un servicio militar exclusivamente compuesto por voluntarios, ya que los medios económicos del país impedían la incorporación a filas de todos los mozos en edad militar:

"[...] el propósito de una ley de Servicio militar obligatorio tiene que ser para nosotros gratísimo, digno de encomio, de caluroso aplauso. Los propósitos que enunciaba el Sr. Ministro de la Guerra en la exposición de motivos que precedía al proyecto presentado a las Cortes, ¿cómo no han de tener nuestro entusiasta apoyo? El Ministro de la Guerra decía al presentar esta ley que se proponía que se cumpliese el deber militar por todos los ciudadanos españoles, sin distinción de clases, que se diese a todos la más perfecta instrucción militar, y que estos dos fines, que nosotros tenemos que aplaudir sin reserva, se llevasen a cabo salvando todas las dificultades económicas. ¿Cómo hemos de regatear nuestro apoyo a estos propósitos? [...] pero los señores de la Comisión habrán de reconocer que cuanto más entusiastas seamos los que nos sentamos en estos bancos de esos tres propósitos fundamentales señalados por el Sr. Ministro de la Guerra al presentar su proyecto, tanto mayor será nuestro deber de censurar el proyecto si no cumple esos propósitos.

${ }^{1610}$ El Siglo Futuro, 13/05/1911, no 1155, p. 1. 
Precisamente por dejar sentados nuestra adhesión firme y nuestro entusiasmo por esos tres principios, tenemos que combatir el proyecto en todo aquello en que se aparte de ellos, siquiera no hagamos una impugnación sistemática y apasionada. En principio estamos conformes con el proyecto, pero debemos hacer notar aquellos puntos en que se aparta de tales propósitos.

¿Cómo habíamos nosotros de negar el aplauso a una ley que se propone acabar con la redención a metálico, con esa redención cuyo sólo nombre decía elocuentemente el Sr. Canalejas que le quemaba los labios, con esa redención que el jefe ilustre de esta minoría ha calificado tantas veces de una de las dos bofetadas que anualmente se dan al proletariado español? No podíamos, pues, dejar de prestar nuestra cooperación y nuestro voto á este proyecto, pero con las salvedades que voy a formular; y no siendo obstáculo para este aplauso al principio del servicio militar obligatorio, considerándolo como un gran avance, como una gran justicia respecto del sistema actual, el que muchos de los que nos sentamos en estos bancos, y yo entre ellos, no tengamos el servicio militar obligatorio como ideal, y nos inclinemos más y queramos caminar hacia el ideal de una instrucción militar obligatoria y de un servicio militar voluntario. ¿Es que se cumple en la ley, Sres. Diputados, el propósito de que soporten la carga militar todos los ciudadanos, sin distinción de clases? A mi juicio, no"1611.

Y en lo que respecta a los republicanos federales, también éstos mostraron una enérgica oposición al proyecto por el carácter de forzoso que tenía el servicio militar para toda la población, aunque lo aceptaban como un mal menor que permitía una distribución más equitativa de la injusticia. Además, constituía una carga que recaía primordialmente sobre las clases populares, y prueba de ello era que prácticamente ningún diputado, ni tampoco sus hijos, habían ejercido como soldado raso, muestra ésta de clara hipocresía. Apostaron por ello por el voluntariado como el sistema más justo para nutrir de hombres al Ejército, ya que un Estado como el español sólo debía

1611 Discurso del Sr. Pedregal, Diario de sesiones de las Cortes, 10/05/1911, no 31, p. 750 . 


\section{tener un Ejército para mantener su seguridad en caso de agresión externa y olvidarse de veleidades expansionistas como la que se estaba practicando en Marruecos:}

"El partido republicano federal a que pertenezco no es partidario del servicio militar obligatorio. Lo acepta, sin embargo, como un mal menor; lo acepta como una más equitativa distribución de la injusticia; lo acepta, claro es, para el caso de guerra. Mi partido entiende que el servicio militar obligatorio tiene grandes defectos, porque ya un servicio, en el cual se admite la redención a metálico, sería por este solo hecho una injusticia [...].

No nos hagamos ilusiones. No pretendamos engañarnos aquí con lirismos y con retóricas. Hay un hecho claro y manifiesto por el cual se demuestra la repugnancia que todos tenemos a pertenecer al Ejército en clase de soldado. La prueba es que de cuatrocientos y pico de Diputados de que se compone la Cámara, excepto aquellos voluntarios que han emprendido la honrosa carrera de la milicia, los demás nos hemos voluntariamente sustraído a este deber consignado en la Constitución y sustraeremos de él a nuestros hijos si podemos. De modo que siendo muy honroso según se dice, y muy patriótico según se afirma, verter la sangre por la Patria, nosotros somos tan modestos que dejamos a las clases humildes de la sociedad ese honor tan grande y esa honra tan extraordinaria. Por esto es evidente que el servicio militar obligatorio adolece de un gravísimo defecto, y es que a él se va forzado, que se acata y se soporta una Ordenanza que tiene que ser rigurosísima; pero sólo se la soporta porque no hay más remedio.

Por otra parte el servicio militar obligatorio tiene una única ventaja, la de que cuando entren en él, cuando sufran algún perjuicio con él las clases altas, siempre directoras, tendrán más cuidado y prudencia en promover guerras, en proponerlas, en aceptarlas, en llegar a ellas. Pero no compensa, en verdad, esta lejana ventaja ni otros muchos inconvenientes.

Queremos nosotros un servicio voluntario; queremos que la milicia sea una carrera en la cual los soldados, como los oficiales, puedan ganar sus grados, que constituya una verdadera profesión, de modo que todos los soldados (parodiando la frase de un tirano) lleven 
en su mochila el bastón de general si saben ganarlo y saben merecerlo, y que se confieran los ascensos por antigüedad, como no se ganen por señaladísimos méritos, a juicio de los militares de su empleo y grado.

En un voluntariado, en un Ejército profesional voluntario, nadie puede quejarse, nadie puede protestar de la crueldad, si se quiere, de los rigores, de la disciplina militar; porque lo habrá cada cual aceptado así y, además, podrán ir á él todos aquellos que se sientan con vocación para el servicio de las armas. No sucederá lo que ahora; porque no es un delito el no sentirse con vocación militar; se puede ser un excelente ciudadano sirviendo a la Patria de otra manera, y carecer de las condiciones necesarias para servir en el Ejército.

Si nosotros aspirásemos, como todos esos pueblos aspiran, a una vida guerrera y a una política de expansiones, es indudable que necesitaríamos también el servicio obligatorio; pero nosotros los federales entendemos, en cuanto a esa política, que debemos ser muy parcos, porque creemos que el Estado español, que la Nación española no puede lanzarse a aventuras de ninguna clase [...].

Nosotros creemos que España tiene su misión dentro de sí misma, y que ha de estar bastante escarmentada para no apetecer luchas de ninguna clase. En todo caso, si hubiésemos de ser guerreros, si hubiésemos de ser conquistadores, tendríamos dentro de nuestra casa algo que hacer antes de ir á a ajena, tendríamos que reconquistar algún pedazo de tierra española antes de ir á Marruecos ni a ninguna parte a realizar conquistas. Nosotros, en fin, entendemos que nuestra política ha de ser tan parca en este punto que no queremos ni siquiera Ejércitos permanentes numerosos, que sólo sirven para arrastrarnos a lados que justifique su resistencia. [...]. Nosotros somos, pues, completamente contrarios a todo lo que se está haciendo en Marruecos"1612.

Una postura muy similar mostró el partido Radical de Alejandro Lerroux, ferviente defensor del voluntariado aunque admitiendo un servicio obligatorio para todos los ciudadanos exclusivamente en caso

1612 Discurso del Sr. Pi Y Arsuaga, Diario de sesiones de las Cortes, 12/05/1911, no 33, pp. 811 y 812 . 
de conflicto bélico, y apostando por una instrucción militar y cívica para toda la ciudadanía desde la escuela:

"El partido radical es partidario decidido, entusiasta fervoroso, del servicio voluntario. El partido radical solamente puede admitir el servicio militar obligatorio en cuanto, en ocasión de una guerra, ese elemento voluntario del Ejército que a la guerra vaya, no tenga los contingentes necesarios para la efectividad de la campaña, tal como los exigen el servicio y el interés de la patria; y nosotros entendemos asimismo que es indispensable la instrucción militar obligatoria, para preparar a todos los ciudadanos no solamente con la instrucción militar, sino con la cívica, y que esta instrucción militar y esta educación cívica debe originarse en la escuela, porque precisamente es donde más labor y más intensa tienen que realizar todos los Gobiernos que quieran realizar una obra altamente beneficiosa para los interés de la patria.

Es en la escuela donde debe formarse principalmente el alma del niño, aprovechando su natural propensión a amar aquello que por determinadas circunstancias le atrae y le seduce, aprovechando la fácil retentiva del niño, la simplicidad de su condición, para despertar su afición y su cariño a las instituciones armadas [...].

Y luego, cuando esta impresionabilidad, esta sensibilidad, se hace más racional, cuando la razón actúa, cuando el sentimiento está más depurado, desaparecerá todo lo que tiene de externo y aparatoso, para quedar en el alma de aquellos españoles el sentimiento del deber para con la Patria, deber que han de cumplir en todo momento sin espera de premio alguno, llegando a todos los sacrificios necesarios, del mismo modo que se presta ese concurso incondicional al interés supremo de la madre, porque la madre para todos los españoles debe ser, lo mismo que la que nos dió el ser, la Patria, a la que todos nos debemos y a la cual todo debemos sacrificarlo cuando sea preciso"1613.

1613 Discurso del Sr. Santa Cruz, Diario de sesiones de las Cortes, 12/05/1911, no 33, p. 813 
Los socialistas por su parte achacaron los cambios legislativos, sin introducirse desde la prensa en su análisis, a los acontecimientos ocurridos en una guerra imperialista como era la africana: "Una vez más han fracaso en su gestión los actores de la política imperialista seguida en Marruecos"1614. Además, culparon a este conflicto del despilfarro que se estaban produciendo en las arcas públicas y "[...] del abandono en que se tiene a cuantos, después de ser arrancados de sus hogares, tienen que ir a parar a un hospital a curarse las heridas recibidas en el campo de batalla $o$ a reponerse las enfermedades que les causan las muchas penalidades que sufren" ${ }^{1615}$.

a) Disposiciones generales: el intento por incorporar a los estratos sociales superiores al servicio

Comenzó la Ley de 1912 declarando el servicio personal obligatorio para todos los españoles ${ }^{1616}$, logrando según sus

\footnotetext{
${ }^{1614}$ El Socialista, $12 / 01 / 1912$, no $^{\circ} 1344$, p. 1.

1615 El Socialista, 19/05/1911, no 1345, p. 2.

1616 Según el diputado independiente Sr. Amado, este servicio militar obligatorio existía ya desde 1.885, mientras que la redención en metálico no era una inmoralidad que permitiese eximirse a los miembros de las clases altas, sino una facilidad para que no se realizase la prestación en años de paz. Se mostró por tanto contrario al servicio universal, ya que un Ejército desmesurado podría perder su eficacia: "De modo que bien está que modifiquemos la vigente ley de Reclutamiento y reemplazo; bien está que transformemos parte de lo que significa; dignas de aplauso son muchas de las orientaciones que figuran en el proyecto que discutimos; pero, la verdad en su sitio, Sres. Diputados; el servicio militar obligatorio existe en España desde el año 1885, y la redención a metálico no era una inmoralidad que librara al rico del deber de batirse por su Patria, sino que era simplemente una facilidad que se daba para que no se prestara el servicio de guarnición, con obligación por parte de los Gobiernos de llamar a esos redimidos para que, cuando estallara una campaña, se instruyeran y fueran a cubrir las bajas que en esa campaña se produjesen. $Y$ finalmente yo [...] no me asusto de que sirvan todos; me parece admirablemente bien que todos sirvan, ya que por igual a todos nos alcanza el deber de servir y defender a la Patria; lo que me asusta [...] es que con el afán de que vengan a servir todos, se instruyan poco los que ingresen en filas y no tenga el Ejército la eficacia que debe tener en el momento en que haya de cumplir su altísima misión" (Discurso del Sr. Amado, Diario de sesiones de las Cortes, 11/05/1911, no 32, p. 771 y 775).
} 
defensores una distribución equitativa de la carga y la incorporación de los miembros de las clases altas a la institución armada ${ }^{1617}$, siguiendo así el artículo $3^{\circ}$ de la Constitución de 1875, situación que constituía además un "[...] título honorífico de ciudadanía"1618. Condición expresa para servir en el Ejército era el ser español o naturalizado en España, con la única excepción de los voluntarios que nutriesen las unidades indígenas de los territorios coloniales y los españoles inscritos en las listas de reclutamiento de la Armada o que perteneciesen a la misma. Quedó así recogida una de las ideas clave de los proyectos legislativos de 1909 y 1910, la constitución de unidades indígenas en territorios coloniales.

En función de la nueva ley de reclutamiento, serían motivos de exclusión del servicio la talla inferior al 1,500 metros, el peso inferior a los $48 \mathrm{Kg}$. y, por primera vez, el presentar un perímetro torácico inferior a los $75 \mathrm{~cm}$. La nueva ley expresamente prohibió la redención en metálico y la sustitución ${ }^{1619}$. Constituyó esta prohibición una de las claves del texto legislativo, ya que por primera vez una norma de

1617 "[...] esta ley, no sólo satisface necesidades de un orden militar, como acabo de decir, sino de un orden esencialmente político y social. Es evidente que una función tan sagrada como la defensa de la patria, la manifestación ostensible de una condición a la que atribuyo primacía en toda colectividad, como es la representación de su fuerza, no puede atribuirse a una clase sola de la sociedad y una clase que quizá es la que menos integra, la que menos representa la fuerza de la Nación. Pues bien; si desde ese punto era el servicio militar obligatorio una necesidad unánimemente sentida, viene esta ley a satisfacerla cumplidamente. [...]. El personal, en general, cuanto más elevada y pudiente es la clase a que pertenece, reúne mayor aptitud para ser soldado. Lo que se dice con frecuencia, de que el mejor soldado es el que pertenece a las clases pobres, a las menos cultas, es un error grandísimo. ¿Cómo vamos a aceptar la doctrina de que un espíritu menos culto, colocado en un cuerpo más débil, es un soldado mejor? Por consiguiente, desde el momento en que esta ley lleva a filas elementos más valiosos, es beneficiosa para el Ejército" (Discurso del Sr. Suárez Inclán, Diario de sesiones de las Cortes, 10/05/1911, no 31, p. 747).

1618 Ley de reclutamiento y reemplazo de 19 de Enero de 1912, art. 1.

1619 Ley de reclutamiento y reemplazo de 19 de Enero de 1912, arts. 2-4; y Cuadro de inutilidades con relación a la aptitud física para el ingreso en el servicio del Ejército de 10 de Enero de 1912, arts. 13-15, Gaceta núm. 21 de 21/01/1912. En adelante, Cuadro de inutilidades con relación a la aptitud física para el ingreso en el servicio del Ejército de 10 de Enero de 1912, Gaceta núm. 21 de 21/01/1912. En adelante, Cuadro de inutilidades físicas de 10 de Enero de 1912. 
reclutamiento no ya solo ponía límites a la redención y la sustitución, sino que las prohibió totalmente.

Como objetivos básicos de la nueva ley se establecieron los siguientes:

- Nutrir las filas del Ejército y la Marina y constituir reservas que permitiesen elevar sus efectivos en tiempos de guerra.

- Instruir militarmente a los mozos útiles.

- Preparar una pronta y ordenada movilización.

- Constituir cuadros gratuitos de oficiales y clases complementarias de los profesionales retribuidos ${ }^{1620}$.

Las operaciones de alistamiento y sorteo se debían realizar en todos los municipios del Reino y en los consulados de España en el extranjero en función de los plazos que estableciese la ley, si bien estos plazos se podrían acortar cuando existiesen circunstancias extraordinarias. El contingente anual salido del proceso se dividiría en dos agrupaciones: el cupo en filas, es decir, aquellos que servirían como fuerzas activas del Ejército; y el cupo en instrucción, es decir, aquellos que hubiesen excedido el cupo pero que estarían obligados a recibir instrucción militar y a incorporarse a filas cuando se les ordenase. Sobre estas bases, la fuerza militar se reemplazaría con los mozos del cupo en filas del contingente de cada año, con los individuos del cupo en filas menores de treinta años que deseasen permanecer en el Ejército en el momento de ser licenciados; con los mozos entre dieciocho y veintiún años que solicitasen su incorporación hasta un mes antes de su ingreso en caja, y con los pertenecientes al cupo en instrucción, que pasado el primer año a partir del destino al cuerpo de su reemplazo y antes de cumplir treinta años de edad, quisieran prestar sus servicios en filas. Los

${ }^{1620}$ Ley de reclutamiento y reemplazo de 19 de Enero de 1912, art. 5. 
individuos que no acreditasen haber cumplido los deberes militares no podrían desempeñar ningún cargo de elección popular, ni ser admitidos al servicio de la Administración pública ${ }^{1621}$.

b) Autoridades que intervienen en las operaciones de reclutamiento y reemplazo: la importancia de Ayuntamientos y consulados

Por primera vez una ley sobre reclutamiento dedicó dos capítulos exclusivos, el segundo y el noveno, a establecer qué instituciones quedarían involucradas en el proceso y cuales serían sus competencias. Para atender a las operaciones del reemplazo, el territorio español se dividiría en zonas militares, cada una de las cuales contaría con el número de cajas de reclutas que se considerase oportuno ${ }^{1622}$.

Vuelven a ser las autoridades municipales la clave en la ejecución de todo el proceso. Para su buen desarrollo deberían seguir las instrucciones dadas por el ministerio de la Guerra, organizador del mismo, y las prescripciones que señalase la ley. Los términos municipales de mucho vecindario podrían dividirse en secciones de recluta de alrededor de 5.000 vecinos, siempre que el gobernador civil de la provincia lo estimase oportuno. Cada sección sería considerada como un pueblo distinto para las operaciones del reemplazo, que serían dirigidas por una Comisión formada, al menos, por tres individuos del consistorio. Por el contrario, los términos municipales compuestos por poblaciones dispersas serían considerados como un solo municipio para las operaciones del

${ }^{1621}$ Ley de reclutamiento y reemplazo de 19 de Enero de 1912, arts. 6-10 y 12.

${ }^{1622}$ Ley de reclutamiento y reemplazo de 19 de Enero de 1912, art. 22. 
reclutamiento siempre que no excediese la suma total de las feligresías los 5.000 vecinos $^{1623}$.

Las operaciones serían distintas para los consulados de España en el extranjero. Sería el ministerio de Estado, de acuerdo con los de Gobernación y Guerra, el encargado de señalar cuáles de estos consulados iban a ser habilitados para las operaciones de reclutamiento y cuál sería su ámbito de actuación en función del número de residentes españoles en los distintos países. Los españoles residentes en el extranjero que se alistasen en los consulados ingresarían en las cajas de recluta que se designasen por disposiciones del ministerio de la Guerra ${ }^{1624}$. Cada uno de estos consulados sería considerado a todos los efectos como un municipio, y para el cumplimiento de sus funciones sería designada una junta

"[...] formada por dos individuos que designará la Cámara de Comercio española que estuviese constituida oficialmente, donde la haya, dos más, nombrados por el representante diplomático de España, si lo hubiere, a propuesta del Cónsul, o por éste si dicho representante no residiera en la demarcación consular, y, finalmente, otros dos, previa votación de los residentes españoles inscritos en el Consulado, efectuada ante el Cónsul, siendo Secretario el canciller del Consulado"1625.

Para el caso de los españoles sujetos al servicio militar residentes en las posesiones españolas del Golfo de Guinea, el proceso sería ejecutado por una junta con sede en la ciudad de Santa Isabel de Fernando Poo presidida por el secretario del Gobierno general. De igual forma y cuando fuese necesario se procedería con otros territorios españoles del continente africano. Por primera vez se desciende hasta este nivel de detalle en lo que se refiere al

1623 Ley de reclutamiento y reemplazo de 19 de Enero de 1912, arts. 13-15.

1624 Ley de reclutamiento y reemplazo de 19 de Enero de 1912, arts. 16 y 23.

${ }^{1625}$ Ley de reclutamiento y reemplazo de 19 de Enero de 1912, art. 17. 
reclutamiento colonial. Todas las juntas, ya sea de los consulados o las establecidas en colonias africanas, tendrían un funcionamiento similar a los municipios en lo que se refiere a las operaciones de reemplazo ${ }^{1626}$.

Por encima de las instituciones municipales en cada provincia existiría una comisión mixta de reclutamiento presidida por el gobernador civil, cuyos trabajos se realizarían en las oficinas de la Diputación provincial, a quien se podrían apelar las decisiones de los municipios. Su actuación y funciones fueron regladas en el capítulo VIII de la ley.

La comisión se constituyó como una institución fundamental en la regulación de todo el proceso de reclutamiento, aunque sus decisiones, y las de las juntas consulares, podrían ser recurridas, mediante recurso de alzada, ante al ministerio de la Gobernación. La comisión, institución de carácter provincial, estaría compuesta, además de por el gobernador civil, por el coronel jefe de la zona, dos diputados provinciales, los jefes de la caja de recluta, un delegado de la autoridad militar, un médico civil nombrado por la propia comisión y un médico militar nombrado por el capitán general de la región. También formaría parte de la Comisión el secretario de la Diputación Provincial, que actuaría como secretario de la misma pero sin voto. Asimismo sin voto, aunque con voz, participaría en sus reuniones un delegado del Ayuntamiento afectado por las reclamaciones ${ }^{1627}$.

Las competencias que la ley otorgó a la comisión provincial de reclutamiento fueron amplias e importantes, ya que no sólo se encargarían de revisar las reclamaciones presentadas ante las decisiones tomadas por las autoridades municipales, sino que también asumieron la función de repartir el cupo entre los pueblos de su provincia y eran las encargadas de conceden las prórrogas para el

${ }^{1626}$ Ley de reclutamiento y reemplazo de 19 de Enero de 1912, arts. 18-20.

1627 Ley de reclutamiento y reemplazo de 19 de Enero de 1912, arts. 21, 24, 120 y 121. 
ingreso en el servicio. De forma global, sus competencias serían las siguientes:

"10.- Conocer en los recursos que se promuevan contra los acuerdos dictados por las Autoridades municipales de su provincia con motivo de las operaciones relativas al reemplazo del Ejército.

20. - Revisar y fallar todos los expedientes de los mozos que los Ayuntamiento hayan declarado excluidos, exceptuados o pródigos.

30.- Revisar y fallar los expedientes de clasificación, cualquiera que ésta sea, en que el acuerdo del Ayuntamiento haya sido impugnado o protestado.

40.- Fallar los expedientes de los prófugos cuando éstos se presenten o sean aprehendidos.

50.- Revisar y fallar los expedientes de los mozos de los reemplazos anteriores, que con arreglo a los preceptos de esta Ley están sujetos a revisión.

60. - Formar el padrón militar.

70. - Conceder prórrogas para el ingreso en filas.

8०. - Repartir el cupo entre los pueblos.

90.- Imponer las multas que esta Ley señala para las infracciones cometidas con anterioridad al ingreso de los mozos en Caja $[\ldots]^{\prime 1628}$.

Un puesto de relevancia dentro de la comisión lo ocupaba el oficial mayor, encargado de informar a la institución de los expedientes de excepción del servicio o de solicitud de prórrogas, de elaborar una estadística sobre excluidos y prófugos y de confeccionar el padrón militar. Una vez que el gobernador civil hubiese recibido esta información por parte del oficial mayor, se desarrollaría, entre el día primero de abril y el primero de junio, el acto de revisión de las excepciones y exclusiones en los locales de la Diputación provincial. El gobernador designaría un día para que cada municipio celebrase su juicio de revisiones. Al acto deberían acudir todos los mozos excluidos

${ }^{1628}$ Ley de reclutamiento y reemplazo de 19 de Enero de 1912, art. 122. 
temporal y totalmente del servicio, los que hubiesen reclamado o sido reclamados por existir dudas sobre la enfermedad o defecto físico alegado, los excluidos temporalmente sometidos a revisión y aquellos que hubiesen presentado reclamación contra algún acuerdo del Ayuntamiento. Estos mozos marcharían a cargo durante su traslado de un comisionado del consistorio, siempre un concejal no interesado en el reemplazo y que tendría derecho a percibir unas cantidades oportunas en compensación a su labor. Iría además acompañado de una relación con todas las diligencias practicadas por el Ayuntamiento durante los actos de alistamiento y clasificación de los reclutas. Llevaría también las filiaciones de los reclamados soldados, un certificado de medidas y reconocimientos de todos los alistados y una relación de los excluidos y exceptuados. Los mozos que se desplazasen también serían socorridos, a cuenta de los fondos municipales, con la cantidad de 50 céntimos de peseta diarios ${ }^{1629}$.

Una vez examinados por parte de la comisión los acuerdos de los Ayuntamientos, los argumentos de los reclamantes y la documentación y pruebas presentadas, dictaría una resolución que se publicaría inmediatamente y se ejecutaría sin perjuicio de los recursos que se pudiesen presentar ante el ministerio de la Gobernación. El delegado municipal comunicaría tales decisiones al alcalde de la localidad, quien a su vez se las transmitiría a los interesados. El juicio se podría alargar hasta seis meses si la comisión decidiese aumentar el plazo para presentar pruebas o para practicar las diligencias oportunas ${ }^{1630}$.

Lógicamente, las reclamaciones presentadas podían versar sobre la talla, el peso, las condiciones físicas y errores por parte de las autoridades municipales en la clasificación de los mozos. Por ello la comisión contaría con dos sargentos talladores y otros dos

1629 Ley de reclutamiento y reemplazo de 19 de Enero de 1912, arts. 123-126 y 128-130.

${ }^{1630}$ Ley de reclutamiento y reemplazo de 19 de Enero de 1912, arts. 132 y 133. 
pesadores nombrados por la autoridad militar de la provincia y con dos médicos nombrados por la propia comisión, pero pagados a cargo de los fondos provinciales a razón de 2,50 pesetas por cada reconocimiento, encargados de realizar los reconocimientos oportunos. Los acuerdos tomados en relación con la enfermedad o defecto físico de un mozo serían definitivos a no ser que se reclamase de nuevo ante el tribunal médico militar del distrito. Todos los exámenes médicos serían realizados en el hospital militar de la localidad $y$, de no haberlo, en el civil. De nuevo la Diputación provincial asumiría los gastos de estos reconocimientos ${ }^{1631}$.

Como instancia de reclamación para las decisiones de las comisiones mixtas encontramos al ministerio de la Gobernación. La posibilidad de acudir a él es reducida y sólo admitida en determinados supuestos recogidos en el capítulo IX de la ley. Así, no podrían apelarse los fallos de las comisiones confirmando los acuerdos municipales ni los que versasen sobre la aptitud física del mozo. Estos recursos, que nunca supondrían la suspensión en la ejecución de lo acordado por la comisión, deberían presentarse ante esta misma institución provincial en un plazo máximo de cinco días. También las autoridades militares podrían presentar reclamaciones como representantes del Ejército en todas las incidencias del reemplazo. Cuando fuese presentada una reclamación, además de extender un certificado de la misma al interesado, la comisión se dispondría a iniciar un expediente, cuya instrucción no debería durar más de un mes, donde se incluyesen todos los acuerdos adoptados y las pruebas presentadas, para ser enviado al ministerio, quien debería resolver de forma definitiva antes del día 10 de diciembre. El ministerio también podría revisar y anular cualquier resolución que hubiese infringido la ley aunque no mediase ninguna reclamación. También los fallos de

${ }^{1631}$ Ley de reclutamiento y reemplazo de 19 de Enero de 1912, arts. 135-139. 
las juntas consulares podrían ser recurridos ante el ministro de la Gobernación por conducto del cónsul ${ }^{1632}$.

Como últimas autoridades involucradas en el proceso de reclutamiento encontramos las figuras del comisario regio de la clase de jefe superior de la administración civil, o de general del Ejército, cuya misión era revisar todas las operaciones relativas al reemplazo, ya sean las realizadas por los Ayuntamientos o por las comisiones mixtas. Podrían además ir acompañados de personal facultativo y auxiliar que le asesorasen en la toma de decisiones. Sus fallos serían definitivos previa confirmación del Gobierno ${ }^{1633}$.

c) El alistamiento y su rectificación

Son los capítulos III, IV y V los que se encargaron de regular la primera fase del proceso: el alistamiento y su rectificación. El alistamiento se efectuaría anualmente el mes de enero por parte de las autoridades municipales o consulares. Para su elaboración todos los jóvenes de veinte años estarían obligados a solicitar su inclusión en las listas del municipio o consulado donde residiesen, bien ellos mismos, bien sus padres o tutores, entre el día 1 y el 15 de enero. Los mozos que residiesen en el extranjero deberían solicitar su inscripción en el Ayuntamiento donde hubiesen habitado sus padres en el último año o en el lugar en que ellos mismos hubiesen residido. Para que las autoridades municipales y consulares pudiesen asegurarse de que todos los mozos con la edad señalada se inscribiesen en el alistamiento, los jueces municipales deberían remitir al Ayuntamiento y a la comisiones mixta durante los meses de agosto y septiembre una relación con los mozos registrados a su

1632 Ley de reclutamiento y reemplazo de 19 de Enero de 1912, arts. 145-150 y 153.

${ }^{1633}$ Ley de reclutamiento y reemplazo de 19 de Enero de 1912, arts. 154-156. 
cargo que contasen con la edad precisa para ser alistados en el año inmediato. Teniendo en cuenta esta relación, el listado con los jóvenes inscritos, el padrón municipal y los libros parroquiales, durante la primera quincena del mes de enero se procedería a elaborar el alistamiento, acto en el que deberían estar presentes el alcalde, los concejales, el juez municipal y los curas párrocos que éstos designasen, pudiendo además asistir un delegado de la autoridad militar competente si ésta lo estimase necesario. Del alistamiento formarían parte todos los mozos que cumpliesen veintiún años durante el año en cuestión, independientemente de si se desconocía su paradero, y aquellos jóvenes que, sin haber cumplido los treinta y nueve años de edad, no hubiesen formado parte de alistamientos anteriores. Copias del documento de alistamiento se debían fijar, antes del 15 de enero, en los sitios públicos habituales de cada localidad ${ }^{1634}$.

Por lo que se refiere al alistamiento de las juntas consulares de reclutamiento, éste comprendería a todos los españoles de la edad indicada que residiesen en la demarcación consular correspondiente a no ser que acreditasen el haber solicitado su alistamiento en algún municipio del territorio nacional. En el caso de jóvenes que residiesen en territorios extranjeros donde no hubiese cónsul o éste no estuviese autorizado para las operaciones de reclutamiento, serían alistados en el territorio del Ayuntamiento donde hubiese estado su última residencia antes de salir del país. Los españoles nacidos en el extranjero serían alistados en el Ayuntamiento de Madrid. Para el caso de los jóvenes de veintiún años que debiesen servir en la Armada por hallarse inscritos en las industrias de pesca y navegación, serían los comandantes de Marina los encargados de remitir a los gobernadores civiles correspondientes la relación de los individuos

1634 Ley de reclutamiento y reemplazo de 19 de Enero de 1912, arts. 26-30, 32, 34, 35,39 y 42 . 
que deberían ser alistados para la Armada, quedando excluidos del alistamiento del Ejército ${ }^{1635}$.

También se impusieron sanciones para aquellos que no formasen parte de su alistamiento correspondiente. Así, los que no hubiesen sido comprendidos en su alistamiento y no se presentasen para ser incluidos en el del año siguiente, serían incluidos en el inmediato existente tras descubrirse la omisión, siendo además declarados soldados sin posibilidad de ser exceptuados, disfrutar de prórrogas ni reducción en el tiempo de prestación, sin perjuicio de las penas en que pudiesen incurrir por fraude u omisión ${ }^{1636}$.

La rectificación del alistamiento se haría el último domingo del mes de enero, y en los siguientes domingos sino se pudiese concluir en el primero, tras anuncio público de su celebración a través de edictos o pregones por parte del Ayuntamiento y una citación personal a todos los interesados. En este acto se escucharían las reclamaciones que presentasen el síndico municipal y los propios mozos, ya sea por exclusión o inclusión indebida en el alistamiento de algún mozo. El Ayuntamiento escucharía las reclamaciones y examinaría las pruebas presentadas, pudiendo establecer un plazo, que no excedería el segundo domingo del mes de febrero, para la presentación de las mismas, tomando una decisión por mayoría absoluta. Todo lo expuesto, reclamación, pruebas presentadas y resolución, sería recogido en un acta, y a los reclamantes se les expediría un certificado sin coste alguno donde se recogiesen todas estas circunstancias. En su toma de decisiones, los Ayuntamientos podrían declarar excluido a un joven que no debiese estar incluido en el alistamiento o que hubiese sido incluido en el de otro municipio aunque el interesado no lo reclamase. Sería en la fecha del segundo domingo de febrero cuando los consistorios deberían publicar las

1635 Ley de reclutamiento y reemplazo de 19 de Enero de 1912, arts. 36-40.

${ }^{1636}$ Ley de reclutamiento y reemplazo de 19 de Enero de 1912, art. 41. 
listas rectificadas. De una forma similar procederían las juntas consulares de reclutamiento ${ }^{1637}$.

La ley contempló la posibilidad de reclamación contra las resoluciones relacionadas con el alistamiento tomadas por los Ayuntamientos y las juntas. Se incrementó así el control sobre las decisiones municipales y se abrió la posibilidad de luchar contra las resoluciones tomadas por las autoridades locales. Para ello los interesados deberían presentar una reclamación por escrito o por comparecencia ante el secretario municipal a los tres días de ser publicado el alistamiento rectificado, recibiendo a cambio un certificado de su protesta. En un plazo máximo de quince días debería acudir a la comisión de reclutamiento con tal certificado. Esta institución tomaría una decisión ejecutiva sin perjuicio de la posibilidad de recurso ante el ministerio de la Gobernación ${ }^{1638}$. En el caso de que un mozo hubiese sido comprendido simultáneamente en los alistamientos de dos o más pueblos,

"[...] sus respectivos Ayuntamientos se pondrán de acuerdo para decidir a cual de ellos corresponde. Si se hallasen disconformes, remitirán los expedientes a la Comisión Mixta de Reclutamiento y ésta resolverá dentro del término de un mes, en el caso de que los pueblos interesados correspondan a la misma provincia.

Si perteneciesen los pueblos a distintas provincias procurarán ponerse de acuerdo las respectivas Comisiones Mixtas, y de no conseguirlo, remitirán los expedientes al Ministerio de la Gobernación en el plazo menor posible, que en ningún caso podrá pasar de ocho días, a fin de que en los dos meses siguientes resuelva dicho Ministerio lo que estime procedente" ${ }^{\prime 1639}$.

1637 Ley de reclutamiento y reemplazo de 19 de Enero de 1912, art. 45-54.

1638 Ley de reclutamiento y reemplazo de 19 de Enero de 1912, arts. 55-58 y 61.

1639 Ley de reclutamiento y reemplazo de 19 de Enero de 1912, art. 60. 
Para el caso de las reclamaciones presentadas en el extranjero o en los territorios coloniales, sólo sería posible hacerlo ante el ministerio de la Gobernación, que asumiría en este supuesto las funciones de los municipios y de las comisiones de reclutamiento ${ }^{1640}$.

d) El sorteo y la lucha por su no repetición

El acto más trascendental de todo el proceso, el sorteo, de cuya legalidad eran responsables todos los miembros del Ayuntamiento, se celebraría, previo anuncio público por parte de las autoridades locales y citación personal a los interesados, el primer domingo del mes de febrero a las 7 de la mañana en todos los municipios y consulados autorizados para ello, sin posibilidad de ser aplazado aunque quedasen recursos pendientes. De él formarían parte todos los jóvenes alistados. El sorteo se verificaría en una sesión pública del Ayuntamiento con las presencia de todos aquellos que lo deseasen. Para su celebración se escribirían en papeleta iguales el nombre de los mozos sorteables $y$, en otras papeletas, también iguales, se escribirían tantos números como mozos participantes en el sorteo. Las papeletas se introducirían en dos bolas iguales y éstas en globos, uno con los nombres y otro con los números. Una vez introducidas las papeletas y removidos los globos, serían dos niños menores de diez años los encargados de verificar su extracción, uno por cada globo. Síndico y presidente del Ayuntamiento leerían en voz alta las papeletas extraídas por los niños y las conservarían unidas, mientras que el secretario anotaría en un acta el nombre de los mozos que fuesen saliendo y el número que les hubiese correspondido. Al mismo tiempo un concejal anotaría el nombre de los jóvenes sorteados y el número obtenido de menor a mayor. Finalizado el sorteo y la redacción del acta, copias de la misma, firmadas por todos los

1640 Ley de reclutamiento y reemplazo de 19 de Enero de 1912, art. 63. 
miembros del consistorio y el secretario, se fijarían en los lugares públicos de costumbre. Tres copias del acta serían además enviadas por parte del alcalde a la comisión de reclutamiento correspondiente en un plazo máximo de tres días desde la celebración del sorteo. El presidente de la comisión se quedaría con una en su poder, otra la pasaría a la institución que preside y una tercera la enviaría al ministerio de la Gobernación ${ }^{1641}$.

Se intentó por todos los medios evitar la repetición de un sorteo por los atrasos que esto suponía para el desarrollo de todo el proceso. No existía la posibilidad de que se repitiese el sorteo a no ser que así lo indicase expresamente el Gobierno por ser imposible subsanar los defectos que hubiesen acompañado al acto. En el caso de que prosperase alguna reclamación ante la comisión mixta o el ministerio de la Gobernación y hubiese que excluir del alistamiento a algún individuo, así se haría cuando lo indicase la comisión mixta o el ministerio, y se descenderían sucesivamente los nombres correspondientes a los números que siguiesen al del individuo excluido, pero sin practicar un nuevo sorteo. Si por el contrario hubiese que incluir en el alistamiento a algún individuo cuando el sorteo ya se hubiese celebrado, se realizaría otro supletorio que seguiría las mismas directrices que el primero ${ }^{1642}$.

e) Exenciones y excepciones del servicio militar

Diferenció la Ley de 1912 en su capítulo VII entre exclusiones y excepciones del servicio militar ${ }^{1643}$. Las primeras, que se dividían en totales y parciales, serían aquellas motivadas por la falta de talla, enfermedades o defectos físicos recogidos en el Reglamento de

${ }^{1641}$ Ley de reclutamiento y reemplazo de 19 de Enero de 1912, arts. 64-67, 69-73 y 81.

1642 Ley de reclutamiento y reemplazo de 19 de Enero de 1912, arts. 74-80.

1643 Ley de reclutamiento y reemplazo de 19 de Enero de 1912, art. 83. 
exenciones adjunto a la ley ${ }^{1644}$. La exención parcial "[... ] alcanza a los mozos que no están en condiciones de prestar el servicio en filas, bien por padecer enfermedades o defectos físicos que puedan desaparecer en un periodo de tiempo determinado, o bien por impedirlo circunstancias, también determinadas, de carácter transitorio $[\ldots]^{1645}$.

Las causas de exclusión temporal serían las siguientes:

"10.- Los Oficiales de todas las Armas, Cuerpos e Institutos del Ejército.

20. - Los alumnos de las Academias Militares.

30.- Cuantos padezcan enfermedades de las comprendidas en la clase $4^{a}$ y $5^{a}$ del cuadro de inutilidades físicas [...], por considerarse que éstas pueden curarse en un periodo menor de tres años.

40.- Los comprendidos en la cifra absoluta o relativa, según los casos, de peso, talla y capacidad torácica, fijados en la clase $4^{a}$ de dicho cuadro $[\ldots]$.

50.- Los que estuvieran sufriendo penas correccionales.

60. - Los mozos que sufran las penas de cadena temporal, reclusión temporal, extrañamiento, presidio o prisión, que hayan de cumplir antes de los 39 años de edad.

70. - Los que se hallen procesados por causa criminal ${ }^{\prime 1646 .}$

En el caso de los oficiales, si causasen baja del Ejército antes de transcurridos 18 años de servicio, pasarían a figurar como oficiales de la reserva gratuita, situación que introducía por primera vez una ley.

\footnotetext{
1644 "Serán excluidos totalmente del servicio militar.

$1^{0}$.- Los mozos inútiles por defecto físico que figuren en la clase $1^{a}, 2^{a}$ y $3^{a}$ del cuadro de inutilidades físicas que acompañan a esta Ley, por considerarse las enfermedades en ellas comprendidas como incurables, en un periodo no menor de tres años.

20.- Los que no alcancen la cifra absoluta mínima de talla, peso y capacidad torácica fijados en la clase $2^{a}$ de dicho cuadro.

30.- Los que estuvieran sufriendo condena que no cumplan antes de los 39 años nuevos" (Ley de reclutamiento y reemplazo de 19 de Enero de 1912, art. 84).

1645 Ley de reclutamiento y reemplazo de 19 de Enero de 1912, art. 85.

1646 Ley de reclutamiento y reemplazo de 19 de Enero de 1912, art. 86.
} 
Los alumnos de las academias militares que abandonasen su plaza les correspondería servir con los reclutas de su reemplazo. Los que padeciesen enfermedades temporales o fuesen faltos de talla deberían pasar revisiones médicas durante tres años consecutivos, quedando excluidos totalmente del servicio si tras el último examen resultasen inútiles. Por el contrario, si fuesen conceptuados como útiles en cualquiera de las tres revisiones, serían de nuevo clasificados y deberían incorporarse al contingente en función de la suerte que obtuviesen en el sorteo. Por lo tanto, los inútiles temporales también debían participar en el sorteo. Los que estuviesen sufriendo penas correccionales 0 temporales $y$ extinguiesen su castigo, también deberían ingresar en filas ${ }^{1647}$.

En cuanto a las excepciones, se encargó la ley de definirlas como exenciones del servicio ordinario causadas no por motivos físicos, sino familiares (hijos y nietos únicos que mantengan con su trabajo a padres, abuelos o hermanos menores de diecinueve años pobres $^{1648}$, impedidos o sexagenarios) o de interés nacional ${ }^{1649}$.

Se incluyeron en esta categoría los mineros de Almadén que demostrasen que habían trabajado al menos cincuenta jornadas en el trabajo subterráneo o en la fundición en el año anterior a su alistamiento. Estos exceptuados también se debían someter, durante los tres años siguientes a su alistamiento, a la revisión de las causas que determinaron su situación y, pasados estos tres años, ingresarían en la segunda situación del servicio activo hasta extinguir el tiempo total de su prestación, pasando por las mismas situaciones que los

\footnotetext{
1647 Ley de reclutamiento y reemplazo de 19 de Enero de 1912, art. 86.

1648 No se define sin embargo en qué situación un mozo sería considerado pobre.

1649 ""A partir de 1912, los motivos de exclusión fueron reducidos considerablemente. La presión del Ejército y la sociedad en contra de los privilegios de que gozaban los mozos de cuota, Ilevaron no sólo a la abolición de estos privilegios [...] sino también de otros privilegios, como la exclusión total a los religiosos o a los operarios de minas. A cambio de ello, se instituyeron prórrogas por estudios, por asuntos de familia, por abandono de tareas agrícolas, etc." (MOLINA LUQUE, J.F., Quintas y servicio militar: aspectos sociológicos y antropológicos de la conscripción (Lleida, 1878-1960), P. 53).
} 
quintos de su reemplazo, con la obligación además de adquirir la formación militar e incorporarse a filas cuando se dispusiese. Si cesaran las causas de su excepción en alguna de las revisiones anuales, servirían en el cupo de su reemplazo. Igualmente en situación de guerra todas estas excepciones quedarían anuladas, aunque el Gobierno debería socorrer a las familias cuyo sustento dependía del trabajo del recluta ${ }^{1650}$.

También quedó contemplada en la ley la posibilidad de que un mozo solicitase la excepción una vez que hubiese ingresado en filas, ya que las causas que motivaron la misma se habían generado una vez que el recluta había ingresado en caja, situación ésta que es la primera vez que se recogía en una ley española de reclutamiento. La solicitud de este tipo de excepciones deberían los soldados alegarlas a través de sus jefes militares para que resolviese la comisión mixta y, en última instancia, el ministerio de la Guerra. A los individuos a quienes se concediese este tipo de excepción serían dados de baja de los cuerpos del Ejército y podrían regresar a sus casas, aunque también estarían sometidos a las revisiones correspondientes. Si cesara la causa de la excepción, tendrían la obligación de regresar al servicio activo ${ }^{1651}$.

La no inclusión entre los exceptuados de los ordenados in sacris y de los profesores de religión suscitó las protestas entre los grupos más conservadores de la Cámara, utilizando como argumentos la elevada misión que les estaba conferida a los sacerdotes, el predominio absoluto de la religión católica en España y a la posible desincentivación que, de cara al ingreso en la vida monacal y el sacerdocio, podría tener el fin de esta excepción:

1650 Ley de reclutamiento y reemplazo de 19 de Enero de 1912, arts. 88-91, 95, 96 y 327.

${ }^{1651}$ Ley de reclutamiento y reemplazo de 19 de Enero de 1912, art. 93. 
"Pero hay en esta ley un punto principal que se refiere a una excusa del servicio en filas, y que va a motivar también alguna observación de mi parte, porque ello entraña un problema de la mayor transcendencia e importancia: me refiero a los ordenados in sacris y a los profesos en religión. [...].

Yo no puedo olvidar, creo que la Cámara no lo olvida tampoco, que es la ley de Reclutamiento de un país católico; que la religión católica, no sólo por estar así precisamente declarado en la Constitución, es la religión del Estado, sino por ser, en realidad, la religión de los españoles en su inmensa mayoría, en su casi totalidad; $y$ todo eso no lo podemos desconocer al dirigirnos a la sociedad española y tratar de dictar leyes que a todos, absolutamente a todos, personalmente nos alcanzan.

Y cuando no se excluye a nadie de esta profesión, cuando el sacerdocio significa todo esto, a mi entender, magisterio, enseñanza, vocación, virtud, prestar inmensos servicios a todos sus semejantes, bien merece la pena que hagamos una comparación de lo que es el sacerdocio y lo que es la necesidad del servicio militar. [...]

Si además de sentirse el joven con vocación para el sacerdocio, para el magisterio de la Iglesia, magisterio por excelencia, se siente poseído de esos íntimos afectos, de esos espirituales sentimientos, y cree que profesando votos de más estrecha regla que los del secular sacerdocio, viviendo en religión, consagrado con otros, o en más estrecha vida todavía, a las Ordenes religiosas, piensa consagrar su existencia a esta práctica de la religión, al amor de sus semejantes, a la enseñanza de la religión, a conquistar para su fe y para su Iglesia más almas, que es lo que puede ofrecer para la redención de la snva, el ordenado in sacris y el que profesa en religión merecen, para el que opina como opino yo, una consideración, un respeto $y$, en relación con el servicio militar, tener en cuenta su situación tan singular y especial, pues yo, que vivo en la ley militar, entiendo que es aquella religión de ley más estrecha, de un respeto mayor todavía que la de la disciplina en que vivo.

[...].

Si al joven que siente en sus primeros años la fe calurosa, la vocación por la profesión del sacerdocio en el orden general del presbiterado o en el particular de las Congregaciones religiosas, en esa época le apartáis del seminario o le obligáis a salir de su 
Comunidad, ¿no entendéis, señores de la Comisión, no opina conmigo el Congreso que es una ley, que no digo que esté hecha en su contra, pero que, produciendo sus efectos en los años en que más necesario le es vivir y convivir en esa situación, al sacarle de ella para que venga a prestar el servicio militar podremos dañar esas profesiones, podremos contribuir, aunque no queramos, sin espíritu de escuela, pero en realidad a que sea más difícil la perseverancia en los seminarios $y$ en los conventos? ${ }^{1652}$.

La respuesta del Gobierno y la comisión que elaboró la ley en este sentido fue muy clara, ya que admitió la importancia y peculiaridad de la labor sacerdotal, por lo que, sin ser excluidos del servicio, los ordenados in sacris que obtuviesen la suerte del soldado serían destinados a funciones especiales, y así se recogía en el Capítulo XVI de la ley ${ }^{1653}$.

f) Clasificación de los soldados: la aptitud o ineptitud para el servicio

Se centró el capítulo VIII en el importante acto de clasificación de los mozos, donde se decidiría qué jóvenes eran aptos para el servicio en función de sus cualidades físicas.

Este acto debería celebrarse el primer domingo del mes de marzo en los distintos municipios previa convocatoria de todos los mozos que hubiesen participado en el sorteo. Aquellos que no se presentasen serían declarados prófugos. Para este acto de la clasificación deberían reunirse todos los representantes municipales junto al médico titular de la localidad, que cobraría 2,50 pesetas por cada recluta examinado, y un hombre encargado expresamente de

1652 Discurso del Sr. Amat, Diario de sesiones de las Cortes, 12/05/1911, no 33, pp. 817-819.

1653 Discurso del Sr. Ruiz Jiménez, Diario de sesiones de las Cortes, 12/05/1911, no 33 , pp. 819 y 820. 
tallar y pesar a los mozos, un sargento del Ejército prioritariamente $y$, en su defecto, un vecino de probada aptitud. Todos los mozos alistados deberían ser tallados y pesados en este acto, mientras que el médico se encargaría de realizar el reconocimiento pertinente y de obtener la medida torácica de los jóvenes, decidiendo en función de este dato, junto a la talla y el peso, el coeficiente de aptitud física ${ }^{1654}$. Por primera vez en la legislación española sobre reclutamiento quedó establecido el cálculo de un coeficiente físico en función de las características del mozo para permitir su clasificación, y por primera vez también se permitió la posibilidad de que, previa solicitud, un mozo fuese reconocido, pesado y tallado en el Ayuntamiento de su lugar de residencia y no del lugar donde hubiese sido alistado ${ }^{1655}$.

Era durante el acto de clasificación el momento en el que los mozos podrían presentar alegaciones para ser excluidos o exceptuados del servicio junto a las pruebas, justificaciones y documentos que demostrasen los motivos alegados para ello. El consistorio podría establecer un plazo, no más allá del tercer domingo del mes de marzo, para la presentación de las pruebas. El Ayuntamiento debería expedir al joven un certificado en el que constasen los motivos expuestos, pero al mismo tiempo debería decidir, sin perjuicio de alegaciones ante la Comisión mixta, en cual de estas cinco situaciones quedan todos los mozos alistados, a saber: excluidos totalmente del servicio, excluidos temporalmente del contingente, soldados, soldados con excepción del servicio en filas o prófugos. Estos acuerdos serían ejecutorios a no ser que se presentasen reclamaciones contra ellos por escrito o de palabra ante el alcalde, quien debería de hacerlo constar en el expediente de declaración de los soldados. Tampoco serían ejecutorios los acuerdos referentes a los excluidos totalmente del servicio, excluidos temporalmente y exceptuados, ya que deberían someterse a la 
revisión por parte de la comisión mixta respectiva. Las resoluciones dictadas en este acto de clasificación por parte de las juntas consulares de reclutamiento y de la Junta de Reclutamiento del Golfo de Guinea si serían en cambio ejecutivas en todos los casos a no ser que se presentasen reclamaciones ante el ministerio de la Gobernación por conducto del cónsul respectivo. Si las causas que habían determinado la exclusión de algún mozo hubiesen cesado con posterioridad al acto de clasificación, el Ayuntamiento o los interesados podrían alegar esta circunstancia ante la Comisión mixta, que debería iniciar un expediente aclaratorio ${ }^{1656}$.

Una vez que hubiese finalizado la clasificación de los mozos alistados en el año del reemplazo, se procedería a realizar similares operaciones con los excluidos temporalmente y exceptuados de los tres reemplazos anteriores ${ }^{1657}$.

g) La lucha contra el prófugo: el papel de las comisiones mixtas de reclutamiento

Se encargó el capítulo XI de la regulación, persecución e imposición de penas para los huidos del servicio militar. Se consideró prófugo "[...] a los mozos incluidos en algún alistamiento que no se presenten personalmente al acto de la clasificación [...] y los que debiendo hacer su presentación personal ante las comisiones mixtas para los efectos de revisión, dejaron de hacerlo sin causa justificada"1658.

La instrucción del expediente para que un mozo fuese declarado prófugo correspondía a los Ayuntamientos, pero su resolución

\footnotetext{
1656 Ley de reclutamiento y reemplazo de 19 de Enero de 1912, arts. 105, 107, $110-114$ y $117-119$.

${ }_{1657}$ Ley de reclutamiento y reemplazo de 19 de Enero de 1912, art. 116.

1658 Ley de reclutamiento y reemplazo de 19 de Enero de 1912, art. 157.
} 
definitiva correspondía a las comisiones mixtas. Todo prófugo capturado debería comparecer ante la comisión mixta para que su expediente fuese resuelto, ingresando inmediatamente en la caja de reclutas sin tener en cuenta la fecha de su aprehensión. Aquellos prófugos útiles que se presentasen antes o durante el acto de concentración de reclutas, además de incorporarse inmediatamente a filas con los restantes miembros de su reemplazo, perderían todos sus derechos a la hora de solicitar una prórroga, solicitar excepciones o disfrutar de reducciones en el servicio o licencias temporales. No sufrirían sin embargo ningún aumento en su tiempo de prestación. Por el contrario, los prófugos presentados después de la concentración de reclutas, además de perder todos los derechos anteriormente mencionados, serían destinados a las guarniciones españolas en África. Si se hubiesen presentado voluntariamente, servirían cuatro años en activo, mientras que si fuesen aprehendidos lo harían durante cinco años. En el caso de resultar inútiles para el servicio, pagarían una multa de entre 50 a 250 pesetas. Los gastos que hubiesen ocasionado su captura serían además abonados por ellos mismos. Aquellos que hubiesen colaborado en la fuga $u$ ocultamiento de un prófugo también serían castigados, en este caso con una multa de entre 100 y 500 pesetas $^{1659}$.

h) Las prórrogas: el retraso en la incorporación al servicio

El capítulo XII se centró en este importante capítulo legislativo, ya recogido en proyectos previos, como es la concesión de prórrogas temporales para retrasar la incorporación al servicio ${ }^{1660}$. Estas

${ }^{1659}$ Ley de reclutamiento y reemplazo de 12 de Enero de 1912, arts. 158-164, 302 y 303.

1660 " $\mathrm{Si}$ bien es cierto que este tipo de medidas [cuotas y prórrogas] está enfocado a adecuar el ahora "obligatorio" servicio militar a las clases más desfavorecidas económicamente, también supone la modernización del regulamiento de la quinta 
prórrogas tendrían un carácter anual, sin bien se podrían ampliar durante otros tres años consecutivos. Las solicitudes de prórroga deberían presentarse ante el presidente de la comisión mixta respectiva antes del primero de junio. Los motivos que un joven podía aducir para solicitar una prórroga eran ciertamente limitados, a saber: estudios ya comenzados, asuntos de empresa comerciales o industriales, abandono inevitable de las tareas agrícolas en el caso de incorporarse al servicio y la existencia de un hermano legítimo en la primera situación del servicio activo. Esta última posibilidad finalizaba cuando el hermano pasase a la segunda situación del servicio $\operatorname{activo}^{1661}$.

La concesión de prórrogas por asuntos familiares suscitó el rechazo por parte del conservador García de Leániz, que consideraba imprescindible, de cara a la concesión de una prórroga, el que el candidato pudiese demostrar una adecuada instrucción militar previa:

"La concesión de prórrogas hecha oportuna, autorizada y justificadamente merece mi aprobación. No cabe duda que aquel que está dedicado al estudio de una carrera y le falta un año, o tal vez meses para terminarla, no debe interrumpir sus estudios para incorporarse a filas, y lo mismo el que está dedicado a una empresa industrial importante o a una empresa comercial o a faenas agrícolas donde seriamente sufriera material perjuicio interrumpiéndolas. En todos estos casos encuentro justificada la prórroga, pero no así en el caso de los asuntos de familia que indicáis en vuestro dictamen, porque los asuntos de familia deben siempre dejarse a un lado ante la sagrada obligación de servir a la Patria. Y aun tratándose de esos motivos justificados de prórroga, yo admito que se difiera la incorporación a filas, pero sin que eso sea puerta abierta al favor, sin

frente a las características de una sociedad que se recupera de la crisis finisecular y en la que el porcentaje de analfabetización va disminuyendo progresivamente, así como aumentando el número de trabajadores ocupados en el sector comercial en industrial" (FRIEYRO DE LARA, B., El reclutamiento militar en la crisis de la Restauración: el caso riojano (1896-1923), p. 67).

${ }^{1661}$ Ley de reclutamiento y reemplazo de 19 de Enero de 1912, arts. 166-169. 
que eso sea pretexto para que en determinadas ocasiones las personas encargadas de conceder la prórroga sean árbitras para definir si Fulano o Mengano está en las condiciones exigidas para concedérsela, por razón de carrera o por razón de ejercicio del comercio o de la industria, etc.

Contra eso protesto, porque yo persigo que todos los españoles seamos iguales para servir a nuestra Patria, $y$, por tanto, no puedo admitir que la influencia de un recluta pueda colocarlo en situación privilegiada respecto a los demás. Yo sólo admito que cuando un recluta, al ser llamado a filas, acredite verdadero conocimiento de la instrucción militar, del manejo de las armas, de todo aquello que le pueda hacer en un momento determinado útil para la defensa de su Patria, se le concedan ciertas ventajas, y todas en ese caso me parecerán pocas. Pero en cambio por digno de consideración que sea el estudiante, el comerciante, el industrial o el agricultor, si ignora la instrucción militar, me parecerá contraproducente que la prórroga se le conceda.

$[\ldots]$.

Respecto de prórrogas [...], lo que quiero es que la Comisión declare que todas las que se concedan o puedan concederse quedarán siempre subordinadas a la demostración de que se posee la instrucción militar"1662.

La decisión en la concesión de prórrogas correspondía a la comisión mixta de cada provincia, a las juntas de los consulados autorizados en el extranjero y a la Junta de Reclutamiento en el caso de la colonia del Golfo de Guinea, si bien era el ministerio de la Gobernación el encargado de determinar el número de prórrogas que podría concederse en cada caja de reclutas en función de las necesidades militares y de las solicitudes presentadas, no pudiendo nunca exceder el diez por ciento de los ingresados en caja cada año. La duración de las prórrogas y su ampliación también sería decidida por la comisión antes del primero de noviembre de cada año. Sus

1662 Discurso del Sr. García de Leániz, Diario de sesiones de las Cortes, 13/05/1911, n० 34, p. 832. 
fallos podrían ser impugnados ante el ministerio de la Gobernación $^{1663}$.

En el caso de que el número de solicitudes de prórroga excediese el cupo concedido por el ministerio, la ley estableció una serie de criterios de prioridad. Así, para el primer grupo tendrían preferencia los que estuviesen más cerca de finalizar sus estudios y, en igualdad de condiciones, los de mayor edad y, en último extremo, los que careciesen de medios de fortuna. En el segundo grupo tendrían preferencia los dedicados al comercio al por menor o pequeñas industrias, mientras que en el tercer grupo la tendrían los propietarios de tierras o arrendatarios con menor importancia. Para los que solicitasen la ampliación de la prórroga, los interesados deberían acreditar ante la comisión mixta que continuaban con sus estudios o que subsistían las causas por las que obtuvieron la primera prórroga. No disfrutarían de ninguna ampliación los que durante el último año hubiesen sido condenados por delitos o los que hubiesen abandonado los estudios sin causa justificada. Tampoco podrían disfrutar de prórrogas los prófugos y los que hubiesen abandonado por su propia voluntad la causa de su excepción. Por supuesto los reclutas que deseasen renunciar a su prórroga podrían hacerlo incorporándose a filas en el primer reemplazo siguiente. Los individuos que hubiesen disfrutado de prórroga deberían incorporarse a filas al finalizar ésta, si bien su disfrute era compatible con la reducción de servicio en filas que desarrolla el capítulo segundo. En caso de guerra o en situaciones excepcionales, no se concederían prórrogas y podrían declararse nulas todas las existentes, ingresando en el Ejército los mozos que estuviesen disfrutando de ellas ${ }^{1664}$.

1663 Ley de reclutamiento y reemplazo de 19 de Enero de 1912, arts. 170-175 y 185-188.

1664 Ley de reclutamiento y reemplazo de 19 de Enero de 1912, arts. 178-181, 184 y $189-191$. 
i) Conducción e ingreso de los reclutas en la caja de la provincia

Estableció la ley el día primero del mes de agosto como la fecha en la que tendría lugar el ingreso de los mozos en caja o en las juntas consulares de reclutamiento, previa convocatoria de los afectados a través del Boletín Oficial de la provincia por parte del gobernador civil y a través de edictos publicados en los lugares habituales por parte del alcalde de cada localidad. Los mozos, que una vez ingresados pasaban a depender de la jurisdicción militar, serían acompañados en su viaje y hasta el ingreso en caja por un comisionado del Ayuntamiento, que debería ir acompañado de una relación por duplicado con los mozos alistados, entregando una de las copias al jefe de la caja. El jefe de la caja entregaría a los comisionados una cartilla militar para cada mozo ingresado del municipio correspondiente ${ }^{1665}$. En esta cartilla, utilizada a modo de cédula personal y cuya pérdida conllevaba una multa de cinco pesetas para su titular, se incluirían datos como "[...] la Caja que la expide, el año, el número de orden, situación y nombre del interesado, su media filiación, impresión digital, excepciones, exclusiones o prórrogas que haya disfrutado y las causas que la motivaron, sus deberes y derechos en las diferentes situaciones militares, y los castigos o penas a que puede hacerse acreedor en caso de falta o delito militar"1666.

1665 Ley de reclutamiento y reemplazo de 19 de Enero de 1912, arts. 193, 194, 196 y 198,200 y 202.

${ }^{1666}$ Ley de reclutamiento y reemplazo de 19 de Enero de 1912, art. 197. 
j) Las diferentes situaciones militares a los largo de los dieciocho años de servicio militar

En el capítulo XIV se definieron y computaron temporalmente las distintas situaciones militares por las que pasarían los reclutas a lo largo de sus dieciocho años de servicio militar. Sin embargo, el Gobierno podría suspender, mediante real decreto, el pase de una situación a otra y la expedición de licencias absolutas en caso de guerra y en situaciones extraordinarias. Las situaciones definidas fueron las siguientes ${ }^{1667}$ :

10.- Reclutas en caja (plazo variable).

20.- Primera situación del servicio activo (tres años).

30.- Segunda situación de servicio activo (cinco años).

40.- Reserva (seis años).

50.- Reserva territorial (resto de los dieciocho años) ${ }^{1668}$.

A la primera tipología pertenecerían todos los mozos sorteados no excluidos del servicio, que quedarían en sus casas durante el plazo máximo de un año hasta su ingreso en el servicio activo. Los que hubiesen obtenidos prórrogas y los exceptuados permanecerían en esta situación de recluta en caja hasta que caducasen sus prórrogas o se investigasen los motivos de su excepción. Los reclutas en caja pasarían a la primera situación de servicio activo, ya perteneciesen al cupo de filas o al de instrucción del contingente. Los primeros ingresarían en filas para completar las unidades orgánicas, mientras que los segundos estarían destinados a cubrir las bajas que ocurriesen en el cupo de filas de su municipio. La duración de la

1667 "Esta disparidad de situaciones también existió en Europa, donde la edad de reclutamiento osciló entre los diecisiete y cuarenta y cinco años en Alemania e ingreso en filas a los veinte, en Austria entre diecinueve y cuarenta y dos años y e ingreso a los veintiuno y cincuenta en Bélgica e ingreso a los veinte" (FEIJÓo GÓMEZ, A., Quintas y protesta social en el siglo XIX español, p. 227).

1668 Ley de reclutamiento y reemplazo de 19 de Enero de 1912, arts. 204 y 212. 
primera situación del servicio activo sería normalmente de tres años, si bien el Gobierno podría reducir este periodo de tiempo a través de licencias temporales si así lo considerase oportuno ${ }^{1669}$.

Por lo que respecta a la segunda situación del servicio activo, a ella pertenecerían todos los reclutas que hubiesen cumplido los tres primeros años del servicio activo, estando obligados a servir en el Ejército de nuevo en caso de movilización. Superados los cinco años en esta situación, los mozos pasarían a servir en la reserva durante otros seis $y$, finalizado este plazo de tiempo, pasarían a la reserva territorial hasta completar los dieciocho años de servicio, recibiendo entonces la licencia absoluta. Independientemente de la situación en la que se encontrase el recluta, debería pasar revista anual ante las autoridades militares locales durante los meses de noviembre y diciembre. Los soldados pertenecientes a la primera situación del servicio activo podrían viajar, con el permiso de sus jefes, por el territorio peninsular, los archipiélagos y las posesiones africanas. También podrían disfrutar de licencias temporales o ilimitadas, pero no podrían contraer matrimonio. Todos los soldados en segunda situación de servicio activo, en reserva y reserva territorial podrían, con conocimiento de sus jefes, residir en el extranjero y viajar libremente dentro o fuera de la península. Esta autorización no les eximiría de la obligación de pasar revista anual y de incorporarse al servicio en caso de guerra o de alteración del orden público. También tenían el deber de acudir al llamamiento que se les hiciese por sus jefes militares, bien sea para asambleas, maniobras, funciones de guerra u otro cualquier propósito, que en ningún caso podría superar el mes de duración. Sí que podrían en cambio contraer matrimonio libremente ${ }^{1670}$.

1669 Ley de reclutamiento y reemplazo de 19 de Enero de 1912, arts. 205-208.

1670 Ley de reclutamiento y reemplazo de 19 de Enero de 1912, arts. 209-211, 213216 y 218. 
Además de los reclutas forzosos, la Ley de 1912 admitió la posibilidad de ingreso voluntario en el Ejército con destino preferente a las guarniciones del norte de África ${ }^{1671}$, cuya composición se basaría, siempre que fuese posible, en el voluntariado ${ }^{1672}$. Para ello se establecieron unos requisitos mínimos: ser español o indígena residente en las colonias españolas; tener entre dieciocho y treinta años de edad o más de catorce para los hijos de los oficiales del Ejército y la Armada o para los destinados a las bandas de cornetas, trompetas y tambores de los cuerpos y unidades del Ejército; demostrar aptitud física para el manejo de las armas y no pertenecer a la situación de reclutas en caja ni a la primera de servicio activo, los del cupo de filas o los del cupo de instrucción. Sí que podrían ingresar como voluntarios los individuos de la reserva de la Armada. Se remitió la legislación a un futuro reglamento de voluntarios, enganchados y reenganchados, el desarrollo de las formalidades del contrato, premios, duración y derechos y deberes de los mismos ${ }^{1673}$.

\footnotetext{
1671 "[...] hay que dar un carácter mixto a las leyes de reclutamiento, sin que nosotros destruyamos el principio del voluntariado. Ahí lo tiene S. S. establecido en un artículo, creándolo a fin de que sirva para aquello para lo que el voluntariado es más apropiado, para aquello que está probado que es más necesario y más eficaz, para el servicio en las colonias, para el servicio fuera de la Patria" (Discurso del Sr. Armiñán, Diario de sesiones de las Cortes, 11/05/1911, no 32, p. 776).

1672 "Por primera vez parece haber una clara intención de cubrir el reemplazo de las tropas coloniales con voluntarios, invirtiendo la contratación de los soldados de cuota en su contratación, pero estos voluntarios nunca fueron suficientes y la situación económica del Estado dificultó la empresa, limitándose a tamizar la admisión de voluntarios para África [...] y a potenciar el reclutamiento de voluntarios en el extranjero a través de la creación de Juntas Consulares encargadas de su contratación en Rabat, Berbam Saint Nazarie, Mogador, Perpignan, Sofi, Bayona, Casablanca, Tánger, Tolouse, Manila, El Havbre, Cette, Pau, Mazagón, Burdeos, Santo Domingo, Marsella, Nueva York, Orán, Galvestón y Guayra. Gracias a estos se logró formar el cuerpo de la Legión, a imitación de Francia, pero no se creó un Ejército colonial voluntario que acabase con los problemas de reclutamiento decimonónicos y que dulcificase la contribución de sangre" (FEIJÓO GÓMEZ, A., Quintas y protesta social en el siglo XIX español, p. 233).

1673 Ley de reclutamiento y reemplazo de 19 de Enero de 1912, arts. 251-259 y 329.
} 
k) La distribución del contingente y destino de los mozos sorteados

Fuero los capítulos XV y XVI los que regularon estas cuestiones. Ya indicamos anteriormente que una de las competencias que asumió la comisión mixta de reclutamiento fue la de distribuir el cupo asignado a su provincia entre sus municipios. Para iniciar este trámite la comisión debía elaborar un documento para ser enviado al ministerio de la Guerra durante la primera quincena del mes de septiembre donde se indicase el número de mozos sorteados en cada caja y las prórrogas concedidas. Para fijar los cupos se debían tener en cuenta el número de vacantes por cuerpo, las bajas que se considerasen probables y el número de hombres de los distintos cuerpos del Ejército a quienes correspondiese pasar a la segunda situación de servicio activo.

Una vez recibida esta documentación, el ministerio debía publicar un real decreto señalando el número total de hombres que debían constituir el cupo total de filas en función de las necesidades existentes, así como su distribución por cajas. Para calcular el cupo de filas se tomaría como base del contingente la suma de los individuos del reemplazo anual ingresados en todas las cajas. Una vez que las comisiones hubiesen recibido esta documentación, procederían a repartir el cupo de cada caja entre los términos municipales de su demarcación ${ }^{1674}$.

La concentración de los reclutas en sus respectivas cajas se produciría a partir del día 1 de noviembre. El llamamiento para este acto se realizaría, dentro de cada municipio o demarcación consular, empezando por el mozo que hubiese obtenido el primer número en el sorteo ${ }^{1675}$. Sin embargo, "los mozos que en el acto de la 
concentración resulten inútiles o presuntos inútiles para el servicio militar, así como los desertores, serán reemplazados por los números más bajos del cupo de instrucción del Municipio correspondiente, tan pronto se compruebe la no aptitud de los primeros y la deserción de los últimos"1676.

En su viaje los mozos serían socorridos con la cantidad de cincuenta céntimos de peseta diarios abonados por el comisionado municipal que los acompañase, mientras que los mozos pobres residentes en el extranjero realizarían su viaje a cuenta del Estado ${ }^{1677}$.

Todos los reclutas concentrados en las cajas serán tallados y pesados por sargentos del Ejército y reconocidos por médicos militares como paso previo al envío a su destino correspondiente en los distintos cuerpos y armas de la institución armada en función de las necesidades encontradas y de la posibilidad de una rápida movilización. Los mozos que al corresponderles ingresar en filas poseyesen cualquier título de determinada profesión útil y de aplicación para funciones especiales del Ejército, y los ordenados in sacris, serían destinados a funciones especiales, pero no excluidos del servicio. Los residentes en Baleares, Canarias y las posesiones del Golfo de Guinea serían destinados normalmente dentro de sus respectivos ámbitos de residencia, mientras que los individuos de las congregaciones de misioneros que prestasen el servicio propio de su ministerio en las misiones españolas de África, América y Asia recibirían un destino en estos ámbitos coloniales. Para los mozos del cupo de instrucción se procuraría el destino en los cuerpos y unidades más próximas a su lugar de residencia ${ }^{1678}$.

\footnotetext{
1676 Ley de reclutamiento y reemplazo de 19 de Enero de 1912, art. 232.

1677 Ley de reclutamiento y reemplazo de 19 de Enero de 1912, arts. 233 y 234.

1678 Ley de reclutamiento y reemplazo de 19 de Enero de 1912, arts. 235-238, 240, 243 y 244.
} 
I) La posibilidad de concesión de licencias temporales a los reclutas

La Ley de 1912 recogió un capítulo exclusivo, el XVIII, para regular la concesión de licencias temporales a los reclutas, que se considerarían como tiempo efectivo servido en filas pero sin cobrar los haberes que les correspondiesen por su situación militar.

En lo que respecta a los individuos del cupo de filas en la primera situación de servicio activo, estas licencias podrían alcanzar a todo el Ejército, o solo a determinadas regiones, armas, cuerpos o unidades, según las necesidades del servicio y a juicio del Gobierno. Las licencias concedidas a esta tipología de soldados podrían ser bimensuales, trimestrales, cuatrimestrales o ilimitadas, si bien estas últimas serían exclusivas de los soldados que se encontrasen en el tercer año de servicio. Tendrían preferencia en la concesión de estas licencias aquellos que llevasen más tiempo sirviendo en el Ejército y, dentro de éstos, los que poseyesen la instrucción primaria; los que tuviesen el título de tiradores de primera en el caso del cuerpo de Infantería o hubiesen alcanzado premios en los concursos de tiro nacionales o provinciales; los individuos que acreditasen, mediante la documentación correspondiente, el haberse distinguido en cualquier profesión y, por último, los que por su aptitudes y méritos militares se hubiesen hecho merecedores de la licencia a juicio de sus jefes militares ${ }^{1679}$.

1679 Ley de reclutamiento y reemplazo de 19 de Enero de 1912, arts. 245-250. 
m) La importancia concedida a la instrucción militar

La nueva ley concedió una importancia que hasta ahora ningún texto legislativo había recogido hacia la instrucción militar ${ }^{1680}$. Por primera vez se dedica un capítulo exclusivo a esta temática, síntoma de la reconocida necesidad de tener un Ejército con suficiente número de efectivos, pero también lo suficientemente formados para el arte de la guerra. La ley de nuevo se remitió a reglamentos posteriores para regular la necesaria instrucción, pero sí que recogió algunas pinceladas a tener en cuenta.

En primer lugar, la instrucción quedó establecida como una obligación de todos los reclutas que se debería realizar durante el primer año de prestación en los cuerpos donde estuviesen destinados, sin precisar su duración, intensidad y forma de ejecución. Se completaría esta formación con la asistencia de los soldados a los ejercicios y maniobras que realizasen sus cuerpos durante el segundo y tercer años de servicio. A la formación militar se unió la nueva obligación de educar en las primeras letras a todos los reclutas de forma que, al salir de filas, no existiese ningún soldado analfabeto. Además, para facilitar la instrucción de los individuos de la segunda agrupación del contingente que aspirasen a permanecer en filas el menor tiempo posible, de los que pretendiesen acogerse a los beneficios de la cuota, $y$, en general, de todos los mozos que voluntariamente lo deseasen, se crearían escuelas militares, dependientes del Estado y particulares ${ }^{1681}$.

1680 "¿Cuál es la finalidad primordial y principal que persigue la ley? La instrucción militar obligatoria [...]. Sí; no lo rectifico, porque con ello se evidencia que no es un sueño ni un ideal irrealizable lo que se persigue en este proyecto. Esta instrucción militar obligatoria es la base fundamental del servicio militar obligatorio [...]" (Discurso del Sr. Conde de Santa Engracia, Diario de sesiones de las Cortes, 10/05/1911, no 31, p. 756).

${ }^{1681}$ Ley de reclutamiento y reemplazo de 19 de Enero de 1912, arts. 260-266. 
La escasa concreción respecto a la aplicación de estas medidas y al esfuerzo educativo en el seno del Ejército encontró las críticas del partido Reformista, que acusó al Gobierno de inconcreción y de vender un producto escasamente perfilado:

"La ley respecto de la instrucción militar se limita a un buen deseo, a establecer que deberán instruirse todos, que a todos los del cupo de instrucción se les debe dar la instrucción. ¿Como va a ser esa instrucción? En dónde la van a recibir sí lo sabemos, pero precisamente porque dice dónde la van á recibir es por lo que podemos creer que no la van a recibir, porque dice que la van a recibir en los cuerpos. [...]. Si al lado o a continuación de esa afirmación viniese explicado cómo va a ser esa instrucción y cuánto va a costar, podríamos pensar que quizá se diese; pero la Comisión no nos dice cuánto va a costar [...].

De modo que esta es una ley en la que se fija el ideal. Aquí la Comisión nos dice, por lo visto, cuál es el mejor Ejército que se puede crear, y no se ha preocupado [...] de adaptar esa ley a los medios económicos de la Nación ${ }^{\prime 1682}$.

n) Reducción del tiempo de servicio en filas: el soldado de cuota o el mantenimiento de la discriminación

Eliminadas definitivamente la redención y la sustitución, recogió la ley la posibilidad de reducir el tiempo de prestación por distintos motivos, entre los cuales se volvió a contemplar la desigualdad por motivos económicos, ya que tan solo una minoría de la población podría soportar, en función de sus condiciones económicas, el pago

1682 Discurso del Sr. Pedregal, Diario de sesiones de las Cortes, 10/05/1911, no 31, p. 752. 
de la cuota ${ }^{1683}$, y permitiendo además con este pago al Estado recibir ingresos extra:

1. Aquellos que, perteneciendo al cupo de filas, acreditasen conocer la formación teórica y práctica del recluta a través de un examen o un certificado del Ejército, abonasen la cantidad fija, y no progresiva en función de su riqueza, de 1.000 o 2.000 pesetas en concepto de cuota militar en las delegaciones de Hacienda del Estado, y fuesen capaces de sustentarse por su cuenta y de costear su propio equipo. Su prestación se vería reducida a diez meses para el caso de los que abonasen 1.000 pesetas y a cinco para los que pagasen el doble de esa cantidad, pudiendo además residir fuera del cuartel y elegir su lugar de destino militar para evitar las peores plazas y poder residir en su ámbito geográfico que deseasen, si bien el pago de la cuota no permitía evitar el traslado a las guarniciones africanas en caso de guerra $^{1684}$.

2. Los padres que contasen con tres o más hijos alistados podrían ver reducido su tiempo de prestación pagando la cuota íntegra por dos de ellos, la mitad por un tercero y una cuarta parte por el cuarto y siguientes ${ }^{1685}$.

\footnotetext{
1683 "Este grupo social era el mismo que defendió la sustitución y redención a lo largo de todo el siglo, el mismo que se benefició del negocio de seguros de quintas y contratación de sustitutos, el mismo que impidió el encarecimiento de la redención $[\ldots]$ y que luchó por su abaratamiento $[\ldots]$, y los mismos que consideraron un abuso las cuotas decretadas en 1912" (FEIJÓo GÓMEZ, A., Quintas y protesta social en el siglo XIX español, p. 274).

1684 "[...] la legislación de 1912 sigue lastrada por cierta discriminación económica, pues aunque había abolido la redención, al establecer un sistema de pago posibilita la aparición de un recluta -el soldado de cuota- que vuelve a establecer una discriminación positiva para las familias con ciertas posibilidades económicas" (FERNÁNDEZ VARGAS, V., Sangre o dinero: el mito del Ejército nacional, p. 79).

1685 Ley de reclutamiento y reemplazo de 12 de Enero de 1912, arts. 267-271, 276, 277 y $279-282$.
} 
Los individuos que gozasen de los beneficios de la cuota ${ }^{1686}$ cubrirían cupo por su pueblo o demarcación consular, no recibirían ningún haber y costearían por su cuenta los gastos ocasionados por su desplazamiento a la concentración en caja o la incorporación a los cuerpos que hubiesen elegido, pero sí que podrían optar a ocupar los puestos de cabo, sargento o segundo teniente de la escala gratuita sin necesidad de realizar los cursos reglamentarios pero sí de superar la prueba correspondiente. Estos individuos recibirían además licencia ilimitada una vez que hubiese finalizado el último periodo de instrucción. Deberían sin embargo incorporarse a filas en caso de guerra o en situaciones extraordinarias, y la cuota sólo sería devuelta en el caso de fallecimiento del interesado antes de su incorporación a filas. Los individuos catalogados como prófugos perderían el derecho a los beneficios de la cuota, aunque se les hubiera concedido previamente, sin serles además devuelto el importe ${ }^{1687}$.

Esta fórmula, a pesar de ser presentada como una medida democrática que acabaría con las injusticias sociales inherentes a la sustitución y la redención, mantuvo los antiguos privilegios, si bien limitados, de las capas económicamente más poderosas del país, sin que el resto de la población apenas sufriese ningún cambio en el cumplimiento de sus obligaciones militares. La medida causó gran conmoción entre los grupos más poderosos del país, ya que suponía el fin de la posibilidad de eximirse completamente del servicio militar, aunque si se reconocía la reducción de su duración. Así define Puell de la Villa la nueva situación en el servicio que se abre tras la

1686 "Quienes no pudieran pagar cuota, harían un servicio militar de 3 años. Y como la cuota más barata suponía 12-18 meses de jornal medio de campesino o 6-8 meses del industrial, sin contar los gastos de manutención, equipo y caballo, al servicio militar fueron obligados los de siempre. Acompañados ahora, durante unos meses por los soldados de cuota" (CARDONA, G., El poder militar en la España contemporánea hasta la guerra civil, p. 8).

1687 Ley de reclutamiento y reemplazo de 19 de Enero de 1912, arts. 272-274 y 284-288. 
supresión de la redención y la sustitución y la implantación de las cuotas:

"Aunque los jóvenes de la burguesía seguían exentos de hacer vida cuartelera gracias al pago de una cuota, sí empezaron a compartir instrucción, servicios y locales de trabajo con los que procedían del proletariado: los señoritos andaluces aparecerían formados codo con codo con los jornaleros extremeños, los universitarios madrileños podrían relevar a un albañil levantino en un puesto de centinela o un obrero vasco o catalán colaborar en sus tareas burocráticas u hospitalarias con el hijo de un cerealista castellano"1688.

Fueron los miembros del partido Reformista los primeros en hacer frente a este sistema de cuotas por antidemocrático y por mantener las diferencias de clase no ya en cuanto a la incorporación al servicio, pero sí en cuanto a su duración, ya que no se aseguraba a los reclutas ningún tiempo exacto de prestación. Por ello apostaron por un sistema de cuotas progresivo en función de la riqueza del interesado y no por una cuota única:

"[...] cuando podía pensarse que al aceptar un Gobierno liberal y demócrata el proyecto presentado por el Ministro de la Guerra conservador iba á introducir en él modificaciones que respondiesen a su sentido político, parecía natural que una de esas modificaciones fuese señalar más, hacer más viva, hacer más notoria la progresión de esas cuotas, y lejos de eso, con gran sorpresa mía, en el proyecto del Sr. Ministro se mantenían las dos cuotas de 1909, una que seguía siendo progresiva, la otra que era ya fija, como en 1909. Sale así del Senado el proyecto, llega a la Cámara popular, dictamina la Comisión, y esta Cámara, que por su carácter parecía natural que acentuase el sentido democrático de la ley, opta por refundir las dos cuotas militares. $Y$ esto estaría bien, yo no tendría que objetar nada respecto

1688 PUELL DE LA VILLA, F., El soldado desconocido: de la leva a la "mili" (17001912), p. 211. 
de la refundición, si de ella resultase que se tomaba el principio progresivo, si esa cuota única aceptada por la Comisión para atenuar el servicio militar estuviese en relación constante con los medios de fortuna de aquel a quien va a gravar; pero, Sres. Diputados, al encontrarnos con que la modificación que la Comisión de la Cámara popular tiene que hacer al refundir estas dos cuotas es la de hacerlas de tipo único, pensamos que en apoyo de esa modificación podrá hacerse cualquier clase de argumentos, pero no podrá nadie demostrar que eso responde a un sentido democrático.

Tal como queda, con el tipo único, la atenuación de ese servicio costará lo mismo a las clases medias que a las clases más ricas, y no digo a las clases pobres porque para esas es inasequible; esas no pueden alcanzar esa atenuación o redención, cualquiera que sea la índole del trabajo a que se dediquen, para demostrar su capacidad y que no necesitan una larga permanencia en filas. Resulta, pues, evidentemente ventajoso tan solo para las clases más elevadas, para las cuales representará un pequeño sacrificio esa cuota. [...].

Vosotros en eso sois ]o mismo [que el partido Conservador]: el ciudadano español, el pobre, aquí vuelve a surgir la distinción, el ciudadano español corriente, el no exceptuado, el que no está entre las clases más superiores, porque solamente a las clases más superiores es asequible la cuota de las 3.000 pesetas, el ciudadano español corriente no sabe el tiempo que va á servir, nadie le garantiza lo que va a servir: de uno a tres años, lo que resulte de las combinaciones del Ministerio de la Guerra, combinaciones que claro es, ni que decir tiene, siempre han de ser inspiradas en el mejor servicio de la Patria. Pero eso no basta; era necesario que a este ciudadano pobre se le dijera, como se le dice en otras partes, el tiempo que va a servir por años, por meses o por días; como se le dice, $y$ es lamentabilísimo que haya también entre otras esta diferencia, al ciudadano de las 3.000 pesetas, porque el de las 3.000 pesetas sí sabe que en tiempo de paz tiene cinco meses en filas $y$ después por días tasado lo que ha de ir a maniobras. De modo que para el rico hay la perfecta garantía de la carga con que ha de 
contribuir. Al pobre no; de un año a tres, lo que resulte; y esta es una cosa que repugna á todo demócrata"1689.

o) Disposiciones penales, especiales y transitorias

Finalizó la Ley de 1912 con dos capítulos centrados en una serie de disposiciones penales, especiales y transitorias destinadas a castigar el incumplimiento de la misma y a aclarar posibles dudas respecto a su aplicación.

En primer lugar se estableció que el conocimiento de los delitos cometidos por los mozos para eludir el cumplimiento de la ley hasta su ingreso en caja, así como los cometidos por funcionarios públicos que interviniesen en las operaciones de reemplazo, correspondía a la jurisdicción ordinaria y no a la militar, estableciéndose las penas de presidio en función del Código Penal. La tramitación del expediente sancionador no debería superar el plazo de un mes. Una vez ingresados en caja, los reclutas serían juzgados en función del Código Militar. Además, las sanciones debían ser impuestas por los capitanes generales de las distintas regiones militares. También se prohibió expresamente la creación de empresas, sociedades o cualquier entidad que se dedicase a asegurar a los reclutas la obtención de las ventajas o dispensas señaladas por la ley, y se prohibió a cualquier mozo que acudiese a estas entidades ilegales disfrutar de ninguna dispensa o licencia temporal, además de ser los últimos de su reemplazo en recibir la licencia ilimitada ${ }^{1690}$.

A continuación se enumeraron las penas que se impondrían por el incumplimiento de la ley:

\footnotetext{
1689 Discurso del Sr. Pedregal, Diario de sesiones de las Cortes, 10/05/1911, no 31, pp. 752-755.

1690 Ley de reclutamiento y reemplazo de 19 de Enero de 1912, arts. 301, 314, 318, 320 y 324.
} 
1. A los cómplices o colaboradores de la fuga de un mozo declarado prófugo se les impondría una multa de 100 a 500 pesetas $y$, en caso de ser insolventes, sufrirían penas de cárcel en función de lo establecido en el Código Penal.

2. El prófugo que resultase inútil para el servicio pagaría una multa de 50 a 250 pesetas y, en el caso de insolvencia, sufriría penas de prisión nunca mayores de un mes.

3. Los que omitiesen su obligación de inscribirse en el alistamiento serían castigados con una multa de 250 a 500 pesetas.

4. Aquellos mozos que a través del fraude o el engaño procurasen su omisión en el alistamiento, caso de resultar inútiles para el servicio cuando fuesen alistados, sufrirían arresto de un mes y un día a tres meses, y la multa de 50 a 200 pesetas.

5. Los funcionarios públicos que participasen en las operaciones de reclutamiento también serían castigados en caso de omisión de datos con una multa de entre 100 y 200 pesetas por cada mozo omitido sin causa justificada o penas de cárcel en caso de insolvencia. Si algún mozo resultase indebidamente incluido, el funcionario público culpable del error debería recompensarle con una indemnización de 2.000 pesetas.

6. Las personas que suscribiesen listas de alistamiento, sorteos, situación de mozos o cualquiera otra relación que afectase a las operaciones del reemplazo, serían responsables de su exactitud e incurrirían en una multa de 250 pesetas por cada uno de los mozos que se hubiesen incluido o excluido indebidamente del proceso. 
7. Los que se automutilasen o mutilasen a otro mozo con el objeto de eludir el servicio serían castigados a penas de prisión en función de lo prescrito en el Código Penal y a una multa de 1.500 pesetas si el joven quedase exento por los daños causados; si no lo quedase, el culpable quedaría privado de los beneficios que pudieran comprenderle por abono de tiempo servido y de obtener licencia temporal durante el mismo.

8. Los culpables de la omisión fraudulenta de un mozo del alistamiento y sorteo, incurrirían en la pena de prisión y en una multa de 125 a 1.500 pesetas por cada soldado que, a consecuencia de la omisión, haya dado de menos el municipio donde ésta se hubiese cometido.

9. Aquellos reclutas que, ya cumpliendo el servicio militar, contrajesen matrimonio cuando lo tuviesen prohibido, o dejasen de pasar revista anual, viajasen o cambiasen de residencia sin los debidos permisos, serían castigados con una multa de 25 a 1.000 pesetas, y sufrirían penas de prisión en caso de insolvencia.

10. Los dueños, directores, gerentes o administradores de empresas o sociedades que tuviesen contratos con el Estado, las provincias o los municipios, si admitían a su servicio individuos que no acreditasen haber cumplido sus deberes militares, incurrirían en la multa de 50 a 1.000 pesetas por cada individuo colocado, y las empresas nacionales de vías marítimas que les diesen destino o los embarcasen como pasajeros para salir de España, serían multados con 1.000 pesetas la primera vez y con 2.000 en los casos de reincidencia, sufriendo la prisión subsidiaria correspondiente en caso de insolvencia. 
11. Aquellos que omitiesen, retrasasen o impidiesen el curso - efecto de las órdenes emanadas de la autoridad competente para el llamamiento o concentración de los mozos en caja y los que de algún modo dificultasen el cumplimiento de dichas órdenes en perjuicio de tercero o del servicio público, y los que no las notifiquen individualmente a los interesados, teniendo el deber y la posibilidad de hacerlo, incurrirían en las penas de prisión correccional en su grado máximo e inhabilitación temporal. Estos delitos serían además juzgados por la jurisdicción militar.

12. Aquellos soldados que perdiesen su cartilla militar serían sancionados con una multa de 5 pesetas ${ }^{1691}$.

El conjunto de recursos obtenidos por la imposición de estas multas y por otros conceptos consignados en la ley serían destinados, preferentemente, a satisfacer el contenido de la misma, estableciéndose los siguientes capítulos prioritarios:

- Pago de haberes para los cuerpos de voluntarios destinados a África y para sus reservas.

- Construcción de cuarteles que contasen con los departamentos adecuados.

- Prevenir los gastos que originase la permanencia en filas del cupo de instrucción del contingente.

- Adquisición de material.

- Atender a los gastos que requiera la aplicación de la ley.

- Sufragar gastos de maniobras y ejercicios ${ }^{1692}$.

1691 Ley de reclutamiento y reemplazo de 19 de Enero de 1912, arts. 302-313, 315317,319 y $321-324$.

1692 Ley de reclutamiento y reemplazo de 19 de Enero de 1912, arts. 325. 
p) Un Reglamento de exenciones físicas que contempla nuevas categorías de enfermedades y defectos físicos

La Ley de 1912 vino acompañada por un reglamento de exenciones físicas ${ }^{1693}$ que recogió la tipología de las exenciones y un exhaustivo catálogo de las distintas enfermedades y defectos físicos que las motivaban. Como principal novedad del reglamento podemos destacar que se recogieron nuevas lesiones como motivos de exención relacionadas con la medicina interna y los trastornos audiovisuales que hasta ahora nunca habían sido contempladas. Se diferenciaron cinco clases de inutilidades físicas que eximían, en distinto grado, del servicio militar:

1. Inutilidades físicas que excluían totalmente del servicio militar declaradas por los Ayuntamientos a juicio de la autoridad sanitaria y falladas definitivamente por las comisiones mixtas de reclutamiento. Aquí se incluían las enfermedades y defectos físicos más graves que incapacitaban totalmente del servicio militar ${ }^{1694}$.

2. Inutilidades físicas que determinaban la exclusión total del servicio y cuya declaración corresponda a las comisiones mixtas de reclutamiento, atendiendo solo a lo que resultase del acto del reconocimiento. Se incluían en esta clase la falta de talla, peso o perímetro torácico, defectos 0 estados morbosos generales y afecciones constitucionales, problemas relacionados con los tejidos cutáneo celular y óseo y sistema linfático, inutilidades físicas correspondientes a la visión, cráneo, sistema

${ }^{1693}$ Cuadro de inutilidades físicas de 10 de Enero de 1912.

1694 Cuadro de inutilidades físicas de 10 de Enero de 1912, arts. 1-12. 
nervioso, locomotor, aparatos digestivo, circulatorio, respiratorio y genito-urinario ${ }^{1695}$.

3. Inutilidades físicas que determinaban exclusión definitiva del servicio, y cuya declaración corresponde a las comisiones mixtas de reclutamiento, atendiendo a lo que resultase del acto de reconocimiento y de la observación preceptuada de los artículos del Reglamento. Dentro de esta clase de inutilidades se incluía la misma tipología que la anterior pero que necesitaban una observación a largo plazo para ser detectadas ${ }^{1696}$.

4. Inutilidades físicas que determinaban exclusión temporal del contingente y cuya declaración correspondía a las comisiones mixtas de reclutamiento, atendiendo sólo a lo que resultase del acto del reconocimiento. En este apartado se incluían las enfermedades y problemas físicos relacionados con la talla, peso, tejidos cutáneo y óseo, aparatos digestivo, locomotor y génito-urinario que incapacitaban, sólo de forma temporal, para la realización del servicio ${ }^{1697}$.

5. Inutilidades físicas que determinaban exclusión temporal del contingente y cuya declaración corresponde a la comisión mixta de reclutamiento, atendiendo a lo que resultase del acto del reconocimiento y de la observación futura de los reclutas afectados. Se incluían aquí inutilidades relacionadas con la visión, audición, piel, sistema nervioso, aparatos digestivo, circulatorio, respiratorio, locomotor y urinario ${ }^{1698}$.

\footnotetext{
${ }^{1695}$ Cuadro de inutilidades físicas de 10 de Enero de 1912, arts. 13-106.

1696 Cuadro de inutilidades físicas de 10 de Enero de 1912, arts. 107-195.

1697 Cuadro de inutilidades físicas de 10 de Enero de 1912, arts. 196-208.

1698 Cuadro de inutilidades físicas de 10 de Enero de 1912, arts. 209-248.
} 



\section{Conclusiones}

Se ha pretendido con este estudio profundizar en la incidencia política y legal que, en el conjunto de la sociedad española del siglo XIX y hasta 1912, tuvo el Ejército ${ }^{1699}$, el servicio militar y la puesta en práctica jurídica del mismo, incidiendo en el enorme impacto que, para la población española de la época, tuvo el reemplazo, proceso en cuya ejecución intervenía toda la administración del Estado, desde la central hasta la local. Como conclusión global, tal y como planteamos en las hipótesis de trabajo, la legislación en materia de reclutamiento durante el siglo XIX conformó un cuerpo legislativo de gran importancia en la vida social y política del país, ya que afectaba al conjunto de la población joven, y así se refleja en los distintas normas, leyes, reglamentos, etc. que se fueron aprobando a lo largo de la centuria decimonónica, así como en la frecuencia e intensidad de los debates parlamentarios que trajeron su aprobación, que alcanzaron su máximo durante el Sexenio Revolucionario.

A continuación exponemos, a modo de conclusión, las novedades que recogieron las distintas leyes aprobadas en materia de reclutamiento y la incidencia política que éstas tuvieron.

\footnotetext{
1699 "De todo lo anteriormente descrito se deduce una considerable intervención del Ejército en la vida española a lo largo de la pasada centuria. Intervención que no se limita a una presencia en los foros de actuación política o en las salas de banderas para presidir consejos de guerra, sino también en las calles, con la bayoneta calada, tras los cañones frente a las barricadas, o a caballo, sable en mano. Hay que tener en cuenta además los conflictos de carácter puramente militar como los enfrentamientos generados por la actividad carlista, o las acciones en el exterior como la guerra de África de 1859-1860" (GONZÁLEZ ASENJO, A. J., "La resistencia al servicio militar en Galicia", p. 200).
} 
Los precedentes: el reclutamiento durante el siglo XVIII mantiene los sistemas heredados del pasado

Con Carlos V y Felipe II se consolidaron los dos sistemas de reclutamiento preferentes durante los años modernos ${ }^{1700}$, el voluntariado a través de banderines de enganche, y la leva forzosa, empleado en menor medida por el malestar social que generaba. El siglo XVII fue un periodo de transición hacia la aceptación del servicio militar como un deber más de los súbditos de la Corona, y continuó la movilización de voluntarios, a través de capitanes de enganche y asentistas, para ser destinados principalmente a las campañas de Flandes e Italia. Este sistema, argumentaban sus defensores, garantizaba una mayor calidad de las tropas y tenía menos incidencia para la vida del país y para sus miembros. También se emplearon para nutrir de efectivos al Ejército las levas forzosas de vagabundos, presos y ociosos, método utilizado cuando se requería una enorme cantidad de soldados para hacer frente a enemigos en el propio territorio español. Este era un medio que permitía además reducir el número de marginados sociales que acudían a las ciudades y a quienes se les responsabilizaba de la inseguridad y el malestar ciudadanos. La parte negativa residía en la escasa calidad de los nuevos soldados forzosos, su inexperiencia y pasividad.

Un tercer sistema utilizado durante el siglo XVII fueron los servicios de milicias, tropas populares voluntarias encargadas de defender su territorio de agresiones extranjeras, y que se constituyeron como la reserva del Ejército. También se acudió durante esta centuria, de forma esporádica, al reclutamiento y repartimiento forzoso. El repartimiento era elaborado por el Consejo

1700 "Todos sabemos que tanto el Ejército Nacional como el Servicio Militar tienen sus orígenes en la Revolución Francesa, aunque por lo que se refiere al Servicio Militar en concreto, se suelen citar como antecedentes remotos los alistamientos de voluntarios y las levas forzosas que aparecen [...] ya en el siglo XVI" (FERNÁNDEZ VARGAS, V., "El servicio militar en el siglo XIX. Una percepción social", p. 102). 
de Castilla en función de la población de cada provincia castellana, si bien eran las instituciones locales las encargadas de ejecutarlo. También las villas y ciudades podían acudir a la contratación de voluntarios o al pago de sustitutos para el cumplimiento de su obligación. Si no tuviesen los fondos económicos para ello, deberían acudir al sorteo, procedimiento que generaba un enorme descontento popular. Durante el siglo XVII, de una forma ya residual, continuó el servicio de la Nobleza, sistema heredado del Medievo que fue utilizado esporádicamente durante esos años.

El siglo XVIII fue un claro precedente del XIX en materia de reemplazo, pues en esos años se pusieron las bases y se realizaron las primeras pruebas de los sistemas empleados posteriormente. La llegada al trono de una nueva dinastía reformista, la Borbónica, tras un intenso conflicto bélico, y la acuciante necesidad de tropas durante toda la centuria, se tradujo en la implantación de métodos coercitivos para nutrir de efectivos al Ejército y en la diversificación de los sistemas, sin existir un método fijo y uniforme ${ }^{1701}$. Durante el siglo XVIII encontramos hasta cinco sistemas de reemplazo para el Ejército español, ya utilizados durante la centuria previa, si bien los sistemas forzosos fueron ganando peso:

- Reclutas o levas voluntarias;

- El servicio militar de la Nobleza;

- Levas de vagos, mendigos, ociosos y maleantes;

- Las milicias Provinciales, que adquirieron un carácter forzoso y no ya voluntario para la defensa de los territorios fronterizos;

- El reclutamiento forzoso.

\footnotetext{
1701 "Es con los Borbones, a lo largo del siglo XVIII, aunque de modo reticente al principio [...], cuando el servicio militar obligatorio queda regulado definitivamente como medio fundamental de reclutamiento de soldados" (HERRERO BRASAS, J. A., iRompan filas! La cara oculta del servicio a la patria, p. 159).
} 
Este sistema alcanzó una importante extensión ante la escasez de tropas voluntarias y las necesidades cada vez mayores de efectivos. Precedente del reclutamiento obligatorio, afectaba a aquellos que se viesen designados como reclutas en función del sorteo celebrado para uno de cada cinco mozos útiles. Existía sin embargo una enorme cantidad de exenciones de tipo nobiliario, laboral (oficios "útiles") y territorial (Cataluña y País Vasco). Este método coercitivo, en un principio esporádico en función de las necesidades bélicas, adquirió un carácter anual a fines del siglo XVIII, consolidándose ya entrado el siglo XIX, y no suponía la quinta propiamente dicha, ya que los pueblos podían cubrir el cupo solicitado por la Corona a través de vagos y vagabundos. Terminó regularizándose a fines del siglo XVIII con la aprobación de la Real Ordenanza para el reemplazo del Ejército de 1770 en tiempos de Carlos III, que venía a establecer la quinta como una obligación anual y permanente que tenía la población con la Monarquía.

Se trata del primer intento de introducir definitivamente el servicio militar obligatorio al prohibirse la sustitución. La quinta no supuso sin embargo la anualidad en la incorporación de nuevas tropas al Ejército, ya que sólo se llegaron a realizar reemplazos en $1771,1773,1775$ y 1776.

La Ordenanza de 1800 o la consolidación del sistema de quintas

Se trata de una norma renovadora, de inspiración ilustrada, aprobada en el contexto europeo de la Revolución Francesa, que vino a regularizar y consolidar el servicio militar obligatorio periódico, es decir, el sistema de quintas, un verdadero cambio de rumbo en los sistemas de reclutar los soldados. Inspirada en la Ordenanza de 1770, su aprobación se debió a la situación de quiebra en que se 
encontraba el Ejército español tras los numerosos conflictos internacionales que España conoció durante el reinado de Carlos IV. Las quintas decimonónicas encuentran su precedente en este texto legislativo ${ }^{1702}$.

La Ordenanza de 1800 tenía como objetivo modernizar todas las operaciones relacionadas con el reclutamiento, y fue empleada, con modificaciones en 1817 y 1819 , para nutrir al Ejército de tropas durante la Guerra de Independencia, el proceso emancipador iberoamericano y el conflicto carlista ${ }^{1703}$. Su objetivo básico, además de la modernización de las operaciones de reemplazo, era reducir el número de exenciones existente para evitar un peso excesivo sobre los grupos populares.

Los poderes locales tenían una enorme importancia para la aplicación de la ordenanza: los corregidores y justicias de cada localidad, con la ayuda del Ayuntamiento, serían los encargados de elaborar el padrón, instrumento básico para el reparto de los cupos, para luego ser enviado al intendente que elaboraría un padrón general de la provincia. El justicia de cada localidad sería además el encargado de elaborar el alistamiento de los mozos útiles. Sin embargo, son las autoridades gubernativas quienes tienen un mayor peso: el centralismo borbónico también queda patente con la participación en el proceso de corregidores e intendentes, estos

1702 CRESPO-FRANCÉS Y VALERO, J.A., A las armas: Reclutamiento y servicio militar en España desde sus orígenes hasta nuestros días, p. 237.

1703 "Después de este conflicto [la guerra de los Pirineos], la guerra no desaparece, ya sea contra Inglaterra(1796-1802 y 1804-1808), que provoca la quiebra de nuestra Armada, ya sea contra Portugal (Guerra de las Naranjas, 1801), ya contra la misma Francia (Guerra de la Independencia, 1808-1814), que convirtieron a toda la Península en un gigantesco campo de batalla. Y, además, la sublevación de las colonias americanas (perdidas las continentales en 1824). Son unos años en los que se produce la transición del Ejército real al Ejército nacional y de gran necesidad de efectivos para atender todos estos frentes. No hubo más remedio que acudir a las quintas y el punto de arranque será una nueva Ordenanza, la de 1800 (MARTÍNEZ RUIZ, E., "Condiciones básicas del reclutamiento militar en España, 1768-1885, pp. 162-163). 
últimos encargados de asegurar la actualización del padrón cada diez años y de realizar el reparto de los cupos entre localidades.

Los mozos que deberían ser incluidos en el sorteo eran los comprendidos entre los diecisiete y los treinta y seis años, con una altura superior a $1.625 \mathrm{~m} .$, y que no gozasen de alguna de las exenciones reconocidas. Se prohibía expresamente la sustitución. En lo que se refiere a las excepciones por motivos físicos, para su reconocimiento se realizaría un juicio de excepciones al que debían de acudir todos los mozos alistados, y donde dos médicos serían los encargados de examinar los problemas físicos señalados para justificar la exención. En el caso de disconformidad con la resolución médica, existía la posibilidad de acudir a la junta Provincial de agravios o incluso al Consejo de Guerra. En lo que respecta a las exenciones, éstas eran muy numerosas, propias de una mentalidad del Antiguo Régimen y muy lejos de la igualdad jurídica liberal, si bien menores en número que las reconocidas por textos legales anteriores. Su elevado número causó "[...] injusticias y protestas, además de sentimientos de frustración que animaban a eludir el servicio de las armas"1704. Aquí se incluían a nobles y religiosos, que conservaban su posición de privilegio, los que empeñasen determinados oficios de interés para el Estado (educación, sanidad, cargos públicos, industria textil) y a los que, por motivos familiares, su ingreso en la milicia supondría un grave quebranto para la subsistencia de sus parientes.

En lo que respecta al sorteo, éste sería celebrado en los locales del Ayuntamiento de cada localidad, introduciéndose en un cántaro las papeletas con el nombre de los soldados y en otro tantas papeletas con el concepto "soldado" como mozos fuesen exigidos a cada localidad en el reparto de los cupos. Los reclutas debían cumplir un total de ocho años sirviendo en la Milicia, extendiéndose hasta los

1704 MARTÍNEZ RUIZ, E., "Condiciones básicas del reclutamiento militar en España, 1768-1885", p. 165. 
dieciséis para aquellos prófugos que fuesen capturados. Un informe elaborado por el intendente de la provincia, donde se recogiese la situación del reclutamiento en la misma, sería enviado al Consejo de la Guerra para asegurar un conocimiento concreto de la situación de cada provincia. De nuevo las autoridades del Estado central, en este caso la intendencia, ejercían una misión importante de supervisión, atendían quejas y reclamaciones e imponían multas y penas a los que hubiesen violado la ordenanza.

La Ordenanza de 1800 no fue aplicada de manera regular hasta el regreso de Fernando VII en 1814 y el fin de la Guerra de la Independencia: "[...] la guerra de 1808 a 1814 y las campañas coloniales de de 1815 a 1824 crearon una mayor necesidad de hombres que se resolvió recurriendo de nuevo a la quinta"1705. Sí se aplicó de forma irregular en tiempos de la guerra contra los franceses para abastecer de soldados al Ejército, completándose con diversos textos legislativos ${ }^{1706}$ que venían a reducir el número de exentos ante la situación de excepcionalidad que vivía el país, y a incrementar el margen de edades de los mozos que debían de participar en los sorteos, entre los dieciséis y los cuarenta años. La nobleza dejaría de estar exenta del servicio, si bien se realizaría un sorteo exclusivo para este grupo social, al igual que tonsurados y novicios de las órdenes religiosas y miembros del Tercer Estado por motivos profesionales. La guerra obligó por tanto a reducir el número de exentos y a poner fin a privilegios estamentales con el objetivo de incrementar las tropas del Ejército, si bien se abrió por primera vez la posibilidad, para el caso en exclusiva de los hidalgos, de la redención en metálico ${ }^{1707}$.

1705 BORREGUERO BELTRÁN, C., Reclutamiento militar por quintas en la España del siglo XVIII: orígenes del servicio militar obligatorio, p. 114.

1706 "Pero la proliferación legislativa, continua y machacona, hizo posible salir al paso de errores, dudas e inconvenientes" (BORREGUERO BELTRÁN, C., Reclutamiento militar por quintas en la España del siglo XVIII: orígenes del servicio militar obligatorio, p. 118).

1707 La impopularidad del reclutamiento se mantuvo con el paso del tiempo debido, según el profesor Martínez Ruíz, a tres factores significativos: "las dificultades y 
El triunfo de la doctrina liberal en la legislación de las Cortes de Cádiz y del Trienio Liberal

Intensos aires reformistas llegaron a España al calor de la Revolución Francesa y de la invasión napoleónica de 1808, y también el reclutamiento se vería afectado por estos deseos de cambio, situación legislativa reflejada en las Cortes de Cádiz y desarrollada durante el Trienio Liberal basándose en la doctrina jurídica liberal. EI modelo a seguir fue el francés: un Ejército permanente formado por ciudadanos basado en su obligación de defender a la Patria con las armas en la mano. Fue en Cádiz donde se fraguó tal modelo de Ejército y de sistema de reclutamiento ${ }^{1708}$, y ello a pesar del caos normativo que acompañó al proceso de reemplazo en un contexto bélico y de derrumbe de las instituciones borbónicas. Hasta 1810 tal proceso no se ajustó a la normativa vigente, quedando en manos de los líderes militares, y no sería hasta 1810 cuando la Junta Suprema Central ordenase un alistamiento general siguiendo las directrices de la Ordenanza de 1800, aunque eliminando exenciones.

Los temas militares en general y el reclutamiento en particular constituyeron uno de los asuntos estrella en los debates de las Cortes gaditanas. Los asuntos militares también eran prioritarios para la prensa, tanto liberal como absolutista, si bien el asunto del reclutamiento apenas atrajo la atención periodística, centrada en el

peligros de la vida castrense, la duración del servicio militar con sus consecuencias de desarraigo y distanciamiento para los mozos y las injusticias existentes en el reclutamiento, favorecedoras de los más poderosos económica, social y políticamente" (MARTÍNEZ RUIZ, E., "Condiciones básicas del reclutamiento militar en España, ,1768-1885", p. 166).

1708 " [...] las Cortes de Cádiz intentaron crear un nuevo modelo de Ejército Nacional acorde con las ideas de la nueva época, a pesar de lo cual permitieron la exención por donativo que pasó a denominarse posteriormente redención en metálico, dando a esta medida una justificación puramente de carácter económico [...]" (CRESPOFRANCÉS Y VALERO, J.A., A las armas: Reclutamiento y servicio militar en España desde sus orígenes hasta nuestros días, p. 241). 
desarrollo de las operaciones militares y en los excesos cometidos por las tropas francesas.

La situación de excepcionalidad por la que atravesaba el país llevó a diputados moderados como Canga Argüelles a defender el alistamiento universal sin la posibilidad de exención, mientras que otros diputados defendían las exenciones en función de las capacidades físicas y de determinadas situaciones familiares. La posibilidad de redención en metálica fue reconocida en 1811 a cambio del pago de 10.000 reales con el argumento de la delicada situación económica por la que pasaba la Hacienda pública, encontrando la oposición de diputados exaltados al considerar que violaría el espíritu de la futura carta magna.

La Constitución de 1812 supuso un verdadero cambio en los conceptos de Ejército y de reclutamiento ${ }^{1709}$, al representar la transición de la noción de soldado-súbdito sometido a la autoridad monárquica a la de ciudadano-soldado con la obligación universal de defender a la Patria con las armas en la mano, bajo el auspicio de la soberanía nacional y de la igualdad ante la ley, si bien esta supuesta igualdad quedará quebrantada en función de las capacidades económicas de cada familia y su posibilidad de hacer frente a la redención. Quedó por tanto implantado el servicio militar obligatorio. El número de reclutas era además fijado anualmente por las Cortes y no por el Monarca. La ley destinada a fijar la regulación en el proceso de reclutamiento quedó truncada con el regreso de Fernando VII a España en 1814, su reacción absolutista, la derogación de la legislación gaditana y el regreso a la normativa del Antiguo Régimen, es decir, a la Ordenanza de 1800, con ligeros retoques en 1817 y

1709 "La obligatoriedad del servicio militar en el sentido actual, en general, puede decirse que tiene su origen en la Revolución Francesa aunque para nosotros arranca de las Cortes de Cádiz de 1812" (CRESPO-FRANCÉS Y VALERO, J.A., A las armas: Reclutamiento y servicio militar en España desde sus orígenes hasta nuestros días, p. 244). 
1819. Durante el reinado de Fernando VII, en especial en sus primeros años, no hubo apenas novedades reseñables en el proceso de reemplazo del Ejército.

El triunfo del levantamiento de Riego y el inicio del Trienio Liberal en 1820 trajo consigo la vuelta al poder de los liberales y el restablecimiento de la Carta Magna gaditana. Nuevas leyes y decretos aprobados entre 1820 y 1823 vinieron a desarrollar las ideas acerca de reclutamiento recogidas en la Constitución de 1812. En mayo de 1821 una nueva ley concedió un papel de gran importancia a las Diputaciones provinciales al ser las encargadas de realizar el reparto de los cupos entre los pueblos de la provincia en función de su población, además de permitir a cada provincia la posibilidad de reclutar a los mozos que le hubiesen asignado a través de sustitutos voluntarios. La Ley de 1821 suprimía cualquier exención nobiliaria y clerical y no permitía la redención en metálico.

Un nuevo texto legal, también aprobado en 1821, se presentó como el documento encargado de organizar el entramado del Ejército español. La prensa liberal, tanto moderada como exaltada, aplaudió una nueva legislación que venía a asegurar el fin de las diferencias estamentales en el acceso al Ejército y a poner fin a numerosas exenciones. Las cuestiones referentes al reclutamiento volvieron a ser prácticamente ignoradas por la prensa adicta al nuevo régimen, si bien sí que presentaron al Ejército como un seguro para la libertad y para la soberanía nacional.

La nueva Ley de señaló a las Cortes como las encargadas de fijar los efectivos militares en función de la población de cada territorio y se remarcó la obligatoriedad de todos los españoles de defender a la Patria con las armas en la mano al ser todos los hombres ciudadanos iguales en derechos y en cargas. Además, se concedió al Ejército la función de defender el nuevo orden constitucional frente a las agresiones absolutistas. Se fijaron además 
tres medios para suministrar de efectivos al Ejército: miembros de las milicias Provinciales (cuerpos armados encargados de asegurar el orden constitucional), contribución provincial en función del cupo asignado, y voluntariado a cambio de un puesto y un salario fijos. Estas milicias provinciales deberían ser los cuerpos principales en tiempos de paz, mientras que el Ejército permanente sólo adquiriría un papel relevante en un contexto bélico. En el caso de no ser suficiente con los efectivos suministrados por las milicias, las Cortes realizarían el reparto del cupo entre provincias en función de su población. Quedaba prohibida la redención en metálico pero nada se comentaba en la ley sobre la sustitución.

Un nuevo decreto aprobado en octubre de 1822 vino a aclarar la forma de realizarse las operaciones de reemplazo, modificando la Ordenanza de 1800 y la Ley constitutiva del Ejército de 1821. El objetivo era asegurar la eficacia en las operaciones y en las autoridades encargadas de ejecutarlo. Del sorteo se encargarían las Diputaciones provinciales, y en él participarían todos los mozos entre dieciocho y treinta y seis años aunque gozasen de alguna excepción física o legal. Serían los Ayuntamientos quienes decidirían sobre las solicitudes de exención presentadas, quedando la posibilidad de reclamar ante la Diputación. El decreto también enumeró las exenciones reconocidas para el servicio militar, y se admitió, además de los incapacitados físicos y de aquellos que no alcanzasen la talla mínima, los ordenados in sacris, los que presentasen un sustituto y los redimidos en metálico. Se abre de nuevo la puerta a la exención de clérigos y a la exención en metálico, expresamente prohibida en la Ley de 1821 , si bien no se fijó la cantidad a entregar. También se reconocieron otras exenciones por motivos familiares o por ocupar determinados puestos políticos, situación ésta denunciada por algunos diputados ante el descontento popular que un excesivo número de exentos podía originar. 
Una nueva ordenanza general para el reemplazo apareció en febrero de 1823. Su aplicación práctica fue nula, al ponerse fin a la experiencia liberal y volverse al más rígido absolutismo tras la intervención de la Santa Alianza a través de los Cien Mil Hijos de San Luis tan sólo dos meses después de su aprobación. El proceso de reclutamiento se iniciaría con la elaboración del padrón por parte de los Ayuntamientos para ser enviados a las respectivas Diputaciones, encargada de velar por la legalidad de todos los actos y con capacidad para imponer multas a las autoridades que incumpliesen las disposiciones legales. Las mismas Diputaciones serían las encargadas de realizar el repartimiento de los mozos por localidades en función de su población y del reparto de los cupos realizado por el gobierno. Una vez elaborado el padrón, los distintos Ayuntamientos procederían a realizar el alistamiento de todos los jóvenes solteros y viudos sin hijos entre dieciocho y veinticinco años. Las rectificaciones del alistamiento las podía realizar el propio Ayuntamiento una vez presentadas las reclamaciones, quedando la posibilidad de acudir a la Diputación Provincial. Del sorteo quedaba asimismo encargado el Ayuntamiento. Este no sería puro, sino que se realizaría en función de las franjas de edad de los mozos, siendo los primeros en ingresar en filas los de dieciocho y diecinueve años de edad. También el consistorio sería el encargado de decidir por votación qué mozos quedaban excluidos del servicio, quedando la Diputación como tribunal de apelación. Entre los exentos no se declaró a los eclesiásticos, pero sí a los que presentasen sustituto y a los redimidos en metálico. Tampoco se reconocen las exenciones por motivos familiares, sin bien se establecía la obligación de las instituciones públicas, Ayuntamiento y Diputación, de socorrer a aquellas personas que, sin la ayuda del recluta, podían ver en peligro su supervivencia.

Esta ordenanza, así como el resto de textos legales aprobados durante el Trienio, fueron derogados con el fin del Trienio y el inicio 
de la Década Ominosa, recuperándose la vigencia de la Ordenanza de 1800 .

El fin de los sistemas antiguorregimentales en la Ley de 1837

Con la muerte de Fernando VII el número de disposiciones legales relativas al reclutamiento aumentó de forma considerable, y por ello hemos debido realizar una selección de los textos de mayor importancia que afecten al reemplazo, y en este capítulo incluimos la Ley de 1837 por constituirse en el eje fundamental de la legislación sobre quintas hasta mediados del siglo XIX y suponer una importante reforma en el proceso de reclutamiento ${ }^{1710}$. Esta norma, que puso fin a los sistemas de reemplazo propios del Antiguo Régimen, concedió a las Cortes la capacidad para fijar el contingente anual y puso nuevas reglas para la realización del reemplazo. Se pusieron con ella las bases para el alistamiento militar liberal, al regularse anualmente todas las operaciones y establecer órganos encargados de la gestión y control del reclutamiento ${ }^{1711}$, y sirvió de modelo incluso hasta 1912.

1710 "A partir de 1837 la renovación anual de la Ley de Reclutamiento será casi automática hasta fin de siglo, con las reformas anuales orientadas a la mejora del mecanismo y a cubrir vacíos legales (CRESPO-FRANCÉS Y VALERO, J.A., A las armas: Reclutamiento y servicio militar en España desde sus orígenes hasta nuestros días, p. 252).

1711 "Las instancias oficiales incluían desde el Gobierno que fijaba el número de hombres por casa quinta y los distribuía entre las provincias, las Diputaciones Provinciales encargadas de repartir el cupo correspondiente a la provincia entre los distintos Ayuntamientos que la componían, con arreglo al volumen de población de estos (además de velar por la recta y veraz consecución de las labores de reclutamiento que afectaba a cada Ayuntamiento, recoger las quejas y protestas de particulares y por último entregar a los quintos en la Caja Provincial), hasta los Ayuntamientos, que por su parte debían realizar primeramente un padrón general de los habitantes del municipio; de este recuento de población saldría el alistamiento de los mozos que por su edad se encontraran en situación militar aptos para el reclutamiento; a continuación proceder al sorteo, declaración de soldados y suplentes escuchando sus reclamaciones para ser eximidos, exentos o exceptuados en su caso; decidir sobre esto teniendo en cuenta las reclamaciones de los particulares que se sintieran perjudicados por las decisiones municipales, y por fin entregar el cupo de soldados y suplentes a la Diputación para que esta a su vez los 
Esta norma, así como todas las leyes globales aprobadas en los años sucesivos, viene a confirmar nuestra segunda y cuarta hipótesis de trabajo: la implicación de los poderes constitucionales, Cortes y poder ejecutivo en el proceso legislativo sobre reclutamiento militar, así como la implicación de los principales ejes institucionales del Estado, poderes políticos, judiciales, militares e incluso eclesiásticos, en su desarrollo y puesta en práctica. El conjunto de normas aprobadas y puestas en práctica, también la Ley de 1837, nos muestra asimismo una afectación vertical del proceso de reclutamiento a todos los niveles de la administración y de las instituciones: gobierno de la nación, diputaciones provinciales, municipios.

La nueva ley sólo puede entenderse encuadrada en el contexto de la guerra carlista y de las necesidades del bando isabelino de nutrir su Ejército de hombres para salir victorioso del conflicto civil. La guerra civil pondría de manifiesto la necesidad de mejorar las normas de reclutamiento y poner fin al caos normativo heredado del siglo XVIII, imponiéndose el modelo liberal ${ }^{1712}$. La norma se empezó a gestar en 1836, con el Motín de los Sargentos de la Granja y el acceso de los liberales radicales al poder. A pesar de la recuperación de la legislación gaditana y del Trienio en materia castrense en ese año, su vigencia fue efímera, ya que en 1837 se aprobaría una nueva constitución y una nueva ley para el reemplazo del Ejército. Ya la nueva Constitución establecía la obligación de todos los españoles de defender a la Patria cuando fuese necesario, pero nada señalaba respecto a los métodos de reclutamiento. Éstos quedaron fijados en

entregara a la Caja de quintos como se dijo anteriormente" (GONZÁLEZ ASENJO, A. J., "La resistencia al servicio militar en Galicia", p. 211).

1712 "[...] la Ordenanza de 1837 estaba marcada por la aplicación egoísta de los principios del liberalismo, que dejaba la guerra y el servicio militar para los que no tenían nada que perder y permitía que eludieran esa obligación los que sí tenían algo que perder. Era la consagración de una desigualdad o injusticia que influiría negativamente en la valoración popular del servicio militar y, de rechace, en la valoración de las mismas fuerzas armadas [...]" (MARTÍNEZ RUIZ, E., "Condiciones básicas del reclutamiento militar en España, 1768-1885", p. 168). 
la Ley de 1837, redactada durante el gobierno progresista de Calatrava aunque aprobada durante un gobierno moderado, y cuya vigencia se extendería hasta el Proyecto de ley de reemplazos de 1850.

De nuevo la primera obligación que establecía la nueva norma, para poder realizar el reparto de los cupos en función de la población de cada localidad, era la confección del padrón de vecinos, documento que deberían elaborar anualmente los Ayuntamiento. Una vez diseñado el padrón, los Ayuntamientos debían elaborar el alistamiento en un acto público con todos los mozos entre dieciocho y veinticinco años, franja de edad menor que en leyes anteriores. Reclamaciones sobre el alistamiento las podrían presentar los mozos bien ante el propio consistorio, bien ante la Diputación provincial.

El sorteo, de competencia municipal, no sería puro, sino que se realizaría por franjas de edades, un total de seis sorteos, empezando por los comprendidos entre los dieciocho y diecinueve años. Encargada de vigilar el proceso, en especial el sorteo, y de realizar el reparto de los cupos en función de la población de cada localidad, quedaba la Diputación provincial, institución clave en el organigrama liberal y en la ejecución del proceso de reclutamiento, con el objetivo principal de hacer respetar la legalidad y evitar fraudes y engaños, tanto de Ayuntamiento como de particulares, pudiendo imponer penas económicas e incluso imponer a los Ayuntamiento defraudadores la obligación de que la localidad de su competencia aportase un mayor número de jóvenes al Ejército. Sin embargo, las denuncias por fraude en el proceso hacia las Diputaciones provinciales fueron muy habituales con el paso de los años. La participación del Estado central fijando las Cortes el contingente anual y con la posibilidad, reconocida por la ley, de realizar llamamientos extraordinarios, de las Diputaciones como garantes del proceso, y de los Ayuntamientos para la elaboración del padrón, pero 
también para el llamamiento, declaración y reconocimiento médico de los reclutas y su conducción a la caja de quintos, muestran la participación de la administración pública a todos los niveles en el proceso de reclutamiento, desde la central hasta local.

La estatura mínima exigida a los reclutas era de cinco pies menos una pulgada $(1,597 \mathrm{~m}$.), y el Ayuntamiento era el encargado de declarar apto o excluido a un mozo en función de sus condiciones físicas, pudiendo contar para ello con el reconocimiento médico realizado por un facultativo. Además de los motivos físicos, otras causas de exención fueron la inclusión en la matrícula de mar, el servicio en la Milicia Nacional, la extranjería, las motivaciones relacionadas con la pobreza familiar, y los redimidos o que presentasen un sustituto. El número de exenciones, en comparación con la Ordenanza de 1800, es menor, al quedar suprimidas las exclusiones nobiliarias. Triunfaba por tanto el modelo liberal de igualdad ante la ley, si bien las diferencias económicas, véase la sustitución y la redención, podían conllevar enormes diferencias en la obligación de servir a la Patria ${ }^{1713}$. La redención era admitida por la nueva ley ante la situación cercana a la bancarrota en que se encontraba la Hacienda pública, si bien no se fijó el montante económico a desembolsar para evitar el reclutamiento y no sería puesta. La sustitución, privilegio de los grupos adinerados al igual que la redención en perjuicio de las clases más humildes incapaces de asumir semejantes gastos ${ }^{1714}$, también quedaba admitida, tanto la

1713 "La resistencia al servicio militar no es una novedad en los años que corren para el marco histórico de nuestra investigación. Puede asegurarse que esta actitud surje (sic) desde el mismo momento en que se crea un Ejército nutrido por individuos reclutados obligatoriamente. [...]. La novedad que introdujo la legislación liberal-burguesa en este sentido estuvo en creer que los ciudadanos, imbuidos de un nuevo sentido político y nacional, prestarían su concurso personal en la tarea de defender la soberanía nacional por convicción y no por pura imposición" (GONZÁLEZ ASENJO, A. J., "La resistencia al servicio militar en Galicia", p. 309).

${ }_{1714}$ Resulta obvio que la posibilidad de la redención quedaba lejos del alcance de la gran mayoría de la sociedad española, "incluso para muchos componentes de las clases medias la redención no resultaría asequible salvo, claro está, que acudieran 
individual como, para situaciones excepcionales, la de todos los mozos de una provincia. Durante los años cuarenta diversas disposiciones trataron de aclarar los mecanismos de la sustitución y establecer un mayor rigor en la misma para evitar la entrada de personas indeseables en el Ejército ${ }^{1715}$.

En la Ley de 1837 se fijaron por primera vez penas para aquellos que se automutilasen para evitar el servicio, práctica ésta cada vez más extendida, y cuyo descubrimiento implicaba el trabajo forzado en obras públicas por un máximo de cuatro años. Las penas impuestas a prófugos y desertores también eran de menor dureza que en disposiciones anteriores, incrementándose su tiempo de prestación, una vez que fuesen capturados, un máximo de dos años. En 1845 se dispondría un nuevo destino para estas figuras delictivas: Ios territorios ultramarinos.

Las primeras críticas progresistas hacia el sistema de quintas surgieron en la década de 1840, al ser tildadas de injustas y onerosas para la Hacienda pública, reclamando incluso su abolición y su sustitución por un ejército de voluntarios.

a alguna de las múltiples sociedades de seguros contra las quintas que tanto proliferaron en aquellos años (FERNÁNDEZ BASTARRECHE, F., "El servicio militar en la España del siglo XIX. Una epidemia de los tiempos contemporáneos", p. 30).

1715 "Una consecuencia natural del reclutamiento por sorteo y del sistema de las redenciones fue el auge de las empresas capitalistas que se beneficiaron de esta situación. Tales fueron los bancos y las sociedades financieras que prestaban dinero para las redenciones a unos intereses que iban del 36 al $60 \%$ anual. Lo mismo ocurría con las agencias que proporcionaban sustitutos. Sin embargo, las más importantes fueron las sociedades de seguros contra las quintas. En cualquier momento, durante los primeros años de la vida de su hijo, cualquier familia podía contratar una póliza contra la posibilidad de que aquel fuese Ilamado a filas. La prima variaba naturalmente conforme la fecha de contratación y el tipo de riesgo a cubrir con la póliza. [...].

Estos sistemas gozaron de gran popularidad a principios de los años sesenta. Las sociedades fueron fundadas por miembros de la aristocracia y financieros, incluso en algunas ocasiones por funcionarios o eclesiásticos. Las quiebras que se produjeron durante la depresión de 1866-69 dieron lugar a la desaparición de muchas de estas sociedades, dejando a los infelices aseguraros a la merced de los reclutamientos [...]" (HEADRICK, D. R., Ejército y política en España (1866-1898), pp. 102-103). 
La modernización del reemplazo en el Proyecto de ley de 1850

Aunque se trata de un proyecto de ley que fue aprobado por el Senado en 1850 y que no se hizo realidad hasta 1856 por los vaivenes políticos del momento, la convocatoria de quintas hasta esa última fecha en función de su articulado determinaron la necesidad de su estudio. Se convirtió además, junto a las Leyes de 1856 y 1885 , en un modelo a seguir para la legislación de quintas durante la segunda mitad del siglo XIX. Se trató de un proyecto, impulsado por el partido Moderado en el poder y auspiciado por su principal líder, el general Narváez, que trató regular con precisión y modernizar las fases del reemplazo, sobre todo en lo que se refiere a las exenciones para evitar irregularidades. La prensa del momento, tanto progresista como conservadora, apoyó la elaboración de un nuevo texto legislativo. Aunque la dimisión de Narváez y su Gobierno impidieron su aprobación por el Congreso, el proyecto quedó implantado por parte de Bravo Murillo como la norma a seguir para las siguientes llamadas a filas. La base legislativa de este proyecto se encuentra en la Constitución doctrinaria de 1845, que concedía importantes poderes a la Corona en materia militar, estando encargada de presentar a las Cortes anualmente el contingente militar necesario para el país.

El proyecto de ley de 1850 fue un texto amplio y minucioso que originó intensos debates en el Senado, en especial en lo que se refiere a las edades en que los jóvenes debían ingresar en el Ejército y a la siempre polémica sustitución-redención. En su preámbulo se justificaba su necesidad en base a la heterogeneidad y confusión que habían generado las normas previas en materia de reclutamiento. El texto reconocía la posibilidad del voluntariado, pero la escasez de de jóvenes que ingresasen en el Ejército por iniciativa propia obligaba a celebrar un quinta anual. Una de las novedades más importantes del 
proyecto, y que más controversia originó en los debates del Senado, fue el establecimiento de la obligatoriedad de la celebración de un sorteo anual para incorporar a filas un contingente fijo de 25.000 reclutas todos los años. La quinta sería por tanto anual y fija, sin tener en cuenta las necesidades militares del momento y sin ser necesaria la propuesta de las Corona y la aprobación de las Cortes, lo que suponía pasar por alto las facultades constitucionales que, en materia de reemplazo, se concedía a las cámara legislativas en el artículo 79 de la Constitución de 1845. Esta circunstancia generó las primeras críticas al Proyecto en el Senado, justificándose desde el ministerio de Guerra en la necesidad de evitar la incertidumbre que vivían los jóvenes por no saber cuando se iba a celebrar la quinta y el número de reclutas solicitados. La cifra de 25.000 mozos también encontró controversia, al ser considerada excesiva por algunos senadores e insuficiente por otros.

El proyecto de ley no señaló el número de años del servicio militar, limitándose a establecerse en un máximo de ocho, quedando excluidos los jóvenes residentes en Canarias y en los territorios coloniales. Sí que quedó fijada la edad de los mozos que habían de ser quintados, acabándose con la diversidad de sorteos en función del año de nacimiento que establecía la Ley de 1837, y situándose en los veinte años. Este retraso en la edad de ingreso en el Ejército se justificó en la elevada mortalidad que sufrían los mozos más jóvenes en los primeros meses del servicio.

La elaboración del padrón de vecinos, de competencia municipal y que debía incluir a todos los hombres y mujeres del municipio aunque estuviesen ausentes provisionalmente, continuó siendo un documento fundamental para conocer el número de jóvenes en edad militar y para el reparto de los cupos. En función de este padrón el Ayuntamiento procedería a la formación del alistamiento, que incluiría a todos los jóvenes de veinte años. Las reclamaciones respecto al 
alistamiento, talla y aptitud física de los reclutas podrían interponerse en tres instancias: el propio Ayuntamiento, el consejo provincial y, como instancia superior y cuya resolución era inapelable, el ministerio de la Gobernación. Es por tanto un ministerio civil, y no militar, el responsable de todo el proceso. El sorteo sería asimismo responsabilidad del consistorio, así como el llamamiento y la decisión sobre la aptitud de los nuevos soldados y su entrega en la caja de reclutas, pudiendo intervenir el ministerio a través del jefe político de la provincia para corregir irregularidades. La declaración y tallaje de los soldados pasan a ser competencia directa de la institución militar. Se observa una menor intervención de las Diputaciones provinciales en la ejecución de todo el proceso.

Las exenciones quedaron de forma similar a las establecidas en la Ley de 1837. La altura mínima exigida continuó siendo la misma, 1,596 y continuaron siendo motivo de exención el defecto físico y la enfermedad. En el año 1851 se publicaría un meticuloso reglamento que establecía las indisposiciones físicas y enfermedades que eximían del servicio militar. Una segunda tipología de exención estaba relacionada con los intereses económicos y estratégicos del país, y aquí se incluían a los mozos que formasen parte de la matrícula de mar, los carpinteros de arsenales y los trabajadores de las minas de Almadén. Entre los exentos también se incluían los ordenados in sacris, los redimidos a cambio de 6.000 reales, los que presentasen un sustituto y los que viviesen en un contexto familiar y económico con evidentes dificultades. Sustitución y redención quedaron admitidas sin debate político parlamentario, al existir una práctica unanimidad entre los senadores sobre su beneficio económico para la Hacienda pública. La sustitución quedó admitida de forma individual y no grupal, si bien el gobierno, en circunstancias excepcionales, podría impulsar una sustitución colectiva para una localidad o provincia. Sustitución y redención quedaban equiparadas, ya que el sustituido debía de consignar las cantidad de 6.000 reales como garantía de que 
su sustituto cumpliría todos sus años de servicio. Este montante económico quedaba muy lejos de las posibilidades de los grupos más humildes de la sociedad.

En el caso de un joven huido para evitar el servicio, se exigía al Ayuntamiento la tramitación de un expediente que lo declarase prófugo, documento que sería remitido al consejo provincial. Cuando el prófugo fuese apresado sería destinado a las guarniciones africanas con un recargo en el servicio de entre uno y cuatro años a juicio de la institución provincial, penas económicas si fuese considerado no apto para el servicio e incluso penas de prisión si no pudiese hacer frente a las multas impuestas. Los que colaborasen en la captura de un prófugo recibirían compensaciones económicas e incluso una reducción en el tiempo de prestación para aquellos que se encontrasen sirviendo en el Ejército en esos momentos. Al igual que en la Ley de 1837, y para evitar la huida al extranjero de jóvenes en edad militar, se prohibió la salida del país de aquellos mozos comprendidos entre los dieciséis y los veintitrés años si no presentaban un certificado que asegurase el cumplimiento de sus obligaciones con el Ejército y el depósito de una fianza no especificada por la propia ley. Aquellos que fuesen considerados culpables de haberse automutilado o inutilizado para el servicio serían destinados a guarniciones africanas $y$, en el caso de no poder servir en el Ejército, sufrirían penas de prisión en tales territorios coloniales.

La convocatoria de quintas en función de un proyecto de ley aprobado por el Senado generaría polémicas políticas en el Congreso entre Moderados y Progresistas, y entre la propia prensa de distinto color político. Las críticas se endurecieron ante el numeroso número de reclutas solicitados y la posibilidad de la sustitución, que suponía el mantenimiento de unas especuladoras sociedades que se dedicaban a gestionar la sustitución de los reclutas y que ejercían como verdaderos mercaderes de hombres. A ello se unía la injusticia 
social y las desigualdades territoriales que se podrían generar por las diferencias de riqueza existentes entre los territorios españoles ${ }^{1716}$.

\section{La implantación de ideas progresistas con La Ley de 1856}

En enero de 1856 una nueva ley en materia de reclutamiento fue aprobada por el Congreso. Elaborada por el gobierno progresista de Espartero, y con apoyo moderado, encontró duras críticas en aquellos grupos políticos que por primera vez entraban en las Cortes, esto es, demócratas y republicanos, radicalmente contrarios a las quintas, convirtiendo su abolición en uno de sus principios programáticos básicos. El objetivo de la nueva norma era mejorar y completar el Proyecto de ley de 1850, aunque aportando novedades de corte progresista. Aunque sometida a diversas modificaciones en el futuro, fue una norma esencial para el proceso de reclutamiento durante la segunda mitad del siglo XIX. Se trata de un texto exhaustivo, con una estructura similar al Proyecto de ley de 1850, cuyo trámite parlamentario fue breve. La influencia progresista se observa en la ley al constituirse el voluntariado retribuido como la primera herramienta para nutrir de reclutas al Ejército ${ }^{1717}$, quedando las

1716 "Pero, ¿era tan mala la situación del soldado en España? Las continuas guerras, ya en la Península, ya en las colonias, que menudean a lo largo del siglo; la elevada mortalidad; la propia dureza del servicio; el peligro de perder el oficio tras el largo periodo de servicio; o el riesgo de ser nuevamente movilizado una vez ya en al reserva, son factores que convierten en realmente crítica la situación del mozo quintado en España.

$[\ldots]$.

Este deseo del soldado español por escapar del servicio, aparte de entenderse por la duración del mismo y por la posibilidad de ser destinado a las colonias, hay que interpretarlo sobre todo en función de su dureza. Las condiciones materiales de vida del soldado eran muy malas. Mal vestidos, mal alimentados y mal alojados, los soldados eran fácil víctima de las enfermedades, que se convirtieron en la causa de mortalidad más importante del Ejército español a lo largo de todo el siglo XIX" (FERNÁNDEZ BASTARRECHE, F., "El servicio militar en la España del siglo XIX. Una epidemia de los tiempos contemporáneos", p. 30.)

1717 "La impopularidad del servicio militar entre las gentes explica la preferencia por el alistamiento voluntario que tienen los medios gubernamentales para cubrir las exigencias del reemplazo, cuyas bajas se desean llenar con veteranos o bisoños 
quintas como segunda opción si no existía un número suficiente de voluntarios. Además, al finalizar sus años de servicio, los reclutas recibirían la cantidad de 2.000 reales. En 1861 esta paga quedaría suprimida. Por tanto, el objetivo final sería la constitución de un Ejército sin quintas, consideradas por el partido en el poder como un instrumento doloroso pero necesario en ausencia de voluntarios. La respuesta demócrata a esta idea fue contundente: las quintas eran injustas, inconstitucionales y recaían sobre las clases humildes, acusando a los progresistas de traicionar los principios revolucionarios de 1854 .

Los jóvenes sobre los que recaería el alistamiento no variaron con respecto al Proyecto de ley de 1850, es decir, quedaban excluidos los residentes en Canarias y territorios americanos, y se incluían a todos los mozos de veinte años. La duración del servicio tampoco varió y se situó en ocho años, rebajándose a seis para los que fuesen destinados a Ultramar. A diferencia del proyecto de ley del Senado, no se estableció un cupo fijo anual de soldados que debía ingresar en el Ejército, sino que su número sería establecido anualmente por las Cortes. Se suprime así uno de los puntos más polémicos del Proyecto de ley de 1850. Otra diferencia reside en que el reparto del contingente, elaborado anualmente por el Gobierno en función de los mozos sorteados en el año anterior, y presentado a las Cortes para su aprobación, sería realizado una vez que se hubiese elaborado el padrón y el alistamiento, ambas de competencia municipal, y se hubiese materializado el sorteo, encargado también a los Ayuntamiento, y no antes como establecía el proyecto del Senado.

voluntarios, a los que se ofrecen premios en metálico si se reenganchaban o se incorporaban a filas. Pero estos reclamos no son muy eficaces, por lo que se ha de recurrir siempre al alistamiento obligatorio. El convencimiento que poseen los medios dirigentes de la impopularidad del servicio militar es tal que durante unos años se conceden a los reclutas procedentes de las quintas unos premios pecuniarios a fin de compensar a las familias y hacer menos duro el ingreso en el Ejército, pero semejante práctica, demasiado costosa para el Erario, no iba a perdurar" (MARTÍNEZ RUIZ, E., "Condiciones básicas del reclutamiento militar en España, 1768-1885", p. 169). 
El sorteo sería por tanto posterior al reparto del contingente. Las Diputaciones provinciales por su parte eran las encargadas de repartir el cupo señalado para su provincia entre los municipios de la misma en función del número de sorteados que tuvieron el año anterior. En cuanto a los Ayuntamientos, además de la elaboración del padrón, debían realizar el alistamiento, llamamiento, tallaje, declaración, reconocimiento médico y entrega en caja de los reclutas, y podría declarar a jóvenes excluidos del mismo por enfermedad o defecto físico sin ser necesaria la presentación por parte de los interesados de una reclamación y sin ser necesario acudir a la Diputación provincial, que quedó como instancia de reclamación: licenciados en el Ejército, redimidos y sustituidos, así como los menores de veinte años y mayores de veinticinco. Las reclamaciones por las actuaciones de los Ayuntamientos serían remitidas a la Diputación provincial, encargada de resolver y vigilar el cumplimiento de la legalidad. Como última instancia de reclamación continuaba el ministerio de la Gobernación, a quien sólo se podría reclamar, vía Gobernador Civil, cuando el fallo de la Diputación fuese contrario a lo establecido por talladores y facultativos. De nuevo un ministerio civil y no militar asume las competencias sobre reclutamiento. La Diputación tendría además una nueva función administrativa: elaborar un doble informe que viniese a resumir la ejecución del proceso en la provincia para ser enviado a los ministerios de Guerra y Gobernación.

Respecto a las exenciones y exclusiones del servicio militar, éstas fueron muy similares en comparación con legislaciones previas aunque inferiores en número. Además de los faltos de talla, establecida por primera vez en metros y similar a la estatura mínima exigida en el Proyecto de ley de 1850, 1,596 m., quedarían excluidos del servicio los considerados inútiles por enfermedad o defecto físico, si bien nada se señala respecto a las autoridades encargadas de realizar los reconocimiento médicos y de declarar la exención. Excluidos del servicio también quedaban aquellos cuyo oficio 
revirtiese un especial interés para el Estado, caso de los mineros de Almadén o los alumnos de academias y colegios militares, pero no los ordenados in sacris. Una tercera tipología de exención la constituían las motivaciones personales relacionadas con la pobreza de las familias. La lucha contra el prófugo apenas varió en comparación con el Proyecto de ley de 1850, siendo las administraciones provincial y local las encargadas de capturar y castigar al prófugo, quedando al margen las autoridades militares. Las decisiones tomadas por los consistorios a este respecto podían ser revocadas por las Diputaciones. Los cómplices del prófugo serían juzgados por un juez ordinario, y los que colaborasen en su detención podrían recibir compensaciones económicas o reducción en el tiempo de prestación si se tratase de un soldado o un familiar suyo. Los mozos que por su parte hubiesen actuado de forma fraudulenta $o$ se hubiesen automutilado para evadir el servicio, recibirían penas de prisión y su servicio militar lo harían en tierras africanas.

La Ley de 1856 supuso importantes novedades en las cuestiones de la sustitución y la redención en metálico, al reconocer de forma expresa la redención como una forma de sustitución y admitir la posibilidad de sustitución o redención global de los mozos de una localidad o provincia por parte de sus respectivos Ayuntamientos o Diputaciones. Se reconocieron cuatro formas de sustitución: el cambio del número del sorteo entre mozos, a través de soldados ya licenciados en el Ejército menores de treinta y dos años, a través de cualquier mozo entre veintitrés y treinta años soltero o viudo sin hijos, y mediante la redención en metálico, con la entrega de 6.000 reales al ministerio de Guerra para ser invertidos exclusivamente en el enganche de voluntarios o en el reenganche de veteranos del Ejército. Esta labor sería ejecutada por el Consejo de Redención y Enganche del Servicio Militar, institución creada en 1859 encargada de la gestión de esos fondos económicos, cuyo destino sería la contratación de voluntarios, pero que frecuentemente 
acabaron englobados en los presupuestos del Estado. En momentos de crisis económica se incrementaron las peticiones de soldados para así aumentar las redenciones $y$, de esta forma, los ingresos económicos del Estado. Ese mismo año de 1859 la cantidad económica entregada por los redimidos subió hasta los 8.000 reales.

Durante los catorce años de vigencia de la ley las modificaciones introducidas fueron de escasa importancia a pesar de la presencia en el Gobierno de partidos más moderados, ya sea el Moderado o la Unión Liberal. Entre ellas, se puede destacar que los ordenados in sacris volvieron a ser considerados exentos del servicio. Las críticas más incisivas provinieron en las Cortes de las filas del partido Demócrata, al considerar inútiles e injustas las quintas y desproporcionado el contingente militar solicitado año a año durante los últimos años de la década de los cincuenta y los primeros sesenta. La justificación de este incremento la encontraron los diputados moderados y unionistas en las numerosas intervenciones militares, principalmente de tipo colonial, en las que participó España por aquellos años, además de la necesidad de defender los territorios americanos del imperialismo de los Estados Unidos. A esta inestabilidad internacional se unía la necesidad de conservar el orden público. Los motivos del rechazo a las quintas también encontraron justificación para los demócratas en el lastre que suponía para el desarrollo de la economía española y en el excesivo poder que se concedía a los militares, que podían convertirse en un peligro para las instituciones liberales. Como novedad previa al estallido de la Revolución Gloriosa, destacar la ley que, en 1867, estableció un llamamiento anual fijo de 40.000 hombres sin necesidad de que el Gobierno consultase a las Cortes. Las necesidades militares podrían no ser de tal magnitud, pero se incrementaban los beneficios obtenidos por el Estado a través de la redención. 
El desencanto por las promesas revolucionarias del Sexenio producido por La Ley de 1870

La convulsión que supuso el estallido de la Revolución Septembrina de 1868, el inicio del Sexenio Revolucionario y el establecimiento de unas nuevas autoridades democráticas conllevaron intensas transformaciones en la regulación del reclutamiento. La existencia de desigualdades en la afectación de la quinta y las lamentables condiciones higiénicas y sanitarias en el Ejército, supusieron el rechazo de la misma por parte de los primeros partidos de componente popular, republicanos, demócratas y socialista, que aparecieron en el panorama político español. La abolición de la quinta se convirtió en una de sus principales propuestas políticas, y las agitaciones populares en contra de sus injusticias ya se habían manifestado desde la década de 1840. La solicitud de abolición fue recogida por los grandes líderes revolucionarios y sus respectivos partidos. Sin embargo, el convulso panorama político español, con el levantamiento carlista, las agitaciones cantonalistas y las guerras de independencia coloniales, obligarían a un cambio en su postura. Las críticas republicanas y de su prensa afín por el mantenimiento de las quintas no se harían esperar. Los intensos debates parlamentarios existentes durante el Sexenio vienen a confirmar nuestra séptima hipótesis de trabajo: la preocupación social sobre el reclutamiento y el rechazo de amplias capas de la población hacia el mismo, hacia la legislación que lo regulaba y hacia sus injusticias, tiene su reflejo en los debates políticos, visibles a través de las crónicas parlamentarias y de los artículos de prensa, y en la toma de posición al respecto por los diferentes grupos y partidos políticos.

Uno de los principales líderes revolucionarios, y ministro de Guerra con el Gobierno provisional salido de la Gloriosa, Juan Prim, 
aunque se mostró contrario a las quintas por injustas e inconvenientes, apostó por el mantenimiento de los Ejércitos permanentes, de mayor fuerza y cohesión que los batallones de voluntarios propuestos por los republicanos en una situación tan delicada como en la que se encontraba España, amenazada por la sublevación carlista y el independentismo cubano. Estas circunstancias, junto a la catastrófica situación de la Hacienda pública que se vería aún más dañada con la contratación de voluntarios, le llevaron a apostar por un aplazamiento en la abolición de las quintas, que serían suprimidas en cuanto fuese posible para ser sustituida por un ejército de voluntarios. El mantenimiento de la quinta por parte del Gobierno provisional, formado por unionistas, progresistas y demócratas, trajo aparejado la acusación de traición a la Revolución por parte de los republicanos, con Emilio Castelar al frente, al mantener tal infame contribución ${ }^{1718}$. Nuevas quintas, anunciadas para el periodo $1869-1870$ y 1870-1871 por parte del ya Presidente del Gobierno Juan Prim, vinieron a encender aún más los ánimos republicanos, que identificaron los Ejércitos permanentes con monarquía, militarismo y tiranía, y la república con el fin de la contribución de sangre.

Las nuevas circunstancias implementadas por la situación revolucionaria desembocaron a la postre en la implantación de una nueva ley en marzo de 1870, que no trajo sin embargo la abolición de las quintas como las ansias populares habían reclamado en los años previos a la Revolución y durante los propios años del Sexenio. La nueva ley tuvo como base el Proyecto presentado a las Cortes por el Presidente del Gobierno, el General Prim, en febrero de ese mismo

1718 "El Gobierno Provisional, con el general Prim en la cartera de Guerra, comprobó enseguida la imposibilidad de cumplir las promesas hechas el inicio de los preliminares de las quinta de 1869 fue el comienzo de una ofensiva en pro de la abolición dirigida por los grupos republicanos contra el Gobierno, ofensiva que fracasó, pues en 29 de marzo de 1870 se aprobaba la Ley Prim, más equitativa que las anteriores, pero mantenedora de las quintas" (MARTÍNEZ RUIZ, E., "Condiciones básicas del reclutamiento militar en España, 1768-1885", p. 170). 
año. Sin embargo, Proyecto de ley y Ley resultante presentaron unas diferencias muy significativas. El motivo se encuentra en la grave situación militar por la que atravesaba España en aquellas fechas, acosada en tres frentes: carlista, cubano y, una vez proclamada la República, los levantamientos cantonalistas. La perentoria necesidad de soldados impidió la aprobación de una ley que pusiese fin a las quintas. Los sucesores de Prim al frente del Gobierno de la Monarquía, Sagasta y Ruiz Zorrilla, a pesar de su inicial rechazo a las quintas, continuaron con los llamamientos al reemplazo ante la situación excepcional por la que atravesaba el país.

Como novedades de la Ley de 1870 , si lo comparamos con las normas previas del siglo XIX, podemos destacar su menor extensión y meticulosidad a la hora de describir las operaciones del reemplazo. Nada se indicaba de las distintas fases del proceso ni de la lucha contra el prófugo, aunque sí breves referencias hacia la sustitución, la redención en metálico o la posibilidad de reclamación ante las ilegalidades cometidas. La nueva ley abrió la puerta al voluntariado retribuido, que quedaba constituido según el texto como el principal aporte de efectivos al Ejército, sin señalar los requisitos exigidos a los voluntarios, y declaró el servicio militar obligatorio para todos los españoles de veinte años de edad. Serían las Cortes quienes, anualmente, fijarían el número de hombres que debían ingresar en filas. Si no hubiese un número suficiente de voluntarios, se procedería a celebrar un sorteo entre todos los mozos de veinte años. Los que no tuviesen que incorporarse al servicio activo pasarían a formar parte de la segunda reserva. Por tanto, todos los jóvenes se verían afectados, de una forma u otra, por el servicio, que no sería universal, y esta es una de las grandes novedades de la ley.

La duración del servicio quedó reducida a seis años divididos en dos fases: cuatro años de servicio activo y otros dos en la primera reserva. Los mozos que no hubiesen obtenido la suerte del soldado 
en el sorteo pasarían a formar parte de la segunda reserva, con una duración de seis años. La talla mínima exigida a los reclutas continuó establecida en los 1,560 m. y las exenciones, físicas, personales o de interés económico o estratégico para el Estado, las mismas que las establecidas en la Ley de 1856. También se mantuvo la sustitución tal y como se había recogido en la legislación previa. Esta circunstancia fue duramente criticada por los republicanos, que compararon la existencia de sustitutos con el tráfico de esclavos. La redención también quedó legalizada, de forma contraria a lo contenido en el proyecto inicial del General Prim.

La Ley de 1870 tuvo una aplicación temporal muy reducida, ya que fue derogada con el regreso de los Borbones. En sus apenas cuatro años de implantación, con continuas promesas de abolición por parte de los Gobiernos en cuanto la situación lo hiciese posible y las consecuentes críticas republicanas hacia la traición que suponía hacia la Revolución y la igualdad ante la ley, se vio además afectada por pequeñas reformas que introducían ligeras modificaciones. Así por ejemplo se confirmó la exención del servicio para los jóvenes de las provincias Vascongadas.

En septiembre de 1872, el Gobierno del radical Ruiz Zorrilla presentó un proyecto de ley, a la postre no aprobado ante la llegada del nuevo régimen republicano, que abolía las quintas pero no el servicio militar obligatorio para todos los jóvenes entre los veinte y los veintisiete años de edad, ante la imposibilidad de nutrir el Ejército exclusivamente de voluntarios. Redención y sustitución quedarían totalmente prohibidas. El criterio propuesto para establecer que jóvenes se debían incorporar a filas ya no era el sorteo, sino la capacidad de leer y escribir, ya que serían los analfabetos los que debían incorporarse a filas. Se defendió este sistema como modo de impulsar la alfabetización de la población, pero de nuevo eran los 
criterios económicos, muy relacionados con las posibilidades de estudio, los que determinaban la incorporación al servicio militar.

Frustrado el proyecto de Ruiz Zorrilla con la proclamación de la República en febrero de 1873, las nuevas autoridades republicanas aprobaron una nueva ley de reclutamiento, que venía a recoger los ideales republicanos en materia de reemplazo pero cuya vigencia fue tan sólo de seis meses. Se trata de un texto muy breve que no pormenorizó en las distintas fases del proceso. Lo más destacado de la misma fue su declaración de abolición de las quintas, que nunca llegó a cumplirse ya que en agosto de 1873 se movilizó a 80.000 reservistas ante la falta de voluntarios ${ }^{1719}$, un rotundo fracaso para las nuevas autoridades que trataban de ganarse el favor popular. El texto legislativo sustituía el servicio militar obligatorio por una milicia de voluntarios remunerados a razón de una peseta diaria para el caso del servicio activo. Situación distinta era la de la reserva, formada por todos los mozos de veinte años, que debían formar parte de ella durante tres años. Si situación normal sería pasiva, si bien podía ser movilizada en caso de necesidad o de no existir un número suficiente de voluntarios. Redención y sustitución quedaban eliminadas. La aplicación real del texto fue nula ante el inicio de la Restauración Borbónica. Estos vaivenes y convulsiones políticas propias del Sexenio vienen a confirmar nuestra quinta hipótesis de trabajo: El desarrollo de la legislación sobre reclutamiento militar no fue un proceso sistemático unidireccional, sino que estuvo condicionado por los avatares políticos de la España de su tiempo, de forma que con frecuencia una ley contradecía o desandaba los preceptos y los planteamientos de sus predecesoras. Asimismo, podemos observar

1719 "La República se encontró en la disyuntiva de cumplir su promesa o intentar devolver al país una mínima normalidad, decidiéndose por la primera opción, lo que, inevitablemente, la incapacitó para mantener un mínimo orden, lo cual acabaría obligándola a echar marca atrás en su postura abolicionista que, de hecho, resultaba imposible de llevar a buen puerto sin una previa organización del Ejército, cosa que no se realizará en todo el Sexenio" (FERNÁNEZ BASTARRECHE, F., "La cuestión de las quintas en el Sexenio Revolucionario", p. 17). 
como las propias leyes puestas en vigor contradecían los planteamientos ideológicos previos de sus máximos adalides, que terminaron justificando la quinta en la excepcionalidad política que vivía el país.

El regreso al pasado en la Ley de 1877

El regreso de los Borbones como dinastía reinante de manos de Alfonso XII, con Cánovas del Castillo como hombre fuerte del nuevo régimen, supuso un regreso a las concepciones previas y a la legislación isabelina en materia de reclutamiento. La posibilidad de abolición de las quintas quedaba totalmente aparcada. Cánovas sí que abolió el privilegio de exención del servicio militar para los jóvenes del País Vasco en 1876:

"Art. I. Los deberes que la Constitución política ha impuesto siempre a todos los españoles de acudir al servicio de las armas cuando la Ley los llama, de contribuir en proporción a sus haberes a los gastos del Estado, se extenderán, como los derechos constitucionales se extienden, a los habitantes de las provincias de Vizcaya, Guipúzcoa y Álava, del mismo modo que a las demás de la Nación.

Art. $2^{\circ}$. Por virtud de lo dispuesto, en el artículo anterior, las tres provincias referidas quedan obligadas [...] a presentar, en los casos de quintas o reemplazos ordinarios y extraordinarios del Ejército, el cupo de hombres que les correspondan con arreglo a las Leyes" ${ }^{\prime \prime 1720}$.

En 1877 y 1878 se aprobaron dos nuevas leyes de reclutamiento que pusieron las bases del reemplazo durante la

1720 Ley de 21 de julio de 1876 sobre quintas en las Provincias Vascongadas, Gaceta Núm. 343, de 23/07/1876. 
Restauración. Asimismo destacar un reglamento que vino a desarrollar la primera ley un nuevo texto legislativo, aprobado en 1882, que vino a reformar parcialmente la segunda. Los distintos textos legales que se fueron aprobando durante los primeros años de la Restauración, ya fuesen impulsados por Gobiernos conservadores o liberales, apenas supusieron cambios en materia de reemplazo hasta la Ley de 1912. La impronta de la Revolución Septembrina en este sentido no fue apenas importante, ya que la base teórica y la ejecución práctica del reclutamiento se encontraba ya establecida en las legislaciones previas al Sexenio. Además, debemos tener en cuenta las nuevas funciones otorgadas al Ejército tras la vuelta de los Borbones: además del instrumento de guerra, la fuerza militar se convirtió en la ejecutora de la represión de los movimientos populares revolucionarios y obreros; se convirtió por tanto en garante del orden social burgués.

Otra nueva función del Ejército, especialmente de los reclutas quintados, va a ser la de trabajar como mano de obra barata cuando estallaban conflictos laborales y escaseaban los trabajadores que se encontraban en plena protesta. La fuerza armada española también se vio marcada por el impacto que tuvo en toda Europa la guerra franco-prusiana de 1870 y la victoria de las armas germanas en Sedán. La victoria de la Prusia bismarckiana elevó al modelo alemán de reclutamiento, que tenía como objetivo tener a la población preparada para una rápida movilización y para la guerra, como modelo a imitar y germanizaron las leyes de reclutamiento. Sin embargo, en España el servicio militar no se universalizó, ya que, aquellos que tuviesen la capacidad económica para ello, pudieron continuar eximiéndose de la prestación. El modelo prusiano quedaba en España pospuesto ante la oposición de las clases acomodadas.

Las Leyes de 1877 y 1878, aprobadas por Gobiernos conservadores, marcarán la política española de reclutamiento hasta 
la reforma de 1912. Su debate en Cortes y en prensa fue mínimo, ya que todos los grupos, estando fuera del sistema los contrarios a la Restauración, estuvieron de acuerdo en la necesidad de ejércitos permanentes y quintas. Las únicas voces críticas se alzaron por parte de los liberales en contra de la sustitución y la redención, ya que suponían un menosprecio hacia la institución armada al excluir del servicio a las clases más pudientes. Apostaban por un servicio obligatorio universal para garantizar una rápida movilización de las tropas y la igualdad ante la ley. La cuestión de las quintas pasó a un segundo plano ante la debilidad de los republicanos y la represión que se ejerció sobre las protestas populares. Señalar asimismo que uno de los objetivos básicos de ambos textos fue el de captar soldados para ser destinados a Ultramar.

La Ley de 1877 es un texto breve, que no pormenoriza las operaciones del reemplazo, aunque sí que lo hará el reglamento, aprobado en octubre de ese mismo año, que la desarrolló. La Ley de 1877 dividió el Ejército en dos grupos, permanente y reserva, debiendo los reclutas quintados servir en ambos durante ocho años. La edad de reclutamiento se situó en los veinte años y la estatura mínima, en los 1,540 m. Los cupos de Ultramar se cubrirían en primer lugar con voluntarios, que verían compensado su destino con el servicio exclusivamente de sus cuatro años en activo y quedando exentos de servir en la reserva. La sustitución quedaba legalizada, aunque solo entre parientes de hasta cuarto grado inclusive. Esta limitación no existía para los destinados a Ultramar. La redención en metálico se situó en las 2.000 pesetas. Las cantidades recaudadas serían gestionadas por el Consejo de Redenciones y Reenganches militares, que las debía utilizar preferentemente para la contratación de enganchados y reenganchados, pero por primera vez no exclusivamente, ya que si existiese un remanente sobrante lo podría utilizar para adquirir material de guerra. 
El Reglamento de octubre de 1877 y la Ley de agosto de 1878 fueron los desarrollaron los principios generales establecidos en la Ley de 1877 y desarrollaron las operaciones del reemplazo. La Ley de 1878, de gran amplitud, tenía como objetivo unificar los dos textos anteriores y estabilizar la política de reclutamiento. Su aprobación en el Parlamento apenas encontró oposición. Ambos textos declararon la obligatoriedad del servicio militar para todos los españoles de veinte años de edad, excepto los nacidos en Canarias, con una duración de ocho años, cuatro en activo y cuatro en la reserva. Sería el ministerio de la Gobernación quien anualmente, a propuesta del ministerio de Guerra y de acuerdo con el Consejo de Ministros, establecería el número de reclutas necesarios para cubrir las necesidades existentes. Este mismo ministerio sería el encargado del reparto del contingente entre las provincias, mientras que el de Guerra haría la distribución de los reclutas entre las distintas Armas. Las comisiones provinciales de reclutamiento harían el reparto del contingente entre las distintas localidades de su provincia. Los nuevos textos aprobados crearon la figura del recluta disponible, soldado del servicio activo que, por exceder del contingente anualmente fijado, gozaría de licencia ilimitada para regresar a sus casas, aunque tenían prohibido contraer matrimonio. Se trata por tanto de reclutas que, habiendo obtenido la suerte del soldado, no serían llamados a filas y cuya incorporación quedaba pendiente de las bajas que se produjesen en el seno del Ejército, de las necesidades bélicas o de posibles problemas de orden público. Soldados disponibles y soldados en la reserva deberían asistir, cada dos años, a las asambleas, reuniones periódicas con una duración máxima de seis semanas, con el objetivo de mantener su disciplina militar y actualizar su formación. Los soldados en la reserva solo podrían ser llamados a filas si las necesidades efectivas de tropas no se cubriesen con soldados en activo ni con reclutas disponibles. 
Las exenciones recogidas en la Ley de 1878, que incluía un reglamento de exenciones físicas, fueron muy similares a las contempladas en las sucesivas leyes del siglo XIX, aunque en menor número, a saber: físicas y falta de talla, de interés estratégico o económico para el país (por primera vez se incluyen en esta capítulo a los colonos agrícolas), familiares, sustituidos y redimidos a cambio de 2.000 pesetas. Para los que se quisiesen acoger a la redención en metálico, se les exigía además la acreditación de haber terminado o estar realizando unos estudios o estar ejerciendo algún oficio. Se intentaba potenciar así una imagen más positiva de la redención, vinculada al estudio y al trabajo.

El alistamiento sería elaborado anualmente por los Ayuntamientos, cuyas decisiones podrían ser reclamadas ante la comisión provincial de reclutamiento $y$, en última instancia $y$ solamente debido a la inclusión o exclusión indebida de algún joven en el alistamiento, ante el ministerio de la Gobernación. El sorteo continuaba asimismo siendo de competencia municipal, al igual que el llamamiento, declaración y tallaje de los nuevos soldados y la lucha contra el prófugo. Pasarían a depender de la jurisdicción militar los reclutas una vez que hubiesen sido entregados en la caja de reclutas, ubicadas en las capitales provinciales.

La Ley de 1878 vino acompañada por un amplio reglamento de exenciones físicas que vino a regular las exenciones del servicio por cuestiones de inutilidad física y enfermedad. Este Reglamento destacó por prestar una mayor atención a las exclusiones derivadas de patologías psiquiátricas. Sólo las exenciones relacionadas con las enfermedades más graves serían reconocidas y otorgadas por los Ayuntamientos tras el juicio de exenciones, cuya labor sería además vigilada por las comisiones provinciales de reclutamiento. El resto de exenciones, encuadradas en tres clases y diecisiete órdenes, deberían ser analizadas por dos facultativos médicos, uno civil designado por la 
comisión y otro castrense nombrado por la autoridad militar superior de la provincia.

El intento de asegurar una rápida movilización en la Ley de 1882

En enero de 1882 una nueva ley, aprobada por el Gobierno liberal de Sagasta y con el ministro de Guerra Martínez Campos como principal defensor y sin apenas oposición parlamentaria, reformó parcialmente la Ley de 1878, con el objetivo de asegurar una rápida movilización militar aumentando el número de soldados instruidos para la guerra en situación de reserva. Para ello se incrementó el número de años que los reclutas debían permanecer en la reserva, que fue dividida en reserva activa (tres años) y segunda reserva (seis años), posteriores al servicio activo que presentaba una duración de seis años máximo, periodo que podría ser acortado hasta los tres años si así lo decidiese el ministerio de Guerra. La altura mínima exigida para el ingreso en el Ejército se elevó ligeramente hasta los 1,545 m. El objetivo era asegurar la movilización rápida de un Ejército de 400.000 efectivos preparados para el conflicto, sin incrementar el presupuesto militar en tiempos de paz. Aún con estos cambios, la capacidad de movilización del Ejército español era muy inferior a la de otras potencias europeas. Otros de los objetivos de la nueva ley era mejorar la instrucción militar de los reclutas. Para ello se mantuvieron las asambleas anuales a las que deberían acudir los individuos de la reserva activa y segunda reserva con el objeto de mantener su formación militar necesaria para una rápida movilización.

Otro de los cambios introducidos por la Ley de 1882 fue, por primera vez, la inclusión de los mozos canarios en las operaciones de reemplazo, si bien sólo podrían prestar sus servicios en tiempos de 
paz y en su territorio de residencia. Además, cualquier mozo del servicio activo o la reserva podía ser movilizado por el Gobierno en circunstancias excepcionales. Para cubrir las bajas del Ejército activo puesto en pie de guerra se acudiría a los reclutas disponibles. Si fuese insuficiente, se movilizaría a la segunda reserva. Otra novedad hacía referencia al medio de cubrir los cuerpos destinados a Ultramar. Para ello se acudiría a voluntarios o antiguos soldados menores de treinta y cinco años y, en caso de ser insuficiente, se enviaría a los reclutas designados a través de un sorteo.

El aspecto más significativo del nuevo texto legislativo fue la reducción de la cuota a entregar por los redimidos en metálico, que disminuyó de 2.000 a 1.500 pesetas. Sin embargo, estos reclutas sólo quedarían exentos del servicio activo, debiendo ingresar en la institución castrense como reclutas disponibles y acudir a las asambleas anuales donde recibirían una mínima instrucción y al llamamiento en caso de conflicto bélico. El redimido no recibía por tanto licencia absoluta y mantenía ciertas obligaciones con la institución armada. Además, se prohibió la sustitución a no ser que fuese entre hermanos. También se permitió para aquellos que fuesen destinados a Ultramar. La sustitución no suponía además una desvinculación total del Ejército, ya que permanecerían en el mismo como reclutas disponibles.

El intento de superar las críticas a la existencia de privilegios económicos: La Ley de 1885

En 1885 una nueva ley de reclutamiento y reemplazo venía a sustituir a la aprobada apenas tres años antes. Esta misma Ley de 1885 encontró una nueva reforma en 1896. Diseñada por el Gobierno conservador de Cánovas, la norma de 1885 tenía como principal 
objetivo no declarado maquillar las enormes críticas provenientes de sectores populares, pero también militares, hacia la conservación de privilegios económicos en el cumplimiento del servicio militar. A ello se unía el triple objetivo, sí declarado, de ajustar y adecuar el reclutamiento a la nueva división en zonas militares del Estado español y a las nuevas cajas de reclutamiento, así como de reducir la complejidad administrativa del proceso, en especial del sorteo. Por ello se redujeron los tres sorteos existentes (en el Ayuntamiento de cada pueblo; en la caja para designar los destinados a Ultramar; en cada batallón de depósito para cubrir las bajas del servicio activo) a uno solo a celebrar en la cabecera de cada zona militar para fijar definitivamente la distinta suerte y las distintas situaciones en las que quedaban los mozos.

Como tercer objetivo la Ley de 1885 también pretendió reducir el número de exenciones y elevó el precio de la redención a 2.000 pesetas para aquellos que fuesen a ser destinados a Ultramar. Sin embargo, su mayor novedad residió en el traslado de las competencias en materia de reclutamiento del ministerio de Gobernación al ministerio de Guerra, militarizándose el reemplazo.

Al igual que en la Ley de 1882, la prestación, con una duración de doce años y que afectaba a los mozos de veinte años, se dividió en servicio activo y segunda reserva. La primera situación a su vez se dividió en servicio activo permanente con una duración máxima de tres años y a juicio del Gobierno, reserva activa y reclutas en depósito. Los soldados en reserva activa, con licencia para marchar a sus hogares, podrían ser llamados a filas cuando el Gobierno estimase conveniente. La segunda reserva tendría una duración de seis años. A la situación de reclutas en depósito pertenecerían durante seis años los mozos declarados soldados que, por exceso de cupo, no tendrían que cubrir bajas en el servicio activo; los redimidos en metálico o sustituidos y los eximidos por motivos familiares o falta 
de talla. Una vez transcurridos los seis años de servicio activo, reserva activa o reclutas en depósito, todos los soldados pasarían a la segunda reserva. Para los reclutas en depósito, así como para los pertenecientes a la segunda reserva, se mantuvieron las asambleas de instrucción ${ }^{1721}$. Para el cupo destinado a Ultramar, se trató de incentivar los reenganches voluntarios, con un servicio activo de sólo cuatro años. La exención para los jóvenes canarios no se recuperó con la nueva ley.

La elaboración del alistamiento por parte de los Ayuntamientos fue ampliamente regulada, sin presentar apenas diferencias con la Ley de 1882. Las reclamaciones a su errónea elaboración, así como al acto de clasificación y declaración de los soldados y a todas las tareas municipales relacionadas con el reemplazo, se podían presentar ante el propio Ayuntamiento para que las dirigiese a la comisión provincial de reclutamiento. Como última instancia, las reclamaciones se podían dirigir al ministerio de la Gobernación, si bien no serían admitidas aquellas en las que Ayuntamiento y comisión provincial estuviesen de acuerdo ni aquellas que versasen sobre la talla o aptitud física de un mozo.

La Ley de 1885 no recogió una fase tan importante como era el sorteo, que quedó exactamente igual a lo establecido en la Ley de 1882, aunque sí que se reguló el sorteo que designaba a los reclutas destinados a Ultramar. Además, la distribución del contingente, por primera vez en toda la legislación decimonónica, se realizaría después y no antes del sorteo por parte del ministerio de Guerra en función de las bajas habidas ese año en el seno del Ejército. Se establecieron

\footnotetext{
${ }^{1721}$ La aplicación real de estas asambleas fue prácticamente nula: "Estas asambleas podrían acortar el tiempo de empeño al tener como misión impartir enseñanzas militares a todos los españoles aptos para el servicio con objeto de que ingresaran ya iniciados en la instrucción los que tuvieran que cubrir las bajas que quedaran vacantes y los demás poseyeran cierta preparación que reduciría mucho el periodo de entrenamiento en caso de guerra. Las dificultades para poner en funcionamiento las asambleas de instrucción son obvias, tanto en lo referente a su eficacia como en su coste" (MARTÍNEZ RUIZ, E., "Condiciones básicas del reclutamiento militar en España, 1768-1885" p. 173).
} 
además unos criterios fijos que debían guiar tal distribución. Aquellos mozos sorteados que no tuviesen que ingresar en los cuerpos armados por exceder el cupo señalado a su zona, quedarían como reclutas de depósito. En el caso de no cubrirse las bajas con los reclutas excedentes de cupo, se podría acudir a los reclutas excedentes del sorteo anterior, a los mozos que se hubiesen redimido o sustituido y a las fuerzas de la segunda reserva. De nuevo sustitución y redención no eximían completamente del servicio, ya que podían ser llamados a filas en caso de conflicto bélico y en circunstancias excepcionales, además de acudir a las asambleas de instrucción, circunstancia ésta que nunca se produjo. La cuota establecida para los redimidos fue de 1.500 pesetas para los destinados a territorios peninsular y 2.000 para los destinados a Ultramar. Por primera vez se realizó una distinción económica en función del destino del recluta, sin quedar además completamente exentos del servicio ya que podían ser llamados en circunstancias excepcionales. La sustitución, socialmente mal conceptuada, sólo se permitió entre hermanos a no ser que el destino del mozo fuese el territorio ultramarino. Las penas impuestas a los prófugos se redujeron en comparación con la legislación previa: se pasó de cuatro a dos años en el incremento de la prestación, aunque se mantuvo el destino ultramarino.

Una importante novedad que contempló el nuevo texto legislativo fue la diferenciación entre exenciones totales del servicio y las parciales, que solamente permitían eludirlo en tiempos de paz, pero no de guerra. Entre las primeras destacamos las exenciones físicas y falta de talla mínima $(1,545 \mathrm{~mm}$.), religiosos y novicios de las órdenes dedicadas a la enseñanza, los operarios de las minas de Almadén, los oficiales del Ejército y la Armada y los condenados a largas penas de prisión. Entre las exenciones parciales incluyó la ley las ocasionadas por motivos económico-familiares. La aprobación de ambos tipos de exenciones se realizaría tras la celebración del juicio 
de exenciones. El reglamento de exenciones físicas adscrito a la ley no recogió novedades en cuanto a la tipología de exenciones, aunque sí sobre el procedimiento y la forma de actuar de las autoridades competentes a la hora de declarar una exención, a saber, Ayuntamientos, comisiones provinciales de reclutamiento y ministerio de Gobernación en caso de supuesto fraude.

La Ley de 1885 no supuso una estabilización legislativa en materia de reclutamiento, ya que fue acompañada, en los años sucesivos, por numerosas disposiciones aclaratorias de la misma y que vinieron a ampliarla. Así por ejemplo se concedió la exención del servicio a los miembros de numerosas órdenes religiosas dedicadas a la enseñanza.

Esta inestabilidad quedó confirmada con los dos proyectos ley sobre el reemplazo que fueron presentados y discutidos en Cortes en 1887 y 1891 ya que, aunque no fueron aprobados, mostraron los deseos de reforma que existían entre algunos sectores políticos y militares. El primero, impulsado por el ministro de Guerra liberal Cassola ${ }^{1722}$ y con Canalejas como Presidente del Gobierno, suponía un proyecto de reforma muy amplio de toda la institución castrense y generó una importante polémica, ya que propuso el servicio militar obligatorio para todos los jóvenes de veinte años de edad independientemente de su situación socioeconómica. Se excluía por tanto la posibilidad de sustitución y redención en metálico, excepto para los destinados a Ultramar a cambio de la entrega de 2.000 pesetas. Además, estos reclutas sustituidos o redimidos para el servicio ultramarino deberían cumplir con la prestación en territorio peninsular. Los intereses de las clases altas, que se oponían a ver a sus hijos cumpliendo con el servicio militar junto al resto de la

1722 "Cassola era consciente de la injusticia del sistema de reclutamiento vigente, basado en la exclusión de determinados ciudadanos por causa de su posición social, su grado de cultura o la suerte de su origen [...]" (CRESPO-FRANCÉS Y VALERO, J.A., A las armas: Reclutamiento y servicio militar en España desde sus orígenes hasta nuestros días, p. 265). 
población, y el regreso de los conservadores al poder, impidió la aprobación del proyecto Cassola, cuyas ideas serían recogidas en la legislación de 1912.

El segundo de los proyectos, esta vez presentado ante las Cortes por el ministro conservador Marcelo Azcárraga en 1891 y tampoco aprobado, admitía la sustitución y redención igualmente solo para el territorio de Ultramar. Proponía asimismo la reducción de las competencias municipales en materia de exenciones para reducir fraudes y contemplaba la posibilidad de solicitar prórrogas de hasta cuatro años en la incorporación al servicio por motivos laborales o de estudios.

La reforma definitiva de la Ley de 1885 llegó en 1896 con un nuevo texto legislativo y un nuevo reglamento, impulsadas de nuevo por Azcárraga y con Cánovas con Presidente. Presentó como objetivo principal la lucha contra la corrupción, los abusos y los fraudes en materia de reemplazo, así como cubrir los cupos del Ejército ultramarino. La organización del servicio apenas fue modificada. Con ese objetivo se incrementó el control sobre los Ayuntamientos con la presencia durante las operaciones del reemplazo de un delegado de la autoridad militar ${ }^{1723}$, se implantaron medidas para asegurar la realización del servicio por parte de los jóvenes residentes en el extranjero, se simplificó el sorteo al decretarse la posibilidad de celebrarse de forma conjunta en la cabecera de las zonas militares y no individualmente en cada municipio, se reguló de forma muy precisa el tallaje de los mozos y se sustituyeron las Comisiones

1723 "El proceso de militarización del reemplazo, iniciado con la Ley de 1885, se confirmó con la Real Orden de 15 de Julio de 1889, que consideró a los Gobernadores Militares como la única autoridad competente para conceder sustituciones y cambio de número, y que concluyó con la referida Ley de 1896 (CRESPO-FRANCÉS Y VALERO, J.A., A las armas: Reclutamiento y servicio militar en España desde sus orígenes hasta nuestros días, p. 266). 
provinciales de reclutamiento por las comisiones mixtas ${ }^{1724}$ de reclutamiento, con presencia de autoridades civiles y militares y con mayores competencias. Además se incrementó el número de órdenes religiosas cuyos miembros quedaban exentos de prestar el servicio y se estableció el envío de los prófugos capturados a territorio ultramarino para cumplir con el servicio, si bien las penas impuestas a los mismos fueron suavizadas. Años más tarde, en 1904, el territorio peninsular fue dividido en 116 circunscripciones a efectos de remplazo y movilización del Ejército. En cada una de ellas existiría una caja de reclutamiento.

El desastre del 98 determinó el inicio del cambio de rumbo en el remplazo ante las exigencias de regeneracionistas y sectores civiles y militares de acabar con los privilegios económicos que existían en el acceso al Ejército, situación que no se plasmaría desde el punto de vista legal hasta 1912. Las pérdidas coloniales supusieron un enorme desprestigio para la institución castrense y un incremento en las críticas desde las tribunas parlamentarias y desde la prensa escrita, especialmente republicanas, hacia un sistema de reclutamiento injusto que mantenía la redención en metálico y hacia una institución ineficaz que consumía una enorme cantidad de recursos. Solicitaban un servicio realmente universal o un voluntariado reducido ante las escasas necesidades militares que tenía España. Estas circunstancias motivaron la presentación por parte del ministro de Guerra Valeriano Weyler de un nuevo proyecto en 1902, a la postre no aprobado, para regular el remplazo, que sin embargo mantenía la redención en metálico, establecida en 2.000 pesetas. Sí que reducía en cambio el número de exenciones, ya que se suprimía la exclusión por cortos de talla, miembros de las órdenes religiosas y mineros de Almadén, y se mantenía la posibilidad de la prórroga por motivos de estudio o

1724 Presididas por el gobernador civil o por el vicepresidente de la Comisión Provincial, siendo el secretario de cada Diputación provincial también el secretario de la Comisión Mixta. 
trabajo, si bien los mozos que disfrutasen de las mismas debían de contribuir con impuesto proporcional a su fortuna o a la de sus padres. El proyecto de Weyler también contempló el establecimiento de un sistema de cuotas, cantidad económica que debían abonar los mozos en situación de licencia ilimitada no llamados a filas, excluidos, exceptuados y padres de prófugos en función de su riqueza.

En 1903, un nuevo proyecto de ley que recogía las bases para la reforma del reclutamiento fue presentado ante las Cortes por el ministro de Guerra conservador Arsenio Linares. El periodo de prestación, según el citado proyecto, se incrementaría hasta los quince años. Se establecían además facilidades para el ascenso en el escalafón militar para los jóvenes con estudios universitarios. Se intentaba así mejorar la formación académica de la oficialidad. Un privilegio económico que recogía el proyecto fue la posibilidad de que, aquellos individuos que pagasen una cuota no menor de 250 pesetas, prestasen un servicio activo de tan solo seis meses durante los tres años de duración del mismo. Por lo tanto se planteó la supresión la redención en metálico y la sustitución, pero se mantenían ciertos privilegios al contemplarse la posibilidad de reducir el periodo de permanencia en filas a través del pago de una cuota. Esta posibilidad, la del soldado de cuota, sería definitivamente implantada con la Ley de 1912. También se recogía la posibilidad de las prórrogas, cuya concesión incluía el pago de un impuesto anual.

En 1906 encontramos un nuevo proyecto de ley, tampoco aprobado, para el reemplazo presentado ante las Cortes por el ministro de Guerra liberal Agustín Luque. Con contenidos y reformas similares a las planteadas en los proyectos de ley de 1902 y 1903, su objetivo principal era mejorar la formación de los soldados. Como novedades destacar la ampliación del servicio hasta los quince años de duración, la eliminación de la exención por corto de talla, de la 
redención y la sustitución, así como el mantenimiento de las prórrogas y de las cuotas.

El fin de la redención y la sustitución, el inicio de las cuotas: La Ley de 1912

La primera de las leyes sobre reclutamiento aprobada durante el siglo XX vio la luz con el objetivo de acabar con las injusticias del sistema. Sus principios básicos se mantuvieron en vigor hasta las reformas de Azaña durante la II República. El desastre del 98 puso en evidencia la necesidad de reformar el sistema, aunque tuvieron que pasar todavía catorce años para que Canalejas pudiese por fin universalizar el servicio. El descrédito tras las pérdidas coloniales, los acontecimientos ocurridos en territorio colonial marroquí, con desastres militares como el acaecidos en el Barranco del Lobo, que le costó al Ejército español más de mil bajas, y el descontento popular observado en la prensa de izquierdas ante la posibilidad de que los más pudientes pudiesen eludir el servicio, impulsaron la aprobación de esta norma. El llamamiento a filas de 14.000 reclutas de la reserva activa para paliar los efectos del desastre militar marroquí derivó en los acontecimientos de la Semana Trágica de Barcelona de 1909, la caída del Gobierno Maura y la llegada al poder de Canalejas, dispuesto a reformar definitivamente el sistema de reemplazos en un sentido democrático ${ }^{1725}$.

Esta nueva ley tiene una enorme importancia histórica al universalizar el servicio militar, convertirlo en un deber personal e intransferible y abolir la redención y la sustitución, si bien se creó la figura del soldado de cuota, quien podría ver reducido su tiempo de

1725 CRESPO-FRANCÉS Y VALERO, J.A., A las armas: Reclutamiento y servicio militar en España desde sus orígenes hasta nuestros días, p. 270. 
servicio a cambio del pago de una cantidad en metálico. El mantenimiento de privilegios económicos volvería a provocar el malestar popular al verse como una prerrogativa de las clases pudientes en un Parlamento con presencia socialista y con un Pablo Iglesias enormemente crítico con todos los asuntos relacionados con la quinta. Viene a confirmar esta nueva norma la existencia de unos ejes evolutivos generales que trazan unas líneas de avance que van consolidándose con el tiempo, como el rechazo a los privilegios de clase o la paulatina supresión de figuras como la sustitución o la redención en metálico, si bien la existencia de soldados de cuota mostraba la resistencia de las clases altas a su definitiva eliminación. Asimismo, podemos confirmar que la preocupación social hacia el reclutamiento quedó reflejada en los debates políticos, tanto en prensa como en el Parlamento, que afloraron a raíz de la Semana Trágica de Barcelona, en especial en lo que se refiere al Partido Socialista y sus órganos de expresión.

La Ley de 1912 se vio precedida por dos proyectos de ley muy similares, que no llegaron si quiera a ser debatidos en el Parlamento, presentados en 1909 y 1910 por Arsenio Linares y Ángel Aznar respectivamente. Se justificaron en la necesidad de contar con una reserva bien instruida para ser movilizada rápidamente en el caso de conflicto bélico. Para ello se propuso incrementar la duración del servicio hasta los dieciocho años de duración y aumentar el número de jóvenes que recibiesen formación castrense, manteniéndose las asambleas anuales de instrucción militar aunque también la posibilidad de las prórrogas excepto en caso de guerra. Se propuso además la creación de una reserva territorial para proteger las plazas y ciudades más importantes, así como la creación de un cuerpo indígena de voluntarios en Marruecos y el Golfo de Guinea.

La novedad más importante que recogieron ambos proyectos de ley, y que luego sería aprobada con la Ley de 1912, fue la supresión de la redención en metálico. También se propuso la reducción en el 
tiempo de prestación para aquellos que mostrasen un mayor grado de formación y cuyo periodo de instrucción requiriese menos tiempo. Se imponían las cuotas para aquellos que quisiesen ver reducido su tiempo de prestación y para los que disfrutasen de prórroga. Como última novedad destacar la propuesta que se hizo de modificar el cuadro de exenciones físicas y dividir a los exentos en dos categorías: aptos para el servicio y aquellos que, por algún problema físico, serían destinados a funciones militares auxiliares. El Proyecto de ley de 1910, pero no el de 1909, anulaba la exención para los religiosos, que debían colaborar con el Ejército, no en funciones bélicas, sino eclesiásticas.

La Ley de 1912, presentada por el ministro de Guerra liberal Agustín Luque, vino a cambiar un sistema de reemplazos casi invariable desde la Ley de 1837. El objetivo básico de la norma era universalizar el servicio y suprimir la redención en metálico, para que así todos los jóvenes españoles recibiesen instrucción militar, además de asegurar una pronta y ordenada movilización.

En esta ocasión fueron los conservadores quienes se opusieron al proyecto de ley, al no recoger herramientas que permitiesen la exención para los jóvenes más útiles de la sociedad y ante la carencia de recursos económicos suficientes para implantar un servicio militar universal y para hacer frente a un crecimiento desmesurado de la plantilla del Ejército, que además perdería eficacia. Los republicanos reformistas de Melquiades Álvarez apostaban por su parte por una instrucción militar obligatoria para todos los ciudadanos, pero por un servicio militar compuesto exclusivamente por voluntarios ante las limitaciones económicas. En lo que se refiere a los republicanos federales, se oponían al carácter forzoso del servicio militar, aunque lo aceptaban como un mal menor. Defendían, con el objetivo de acabar con todo injusticia, un ejército de voluntarios. Una postura coincidente mostró el partido Radical de Lerroux, defensor del 
voluntariado aunque admitiendo un servicio obligatorio para todos los ciudadanos exclusivamente en caso de conflicto bélico.

El servicio militar obligatorio para todos los españoles no excluía la presencia de extranjeros voluntarios en las unidades indígenas, idea ésta recogida en los proyectos de 1909 y 1910. En función de la nueva ley, serían motivos de exclusión del servicio la talla inferior al $1,500 \mathrm{~m}$., el peso inferior a los $48 \mathrm{Kg}$. y el presentar un perímetro torácico inferior a los $75 \mathrm{~cm}$. El nuevo texto legislativo prohibió expresamente la redención en metálico y la sustitución. El contingente anual salido del proceso se dividiría en dos tipologías: el cupo en filas, es decir, aquellos que servirían como fuerzas activas; y el cupo en instrucción, es decir, aquellos que hubiesen excedido el cupo pero que estarían obligados a recibir instrucción militar y a incorporarse a filas cuando se les ordenase.

Para la ejecución del reemplazo, el territorio español quedó dividido en zonas militares, cada una de las cuales contaría con el número de cajas de reclutas que se estimase necesario. Las autoridades municipales continuaron teniendo gran importancia en todo el proceso (elaboración y rectificación del alistamiento, sorteo, clasificación de los soldados y apertura del expediente contra el prófugo y traslado de los mozos a las cajas de reclutamiento), debiendo seguir las instrucciones dadas por el ministerio de Guerra. Para el caso de los consulados en el extranjero, debían de seguir las instrucciones del ministerio de Estado. Por encima de las autoridades locales en cada provincia existiría una comisión mixta de reclutamiento presidida por el gobernador civil de la provincia. Estas comisiones quedaban constituidas como institución clave en todo el proceso, ya que atendían a las reclamaciones presentadas ante los Ayuntamientos, repartían el cupo entre los pueblos de su provincia, resolvían los expedientes de prófugos y concedían las prórrogas, aunque sus decisiones, excepto las que versasen sobre los fallos que 
confirmasen los acuerdos municipales o sobre la aptitud física de un mozo, podían ser recurridas ante el ministerio de la Gobernación. Un comisario regio revisaría todas las operaciones realizadas por Ayuntamientos y comisiones mixtas.

El servicio militar, con una duración total de dieciocho años, quedaba dividido en las siguientes situaciones: reclutas en caja, primera situación del servicio activo, segunda situación de servicio activo, reserva y reserva territorial. Además de los reclutas forzosos, la norma de 1912 admitió la posibilidad de ingreso voluntario en el Ejército con destino preferente al norte de África. El objetivo era formar un ejército colonial a imitación del francés y dulcificar el reclutamiento forzoso, pero el número de voluntarios nunca fue el suficiente. La norma concedió una enorme importancia a la instrucción militar de los nuevos reclutas, que debía completarse durante el primer año de servicio. Además se estableció la obligación de educar en primeras letras a todos los soldados y la creación de escuelas militares.

En lo que respecta a las exceptuados y exentos del servicio militar, aquí se incluía a los faltos de talla, peso o capacidad torácica, y los que padeciesen enfermedades o defectos físicos recogidos en el reglamento de exenciones que adjuntaba la ley, y a los presos y procesados por causa criminal. Las excepciones, no por motivo físico, sino familiar o de interés nacional, fueron reducidas notablemente por el descontento social que generaban. Así por ejemplo los ordenados in sacris no fueron excluidos del servicio, aunque sí dedicados a tareas especiales, lo que suscitó fuertes reproches entre los grupos más conservadores del Parlamento. A tareas especiales también serían dedicados los que poseyesen un título acreditativo de su dedicación a una profesión útil.

La posibilidad de acogerse a una prórroga temporal por motivos de estudio o económico-empresariales, hasta un máximo de tres años 
consecutivos, para retrasar la incorporación al servicio, también fue recogida por la Ley de 1912. La concesión de prórrogas era competencia de la comisión mixta de reclutamiento de cada provincia, si bien era el ministerio de la Gobernación el encargado de determinar el número de prórrogas que podría concederse, no pudiendo nunca exceder el diez por ciento de los ingresados anualmente en cada caja de reclutas. Serían anuladas las prórrogas concedidas y no se concederían más en caso de guerra o en situaciones excepcionales. Anuladas la redención y sustitución, se mantuvo la desigualdad en el acceso al Ejército al mantener la posibilidad de las cuotas, que permitía reducir el tiempo de prestación a cambio del pago de una cantidad económica (cinco o diez meses de servicio si se entregaban 2.000 o 1.000 pesetas respectivamente). Se estableció de esta manera una nueva discriminación en función de las posibilidades económicas.

Como resumen global, señalar que el reclutamiento en España mantendría su sesgo de injusticia social hasta bien entrado el siglo XX: "el sistema militar imperante puede ser tachado de legalmente discriminatorio y socialmente opaco"1726, lo que llevó a un intenso rechazo social. El mantenimiento de la sustitución, la redención y, más tarde, las cuotas (pagar con sangre o pagar con dinero) ${ }^{1727}$, tuvo enormes repercusiones en el terreno social que vino a agravar las diferencias existentes ${ }^{1728}$. Los hijos de labradores y trabajadores en general eran arrancados de sus casas para ser enviados durante años a unas lejanas guerras, de las que en muchas ocasiones no volvían, o a cumplir con un servicio militar en unas condiciones muy precarias,

1726 FERNÁNDEZ VARGAS, V., Sangre o dinero: el mito del Ejército nacional, p. 23.

1727 FERNÁNDEZ VARGAS, V., Sangre o dinero: el mito del Ejército nacional, p. 45.

1728 "Para los pobres que no podían pagar la redención del servicio, esto suponía un impuesto de sangre, sobre todo en tiempo de guerra, cuando las probabilidades que el quinto tenía de regresar vivo era de uno contra dos. [...]. Esta cuestión fue uno de los grandes factores que distanciaron a la clase media liberal de los pobres, con la consiguiente ventaja para la oligarquía" (PAYNE, S. G., Los militares y la política en la España contemporánea, p. 102). 
mientras los hijos de las familias acomodadas continuaban con su vida en sus casas y su tributo de sangre se veía reducido al pago de una cantidad económica. Este malestar social y el descontento hacia la institución armada y los políticos que la gestionaban, considerados ambos culpables de la pérdida de vidas en territorios lejanos y desconocidos, derivaron a lo largo del siglo XIX en estallidos violentos como oposición a las quintas ${ }^{1729}$.

Además, las figuras del prófugo y del desertor estuvieron siempre presentes como muestran las disposiciones que se aprobaron para luchar contra ambos, síntoma de un sistema de reclutamiento socialmente lesivo en un Ejército mal equipado y numeroso, carente de brillantez en las operaciones militares a las que tuvo que hacer frente. Incluso el rechazo al sistema llegó a sectores militares "[...] escandalizados por la corrupción que genera y horrorizados por las condiciones de inexperiencia e indefensión con que las tropas se enfrentan al enemigo, sobre todo, en las Guerras Coloniales"1730.

Señalar también como conclusión global que, sorprendentemente, el reclutamiento en España fue un proceso fundamentalmente civil y no militar, es decir, eran las autoridades civiles las principales encargadas de regular y ejecutar todo el proceso aunque el fin último fuese el de nutrir de efectivos al Ejército. Esta característica viene confirmada por el hecho de que el reemplazo estuviese vinculado en sus características más al partido gobernante de turno y sus principios ideológicos que a las necesidades militares

\footnotetext{
1729 "Conforme avanzan las ideas internacionalistas y la influencia y afiliación a los partidos obreros aumentan, esta protesta va a dejar de ser puntual para ser colectiva y radicalizarse, llegándose a pedir la abolición de las quintas.

Si repasamos los textos legales la doctrina que identifica la defensa patria con los deberes ciudadanos es omnipresente; pero, a continuación se establecen tal cúmulo de exenciones que el colectivo afectado es uno y muy concreto. Pues todo aquel que legal, o ilegalmente, puede eludir el Servicio Militar, lo eludirá" (FERNÁNDEZ VARGAS, V., "El servicio militar en el siglo XIX. Una percepción social", p. 104).

1730 FERNÁNDEZ VARGAS, V., "El servicio militar en el siglo XIX. Una percepción social", p. 106.
} 
del momento o a los intereses y características de la institución armada. 



\section{Bibliografía}

- ALBI, J., Banderas olvidadas: el Ejército realista en América, Madrid, Ediciones de Cultura Hispánica, 1990.

- ALEJANDRE, J.A., "El Pacto de El Pardo", Historia 16, 116 (1985), Madrid, pp. 19-28.

- ALÍA MIRANDA, F. (coord.), La guerra de Marruecos y la España de su tiempo (1909-1927), Ciudad Real, Sociedad Don Quijote de conmemoraciones culturales Castilla la Mancha, 2009.

- ALONSO BAQUER, J.R., El modelo español de pronunciamiento, Madrid, Rialp, 1983.

- ALONSO BAQUER, M., El Ejército en la sociedad española, Madrid, Ediciones del Movimiento, 1971.

- ALONSO, J.R., Historia política del Ejército español, Madrid, Ediciones del Movimiento, 1974.

- ANDÚJAR CASTILlO, F., Los militares en la España del siglo XVIII: un estudio social, Granada, Universidad de Granada, 1991.

- ANES, G., España a fines del siglo XVIII, Tarragona, Hemeroteca de Tarragona, 1982.

- AZCÁRATE, P., La tradición liberal del Ejército español en el siglo XIX, Roma, Realidades, 1966.

- BACHOUD, A., Los españoles ante las campañas de Marruecos, Madrid, Espasa-Calpe, 1988.

- BALLBÉ, M., Orden público y militarismo en la España constitucional (1812-1983), Madrid, Alianza, 1985.

- BALFOUR, S., Abrazo mortal: de la guerra colonial a la guerra civil en España y Marruecos (1909-1939), Barcelona, Península, 2002. 
- BLANCO VALDÉS, R. L., Rey, Cortes y fuerza armada en los orígenes de la España liberal, 1808-1823, México, Siglo XXI, 1988.

- BERMERJO, F., Espartero, hacendado riojano, Logroño, Colección Logroño 24, Instituto de Estudios Riojanos, 2000.

- BORREGUERO BELTRÁN, C., "Administración y reclutamiento militar en el Ejército borbónico del siglo XVIII", Cuadernos de investigación histórica, 12 (1989), Valladolid, Universidad de Valladolid.

- BORREGUERO BELTRÁN, C., Reclutamiento militar por quintas en la España del siglo XVIII: orígenes del servicio militar obligatorio, Valladolid, Universidad de Valladolid, 1989.

- BORREgUeRO BELTRÁN, C., "Del Tercio al Regimiento" Estudis: Revista de historia moderna, 27 (2001), Valencia, Universidad de Valencia.

- BORREguero BeltrÁN, C., "El impacto social del reclutamiento y de otros impuestos militares en el siglo XVIII", en MARTÍNEZ RUÍZ, E., PAZZIS PI CORRALES, M., TORREJÓN CHAVES, J. (coords.), Los Ejércitos y las armadas de España y Suecia en una época de cambios (1750-1870), Puertollano, Fundación Berndt Wistedt, 2001.

- BORREGUERO BELTRÁN, C., "Extranjeros al servicio del Ejército español del siglo XVIII", Coloquio Internacional Carlos III y su Siglo, Vol. 2, Poder y sociedad en la época de Carlos III, Madrid, Madrid, Universidad Complutense de Madrid, 1990.

- BORREguero Beltrán, C., "Los motines de quintas", Cuadernos de Historia Moderna, 10 (1989-1990), Madrid, Universidad Complutense de Madrid.

- BORREGUERO BELTRÁN, C.: "El soldado en el nuevo modelo de Ejército", en FRIEYRO LARA, B. (coord.), Guerra, Ejército y 
sociedad en el nacimiento de la España contemporánea, Granada, Universidad de Granada, 2009.

- BOYD, C. P., La política pretoriana en el reinado de Alfonso XIII, Madrid, Alianza Editorial, 1990.

- BULlón DE MENDOZA GómeZ De VAluguerA, A., La primera guerra carlista, Madrid, Universidad Complutense de Madrid, 1992.

- BURDIEL, I., Isabel II. No se puede reinar inocentemente, Madrid, Espasa-Calpe, 2004.

- BUSQUETS BRAGULAT, J., El militar de carrera en España, Barcelona, Ariel, 1984.

- CALVO POYATO, J., "Medio siglo de levas, reclutas y movilizaciones en el Reino de Córdoba: 1657-1712", Axerquia, 3 (1983), Córdoba, Diputación Provincial de Córdoba.

- CANALES, C. y CARRASCO, J. C., La primera guerra carlista, Madrid, Grupo Medusa, 2000.

- CARASA SOTO, P., y ENCISO RECIO, L. M., El sistema hospitalario español en el siglo XIX: de la asistencia benéfica al sistema sanitario actual, Valladolid, Secretariado de Publicaciones de la Universidad de Valladolid, 1985.

- CARASA SOTO, P., "Los peligros de la pobreza, los valores del liberalismo y las soluciones asistenciales burguesas", en VVAA, Antiguo Régimen y liberalismo: homenaje a Miguel Artola, Vol. 2, Madrid, Alianza, 1994, pp. 421-440.

- CARASA SOTO, P., "Perspectivas de la historiografía española en torno a los expósitos e ilegítimos, desde las actuales tendencias de la historia social", en SVEN REHER SULLIVAN, D. (coord.), Actas do III Congresso da ADEH (Associaçao Ibérica 
de Demografia Histórica), Vol. 3, Guimaraes, Afrontamento, 1996, pp. 87-105.

- CARASA SOTO, P., "Isabel II y la cultura de la pobreza", en PÉREZ GARZÓN, S. (coord.), Isabel II: los espejos de la reina, Madrid, Marcial Pons, 2004, pp. 111-140.

- CARDONA, G., El poder militar en la España contemporánea hasta la guerra civil, Madrid, Siglo XXI de España Editores, 1983.

- CARDONA, G., El problema militar en España, Madrid, Historia $16,1990$.

- CARR, R., España, 1808-1975, Ariel, Barcelona, 2005.

- CASADO BURBANO, P., Las fuerzas armadas en el inicio del constitucionalismo español, Madrid, Editoriales de Derecho Reunidas, 1982.

- CASTELLANO GIL, J. M., Quintas, prófugos y emigración: La Laguna (1886-1935), Tenerife, Centro de la Cultura Popular Canaria, 1990.

- CEPEDA GÓMEZ, J., El Ejército español en la política española (1787-1843), conspiraciones y pronunciamientos en los comienzos de la España liberal, Madrid, Fundación Universitaria Española, 1990.

- CEPEDA GÓMEZ, J., Los pronunciamientos en la España del siglo XIX, Madrid, Arco Libros, 1999.

- CHRISTIANSEN, C., Los orígenes del poder militar en España, 1800-1854, Madrid, Aguilar, 1974.

- COMEllAS, J. L., Del 98 a la Semana Trágica: crisis de conciencia y renovación política, Madrid, Biblioteca Nueva, 2002. 
- CONTRERAS GAY, J., "Aproximación al estudio de los sistemas de reclutamiento en la España moderna", Anuario de Historia Contemporánea, 8 (1981), Granada, Universidad de Granada.

- CORONA BARATECH, C., "Las milicias Provinciales del siglo XVIII como Ejército peninsular de reserva", Temas de Historia Militar (1983), Madrid, Servicio de Publicaciones del EME.

- CRESPO-FRANCÉS Y VALERO, J. A., A las armas: Reclutamiento y servicio militar en España desde sus orígenes hasta nuestros días, Madrid, Multimedia Militar, 2009.

- DARDÉ MORALES, C. y VARELA ORTEGA, J., "La Regencia y el Pacto de el Pardo", en ESPADAS BURGOS, M. (coord.), La época de la restauración: (1875-1902), Vol. 1, Madrid, Espasa Calpe, 1996, pp. 359-369.

- DE DIEGO, E., 1895: la guerra en Cuba y la España de la Restauración, Madrid, Editorial Complutense, 1996.

- DE DIEGO, E., Hacia el 98: la España de la Restauración y la crisis colonial (1895-1898), Madrid, Escuela Diplomática, 1997.

- DIEGO PAREJA, L. M., "El motín de Aranjuez", Revista española de historia militar, Madrid, no 90-91 (2007), pp. 220-226.

- DOMÍNGUEZ NAFRÍA, J. C., "Ejércitos permanentes y milicias nacionales en la Constitución de Cádiz", en ESCUDERO, J. A., Cortes y Constitución de Cádiz, Madrid, Espasa Calpe, 2012.

- DUARTE MONTSERRAT, A., "Stanislao Figueras y el quimérico liberalismo manso", en PÉREZ LEDESMA, M., y BURDIEL, I., Liberales eminentes, Madrid, Marcial Pons, 2008.

- ECHANIZ ITUIÑO, M. A., La Milicia Nacional: fuerza popular del liberalismo español, 1974, Memoria de Licenciatura inédita, Universidad de Deusto. 
- ELORZA, A., y HERNÉNDEZ SANDOICA, E., La guerra de Cuba (1895-1898): historia política de una derrota colonial, Madrid, Alianza, 1998.

- ESPARZA ZABALEGUI, J.M., Abajo las quintas: oposición histórica navarra al Ejército español, Tafalla, Txalaparta editorial, 1994.

- ESCUDERO, J. A., (dir.), Los validos, Madrid, Editorial Dyckinson, 2005.

- FEIJÓo GÓMEZ, A., Quintas y protesta social en el siglo XIX español, Madrid, Ministerio de Defensa, 1996.

- FERNÁNDEZ BASTARRECHE, F., "La cuestión de las quintas en el Sexenio Revolucionario", Revista de Historia Militar, 43 (1977), Madrid, Servicio Histórico Militar.

- FERNÁNDEZ BASTARRECHE, F., El Ejército español en el siglo XIX, Madrid, Siglo XXI de España Editores, 1978.

- FERNÁNDEZ BASTARRECHE, F., "El servicio militar en la España del siglo XIX. Una epidemia de los tiempos contemporáneos", Historia 16, 140 (1987), Madrid.

- FERNÁNDEZ BASTARRECHE, F., Los espadones románticos, Madrid, Síntesis, 2007.

- FERNÁNDEZ MIRANDA CAMPOAMOR, C., "La verificación de poderes en el Sexenio Revolucionario", Revista de Derecho Político, Madrid, 55-56 (2002), pp. 343-364.

- FERNÁNDEZ MUÑIZ, A.M., "Las quintas. Sistema de reclutamiento: explotación para unos, negocio para otros (1868-1898), Estudios de Historia Social 1-4 (44-47), 1988, Ministerio de Trabajo y Seguridad Social, Madrid.

- FERNÁNDEZ RODRÍGUEZ, M. y MARTÍNEZ PEÑAS, L., "Problemática social en la legislación de reclutamiento 
decimonónica: exenciones, sustitución y redención", en VVAA, Luces y sombras de la seguridad, Madrid, Instituto Universitario General Gutiérrez Mellado, 2010.

- FERNÁNDEZ RODRÍGUEZ, M., MARTÍNEZ PEÑAS, L., (coords.), Amenazas y orden público: efectos y respuestas, de los Reyes Católicos al Afganistán contemporáneo, Valladolid, Asociación Veritas, 2013.

- FERNÁNDEZ RODRÍGUEZ, M., MARTÍNEZ PEÑAS, L., y GRANDA, S., (coords.), Perspectivas jurídicas e institucionales sobre guerra y Ejército en la Monarquía Hispánica, Madrid, Dyckinson, 2011.

- FERNÁNDEZ RODRÍGUEZ, M., y MARTÍNEZ PEÑAS, L., y (coords.), Reflexiones sobre poder, guerra y religión en la Historia de España, Madrid, Universidad Rey Juan Carlos, 2011.

- FERNÁNDEZ RODRÍGUEZ, M., y MARTÍNEZ PEÑAS, L., y (coords.), El Ejército y la Armada en el Noroeste de América: Nootka y otras cuestiones, Madrid, Dirección General de Relaciones Institucionales del Ministerio de Defensa, 2011.

- FERNÁNDEZ RODRÍGUEZ, M., y MARTÍNEZ PEÑAS, L., (coords.), De las Navas de Tolosa a la Constitución de Cádiz: el ejército y la guerra en la construcción del Estado, Valladolid, Universidad Rey Juan Carlos, 2012.

- FERÁNDEZ RODRÍGUEZ, M., MARTÍNEZ PEÑAS, L., y BRAVO DÍAZ, D., (coords.), La presencia española en África: del fecho de allende a la crisis de Perejil, Valladolid, Asociación Veritas, 2012.

- FERNÁNDEZ RODRÍGUEZ, M., y MARTÍNEZ PEÑAS, L., La guerra y el nacimiento del Estado Moderno, Madrid, Asociación Veritas, 2014. 
- FERNÁNDEZ VARGAS, V., "El servicio militar en el siglo XIX. Una percepción social", en FERNÁNDEZ ALBADALEJO, P. y ORTEGA LÓPEZ, M., (eds.), Antiguo régimen y liberalismo: homenaje a Miguel Artola, Política y cultura, vol. 3, Madrid, Alianza, 1995.

- FERNÁNDEZ VARGAS, V., Sangre o dinero: el mito del Ejército nacional, Madrid, Alianza, 2004.

- FONTANA, J., "La época del liberalismo" en FONTANA, J., y VILLARES, R., Historia de España, Vol. 6, Barcelona, Crítica/Marcial Pons, 2007.

- FRIEYRO DE LARA, B., De campesino a soldado. Las quintas en Granada (1868-1898), Granada, Universidad de Granada, 2002.

- FRIEYRO DE LARA, B., El reclutamiento militar en la crisis de la Restauración: el caso riojano (1896-1923), Logroño, Instituto de Estudios Riojanos, 2000.

- FUSI AIZPURÚA, J. P., Antes del desastre: orígenes y antecedentes de la crisis del 98: Congreso Internacional, Madrid, Universidad Complutense de Madrid, 1996.

- GADOW, R., "Cánovas, del Manifiesto de Manzanares a la Restauración", en QUESADA NIETO, D., Isabel II y la mujer en el siglo XIX, Madrid, MECD, 2010, pp. 189-215.

- GARCÍA GARCÍA, A., y SEMPERE DOMENECH, M., "Conflicto y quintas. Resistencia al servicio militar obligatorio: exenciones, exclusiones, redenciones y sustituciones en la Murcia del siglo XIX", en La era Isabelina y la revolución 1843 - 1875: Actas de las XIII Jornadas Nacionales de Historia Militar, Sevilla, Cátedra General Castaños, 2009, pp. 337-356. 
- GARCÍA GONZÁLEZ, F. (Coord.), La guerra de sucesión en España y la batalla de Almansa: Europa en la encrucijada, Madrid, Sílex, 2009.

- GARCÍA MORENO, J.F., Servicio militar en España (1913-1935), Madrid, Adalid, Servicio de Publicaciones del Estado Mayor del Ejército, 1988.

- GIMÉNEZ LÓPEZ, E., El fin del Antiguo Régimen: el reinado de Carlos IV, Madrid, Temas de Hoy, 1996.

- GODOY, M., Memorias, Alicante, Universidad de Alicante, 2006.

- GONZÁLEZ ASENJO, A. J., "La resistencia al servicio militar en Galicia", Estudios de Historia Social, 34-35 (1985), Madrid, Ministerio de Trabajo y Seguridad Social.

- gonzÁlez CASANOVA, J. A., Historia política de las Diputaciones desde 1812 hasta 1985, Madrid, Mancomunidad General de Diputaciones de Régimen Común, 1986.

- GUTIÉRREZ MACÍAS, V., Las quintas y la tradición extremeña, Badajoz, Diputación Provincial de Badajoz, 1983.

- HAMNET, B.R., La política española en una época revolucionaria, 1790-1820, México, Fondo de Cultura Económica, 1985.

- HEADRICK, D. R., Ejército y política en España (18661898), Madrid, Tecnos, 1981.

- HERRERO BRASAS, J. A., iRompan filas! La cara oculta del servicio a la patria, Madrid, Temas de Hoy, 1995.

- HERRERO BRASAS, J. A., Informe crítico sobre el servicio militar, Madrid, Ars Media, 1989.

- HeRRero MATÉ, G., Liberalismo y Milicia Nacional en Pamplona durante el siglo XIX, Pamplona, Universidad Pública de Navarra, 2003. 
- HOCQUELLET, R., "Élites locales y levantamiento patriótico: la composición de las juntas provinciales de 1808", Historia y política: Ideas, procesos y movimientos sociales, Madrid, no 19 (2008), Ejemplar dedicado a "1808, crisis y soberanía", pp. 129-150.

- JIMÉNEZ GUERRERO, J., El reclutamiento militar en el siglo XIX: las quintas en Málaga (1837-1868), Málaga, Universidad de Málaga, 2001.

- LA PARRA LÓPEZ, E.," La Central y la formación de un nuevo ejercito: la Junta Militar (1808-1809)", en Antiguo Régimen y liberalismo: homenaje a Miguel Artola, Vol. 3, Madrid, Alianza, 1994 (Política y cultura), pp. 275-284.

- LA PARRA LÓPEZ, E. M., Manuel Godoy, la aventura del poder, Tusquets, Barcelona, 2002.

- LA PARRA LÓPEZ, E. M., "De la disputa cortesana a la crisis de la monarquía. Godoyistas y fernandinos en 1806-1807", Cuadernos de Historia Moderna, Anejos, Madrid, no 6 (2007), pp. 255-267.

- LLEIXÁ, J., Cien años de militarismo en España: funciones estatales confiadas al Ejército en la Restauración y el franquismo, Barcelona, Anagrama, 1986.

- LINDO MARTÍNEZ, J. L.," El motín de Aranjuez, inicio de la guerra de la Independencia, un acontecimiento histórico falseado" Ars et sapientia: Revista de la asociación de amigos de la Real Academia de Extremadura de las letras y las artes, Madrid, no. 31 (2010), pp. 59-87.

- LÓPEZ BARRANCO, J. J., El Rif en armas: la narrativa española sobre la guerra de Marruecos (1859-2005), Madrid, Marenostrum, 2005. 
- MADARIAGA, M. R. de, En el Barranco del Lobo: las guerras de Marruecos, Madrid, Alianza, 2005.

- MAQUEDA ABREU, C., "La Restauración de Fernando VII y el reclutamiento militar", Revista de Historia Militar, 62 (1987), Madrid, Servicio Histórico Militar.

- MARÍN SILVESTRE, D., La Semana Trágica: la revuelta popular y la Escuela Moderna, Madrid, La Escuela de los libros, 2009.

- MARTÍN CORRALES, E., Marruecos y el colonialismo español (1859-1912), Barcelona, Bellaterra, 2002.

- MARTÍNEZ PEÑAS, L., "La Casa Real de Felipe V en la jornada de Italia", en LABRADOR, F., y GAMBRA, A., (coord.), Las Casas de la monarquía hispana: La Casa de Castilla, Madrid, Editorial Polifemo, 2010.

- MARTÍNEZ PEÑAS, L., "Pretorianismo en el reinado de Fernando VII: El ejército como defensor del doceañismo", en AGUILAR GIL, M. (coord.), Construcciones y deconstrucciones de la sociedad, Almagro, Sociedad castellano-manchega de Sociología, 2010, pp. 65-76.

- MARTÍNEZ PEÑAS, L., GRANDA, S., Y FERNÁNDEZ RODRÍGUEZ, M. (coords.), Perspectivas jurídicas e institucionales sobre guerra y Ejército en la Monarquía Hispánica, Madrid, Dyckinson, 2011.

- MARTÍNEZ PEÑAS, L., y FERNÁNDEZ RODRÍGUEZ, M. (coords.), Reflexiones sobre poder, guerra y religión en la Historia de España, Madrid, Universidad Rey Juan Carlos, 2011.

- MARTÍNEZ PEÑAS, L., y FERNÁNDEZ RODRÍGUEZ, M. (coords.), El Ejército y la Armada en el Noroeste de América: Nootka y otras cuestiones, Madrid, Dirección General de Relaciones Institucionales del Ministerio de Defensa, 2011. 
- MARTÍNEZ PEÑAS, L., "El ejército", en ESCUDERO, J. A., Cortes y Constitución de Cádiz, Madrid, Espasa Calpe, 2012.

- MARTÍNEZ PEÑAS, L., y FERNÁNDEZ RODRÍGUEZ, M. (coords.), De las Navas de Tolosa a la Constitución de Cádiz: el ejército y la guerra en la construcción del Estado, Valladolid, Universidad Rey Juan Carlos, 2012.

- MARTÍNEZ PEÑAS, L., y FERNÁNDEZ RODRÍGUEZ, M. (coords.), Amenazas y orden público: efectos y respuestas, de los Reyes Católicos al Afganistán contemporáneo, Valladolid, Asociación Veritas, 2013.

- MARTÍNEZ PEÑAS, BRAVO DÍAZ, D., L., y FERNÁNDEZ RODRÍGUEZ, M. (coords.), La presencia española en África: del fecho de allende a la crisis de Perejil, Valladolid, Asociación Veritas, 2012.

- MARTÍNEZ PEÑAS, L. y FERNÁNDEZ RODRÍGUEZ, M., La guerra y el nacimiento del Estado Moderno, Madrid, Asociación Veritas, 2014.

- MARTÍNEZ RUIZ, E., "Algunas disposiciones sobre el reclutamiento de marinos a finales del siglo XVIII", Chrónica Nova, 13 (1982), Granada, Universidad de Granada.

- MARTÍNEZ RUIZ, E., "Condiciones básicas del reclutamiento militar en España", en MARTÍNEZ RUÍZ, E., PAZZIS PI CORRALES, M. y TORREJÓN CHAVES, J. (coords.), Los Ejércitos y las armadas de España y Suecia en una época de cambios (1750-1870); Puertollano, Fundación Berndt Wistedt, 2001.

- MARTÍNEZ RUIZ, E., "Desertores y prófugos en la primera mitad del siglo XIX", Hispania, 107 (1967), Madrid, Consejo Superior de Investigaciones Científicas. 
- MARTÍNEZ RUIZ, E., "El reclutamiento militar y sus implicaciones sociales en el marco de la Constitución de 1845", Revista de Derecho Político, 39 (1994), Madrid, UNED.

- MARTÍNEZ RUIZ, E., "La celebración de quintas, una cadencia temporal en la España del Antiguo Régimen", Revista de Historia Moderna, 11 (1992), Alicante, Universidad de Alicante.

- MARTÍNEZ RUIZ, E., "Reclutamiento y reemplazo en los orígenes de la Guardia Civil", Revista de Estudios Históricos de la Guardia Civil, Madrid, Ministerio de Defensa, 11 y 12 (1973).

- MARTÍNEZ RUIZ, E., Los soldados del rey: los Ejércitos de la monarquía hispánica (1480-1700), San Sebastián de los Reyes, Actas, 2008.

- MARTÍNEZ RUIZ, E.; "Le recrutement militarire espagnol au XIXe siécle", Les cahiers de Montpellier, no 21, t. I, Montpellier, 1990.

- MAS CHAO, A., La evolución de la conciencia africanista en el Ejército español, Madrid, SGE, 1988.

- MOLINA LUQUE, J. F., Quintas y servicio militar: aspectos sociológicos y antropológicos de la conscripción (Lleida, 18781960), Lleida, Server de Publicacions de la Universitat de Lleida, 1998.

- MOLINER PRADA, A., "De las Juntas a la Regencia: la difícil articulación del poder en la España de 1808", Historia mexicana, México, Vol. 58, no 1, 2008 (Ejemplar dedicado a "1808: una coyuntura germinal"), pp. 135-177.

- MONTORO OBRERO, G., "Las clases de tropa en las ordenanzas militares en los siglos XVII y XVIII", Revista de Historia Militar, no 66 (1989), Madrid. 
- MORO BARREÑADA, J.M., "La "contribución de sangre" en Asturias: servicio militar, traficantes y sustitutos de quintas", Astura 1 (1984), Museo de Bellas Artes de Asturias, Oviedo.

- NAVAS SIERRA, J. A., "El tratado de Valençay o el fracaso del pacto imperial napoleónico", Anuario de Historia de América Latina, 27 (1990).

- NUÑEZ FLORENCIO, R., "Militares y política militar en la España de la Restauración", Bulletin d'histoire contemporaine de l'Espagne, 16 (1992), Talence, Maison des Pays Iberiques.

- NUÑEZ FLORENCIO, R., El antimilitarismo en el pensamiento político español en torno al desastre (1891-1906), Madrid, Universidad Autónoma de Madrid, 1989.

- NUÑEZ FLORENCIO, R., El Ejército español en el Desastre de 1898, Madrid, Arco Libros, 1997.

- NUÑEZ FLORENCIO, R., Militarismo y antimilitarismo en España (1888-1896), Madrid, CSIC, 1990.

- OÑATE AlgueRÓ, P., Servir al Rey: la milicia provincial (17341846), Madrid, Ministerio de Defensa, 2001.

- PABÓN Y SUÁREZ DE URBINA, J. y SECO SERRANO, C, Narváez y su época, Madrid, Espasa Calpe, 1983.

- PAYNE, S. G., Ejército y sociedad en la España liberal (18081936), Madrid, Akal, 1977.

- PAYNE, S. G., Los militares y la política en la España contemporánea, Ruedo Ibérico, 1976.

- PEÑA GONZÁleZ, J., "La cultura política en el Sexenio", Revista de Derecho Político, no 55-56 (2002), Madrid, pp. 33-106.

- PÉREZ ALONSO, J. "Ramón María Narváez: biografía de un hombre de estado. El desmontaje de la falsa leyenda del 
"Espadón de Loja", Historia constitucional: Revista Electrónica de Historia Constitucional, no 14 (2013), Madrid.

- PÉREZ FERNÁNDEZ-TURÉGANO, C., "La Armada", en ESCUDERO, J. A., Cortes y Constitución de Cádiz, Madrid, Espasa Calpe, 2012.

- PÉREZ GARZÓN, S., Milicia Nacional y revolución burguesa, Madrid, CSIC, 1978.

- PERfecto GARCÍA, M. A., "El Sexenio Revolucionario y los inicios de la Restauración", en La historia contemporánea en España: primer Congreso de Historia Contemporánea de España, Salamanca, Universidad de Salamanca, 1996.

- PRO RUIZ, J., Bravo Murillo: política de orden en la España liberal, Madrid, Síntesis, 2006.

- PUELL DE LA VILLA, F., "El General Cassola, reformista militar de la Restauración", Revista de Historia Militar, no 45 (1978), Madrid, Ministerio de Defensa.

- PUELL DE LA VILLA, F., "La ordenanza del reemplazo anual de 1770", Hispania 189 (1995), Madrid, CSIC.

- PUELL DE LA VILLA, F., El soldado desconocido: de la leva a la "mili" (1700-1912), Madrid, Biblioteca Nueva, 1996.

- PUELL DE LA VILLA, F., "EL reclutamiento y la movilización", La Guerra de la Independencia Española: Una visión militar. Actas del VI Congreso de Historia Militar, Madrid, Ministerio de Defensa, 2009.

- PUELL DE LA VILLA, F., Historia del Ejército en España, Madrid, Alianza, 2005.

- RIVILLA MARUGÁN, G., y MARTÍNEZ PEÑAS, L., "La pervivencia de elementos del Antiguo Régimen en la Ordenanza de 
reclutamiento de 1800", CODEX. Boletín de Estudios HistóricoJurídicos, no 5 (2012), Córdoba.

- REY VICENTE, M. y CANALES TORRES, C., Breve historia de la guerra del 98, Navarra, Nowtilus, 2010.

- RIBOT GARCÍA, L.A., "El reclutamiento militar en España a mediados del siglo XVII, La "composición" de las milicias de Castilla", Cuadernos de Investigación Histórica, 9 (1986), Madrid, Fundación Universitaria Española.

- ROMANONES, CONDE de, Espartero. El general del pueblo, Madrid, Espasa-Calpe, 1932.

- RUBIO, J., El final de la era Cánovas: los preliminares del desastre de 1898, Madrid, Ministerio de Asuntos Exteriores, 2004.

- SALES DE BOHÍGAS, N., "Esclavos y reclutas en las guerras de independencia de Sudamérica, 1816-1826", Revista de Historia de América, no 69 (1970), México.

- SALES DE BOHÍGAS, N., "Servei militar i societat a L'Espanya del segle XIX", en VVAA, La formación de la Catalunya moderna, Barcelona, Ariel, 1970.

- SALES DE BOHÍGAS, N., "Servei militar i societat a l'Espanya del segle XIX", Recerques, 1 (1970), Barcelona.

- SALES DE BOHÍGAS, N., "Sociedades de seguros contra quintas", en LIDA, C. E. y ZAVALA, I. M. (comps.), La revolución de 1868: historia, pensamiento, literatura, New York, Las Américas publishing, 1970.

- SALES DE BOHÍGAS, N., "Servei militar i societat: la desigualtat enfront del servei militar, seagles XVIII-XIX", L'Avenç, no 98 (1986), Barcelona. 
- SALES DE BOHÍGAS, N., Sobre esclavos, reclutas y mercaderes de quintos, Esplugues de Llobregat (Barcelona), Ariel, 1974.

- SÁNCHEZ, J. P., La guerra cubano-hispano-americáine (1898), Rennes, Laboratoire Interdisciplinaire de Recherche sur les Amériques, 1995.

- SÁNCHEZ MANTERO, R., Fernando VII, Madrid, Arlanza, 2001.

- SANTANA MOLINA, M., BERMúdeZ AZNAR, A., La Diputación Provincial en la España decimonónica, Madrid, Ministerio de Administraciones Públicas, 1989.

- SECO SERRANO, C., "Prófugos y desertores en la Guerra de Cuba", Estudios de Historia Social, 22-23 (1982), Madrid, Ministerio de Trabajo y Seguridad Social.

- SECO SERRANO, C., Militarismo y civilismo en la España contemporánea, Madrid, Instituto de Estudios Económicos, 1984.

- SeOANE M. C. y SANZ. D., Cuatro siglos de periodismo en España. De los avisos a los periódicos digitales, Madrid, Alianza Editorial, 2007.

- SERRANO GARCÍA, R., "La historiografía en torno al Sexenio: entre el fulgor del centenario y el despliegue de lo local", Ayer, no 44 (2001), Madrid, Marcial Pons.

- SERRANO GARCÍA, R. (coord.), figuras de la "Gloriosa": aproximación biográfica al Sexenio Democrático, Valladolid, Universidad de Valladolid, Secretariado de Publicaciones e Intercambio Editorial, 2006.

- SHUBERT, A. "Baldomero Espartero (1793-1879). Del ídolo al olvido", en BURDIEL, I. Y PÉREZ LEDESMA M. (coords.), Liberales, agitadores y conspiradores. Biografías heterodoxas del siglo XIX, Madrid, Espasa Calpe, 2001. 
- SOTTO Y MONTES, J., "El reclutamiento militar en España", en Revista de Historia Militar, 16 (1964), Madrid, Instituto de Historia y Cultura militar.

- TARRAgó, R.E., "La guerra de 1895 en Cuba y sus consecuencias", en Arbor: ciencia, pensamiento y cultura, no 735 (2009), (Ejemplar dedicado a "Los destinos inciertos: el exilio republicano español en América Latina"), Madrid, CSIC, pp. 215-229.

- TONE, J. T., Guerra y genocidio en Cuba: 1895-1808, Madrid, Turner, 2008.

- VILCHES, J, Progreso y Libertad. El Partido Progresista en la Revolución Liberal Española, Madrid, Alianza Editorial, 2001.

- VVAA, Aproximación a la historia militar de España, Madrid, Ministerio de Defensa, 2006.

- VVAA, Las Fuerzas Armadas Españolas. Historia Institucional y Social, Madrid, Alhambra, 1986. 